UNIVERSIDADE DE SÃO PAULO

FACULDADE DE FILOSOFIA, LETRAS E CIÊNCIAS HUMANAS DEPARTAMENTO DE LETRAS CLÁSSICAS E VERNÁCULAS

PROGRAMA DE PÓS-GRADUAÇÃO DE FILOLOGIA E LÍNGUA PORTUGUESA

\title{
CÁTIA SCHREINER
}

Edição de Documentos e Estudo do Vocabulário do Charque na Região Sul do Brasil: contribuição à história do português brasileiro

SÃO PAULO 
UNIVERSIDADE DE SÃO PAULO

FACULDADE DE FILOSOFIA, LETRAS E CIÊNCIAS HUMANAS

DEPARTAMENTO DE LETRAS CLÁSSICAS E VERNÁCULAS

PROGRAMA DE PÓS-GRADUAÇÃO DE FILOLOGIA E LÍNGUA PORTUGUESA

\title{
Edição de Documentos e Estudo do Vocabulário do Charque na Região Sul do Brasil: contribuição à história do português brasileiro
}

\author{
CÁTIA SCHREINER
}

Tese de doutorado apresentada ao Programa de Pós-Graduação em Filologia e Língua Portuguesa, do Departamento de Letras Clássicas e Vernáculas da Faculdade de Filosofia, Letras e Ciências Humanas da Universidade de São Paulo, para obtenção do título de Doutor em Letras.

Orientador:

Prof. Dr. Manoel Mourivaldo Santiago Almeida

VERSÃO CORRIGIDA

SÃO PAULO 
Autorizo a reprodução e divulgação total ou parcial deste trabalho, por qualquer meio convencional ou eletrônico, para fins de estudo e pesquisa, desde que citada a fonte.

Catalogação na Publicação

Serviço de Biblioteca e Documentação

Faculdade de Filosofia, Letras e Ciências Humanas da Universidade de São Paulo

Schreiner, Cátia
Edição de Documentos e Estudo do Vocabulário do
Charque na Região Sul do Brasil: contribuiço à
história do português brasileiro / Cátia Schreiner ;
orientador Manoel Mourivaldo Santiago Almeida. - São
Paulo, 2012 .
$\quad 504$ f.
Tese (Doutorado) - Faculdade de Filosofia, Letras
e Ciências Humanas da Universidade de São Paulo.
Departamento de Letras Clássicas e Vernáculas. Área
de concentração: Filologia e Língua Portuguesa.
1. Filologia. 2. Charque. 3. Lexicografia. 4.
Lexicologia. 5. Glossários. I. Almeida, Manoel
Mourivaldo Santiago, orient. II. Título.




\section{FOLHA DE APROVAÇÃO}

\section{CÁTIA SCHREINER}

Edição de Documentos e Estudo do Vocabulário do Charque na Região Sul do Brasil: contribuição à história do português brasileiro

Tese de doutorado apresentada ao Programa de Pós-Graduação em Filologia e Língua Portuguesa, do Departamento de Letras Clássicas e Vernáculas da Faculdade de Filosofia, Letras e Ciências Humanas da Universidade de São Paulo, para obtenção do título de Doutor em Letras.

Orientador:

Prof. Dr. Manoel Mourivaldo Santiago Almeida

Aprovado em:

\section{Banca Examinadora:}

Prof. Dr. Manoel Mourivaldo Santiago Almeida (Presidente) Instituição: FFLCH - USP Assinatura:

Profa. Dra. Ieda Maria Alves (Titular) Instituição: FFLCH - USP

Assinatura:

Prof. Dr. Ataliba Teixeira de Castilho (Titular)

Instituição: FFLCH - USP

Assinatura:

Prof. Dr. Cesar Nardelli Cambraia (Titular) Instituição: UFMG - Externo

Assinatura:

Prof. Dr. Rogério Luiz de Souza (Titular) Instituição:UFSC - Externo

Assinatura: 
Ao meu marido Marcel, sem ele nada disso seria possível e aos meus filhos, Vicente, Olívia e Santiago, que são a razão de tudo. 


\section{AGRADECIMENTOS}

À Fundação de Amparo à Pesquisa do Estado de São Paulo (FAPESP) pela bolsa concedida durante o doutorado.

Ao Professor Doutor Manoel Mourivaldo Santiago Almeida por toda a orientação, amizade, respeito e horas dedicadas à minha pesquisa, obrigada mesmo, chefe!

Aos Professores Doutores Ataliba Teixeira de Castilho e Ieda Maria Alves por terem aceito o convite e contribuído para o aprimoramento da tese na qualificação.

À toda a minha família, pelo carinho e apoio.

Aos meus filhos, pela compreensão e beijos recebidos nas horas de trabalho.

Ao Marcel e Cláudia que vieram em meu socorro nas horas difíceis, me ajudando na montagem da tese.

Aos meus amigos, que entenderam a distância e deram força com alguma palavra de incentivo.

Às amigas e companheiras aqui de casa, Cláudia e Vera, que se manteram firme ao meu lado, cuidando de tudo para que eu pudesse me dedicar mais à tese.

Ao povo pelotense, pela receptividade ao abrir as portas de suas casas para eu entrar com minha pesquisa.

Em especial aos amigos Rubia e Paulo, que não só me acolheram, mas me incentivaram e ajudaram mais do que eles próprios imaginam.

E a Deus, que ouviu com resignação todas as minhas súplicas. 
Não há sociedade ou homem sem consciência histórica. A humanidade não pode compreender-se, nem delinear seu futuro, sem apreciar seu passado.

(Joachim Hermann) 


\section{RESUMO}

Esta pesquisa tem como objetivo geral estudar o vocabulário do charque no Sul do Brasil, propondo uma discussão sobre as influências e contribuições desse léxico na formação e expansão da variedade do português brasileiro. Para a realização deste estudo, de caráter exploratório e descritivo, são utilizados documentos manuscritos e impressos, antigos e modernos, material oral, dicionários de Língua Portuguesa e atlas linguísticos. A metodologia empregada parte da Filologia, por meio de edições facsimilar e/ou semidiplomática dos documentos escritos, das quais emerge o vocabulário do charque, culminando num estudo lexicográfico. Os atlas linguísticos e suas metodologias são utilizados como base comparativa à pesquisa de campo realizada, permitindo a análise do uso da lexia charque nas comunidades investigadas. Os objetivos específicos deste estudo são definir um glossário a partir do vocabulário charque selecionado dos documentos, dos atlas e da pesquisa de campo, e desenvolver uma análise diacrônica do conteúdo deste glossário, comparando as acepções das lexias listadas às encontradas em dicionários dos séculos XVIII, XIX, XX e XXI. O exame desses dados é feitos à luz de estudos filológicos, lexicográficos e lexicológicos. A partir desta pesquisa, será possível suscitar uma discussão sobre o grau de influência do dialeto caipira paulista no sul do Brasil, considerando os movimentos bandeirante, monçoeiro e tropeiro com a economia do charque.

Palavras-chaves: Charque. Lexicologia. Filologia. Lexicografia. Glossário. 


\begin{abstract}
This research seeks to study the charque - jerked beef - vocabulary in southern Brazil, proposing a discussion over influences and contributions of such lexicon and in forming and expanding the variety of Brazilian portuguese. For this study, which was both exploratory and descriptive, it was used manuscripts and printed documents, both ancient and modern, oral material, portuguese dictionaries as well as linguistic atlases. The methodology employed starts off from philology, through facsimile and/or semidiplomatic editings of written documents, from which the charque vocabulary arises, reaching its lexicographic study. The linguistic atlases and their methodologies are the basis for a field research, analyzing the lexia charque in the investigated communities. From the list of the charque vocabulary, collected in the documents, atlases and field research, the study aims, specifically, to compose a glossary and to develop a diachronical analysis of its content, comparing the meaning of the listed lexia to those found on dictionaries from $18^{\text {th }}, 19^{\text {th }}, 20^{\text {th }}$ and $21^{\text {st }}$ century. The analysis of these data is made in light of philological, lexicographical and geolinguistical studies. This research can also raise a discussion about the level of influence of the dialeto caipira - rustic dialect of São Paulo in southern Brazil, considering the bandeirante, monçoeiro and tropeiro - muleteer movement with the charque economy.
\end{abstract}

Keywords: Jerked beef. Lexicology. Philology. Lexicography.Glossary. 


\section{ÍNDICE DE TABELAS}

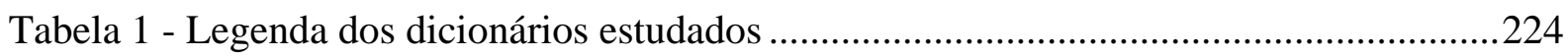

Tabela 2 - Combinações das lexias e correspondências das obras no Glossário.....................412

Tabela 3 - Lista geral das lexias e acepções correspondentes .............................................413

Tabela 4 - Lista geral das lexias e acepções correspondentes em número relativo.................419

Tabela 5 - Lista geral das lexias e acepções correspondentes em percentual.........................420

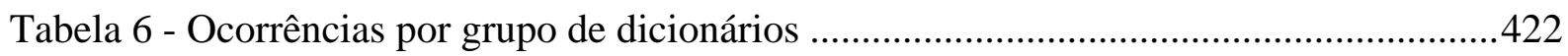

Tabela 7 - Ocorrências por grupo de dicionários (em percentual) .......................................422

Tabela 8 - Número de entrevistas - de acordo com as localidades ......................................444

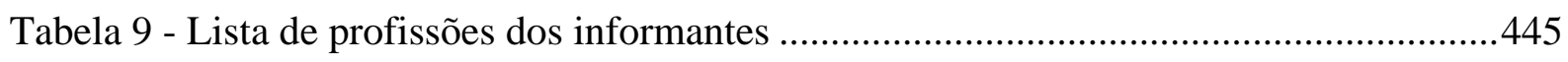

Tabela 10 - Distribuição de Faixa Etária por Localidade ....................................................446

Tabela 11 - Distribuição do Nível de Escolaridade por Localidade .......................................446

Tabela 12 - Distribuição da Naturalidade em cada Localidade ..............................................447

Tabela 13 - Distribuição do Gênero por Localidade ............................................................447

Tabela 14 - Respostas da pergunta 1, por Localidade ......................................................... 448

Tabela 15 - Respostas da pergunta 2, por Localidade ........................................................449

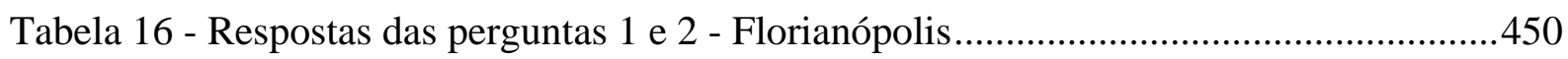

Tabela 17 - Respostas das perguntas 1 e 2 - Pelotas ...........................................................450

Tabela 18 - Respostas das perguntas 1 e 2 - São Paulo .........................................................450

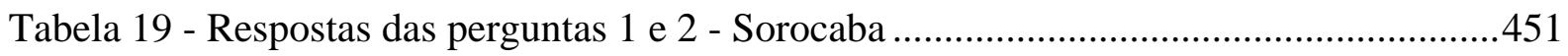

Tabela 20 - Percentual lexia 'Charque' da pergunta 1, conforme Faixa Etária.......................451

Tabela 21 - Percentual lexia 'Charque' da pergunta 1, conforme Escolaridade......................452

Tabela 22 - Percentual lexia 'Charque' da pergunta 1, conforme Gênero ..............................452 


\section{LISTA DE DOCUMENTOS}

Doc 1 - 1896/1901 (Arquivo Público do Estado de Santa Catarina - Florianópolis) ................38

Doc 2 - 1896/1901 (Arquivo Público do Estado de Santa Catarina - Florianópolis) ...............39

Doc 3 - 1896/1901 (Arquivo Público do Estado de Santa Catarina - Florianópolis) ...............40

Doc 4 - 1896/1901 (Arquivo Público do Estado de Santa Catarina - Florianópolis) ...............41

Doc 5 - 1896/1901 (Arquivo Público do Estado de Santa Catarina - Florianópolis) ................42

Doc 6 - 1816 (Arquivo Público do Estado de Santa Catarina - Florianópolis) .........................43

Doc 7 - 1828 (Arquivo Público do Estado de Santa Catarina - Florianópolis) ........................45

Doc 8 - 1797 (Arquivo Público do Estado de Santa Catarina - Florianópolis) .........................47

Doc 9 - 1797 (Arquivo Público do Estado de Santa Catarina - Florianópolis) ........................51

Doc 10 - 1797 (Arquivo Público do Estado de Santa Catarina - Florianópolis) .......................55

Doc 11 - 1798 (Arquivo Público do Estado de Santa Catarina - Florianópolis) ......................57

Doc 12 - 1797 (Arquivo Público do Estado de Santa Catarina - Florianópolis) .......................61

Doc 13 - 1798 (Arquivo Público do Estado de Santa Catarina - Florianópolis) ......................65

Doc 14 - 1798 (Arquivo Público do Estado de Santa Catarina - Florianópolis) ......................69

Doc 15 - 1795 (Arquivo Público do Estado de Santa Catarina - Florianópolis) .......................71

Doc 16 - s/n (Biblioteca Pública Pelotense - Pelotas) ........................................................... 75

Doc 17 - s/n (Biblioteca Pública Pelotense - Pelotas) ............................................................ 76

Doc 18 - 1845 (Biblioteca Pública Pelotense - Pelotas) .......................................................... 77

Doc 19 - 1844 (Biblioteca Pública Pelotense - Pelotas) .......................................................... 79

Doc 20 - 1854 (Biblioteca Pública Pelotense - Pelotas) ............................................................ 81

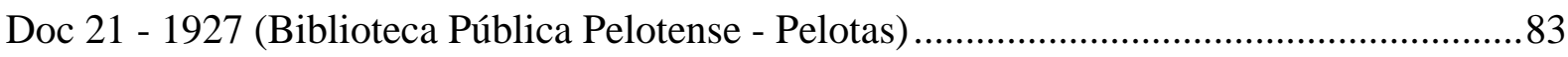

Doc 22 - 1927 (Biblioteca Pública Pelotense - Pelotas) .............................................................8 84

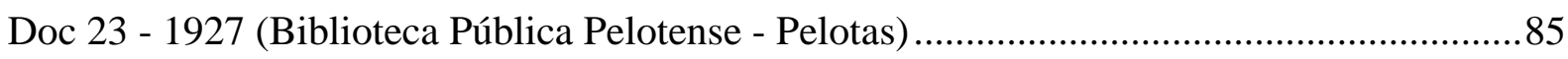

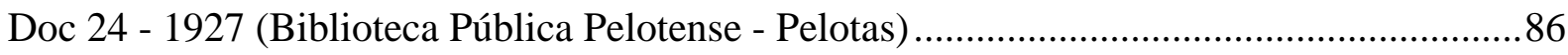

Doc 25 - 1927 (Biblioteca Pública Pelotense - Pelotas) .......................................................... 87

Doc 26 - 1851 (Biblioteca Pública Pelotense - Pelotas) ........................................................... 88

Doc 27 - 1878 (Biblioteca Pública Pelotense - Pelotas) ............................................................90

Doc 28 - 1869 (Biblioteca Pública Pelotense - Pelotas) ...........................................................92

Doc 29 - 1869 (Biblioteca Pública Pelotense - Pelotas) .........................................................93

Doc 30 - 1869 (Biblioteca Pública Pelotense - Pelotas) ...........................................................94

Doc 31 - 1869 (Biblioteca Pública Pelotense - Pelotas) ...........................................................95 
Doc 32 - 1869 (Biblioteca Pública Pelotense - Pelotas) .........................................................96

Doc 33 - 1869 (Biblioteca Pública Pelotense - Pelotas) .......................................................... 97

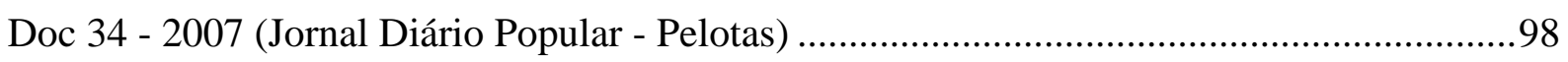

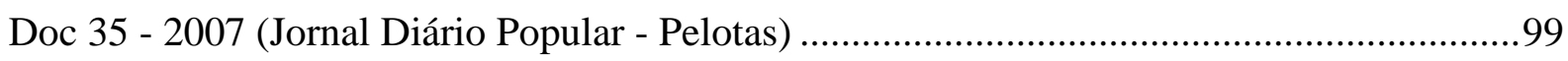

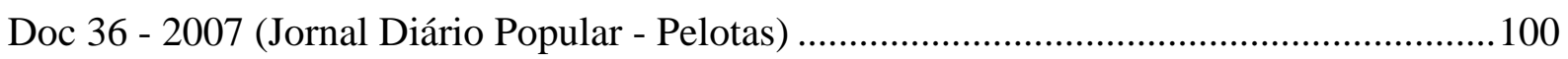

Doc 37 - 2007 (Jornal Diário Popular - Pelotas) ......................................................................... 101

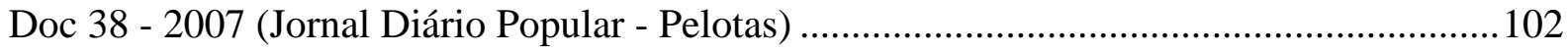

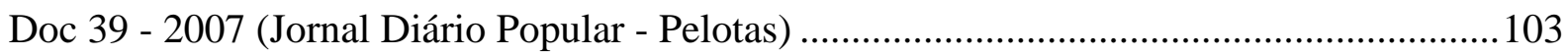

Doc 40 - 2007 (Jornal Diário Popular - Pelotas) ..................................................................... 104

Doc 41 - 2007 (Jornal Diário Popular - Pelotas) …............................................................. 105

Doc 42 - 2007 (Jornal Diário Popular - Pelotas) .................................................................. 106

Doc 43 - 2007 (Jornal Diário Popular - Pelotas) ................................................................... 107

Doc 44 - 2007 (Jornal Diário Popular - Pelotas) …........................................................... 108

Doc 45 - 2007 (Jornal Diário Popular - Pelotas) .................................................................. 109

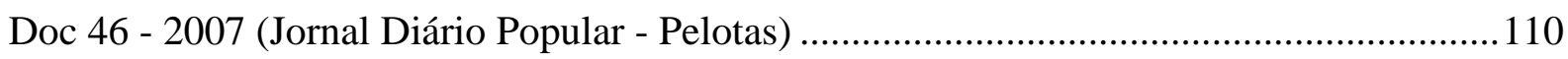

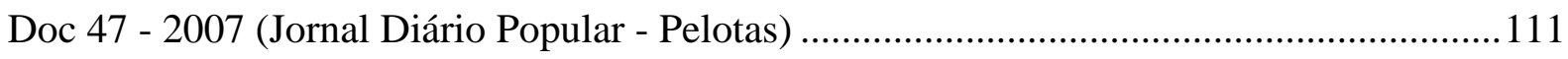

Doc 48 - 2007 (Jornal Diário Popular - Pelotas) ................................................................ 112

Doc 49 - 1870 (Arquivo Público do Estado do Rio Grande do Sul - Porto Alegre) ...............113

Doc 50 - 1870 (Arquivo Público do Estado do Rio Grande do Sul - Porto Alegre) ...............115

Doc 51 - 1870 (Arquivo Público do Estado do Rio Grande do Sul - Porto Alegre) ...............117

Doc 52 - 1872 (Arquivo Público do Estado do Rio Grande do Sul - Porto Alegre) ...............119

Doc 53 - 1872 (Arquivo Público do Estado do Rio Grande do Sul - Porto Alegre) ............... 121

Doc 54 - 1871 (Arquivo Público do Estado do Rio Grande do Sul - Porto Alegre) ...............122

Doc 55 - 1871 (Arquivo Público do Estado do Rio Grande do Sul - Porto Alegre) ...............124

Doc 56 - 1871 (Arquivo Público do Estado do Rio Grande do Sul - Porto Alegre) ............... 126

Doc 57 - 1870 (Arquivo Público do Estado do Rio Grande do Sul - Porto Alegre) ...............128

Doc 58 - 1870 (Arquivo Público do Estado do Rio Grande do Sul - Porto Alegre) ............... 130

Doc 59 - 1870 (Arquivo Público do Estado do Rio Grande do Sul - Porto Alegre) ............... 132

Doc 60 - 1883 (Arquivo Público do Estado do Rio Grande do Sul - Porto Alegre) ............... 134

Doc 61 - 1883 (Arquivo Público do Estado do Rio Grande do Sul - Porto Alegre) ...............136

Doc 62 - 1873 (Arquivo Público do Estado do Rio Grande do Sul - Porto Alegre) ...............138

Doc 63 - 1883 (Arquivo Público do Estado do Rio Grande do Sul - Porto Alegre) ............... 140

Doc 64 - 1873 (Arquivo Público do Estado do Rio Grande do Sul - Porto Alegre) ............... 142 
Doc 65 - 1873 (Arquivo Público do Estado do Rio Grande do Sul - Porto Alegre)

Doc 66 - s/n (Alvarino da Fontoura Marques - A Economia do Charque. O charque nas artes. Culinária do charque)

Doc 67 - s/n (Alvarino da Fontoura Marques - A Economia do Charque. O charque nas artes. Culinária do charque)

Doc 68 - s/n (Alvarino da Fontoura Marques - A Economia do Charque. O charque nas artes. Culinária do charque)

Doc 69 - s/n (Alvarino da Fontoura Marques - A Economia do Charque. O charque nas artes. Culinária do charque)

Doc 70 - s/n (Alvarino da Fontoura Marques - A Economia do Charque. O charque nas artes. Culinária do charque)

Doc 71 - s/n (Alvarino da Fontoura Marques - A Economia do Charque. O charque nas artes. Culinária do charque)

Doc 72 - s/n (Alvarino da Fontoura Marques - A Economia do Charque. O charque nas artes. Culinária do charque)

Doc 73 - s/n (Alvarino da Fontoura Marques - A Economia do Charque. O charque nas artes. Culinária do charque)

Doc 74 - s/n (Alvarino da Fontoura Marques - A Economia do Charque. O charque nas artes. Culinária do charque) 154

Doc 75 - s/n (Alvarino da Fontoura Marques - A Economia do Charque. O charque nas artes. Culinária do charque) 155

Doc 76 - s/n (Alvarino da Fontoura Marques - A Economia do Charque. O charque nas artes. Culinária do charque) 156

Doc 77 - s/n (Alvarino da Fontoura Marques - A Economia do Charque. O charque nas artes. Culinária do charque)

Doc 78 - s/n (Alvarino da Fontoura Marques - A Economia do Charque. O charque nas artes. Culinária do charque) 158

Doc 79 - s/n (Alvarino da Fontoura Marques - A Economia do Charque. O charque nas artes. Culinária do charque)

Doc 80 - s/n (Alvarino da Fontoura Marques - A Economia do Charque. O charque nas artes. Culinária do charque)

Doc 81 - s/n (Alvarino da Fontoura Marques - A Economia do Charque. O charque nas artes. Culinária do charque) 
Doc 82 - s/n (Alvarino da Fontoura Marques - A Economia do Charque. O charque nas artes. Culinária do charque) 162

Doc 83 - 1880 (Louis Couty - A Erva Mate e o Charque) .................................................... 163

Doc 84 - 1880 (Louis Couty - A Erva Mate e o Charque) ...................................................... 164

Doc 85 - 1880 (Louis Couty - A Erva Mate e o Charque) ................................................... 165

Doc 86 - 1880 (Louis Couty - A Erva Mate e o Charque) .................................................... 166

Doc 87 - 1880 (Louis Couty - A Erva Mate e o Charque) .....................................................167

Doc 88 - 1880 (Louis Couty - A Erva Mate e o Charque) ..................................................... 168

Doc 89 - 1880 (Louis Couty - A Erva Mate e o Charque) .................................................... 169

Doc 90 - 1880 (Louis Couty - A Erva Mate e o Charque) .................................................... 170

Doc 91 - 1880 (Louis Couty - A Erva Mate e o Charque) .....................................................171

Doc 92 - 1880 (Louis Couty - A Erva Mate e o Charque) ..................................................... 172

Doc 93 - 1880 (Louis Couty - A Erva Mate e o Charque) ...................................................... 173

Doc 94 - 1880 (Louis Couty - A Erva Mate e o Charque) .................................................... 174

Doc 95 - 1880 (Louis Couty - A Erva Mate e o Charque) ..................................................... 175

Doc 96 - 1880 (Louis Couty - A Erva Mate e o Charque) ....................................................176

Doc 97 - 1880 (Louis Couty - A Erva Mate e o Charque) ..................................................... 177

Doc 98 - 1880 (Louis Couty - A Erva Mate e o Charque) ..................................................... 178

Doc 99 - 1880 (Louis Couty - A Erva Mate e o Charque) ..................................................... 179

Doc 100 - 1880 (Louis Couty - A Erva Mate e o Charque) ................................................... 180

Doc 101 - 1880 (Louis Couty - A Erva Mate e o Charque) ...................................................181

Doc 102 - 1880 (Louis Couty - A Erva Mate e o Charque) .................................................... 182

Doc 103 - 1880 (Louis Couty - A Erva Mate e o Charque) ................................................... 183

Doc 104 - 1880 (Louis Couty - A Erva Mate e o Charque) .................................................... 184

Doc 105 - 1880 (Louis Couty - A Erva Mate e o Charque) ................................................... 185

Doc 106 - 1988 (Antenor Peixoto de Castro - Xarqueadas de Danúbio Gonçalves Um resgate

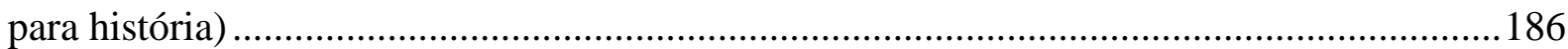

Doc 107 - 1988 (Antenor Peixoto de Castro - Xarqueadas de Danúbio Gonçalves Um resgate para história)

Doc 108 - 1988 (Antenor Peixoto de Castro - Xarqueadas de Danúbio Gonçalves Um resgate para história) 188

Doc 109 - 1988 (Antenor Peixoto de Castro - Xarqueadas de Danúbio Gonçalves Um resgate para história) 
Doc 110 - 1988 (Antenor Peixoto de Castro - Xarqueadas de Danúbio Gonçalves Um resgate para história)

Doc 111 - 1988 (Antenor Peixoto de Castro - Xarqueadas de Danúbio Gonçalves Um resgate para história)

Doc 112 - 1988 (Antenor Peixoto de Castro - Xarqueadas de Danúbio Gonçalves Um resgate para história)

Doc 113 - 1988 (Antenor Peixoto de Castro - Xarqueadas de Danúbio Gonçalves Um resgate para história)

Doc 114 - 1988 (Antenor Peixoto de Castro - Xarqueadas de Danúbio Gonçalves Um resgate para história)

Doc 115 - 1988 (Antenor Peixoto de Castro - Xarqueadas de Danúbio Gonçalves Um resgate para história)

Doc 116 - 1988 (Antenor Peixoto de Castro - Xarqueadas de Danúbio Gonçalves Um resgate para história)

Doc 117 - 1988 (Antenor Peixoto de Castro - Xarqueadas de Danúbio Gonçalves Um resgate para história)

Doc 118 - 1988 (Antenor Peixoto de Castro - Xarqueadas de Danúbio Gonçalves Um resgate para história) 198

Doc 119 - 1988 (Antenor Peixoto de Castro - Xarqueadas de Danúbio Gonçalves Um resgate para história)

Doc 120 - 1988 (Antenor Peixoto de Castro - Xarqueadas de Danúbio Gonçalves Um resgate para história)

Doc 121 - 1988 (Antenor Peixoto de Castro - Xarqueadas de Danúbio Gonçalves Um resgate para história) 201

Doc 122 - 1988 (Antenor Peixoto de Castro - Xarqueadas de Danúbio Gonçalves Um resgate para história)

Doc 123 - 1988 (Antenor Peixoto de Castro - Xarqueadas de Danúbio Gonçalves Um resgate para história)

Doc 124 - 1988 (Antenor Peixoto de Castro - Xarqueadas de Danúbio Gonçalves Um resgate para história)

Doc 125 - 1988 (Antenor Peixoto de Castro - Xarqueadas de Danúbio Gonçalves Um resgate para história) .205

Doc 126 - 1820/21 (Auguste de Saint-Hilaire - Viagem ao Rio Grande do Sul) 206 
Doc 127 - 1820/21 (Auguste de Saint-Hilaire - Viagem ao Rio Grande do Sul) ...................207

Doc 128 - 1820/21 (Auguste de Saint-Hilaire - Viagem ao Rio Grande do Sul) ....................208

Doc 129 - 1820/21 (Auguste de Saint-Hilaire - Viagem ao Rio Grande do Sul) ....................209

Doc 130 - 1820/21 (Auguste de Saint-Hilaire - Viagem ao Rio Grande do Sul) ....................210

Doc 131 - 1820/21 (Auguste de Saint-Hilaire - Viagem ao Rio Grande do Sul) ...................211

Doc 132 - 1820/21 (Auguste de Saint-Hilaire - Viagem ao Rio Grande do Sul) ...................212

Doc 133 - 1820/21 (Auguste de Saint-Hilaire - Viagem ao Rio Grande do Sul) ...................213

Doc 134 - 1820/21 (Auguste de Saint-Hilaire - Viagem ao Rio Grande do Sul) ...................214

Doc 135 - 1820/21 (Auguste de Saint-Hilaire - Viagem ao Rio Grande do Sul) ....................215

Doc 136 - 1820/21 (Auguste de Saint-Hilaire - Viagem ao Rio Grande do Sul) ....................216

Doc 137 - 1820/21 (Auguste de Saint-Hilaire - Viagem ao Rio Grande do Sul) ....................217

Doc 138 - 1820/21 (Auguste de Saint-Hilaire - Viagem ao Rio Grande do Sul) ....................218 


\section{LISTA DE SIGLAS}

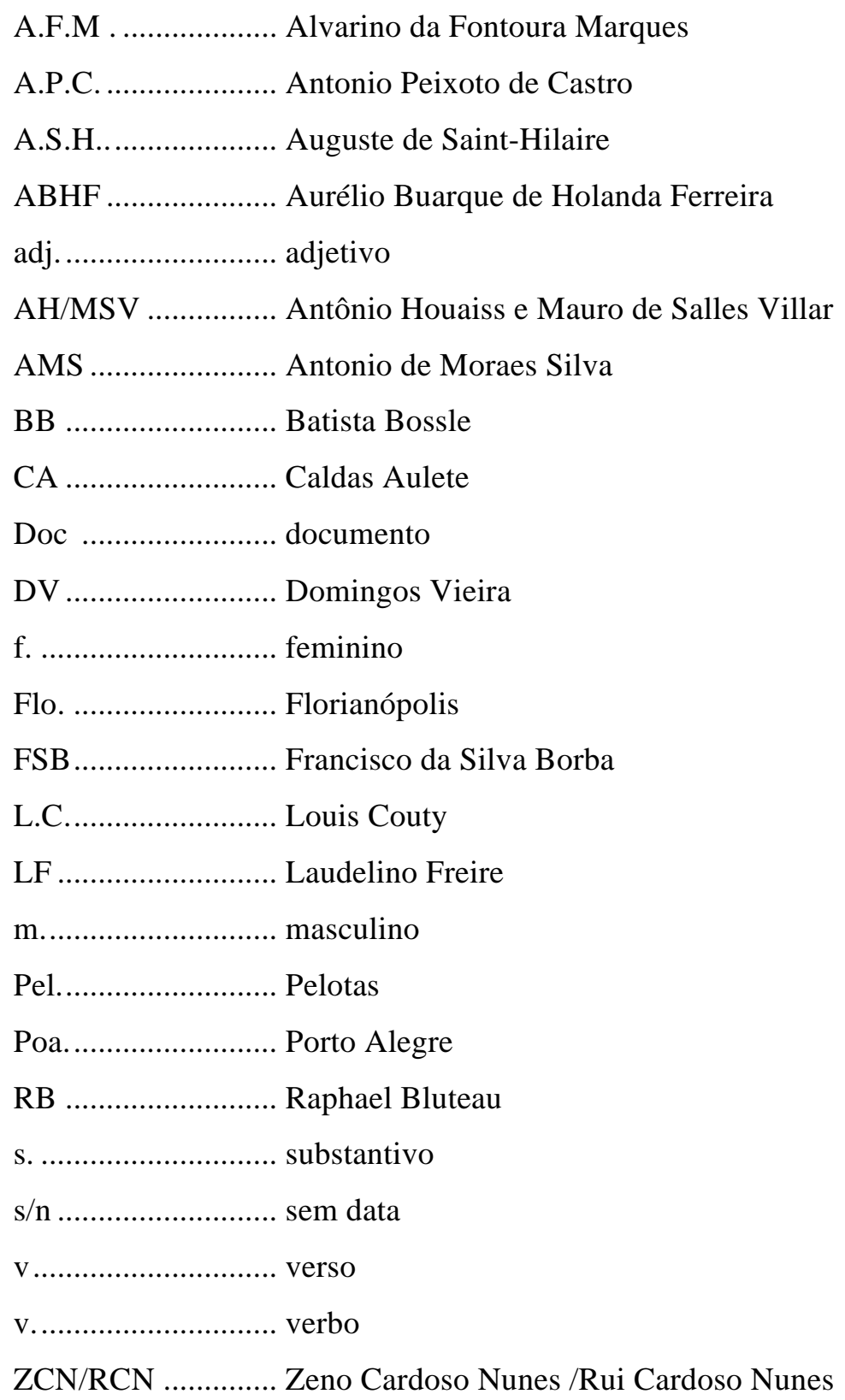




\section{SUMÁRIO}

INTRODUÇÃO ...................................................................................................................................20

Capítulo 1 - O CORPUS .........................................................................................................24

1.1. As primeiras pesquisas bibliográficas................................................................................................24

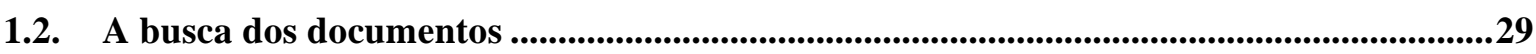

1.3. A composição do corpus ...................................................................................................32

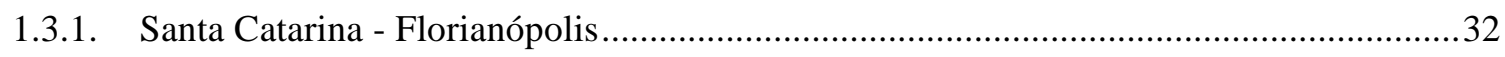

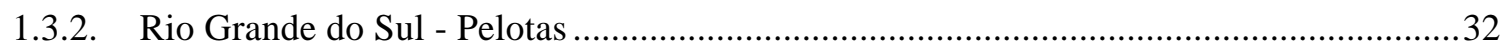

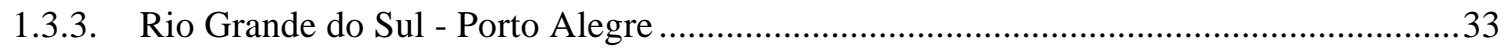

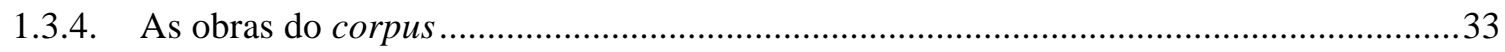

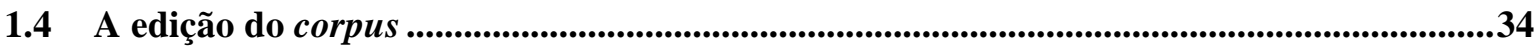

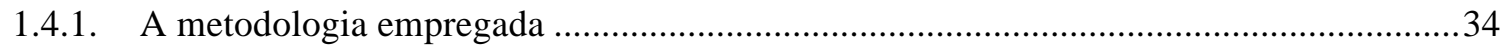

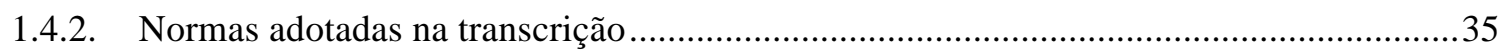

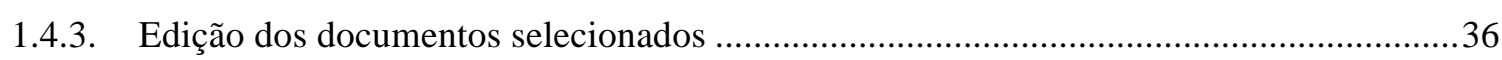

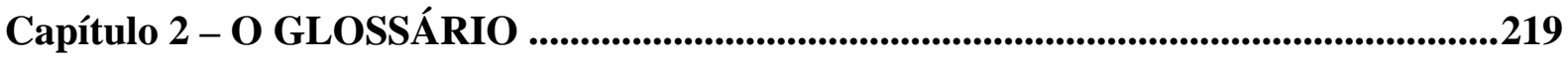

2.1. Aporte teórico metodológico da composiçãa do glossário ..................................................219

2.2. As pesquisas nos dicionários de Língua Portuguesa .....................................................221

2.3. Aspectos adotados definição do glossário................................................................225

2.4. Detalhamento dos verbetes e outras informações sobre a composição do glossário .....226

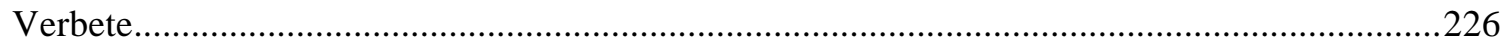

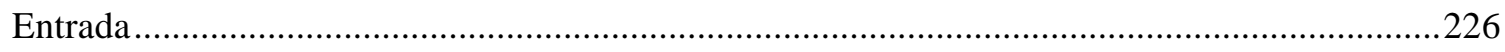

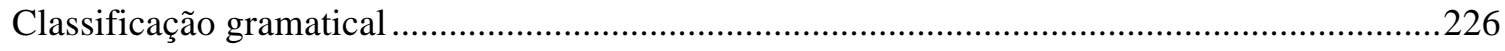

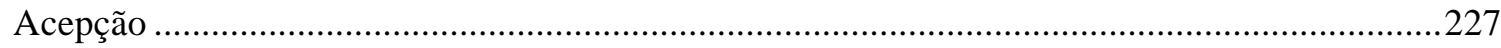

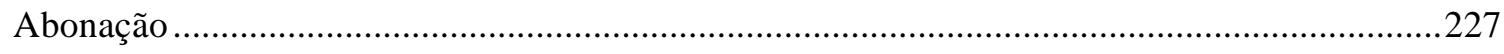

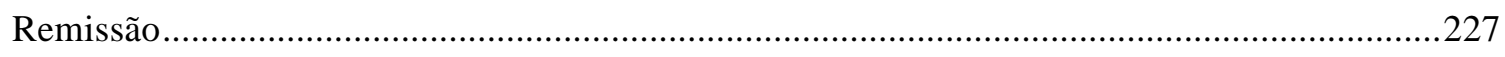

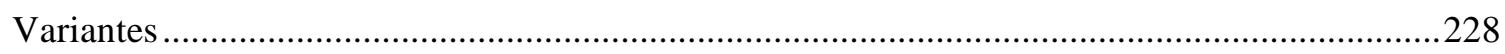

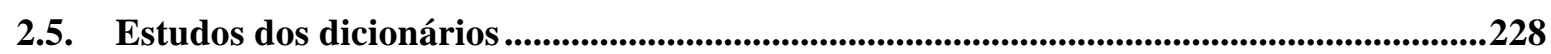

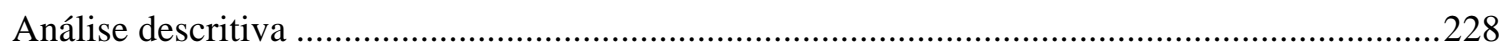

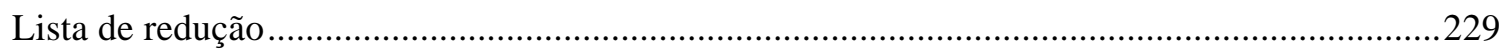

2.6. Lista de figuras do Glossário .........................................................................................................229

2.7. Lista geral de reduções do Glossário ..............................................................................................231

2.8. Glossário ........................................................................................................................................233

2.9. Descrição das lexias do glossário encontradas nos dicionários ...........................................412

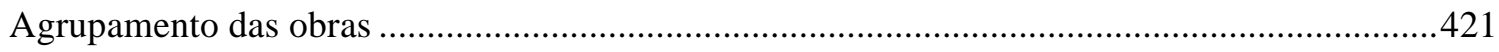


3.1. Bases para Elaboração do Atlas Linguístico do Brasil - ..........................................................425

3.2. Atlas Linguístico do Estado de São Paulo - ALESP ............................................................426

3.3. Comitê Nacional do Projeto ALiB: Atlas Linguístico do Brasil: Questionários.............427

3.4. Atlas Linguístico - Etnográfico da Região Sul do Brasil - ALERS ....................................428

3.5. Atlas Linguístico do Paraná - ALPR .....................................................................................431

3.6. Atlas Linguístico de Mato Grosso do Sul - ALMS ......................................................432

3.7. Esboço de um Atlas Línguístico de Minas Gerais ................................................................434

Capítulo 4 - A PESQUISA DE CAMPO........................................................................................4437

4.1. Questionário da lexia charque - considerações teórico-metodológicas .............................438

4.2. Descrição dos resultados da pesquisa de campo ............................................................444

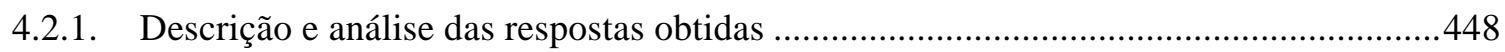

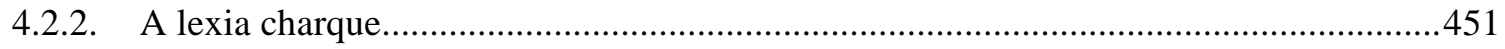

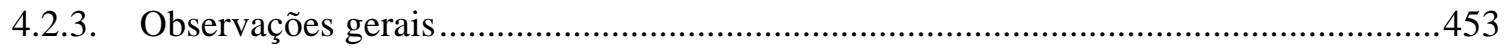

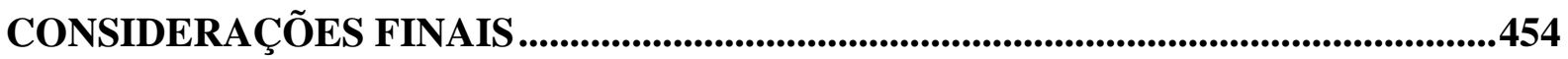

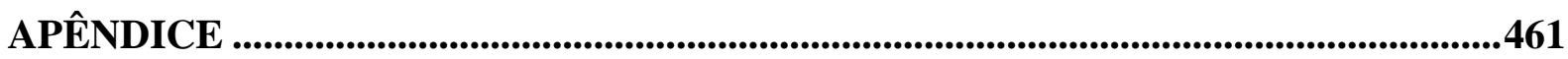

RESULTADOS DAS PESQUISAS DE CAMPO ...................................................462

RESUMO DOS DICIONÁRIOS ..............................................................................469

D. Raphael Bluteau Vocabulario Portuguez e Latino ..................................................................469

Antonio de Moraes Silva Diccionario da Lingua Portugueza.......................................................474

Domingos Vieira Grande Diccionario Portuguez ou Thesouro da Língua Portugueza...........478

Laudelino Freire Grande e Novíssimo Dicionário da Língua Portuguesa .................................481

Caldas Aulete Dicionário Contemporâneo da Língua Portuguêsa ...............................................484

Aurélio Buarque de Holanda Ferreira Novo Dicionário Da Língua Portuguesa .....................486

Zeno e Rui Cardoso Nunes Dicionário de Regionalismos do Rio Grande do Sul .....................488

Antônio Houaiss e Mauro de Salles Villar Dicionário Houaiss da Língua Portuguesa............489

Francisco da Silva Borba Dicionário de usos do Português do Brasil ......................................494

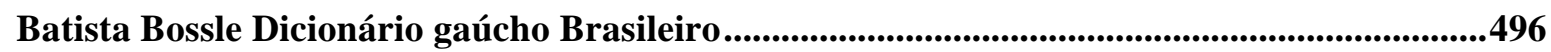

REFERÊNCIAS BIBLIOGRÁFICAS .............................................................................498 


\section{INTRODUÇÃO}

A ideia para esta tese emergiu de um seminário no qual a pesquisadora apresentou um trabalho em 2006, no Rio Grande do Sul, durante o curso de mestrado. Naquela ocasião, foi utilizado um dos documentos que compõem o códice intitulado Ofícios do Vice-Rei para o Governador da Capitania 1793/98, que encontra-se no Arquivo Público do Estado de Santa Catarina sob a cota de número 16.446. O documento em questão trata de um receituário que versa sobre como deveria ser feita a salga das carnes que partiam das capitanias do Sul do Brasil em direção ao Rio de Janeiro e outras localidades.

As hipóteses e questionamentos levantados, durante a apresentação daquele trabalho, a respeito das contribuições e/ou influências linguísticas, sócio-históricas e culturais do charque no Sul do Brasil foram determinantes na escolha do tema desta pesquisa, que - considerando a função transcendente ${ }^{1}$ da Filologia, que, de acordo com um dos seus conceitos amplos dicionarizados, estuda as sociedades e civilizações através de documentação escrita, e tendo como apoio a História Social - tem como objetivo geral realizar um estudo do vocabulário charque no sul do Brasil.

Etimologicamente, a lexia charque é apontada pela maioria dos lexicógrafos, como originária do quíchua ${ }^{2}$, charki, que significa a carne salgada curada ao sol. Outros, simplesmente, fazem a referência: charque, do espanhol, charqui. O dicionário Houaiss (2001), por exemplo, menciona a provável etimologia espanhola de charque, mas sugere que sua origem é obscura. Já Joan Corominas, filólogo e etimólogo espanhol, em sua obra, Diccionário Crítico Etimológico de la Lengua Castelhana (1992), discorre sobre a etimologia da lexia charque, informando que, por muito tempo, afirmava-se ser de procedência do quíchua, mas que esta teoria é questionável, porque em documentos medievais portugueses foram encontradas ocorrências da lexia carne de enxerca, sinônimo de tajano. Corominas afirma que se usava a lexia enxerqueira para designar a mulher que vendia carne enxercada, contraposta à carne de talho, que era fresca. O autor prossegue o debate etimológico, apresentando opiniões de outros pesquisadores sobre as possíveis origens da palavra, e, afirma:

Que charque se emplea en los idiomas indígenas y que por reaccción de éstos se ha extendido en el castellano local una variante charque, de fisonomia aindiada, es

\footnotetext{
${ }^{1}$ A função transcendente, conforme Spina (1977, p. 77), é aquela "em que o texto deixa de ser um fim em si ${ }^{2}$ O quechua, segundo definição de Silva (1993, p.579) é um membro de um povo da América do Sul. O quechua ou quichua é, também definido como uma família de línguas falada por ente 8 e 10 milhões de pessoas, que se extende pela Bolívia, Peru, Chile, Equador e Argentina.
} 
indudable, pero esto no cuenta para el origen último del vocablo. En conclusión el problema es dudoso y debrerá sufrir un examen atento por parte de los especialistas. (COROMINAS, 1991, p. 34)

Se Corominas e outros lexicógrafos afirmam que um estudo etimológico detalhado ainda se faz necessário, nos parece possível levantar a hipótese de que, dada a proximidade geográfica dos povos, a denominação charque para a carne seca e salgada, produzida no Sul do país, tenha sido incorporada por influência dos falantes de quíchua da América do Sul.

Os questionamentos podem, então, extrapolar os limites da origem do vocábulo charque no Sul brasileiro, estendendo-se para a história da localidade. O estado do Rio Grande do Sul, antes denominado de Província de São Pedro do Rio Grande, ainda dava seus primeiros passos, deixando de ser campo de batalhas territoriais, e passando a utilizar seus recursos naturais, com vistas a se tornar um dos mais prósperos Estados do Brasil.

No século XVIII, a rica pastagem da região e os grandes espaços de vegetação rasteira, permitiam a criação de gado em grande escala. Nesta época, o abate do gado tinha duas finalidades: alimentação e obtenção do couro. Grandes quantidades de gado eram abatidos e carneados, e a produção de couro era fomentada para atender às demandas da metrópole. A carne acabava sendo aproveitada pelas tropas e pela coroa, que abasteciam as naus e fragatas da colônia com barris de carne salgada, sendo usadas para consumo das tropas e da coroa, deixando as sobras abandonadas pelo campos.

Neste mesmo período, uma grande seca castigou o Nordeste do Brasil, especialmente o Estado do Ceará, que produzia um tipo de carne salgada e seca ao sol, chamada de carnedo-ceará. A grande seca, conhecida pelo nome de "seca dos três setes" (1777) praticamente extingue a produção de carne seca nordestina. Mediante a este cenário, um fabricante de carne-do-ceará, de espírito empreendedor, desgostoso com a forte estiagem, decidiu atravessar o país mudando a história riograndense ao instalar a primeira charqueada às margens do Arroio Pelotas.

Mas o debate sobre a veracidade histórica parece aproximar-se ao debate etimológico, incitando dúvidas sobre a consideração de José Pinto Martins como o primeiro charqueador. Segundo alguns historiadores,

Até pouco supunha-se, na falta de dados mais concretos, que Pinto Martins era natural do Ceará e que foi o pioneiro do saladerismo no Rio grande do Sul. Hoje se sabe, graças a pesquisas recentes, que Pinto Martins nasceu em Portugal; ultimamente tem-se repetido, talvez até com exagerada insistência, que antes de 
1779 já se praticava a salgação da carne no território sulino ${ }^{3}$. (MAGALHÃES, 2001, p.20)

O que não levanta nenhum questionamento, porém, é que José Pinto Martins introduziu, nas instalações às margens dos arroios, as técnicas usadas no Ceará, transformando-as em indústrias. Assim, impulsionou a economia da região, e mudou o curso da história rio-grandense ${ }^{4}$ e do Sul do país: se antes produzia-se charque em pequena escala, para consumo interno, depois de 1779 essa produção passou a ser realizada para alcançar diversos estados do Brasil e até mesmo outros países e continentes.

Considerando esse cenário, parece indiscutível a importância econômica e sóciohistórica do charque no Sul do Brasil, o que contribui para o interesse desta tese em realizar um estudo do vocabulário do charque, utilizando, para tanto, documentos manuscritos e impressos, antigos e modernos, material oral, dicionários de Língua Portuguesa, assim como atlas linguísticos realizados na referida região. Baseado em Cambraia (2005), Alves (1998), Biderman (2001), dentre outros, esta pesquisa é realizada à luz de estudos filológicos, lexicográficos e lexicológicos.

De modo a organizar o estudo do vocabulário do charque, o trabalho apresenta um glossário, composto de 211 lexias extraídas da documentação selecionada, dos atlas e da pesquisa oral, expondo também um estudo diacrônico dessas lexias em 10 dicionários de língua portuguesa.

Esse conteúdo abarcado no glossário, torna-o, portanto, um instrumento de pesquisa e análise que auxilia e clarifica a discussão sobre as influências e contribuições das lexias do vocabulário do charque na formação e expansão da variedade do português brasileiro.

Vinculada ao projeto de História do Português Paulista (Projeto Caipira), financiado pela FAPESP (termo de outorga e aceitação de auxílio número 2006/55944-0) esta pesquisa permitirá levantar a discussão a respeito do grau de influência do dialeto caipira paulista no Sul do Brasil, atrelando os movimentos bandeirante, monçoeiro e tropeiro com a economia do charque.

\footnotetext{
${ }^{3}$ Grifo nosso.

${ }^{4}$ Pesquisas feitas pelos historiadores da Universidade Federal de Pelotas, Mario Osório de Magalhães e José Plínio Fachel, indicam que no auge do Ciclo do Charque até 38 charqueadas funcionavam numa mesma época e que, a cada ano, eram abatidas entre 400 mil e 1 milhão de cabeças de gado. Juntas, estas charqueadas possuiam mais de 3.000 trabalhadores escravos. Além da relevância histórica e sócio-econômica, atribui-se aos impostos sobre o gado e sobre o charque as causas principais da eclosão da Revolução Farroupilha.
} 
Para a realização deste estudo interdisciplinar, à luz da filologia, da história social, da lexicologia e da lexicografia, de modo a contribuir para os estudos a respeito da história do léxico do português brasileiro, a tese apresenta a estrutura exposta a seguir.

O capítulo 1 - O Corpus, apresenta a bibliografia pesquisada que embasa o estabelecimento das localidades escolhidas para a formação do corpus da pesquisa; narra o caminho percorrido durante a compilação dos documentos; fornece a localização de onde foram pesquisados os documentos; fornece dados como a numeração adotada e a datação dos documentos do corpus. Evidencia a metodologia, os tipos de edição, as normas aplicadas na transcrição e as edições dos documentos que servem de base para a seleção do vocabulário do charque.

No capítulo 2 - O Glossário, estão dispostos o aporte teórico-metodológico da composição do glossário, a apresentação dos 10 dicionários de Língua Portuguesa selecionados para a pesquisa, os aspectos adotados na definição, o detalhamento dos verbetes e outras informações sobre a composição do glossário. O glossário, em si, também está disposto nesse capítulo, precedido da lista de reduções. A descrição dos resultados obtidos com o cotejo das acepções das lexias do glossário e das obras lexicográficas encerram o capítulo 2.

No capítulo 3 - Os Atlas Linguísticos, são disponibilizados os atlas linguísticos selecionados para a pesquisa, seus respectivos resumos e a metodologia aplicada na pesquisa de campo.

No capítulo 4 - A Pesquisa de Campo, discorrem-se, em linhas gerais, sobre os pressupostos teórico-metodológicos e o modelo do questionário utilizados na pesquisa de campo. Encerra-se o capítulo com a descrição dos resultados alcançados.

Nas Considerações Finais, estão expostos os comentários, as análises, os pressupostos e resultados alcançados que respondem às questões propostas na tese. Este trabalho ainda apresenta um resumo das obras lexicográficas pesquisadas, disposto nos apêndices e, por fim, as Referências Bibliográficas utilizadas nas pesquisas. 


\section{Capítulo 1 - O CORPUS}

\subsection{As primeiras pesquisas bibliográficas}

As informações recolhidas neste subcapítulo pretendem justificar a escolha das regiões de coleta de referências bibliográficas para composição do material escrito. Esta pesquisa procura, em obras sobre a história geral brasileira, apontamentos feitos pelos historiadores sobre o charque como bem de consumo e bem de exportação no Sul do Brasil, além de áreas mencionadas e consideradas por eles como relevantes desse objeto.

A seleção dessas referências históricas foi realizada na biblioteca da FFLCH, na Universidade de São Paulo; na biblioteca da Casa de Portugal, no bairro da Liberdade, em São Paulo e em coleção particular.

A primeira obra pesquisada é do autor Roberto C. Simonsen, que, em sua obra, História Econômica do Brasil, inicia a sua exposição sobre a pecuária afirmando que desde o século XVI o gado era produto básico tanto para a alimentação dos trabalhadores quanto para o transporte. Segundo esse autor, a primeira grande fase de criação bovina iniciou-se na zona de açúcar e que, no entanto, com o crescimento da criação, houve a necessidade de penetrar para o interior e evitar o conflito territorial com a produção açucareira. De acordo com o autor, do interior da Bahia a criação irradiou para o Maranhão, Piauí, Rio Grande do Norte e Ceará. Subindo o São Francisco, atingiu o interior mineiro, passando para os sertões de Goiás e Mato Grosso. Ele supõe que a criação de gado no extremo sul - Paraná, Santa Catarina e Rio Grande do Sul - tenha sido introduzida pelas missões jesuíticas.

Ainda descrevendo a criação no norte do país, Simonsen afirma que passou-se a fazer o uso intenso do couro e, com a descoberta de salinas no Ceará e em Alagoas, a expansão criadora no norte foi beneficiada. O surto minerador - como o denominou - acabou produzindo concentrações populacionais em áreas pouco férteis, fazendo com que o preço do gado subisse, gerando insatisfação por parte dos senhores de engenho. Estes e outros fatores, como o clima e a facilidade de locomoção, acabaram favorecendo a instalação de fazendas em Minas Gerais, Mato Grosso e nos campos do sul.

Para Simonsen, o desenvolvimento da indústria de charque na região sul supria, por via marítima, as populações litorâneas do centro-oeste e acabaram substituindo a carne-de-sol ou carne-de-vento produzida principalmente no Ceará. Declarando que o charque, por ser produzido com sal, era de maior duração que o charque nordestino, além do gado no sul 
sempre ter sido mais barato. Discorrendo sobre o preço deste produto, o autor segue tratando sobre a criação de gado e sobre as raças, pastos, climas do gado colonial e dá ênfase ao consumo e produção de couro, atestando que antes da criação das charqueadas, o gado era morto principalmente para a produção coureira.

A obra segue tratando da produção do couro, passando para o gado cavalar, o sal, a mineração e como esta acabou influenciando no surgimento dos tropeiros, discorrendo sobre a pecuária e o seu papel na formação econômica brasileira. Entretanto, o autor cita o charque muito brevemente e não debate sobre o assunto como acaba fazendo acerca do couro e do sal - produtos ligados diretamente na produção deste produto. Mesmo tendo relatado a formação e introdução da pecuária como um todo, e não ter aprofundado os estudos no charque e sua história econômica em particular, esta obra encontra-se em papel de destaque nesta etapa do trabalho por introduzir o assunto em âmbito geral.

A obra História Econômica do Brasil e Formação do Brasil Contemporâneo, de Caio Prado Júnior, trata do charque e da pecuária no capítulo 11, sob o título: Incorporação do Rio Grande do Sul - Estabelecimento da Pecuária. Segundo este autor, é somente na segunda metade do século XVIII que a pecuária rio-grandense começou a contar economicamente como parte importante para a história brasileira. Antes disso, segundo ele, o território e as fronteiras do extremo sul eram disputados militarmente pelos espanhóis, portugueses e também argentinos e uruguaios. $\mathrm{O}$ autor afirma que a pecuária era a base econômica do extremo sul e mesmo sem o trato especial que deveria ter tido, adquiriu uma densidade sem paralelo em outra região da colônia.

Prado Júnior afirma que no princípio a produção de couro era o comércio principal e que a carne ficava desprezada, pois a parca população sulista não dava conta de consumir a produção. O autor, então, atribui ao xarque e às xarqueadas ${ }^{5}$ o "organizador" do caos criado pela produção do couro (pois as sobras de carnes eram imensas). Somada à decadência da pecuária nos sertões do nordeste, esta indústria acaba tendo um papel relevante na economia brasileira. Sobre as localidades de maior relevância, alvo desta pesquisa bibliográfica, o autor discorre o seguinte: "a indústria do xarque 6 , as "xarqueadas, localizam-se num ponto ideal: entre os rios Pelotas e S. Gonçalo, nas proximidades ao mesmo tempo dos grandes centros criatórios da “fronteira”..." (PRADO JR., 1945: 105, 106)

Outra obra consultada foi Formação do Brasil Contemporâneo - Colônia, do mesmo autor. Neste livro, Caio Prado Júnior discorre sobre a pecuária dividindo-a em zonas e fases,

\footnotetext{
${ }_{6}^{5}$ Manteve-se a grafia original do autor da palavra charque com $x$.

${ }^{6}$ Idem ao anterior.
} 
e, em alguns momentos, trechos semelhantes ao da obra anterior são apresentados ao leitor. No início do capítulo, o autor descreve a pecuária em um plano geral, começando pelo norte do país, por ser a zona mais antiga. Neste panorama Prado Júnior não fala sobre o charque e sim sobre o gado em pé. O autor trata do quanto a criação de gado auxiliou no abastecimento populacional da zona litorânea e mineradora, passando a relatar o funcionamento das fazendas criatórias, desde o aproveitamento do gado (para produção de leite, sebo, carne verde etc), como a organização de vigilância das fazendas e marcação das rezes.

Depois de longa descrição sobre a criação de gado, o autor discorre sobre a carne seca, que, segundo ele, veio para "obviar o problema do transporte nas distâncias", colocando o Ceará no centro de fornecimento deste bem de consumo/exportação. Prado Júnior afirma que a prosperidade da carne seca ou carne-do-ceará se mantém nesta zona até fins do século XVIII, e que a chamada Seca Grande (estiagem no Nordeste que durou de 1771 a 1773), acabou transferindo a função de abastecedouro para o Rio Grande do Sul. Seguindo a linha adotada, o autor passa a descrever a denominada segunda zona pecuária colonial, situando-a em Minas Gerais. Ele afirma que esta zona foi grandemente favorecida pela vegetação e pela abundância de água. Prado Júnior também descreve os hábitos dos criadores destes locais, afirmando que neste caso o leite passava a ser muito aproveitado e que a alimentação dada ao gado era mais bem cuidada. Durante toda a descrição desta zona pecuária não se tratou e nem se citou uma só vez algo sobre o charque.

Por fim, sobre a terceira zona pecuária, foco desta pesquisa, o autor acaba por dividí-la em duas partes: as dos Campos Gerais ou de Curitiba, que segundo, o autor inicia abastecendo o Rio de Janeiro e São Paulo e as do Extremo Sul.

As fazendas dos Campos Gerais, - "fazendas" e não "estâncias", como no Sul, que adotou a designação castelhana, - são grandes; mas longe das do Rio Grande.... ...Alíás como notei, não tem esta região a importância da do sul. A indústria da carne-sêca é inexistente ${ }^{7}$, e para o gado em pé, os únicos mercados regulares são o litoral paranaense (Paranaguá), de expressão ínfima, e São Paulo, também pouco vulto. (PRADO JÚNIOR, 1965:205).

A partir desta citação e também por não ter encontrado em nenhuma obra, alguma referência ou ligação dos Campos Gerais com a indústria do charque, optou-se por excluir o estado do Paraná nas pesquisas documentais. Sobre pecuária na região do extremo sul, o autor cita e repete as mesmas expressões usadas na obra anterior, confirma os mesmos dados históricos e reafirma Pelotas como o núcleo das charqueadas.

\footnotetext{
${ }^{7}$ Grifo nosso.
} 
A pesquisa bibliográfica trata agora de uma obra que mostrou-se peculiar, por ser bastante diferenciada das outras obras estudadas. O autor Ernesto Antônio Lassance Cunha O Rio Grande do Sul - contribuição para o estudo de suas condições econômicas - divide a obra em dois momentos. Primeiro, o autor apresenta informações gerais do Rio Grande do Sul sobre o clima, localização geográfica, indústria, fauna, riquezas naturais, mercados, comércio, estado sanitário etc. Em um segundo momento, que julgou-se bastante elucidativo, autor cita uma grande quantidade de municípios gaúchos, fornecendo dados específicos pertencentes a cada uma das cidades detalhadas. Neste capítulo fez-se uma seleção de alguns municípios citados pelo autor, sendo esta feita buscando como critério a presença do charque como produto produzido. Sendo a obra impressa em 1908, salienta-se que as informações apontadas por Cunha são dados econômicos e sociais do início do século XX.

Pelotas: Segundo Cunha, a indústria pelotense dominante é a fabril, abrangendo as charqueadas $^{8}$ e as fábricas de produtos bovinos. Ele classifica como próspera as atividades da indústria saladeril e afirma que nelas são empregados processos modernos de zootecnia. Bagé vem a seguir como município fornecedor de gado para Pelotas, sendo a maior parte utilizada nos abatedouros das charqueadas. Através deste dado, o autor dá indícios de que estes estabelecimentos ainda estavam em franca atividade no início do século XX. Arroio Grande também aparece como município criador e fornecedor de gado para a cidade de Pelotas e Jaguarão. O autor também afirma que Arroio Grande é exportador de gado para os saladeiros da cidade de Quarahy ${ }^{9}$, Barra do Quarahy ${ }^{10}$ e a cidade de Sant'Anna do Livramento ${ }^{11}$. Quarahy é o município que ganha destaque sobre o charque. Cunha afirma que graças à indústria pastoril e um saladeiro (nome dado a uma charqueada) preparado segundo o sistema platino - estabelecimento bem montado, com processos aperfeiçoados e empregando cerca de 400 operários hábeis - esta cidade encontra-se em um elevado "grau de adiantamento". Em seguida, o autor cita cidades como São Gabriel, São Borja e Itaquy ${ }^{12}$ como importantes criadoras e distribuidoras de gado para outros municípios charqueadores.

A obra do historiador Sérgio Buarque de Holanda também foi consultada. História Geral da Civilização Brasileira - I A Época Colonial 2 Administração, Economia, Sociedade acaba por repetir os dados dos outros autores estudados, porém reforça a importância da indústria do charque na região sul. No capítulo IV, intitulado As Áreas de Criação de Gado, o

\footnotetext{
${ }^{8}$ Cunha utiliza o $x$ na ortografia da lexia charque e charqueada.

${ }^{9}$ Atualmente adota a ortografia: Quaraí.

${ }^{10}$ Atualmente adota a ortografia: Barra do Quaraí

${ }^{11}$ Atualmente adota a ortografia: Santana do Livramento.

${ }^{12}$ Atualmente adota a ortografia Itaqui.
} 
autor afirma que, com o estabelecimento das primeiras charqueadas, o extremo sul do país passa a ter importância no abastecimento da população brasileira. Buarque de Holanda afirma que no final do século XVIII a carne-sêca do Nordeste perde a primazia para o Rio Grande do Sul, favorecido pela vegetação, clima, relevo, dentre outros fatores. O autor condiciona à indústria do charque o papel de organizador da criação de gado sulista, antes criado quase de forma semi-selvagem. Este também cita o Arroio Pelotas e o Rio São Gonçalo como municípios importantes no desenvolvimento do produto e apresenta a informação sobre o português vindo do Ceará - José Pinto Martins ${ }^{13}$.

Em seguida, este autor descreve como simples a instalação de uma charqueada. Segundo ele, esta era composta somente por um galpão onde se preparava e salgava a carne e um secador para ser secar a carne ao ar livre. Sobre este bem de consumo e exportação, o autor encerra a explanação citando outros produtos aproveitados nas charqueadas, como o sebo, chifres, crina e reafirma a importância do charque na alimentação dos escravos.

A obra de Afonso Arinos de Melo Franco, Síntese de História Econômica do Brasil, critica, por sua vez, os historiadores e escritores por não darem à criação de gado a devida importância econômica e influenciadora de nossa civilização. Contudo, o próprio autor discorre brevemente sobre o gado, o couro, os vaqueiros, os gaúchos, em como foi introduzido o gado no sul do país, e, em nenhum momento, trata do charque e das charqueadas.

Encerra-se essa parte da pesquisa com a bibliografia de Souza Docca - História do Rio Grade do Sul. A obra apresenta um breve comentário acerca do charque, considera José Pinto Martins fundador da indústria do charque no Rio Grande do Sul, reafirma o Arroio Pelotas como o principal lugar de acontecimento das charqueadas e, diferentemente dos outros autores, apresenta os municípios de São Jerônimo e Jaguarão como importantes localidades produtoras de charque.

Ao término dessa revisão bibliográfica, observa-se que esse estudo foi importante não só para estabelecer as regiões escolhidas para a busca e seleção do material escrito, como também para excluir outras, como foi o caso do Estado do Paraná.

\footnotetext{
${ }^{13}$ Inúmeros autores afirmam que José Pinto Martins foi o grande introdutor das charqueadas no sul. Alguns citam-o como o cearense José Pinto Martins e outros afirmam que era português o primeiro charqueador gaúcho.
} 


\subsection{A busca dos documentos}

Este subcapítulo, que trata da composição e apresentação do corpus, pretende revelar as etapas cumpridas no processo de compilação dos documentos que fazem parte do corpus do trabalho, a partir da pesquisa bibliográfica apresentada anteriormente.

No decurso da revisão bibliográfica, evidenciou-se que a cidade de Pelotas é considerada a principal localidade charqueadora do Rio Grande do Sul. Essa cidade, localizada às margens do Canal de São Gonçalo e que liga as lagoas dos Patos e Mirim, a 250 $\mathrm{km}$ de Porto Alegre, foi o núcleo das charqueadas e, portanto, escolhida como a primeira cidade a ser visitada.

Durante a estada na cidade de Pelotas, visitou-se o Museu da Baronesa, construído em 1863, época em que a cidade viveu o apogeu do do Ciclo do Charque. Este museu, porém, serviu somente como vitrine para contextualizar a vida dos habitantes pelotenses da época, pois não havia no local nenhuma documentação escrita.

O Museu Histórico e Bibliográfico da Biblioteca Pública Pelotense, localizado na praça central da cidade, foi o segundo lugar pesquisado. Na biblioteca do museu histórico, foram selecionadas algumas obras, posteriormente utilizadas tanto para a construção do corpus como para o capítulo sociohistórico. A documentação manuscrita nessa biblioteca, contudo, é bastante limitada. Na época em que a visita ocorreu, o museu passava por uma reforma e os documentos manuscritos estavam ainda sendo organizados e catalogados por estudantes pelotenses da faculdade de História. Em conversa com funcionários do museu e da biblioteca apurou-se que a documentação pertinente à época das charqueadas encontra-se, em sua maioria, nos arquivos públicos na cidade de Porto Alegre, restando pouco material na cidade de Pelotas. Outro dado levantado é que a maioria dos estudiosos e historiadores das charqueadas corresponde a filhos, netos e bisnetos de charqueadores, e muitos deles utilizamse de relatos orais ou de documentação privada em suas pesquisas.

Sendo assim, poucos documentos manuscritos foram fotografados e somente alguns documentos de jornais do século XVIII e XIX foram pesquisados. Mesmo tendo conhecimento da falta de documentação escrita nas charqueadas, decidiu-se por visitar algumas destas propriedades. Estes estabelecimentos encontram-se, hoje em dia, desativados servindo como lugares pitorescos, salões para festas ou como pontos históricos. O próprio Museu do Charque, instalado junto à Charqueada Santa Rita, à beira do Arroio Pelotas, é prova de que não há, na cidade, um local que reúna a documentação manuscrita ou impressa do período conhecido como Ciclo do Charque. 
Uma vez que a documentação pelotense, assim como também de quase todo estado do Rio Grande do Sul, encontra-se arquivada na cidade de Porto Alegre, duas viagens foram realizadas até este município a fim de selecionar e editar facsimilarmente alguns documentos do corpus. Em ambas as visitas ao Arquivo Público do Estado do Rio Grande do Sul, foram selecionados, principalmente, inventários de charqueadores pelotenses.

Embora nenhuma cidade catarinense tenha sido mencionada durante a pesquisa bibliográfica, foi realizada, no Arquivo Público do Estado de Santa Catarina, localizado em Florianópolis, uma busca de documentos manuscritos e impressos que tivessem o charque como tema central. A decisão da procura de documentação catarinense foi exposta na justificativa do capítulo introdutório. Outra razão que influenciou na busca de documentação em Santa Catarina é que, nos estudos de mestrado, comprovou-se que no período colonial brasileiro, as correspondências expedidas entre as capitanias do sul do Brasil e a cidadecapital se entrelaçavam, fazendo com que assuntos comuns tratados na Capitania do Rio Grande, como gado, salga de carne etc, permeiem a documentação catarinense, dada a sua localização geográfica, dentre outros fatores.

Além dos documentos selecionados nos arquivos e bibliotecas, também utilizou-se, na composição do corpus, de uma série de reportagens extraída do Jornal Diário Popular, da cidade de Pelotas, em 2007. Durante 3 dias, o jornal discorreu sobre a história do município, em comemoração ao $195^{\circ}$ aniversário da cidade. Divididas em três partes: Parte 1 - Os Pioneiros, Parte 2 - Os Senhores do Rio Grande, Parte 3 - Do Sal ao Ouro, esta matéria jornalística, que buscou resgatar vários episódios da história durante o Ciclo do Charque, acabou proporcionando ao corpus a modernidade documental pretendida, que buscava não só a seleção de documentos antigos (séculos XVIII e XIX), mas também modernos (séculos XX e XXI).

Durante a busca de documentos para compor o corpus da pesquisa, realizou-se, em paralelo, um estudo em obras que tivessem o charque como assunto principal. Essas leituras tinham como objetivo enriquecer os conhecimentos sobre o charque, seu modo de preparo, tipos, comercialização etc, facilitando o entendimento dos assuntos tratados na documentação selecionada. Obras como A Erva Mate e o Charque, de Louis Couty; A Economia do Charque, de Alvarino da Fontoura Marques Marques; "Xarqueadas" de Danúbio Golçalves: um resgate para história, de José Antônio Mazza Leite e Viagem ao Rio Grande do Sul de Auguste de Saint-Hilaire, por apresentarem detalhadamente as etapas de preparação, os usos, a comercialização, o cotidiano, dentre outras questões relativas ao charque, acabaram sendo 
selecionadas e, após um recorte dos pontos relevantes sobre o assunto, foram incluídas no corpus do trabalho, a saber:

A obra de Alvarino da Fontoura Marques (1992) - A Economia do Charque, O charque nas artes, Culinária do charque ${ }^{14}$ - faz parte de uma trilogia editorial, escrita pelo autor, sobre o charque produzido no Rio Grande do Sul. Esta obra, além de apresentar ao leitor aspectos históricos e econômicos relevantes sobre a produção e comercialização deste produto, revela peculiaridades do charque e sua relação com a culinária, as artes plásticas, a literatura etc.

A segunda obra selecionada tem como título: "Xarqueadas" de Danúbio Golçalves: um resgate para história, de José Antônio Mazza Leite (2006). Esta obra é fruto de um trabalho de pós-graduação do autor que, somado ao seu trabalho como historiador, diretor e co-fundador do Museu do Charque, apresenta um livro centrado em seus estudos sóciohistóricos e culturais sobre o charque. Para o corpus deste trabalho, foi selecionada desta obra, uma carta escrita pelo Senhor Antenor Peixoto de Castro, que chegou às mãos de Mazza Leite através da Professora Heloísa A. Nascimento (IHGPel). Este texto relata detalhes da vida cotidiana de uma charqueada na década de 40 , sob o ponto de vista de Castro, filho de um ex administrador de charqueada. Como não foi possível cotejar a edição apresentada por Mazza Leite com o documento original, este trabalho apóia-se na transcrição apresentados por ele.

A obra - Viagem ao Rio Grande do Sul (1999) do botânico francês Auguste de SaintHilaire foi outra literatura selecionada para esta etapa da pesquisa. Trata-se de um diário de bordo em que os lugares visitados por Saint-Hilaire são apresentados com riqueza de detalhes. As apreciações feitas pelo botânico ultrapassam esta ciência, alcançando observações sobre topônimos, geografia, costumes, cultura em geral, até mesmo a língua, foco deste trabalho. Em alguns momentos, o autor menciona as quantidades de carne exportadas pelo estado gaúcho, chama a atenção para os hábitos carnívoros de seus habitantes, atribuindo-lhes a condição de pessoas frias no trato com a morte e sangue. $\mathrm{O}$ autor discorre sobre o sistema escravagista na indústria saladeril, compara as condições de vida dos escravos no Rio Grande do Sul e Rio de Janeiro, constando que a necessidade de mão-de-obra na indústria do charque era menor do que a dos engenhos e da mineração.

A obra de Louis Couty (2000) - A Erva Mate e o Charque (Le Mate et les Conserves de Viandes) encerra a composição do corpus. Esta obra é fruto de um relatório encomendado

\footnotetext{
${ }^{14}$ A bibliográfica completa das obras estão nas Referências bibliográficas ao final do trabalho.
} 
pelo Ministro da Agricultura e do Comércio francês, datado de 1880, sobre a missão de Couty nos estados do sul do Brasil. Segundo o autor, em sua nota introdutória ao Sr. Ministro, tanto o mate quanto o charque são alimentos pouco conhecidos na Europa e em outros países, mas podem ser considerados como base de uma alimentação sadia e abundante. Sobre o mercado e produção do charque, Couty observa que os processos permanecem estacionários há algum tempo e, por isso, o autor insiste nos estudos sobre o funcionamento das charqueadas. $\mathrm{O}$ modo de descrição, o processo de armazenamento, transporte, comercialização feito por Couty apresentam um caráter científico. $\mathrm{O}$ autor utiliza-se do modo comparativo entre a produção do charque em Pelotas e o na região do Rio da Prata. Para o corpus do trabalho, partes da narrativa de Couty foram descartadas dadas a extensão e nível de detalhamento do autor. Por esta razão, alguns trechos em que o autor discorre sobre o couro, e/ou outras diversas partes do boi, como chifres, ossos, línguas, vísceras, foram excluídas.

\subsection{A composição do corpus}

Após as observações feitas sobre o conjunto de documentos selecionado para a pesquisa, lista-se, a seguir, dados sobre os documentos que compõem o corpus.

\subsubsection{Santa Catarina - Florianópolis}

Arquivo Público do Estado de Santa Catarina:

Os documentos 1, 2, 3 e 4 encontram-se sob registro número 15.375, data: 20/07/1981 - Leis Fpolis 1896/1901 - Codigo de Posturas da Camara Municipal da Cidade do Desterro, Capital da Provincia de Santa Catharina, 1889.

Documento 5 e 6 apresentam a data de 1816.

O documento 7 encontra-se sob registro número 19.865, data: 25/05/1983 - Ofícios Pres. P. (SC) Pres. P. (D) 1827/1831, datado em 1828.

Os documentos $8,8 \mathrm{v}^{15}, 9,9 \mathrm{v}, 10 \mathrm{v}, 11,11 \mathrm{v}, 12,12 \mathrm{v}, 13,13 \mathrm{v}, 14,15$ e $15 \mathrm{v}$ estão sob registro número 16.443, data: 19/08/1981 - F.C.F. HG. - Ofícios do Vice-Rei para o Governador da Capitania 1793/98.

\subsubsection{Rio Grande do Sul - Pelotas}

Biblioteca Pública Pelotense:

A documentação da cidade de Pelotas não apresenta catalogação.

\footnotetext{
${ }^{15} \mathrm{~V}$. verso do documento a que corresponde.
} 
Os documentos pelotenses sem registro referem-se aos de número 16 e 17 não apresentam registro de data.

O documento 18 datado em 1845, número 19 datado 1944 e o documento número 20 apresenta a data 1854 .

Dos documentos 21 a 25 a data que se referem é 1927. Doc 26, 1851, doc 27, 1878. Documentos de número 28 a 32 do Jornal Diário de Pelotas, datado em 1869. Documento 33 datado em 1878.

Jornal Diário de Pelotas:

Os documentos facsimilados do Jornal Diário Popular, data: 05/07/2007 a 07/07/2007, referem-se aos documentos de número 34 ao 48.

\subsubsection{Rio Grande do Sul - Porto Alegre}

Arquivo Público do Rio Grande do Sul:

Documentos de número 49, 50 e 51, encontram-se sob os autos número 2, maço número 1 , estante número 28, data: ano de 1870 - Pelotas. $2^{\circ}$ cartório, Orphãos e Ausentes.

O documento número 52 e 53, localiza-se na série Jornais, Jornal do Commercio data: 20/09/1872 número 221.

Os documentos número 54, 55 e 56. Autos número 68, maço número 2, estante número 30, data: ano de 1871 - Pelotas. $1^{\text {o. }}$ cartório, Civel e Crime Inventário,

Autos número 727, maço número 44, estante número 25, data: ano de 1870 - Pelotas. $1^{\text {o. }}$ cartório, Orphãos e Provedoria Inventário, referem-se aos documentos 57, 58 e 59.

Documentos número 60,61 e 63 datados em 1883.

Autos número 775, maço número 46, Estante número 25, data: ano de 1873 - Pelotas. $1^{\text {o. }}$ cartório, Orphãos e Provedoria Inventario, referem-se aos documentos de número 62, 64 e 65.

\subsubsection{As obras do corpus}

Estes documentos foram selecionados a partir da reprodução parcial de trechos de obras. Nesse capítulo estão somente citados os autores dos documentos.

A Economia do Charque, de Alvarino da Fontoura Marques, edição de 1992. Não consta na obra, referencia da datação dos documentos editados. Refere-se ao documento de número 66 ao documento 82 .

A Erva Mate e o Charque, de Louis Couty. Edição de 2000, apresenta referência da datação dos documentos, a dizer, 1880. Refere-se ao documento de número 83 até o documento 105. 
“Xarqueadas" de Danúbio Golçalves: um resgate para história, de José Antônio Mazza Leite. Edição de 2009, consta a data da composição do documento - 1988. Refere-se ao documento de número 106 até o documento 125.

Viagem ao Rio Grande do Sul de Auguste de Saint-Hilaire. Edição de 1999, consta a datação datação dos documentos, em um período compreendido entre os anos 1820 a 1821. Refere-se ao documento de número 126 até o documento 138.

\subsection{A edição do corpus}

\subsubsection{A metodologia empregada}

Após a busca e seleção dos documentos, que são a base do estudo lexicográfico, o corpus formado para esta pesquisa apresentou-se variações não só tipológicas, como também de suporte. Os documentos variam diacronicamente, abrangendo os séculos XVIII, XIX, XX e XXI.

Durante a seleção desse material, não só buscava-se uma quantidade de documentos que apresentasse um número satisfatório de lexias relacionadas ao vocabulário do charque, como também almejava-se uma variedade documental, que necessitasse de trabalho filológico de edição. Com este corpus, esses propósitos tiveram êxito, e o conjunto de 138 documentos serviram, não só para estudar aspectos do léxico, como também aspectos sócio-históricos e culturais relacionados à produção, consumo e comercialização do charque.

Tendo em vista os objetivos de seleção e análise propostos na pesquisa, a edição do corpus priorizou: apresentar o corpus selecionado em sua totalidade, de modo que o leitor possa consultar o léxico estudado; exibir o trecho que compõe as abonações indicadas no glossário elaborado; reduzir o grau de interferência nos textos dos documentos; facilitar a leitura diminuindo as dificuldades paleográficas; transmitir confiabilidade através do que foi escrito originalmente e, por fim, possibilitar o cotejo da transcrição com os facsímiles dos documentos.

Para atingir esses objetivos, optou-se por empregar, nesta pesquisa, dois tipos de edição. A primeira delas é a chamada edição mecânica ou facsimilar, caracterizada por conceder ao trabalho a mais fiel das edições, ou seja, não há mediação entre o editor e o documento. A edição facsimilar pode ser feita a partir de várias técnicas, como a microfilmagem, a fotocópia etc. Uma vez que os arquivos e locais pesquisados não disponibilizam da técnica do microfilme, optou-se pelo uso da fotografia. No caso dos 
documentos particulares, como por exemplo, as reportagens do Jornal Diário de Pelotas, optou-se pelo uso do scanner.

Porém, de acordo com Cambraia (2005:91,92), este tipo de edição "tem a desvantagem de poder ser consultada apenas por especialistas, porque pressupõe a capacidade de se ler um texto na escrita original”. Portanto, decidiu-se não só apresentar a edição facsimilar dos 138 documentos do corpus, como também realizar a edição semidiplomática nos documentos manuscritos. Esse segundo tipo de edição tem como característica fundamental eliminar as dificuldades paleográficas através do desenvolvimento de abreviaturas e inserção de palavras ou letras. Outra característica da edição semidiplomática é apresentar um grau de interferência médio, preservando a ortografia, a pontuação dos textos, e a sintaxe, fundamental em estudos diacrônicos em lexicografia.

A edição do corpus da pesquisa tem como base as "Normas para Transcrição de Documentos Manuscritos para a História do Português do Brasil", propostas durante o II Seminário para a História do Português Brasileiro, de 1998. Tendo em vista o objetivo principal da edição que é a seleção lexical do vocabulário do charque, alguns critérios, como fronteiras de palavras, dentre outras, foram modificados.

\subsubsection{Normas adotadas na transcrição}

1. A transcrição é conservadora.

2. As abreviaturas, alfabéticas ou não, são desenvolvidas, obedecendo aos seguintes critérios:

a. Respeitar, sempre que possível, a grafia do manuscrito, ainda que manifeste idiossincrasias ortográficas do escriba, como no caso da ocorrência "munto", que leva a abreviatura "m.to." a ser transcrita como "munto"; e

b. No caso de variação no próprio manuscrito ou em coetâneos, a opção é para a forma atual ou mais próxima da atual, como no caso de ocorrências "Deos" e "Deus", que levam a abreviatura "D.s" a ser transcrita como "Deus".

3. É estabelecida a fronteira de palavras que venham escritas juntas. Não se introduz hífen ou apóstrofo onde não houver.

4. A pontuação original é rigorosamente mantida.

5. A acentuação original é rigorosamente mantida, não se permitindo qualquer alteração. Exemplos: "saude"; "sómente"; "algũas"; "Iose de Mattos"; “obzequialo"; “divida”; "obrigadissimo"; "hé seo".

6. Será respeitado o emprego de maiúsculas e minúsculas como se apresentam no 
original.

7. Espaçamento além do marcado em início de parágrafo não é considerado.

8. Eventuais erros do escriba ou do copista são remetidos para nota de rodapé, onde se deixa registrada a lição por sua respectiva correção. Exemplo: "nota 1. "Seriço" por Serviço"; "nota 2. "pestar-lhe" por "prestar-lhe".

9. Inserções do escriba ou do copista na entrelinha ou nas margens superior entram na edição entre os sinais <>, na localização indicada. Exemplo: < Copia >.

10. Supressões feitas pelo escriba ou copista no original são tachadas.

11. Intervenções de terceiros no documento original são desconsideradas.

12. Intervenções do editor são raríssimas, permitindo-se apenas em caso de extrema necessidade, desde que elucidativas a ponto de não deixarem margem a dúvida.

13. Letra ou palavra não legível por deterioração justifica intervenção do editor com a indicação entre colchetes: [ilegível].

14. Trecho de maior extensão não legível por deteriorização receberá a indicação [corroídas + 5 linhas]. Se for o caso de trecho riscado, cortado ou inteiramente anulado por borrão ou papel colado em cima, registra-se a informação pertinente entre colchetes.

15. A transcrição é justalinear.

16. As assinaturas simples ou as rubricas não são sublinhadas. Os arabescos ou adornos do início ou final de assinatura são omitidos.

17. As datas cronológicas ou assinaturas sublinhadas no manuscrito não serão apontadas.

18. As transcrições são apresentadas sem um padrão fixo de espaçamento, sendo este alterado de modo que cada um dos textos editados procure caber em uma página do trabalho.

\subsubsection{Edição dos documentos selecionados}

Como foi dito anteriormente, somente os documentos manuscritos submetem-se à edição semidiplomática, sendo, os demais documentos apenas facsimilados. Por motivo de impressão, alguns documentos facsimilados aparecem no sentido vertical. Acima do facsímile ou da edição dos documentos, no canto superior esquerdo da página, encontram-se: o número correspondente ao documento, o ano em que o foi escrito e, entre parênteses, o local ou obra a que pertence. Os documentos que apresentarem uma parte impressa e outra manuscrita no corpo do texto são editados, semidiplomaticamente, na íntegra. 
A numeração dada aos documentos não segue uma ordem cronológica. Optou-se por agrupar os documentos de acordo com o local onde foram encontrados, e, dentro de cada conjunto, enumerá-los conforme foram sendo selecionados e incluídos no corpus do trabalho. 
Doc 1 - 1896/1901 (Arquivo Público do Estado de Santa Catarina - Florianópolis)

goto a agua servida.

Artigo 65.-O infractor ou infractores de qualquer las dísposições dos artigos 63 e seus paragraphos e du artigo 6 / soffrerîo a multa de $5 \$ 000$ á $12 \$ 000$ réis.

\section{TITUIO $4^{\circ}$ \\ CAPTIUIO I \\ Matança de gado}

Artigo 66.- Sómente nos lugares designados pela Camára serà permittida a matança e esquartejamento do gado para con. sumo publico, assistindo a ella um medico commissionado pela Camara.

Artigo 67.--A matança do gado serà feita regularmente das 2 horas ás 4 horas da tarde no inverno, e das 3 ás 5 no ve. rãn, Єxcepto em èpocas reconhecidamente anormaes, em que se poderà mudar este horario, segundo fôr determinado pela Camara.

Artigo 68.-E' prohibido:

$\S 10^{\circ}$-Matar gado magrissimo, doente, cançado, ou estropeado; bem como esquartejar o que fôr encontrado morto.

§ 2. - Empregar o machado na matança do gailo. O gado que depois de morto fôr reconbecido como doente será logo enterrado por seu dono ou a custa deste.

Artigo 69.-O infractor ou infractores do disposto em qualquer dos artigos 66 a 69 e seus paragraphos soffrerà a multa de $5 \$ 000$ á $8 \$ 000$ rèis. 


\section{Açougues}

Artigo 70.-Os magarefes sãn obrigailns a conservarem sempre em estado de asseio os balcões, balanças, pesos e todos utencilios empregaros no córte e venda da carne; bem como a varrer, lavar os açougues tolos os diás depois de finda a venda.

Artigo 71. - As carnes verdes serão conduzidas do matadouro para os açougues cobertas de panno de brim limpo.

Artigo 72.- Os cortadores de carne nos açougues usarão de camisa de manga curta e avental de panno branco, de 70 certimetros de comprimento, sempre limpos.

Artigo 73.- Os açougueiros são obrigados a vender no ninimo até 500 gramas de carne.

Artigo 74,-E' prohibido:

$\$ 10^{\circ}-$ Receber carne nos açotigues do mercato depois das 6 horas da tarde, salvo caso de força maior. verão.

$\S 2 .{ }^{n}-$ Vender carne depois das tres horas da tarle, no

$\$ 3 .^{\circ}-$ Vender carne alterada ou em máo estado.

$\$ 40^{\circ}$-Conservar a carne sem ser pendurada nos ganchos para isso destinados.

$\S 5 .^{\circ}$ - Talhar carne sobre cepos ou quaesquer objectos que ño seja a banca. seja o serrute.

$\$ 60^{\circ}$ - Cortar os ossos com outro instrumento que não

$\$ 7^{\circ}$-Comprar, vender ou depositar nos açuugues qualquer generc alem da carne verde, ou salgar esta nos açougues.

$8 .^{\circ}$-Conservar-se o açotugueiro do lado de fora do balcão durante a venda da carne.

$\$ 9$. - Fazer alarido, proferir ou praticar actos, gestos e termos deshonestos.

Artigo 75-0 infractor ou infractores de algumà das disposições contidas nos artigos 70 á 74 e seus paragraphos, soffirerão a multa de $5 \$ 000$ á $8 \$ 000$ réis. 


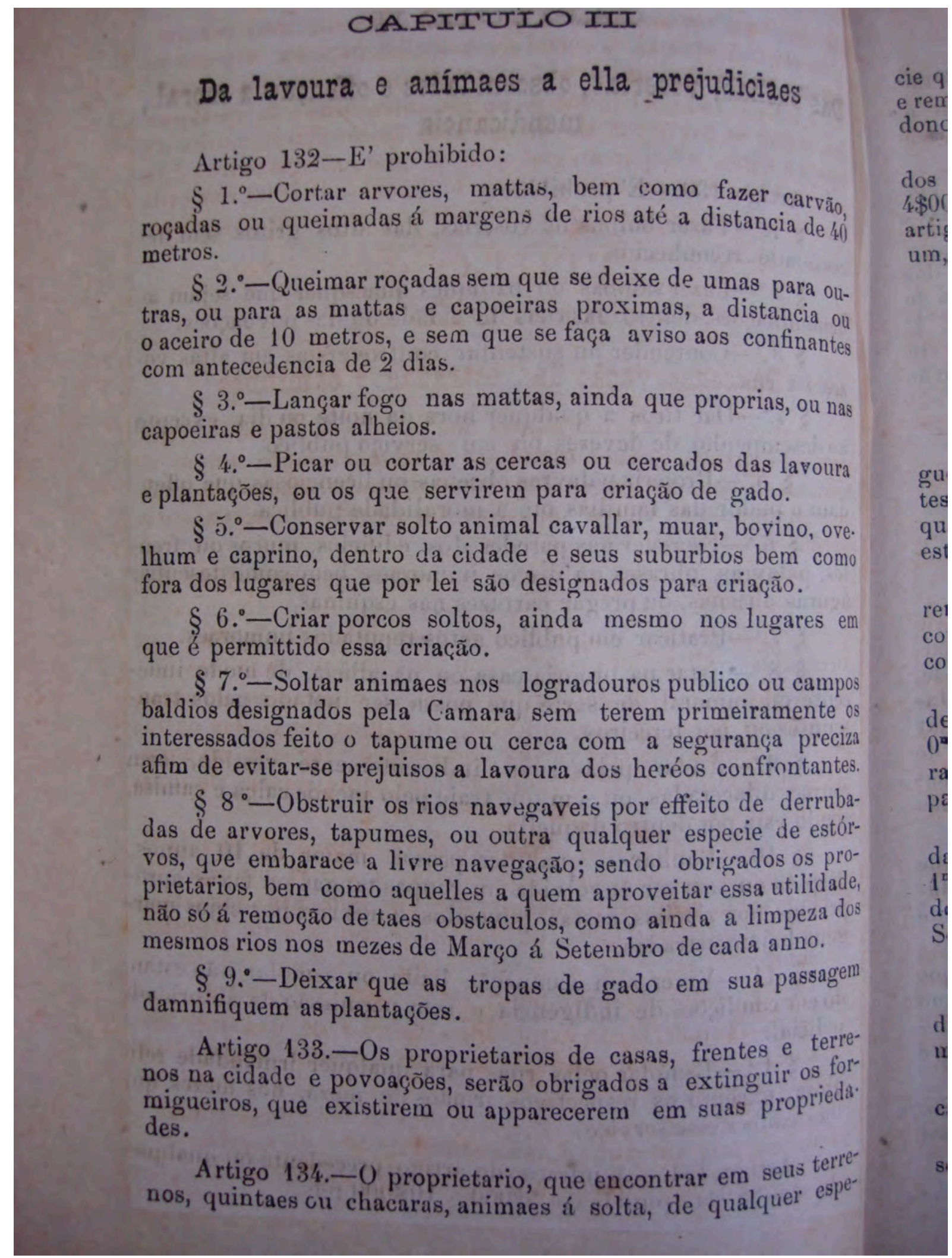


Doc 4 - 1896/1901 (Arquivo Público do Estado de Santa Catarina - Florianópolis)

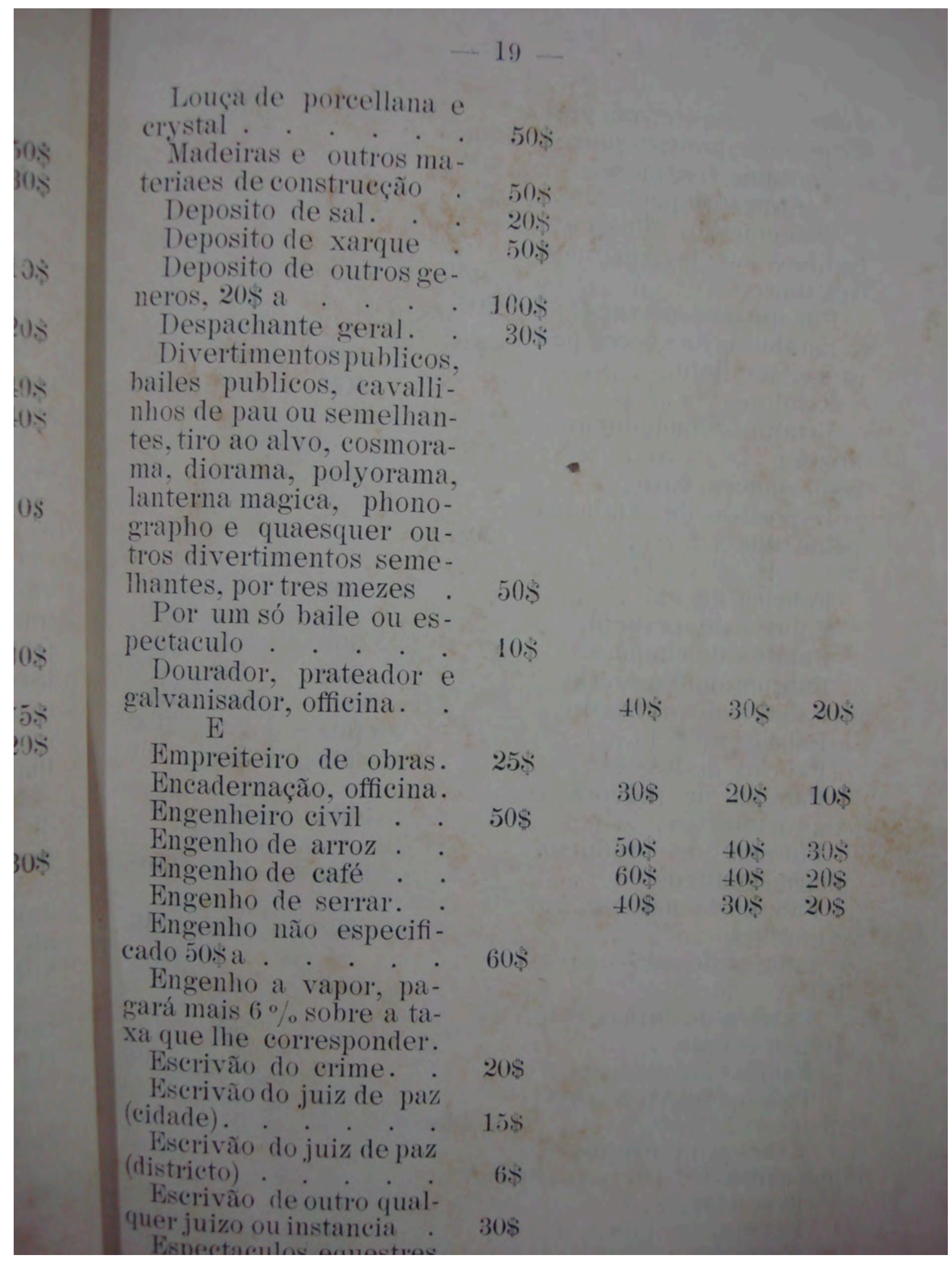


Doc 5 - 1896/1901 (Arquivo Público do Estado de Santa Catarina - Florianópolis)

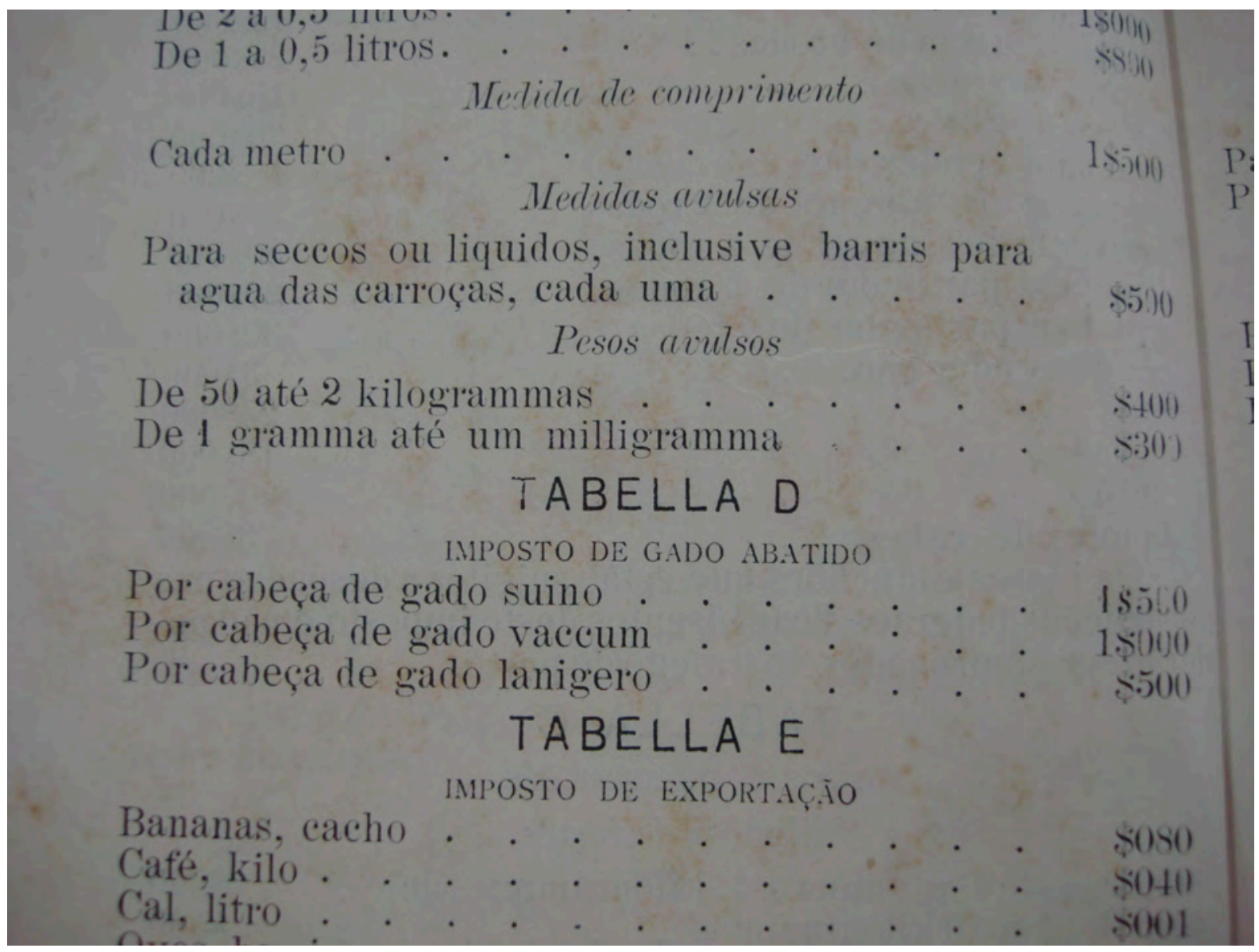


Doc 6 - 1816 (Arquivo Público do Estado de Santa Catarina - Florianópolis)

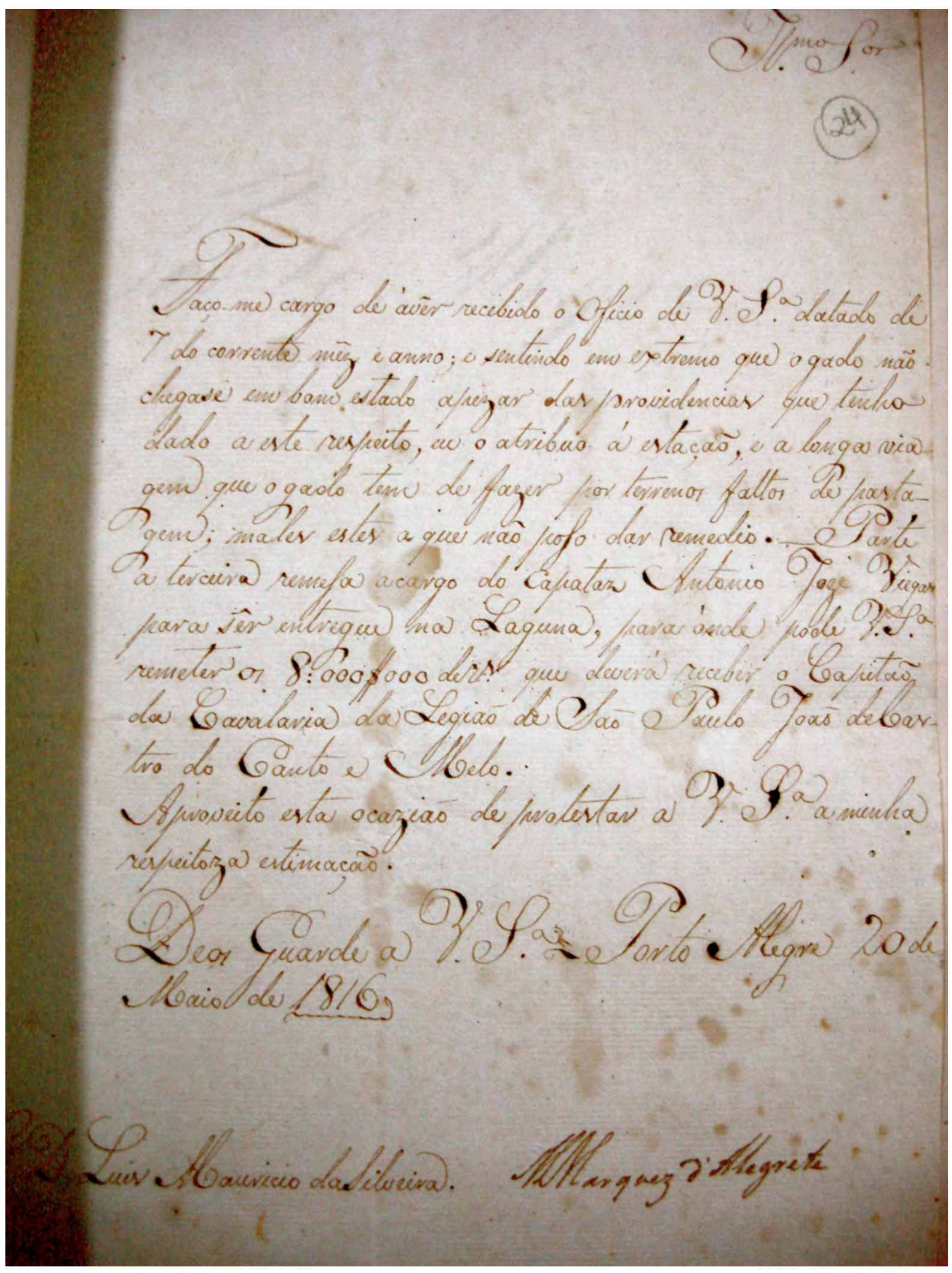


Edição doc 06 - 1816 (Arquivo Público do Estado de Santa Catarina - Florianópolis)

Ilustríssimo Senhor

Faço-me cargo de avêr recebido o Ofício de Vossa Senhoria datado de 7 do corrente mêz e anno; e sentindo em extremo que o gado não chegase em bom estado apezar das providencias que tenha dado a este respeito, eu o atribuo á estação, e a longa viagem que o gado tem de fazer por terrenos faltos de pasta gem; males estes a que não posso dar remedio. Parte a terceira remessa a cargo do Capataz Antonio Joze Viegas para sêr entregue na Laguna, para onde pode Vossa Senhoria remeter os 8:000 \$000 de reis que deverá receber o Capitão da Cavalaria da Legião de São Paulo João de Castro do Couto e Melo.

Aproveito esta ocazião de protestar a Vossa Senhoria a minha respeitoza estimação.

Deos Guarde a Vossa Senhoria Porto Alegre 20 de Maio de 1816

Dom Luis Mauricio da Silveira. Marquez d'Alegrete 
Doc 7 - 1828 (Arquivo Público do Estado de Santa Catarina - Florianópolis)

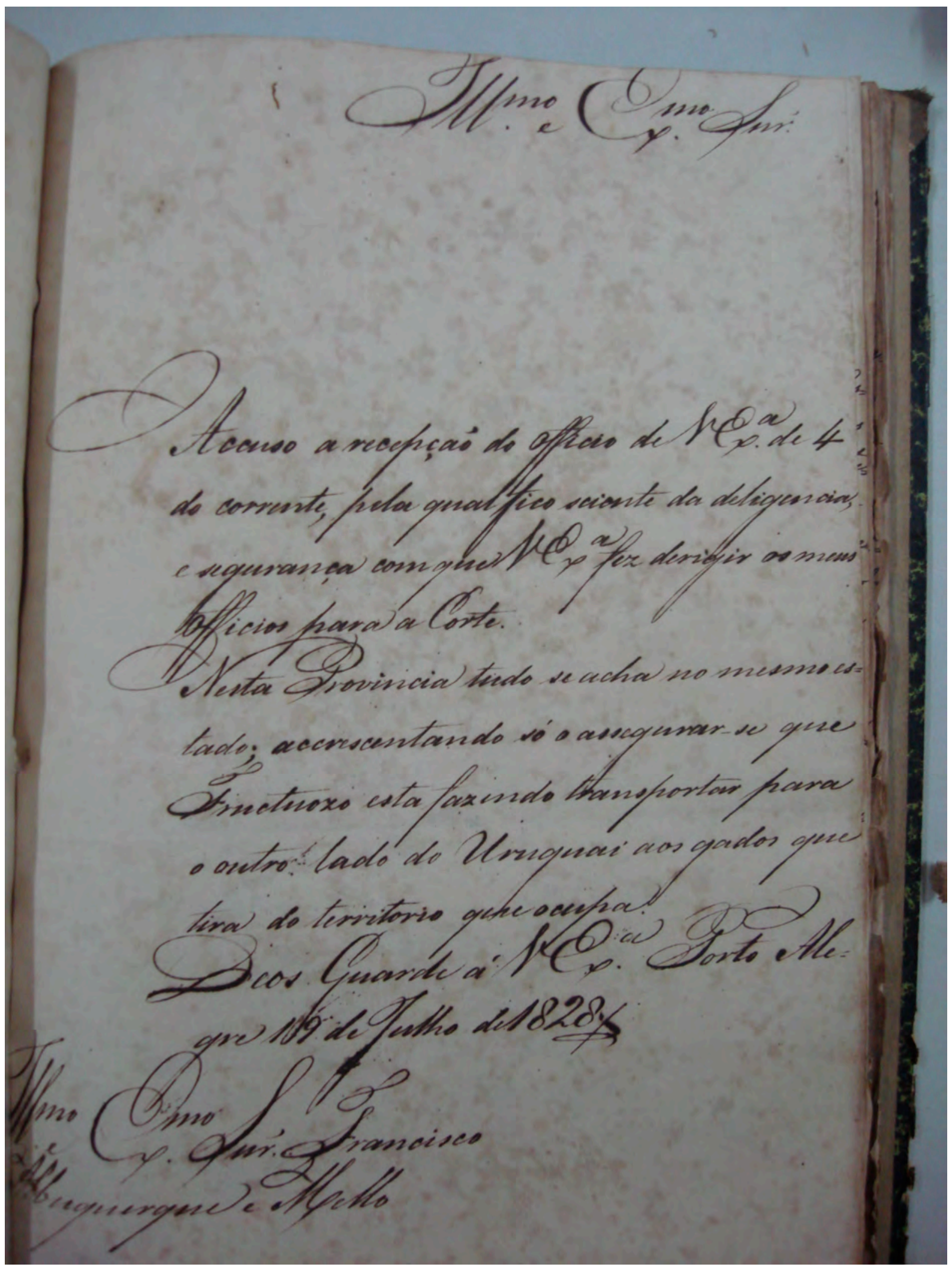


Edição doc 07 - 1828 (Arquivo Público do Estado de Santa Catarina - Florianópolis)

Illustrissimo e Excelentissimo Senhor

Accuso a recepção do Officio de Vossa Excelencia de 4

do corrente, pela qual fico sciente da diligencia,

e segurança com que Vossa Excelencia fez dirigir os meus

Officios para a Corte.

Nesta Provincia tudo se acha no mesmo es=

tado; accrescentando só o assegurar-se que

Fructuozo esta fazindo transportar para

o outro lado do Uruguai aos gados que

tira do territorio que ocupa.

Deos guarde a Vossa Excelencia Porto Ale=

gre 19 de Julho de 1828

Illustrissimo Excelentissimo Senhor Francisco

Albuquerque e Mello 
Doc 8 - 1797 (Arquivo Público do Estado de Santa Catarina - Florianópolis)

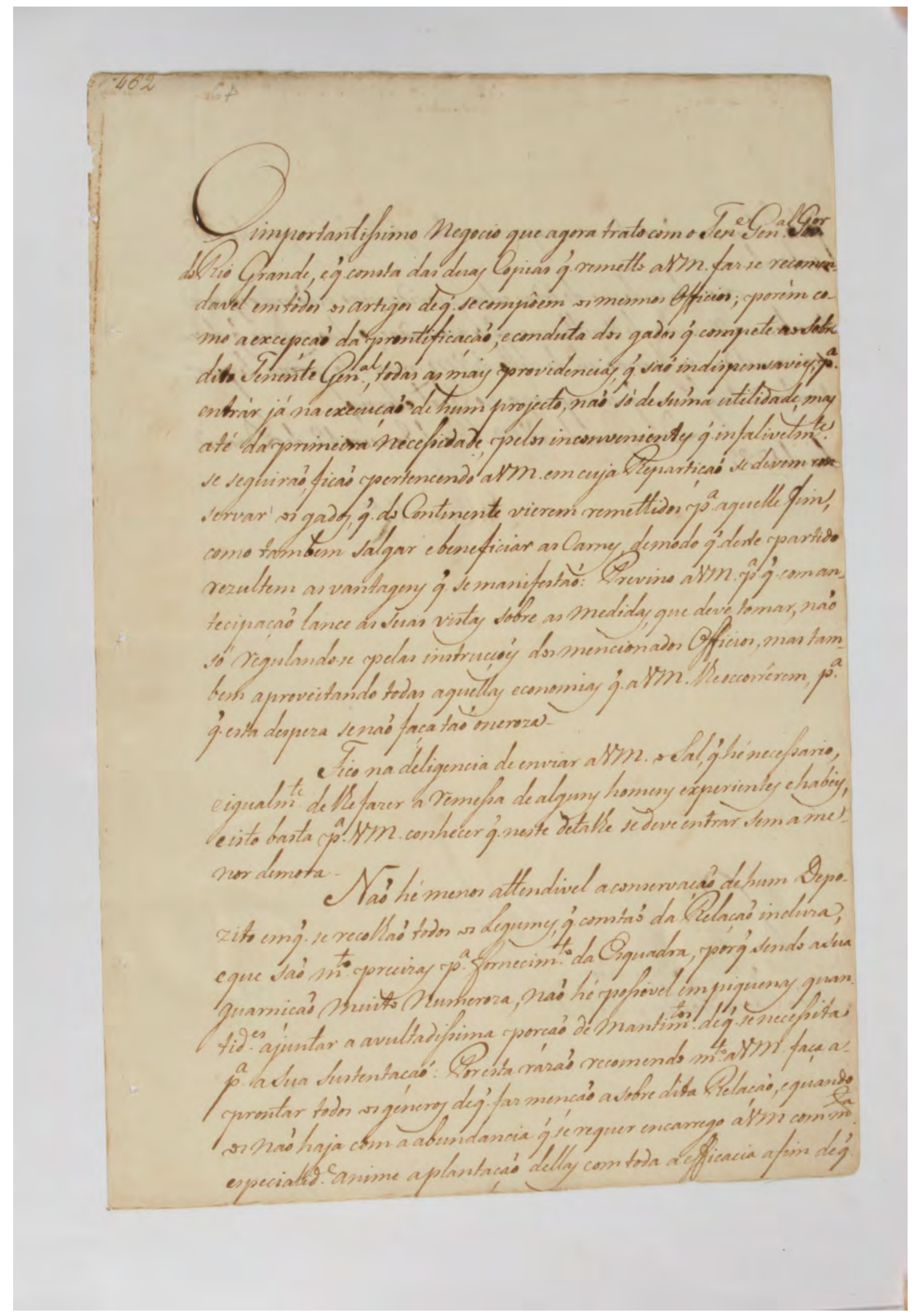


Edição doc 08 - 1797 (Arquivo Público do Estado de Santa Catarina - Florianópolis)

O importantissimo Negocio que agora trato com o Tenente General Governador do Rio Grande, e que consta das duas Copias que remetto a Vossa Merce faz-se recomendavel em todos os artigos de que se compôem os mesmos Officios; porém como a excepção da prontificaçaõ, e conduta dos gados que compete ao sobre dito Tenente General, todas as mais providencias, que saõ indispensaveis para entrár já na execuçaõ de hum projecto, naõ só saõ de suma utilidade, mas até da primeira necessidade, pelos inconvenientes que infalivelmente se seguiraõ, ficaõ pertencendo a Vossa Merce em cuja Repartiçaõ se devem con servar os gados, que do Continente vierem remettidos para aquelle fim, como tambem salgar e beneficiar as Carnes, de modo que deste partido rezultem as vantagens que se manifestaõ: Previno a Vossa Merce para que com antecipaçaõ lance as suas vistas sobre as medidas, que deve tomar, naõ só regulando-se pelas instrucçoēs dos mencionados Officios, mas tam_ bem aproveitando todas aquellas economias que a Vossa Merce lhe ocorrêrem, para que esta despeza se naõ faça taõ oneroza.

Fico na deligencia de enviar a Vossa Merce o Sal, que hé necessario, e igualmente de lhe fazer a remessa de alguns homens experientes e habeis, e isto basta para Vossa Merce conhecer que neste detalhe se deve entrar sem a menor demora.

Naõ hé menos attendivel a conservaçaõ de hum Depozito em que se recolhaõ todos os Legumes, que constaõ da Relaçaõ incluza, e que saõ muito precizas para fornecimento da Esquadra, porque sendo a sua guarniçaõ muito numeroza, naõ hé possivel em piquenas quantidades ajuntar a avultadissima porçaõ de Mantimentos de que se necessita para a sua Sustentaçaõ: Por esta razaõ recomendo muito a Vossa Merce faça aprontar todos os generos de que faz mençaõ a sobredita Relaçaõ, e quando os naõ haja com a abundancia que se requer encarrego a Vossa Merce com muita especialidade anime a plantaçaõ dellas com toda a efficacia a fim de que 
Doc 08v - 1797 (Arquivo Público do Estado de Santa Catarina - Florianópolis)

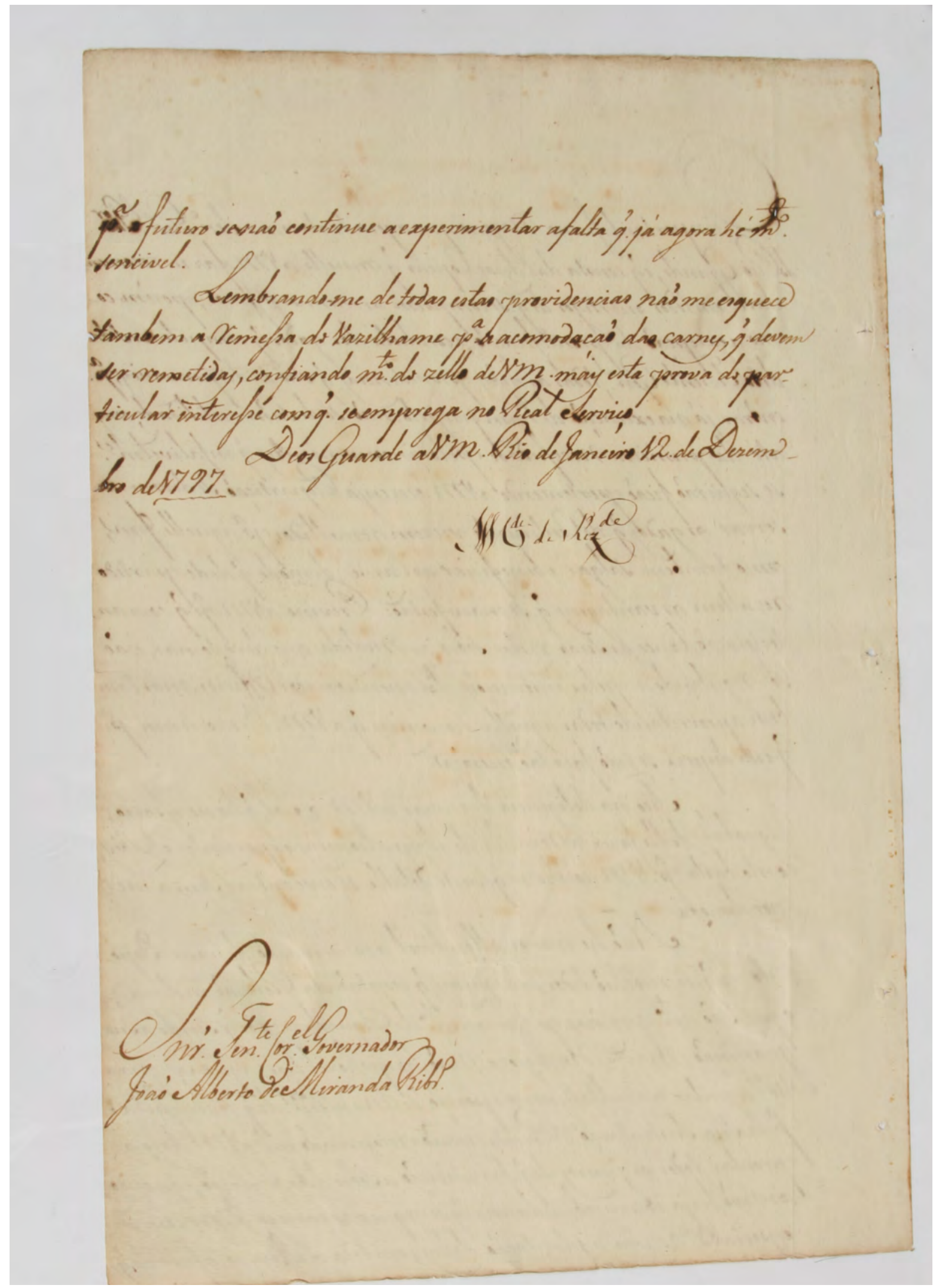


Edição doc 08v - 1797 (Arquivo Público do Estado de Santa Catarina - Florianópolis)

para o futuro se naõ continue a experimentar a falta que já agora hé muito sencivel.

Lembrando-me de todas estas providencias naõ me esquece

tambem a Remessa de Vazilhame para a acomodaçaõ das carnes, que devem ser remetidas, confiando muito do zello de Vossa Merce mais esta prova do particular interesse com que se emprega no Real Serviço

Deos Guarde a Vossa Merce. Rio de Janeiro 12. de Dezem-

bro de 1797

Conde de Rezende

Senhor Tenente Coronel Governador

Joaõ Alberto de Miranda Ribeiro 
Doc 9 - 1797 (Arquivo Público do Estado de Santa Catarina - Florianópolis)

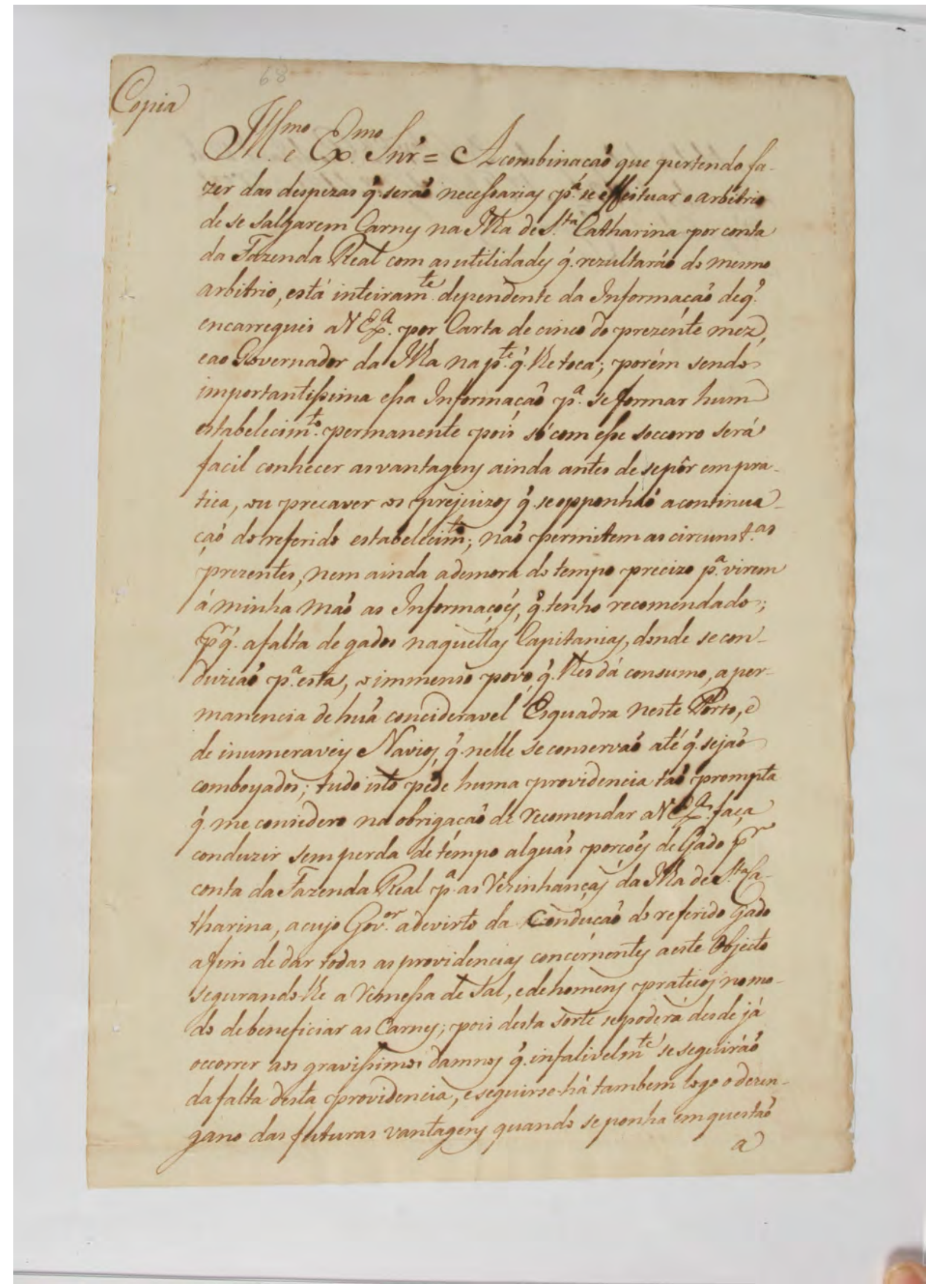


Edição doc 09 - 1797 (Arquivo Público do Estado de Santa Catarina - Florianópolis)

$<$ Copia $>$

Illustrissimo e Excelentissimo Senhor = A combinação que pertendo fazer das despezas que seraõ necessarias para se effeituar o arbitrio de se salgarem Carnes na Ilha de Santa Catharina por conta da Fazenda Real com as utilidades que rezultarão do mesmo arbitrio, está inteiramente dependente da Informaçaõ de que encarreguei a Vossa Excelencia por Carta de cinco do prezente mez, e ao Governador da Ilha na parte que lhe toca; porém sendo importantissima essa Informaçaõ para se formar hum estabelecimento permanente pois só com esse socorro sera facil conhecer as vantagens ainda antes de se pôr em pratica, ou precaver os prejuizos que se opponhaõ a continuaçaõ do referido estabelecimento; naõ permitem as circunstancias prezentes, nem ainda a demora do tempo precizo para virem á minha maõ as Informaçoês, que tenho recomendados; por que a falta de gados naquellas Capitanias, donde se conduziraõ para esta, o immenso povo, que lhes dá consumo, a permanencia de huã consideravel Esquadra neste Porto, e de inumeraveis Navios, que nelle se conservaõ até que sejaõ comboyados; tudo isto pede huma providencia taõ prompta que me considero na obrigaçaõ de recomendar a Vossa Excelencia faça conduzir sem perda de tempo alguãs porções de Gado por conta da Fazenda Real para as Vizinhanças da Ilha de Santa Catharina, a cujo Governador adevirto da Conduçaõ do referido Gado a fim de dar todas as providencias concernentes a este Objecto segurando-lhe a Remessa de Sal, e de homens praticos no modo de beneficiar as Carnes; pois desta sorte se poderá desde já occorrer aos gravissimos damnos que infalivelmente tambem logo o dezingano das futuras vantagens quando se ponha em questão a 
Doc 09v - 1797 (Arquivo Público do Estado de Santa Catarina - Florianópolis)

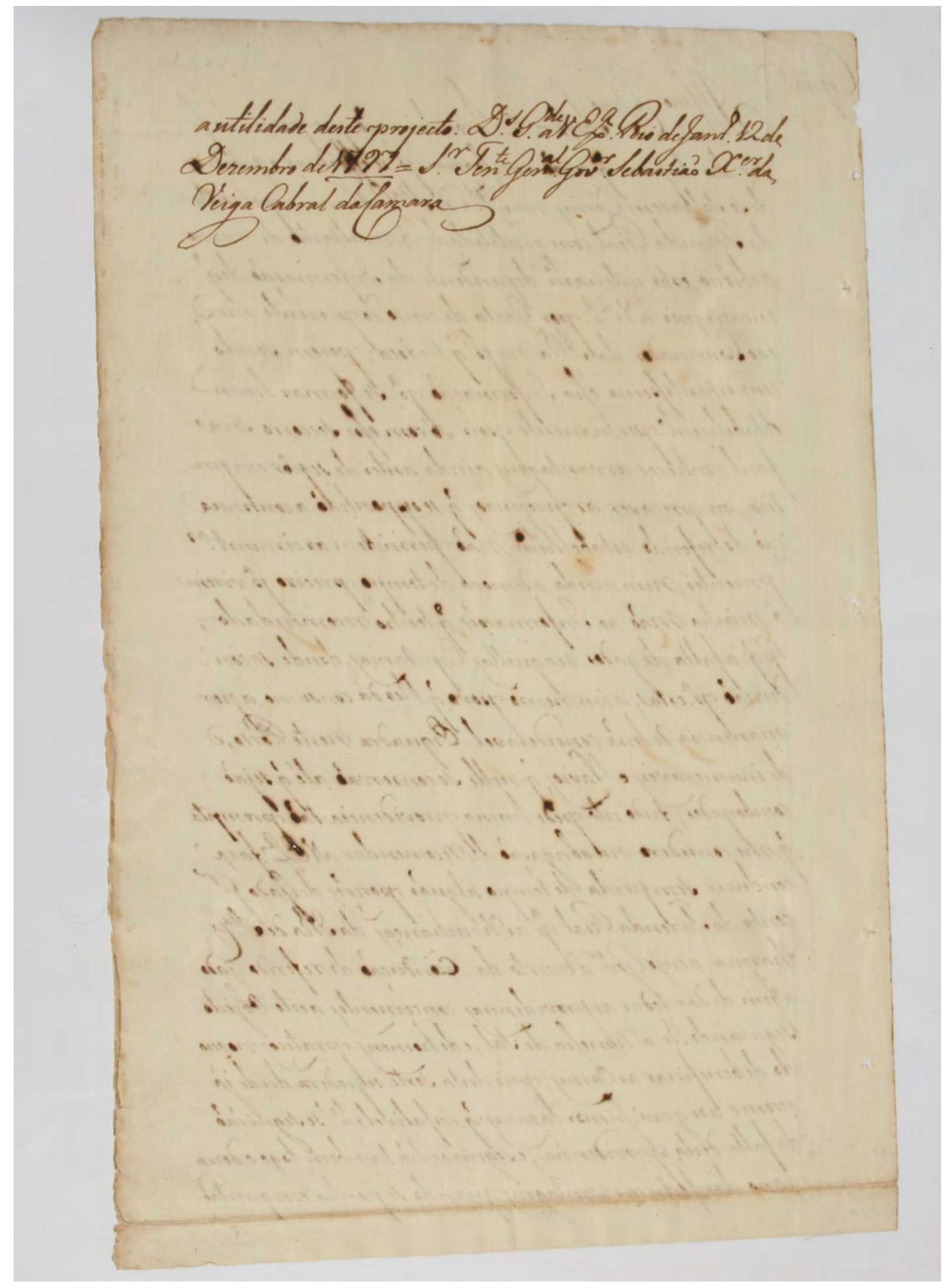


Edição doc 09v - 1797 (Arquivo Público do Estado de Santa Catarina - Florianópolis) a utilidade deste projecto. Deos Guarde a Vossa Excelencia Rio de Janeiro 12 de Dezembro de 1797 = Senhor Tenente General Governador Sebastião Xavier da Veiga Cabral da Camara 
Doc 10 - 1797 (Arquivo Público do Estado de Santa Catarina - Florianópolis)

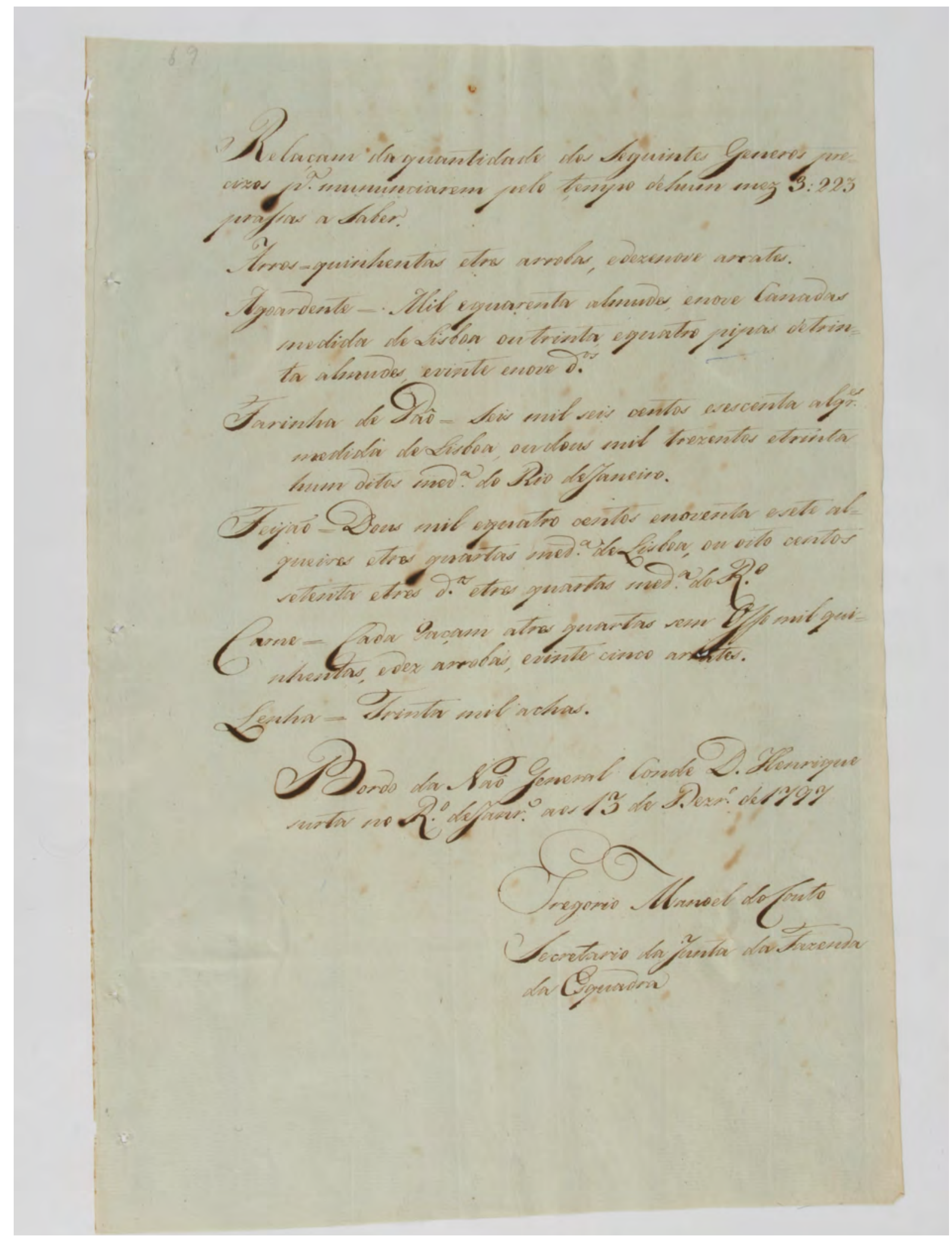


Relaçam da quantidade dos Seguintes Generos pre= cizos para numenciarem pelo tempo de hum mez 3:223 prassas a Saber.

Arros $=$ quinhentas e tres arrobas, e dezenove arrates. Agoardente $=$ Mil e quarenta almudes e nove Canadas medida de Lisboa ou trinta e quarto pipas de trin= ta almudes, e vinte e nove ditos

Farinha de Paô = Seis mil seis centos e secenta alqueires medida de Lisboa, ou dous mil trezentos e trinta hum ditos medida do Rio de Janeiro.

Feijão $=$ Dous mil e quarto centos e noventa e sete al= queires e tres quartas medida de Lisboa, ou oito centos setenta e tres ditos e tres quartas medida do Rio

Carne $=$ Cada raçam a tres quartas sem Osso mil qui= nhentas, e dez arrobas, e vinte cinco arrates.

Lenha $=$ Trinta mil achas.

Bordo da Naô General Conde Dom Henrique surta no Rio de Janeiro aos 13 de Dezembro de 1797

Gregorio Manoel do Couto

Secretario da Junta da Fazenda

da Esquadra 
Doc 11 - 1798 (Arquivo Público do Estado de Santa Catarina - Florianópolis)

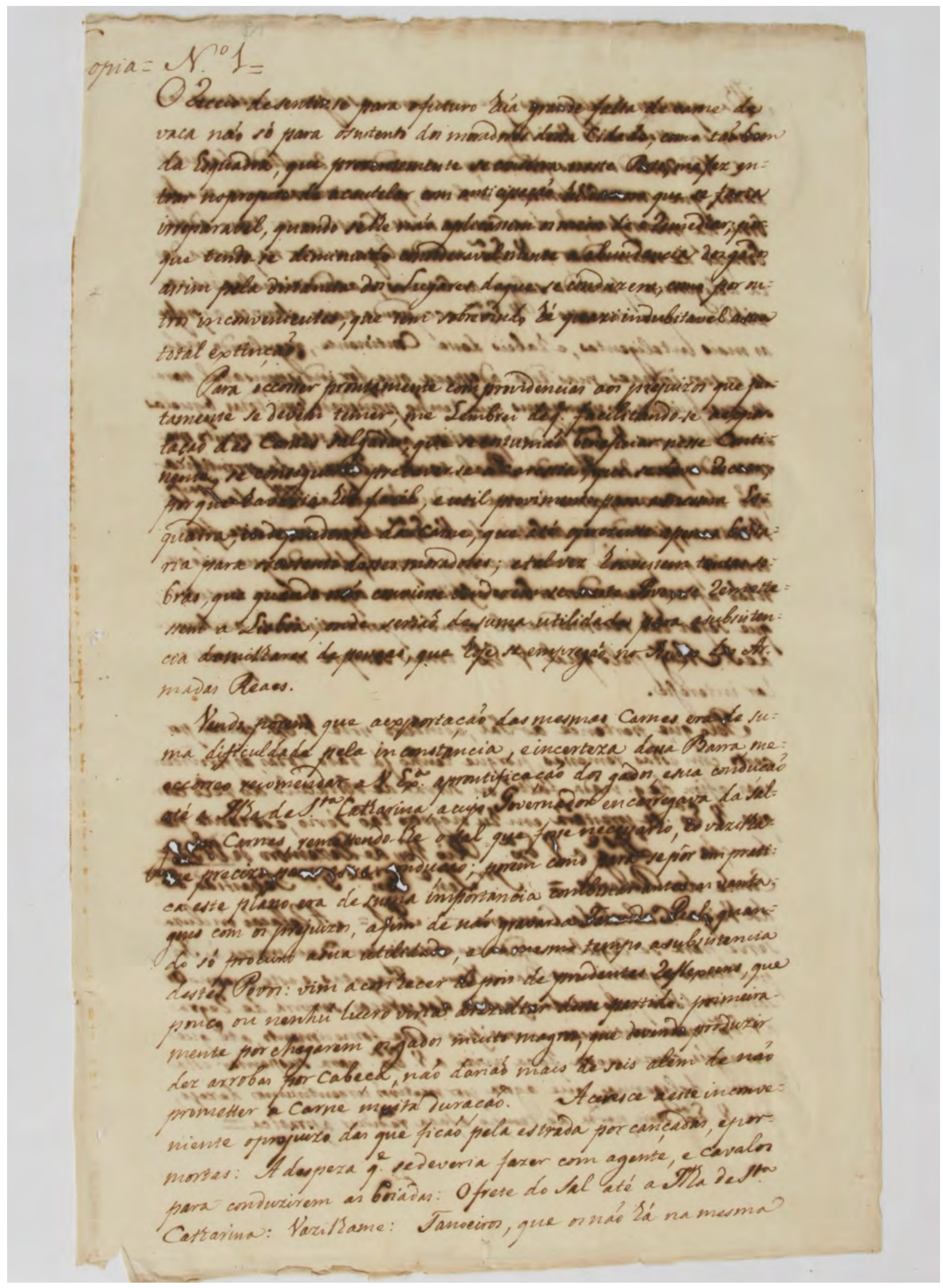


$<$ Copia Numero $1=>$

$\mathrm{O}$ receio de sentir-se para o futuro huã grande falta de carne de vaca não só para o sustento dos moradores desta Cidade, como taõ bem da Esquadra, que prezentemente se conserva neste Porto, me fez en= trar no projecto de acautelar com antecipaçaõ hû danno que se faria irreparavel, quando se lhe naõ aplicassem os meios de o remediar; porque tendo-se diminuido consideravelmente a abundancia dos gados assim pela distancia dos lugares de que se conduzem, como por ou= tros inconvenientes, que tem sobrevindo hé quazi indubitavel a sua total extinçaõ.

Para ocorrer prontamente com providencias aos prejuizos que jus= tamente se devem temer; me Lembrei de que facilitando-se a exportaçaõ das Carnes Salgadas, que se costumaõ beneficiar nesse Conti= nente, se conseguindo-se precaver a carestia, que se deve recear; por que haveria hû facil, e mil provimento para a mesma Es= quadra, independe da Carne, que até o prezente apenas basta= ria para o sustento destes moradores; e talvez houvessem tantas $\mathrm{so}=$ bras, que quando naõ conviesse venderem-se neste Povo, se remette= ssem a Lisboa, onde seriaõ de suma utilizadas para a subsisten= cia de milhares de pessoas, que hoje se empregaõ no Serviço das Armadas Reaes.

Vendo porem que a exportaçaõ das mesmas Carnes era de $\mathrm{su}=$ ma dificuldade pela inconstancia, e incerteza dessa Barra, me $=$ ocorreo recomendar a Vossa Excelencia a prontificaçaõ dos gados, e sua conduçaõ até a Ilha de Santa Catharina, a cujo Governador encarregava da Sal= ga das Carnes, remettendo-lhe o Sal que fosse necessario, e o vazilha= me precizo para a sua conduçaõ; porem como para se pôr em prati= ca este plano era de suma importancia combinar antes as vanta= gens com os prejuizos, a fim de naõ graver a Fazenda Real, quan= do só procuro a sua utilidade, e ao mesmo tempo a subsistencia destes Povos: vim conhecer depois de prudentes reflexoens, que pouco ou nenhûm lucro o devendo produzir dez arrobas por cabeça, naõ dariaõ mais de seis alem de naõ prometer a Carne muita duraçaõ. Acresce a este inconve $=$ niente o prejuizo das que ficaõ pela estrada por cançadas, e pormortas: A despeza que se deveria fazer com a gente, e cavalos para conduzirem as boiadas: O frete de Sal até a Ilha de Santa Catharina: Vazilhame: Tanoeiros; que os naõ há na mesma 
Doc 11v - 1798 (Arquivo Público do Estado de Santa Catarina - Florianópolis)

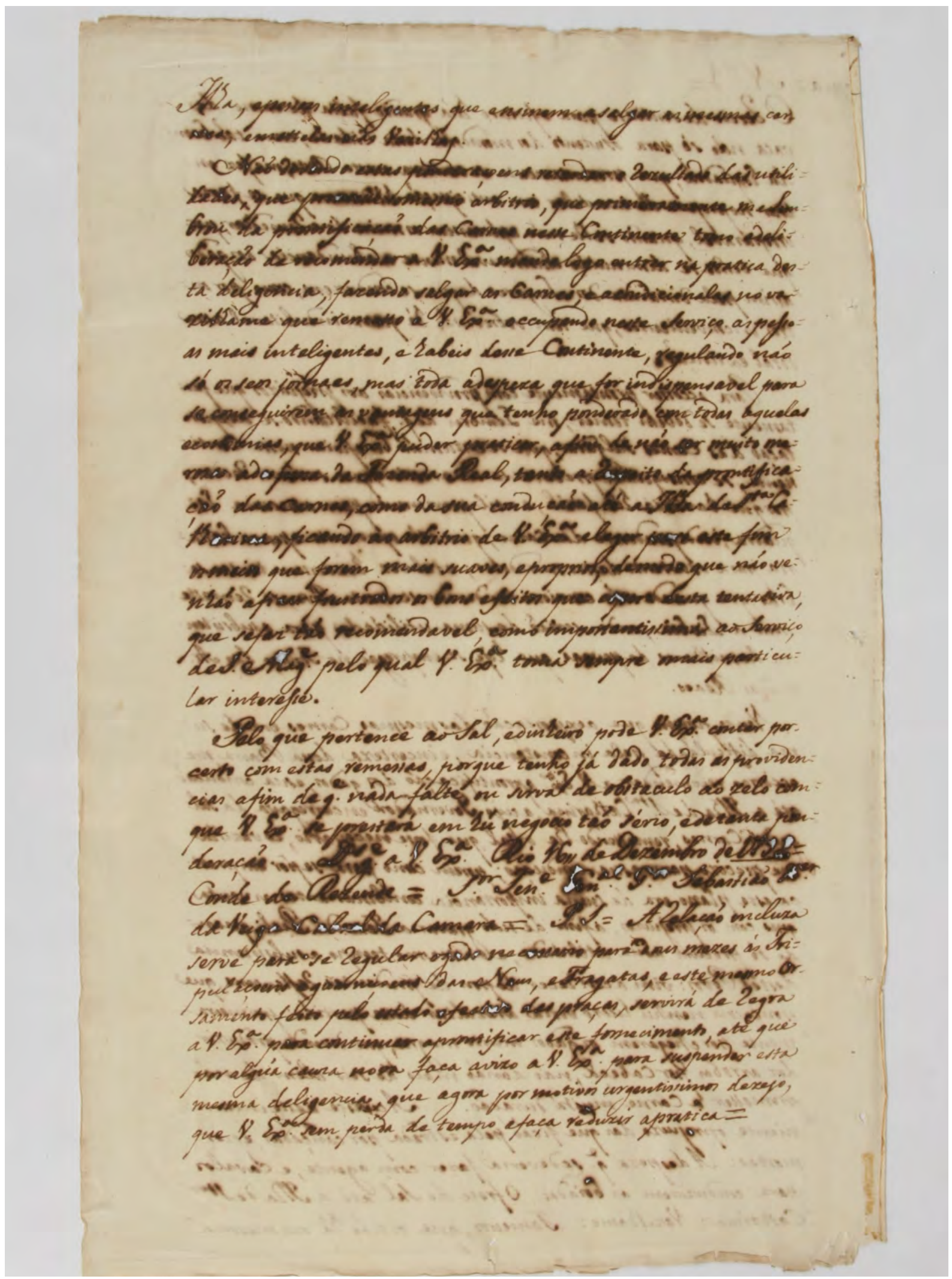


Edição doc 11v - 1798 (Arquivo Público do Estado de Santa Catarina - Florianópolis)

Ilha, e pessoas inteligentes que ensinem a salgar as mesmas carnes, e metelas nas Vazilhas.

Naõ devendo estas ponderações retardar o rezultado das utili= dades, que [corrído] o mesmo arbitrio, que primeiramente me Lem= brou da prontificaçaõ das Carnes nesse Continente tomo a deli= beraçaõ de recomendar a Vossa Excelencia mande logo entrar na pratica des= ta deligencia, fazendo salgar as Carnes, e acondiciona las no va= zilhame que remetto a Vossa Excelencia occupando neste Serviço as pesso= as mais inteligentes, e habeis desse Continente, regulando naõ só os seos jornaes, mas toda a despeza que for indispensavel para se conseguirem as vantagens que tenho ponderado com todas aquelas economias, que Vossa Excelencia puder praticar, a fim de naõ ser muito one= roza a dspeza da Fazenda Real, tanto a respeito da prontifica= çaõ das Carnes, como da sua conduçaõ até a Ilha de Santa $\mathrm{Ca}=$ tharina, ficando ao arbitrio de Vossa Excelencia eleger para este fim os meios que forem mais suaves e proprios, de modo que naõ ve= nhaõ a ficar frustrados os bons efeitos que espero desta tentativa, que se faz taõ recomendavel, como importantissimo ao Serviço de Sua Magestade pelo qual Vossa Excelencia toma sempre o mais particu= lar interesse. Pelo que pertence ao Sal, e dinheiro pode Vossa Excelencia contra porcerto com estas remessas, porque tenho já dado todas as providen= cias afim de que nada falte ou sirva de obstaculo ao zelo com= que Vossa Excelencia se prestará em hû negocio taõ sério, e tenta po= deraçaõ. Deus guarde a Vossa Excelencia Rio 16 de Dezembro de $1798=$ Conde Rezende $=$ Senhor Tenente General Governador Sebastiaõ Xavier da Veiga Cabral da Camara $=$ P. S. $=$ A relaçaõ incluza serve para se regular o gado necessario para dous mezes ás tripu laçoens e guarniçoens das Naus, e Fragatas, e neste mesmo Or samento feito pelo estado efectivo das praças, servirá de regra a Vossa Excelencia para continuar a prontificar este fornecimento, ate que por algûa cauza nova faça avizo a Vossa Excelencia para suspender esta mesma deligencia, que agora por motivos urgentissimos dezejo, que Vossa Excelencia sem perda de tempo a faça reduzir a pratica= 
Doc 12 - 1797 (Arquivo Público do Estado de Santa Catarina - Florianópolis)

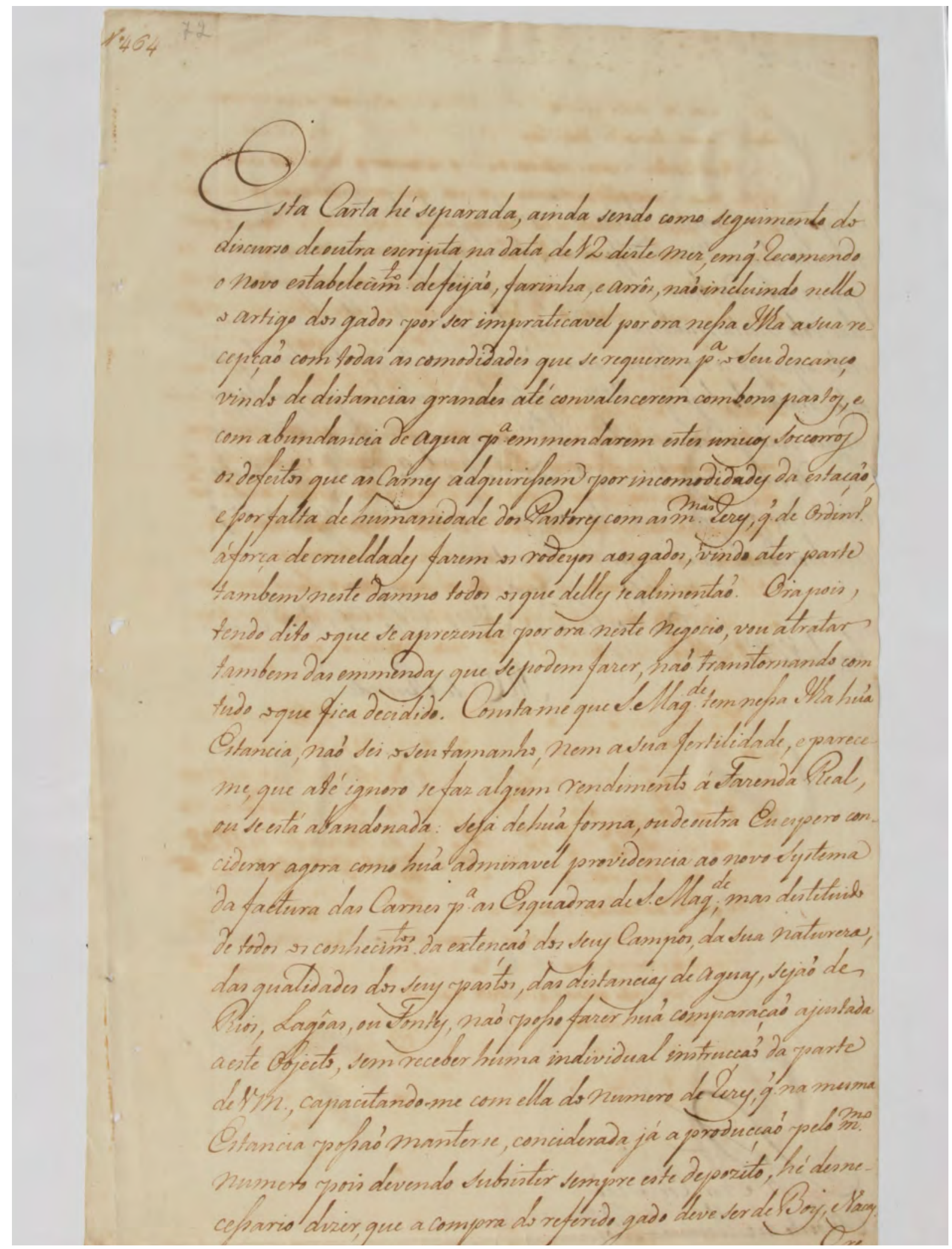


Edição doc 12 - 1797 (Arquivo Público do Estado de Santa Catarina - Florianópolis)

Esta Carta hé separada, ainda sendo como seguimento do

discurso de outra escripta na data de 12 diste mez, em que recomendo

o novo estabelecimento de feijaõ, farinha e arrôz, naõ incluindo nella

o artigo dos gados por ser impraticavel por ora nessa Ilha a sua re-

cepçaõ com todas as comodidades que se requerem para o seu descanço

vindo de distancias grandes até convalescerem com bons pastos, e

com abundancia de agua para emmendarem estes unicos Socorros

os defeitos que as Carnes adquirissem por incomodidades da estaçaõ

e por falta de humanidade dos Pastores com as mesmas Rezes, que de Ordinario

á força de crueldades fazem os rodeyos aos gados, vindos a ter parte

tambem neste damno todos os que delles se alimentaõ. Ora pois,

tendo dito o que se aprezenta por ora neste Negocio, vou a tratar

tambem das emmendas que se podem fazer, naõ transtornando com

tudo o que fica decidido. Consta-se que Sua Magestade tem nessa Ilha huã

Estancia, naõ sei o seu tamanho, nem a sua fertilidade, e parece-

me, que até ignoro se faz algum rendimento á Fazenda Real,

ou se está abandonada: seja de hûa forma, ou de outra Eu espero con-

ciderar agora como huã admiravel providencia ao novo Systema

da factura de Carnes para as Esquadras de Sua Magestade, mas destituido

de todos os conhecimentos da extençaõ dos seus Campos, da sua Natureza,

das qualidades dos seus pastos, das distancias de aguas, sejaõ de

Rios, Lagôas, ou Fontes, naõ posso fazer huã comparaçaõ ajustada

a este Objecto, sem receber huma individual instrucçaõ da parte

de Vossa Merce, capacitando-me com ella do numero de Rezes, que na mesma

Estancia possaõ manter-se, conciderada já a producçaõ pelo mesmo

numero pois devendo subsistir sempre este depozito, hé desne-

cessario dizer, que a compra do referido gado deve ser de Bois e Vacas

[Cre] 
Doc 12v. - 1797 (Arquivo Público do Estado de Santa Catarina - Florianópolis)

Cropo que a sumen destay se requlará ypelo dos boys, suteriécon-

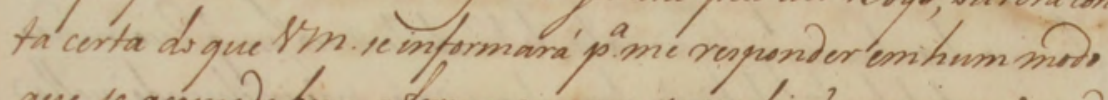

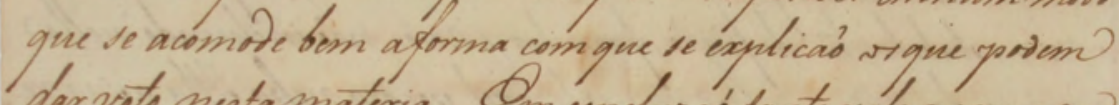
dar vote nesta materia: Om condurab tanto vale nomen con. cesto ique jà ve mi farer, como og. refará neste particular deque

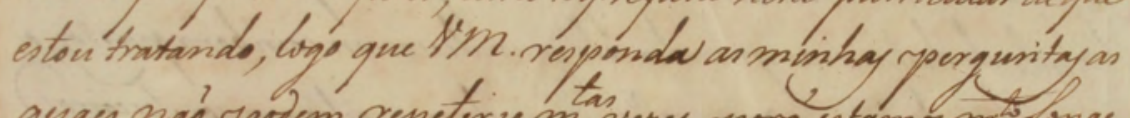
quais ná poot on repeterie misery, pory. entamo mo alonge mair na Demora, quando consiga huma Roticia dequra, Dr?. natrevidade com respostas incertay.

bride1797

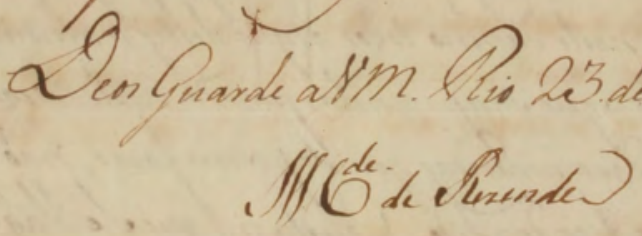

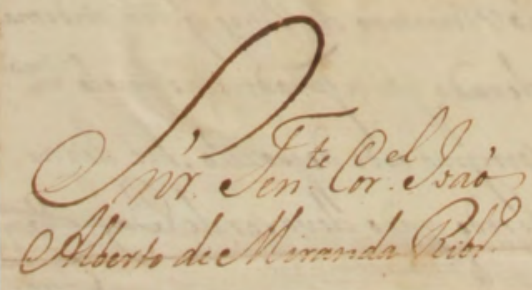

63 
Edição doc 12v - 1797 (Arquivo Público do Estado de Santa Catarina - Florianópolis)

Creyo que o Numero destas se regulará pelo dos Boys, ou terá con-

ta certa do que Vossa Merce se informará para me responder em hum modo

que se acomode bem a forma com que se explicão os que podem

dar voto nesta materia. Em concluzão tanto vale no meu con-

ceito o que já se vai fazer, como o que se fará neste particular de que

estou tratando, logo que Vossa Merce responda as minhas perguntas as

quaes naõ podem repetir-se muitas vezes, porque estamos muito Longe

hum do outro, cuja circunstancia hé taõ attendivel que convenho

mais na demora, quando consiga huma Noticia segura, do que

na brevidade com respostas incertas.

Deos Guarde a Vossa Merce Rio 23 de Dezem-

bro de 1797

Conde de Rezende

Senhor Tenente Coronel Joaõ

Alberto de Miranda Ribeiro 
Doc 13 - 1798 (Arquivo Público do Estado de Santa Catarina - Florianópolis)

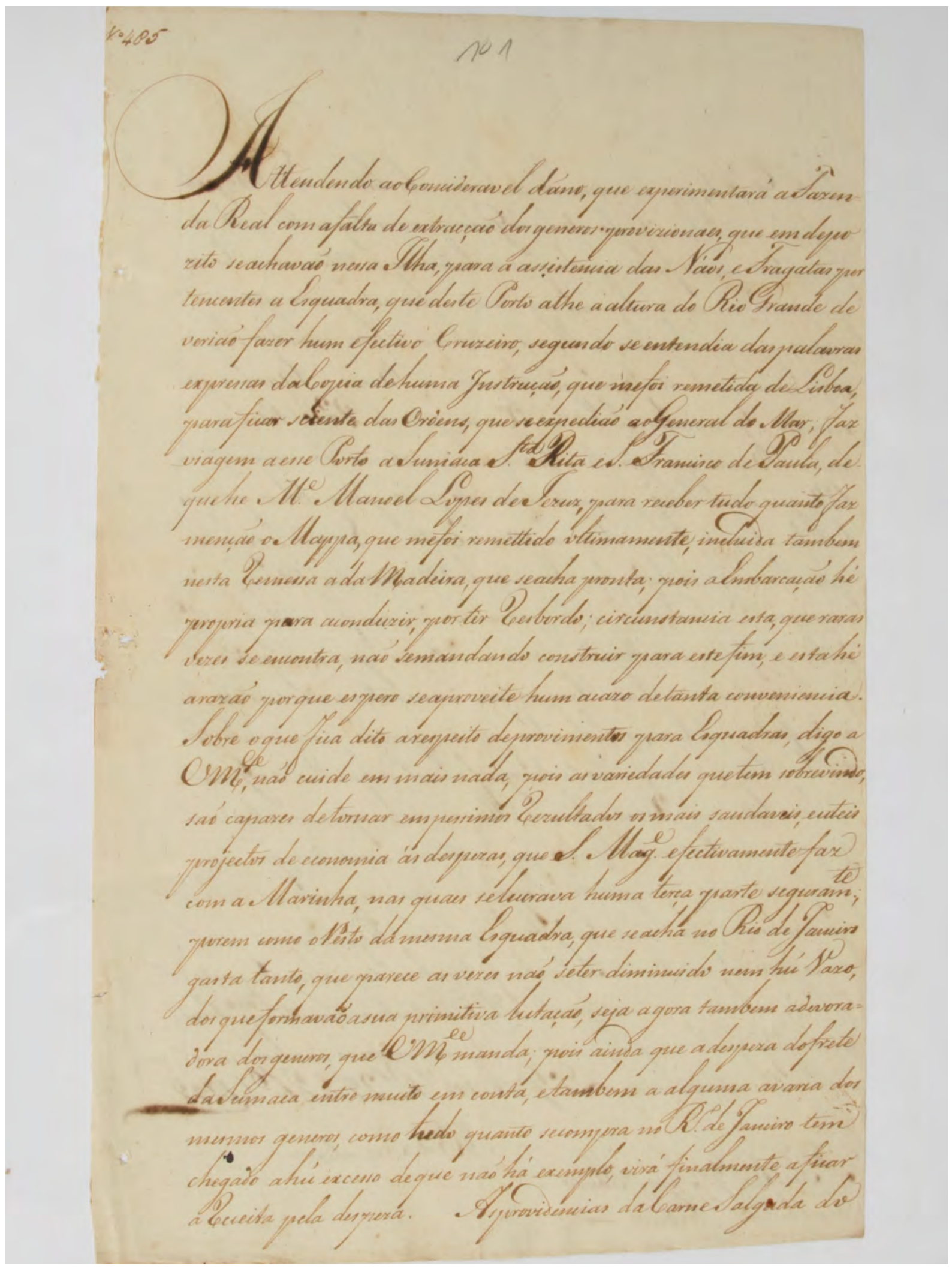


Edição doc 13 - 1798 (Arquivo Público do Estado de Santa Catarina - Florianópolis)

$<$ Numero 485>

Attendendo ao Concideravel dano, que experimentará a Fazen-

da Real com a falta de extracçaõ dos generos provizionaes, que em depo

zito se achavaõ nessa Ilha, para a assistencia das Náos, e Fragatas per tencentes a Esquadra, que deste Porto athe a altura do Rio Grande de veriaõ fazer hum efectivo Cruzeiro, segundo se entendia das palavras expressas da Copia de huma Jnstruçaõ, que me foi remetida de Lisboa para ficar sciente das Ordens, que se expediaõ ao General do Mar, faz viagem a esse Porto a Sumaca Santa Rita e Saõ Franscisco de Paula, de que he Mestre Manoel Lopes de Jezuz, para receber tudo quanto faz mençaõ o Mappa, que me foi remettido ultimamente, incluida tambem nesta Remessa a da Madeira, que se acha pronta, pois a Embarcaçaõ hé propria para aconduzir, por ter resbordo, circunstancia esta, que raras vezes se encontra, naõ se mandando construir para este fim, e esta hé a razaõ porque espero se aproveite hum acazo de tanta conveniencia. Sobre o que fica dito a respeito de provimentos para Esquadras, digo a Vossa Merce naõ cuide em mais nada, pois as variedades que tem sobrevindo saõ capazes de tornar em pessimos resultados os mais saudaveis, e uteis projectos de economia ás despezas, que Sua Magestade efectivamente faz com a Marinha, nas quaes se lucrava huma terça parte seguramente porem como o resto da mesma Esquadra, que se acha no Rio de Janeiro gasta tanto, que parece as vezes naõ se ter diminuido nem hû Vazo dos que formavaõ a sua primitiva lutaçaõ, seja agora tambem a devora= dora dos generos, que Vossa Merce manda, pois ainda que a despeza do frete sa Sumaca entre muito em conta e tambem a alguma avaria dos mesmos generos, como tudo quanto se compra no Rio de Janeiro tem chegado a hû excesso de que naõ há exemplo, virá finalmente a ficar a receita pela despeza. As providencias da Carne Salgada do 
Doc 13v - 1798 (Arquivo Público do Estado de Santa Catarina - Florianópolis)

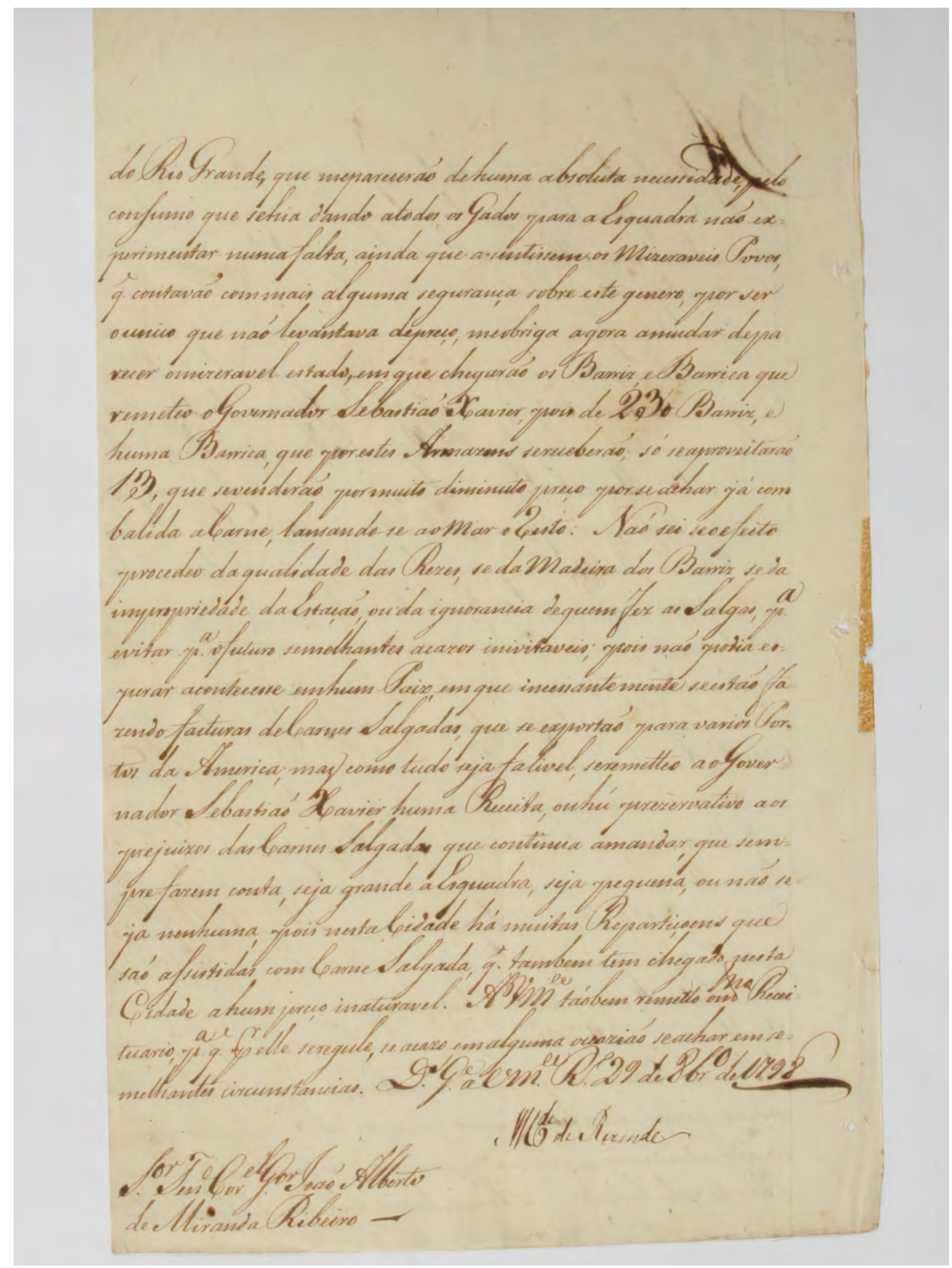


Edição doc 13v - 1798 (Arquivo Público do Estado de Santa Catarina - Florianópolis)

do Rio Grande do Sul, que me pareceraõ de huma absoluta necessidade, pelo consumo que se hia dando a todos os Gados para a Esquadra naõ ex= perimentar numa falta ainda que assentissem os Mizeraveis Povos, que contavaõ com mais alguma segurança sobre este genero, por ser o unico que naõ levantava de preço, me obriga agora a mudar de pa recer o mizeravel estado, em que chegaraõ os Barriz, e Barrica que remeteo o Governador Sebastiaõ Xavier, pois de 23 Barriz, e huma Barrica, que por estes Armazens se receberaõ, só se aproveitaraõ 13, que se venderaõ por muito diminuto peço por se achar já com balida a Carne, lansando-se ao Mar o resto: Naõ sei se o efeito procedeo da qualidade das Rezes, se da Madeira dos Barriz se da û impropriedade da Estaçaõ, ou da ignorancia de quem fez as Salgas, para evitar para o futuro semelhantes acazos inivitaveis, pois naõ podia es= perar acontecesse em hum Paiz, em que incessantemente estaõ fa= zendo facturas de Carnes Salgadas, que se exportaõ para varios Por= tos da America; mas como tudo seja falivel, se remetteo ao Gover= nador Sebastiaõ Xavier huma Receita, ou hû preservativo aos prejuizos das Carnes Salgadas que continua a mandar, que sem= pre fazem conta, seja grande a Esquadra, seja pequena, ou naõ se= jai nenhuma, pois nesta Cidade há muitas Repartiçoens que saõ assistidas com Carne Salgada, que tambem tem chegado nesta Cidade a hum preço inaturavel. A Vossa Merce taõbem remetto o mesmo Recei= tuario para que por elle se regule se acazo em alguma occaziaõ se achar em se= melhantes circunstancias. Deos Guarde a Vossa Merce Rio 29 de 8 bro de 1798

Conde de Rezende

Senhor Tenente Coronel Governador Joaõ Alberto de Miranda Ribeiro 
Doc 14 - 1798 (Arquivo Público do Estado de Santa Catarina - Florianópolis)

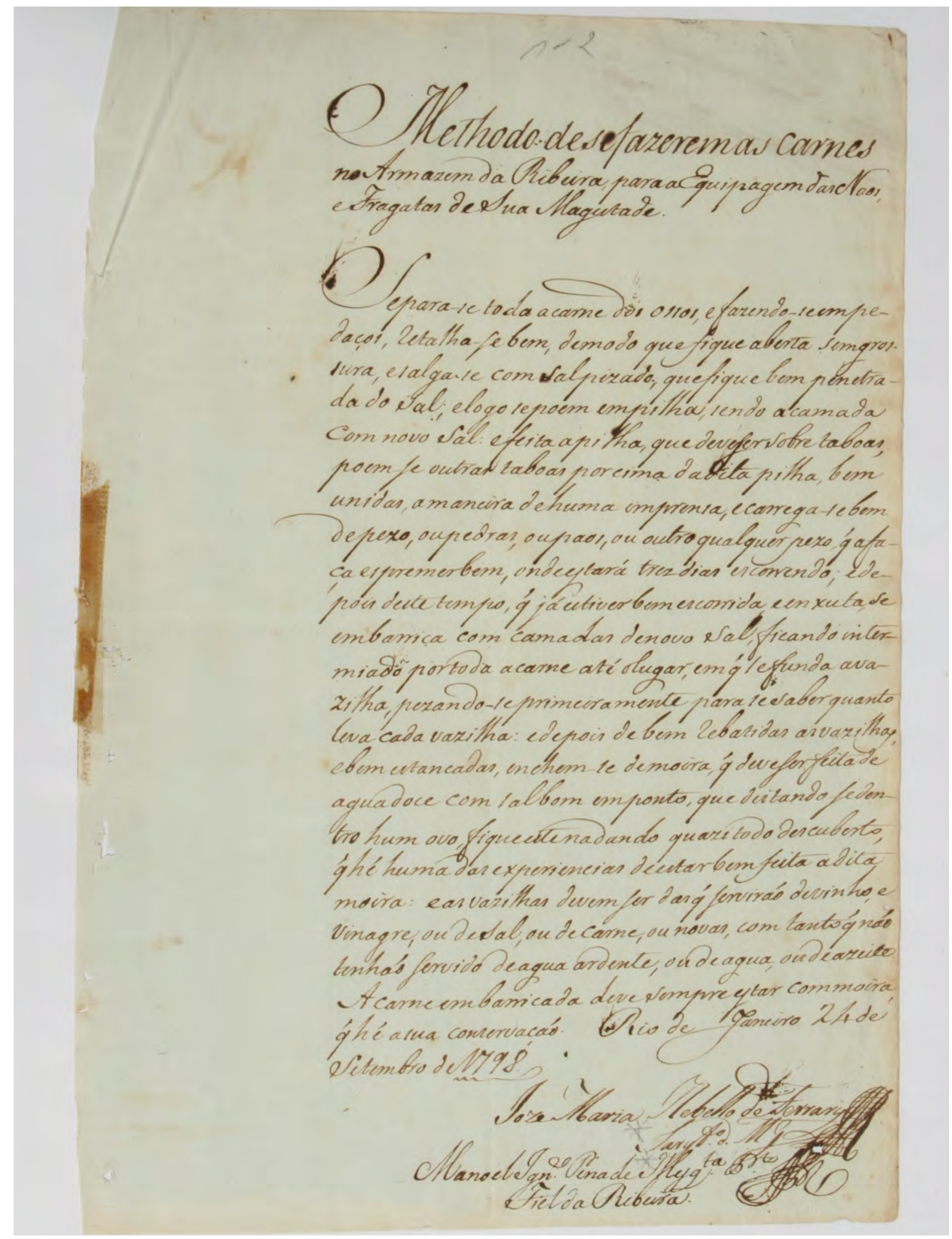


Methodo de se fazerem as Carnes

no Armazen da Ribeira, para a Equipagem das Naos,

e Fragatas de Sua Magestade.

Separe-se toda a carne dos ossos, e fazendo-se empe-

daços, ratalha-se bem, de modo que fique aberta sem gros-

sura, e salga-se com Sal pizado; que fique bem penetra-

da do Sal; e logo se poem em pilha, sendo a camada

com novo Sal: e feita a pilha, que deve ser sobre taboas,

poem-se outras taboas por cima da dita pilha, bem

unidas, a maneira de huma imprensa, e carrega-se bem

depezo, ou pedras, ou paos, ou outro qualquer pezo, que a fa-

ça espremer bem, onde estará trez dias escorrendo; e de-

pois deste tempo, que já estiver bem escorrida e enxuta, se

embarrica com camadas de novo Sal, ficando inter-

miado por toda a carne até o lugar, em que se funda a va-

zilha, pezando-se primeiramente para se saber quanto

leva cada vazilha; e depois de bem rebatida as vazilhas,

e bem estancadas, enchem-se de moira, que deve ser feita de

agua doce com sal bom em ponto, que deitando-se de-

tro hum ovo, fique este nadando quazi todo descuberto,

que hé huma das experiencias de estar bem feita a dita

moira: e as vazilhas devem ser das que serviraõ de vinho, e

vinagre, ou de Sal, ou de Carne, ou novas, com tanto que naõ

tenhaõ servido de agua ardente, ou de agua, ou de azeite.

A carne embarricada deve sempre estar com moira,

que hé a sua conservaçaõ. Rio de Janeiro 24 de

Setembro de 1798

Ioze Maria Rebello de Ferrari

Sargento do Mestre

Manoel Ignacio Pena de Mesquita Pinto

Fiel da Ribeira. 
Doc 15 - 1795 (Arquivo Público do Estado de Santa Catarina - Florianópolis)

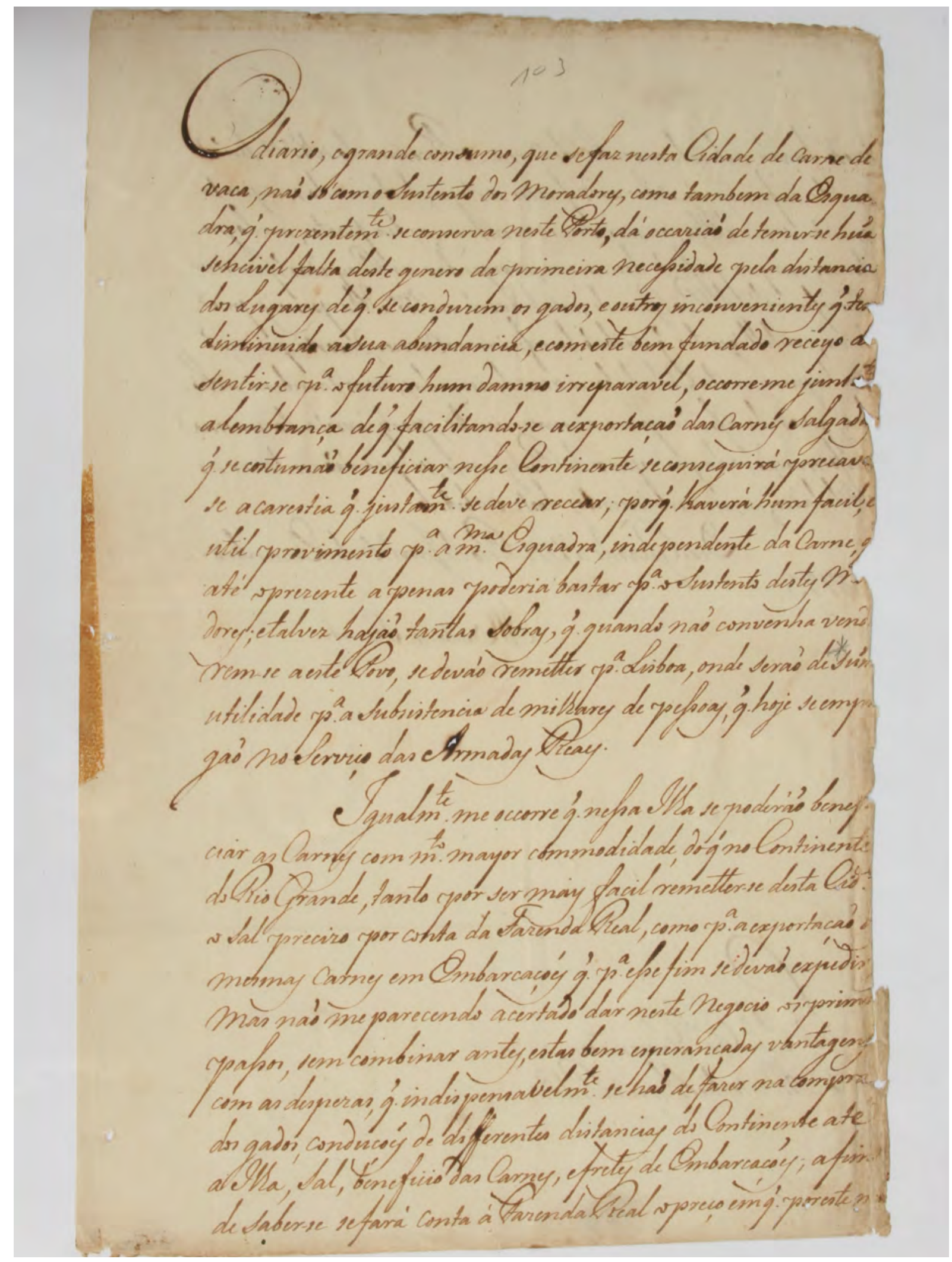


Edição doc 15 - 1795 (Arquivo Público do Estado de Santa Catarina - Florianópolis)

O diario, e grande consumo, que se faz nesta Cidade de carne de vaca , não só com o Sustento dos Moradores, como tambem da Esqudra, que prezentemente se conserva neste Porto, dá occaziaõ de temer-se hûa sencivel falta deste genero da primeira necessidade pela distancia dos Lugares de que se conduzem os gados, e outros inconvenientes que tem diminuido a sua abundancia, e com este bem fundado receyo de sentir-se para o futuro hum damno irreparavel, occore-me juntamente a lembrança de que facilitando-se a exportação das Carnes Salgadas que se costumão beneficiar nesse continente se conseguirá precaver se a carestia que justamente deve recear, porque haverá hum facil, e util provimento para a mesma Esquadra, independente da Carne, que até o prezente apenas poderia bastar para o Sustento destes Mo[ra] dores, e talvez hajaõ tantas Sobras, que quando naõ convenha vend[e] rem-se a este Povo, se devão remetter para Lisboa, onde seraõ de $\mathrm{Su[ma]}$ utilidade para a Subsistencia de milhares de pessoas, que hoje se empr[e] gaõ no Serviço das Armadas Reaes.

Igualmente me occorre que nessa Ilha se poderáõ beneficiar as Carnes com muito mayor commodidade, do que no Continente do Rio Grande, tanto por ser mais facil remeter-se desta Cidade o Sal precizo por conta da Fazenda Real, como para a exportaçaõ d[as] mesmas carnes em Embarcações que para esse fim de devaõ expedir Mas naõ me parecendo acertado dar neste Negocio os primeiros passos, sem combinar antes, estas bem esperançadas vantagens com as despezas, que indispensavelmente se haõ de fazer na compra dos gados, conduções de differentes distancias do Continente ate a Ilha, Sal, beneficio das Carnes, e fretes de Embarcações, a fim de saber-se se fará conta a Fazenda Real o preço em que por este m[esmo] 
Doc 15v - 1795 (Arquivo Público do Estado de Santa Catarina - Florianópolis)

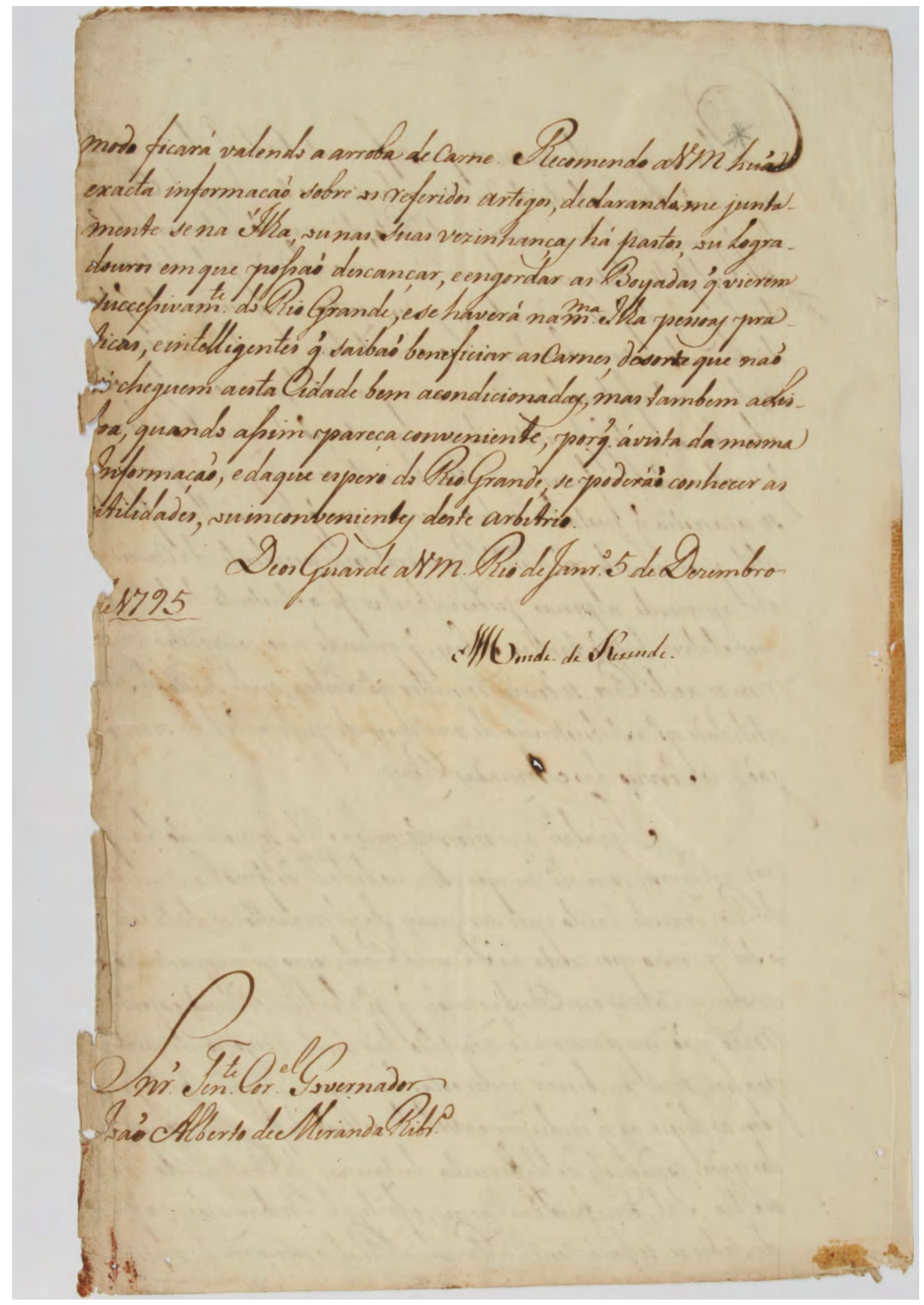


Edição 15v - 1795 (Arquivo Público do Estado de Santa Catarina - Florianópolis)

modo ficará valendo a arroba de carne. Recomendo a Vossa Merce huã exacta informçaõ sobre os referidos artigos, declarando-me juntamente se na Ilha, ou nas suas vizinhanças há pastos, ou Logradouros em que possaõ descançar, e engordar as Boyadas que vierem Successivamente do Rio Grande, e se haverá na mesma Ilha pessoas praticas, e intelligentes que saibaõ beneficiar as Carnes, de sorte que naõ [só] cheguem a esta Cidade bem acondicionadas, mas tambem a Lisboa, quando assim pareça conveniente, porque á vista da mesma Informaçaõ, e da que espero do Rio Grande, se poderáõ conhecer as utilidades, ou inconvenientes deste arbitrio.

Deos Guarde a Vossa Merce Rio de Janeiro 5 de Dezembro [de] 1795

Conde de Rezende

Senhor Tenente Coronel Governador Joaõ Alberto de Miranda Ribeiro 


\section{Leis do Estado Imposto sobre gado exzportado}

- Está sujeito a este imposto todo o animal vaccum, cavallar, muar, lanigero ou suin o, que transpuzer a fronteira do Estado.

N. As taxas são as seguintes :

e 18000 - 3\$000 por cabeca de gado vaceum; $1 \$ 500$ por cabeça de gado cavallar e muar, Paran por cabeça de gado lanigero e suino, quando a exportação se fizer pelas divisas com esanta Catharina.

pela barra do Rio Grande.

N. 3) - Quando a exportação se fizer pela fronteira, as taxas serão as seguintes:

$10 \$ 000$ por cabeca de gado vaccum

$5 \$ 000$ \& * $\&$ muar e cavallar

$28000 *$ \& $\&$ lanigero suino.

- O imposto é pago pelo dono ou conductor da tropa, na estaçâo do municipío em que existir o ponto ou passo habilitado, devidamente guarnecido por empregado do agente fiscal.

- São isentos do imposto os animaes montados, ou carregados com fruetus ou produ. etos do Estado, os que puxarem os vehiculos dos viajantes ou tropeiros e ainda os destinados a esse mister, a juizo do exactor.

- As tropas de animaes, de qualquer proveniencia, que tenham invernado no Estado, quando forem exportadas para outros Estados da União, ficam sujeitas ao imposto.

- Durante o praso de 4 annos, a contar de $1^{\circ}$ de janeiro de 1914 , ficam sujeitos ao im. posto de 308000 por cabeça : o gado vaccum de criar, as vaccas de invernar e as vaccas no* vas, que forem exportadas para os Estados do Norte ou para os paizes visinhos. Lei n. 170, de 17 de dezembro de 1913 .

- A taxa de $3 \$ 000,1 \$ 500$ e $10 \$ 000$ por cabeça de gado vaccum só será cobrada sobro o gado não sujcito á de $30 \$ 000$. 


\section{Leis do Estado}

T'odo cidadão deve conhecer os seus direitos e os seus deveres perante a lei.

\section{IMPOSTO SOBRE GADO ABATIDO}

- Este imposto, que é de $200 \mathrm{rs}$., recae sobre cada cabeça de gado abatido para ex- Tambem incide e em outros estabelecimentos congeneres.

as republicas do Prata e Estados vio sobre cada cabeça de gado de córte que passar para - Este imposto é pago:

1) directamente pelo comprador, dentro do praso de 3 dias, depois de recebido o gado, e sob pena de multa de $12 \%$, quanto ao gado abatido nas xarqueadas e outros estabelecimentos congeneres.

2) directamente pelo dono ou conductor e junto ao imposto sobre animaes exportados, quanto ao que sair do Estado.

- Durante o praso de 4 annos e no periodo que decorre entre $1^{\circ}$ de junho e 30 de novembro de cada anno, ficam sujeitas ao imposto de $5 \$ 000$ por cabeca as vaccas em estado de gestacãu abatidas nas xarqueadas e nos matadouros publicos.

- Estão isentos deste imposto $(5 \$ 000)$ as vaccas velhas, ainda que em estado de gestação, abatidas nos matadouros publicos (Lei n. 170, de 17 de dezembro de 1913).

- A cobrança do imposto de $5 \$ 000$ exclue o de 200 rs., o qual, consequentemente, só é cobrado, quando aquelle não fôr devido. 
Doc 18 - 1845 (Biblioteca Pública Pelotense - Pelotas)

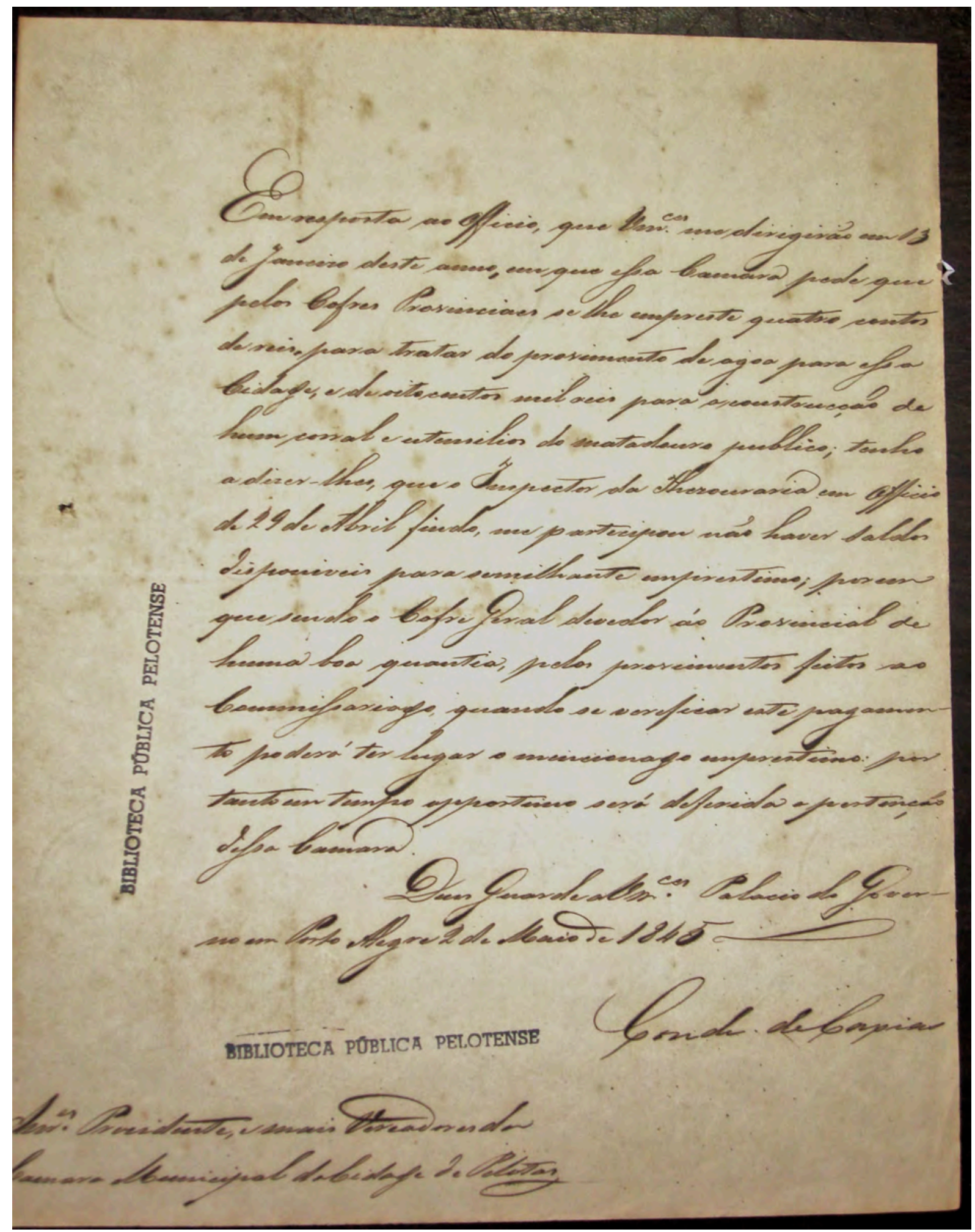


Edição doc 18 - 1845 (Biblioteca Pública Pelotense - Pelotas)

Em resposta ao officio, que vossas merces me dirigirão em 13 de janeiro deste anno, em que essa camara pede que pelos cofres provinciaes se lhe empreste quarto contos de reis, para tratar do provimento de agoa para essa cidade, e de oitocentos mil reis para a construcção de hum canal e utensilios do matadouro publico; tenho a dizer-lhes, que o imposto da thezouraria em officio de 29 de abril findo, me participou não haver saldos disponiveis para semilhante emprestimo; porem que sendo o cofre geral devedor áo provincial de huma boa quantia, pelos provimentos feitos ao commissariado quando se verificar este pagamen to poderá ter lugar o menscionado emprestimo por tanto em tempo opportuno será deferida a pesterção dessa camara.

Deus guarde a vossa merces palacio do governo em Porto Alegre 2 de maio de 1845

$$
\text { Conde de Caxias }
$$

Senhores presidente, e mais vereadores da camara municipal da cidade de Pelotas 
Doc 19 - 1844 (Biblioteca Pública Pelotense - Pelotas)

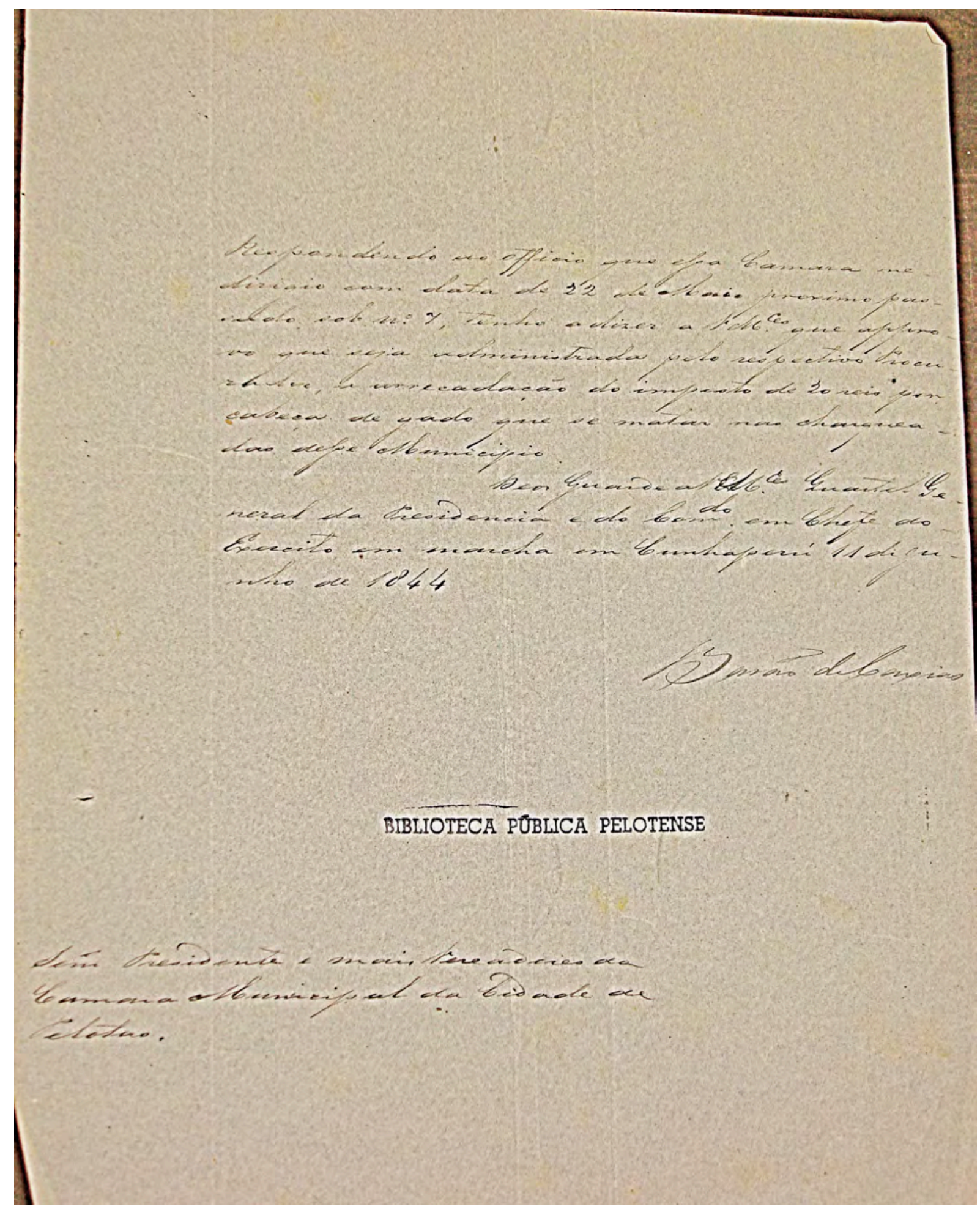


Edição doc 19 - 1844 (Biblioteca Pública Pelotense - Pelotas)

Respondendo ao officio que essa Camara me-

dirigio com data de 22 de Maio proximo pas-

sado, sob número 7, tenho a dizer a Vossa Merces que appro-

vo que seja administrada pelo respectivo Procu-

rador, a arrecadação do imposto de 20 reis por

cabeça de gado que se matar nas charquea-

das desse Municipio.

Deos guarde a Vossa Merces Quartel Ge-

neral da Presidencia e do Comando em Chefe do-

Exercito em marcha em Cunhaperú 11 di Ju-

nho de 1844

Barão de Caxias

Senhor Presidente e mais Vereadores da

Camara Municipal da Cidade de

Pelotas. 
Doc 20 - 1854 (Biblioteca Pública Pelotense - Pelotas)

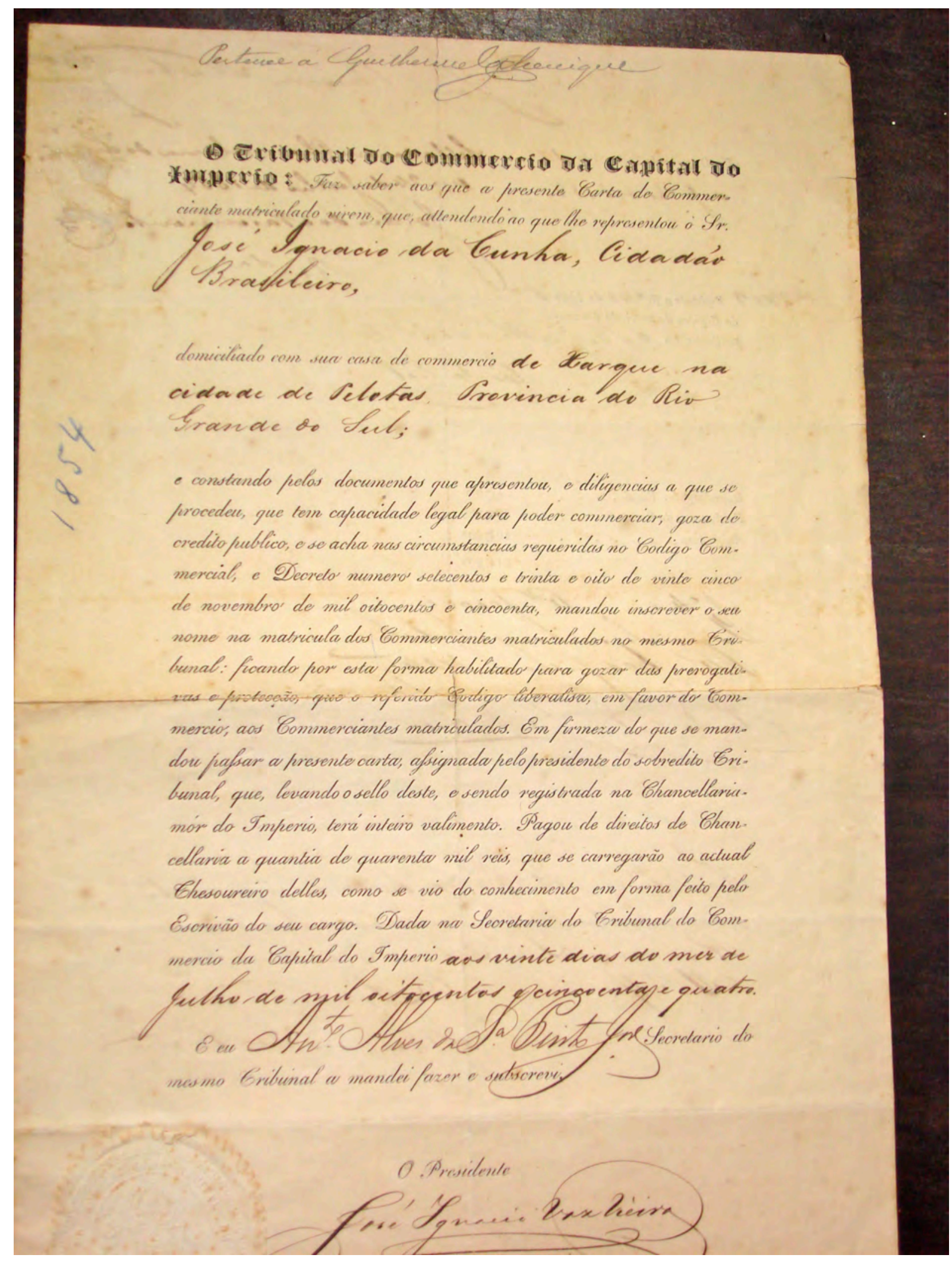


Edição doc 20 - 1854 (Biblioteca Pública Pelotense - Pelotas)

Pertence a Guilherme Echenique

O Tribunal do Commercio da Capital do

Imperio: Faz saber aos que a presente Carta do Commer-

ciante matriculado virem, que, attendendo ao que lhe representou o Senhor

José Ignacio da Cunha, Cidadão

Brasileiro,

domiciliado com sua casa de commercio de Xarque na

cidade de Pelotas, Provincia do Rio

Grande do Sul;

e constando pelos documentos que apresentou, e diligencias a que se procedeu, que tem capacidade legal para poder commerciar, goza de credito publico, e se acha nas circunstancias requeridas no Codigo Commercial, e Decreto numero setecentos e trinta e oito de vinte cinco de novembro de mil oitocentos e cincoenta, mandou inscrever o seu nome na matricula dos Commerciantes matriculados no mesmo Tribunal: ficando por esta forma habilitado para gozar das prerogativas e protecção, que o referido Codigo liberalista, em favor do Commercio, aos Commerciantes matriculados. Em firmeza do que se mandou passar a presente carta, assignada pelo presidente do sobredito Tribunal, que, levando o sello deste, e sendo registrada na Chancellariamor do Imperio, terá inteiro valimento. Pagou de direitos de Chancellaria a quantia de quarenta mil reis, que se carregarão ao actual Thesoureiro delles, como se vio do conhecimento em forma feito pelo Escrivão do seu cargo. Dada na Secretaria do Tribunal do Commercio da Capital do Imperio aos vinte dias de mez de Julho, de mil oitocentos e cincoenta e quarto. E eu Antonio Alves da Silva Pinto Jose Secretario do mesmo Tribunal a mandei fazer e subscrevi.

O Presidente José Ignacio Vaz Vieira 


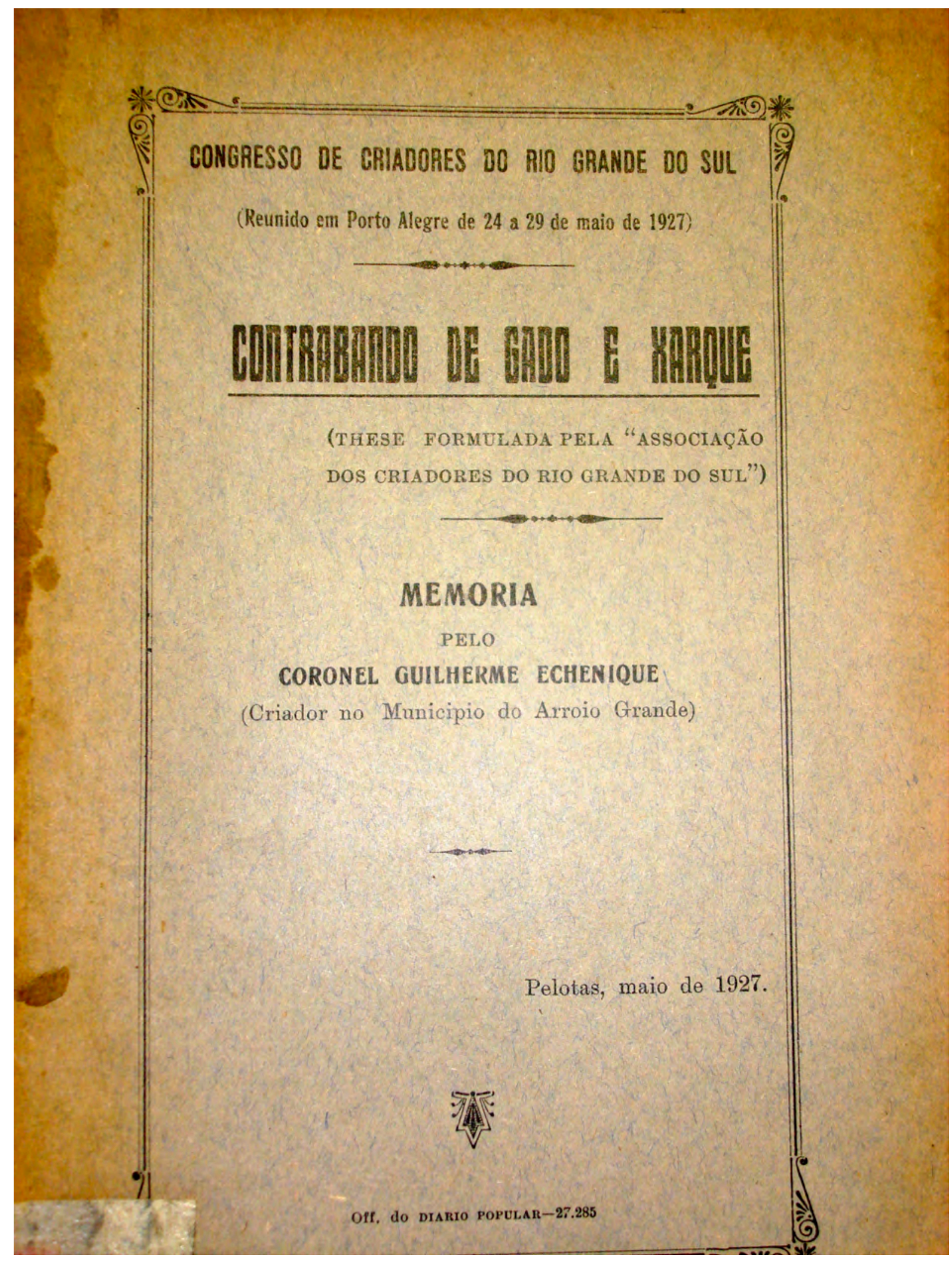


Doc 22 - 1927 (Biblioteca Pública Pelotense - Pelotas)

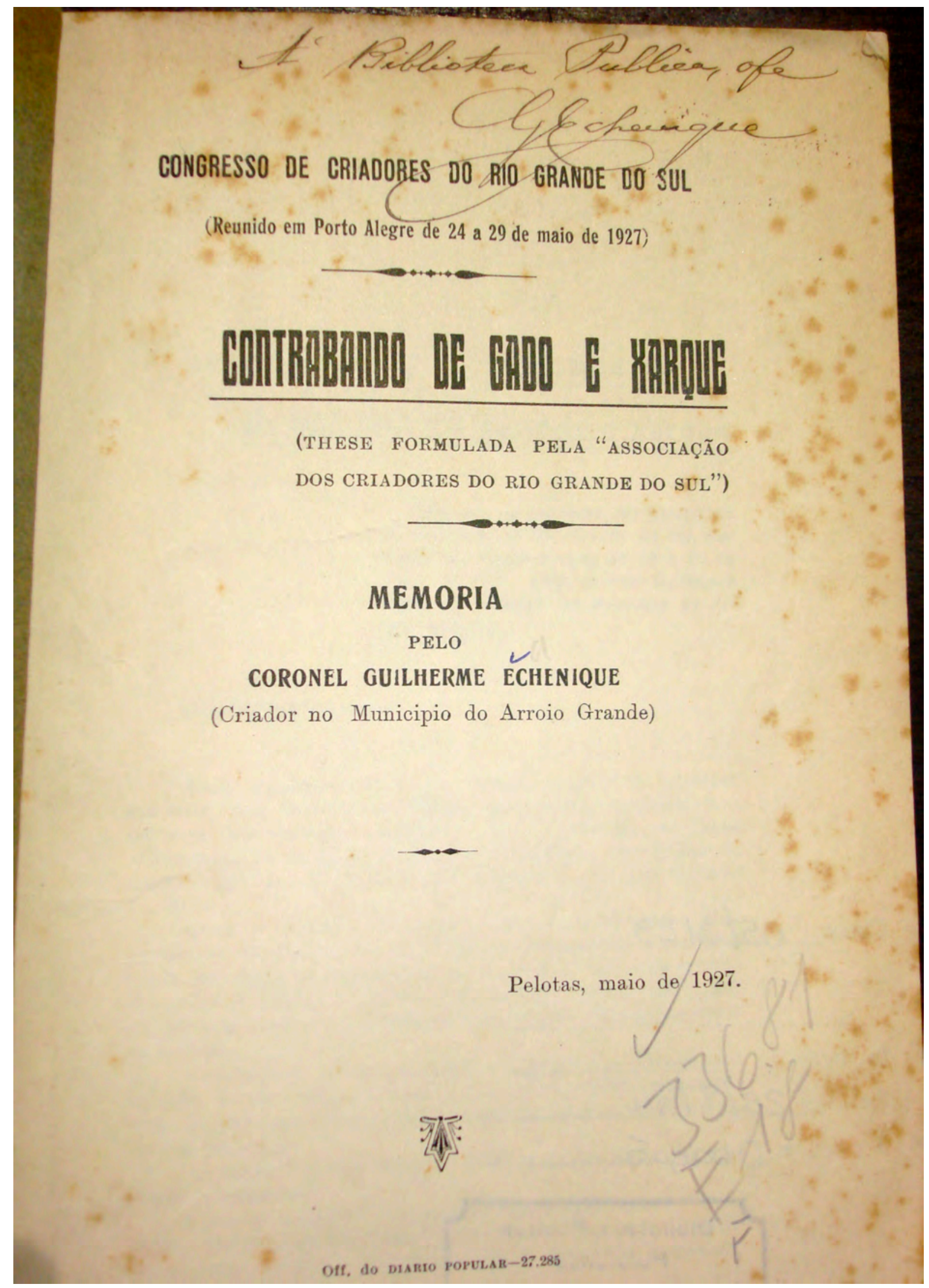




\title{
O contrabando e os impostos
}

\section{de importação de gado e xarque}

\author{
Memoria apresentada ao Congresso \\ de Criadores do Rio Grande do Sul, rea- \\ lisado em Porto Alegre, de 24 a 29 de \\ maio de 1927, pelo coronel Guilherme \\ Echenique, criador no Municipio do Ar- \\ roio Grande.
}

Srs. congressistas,

Para expôr, desde logo, o aspecto geral da questão, em suas duas faces correlativas, inseparaveis, portanto, nos pareceu consentâneo ampliar, aqui, os termos da these "Contrabando de gado e xarque» formulada na circular de convocação do "Congresso de Criadores do Rio Grande do Sul».

Com o intento de evitar, como é mister neste momento - de decisão e de acção - divagações superfluas sobre assumpto já largamente debatido, abordamos, de prompto, o termo nodal da these exarada, o impreterivel ponto de partida para a conveniente explanação do thema controvertido:

- Qual a politica economica em pratica no Brasil, com relação ás industrias nacionaes, em geral, e particularmente com as que tem vida propria, haurida na magnificente natureza patria?

- Qual o principio que a esse respeito deve ser adoptado e mantido?

- O proteccionismo, defensivo, estimulante e vivificador, que vemos imperar por toda a parte, na velha Europa como no novo continente, ou o decahido livre-cam- 
arrendados - além yuo oxpiviam, si proprios, ou a quem para os serviços de estatistica um contingente valioso prevenir o dolo e a habilitaria o Governo a No que fica a cautelar os interesses do fisco.

exposto - deixamos exaradas as suggesgado com referencia ao contrabando do gado de córte, para consumo. Tratemos do

\section{CONTRABANDO DE XARQUE}

O remedio verdadeiramente efficaz para evita-lo, que reverteria em extraordinarias vantagens para o Estado, sob multiplos sentidos, seria, sem duvida nenhuma, o já apontado por outros e tambem por nós, na memoria que, a respeito de these similhante, nos coube apresentar ao Congresso Rural, reunido em Pelotas a 13 de maio de 1926.

Nos referimos á suppressão do livre transito pelas republicas do Prata, ou - como exprimem outros - á desnacionalização dos generos de producção nacional, de qualquer naturesa, que transponham as nossas fronteiras, em demanda, através daquelles paizes, de quaesquer mercados do Brasil. 


\section{Doc 25 - 1927 (Biblioteca Pública Pelotense - Pelotas)}

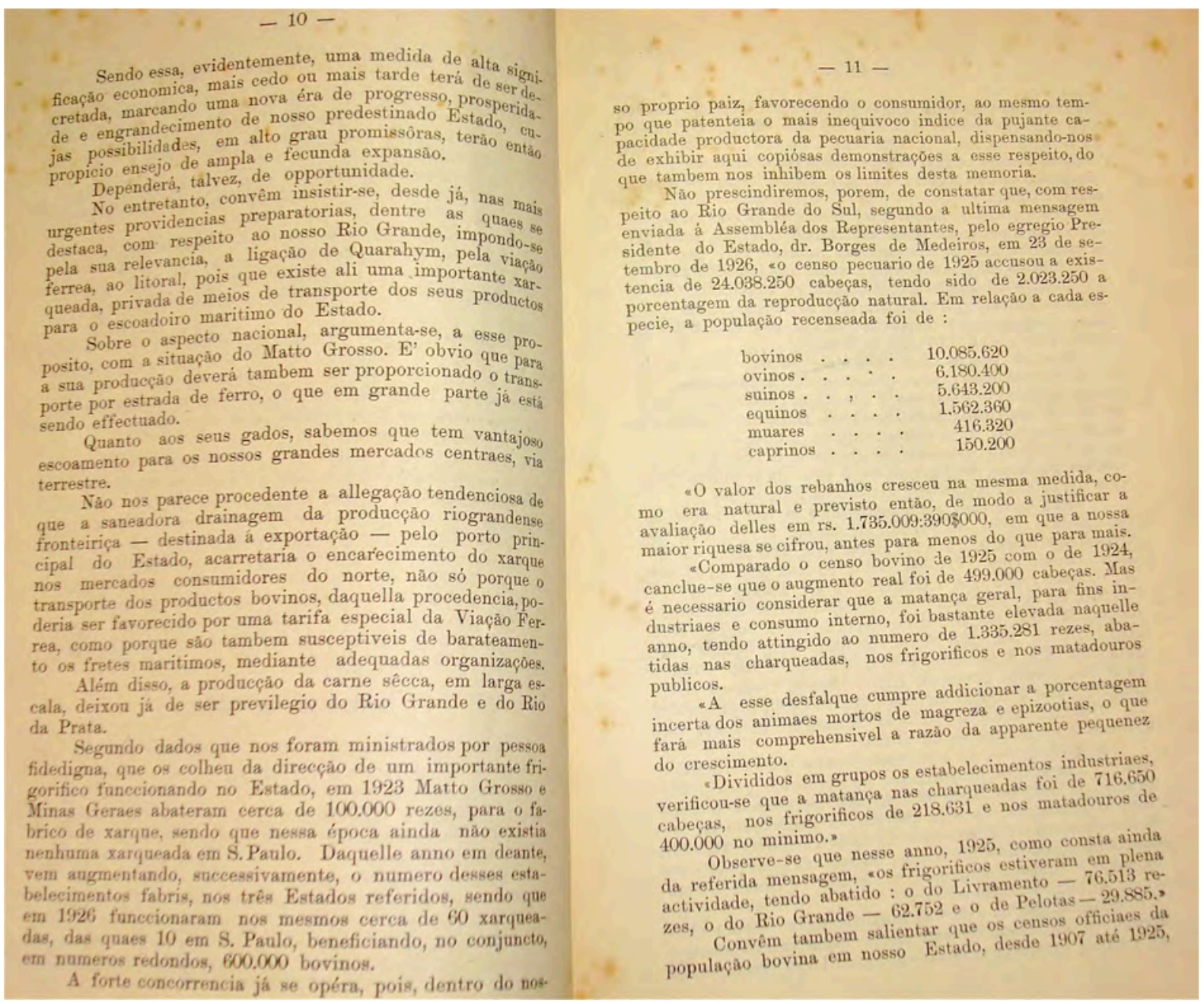


Doc 26 - 1851 (Biblioteca Pública Pelotense - Pelotas)

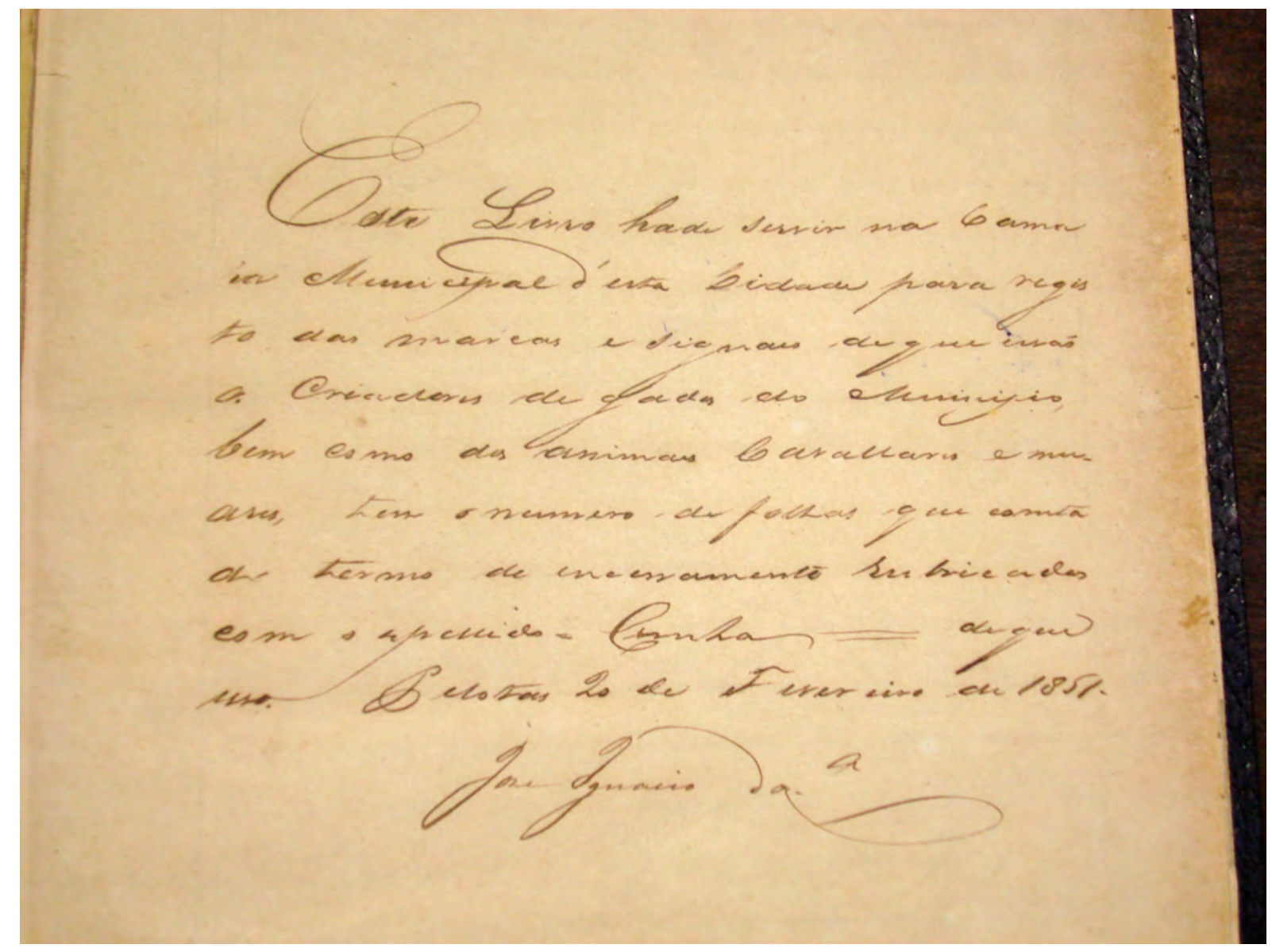


Edição 26 - 1851 (Biblioteca Pública Pelotense - Pelotas)

Este Livro ha de servir na Cama

ra Municipal d'esta Cidade para regis

to das marcas e signais de que usaõ

os Criadores de Gados do Municipio,

bem como dos animaes Cavallares e mu-

ares, tem o numero de folhas que consta

do termo de encerramento rubricados

com o apelido $=$ Cunhas $=$ de que

uso. Pelotas 20 de Fevereiro de 1851.

Jose Ignacio da [ilegível] 
Doc 27 - 1878 (Biblioteca Pública Pelotense - Pelotas)

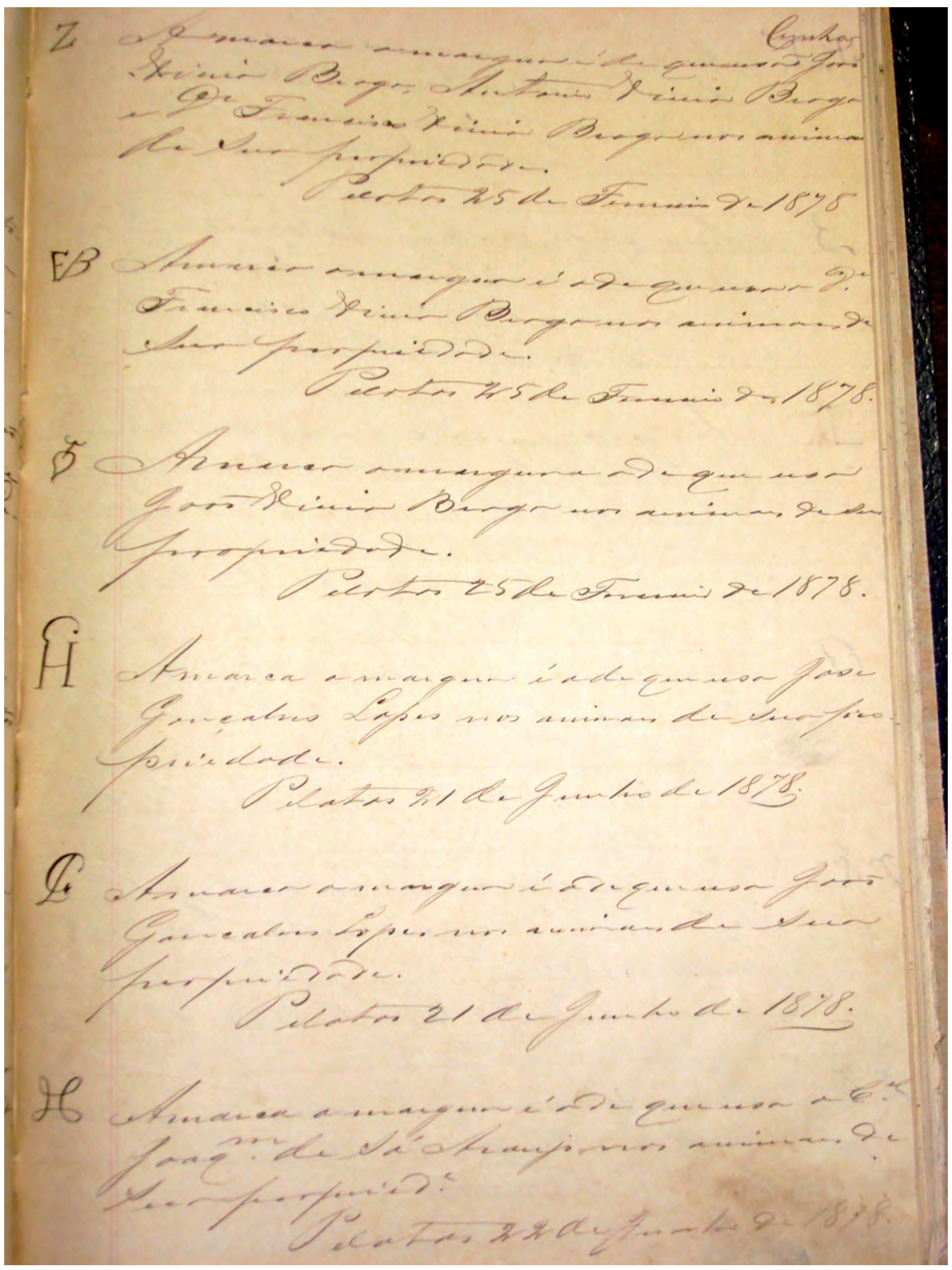


Edição doc 27 - 1878 (Biblioteca Pública Pelotense - Pelotas)

Cunhas

A marca a margem é a de que usão Joaõ

Vieira Braga, Antonio Vieira Braga

e Dona Francisca Vieira Braga nos animaes

de sua propriedade.

Pelotas 25 de Fevereiro de 1878

A marca a margem é a de que usa Dona

Francisca Vieira Braga nos animaes de sua propriedade.

Pelotas 25 de Fevereiro de 1878.

A marca a margem é a de que usa

Joaõ Vieira Braga nos animaes de sua

propriedade.

Pelotas 25 de Fevereiro de 1878.

A marca a margem é a de que usa Jose

Gonçalves Lopes nos animaes de sua pro-

priedade.

Pelotas 21 de Junho de 1878.

A marca a margem é a de que usa Joaõ

Gonçalves Lopes nos animaes de sua

propriedade.

Pelotas 21 de Junho de 1878.

A marca a margem é a de que usa o Coronel

Joaquim de Sá Araujo nos animaes de

sua propriedade.

Pelotas 22 de Junho de 1878. 
Doc 28 - 1869 (Biblioteca Pública Pelotense - Pelotas)

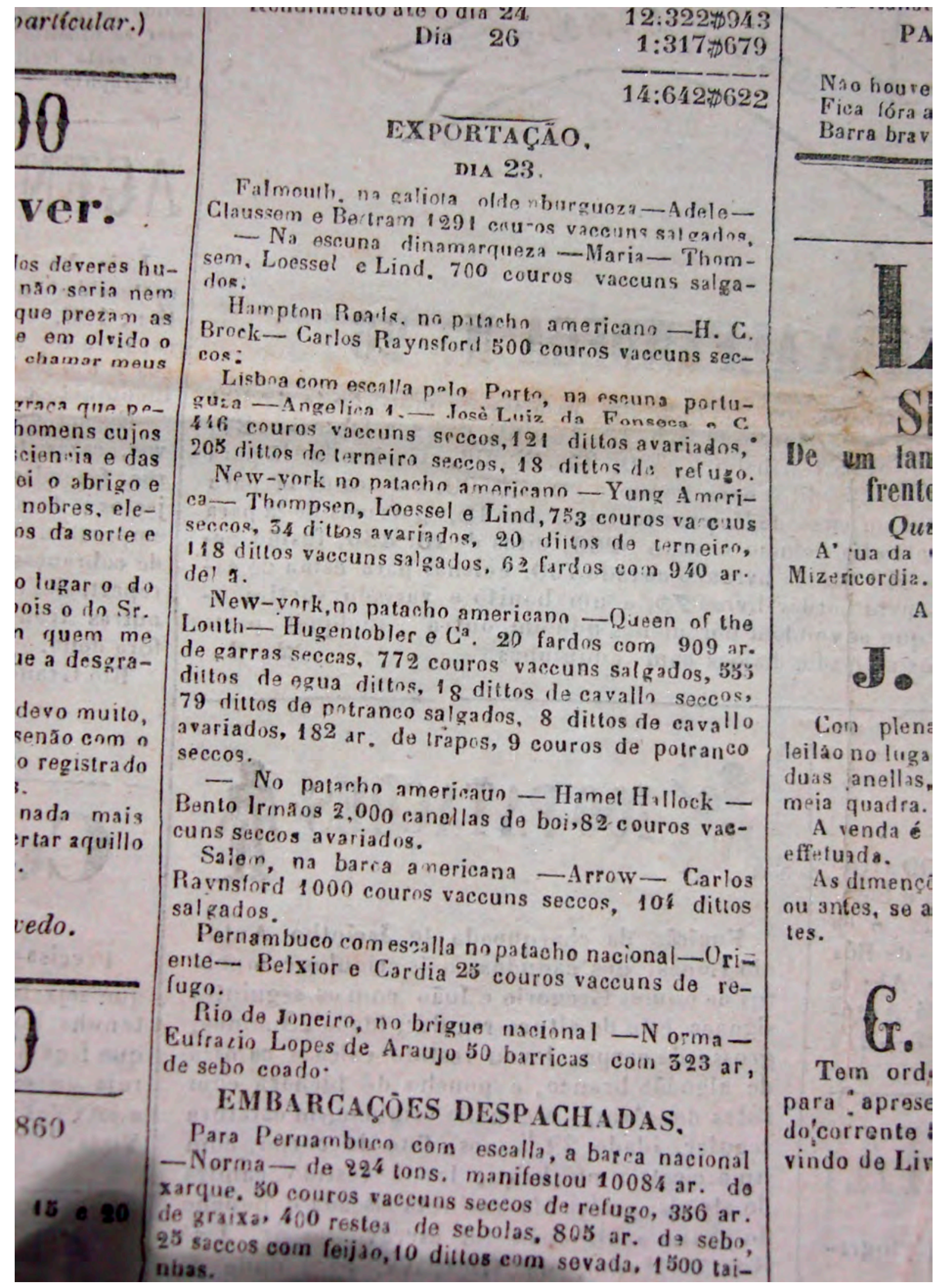


Doc 29 - 1869 (Biblioteca Pública Pelotense - Pelotas)

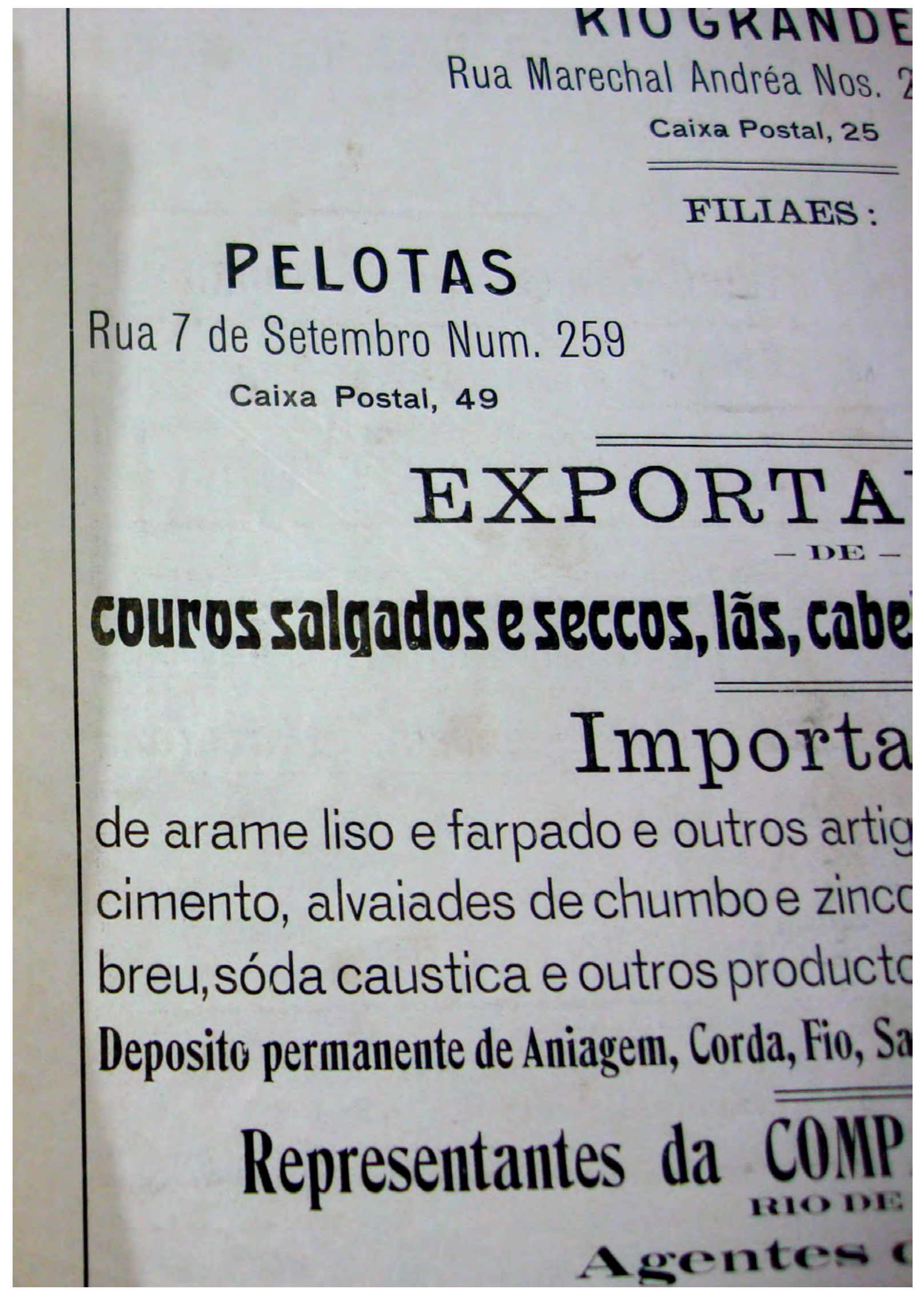


Doc 30 - 1869 (Biblioteca Pública Pelotense - Pelotas)

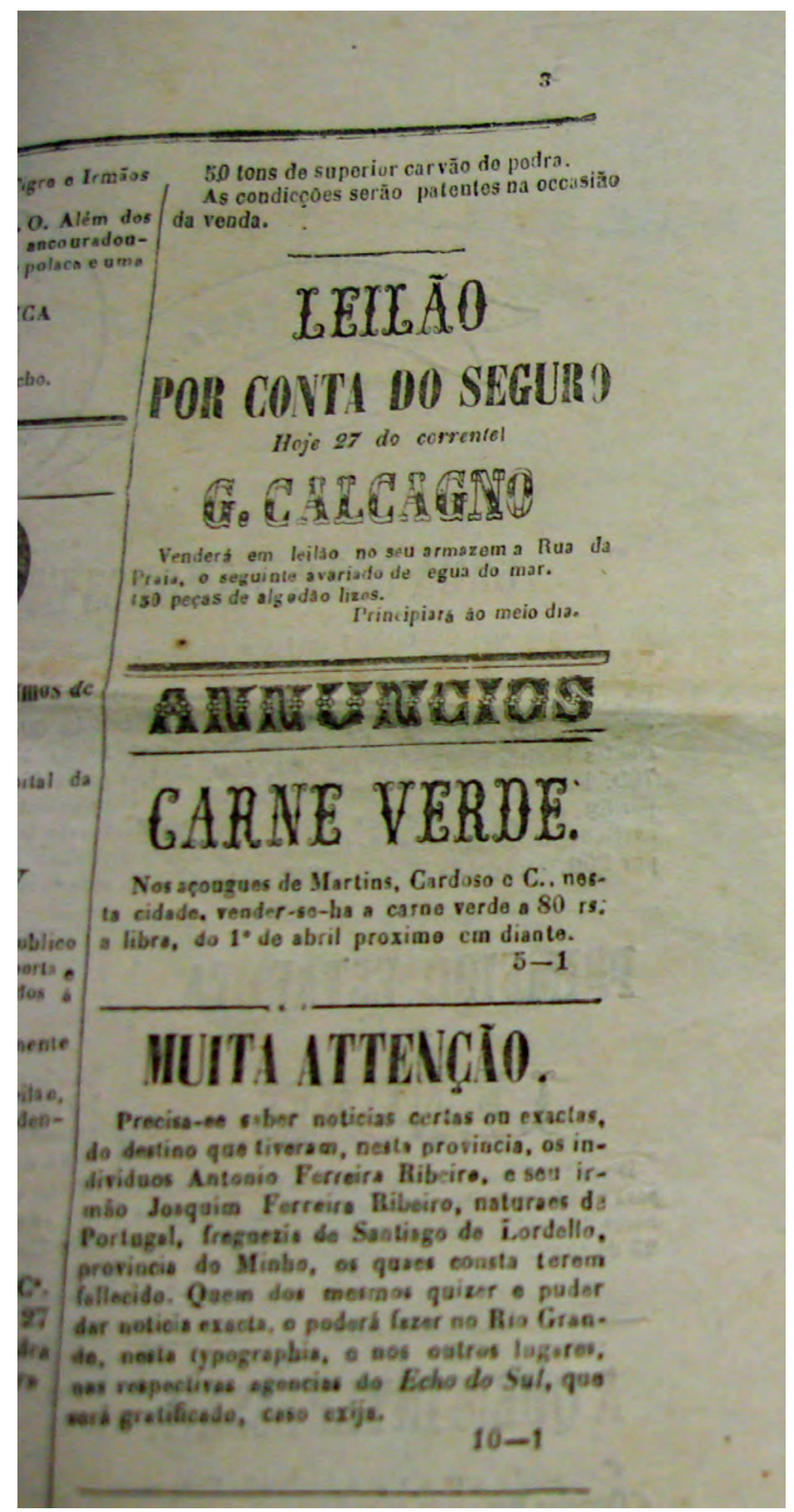




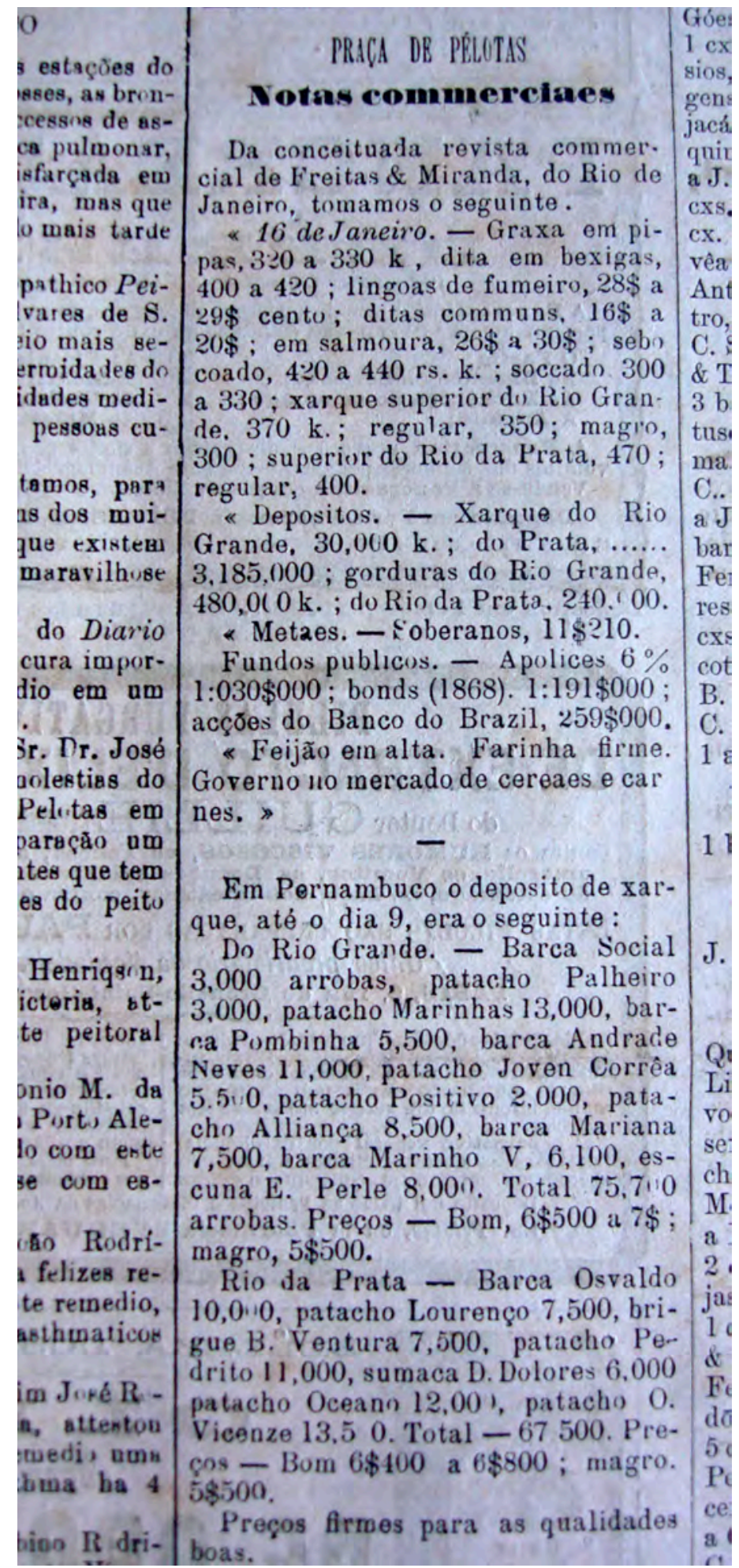




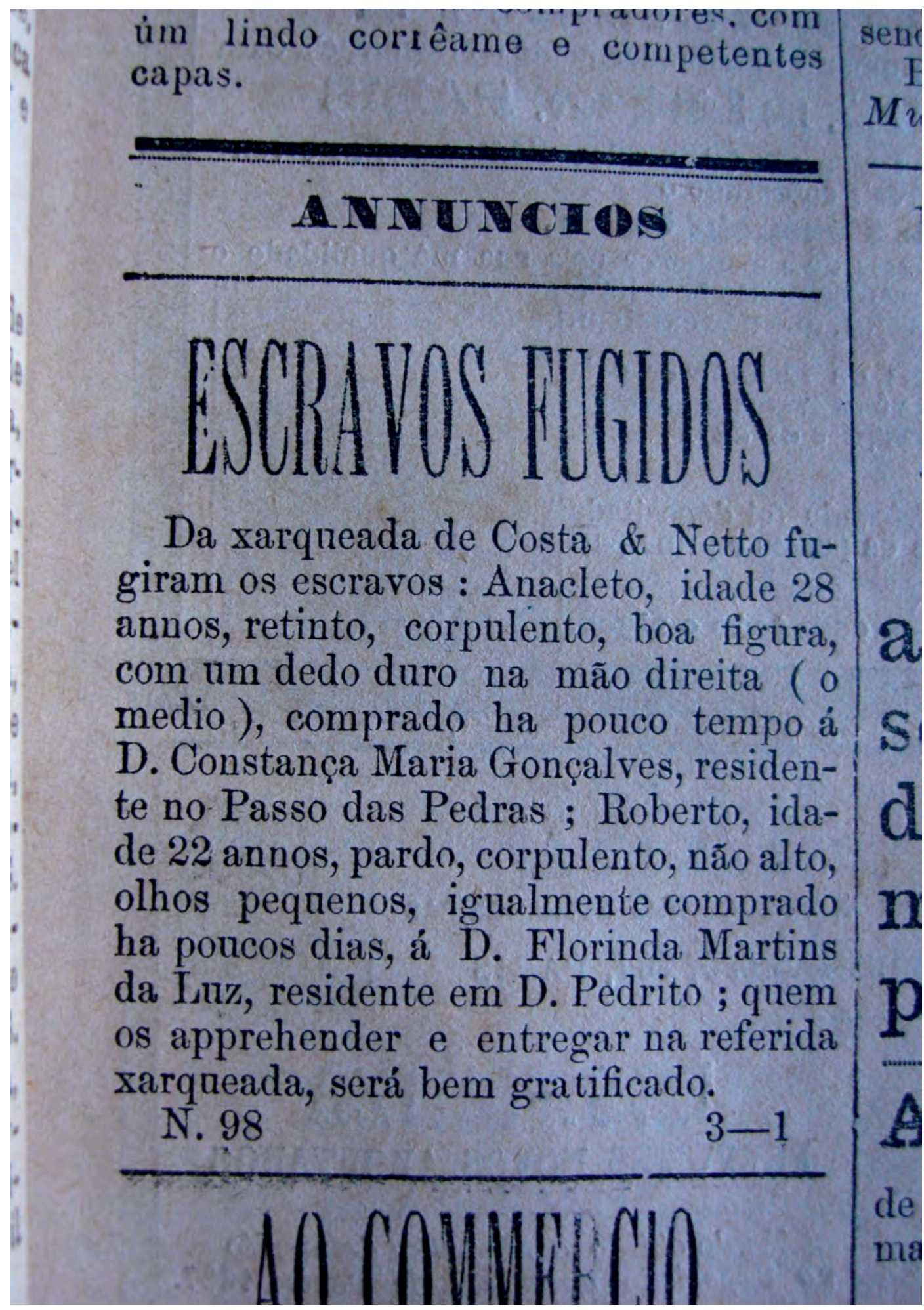


Doc 33 - 1869 (Biblioteca Pública Pelotense - Pelotas)

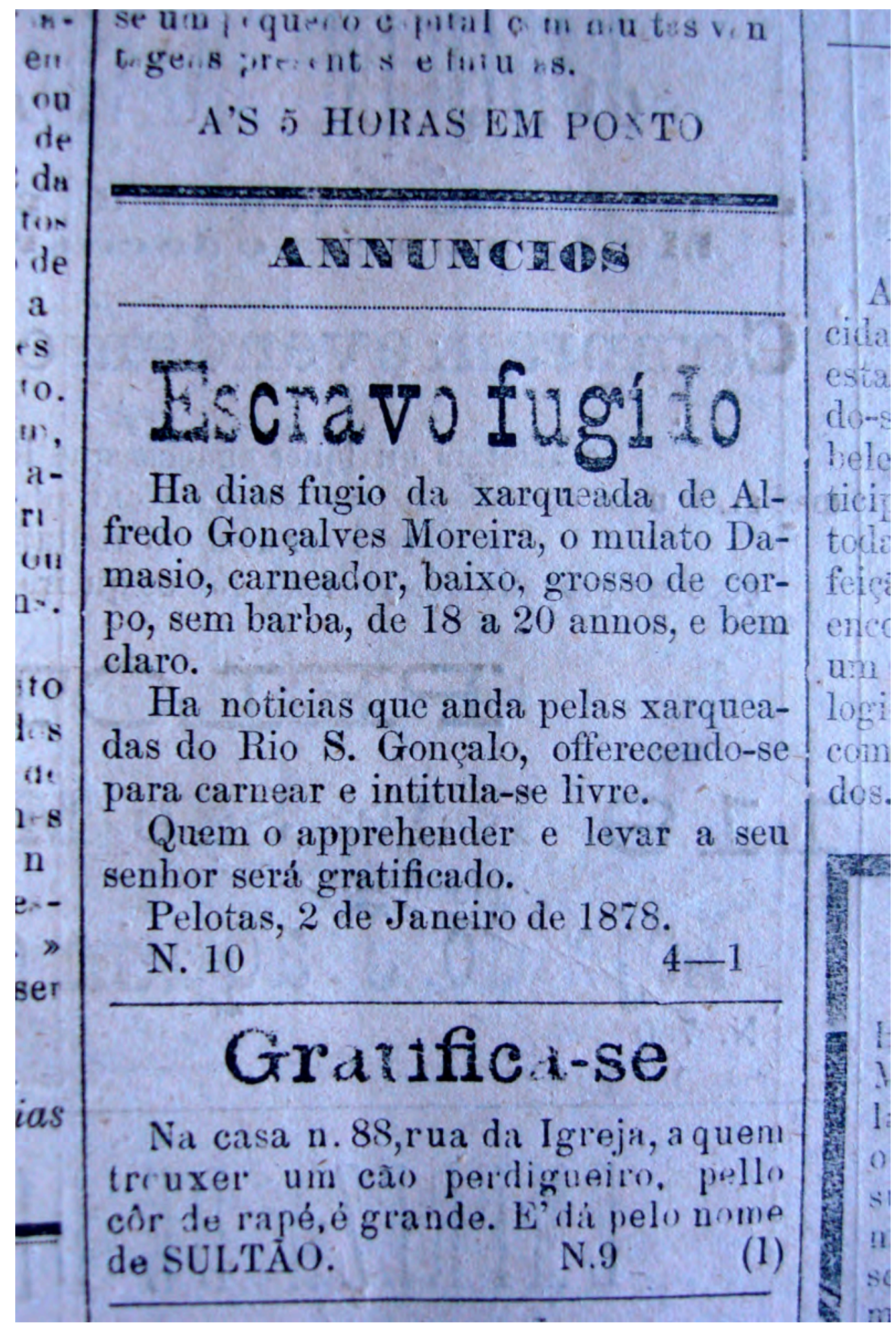




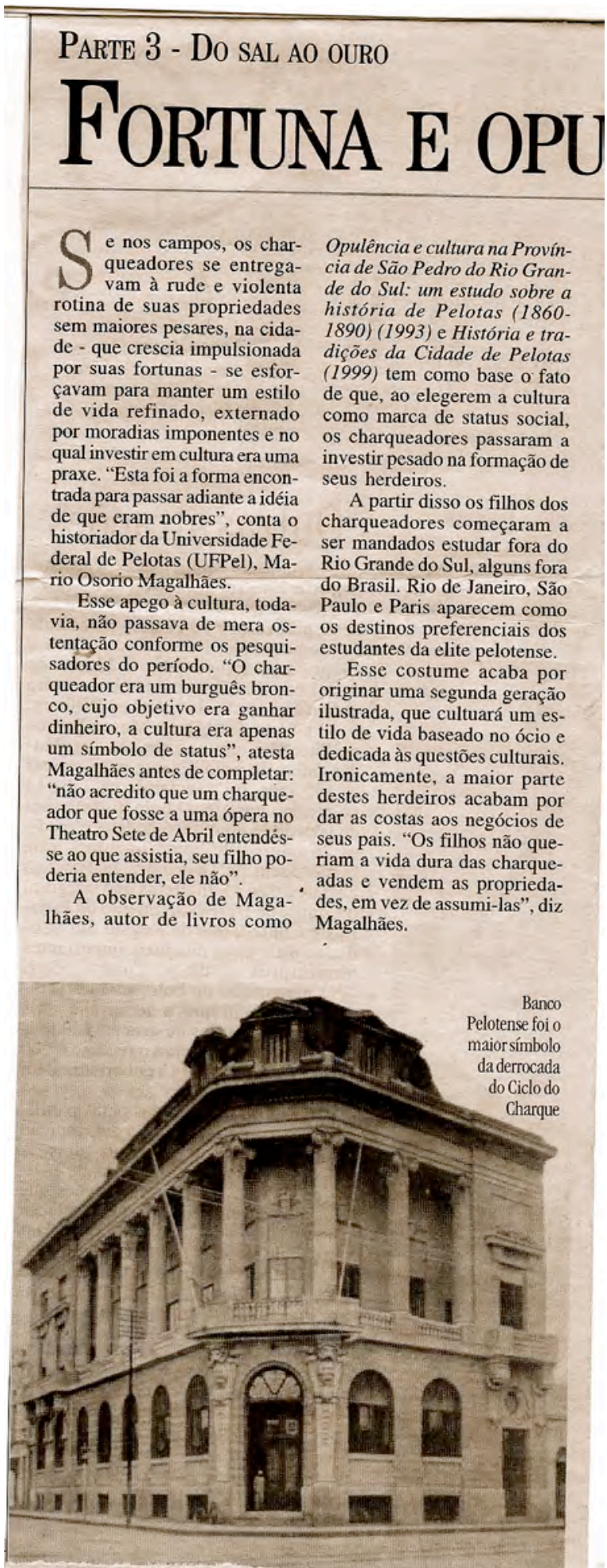




\section{JOVENS RICOS E PRIVILEGIADOS}

Essa valorização da cultura dos filhos beneficiou não apenas os homens, mas também as mulheres, que era incomum no século 19. Exemplos disso são Antonieta Cesar Dias e Rita Lobato Velho Lopes, esta filha do charqueador Francisco Lobato Lopes, que foram as primeiras mulheres a concluir o curso de Medicina no Brasil. Coube à rio-grandina Rita Lobato Lopes ser a primeira mulher brasileira a obter o diploma, no final de 1887, em Salvador, Bahia. Antonieta, que entrou para a Faculdade do Rio de Janeiro, com apenas 15 anos, formou-se dois anos depois e passou para a história como a terceira médica do País.
O ambiente favorável ao desenvolvimento da cultura e das artes, não beneficiou apenas filhos e parentes dos charqueadores pelotenses. Artistas de toda a ordem também colheram os frutos de viver em uma cidade na qual ser culto era indispensável para ascender socialmente. Entre estes "eleitos" estão a cantora lírica Zola Amaro (1891-1944), o poeta Francisco Lobo da Costa (1853-1888), o pintor Leopoldo Gotuzzo (1887-1983) e o pai da literatura regionalista gaúcha, João Simões Lopes Neto (18651916), único do grupo a descender diretamente de um charqueador, no caso João Simões Lopes, o Visconde da Graça.

\section{LIBERDADE E DECADÊNCIA}

No final do século 19 , o destino mais uma vez parece zombar dos charqueadores pelotenses, pois cabe ao pelotense Antônio Ferreira Vianna, nascido na charqueada dos Valadares, a missão de redigir o curto texto que selará para sempre o destino do Ciclo do Charque: a Lei Áurea.

Os dois artigos redigidos por Vian-

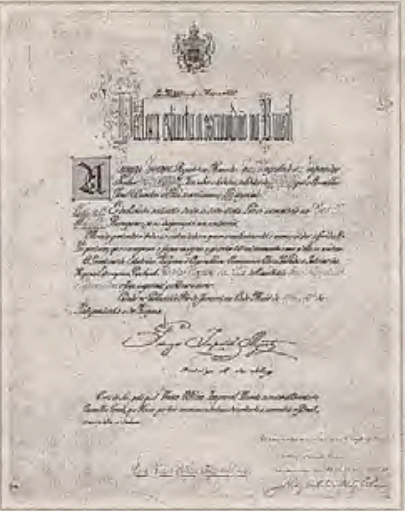

O MITO DA ALFORRIA ANTECIPADA

Ao longo das décadas criou-se o mito de que os charqueadores pelotenses haviam se antecipado à abolição. da escravatura : e na e lidos pela princesa Isabel, em 13 garantido a liberdade de seus de maio de 1888 , prezam pela conci- escravos até quatro anos ansão e, segundo os historiadores, por tes. Mas a história não foi não deixarem margens para qualquer bem assim. tipo de dúvida. "É um texto exemplar, pois embora breve não dá margens para questionamentos, porque declarou a escravidão extinta e não se pode apelar do que foi extinto", analisa o historiador Mario Osorio Magalhães

A concisăo de Vianna, todavia, desencadeou um processo de desmanche das charqueadas de Pelotas, afinal sem a mão-de-obra escrava a atividade era praticamente inviabilizada. "Além da falta dos trabalhadores, os charqueadores perderam também aqueles consumidores garantidos de seu produto", justifica Magalhães. A indisposição dos imigrantes europeus e dos trabalhadores brancos em realizar o servico aumentou ainda mais as dificuldades dos charqueadores, que agora também deveriam buscar novos marcondoc nome sus nroduraz
A partir de 1884 , alguns charqueadores locais passaram a garantir a emancipação de seus escravos, que deveria ser uma espécie de antecipação da abolição, não fosse pelo fato de que ao receber o benefício o escravo assinava um contrato pelo qual se comprometia em continuar a prestar serviços ao seu senhor por mais sete anos como forma de pagar a "dívida" de casa e comida contraída ao longo da vida. Desse modo permaneceriam cativos até 1891 , ou seja, três anos após a aboliçăo. "Os charqueadores desejam manter o sistema escravista, só não o fizeram porque com a abolição isso se tornou impossível", argumenta 0 historiador da Universidade Federal de Pelotas, Agostinho Dalla Vecchia.

Poucos anos depois da abolição as primeiras porteiras de charqueadas começam a fechar definitivamente. $\mathrm{O}$ ciclo que regeu a economia gaúcha por mais de um século e teve seu auge entre 1860 e 1890 começava a se aproximar do fim.

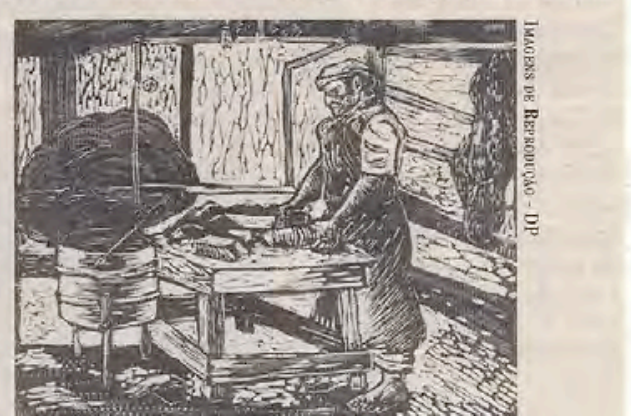




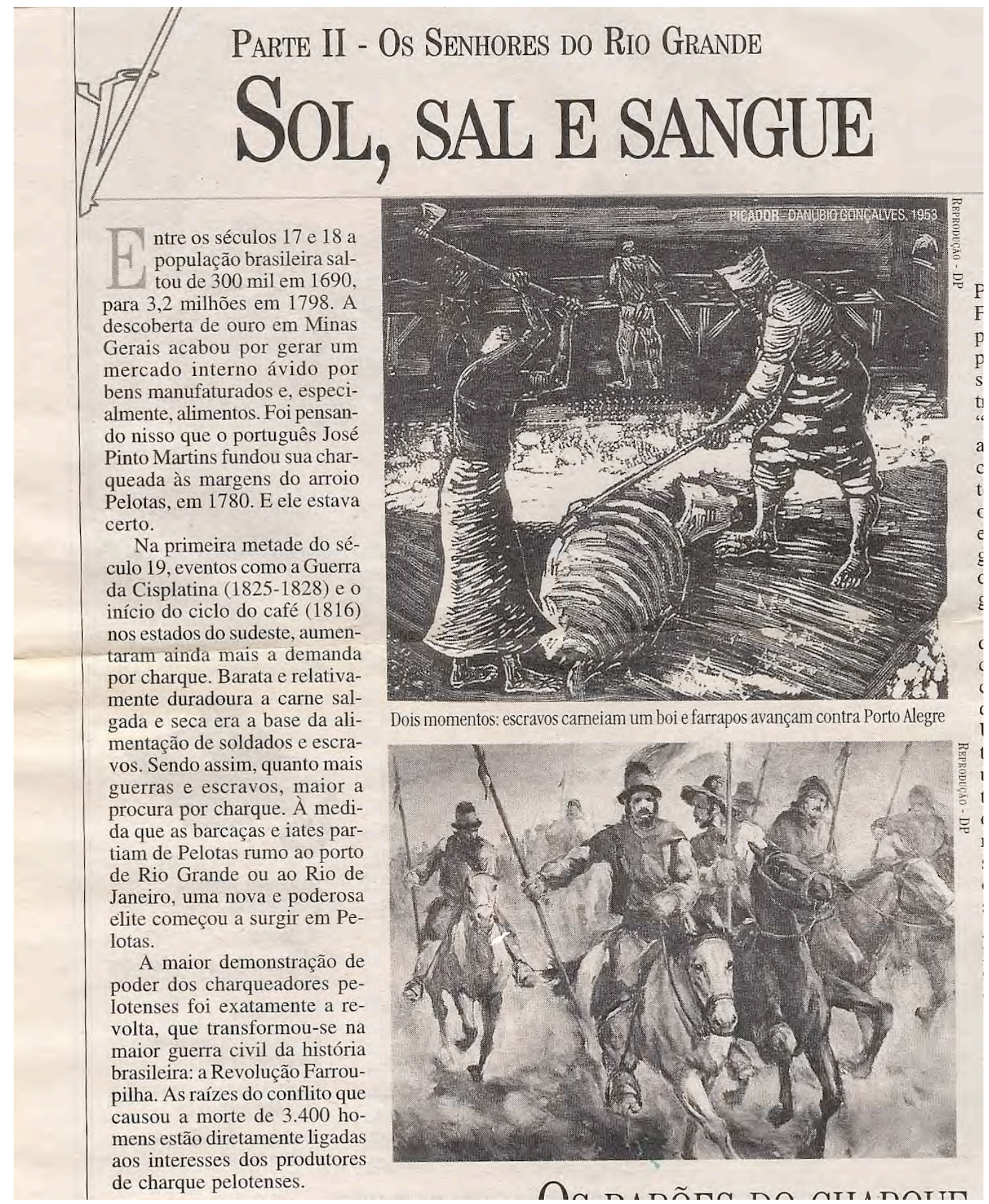


Doc 37 - 2007 (Jornal Diário Popular - Pelotas)

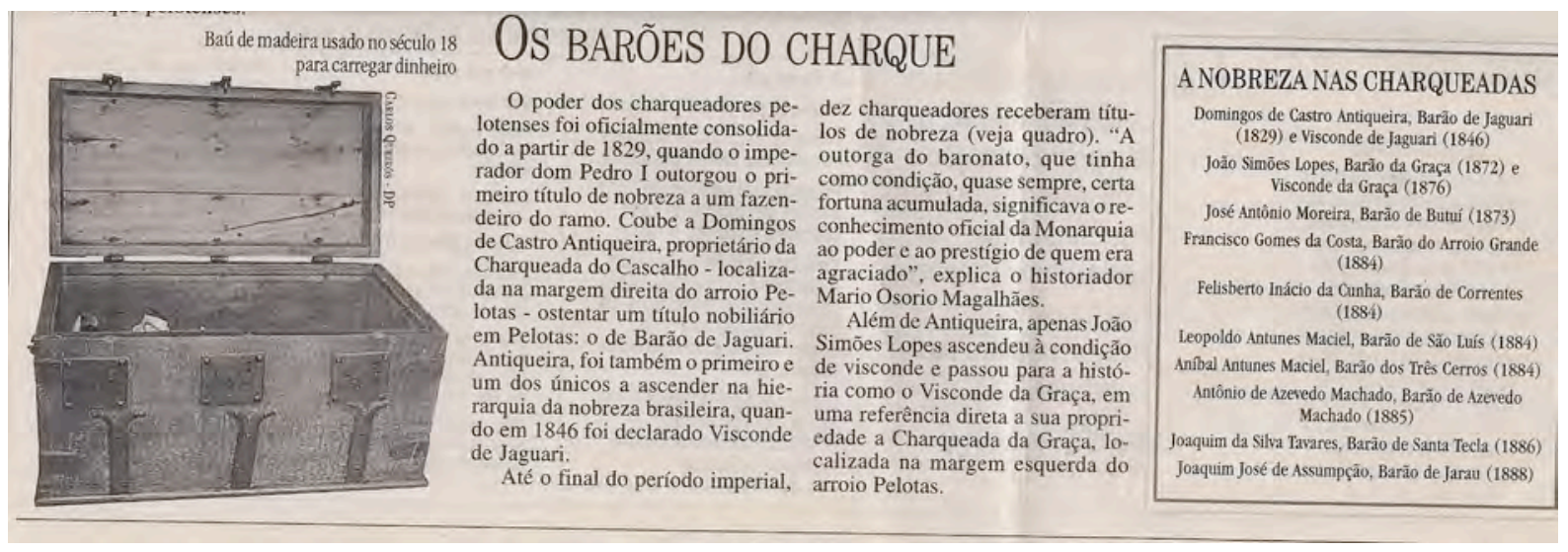




\section{REVOLUÇÃO DE INTERESSES}

Conforme o historiador José Plínio Fachel da Universidade Federal de Pelotas (UFPel) a partir da independência da República do Uruguai estabeleceuse um conflito de interesses entre charqueadores e estancieiros. "Os produtores de gado insistiam em ter livre acesso às terras compradas no país vizinho antes da independência, enquanto os charqueadores de Pelotas eram contrários ao envio de gado gaúcho para o Uruguai e defendiam um controle mais rígido das fronteiras", explica.

A partir da pressão dos charqueadores, o governo imperial começou a instalar postos de controle (aduanas) na fronteira do Rio Grande do Sul com o Uruguai. Em 1831, quatro postos foram montados para cobrar uma taxa de $2 \%$ sobre o gado transportado para o Uruguai e de $15 \%$ sobre toda a mercadoria que fosse importada, inclusive, o gado. Para os charqueadores, no entanto, o tiro havia saído pela culatra. A entrada do gado uruguaio era indispensável para a manutenção de suas indústrias e a taxa de importação cobrada, aumentava significativamente os custos do negócio.

A soma da questão dos postos de fronteira com as queixas de falta de investimentos na infra-estrutura da província explodiu no 20 de setembro de 1835 , quando o estancieiro e general
Bento Gonçalves da Silva, invadiu Porto Alegre à frente de um exército de 400 homens para derrubar o presidente da província, Antônio Rodrigues Fernandes Braga e o chefe-das-Armas (comandante do exército), marechal Sebastião Pereira Pinto. Entre os comandantes da revolta, estava o charqueador pelotense, Domingos José de Almeida.

\section{TEMPO DE GUERRA}

Durante os primeiros meses, a revolução contou com apoio substancial dos charqueadores pelotenses, que começaram a abandonar as fileiras revolucionárias a partir da segunda metade da guerra, quando o governo farroupilha proibiu a atividade de produção do charque por entender que o boi em pé era um produto mais fácil de ser controlado. "Neste momento os farrapos se declaram mais pecuaristas do que charqueadores", comenta o historiador José Fachel.

Quando Luís Alves de Lima e Silva, o Duque de Caxias, assumiu o controle das tropas imperiais que combatiam os farrapos, em 1842, os charqueadores se retiraram de vez da revolução. "A partir desse momento Pelotas e sua elite passaram a ser imperiais e assim permaneceram até o fim do conflito", atesta. 
Doc 39 - 2007 (Jornal Diário Popular - Pelotas)

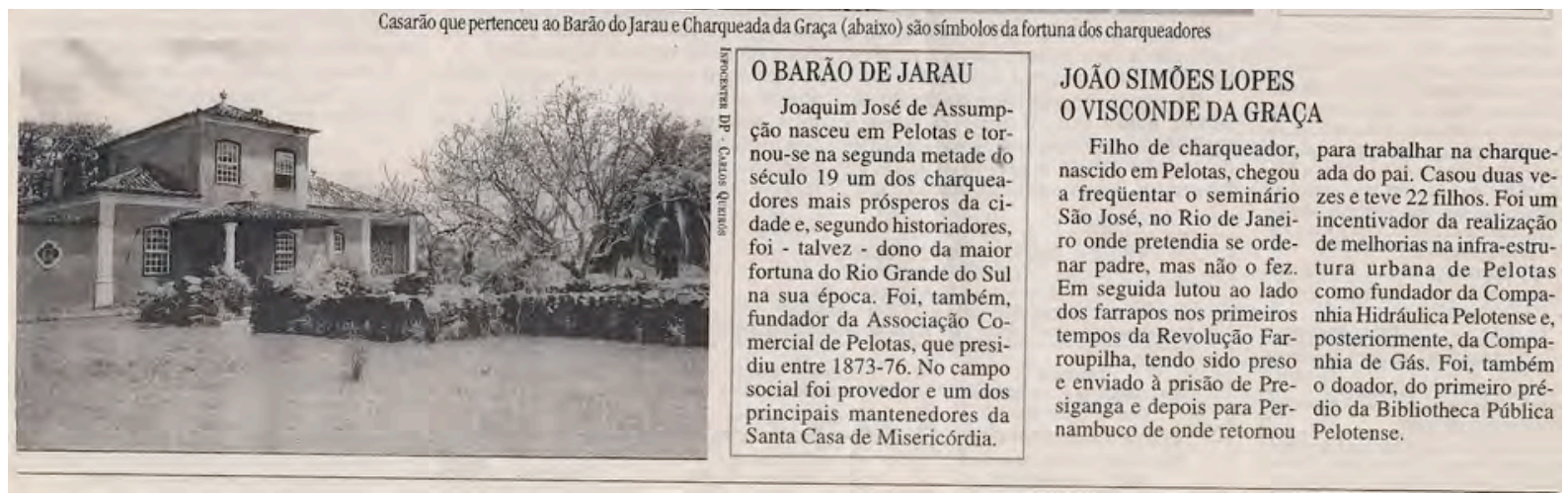




\section{Parte 1 - Os Pioneiros \\ 1777: 0 ANO QUE MUDOU A HISTÓRIA DO Rio GRANDE}

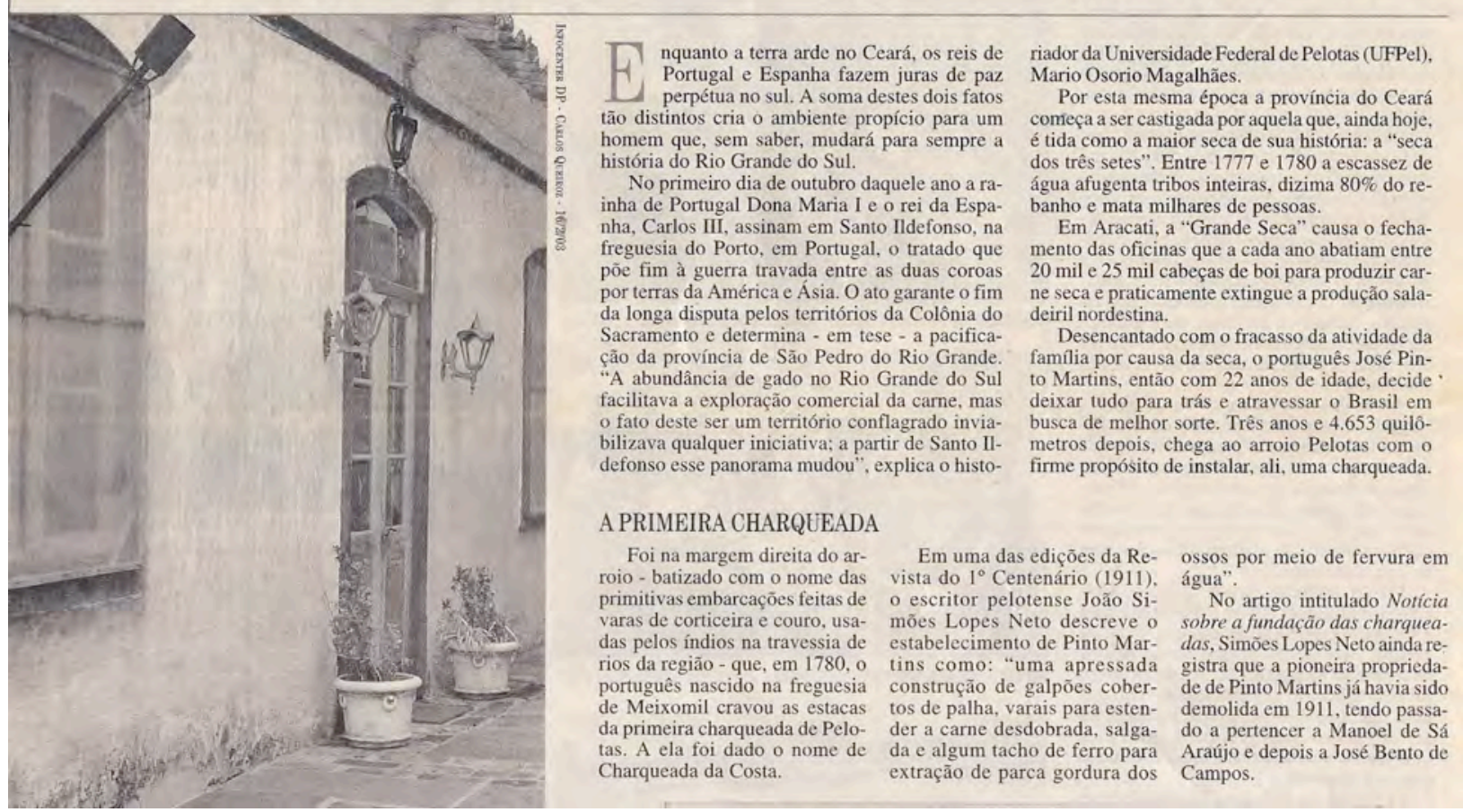


Doc 41 - 2007 (Jornal Diário Popular - Pelotas)

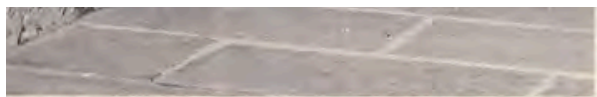

Detalhe da fachada da charqueada São João fundada por Gonçalves Chaves

FILHOS SIM, HERDEIROS NÃO

Os registros biográficos de Pinto Martins são poucos. Além de suas origens, que remontam a Portugal de onde partiu ainda criança e o vínculo de sua famflia com Aracati e a produção de carne seca pouco se sabe sobre o jovem empreendedor que cortou o Brasil de norte a sul para fazer fortuna.

Pesquisadores e historiadores que se debruçaram sobre sua vida registram que morreu solteiro, mas teve três filhos, todos com escravas alforriadas. "O curioso é que nenhuma delas havia sido sua escrava", aponta historiador Mario Osorio Magalhães. Pinto Martins morreu com 71 anos, no dia 18 de junho de 1827 , e seu corpo foi sepultado na capela da Ordem Terceira de Nossa Senhora do Carmo, na vila de Rio Grande.

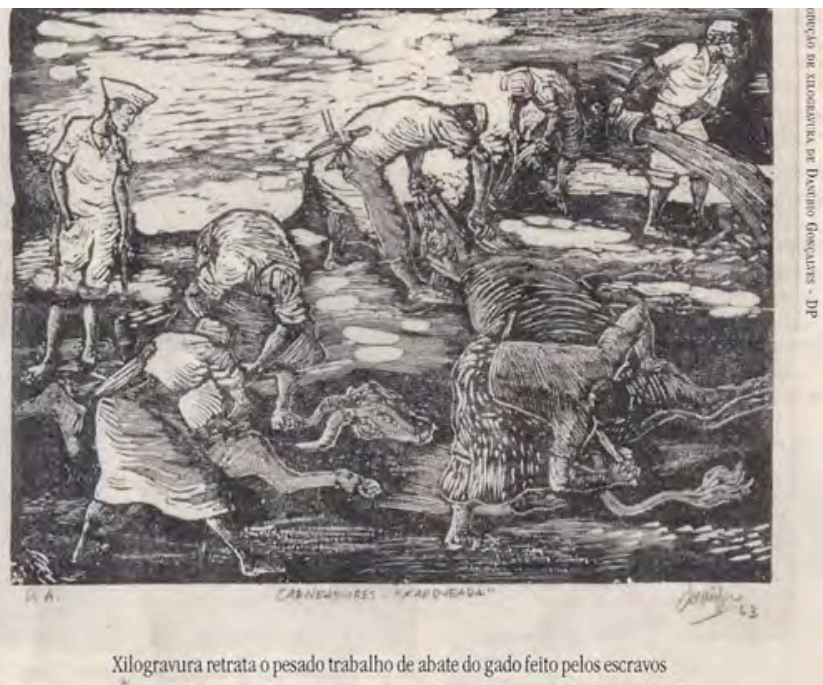


Doc 42 - 2007 (Jornal Diário Popular - Pelotas)

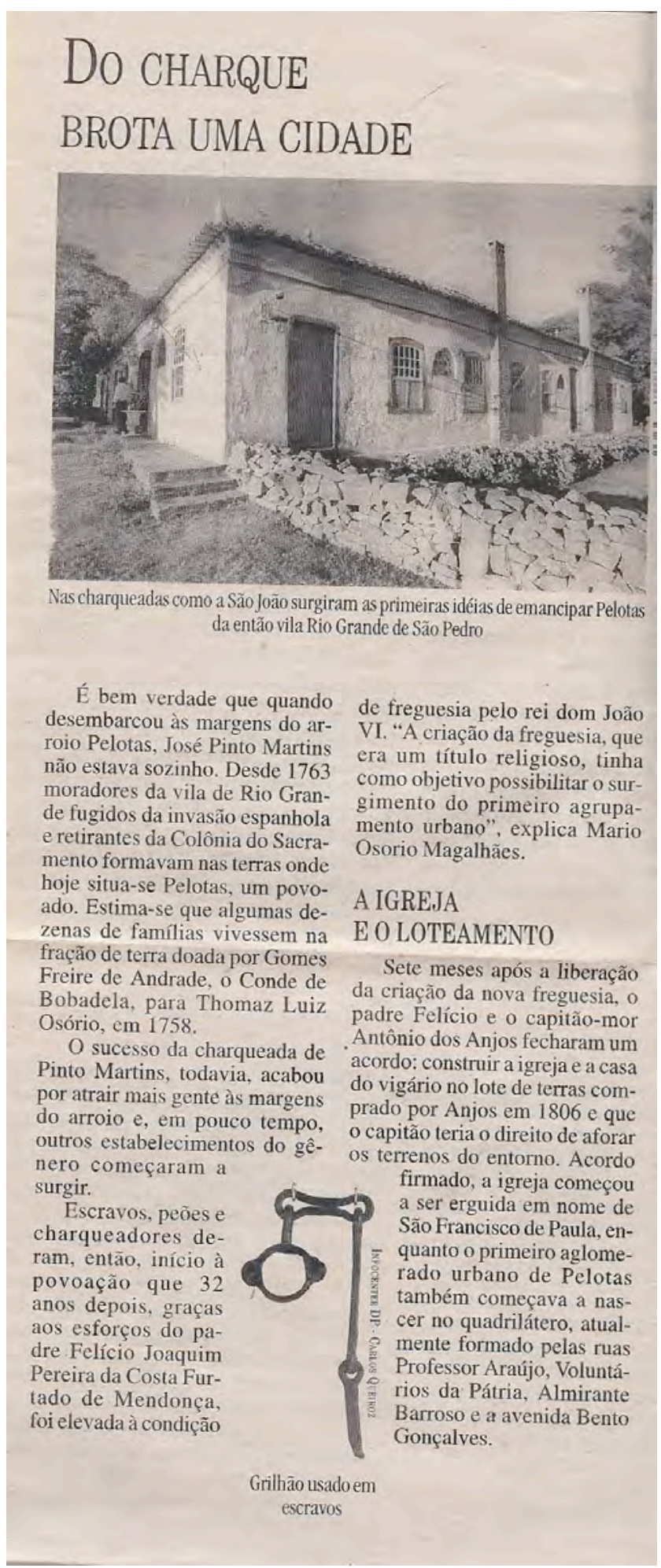




\section{GonÇALves Chaves - Uma eXCEÇÃo entre Seus PARes}

Português nascido em Vila Verde do Ouro, Antônio José Gonçalves Chaves foi um dos pioneiros da atividade saladeiril no sul do Rio Grande. Em 1810 , fundou na margem direita do arroio Pelotas a charqueada São João, uma das mais prósperas da primeira metade do século 19. Culto e liberal, Gonçalves Chaves foi uma exceção entre seus pares.

Em 1822, editou o livro Memórias ecônomo-políticas sobre a administração pública do brasil, no qual analisa a economia e a administração pública brasileira.

Dez anos depois, associouse a outros dois charqueadores - Domingos José de Almeida e José Vieira Viana - em um projeto inédito: construir o primeiro barco a vapor do Rio Grande do Sul. A barca, batizada de Liberal - em uma alusão aos ideais políticos pelos quais se norteava - singrou as águas da Lagoa dos Patos impulsionada por um motor importado dos Estados Unidos até ser confiscada pelo governo imperial durante a Revolução Farroupilha.

Antes de morrer tragicamente durante uma travessia no rio da Prata, no Uruguai, Gonçalves Chaves ainda foi deputado provincial ao lado de Domingos de Almeida e defensor da abolição dos escravos.

\section{Domingos de AlmeidA - O MineIRO QUE VIROU GAÚCHO}

Mineiro de Arraial do Tijuco (hoje Diamantina), José Domingos de Almeida aportou em Pelotas em 1819, como tropeiro em busca de mulas para revender nas Minas Gerais. Entre e idas e vindas, três anos depois, decidiu fixar residência na jovem freguesia.

Intelectual autodidata e liberal convicto, em

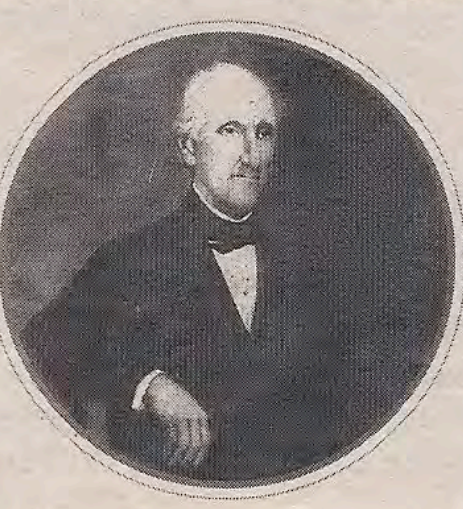
pouco tempo encontrou no poderoso Antônio Gonçalves Chaves a companhia perfeita para longas horas de conversas e trocas de idéias. A amizade abriu-lhe portas e facilitou o casamento com Bernardina Barcelos de Lima, filha de uma próspera família de charqueadores e inseriu-o de vez na elite da futura cidade de Pelotas.

Dono de um gênio inventivo, Domingos de Almeida dedicou tempo e dinheiro na construção de equipamentos capazes de modernizar sua charqueada e facilitar o trabalho. Foi o caso das tinas digeridoras (equipamentos que separavam a graxa dos ossos e possibilitavam o uso do subproduto para a manufatura de velas e sabão) e do uso da energia a vapor para o beneficiamento da carne.

Suas idéias e seu talento para os negócios fizeram de sua propriedade um modelo a ser seguido pelos demais charqueadores das margens do arroio Pelotas. "Domingos de Almeida era um intelectual autodidata que ousou e esteve sempre à frente de seu tempo", atesta a historiadora Carmen Burgert Schiavon, da Universidade Católica de Pelotas (UCPel) e autora do livro Do- mingos de Almeida - Um marco na História rio-grandense (2001).

\section{O IDEALIZADOR DE UMA NAÇÃO}

$\mathrm{O}$ amor pela arte da política e o idealismo liberal e republicano levaram Domingos de Almeida à assembléia provincial no início da década de 1830 e ao convívio dos futuros líderes daquela que seria a maior guerra civil da História brasileira: a Revolução Farroupilha.

Foi uma carta escrita por Domingos de Almeida em 1836 , que convenceu o general Antônio de Souza Neto a proclamar a República Riograndense, nos campos de Seival, no dia 11 de setembro daquele ano. Foi também o grande pensador e o principal financiador da utópica república surgida no pampa que, nove anos depois, sucumbiu diante da força das tropas do Império do Brasil. 
Doc 44 - 2007 (Jornal Diário Popular - Pelotas)

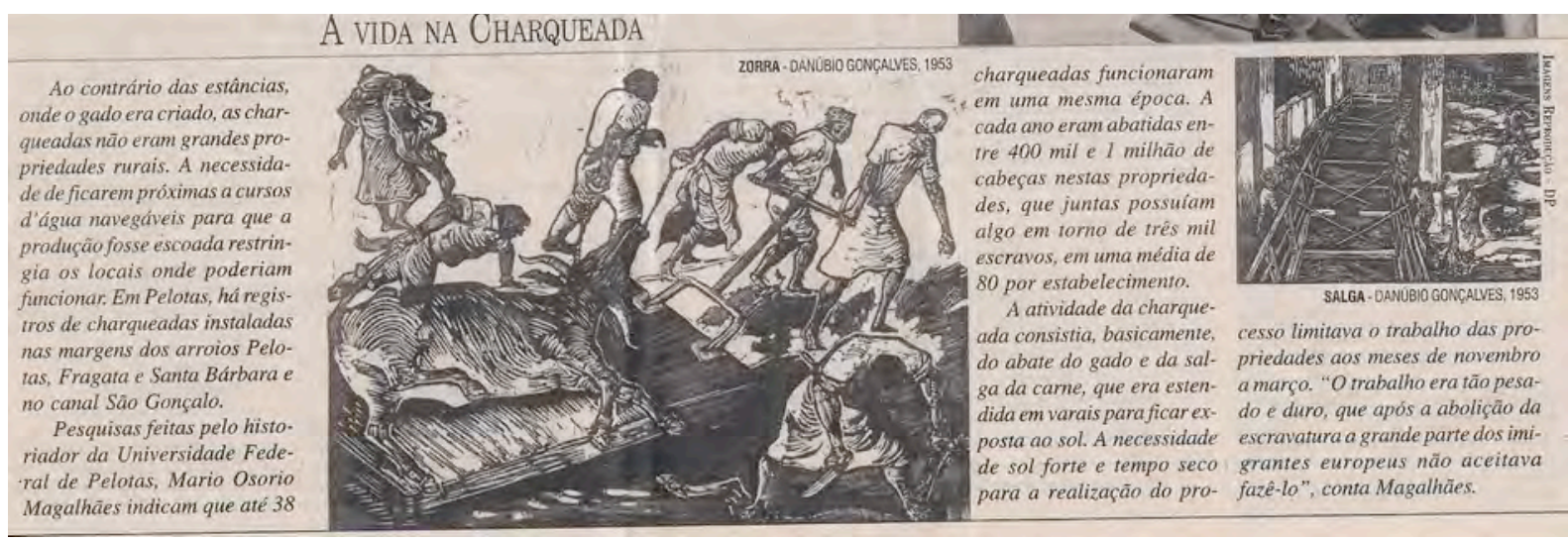


Doc 45 - 2007 (Jornal Diário Popular - Pelotas)

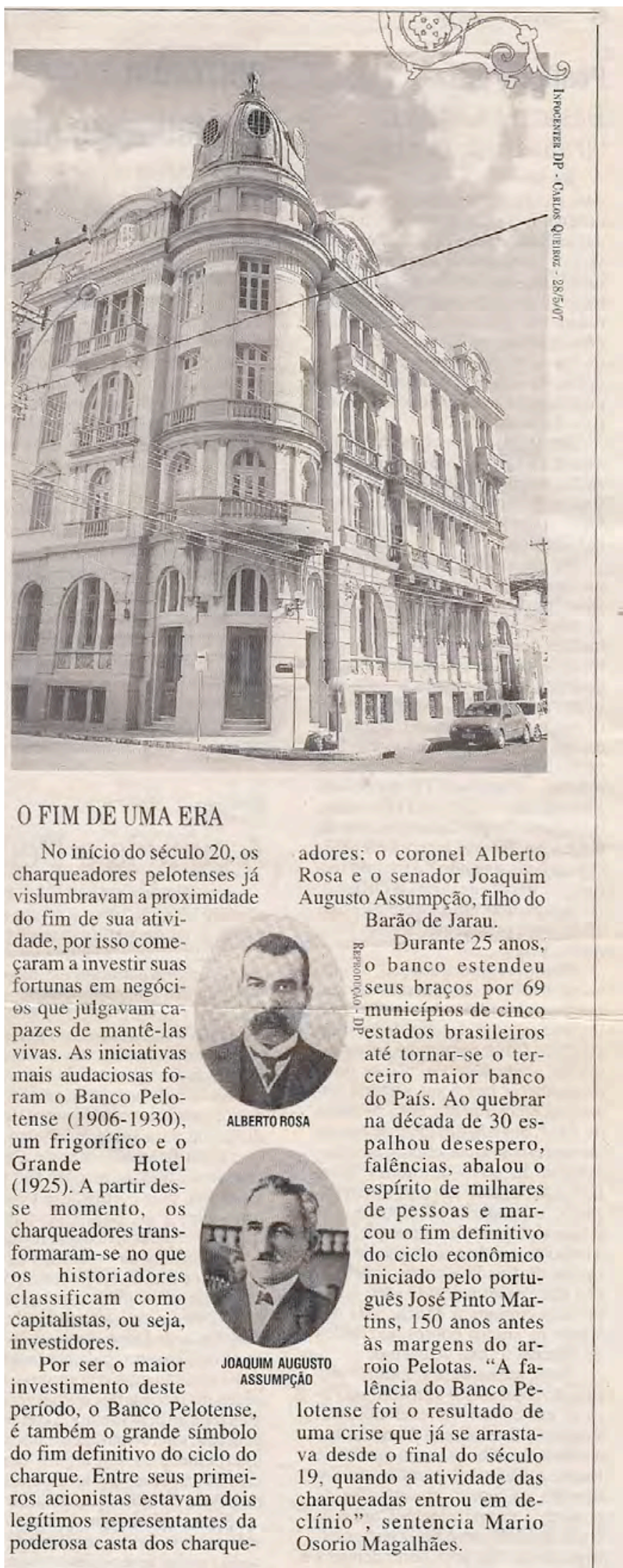




\section{DE CHARQUEADORES A CAPITALISTAS}

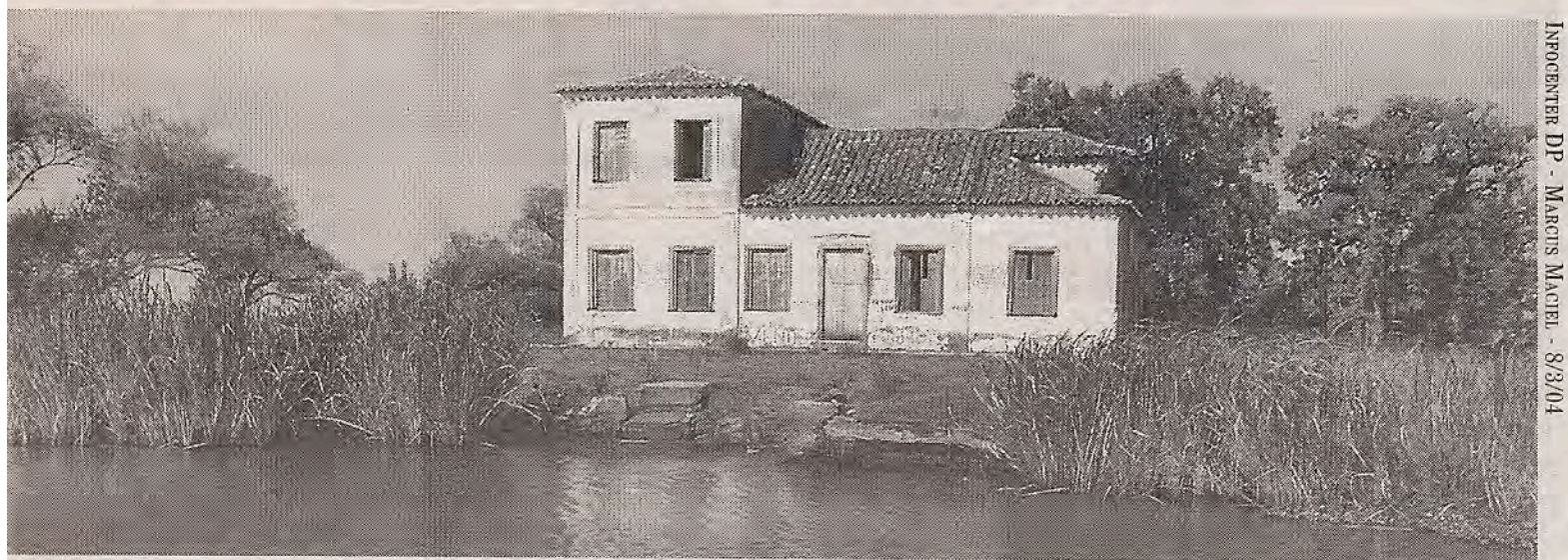

Charqueada do Barão do Butuí é uma das heranças que restaram do período no arroio Pelotas

Entre as últimas décadas do século 19 e o início do século 20 , ıma série de fatores políticos e zconômicos fragiliza o poder dos jarões do charque, obrigando-os a procurar outras alternativas Jara evitar a dilapidação de suas fortunas. Quando os anos 20 chezam com suas idéias revoluciolárias e a modernidade definiti-

vamente finca os pés no Rio Grande, a atividade já dá seus últimos suspiros, mas as marcas deixadas no história e na cidade ficarão para sempre.

Quatro anos antes da abolição da escravidão, a indústria saladeiril de Pelotas já havia tido suas estruturas abaladas com a inauguração da estrada de ferro

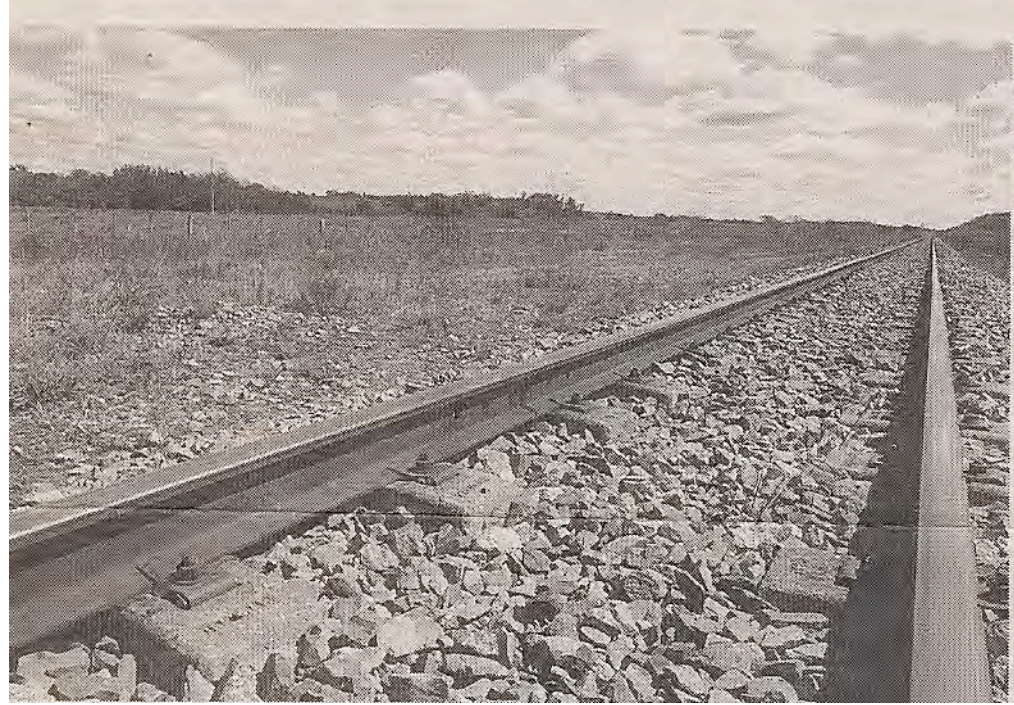

entre Rio Grande e Bagé. O trem havia possibilitado a abertura de novas charqueadas na região da campanha, pois tornava desnecessária a proximidade com rios ou arroios para escoar a produção.

A partir da proclamação da República, em 1889, e dos governos de Júlio de Castilhos e Borges de Medeiros, as políticas públicas do Governo gaúcho passam a favorecer o desenvolvimento do norte do Estado e enfraquecem ainda mais o poder econômico e, principalmente, político dos charqueadores, que representavam a elite derrotada na Revolução Federalista, de 1893. "A questão política foi definitiva para o fim das charqueadas", atesta o historiador Mario Osorio Magalhães.

Estrada de ferro entre Rio Grande e Bagé foi um dos fatores da decadência das charqueadas pelotenses 


\section{Coronel Pedro Osório - \\ DE CHARQUEADOR A ARROZEIRO}

Natural de Caçapava do Sul, Pedro Luís da Rocha Osório passou à história como o "Rei do Arroz", mas foi em uma charqueada e depois como charqueador que deu início à carreira de empreendedor que o tornou um dos homens mais ricos do Brasil. Em 1871, ao chegar a Pelotas com 17 anos, Osório empregou-se em uma loja de tecidos e quatro anos depois foi trabalhar na Charqueada Boa Vista, de Francisco Antunes Gomes da Costa, o Barão do Arroio Grande.

Em 1885, tornou-se charqueador e em pouco tempo fez da Charqueada do Cascalho (antiga propriedade de Domingos de Castro Antiquei$\mathrm{ra}$, o Visconde de Jaguari) um exemplo de produção. Três anos depois assumiu as charqueadas do Areal, da Costa e São Gonçalo.

Ao contrário de seus contemporâneos, Osório não se imobilizou quando o $\mathrm{Ci}$ clo do Charque deu os primeiros sinais de esgotamento e passou a investir na produção de arroz. Durante a $1^{\mathrm{a}}$ Guerra Mundial começou a exportar arroz para Uruguai e Argentina e daí para a Europa e outros países. Quando morreu em 1931, o coronel Pedro Osório havia se tornado um dos homens mais ricos e respeitados do Rio Grande do Sul e um dos poucos charqueadores que soube usar os ensinamentos de uma atividade secular para continuar a gerar riquezas e trabalho.

QUINTA-FEIRA: PARTE I -

OS PIONEIROS

ONTEM: PARTE II - OS

SENHORES Do Rio GRANDE hOJE: PARTE III - Do SAL AO OURO

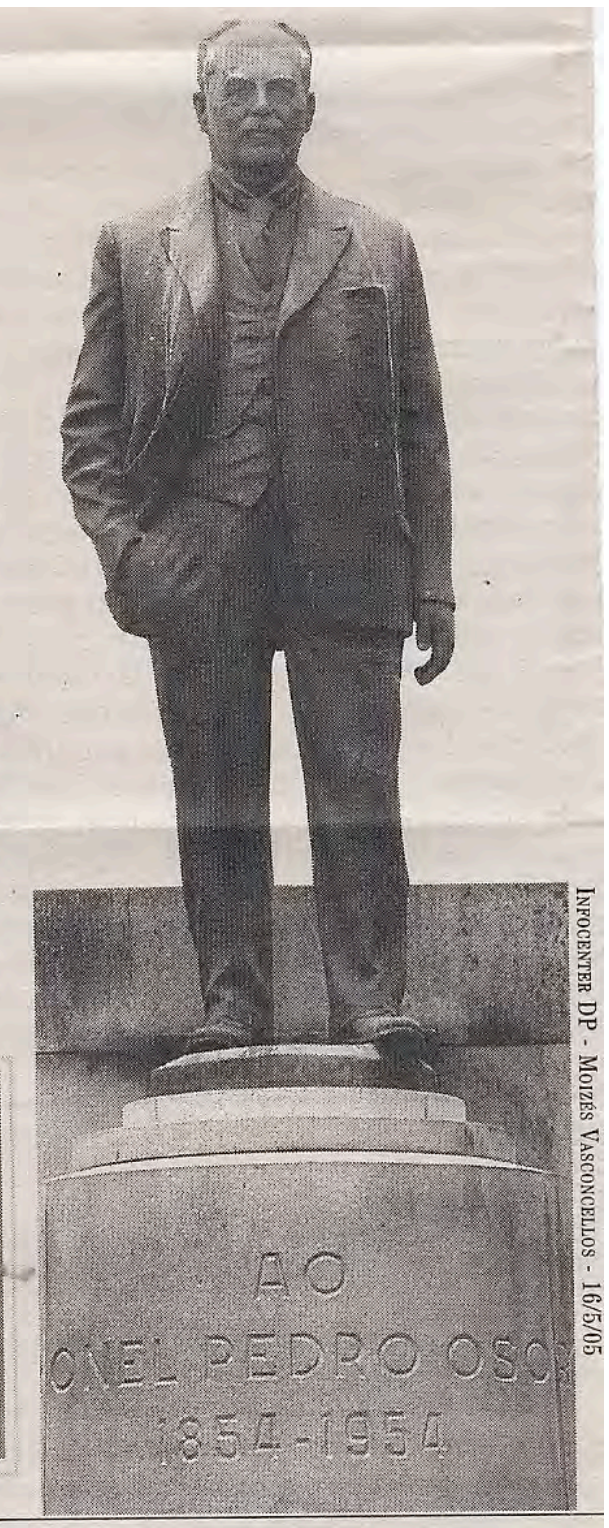


Doc 48 - 2007 (Jornal Diário Popular - Pelotas)

\section{BRAÇOS NEGROS, SANGUE RUBRC}

\begin{tabular}{|c|c|}
\hline $\begin{array}{l}\text { Dessa forma, na segunda } \\
\text { tade do século } 19 \text {, Pelotas } \\
\text { nou-se um dos maiores mer- } \\
\text { dos consumidores de escra- } \\
\text { s do Império do Brasil. Pe- } \\
\text { contas do filósofo e histo- } \\
\text { dor da UFPel, Agostinho } \\
\text { lla Vecchia a proporção en- } \\
\text { ntrada na população era de } \\
\text { is negros para cada branco. } \\
\text { ironia da história reside no } \\
\text { o de que milhares de escra- } \\
\text { s eram usados na fabricação } \\
\text { principal alimento de outros } \\
\text { lhões de escravos, forman- } \\
\text { a engrenagem inicial do cru- } \\
\text { cistem }\end{array}$ & $\begin{array}{l}\text { damente } 20 \text { anos, não } \\
\text { chegava aos } 30 \text { anos } \\
\text { depois de submetido } \\
\text { à rotina de uma char- } \\
\text { queada. "Em média, o } \\
\text { tempo de vida era de } \\
\text { apenas sete anos, en- } \\
\text { quanto a maior parte } \\
\text { das crianças morria } \\
\text { ainda muito peque- } \\
\text { na", confirma. } \\
\text { Em seu livro so- } \\
\text { bre a viagem ao Rio } \\
\text { Grande do Sul, em } \\
\text { 1834, o naturalista } \\
\text { francês Arsénne Isa- } \\
\text { belle registrou o caso do "ne- } \\
\text { grinho de parede", existente na } \\
\text { casa do charqueador Antônio } \\
\text { Gonçalves Chaves e que ajuda } \\
\text { a entender o tratamento dispen- } \\
\text { sado aos escravos nas char- } \\
\text { queadas pelotenses. } \\
\text { Orelato do viajante dá conta } \\
\text { de que o garoto, de não mais } \\
\text { do que dez anos, era obrigado } \\
\text { a permanecer o dia em pé, en- } \\
\text { costado a uma parede da sala } \\
\text { da casa e só se movia dali } \\
\text { quando ordenado a cumprir } \\
\text { alguma missão como levar um } \\
\text { recado ou buscar alguma coi- } \\
\text { sa. Enquanto isso não ocorria } \\
\text { o garoto servia de entreteni- } \\
\text { mento aos filhos do charquea- } \\
\text { dor que se divertiam espancan- } \\
\text { do-o de tempos em tempos, "E } \\
\text { Gonçalves Chaves era um in- } \\
\text { telectualliberal" anonta Dalla }\end{array}$ \\
\hline
\end{tabular}

\section{BARBÁRIE}

"Pelotas foi o exemplo de escravidão mais brutal de toda a história da humanidade", defende Agostinho Dalla Vecchia autor do livro Os fithos da escravidão: memórias de descen dentes de escravos da Região Meridional do Rio Grande do Sul (1994).

$\mathrm{O}$ alto grau de severidade $\mathrm{e}$ violência amprega lo no trato violencia empregado no trato dos negros nas charqueadas seria justificado por senhore e feitores na necessidade de manter sob controle batalhöes de ate 80 escravos por propriedade. A constatação mais trágica feita por Dalla Vecchia sobre esta realidade é a de que um negro jovem, de aproxima-

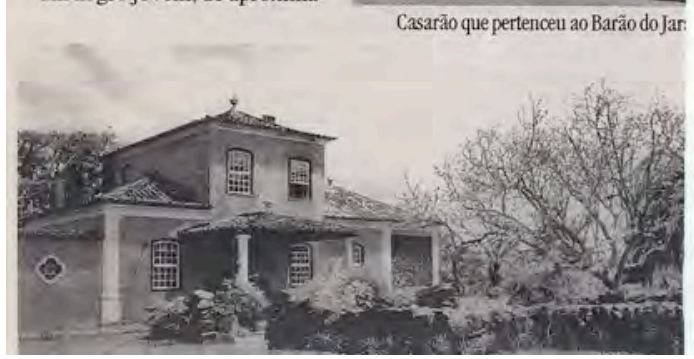


Doc 49 - 1870 (Arquivo Público do Estado do Rio Grande do Sul - Porto Alegre)

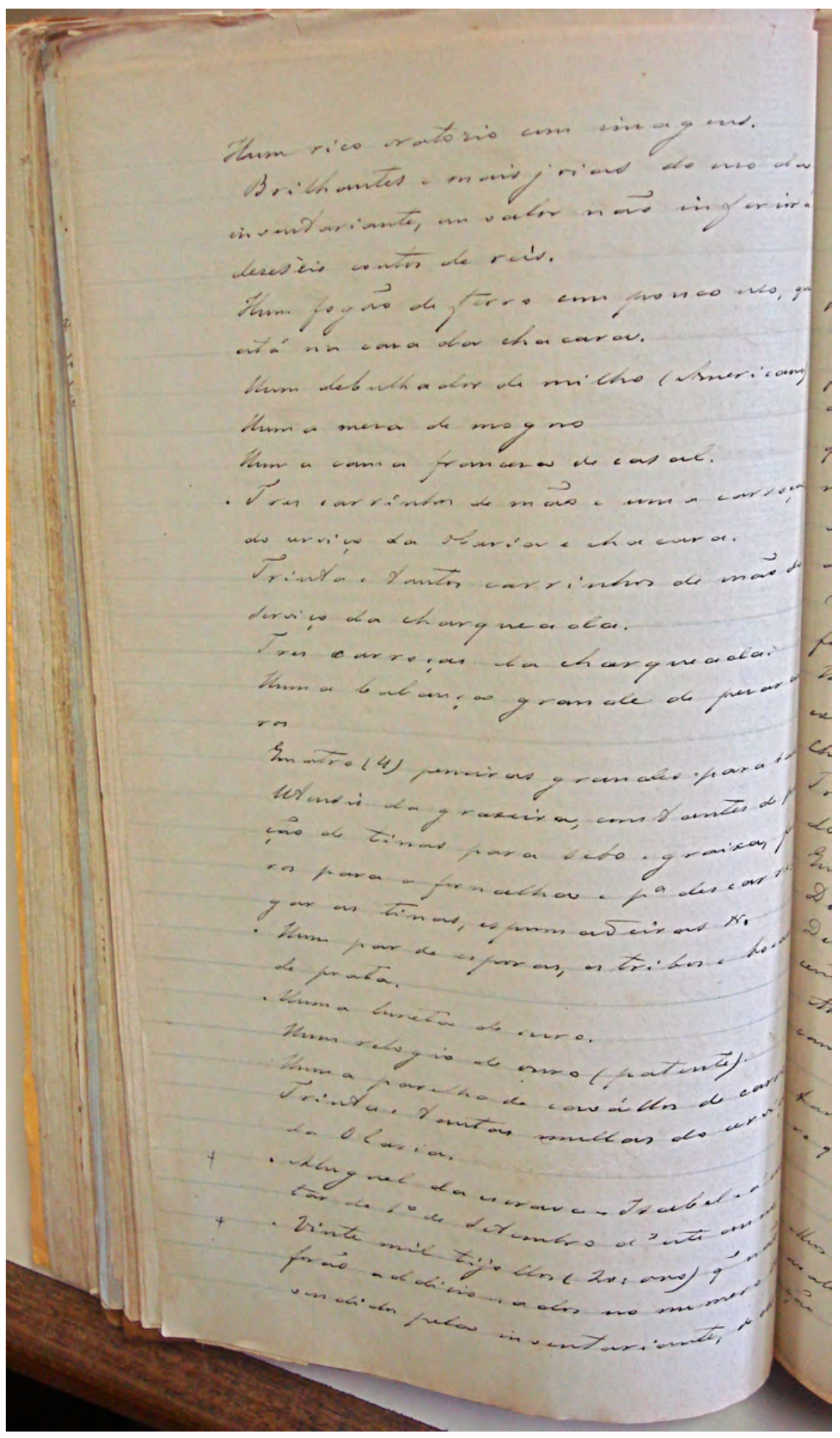


Hum rico oratorio com imagens.

Brilhantes e mais joias do uso da

inventariante, em valor não inferior á

desesèis contos de reís.

Hum fogão de ferro em franco uso, que

está na casa da chacara.

Hum debulhador de milho (Americano)

Huma mesa de mogno

Huma cama francesa de casal.

Tres carrinhos de mão e uma carroça

do serviço da olaria e chacara.

Trinta e tantos carrinhos de mão do

serviço da charqueada.

Tres carroças da charqueada.

huma balança grande de puxar [car]

$\operatorname{ros}$

Quatro (4) peneiras grandes para [lavar]

utensis da graxeira, com [ilegível] de [ilegível]

ção de tinas para sebo e graixa, [ilegível]

ros para a fornalha e para descarre

gar as tinas, espumadeiras [ilegível]

Hum par de esporas, estribos e ([ilegível]

de prata.

Hum a luneta de ouro.

Hum relogio de ouro (patente).

Huma parelha de cavallos de corri[da]

Trinta e tantas mullas do serviço

da olaria.

Aluguel da escrava Isabel á [da]

$\operatorname{tar}$ do $1^{\text {o. }}$ de Setembro d'este anno

vinte mil tijollos (20:000) que não

forão adicionados no numero [ilegível]

indicados pela inventariante, de [ilegível] 
Doc 50 - 1870 (Arquivo Público do Estado do Rio Grande do Sul - Porto Alegre)

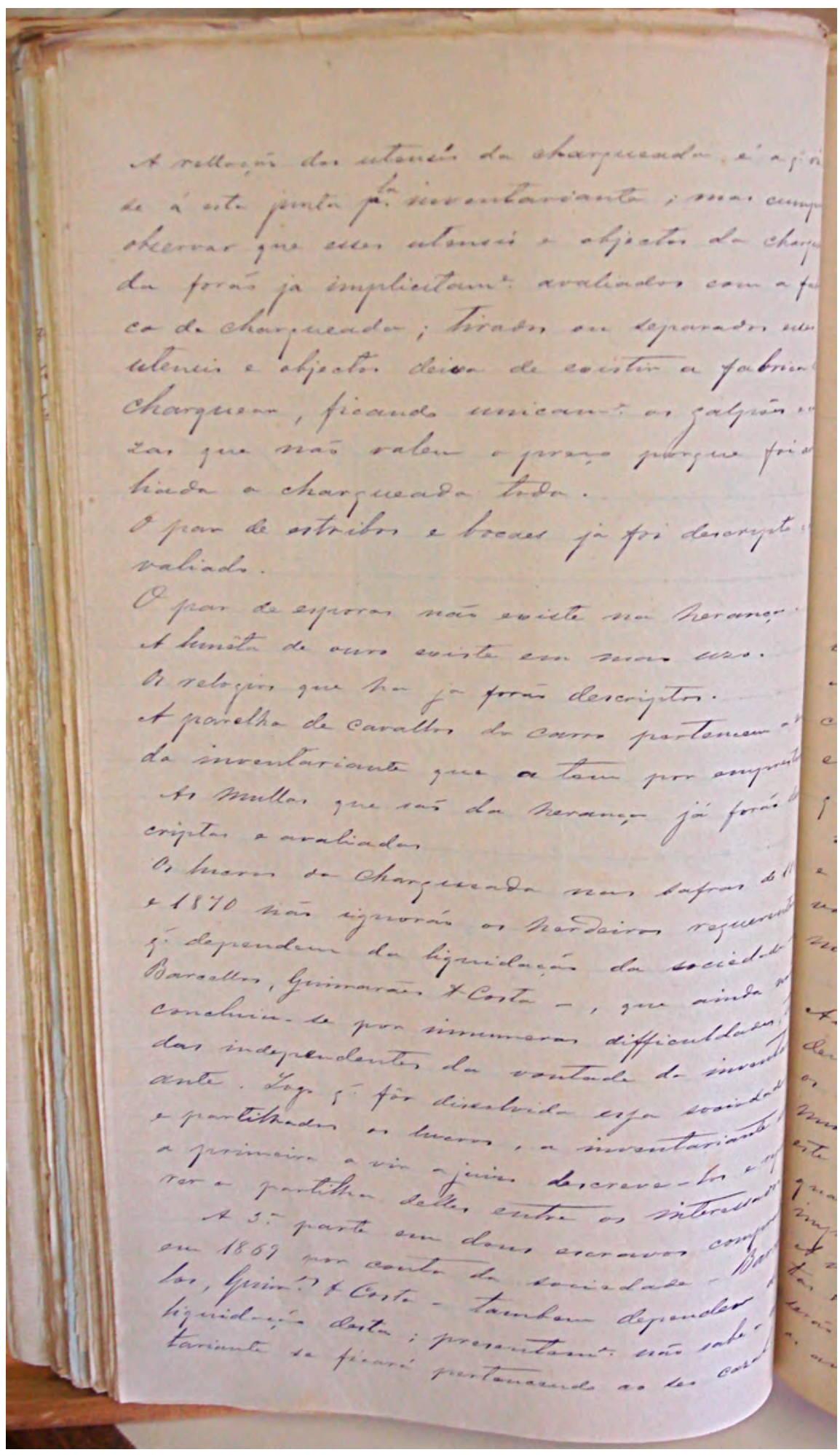


Edição doc 50 - 1870 (Arquivo Público do Estado do Rio Grande do Sul - Porto Alegre)

A rellação dos utensís da charqueada, é a piór de á esta feita pela inventariante; mas cumpre observar que estes utensis e objectos da charquea da forão ja implicitamente avaliados com a [ilegível] ca da charqueada; tirados ou separados estes utencis e objectos deixa de existir a fabrica [de] charquear, ficando unicamente os galpões e [ca] zas que não valem o preço porque foi a [va] liada a charqueada toda.

O par de estribos e bocaes ja foi descripro e [a] valiado.

O par de esporas não existe na herança.

A lunêta de ouro existe em mau uzo.

Os relogios que ha ja forão descriptos.

A parelha de cavallos do carro pertencem a [ilegível] da inventariante que a tem por emprestimo As mullas que são da herança já forão des criptas e avaliadas

Os lucros das Charqueada nas safras de 18[ilegível]

e 1870 não ignorão os herdeiros requerendo que deprendem da liquidação da sociedade [com] Barcellos, Guimarães e Costa, que ainda não concluiu-se por inumeras difficuldades, [ilegível] das independents da vontade da inventari ante. Logo que fôr disolvida essa sociedade e partilhados os lucros, a inventariante [ilegível] a primeira a vir a juizo descreve-los e [ilegível] rer a partilha delles entre os interessados.

A terceira parte em dous escravos compra[dos]em 1869 por conta da sociedade - Barcel los, Guimarães e Costa - tambem dependem [da] liquidação desta; presentemente não sabe a [inven] tariante se ficará pertecendo ao seo casal 
Doc 51 - 1870 (Arquivo Público do Estado do Rio Grande do Sul - Porto Alegre)

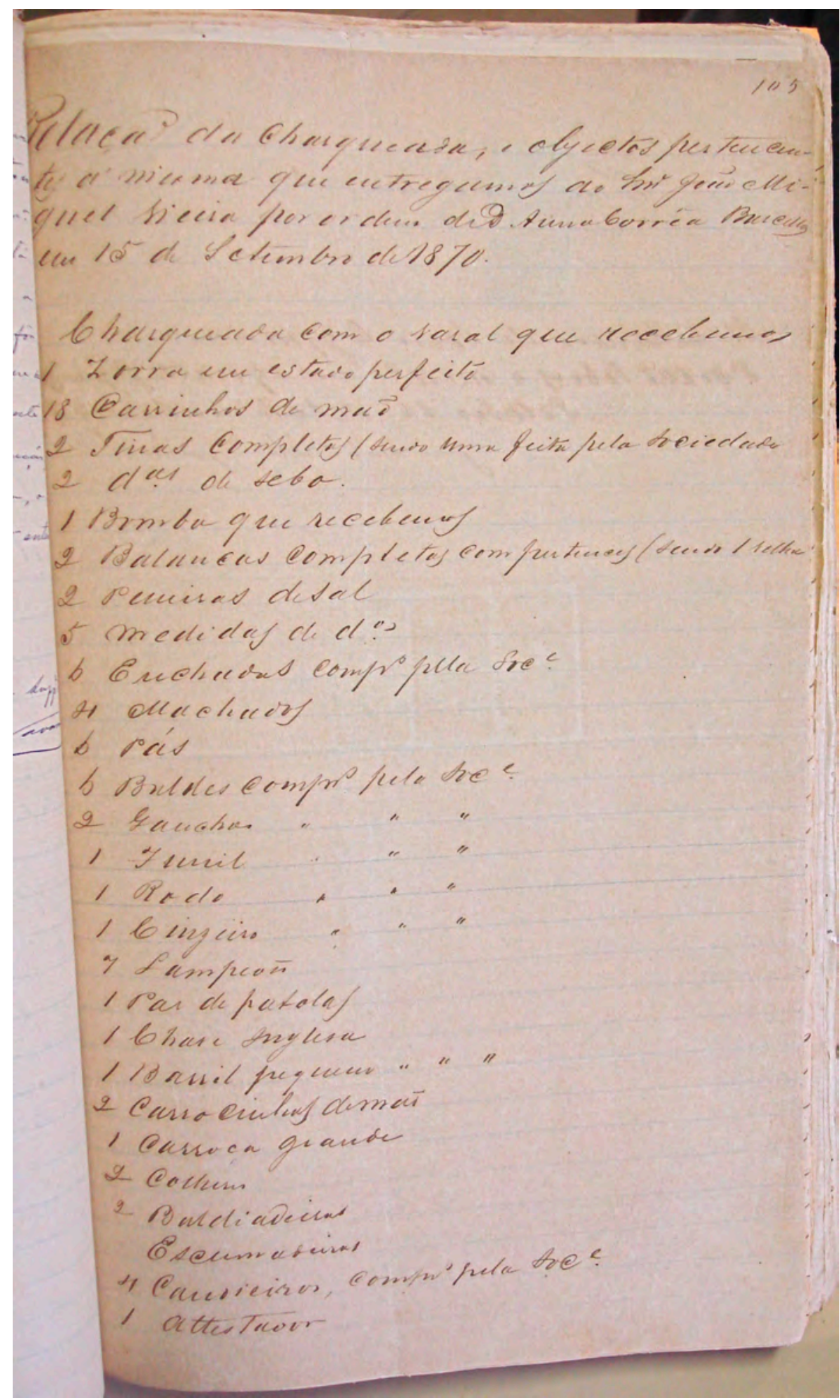


$<105>$

Relação da Charqueada, objectos perencen-

tes á mesma que entregamos ao Senhor João Mi-

guel Vieira por ordem de Dona Anna Corrêa Barcellos

em 15 de Setembro de 1870.

Charqueada com o varal que recebemos

1 Zorra em seu estado perfeito

18 Carrinhos de mão

2 Tinas Completas (sendo uma feita pela sociedade)

2 ditas de sebo

1 Bomba que recebemos

2 Balancas completas com pertences (sendo 1 velha)

2 Peneiras de Sal

5 Medidas de [ilegível]

10 Enchadas comprada pela Sociedade

20 Machados

10 Pás

10 Baldes comprado pela sociedade

2 Ganchos

1 Funil

1 Rodo

1 Cinzeiro

7 Lampeões

1 Par de patolas “ “ “ “

1 Chase Inglesa “ “ “ “

1 Barril pequeno “ “ “ “

2 Carrocinhas de mão

1 Carroça grande

2 Colheres

2 Baldiadeiras

Escumadeiras

4 Candieiros, comprado pela sociedade

1Attestador 
Doc 52 - 1872 (Arquivo Público do Estado do Rio Grande do Sul - Porto Alegre)

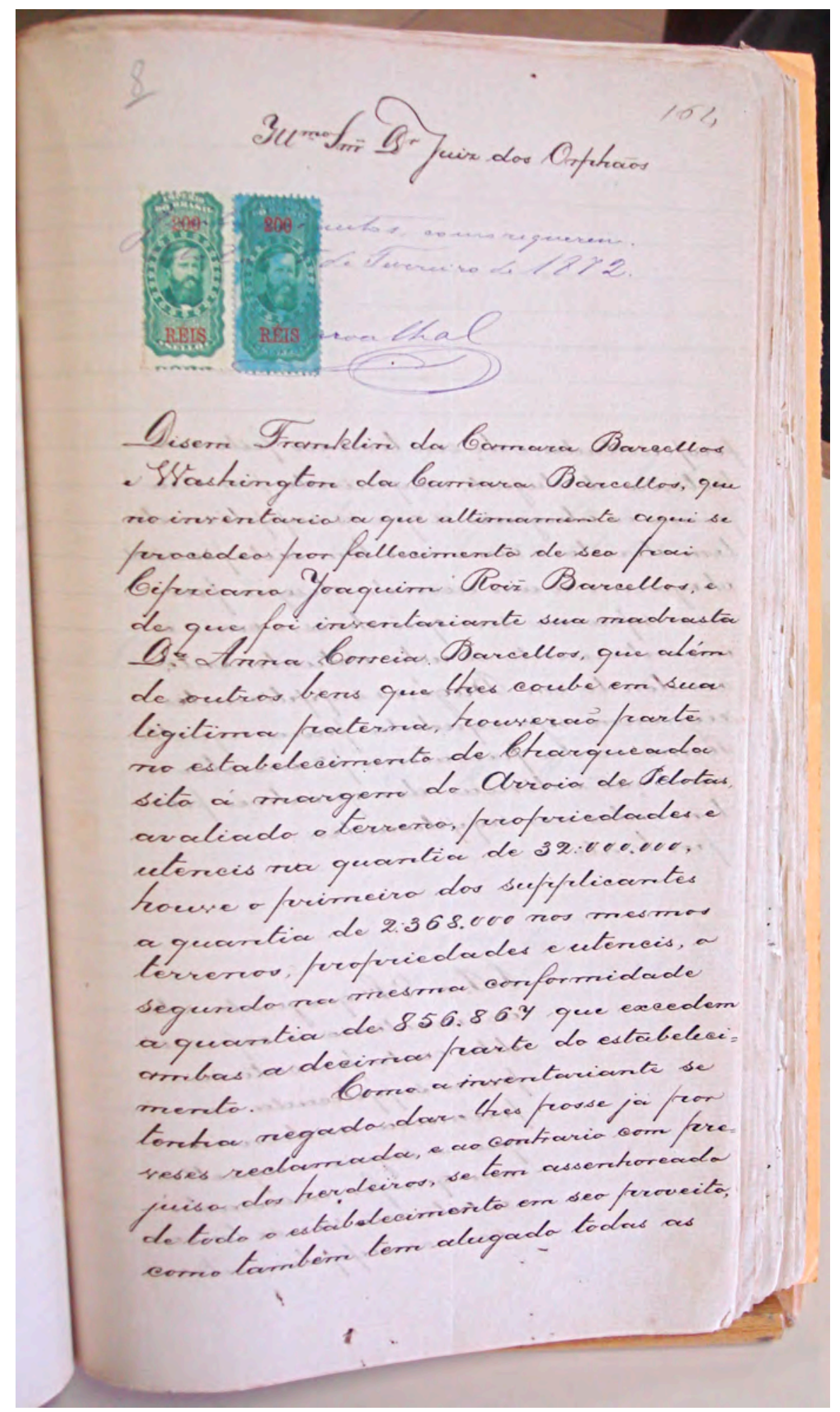


Edição doc 52 - 1872 (Arquivo Público do Estado do Rio Grande do Sul - Porto Alegre)

Illustrissimo Senhor Doutor Juiz dos Orphãos

$<$ [ilegível +2] como requerem.

[ilegível + 2] de fevereiro de 1872

[ilegível] valhal>

Disem Franklin da Camara Barcellos

e Washington da Camara Barcellos, que

no inventario a que ultimamente aqui se

procedeo por fallecimento de seo pai

Cipriano Joaquim Poiz Barcellos, e

de que foi inventariante sua madastra

Dona Anna Correia Barcellos, que além

de outros bens que lhes coube em sua

ligitima fraterna, trouxerão parte

no estabelecimento de Charqueada

sita á margem do Arroio de Pelotas,

avaliado o terreno, propriedades e

utencis na quantia de 32:000.000,

houve o primeiro dos supplicantes

a quantia de 2:368.000 nos mesmos

terrenos, propriedades e utencis, a

segunda na mesma conformidade

a quantia de 856.867 que excedem

ambas a decima parte do estabeleci=

mento. Como a inventariante se

tenha negado dar-lhes posse já por

vezes reclamada, e ao contrario com pre $=$

juiso dos herdeiros, se tem assenhoreada

de todo o estabelecimento em seo proveito,

como tambem tem alugado todas as 
Doc 53 - 1872 (Arquivo Público do Estado do Rio Grande do Sul - Porto Alegre)

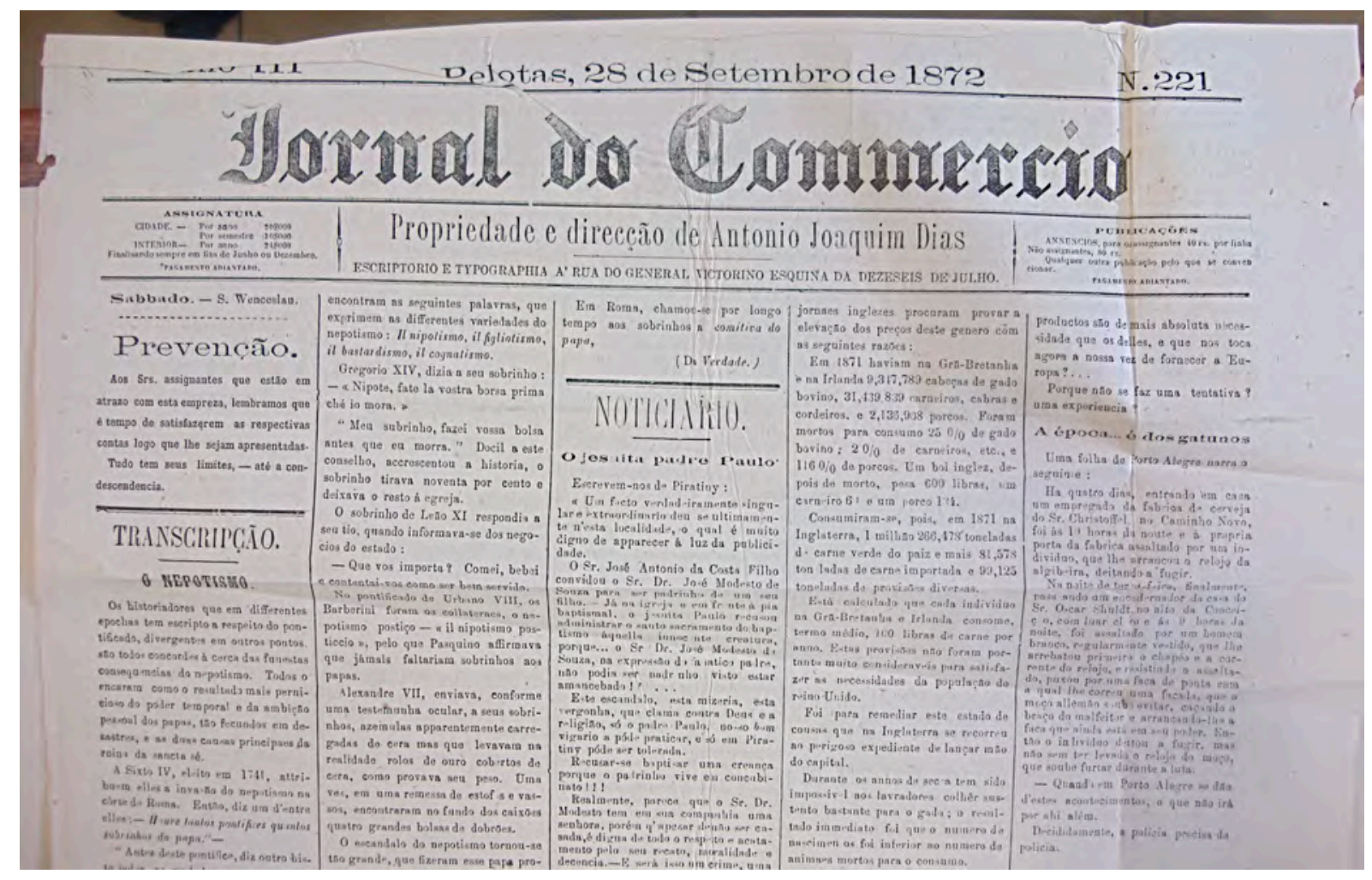


Doc 54 - 1871 (Arquivo Público do Estado do Rio Grande do Sul - Porto Alegre)

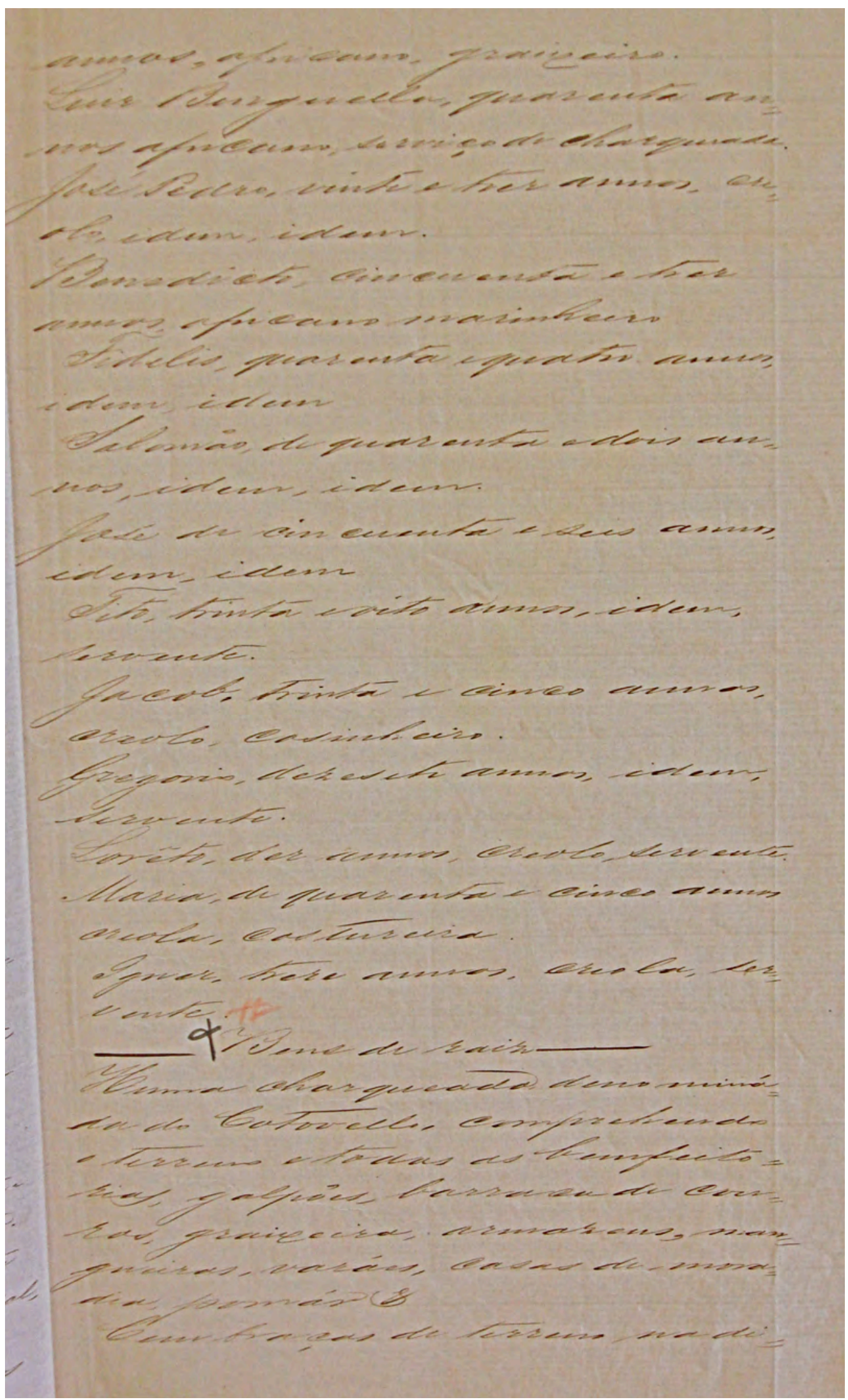


annos, africano, graixeiro.

Luiz Bengacellos, quarenta an=

nos africano, serviço de charqueada.

José Pedro, vinte e tres annos, cri= olo, idem, idem.

Benedicto, cincuenta e tres

annos, africano marinheiro

Fidelis, quarenta e quarto annos, idem, idem

Salomão, de quarenta e dois an= nos, idem, idem.

José de cincuenta e seis annos, idem, idem

Tito, trinta e oito annos, idem, servente.

Jacob, trinta e cinco annos, creolo, cosinheiro.

Gregorio, dezesete annos, idem, servente.

Lorêto, dez annos, creolo, servente.

Maria, de quarenta e cinco annos

creola, costureira.

Ignez, treze annos, creola, ser-

vente.

Bens de raiz

Huma charqueada denominá= da do Catovello, comprehendendo o terreno e todas as benfeito $=$ rias, galpões, barraca de cou= ros, graixeira, armazens, man= gueiras, varáes, casas de mora= dia, pomár Com braças de terreno na di= 
Doc 55 - 1871 (Arquivo Público do Estado do Rio Grande do Sul - Porto Alegre)

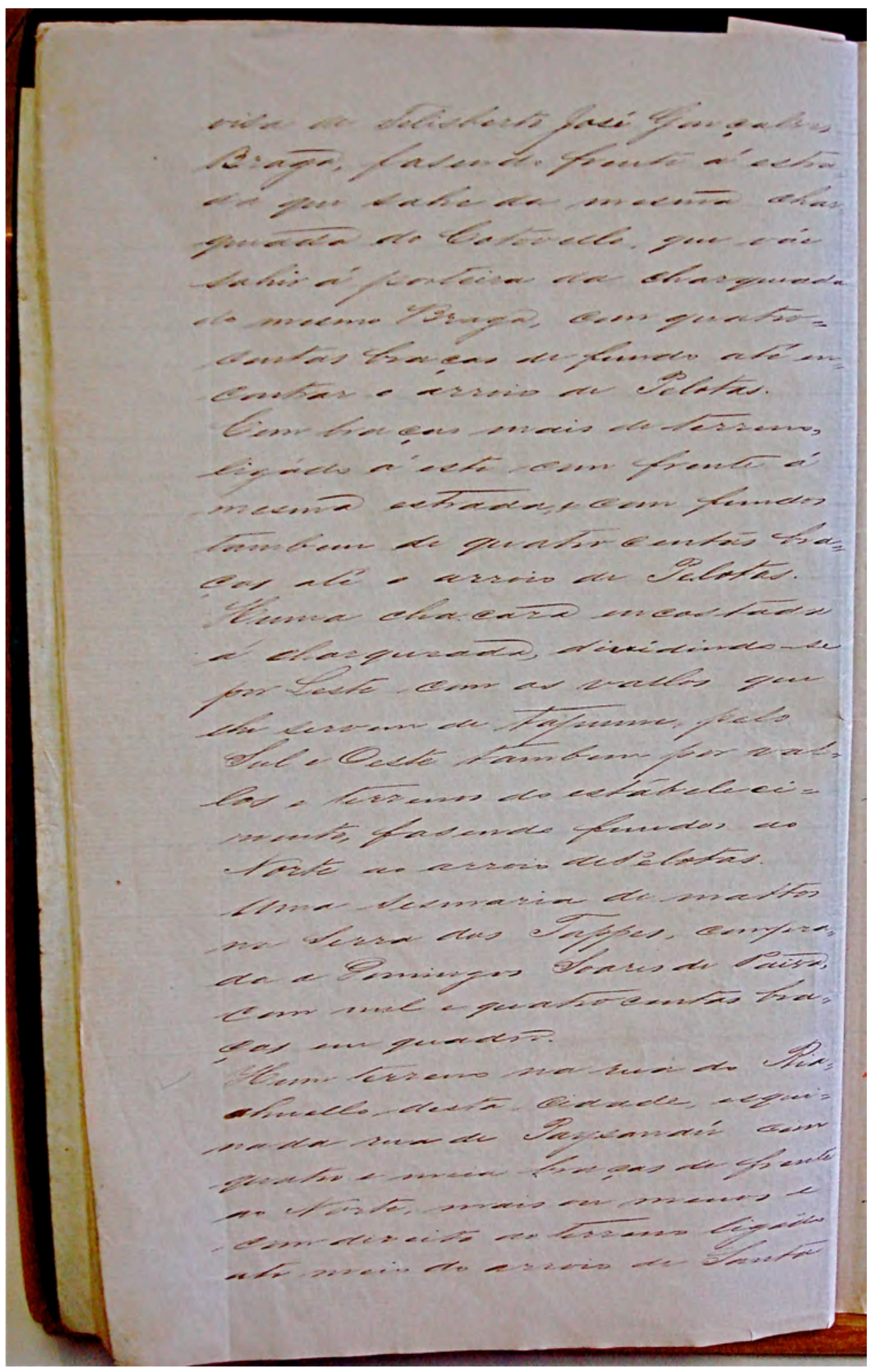


visas de Felisberto José Gonçalves

Bragão, fasendo frente á estra=

da que sahe da mesma char

queada do Cotovello, que váe

sahir á porteira da charqueada

do mesmo Braga, com quarto=

centas braças de fundo até en=

contrar o arroio de Pelotas.

Cem braças mais de terreno,

ligáda á este com frente á

mesma estrada, e com fundos

tambem de quatrocentás bra=

ças até o arroio de Pelotas.

Huma chacara encostada

á charqueada, dividindo-se

por Leste com as vallas que

[lhe] servem de tapume, pelo

Sul e Oeste tambem por val=

las e terrenos do estabeleci $=$

mento, fasendo fundos ao

Norte ao arroio de Pelotas.

Uma Sesmaria de mattos

na Serra dos Tappes, compra=

da a Domingos Soares de Paiva,

com mil e quatrocentos bra=

ças em quadro.

Hum terreno na rua do Ria=

chuello desta Cidade, de qui=

na da rua de Paysandú com

quarto e meis braças de frente

ao Norte, mais ou menos e com direito ao terreno ligado ate mais do arroio de Santa 
Doc 56 - 1871 (Arquivo Público do Estado do Rio Grande do Sul - Porto Alegre)

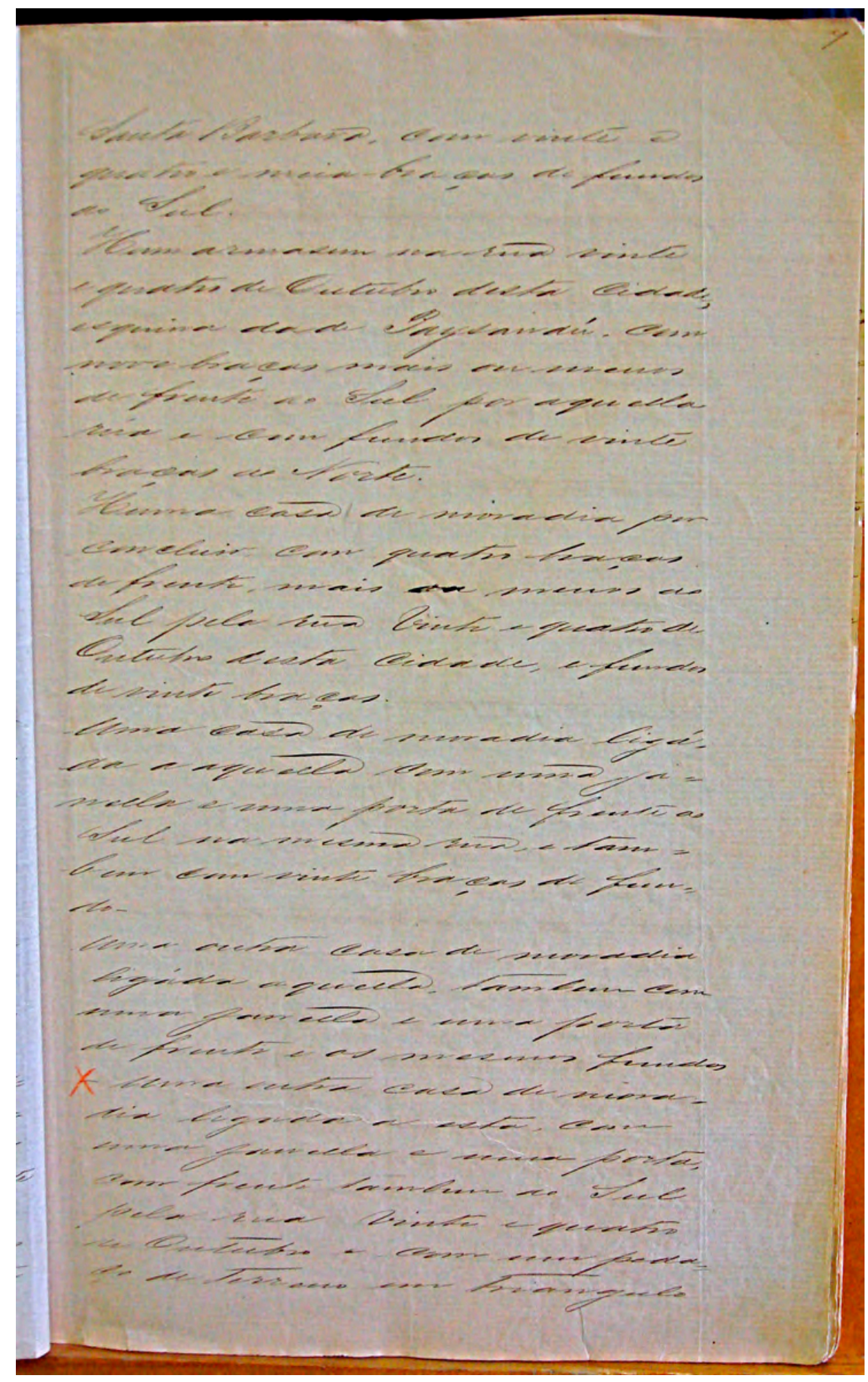


Santa Barbara, com vinte e

quarto e meia braças de fundos

ao Sul.

Hum armasem na rua vinte

e quarto de Outubro desta Cidade,

esquina da de Paysandú, com

nove braças mais ou menos

de fundo ao Sul por aquella

rúa e com fundos de vinte

braças ao Norte.

Huma casa de moradia por

concluir com quarto braças

de frente, mais ou menos dosul pela rua Vinte e quarto de

Outubro desta cidade, e fundos

de vinte braças.

Uma casa de moradia ligá-

da a aquella com uma ja=

nella e uma porta de frente ao

sul na mesma rua, e tam $=$

bem com vinte braças de fundo.

Uma outra casa de moradia

ligáda aquella, tambem com

uma janella e uma porta

de frente e os mesmos fundos

uma outra casa de mora-

dia ligada a esta com

uma janella e uma porta,

com frente tambem ao Sul

pela rua vinte e quarto

de Outubro e com um peda-

ço de tereno em triangulo 
Doc 57 - 1870 (Arquivo Público do Estado do Rio Grande do Sul - Porto Alegre)

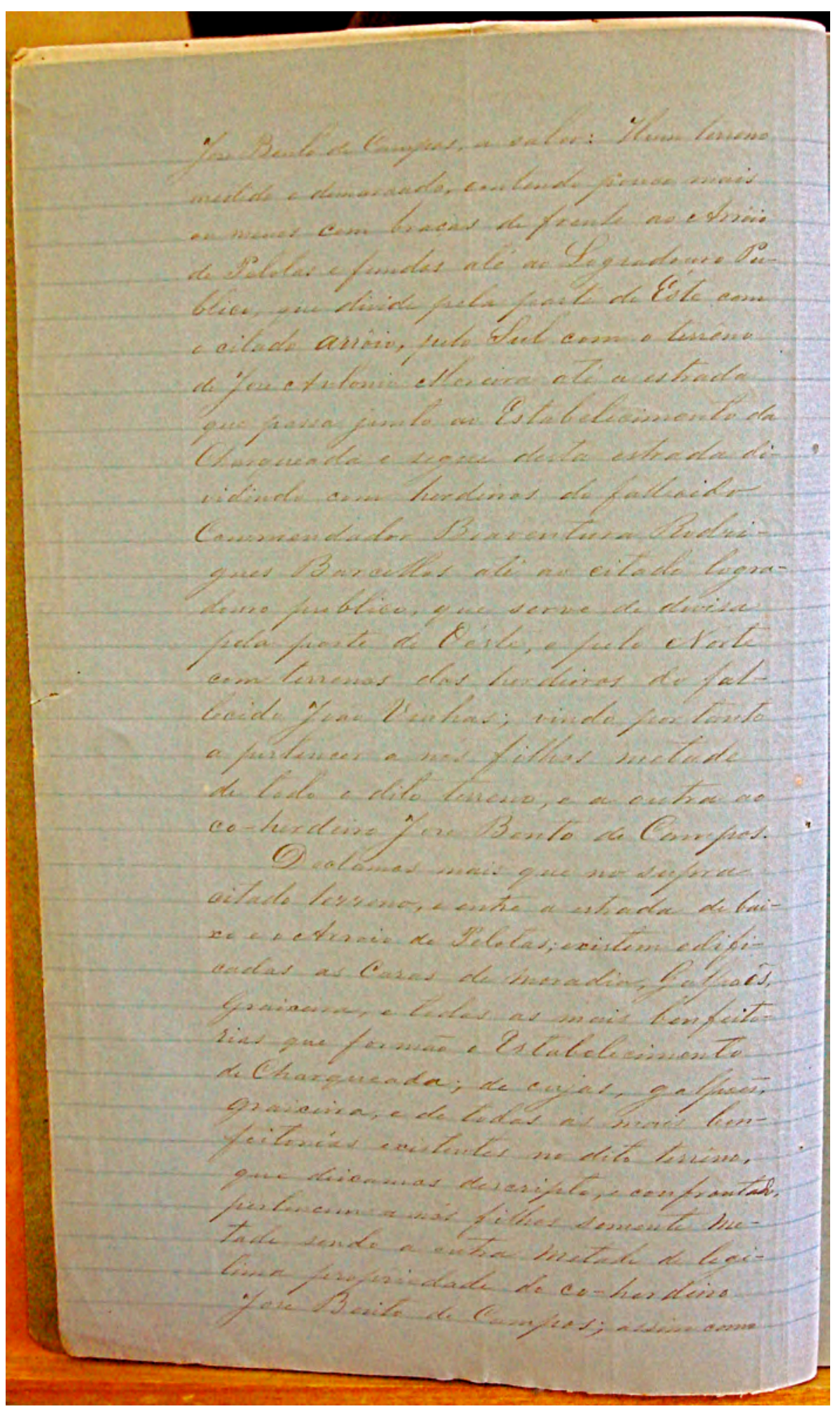


Jose Bento de Campos, a saber: Hum terreno

medido e demarcado, contendo pouco mais

ou menos cem braças de frente ao Arroio

de Pelotas e fundos até ao Logradouro Pu-

blico, que divide pela parte de Éste com

o citado Arrôio, pelo sul com o terrêno

de Jose Antonio Moreira até a estrada

que passa junto ao Estabelecimento da

Charqueada e segue desta estrada di-

vidindo com herdeiros do fallecido

Commendador Boaventura Rodri-

gues Barcellos até ao citado logra-

douro publico que serve de divisa

pela parte de Oéste, e pelo Norte

com terrenos dos herdeiros do fal-

lecido João Vinhas; vindo por tanto

a pertencer a nós filhos metade

de lado e ditto terreno, e a outra ao

co-herdeiro Jose Bento de Campos.

Declaramos mais que no supra-

citado terreno, e entre a estrada de bai-

xo e o Arroio de Pelotas; existem edifi-

cadas as Cazas de Moradia, Galpões,

Graixeiras, e todas as mais benfeito-

rias que formão o Estabelecimento

de Charqueada; de cujas, galpões,

graixeira, e de todas as mais ben-

feitorias existents no ditto terrêno,

que deixamos descripto, e confrontal,

pertencem a nós filhos somente me-tade sendo a outra metade de legi-

tima propriedade do co-herdeiro

Jose Bento de Campos; assim como 
Doc 58 - 1870 (Arquivo Público do Estado do Rio Grande do Sul - Porto Alegre)

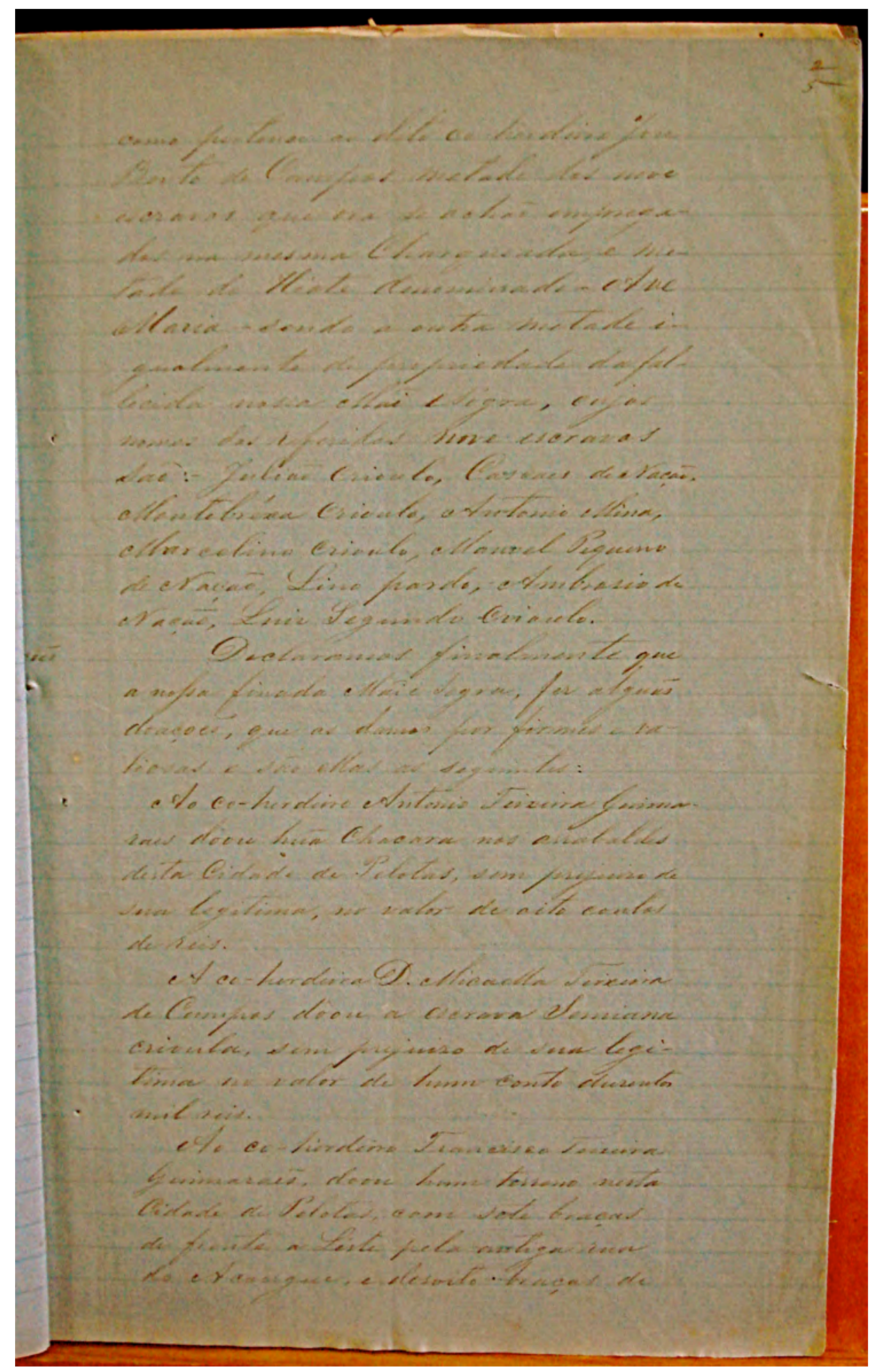


como pretense ao dito co-herdeiro Jose

Bento de Campos metade dos nove

escravos que ora se achaõ emprega-

dos na mesma Charqueada, e me-

tade do Hiate denominado Ave

Maria - sendo a outra metade i-

gualmente de propriedade da fal-

lecida nossa Mãe e Sógra, cujos

nomes dos referidos nove escravos

são: - Julião Cioulo, Cascaes de Nação,

Montebréxa Crioulo, Antonio Mina,

Marcolino Crioulo, Manoel Pequeno

de nação, Lino pardo, Ambrosio de

Nação, Luiz Segundo Crioulo.

Declaramos finalmente que

a nossa finada Mãe e Sogra, fez alguãs

doações, que as damas por firmes e va-

liosas e são ellas as seguintes:

Ao co-herdeiro Antonio Teixeira Guima-

raes doou huã Chacara nos arrebaldes

desta Cidade de Pelotas, sem prejuizo de

sua legitima, no valor de oito contos

de reis.

A co-herdeira Dona Micaella Teixeira

de Campos doou a escrava Semiana

crioula, sem prejuizo de sua legi-

tima no valor de hum conto duzentos

mil reis.

Ao co-herdeiro Trancisco Teixeira

Guimarães, doou hum terreno nesta

Cidade de Pelotas, com sete braças

de frente a Léste pela antiga rua

do Açougue, e desoito braças de 
Doc 59 - 1870 (Arquivo Público do Estado do Rio Grande do Sul - Porto Alegre)

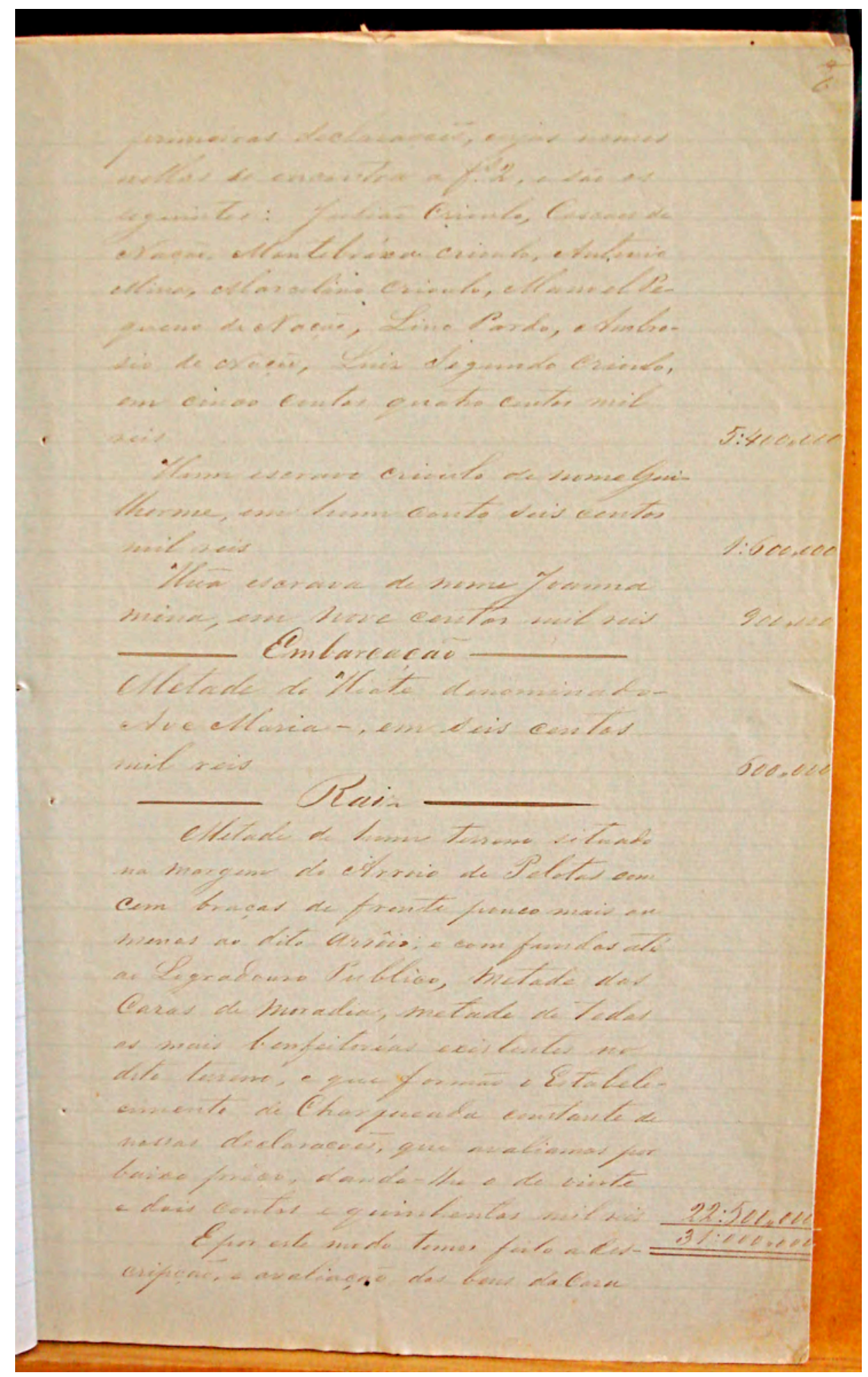


primeiras declarações, cujos nomes nellas se encontra a folha 2, e são as seguintes: Julião Crioulo, Cascaes de Nação, Montebráxa Crioulo, Antonio Mina, Marcolino Crioulo, Manoel Pequeno de Nação, Lino pardo, Ambrosio de Nação, Luiz Segundo Crioulo, em cinco contos quarto centos mil reis $5: 400,, 000$

Hum escravo crioulo de nome Guilherme, em hum conto seis centos mil reis $1: 600,, 00$

Huã escrava de nome Joanna Mina, em nove centos mil reis 900,000 Embarcaçaõ

Metade de Hiate denominado Ave Maria - , em seis centos mil reis $600,, 000$ Raiz

Metade de hum terreno situado na margem do Arroio de Pelotas com cem braças de frente pouco mais ou menos ao ditto arrôio, e com fundos até ao Logradouro Publico, metade das Cazas de Moradia, metade de todas as mais benfeitorias existentes no ditto terreno, e que formão o Estabelecimento de Charqueada constante de nossas declarações, que avaliamos por baixo preço, dando-lhe o de vinte e dois contos e quinhentos mil reis $<22: 500,000>$ E por este modo temos feito a des- $\langle 31$ : 000,,00> cripção e avaliação dos bens da Caza 
Doc 60 - 1883 (Arquivo Público do Estado do Rio Grande do Sul - Porto Alegre)

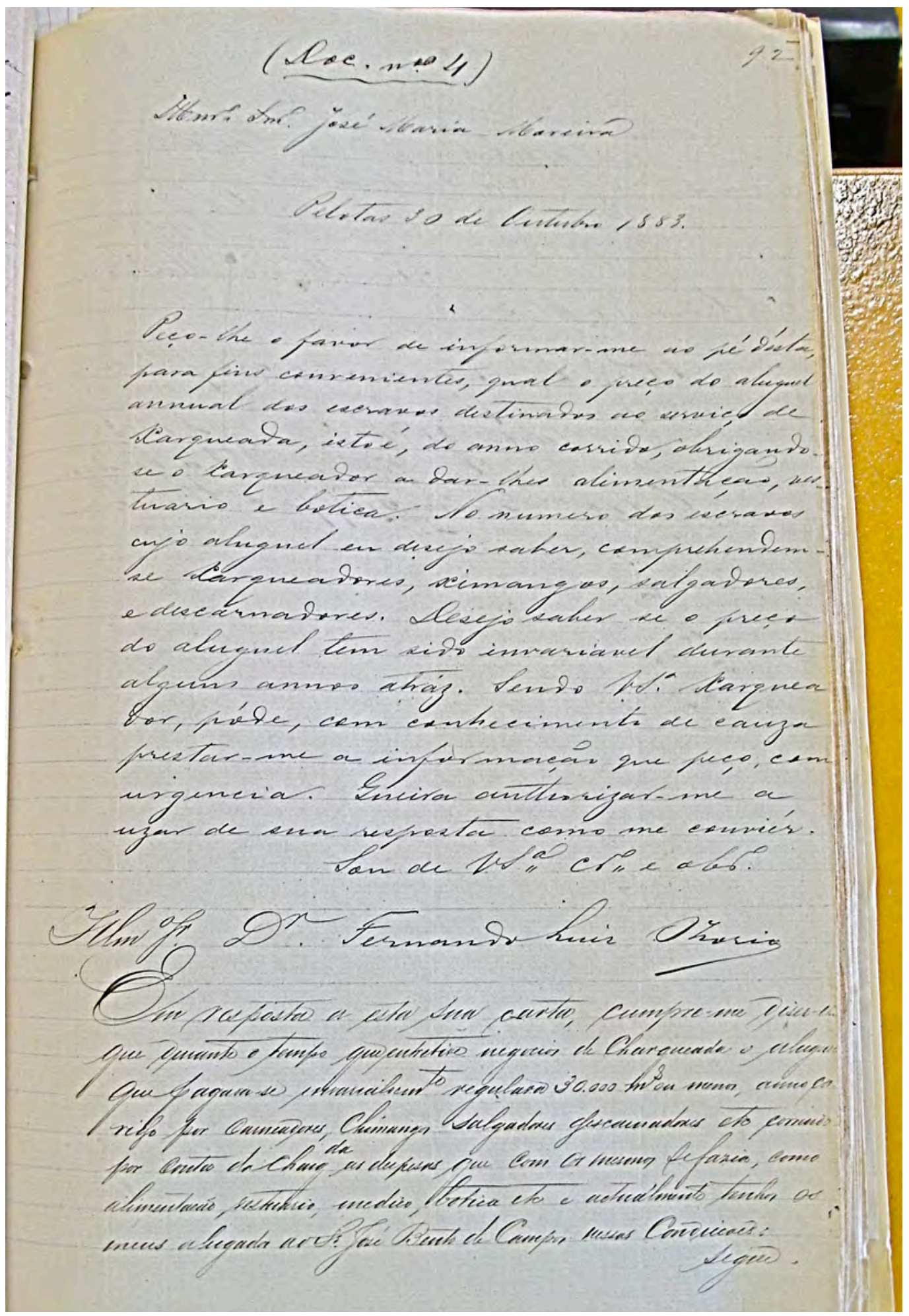


Edição doc 60 - 1883 (Arquivo Público do Estado do Rio Grande do Sul - Porto Alegre)

Illustrissimo Senhor José Maria Moreira

Pelotas 30 de Outubro 1883.

Peço-lhe o favor de informar-me ao pé desta,

para fins convenientes, qual o preço do aluguel

annual dos escravos destinados ao serviço de

Xarqueada, isto é, do anno corrido, obrigando-

se o Xarqueador a dar-lhe alimentação, ves-

tuario e botica. No numero dos escravos

cujo aluguel eu desejo saber, comprehenden-

se Xarqueadores, ximangos, salgadores,

e descarneadores. Desejo saber se o preço

do aluguel tem sido invariavel durante

alguns annos atráz. Sendo Vossa Senhoria Xarquea

dor, póde, com conhecimento de cauza

prestar-me a informção que peço com

urgencia. Queira authorizar-me a

uzar de sua resposta como me conviér

Sou de Vossa Senhoria carríssimo e obrigado

Illustrissimo Senhor Doutor Fernando Luiz Ozorio

Em resposta a esta sua carta, cumpre-me diser-lhe

que quanto o tempo que entretive negocios de Charqueada o alugeu

que pagava-se invariavelmente regulava 30.000 mais ou menos, anno co

rido por carneadores, chimangos salgadores descarneadores etc cento

por cento da Charqueada as despesas que com os mesmos se fazia, como

alimentação, vestuario, medico, botica etc e actualmente tenho os

meus alugados ao Senhor José Bento de Campos nessas Condicões:

Segue 
Doc 61 - 1883 (Arquivo Público do Estado do Rio Grande do Sul - Porto Alegre)

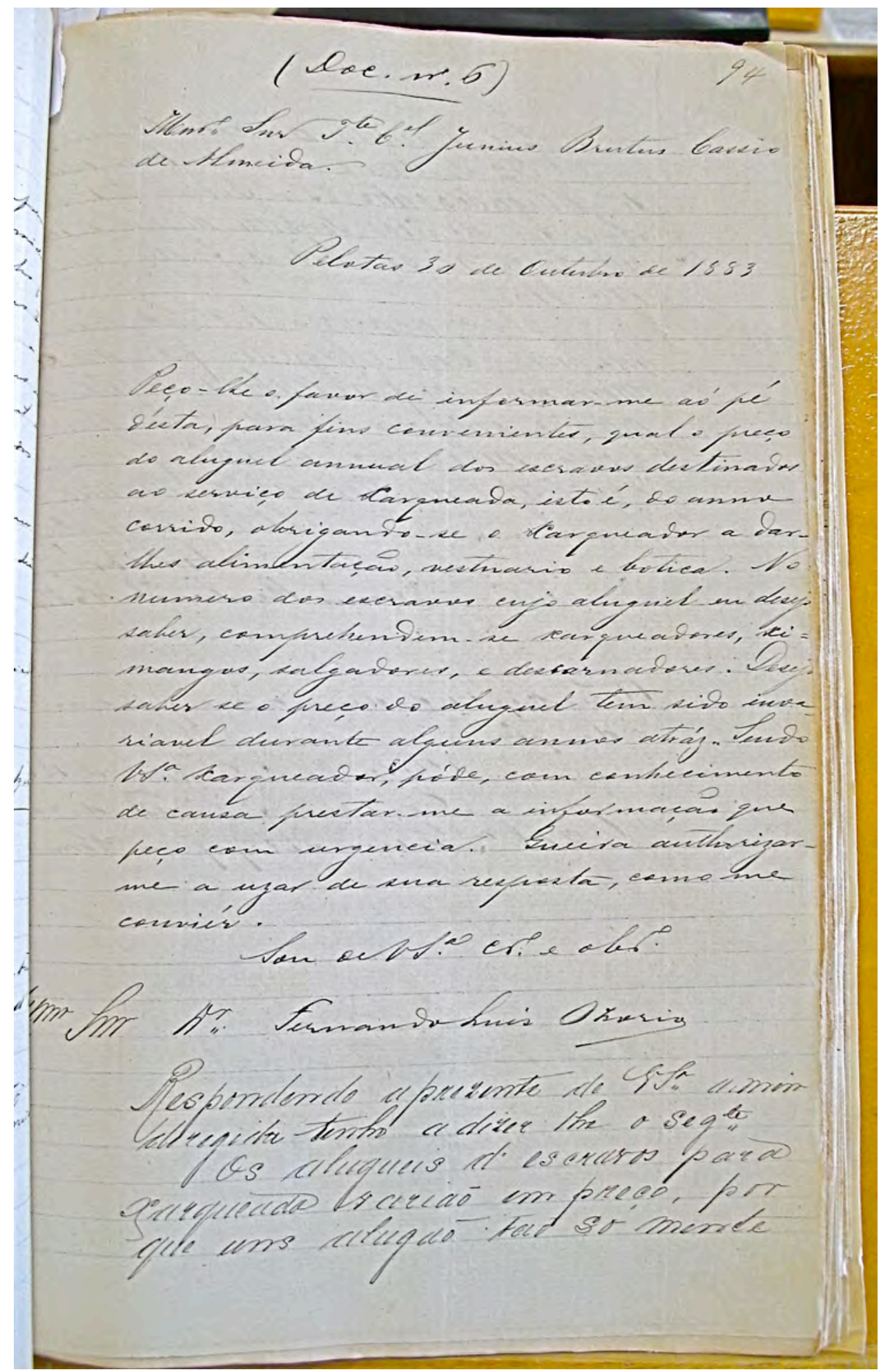


Edição doc 61 - 1883 (Arquivo Público do Estado do Rio Grande do Sul - Porto Alegre)

Illustrissimo Senhor Tenente Coronel Junino Brutus Cassio

de Almeida.

Pelotas 30 de Outubro de 1883.

Peço-lhe o favor de informar-me aó pé

désta, para fins convenientes, qual o preço

do aluguel annual dos escravos destinados

ao serviço de Xarqueada, isto é, do anno

corrido, obrigando-se o xarqueador a dar-

lhes alimentação, vestuario e botica. No

numero dos escravos cujo aluguel eu desejo

saber, comprehendem-se xarqueadores, $\mathrm{xi}$ -

mangos, salgadores, e descarneadores. Desejo

saber se o preço do aluguel tem sido inva-

riavel durante alguns annos atráz. Sendo

Vossa Senhoria Xarqueador, póde, com conhecimento

de causa prestar-me a informação que

peço com urgencia. Queira authorizar-

me a uzar de sua resposta, como me

conviér.

Sou de Vossa Senhoria carríssimo e obrigado

[IIl] ustrissimo Senhor Doutor Fernando Luis Ozorio

Respondendo a presente de Vossa Senhoria a mim

dirigida tenho a dizer lhe o seguinte

Os alugueis d'escravos para

xarqueada varião em preço, por

que uns alugaõ taõ sómente 
Doc 62 - 1873 (Arquivo Público do Estado do Rio Grande do Sul - Porto Alegre)

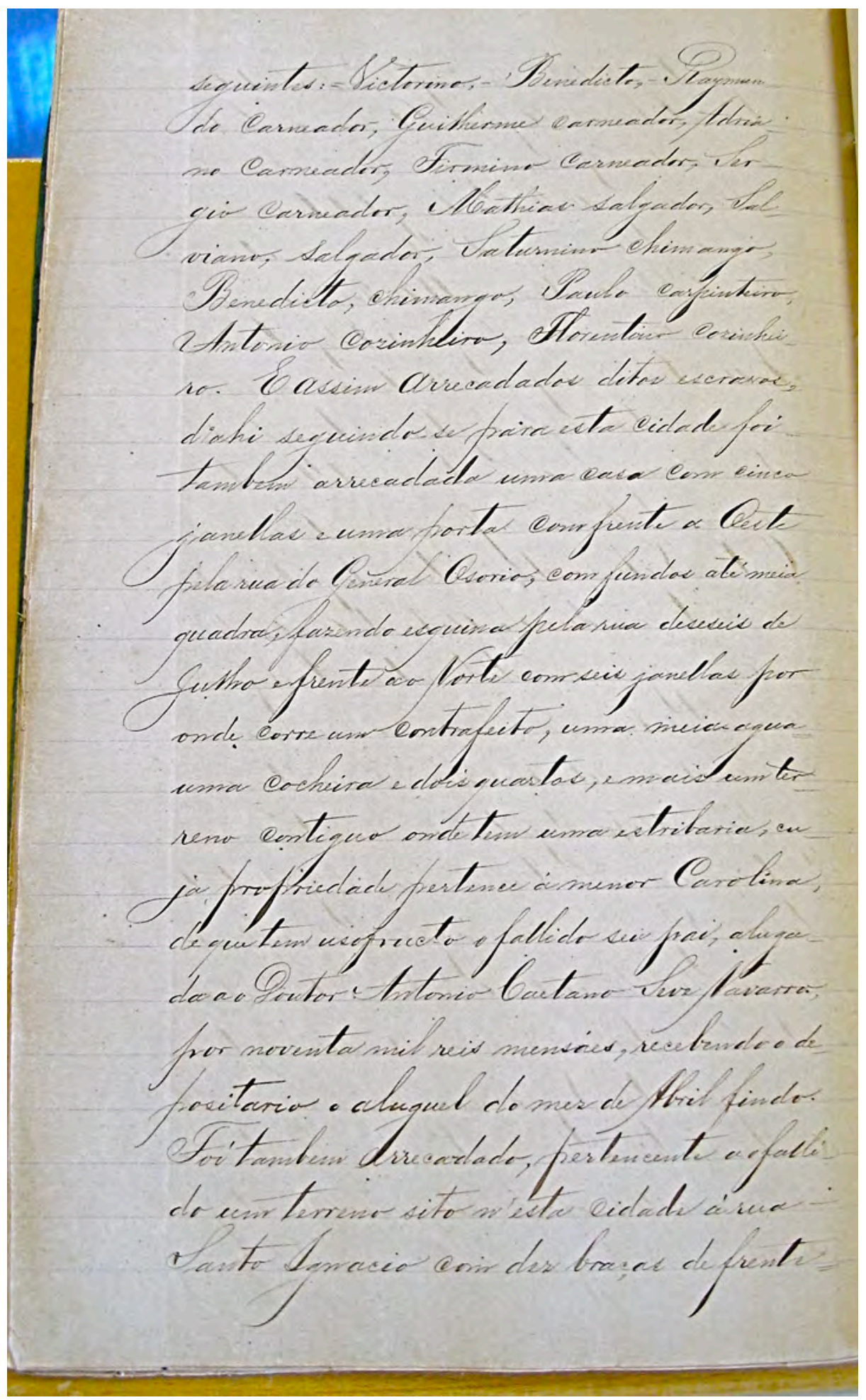


seguintes: = Victorino, Benedicto, Raymun-

do carneador, Guilherme carneador, Adria-

no carneador, Firmino carneador, Ser-

gio carneador, Mathias salgador, sal-

viano, salgador, Saturnino chimango,

Benedicto, chimango, Paulo carpinteiro,

Antonio cozinheiro, Florentino cozinhei-

ro. E assim arrecadados ditos escravos,

di ahi seguindo-se para esta cidade foi

tambem arrecadada uma casa com cinco

janellas e uma porta com frente a esta

pela rua do General Osorio, com fundos até meia

quadra, fazendo esquina pela rua deseseis de

Julho e frente ao Norte com seis janellas por

onde corre um contrafeito, uma meia agua $=$

uma cocheira e dois quartos, e mais um ter-

reno antiguo onde tem uma estribaria, c-

ja propriedade pertence a menor Carolina,

de que tem usofructo o fallido seu pai, aluga-

da ao Doutor Antonio Caetano Seve Navarro,

por noventa mil reis mensaes, recebendo o de-

positario o aluguel do mez de Abril findo.

Foi tambem arrecadado, pertencente ao falli-

do um terreno sito n'esta cidade à rua-

Santo Ignacio com dez braças de frente= 
Doc 63 - 1883 (Arquivo Público do Estado do Rio Grande do Sul - Porto Alegre)

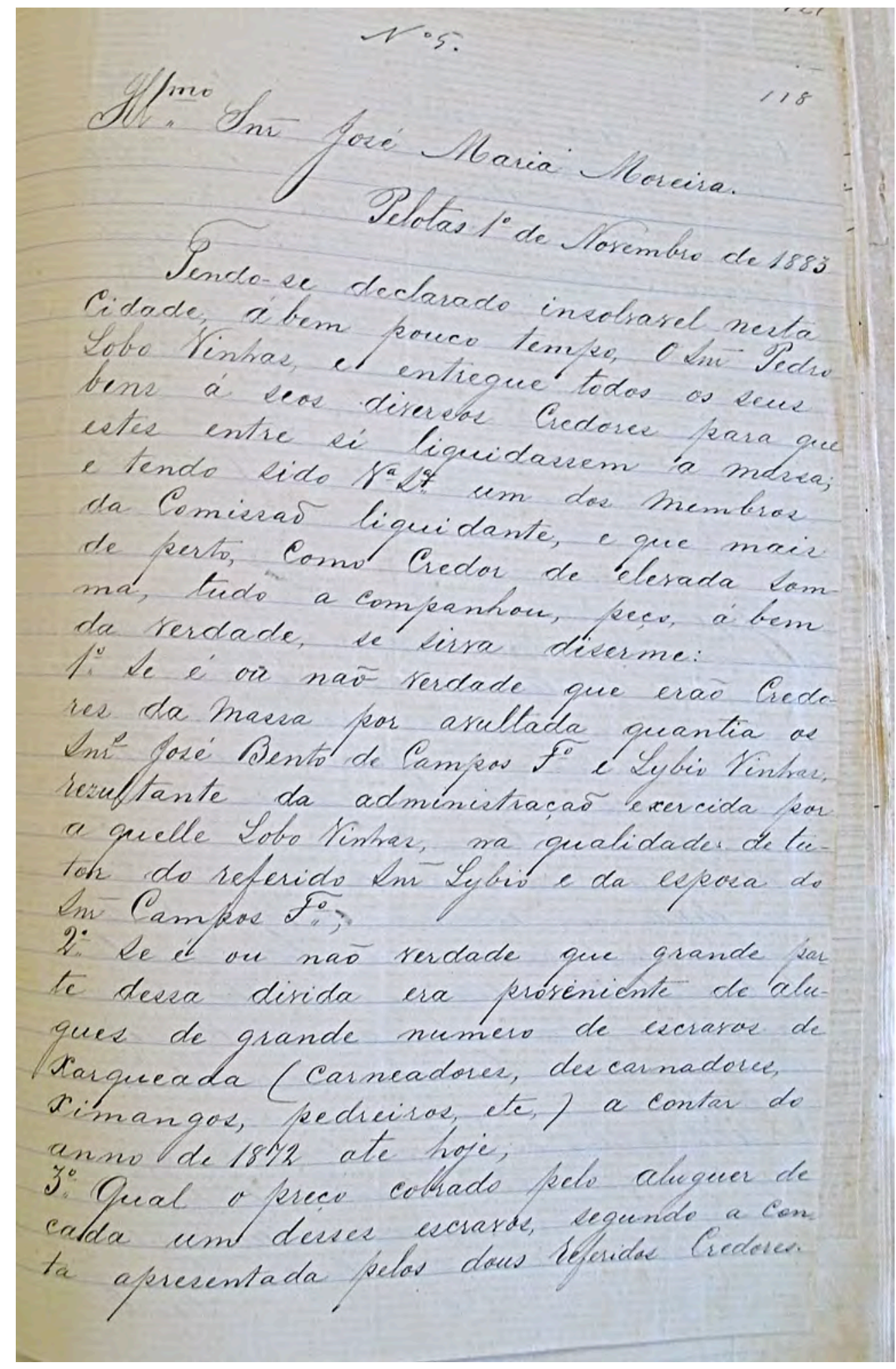


Edição doc 63 - 1883 (Arquivo Público do Estado do Rio Grande do Sul - Porto Alegre)

Illustrissimo Senhor José Maria Moreira.

Pelotas $1^{\text {o. }}$ de Novembro de 1883

Tendo-se declarado insolvavel nesta

Cidade, á bem pouco tempo, a Senhor Pedro

Lobo Vinhas, e entregue todos os seus

bens á seos diversos credores para que

estes entre si liquidassem a massa;

e tendo sido Vossa Senhoria um dos membros

da Comissão liquidante, e que mais

de perto, como credor de elevada som-

ma, tudo acompanhou, peço, á bem

da verdade, se sirva dizerme:

$1^{\text {o. }}$ Se é ou naõ verdade que erão credo-

res da massa por avultada quantia os

Senhores José Bento de Campos Francisco e Lybio Vinhas,

rezultante da administração exercida por

aquelle Lobo Vinhas, na qualidade de tu-

tor do referido Senhor Lybio e da esposa do

Senhor Campos Francisco;

$2^{\text {o. }}$ Se é ou não verdade que grande par-

te dessa divida era proveniente de alu-

gues de grande numero de escravos de

Xarqueadas (carneadores, descarnadores,

Ximangos, pedreiros, etc, ) a contra do

anno de 1872 ate hoje;

$3^{\text {o. }}$ Qual o preço cobrado pelo aluguer de

cada um desses escravos, segundo a con_

ta apresentada pelos dous referidos Credores. 
Doc 64 - 1873 (Arquivo Público do Estado do Rio Grande do Sul - Porto Alegre)

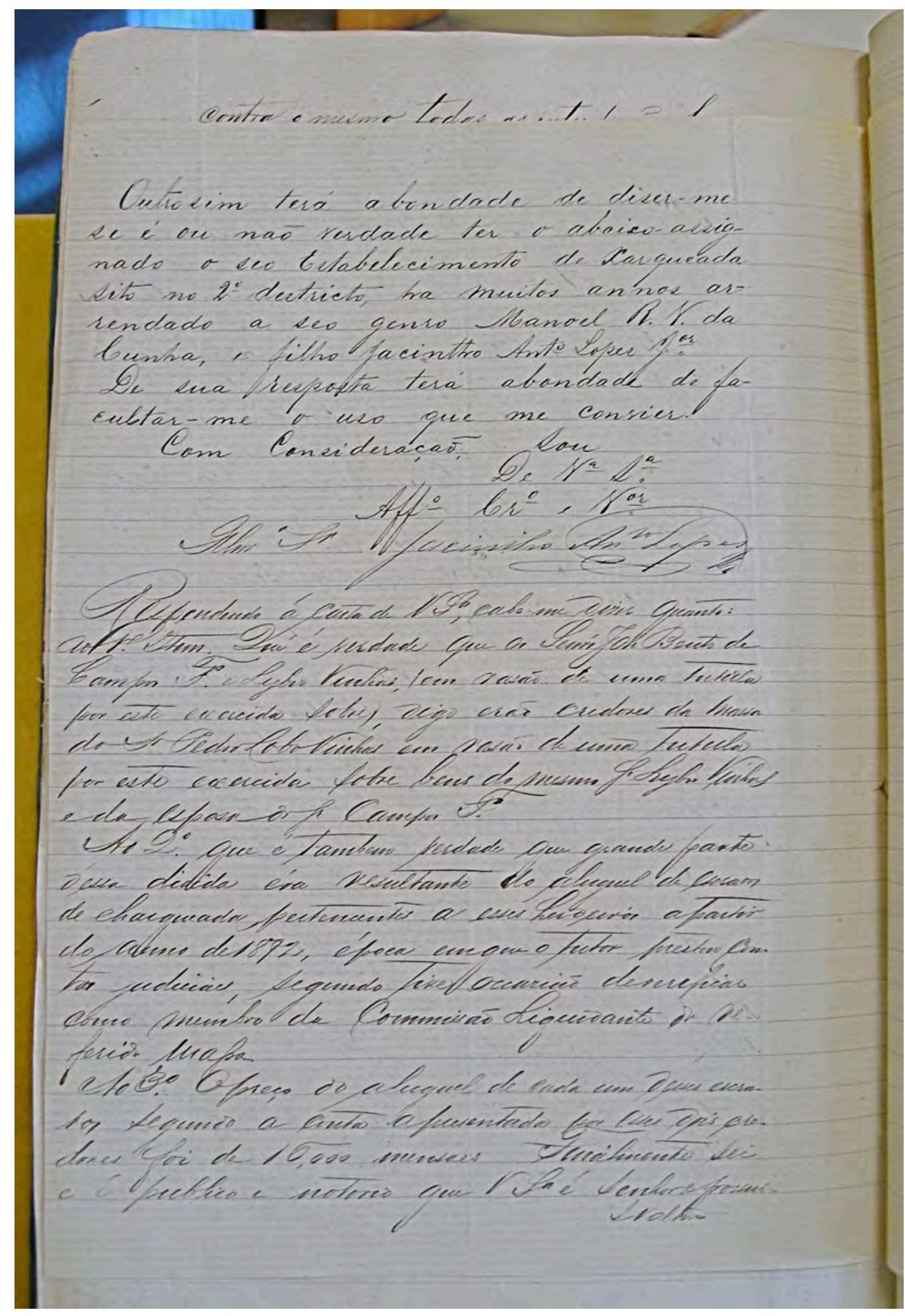


Outro sim terá a bondade de diser-me

se é ou não verdade ter o abaixo - assig-

nado o seo Estabelecimento de Xarqueada

sito no $2^{\mathrm{o}}$ districto, ha muitos annos ar-

rendado a seo genro Manoel Rofrigues Vieira da

Cunha, o filho Jacintho Antonio Lopes [ilegível]

De sua resposta terá a bondade de fa=

cultar-me o uso que me convier.

com consideração. Sou

De Vossa Senhoria

\section{Affetuoso Carissimo Valor}

Illustrissimo Senhor Jacintho Antonio Lopes

Respondendo á carta de Vossa Senhoria cabe a mim dizer quanto:

Ao $1^{\text {o. }}$ Item. Que é verdade que os Senhores José Bento de

Campos Francisco e Lybio Vinhas, tem rezão de uma tutela

por este exercida sobre digo erão criadores de Maria

da Silva Pedro Lobo Vinhas em razão de uma tutella

por este exercida sobre bens do mesmo Senhor Lybio Vinhas

e da esposa do Senhor Campos Francisco

Ao $2^{\text {o. }}$ que é tambem verdade que grande parte

déssa divida éra resultante do aluguel de escravos

de charqueada pertecentes a esses herdeiros a partir

do anno de 1892, época em que o tuctor prestou con-

tas judiciaes, segundo tive occazião de vereficar

como membro da Commisão Liquidante de de-

ferior Massa.

Ao $3^{\text {o. }}$ O preço do aluguel de cada um desses escra-

vos, seguido a conto apresentado por esse tais cre-

dores foi de 16,000 mensais Finalmente sei

e é publico e notorio que Vossa Senhoria é senhor e possui-

(Noltra) 
Doc 65 - 1873 (Arquivo Público do Estado do Rio Grande do Sul - Porto Alegre)

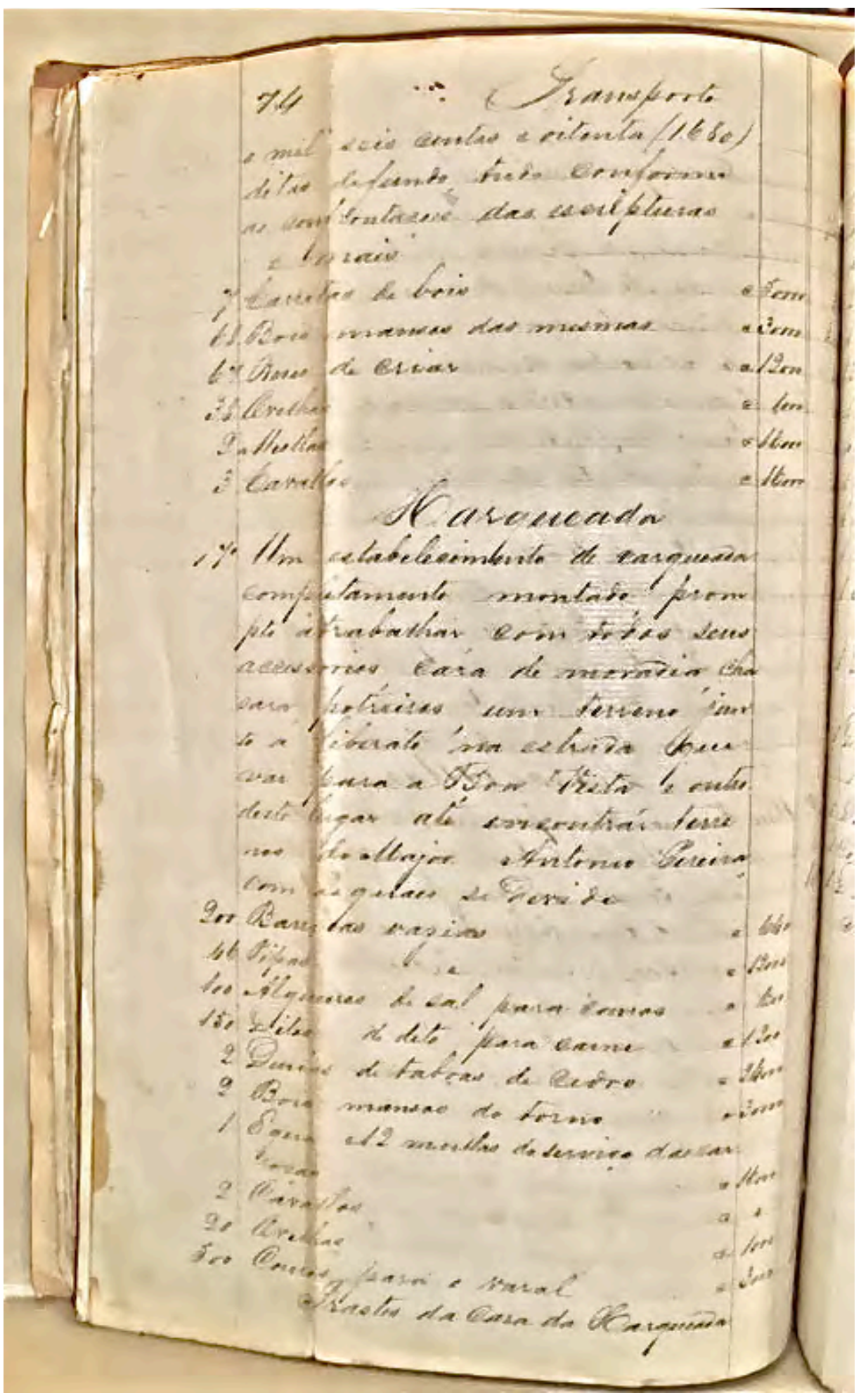


74 Transporte

e mil seis centas e oitenta (1680)

ditas de fundo tudo conforme

de assentação das escripturas

e mais

7 Carretas de bois

68 Bois mansos das mesmas

67 Bois de Criar

38 Ovelhas

2 Mullas

3 Cavalhos

Xarqueada

$1^{\text {o. }}$ Um estabelecimento de xarqueada

completamente montado prom

pto a trabalhar com todos seus

acessorios casa de moradia cha

cara, potreiro, um terreno jun

to a ribera te na estrada que

vai para a Boa Vista e entre

deste lugar até encontrar terre

nos do major Antonio Pereira

com as quaes da devida

200 Bazilas vazias

46 Pipas e

100 Alqueires de sal para carnes

150 [ilegível] do dito para carne

2 Duzias de taboas de sedro

2 Bois mansos de torno

1 Egua e 12 mullas de serviço das car-

[nea]ção

2 Cavallos

20 Ovelhas

500 Couros para o varal

Trastes da Casa da Xarqueada 
Doc 66 - s/n (Alvarino da Fontoura Marques - A Economia do Charque. O charque nas artes. Culinária do charque)

\section{A CONCORRÊNCIA NACIONAL}

Outros Estados faziam charque que concorria com o charque gaú. cho no mercado nacional.

Destacaram-se os saladeiros do Mato Grosso, cujo produto era escoado por via fluvial, descendo os rios Paraguai e Paraná até o Estuário da Prata. O interesse desses saladeiros retardou muito a aplica. çáo de medidas que evitassem a passagem de charque brasileiro pelo estrangeiro, onde estava sujeito a manobras ilícitas de toda ordem.

A conclusão da estrada de ferro de Bauru, em São Paulo, até Porto Esperança e mais tarde Corumbá, às margens do rio Paraguai, no Mato Grosso, possibilitou mais uma saída para o charque do Pantanal, sem ser preciso passar por território estrangeiro.*

O desenvolvimento da pecuária por todo o Brasil possibilitou a fabricação de charque em muitas regiōes que antes eram consumidorás de charque rio-grandense e mesmo de charque platino.

Além do gado mais abundante, vários motivos favoreciam as charqueadas do Centro e do Norte do País, em relação às do Sul:

1: - O charque podia ser fabricado em qualquer época do ano, não dependendo da rigorosa limitação das safras.

O clima quente e ensolarado permite a secagem natural da carne, durante todo 0 ano, especialmente nos meses sem chuvas que correspondem aos do inverno no Rio Grande do Sul.

2:- As charqueadas localizavam-se mais próximas das áreas de consumo.

3:- Os produtores de carne-seca precisavam de menor capital de giro porque, tanto a produção como o transporte e o consumo faziam-se em intervalos de tempo mais curtos.

$4:-O$ rendimento menor do gado das regiōes do Centro e do Norte era compensado por uma carne-seca mais úmida e mais pesada no momento da comercialização.

5:- Fora do Rio Grande do Sul, os produtores de charque geralmente não abatiam os melhores novilhos, que eram reservados para os frigorlficos e destinavam-se ao consumo de carne verde ou à exportação. A matéria-prima que empregavam no charque era mais barata, proveniente de vacas ou de dianteiros rejeitados para o consumo local de

\footnotetext{
- A ligaçăo final com Corumbá sơ se completou na presidência do Gen. Dutra. A importâncla dessa estrada era tamanha que, se tivesse sido construfda a tempo, teria modificado noss as relaçes com o Prata $e$ o Paraguai.
} 
Doc 67 - s/n (Alvarino da Fontoura Marques - A Economia do Charque. O charque nas artes. Culinária do charque)

\section{As arreadas}

Enquanto o domínio português se consolidava, aos poucos, no lito. ral, às margens das lagoas e dos rios, o interior do Rio Grande do Sul era território disputado pelas potências coloniais, e os espanhóis do Prata nele mantinham postos militares.

Os tratados de Madrid, em 1750, e de Santo Ildefonso, em 1777, assim como a Conquista das Missōes, em 1801, possibilitaram a dissemi. nação de estâncias luso-brasileiras em todo o território rio-grandense e a posse definitiva de seu interior.

Novas terras de fronteira abriram-se a aventureiros que tinham como profissão, incursōes nos campos para roubo de gado: as arreadas.

Rio Pardo, posto avançado da fronteira, prestava-se como base de operaçōes para essa atividade, que se não era licita, pelo menos era consentida pelas autoridades e estimulada pelos charqueadores que começavam a surgir por toda parte.

Sebastião Francisco Bettamio, alto funcionário português, em sua "Notícia particular do Continente do Rio Grande do Sul, segundo o que vi no mesmo Continente e notícias que nele alcancei com as Notas, do que me parece necessário para aumento do mesmo Continente $\theta$ utilidade da Real Fazenda", em 1780, registrou, com relação a Rio Pardo: "Nesta povoação ou nas suas vizinhanças, é que por estudo vivem muitos homens separados de comunicação para estarem mais aptos a poderem sair ao campo fazer os roubos de gado (a que chamam arreadas), sendo estes homens havidos por desembaraçados e resolutos campistas, dignos de qualquer empresa; mas quanto a mim são uma peste que ali reside, e uns perturbadores da paz e sossego público, que para se conservar, me parece ser melhor meio, tirá-los de todo das fronteiras, e dar-lhes suas moradas no interior do pals, e até conceder-lhes terrenos equivalentes aos que lá possuírem, não deixando estabelecidos em fronteiras homens que não sejam conhecidos por quietos, sossegad os e sem inclinaçăo a se enriquecerem por meio de arreadas..."

Como em muitas outras ocasiōes, governos valeram-se de aventureiros audaciosos e de foras-da-lei de toda espécie, para hostilizar seus inimigos, sem assumirem as responsabilidades de uma guerra aberta 
Doc 68 - s/n (Alvarino da Fontoura Marques - A Economia do Charque. O charque nas artes. Culinária do charque)

e declarada. Em duas opor tunidades, a Coroa portuguesa, em constante desses expedientes: primeiro, quando estimulou-grandense, utilizou-se para expulsarem os jesuftas, representantes dos inda de bandeirantes segundo, quando permitiu as arreadas na "terra de ningesses espanhois: de Rio Pardo. roubado em sesmarias localizadas cada vaz estabeleciam-se com o gado em conflito. De posse de uma ou mais mara dentro do território pouco gado e as vendiam a novos povoadias, mantinham-nas com especuladores de terras com funçōes muito de nossos dias.

O desenvolvimento das charqueadas, no fim dos anos mil e setecentos estimulou mais ainda a atividade desses aventureiros. As arreadas correspondiam à atividade semelhante, praticada anteriormente, nas vacarias, por faeneros e changadores, para a caça ao gado xucro e retirada do couro e do sebo.

No conceito de Mrs. Madaline Wallis Nichols, a "schoolar" norte-americana que escreveu um dos melhores estudos que existem sobre o gaúcho ("O Gaúcho. Livraria Editora Zélio Valverde, Rio, 1946), o contrabando foi, possivelmente, o maior fator isolado da origem desse extraordinário tipo social sul-americano.

\section{O CONTRABANDO DURANTE A REVOLUÇĀo FARROUPILHA}

No decorrer da Campanha de Farrapos, o contrabando era uma questão de sobrevivência dos rebeldes da República de Piratini e tornouse indispensável para a obtençăo de recursos de toda ordem.

Desde o inf́cio, os revolucionários tinham perdido o cordăo umbelical da Província, representado pelo porto e a barra de Rio Grande. Sem uma salda para o mar, só tinham contato com o extarina.

das fronteiras com o Uruguai, a Argentina $\theta$ Santa Catariras, sobretudo O contrabando foi grande ao longo dessas os poucos produtos de com o Estado Oriental, por onde se escoavam cavalos, imprescindiveis numa exportação, em troca de armas, muniçáo e cavo o resto do pals. guerrilha de 10 anos de duraçăo contra todo 0 resto do pals. 
Doc 69 - s/n (Alvarino da Fontoura Marques - A Economia do Charque. O charque nas artes. Culinária do charque)

O contrabando, tanto o de gado como o de charque, trazia grandes lucros às charqueadas e frigorificos da Fronteira, a ponto de muitos deverem sua propriedade, exclusivamente ao fato de estarem localizados junto à linha divisória, dispondo de todas as facilidades para transaçōes clandestinas.

Até os dias atuais, persiste o contrabando de gado na fronteira uruguaia, facilitado pelas caracter/sticas geográficas de grande parte das divisas entre os dois países, constituídas, em mais da metade de sua extensáo, por uma linha seca que corre entre marcos e atravessa grandes propriedades.

Outro fator que colabora no contrabando fronteiriço de gado são os latifúndios existentes ao longo da linha divisória, de um e de outro lado, sobretudo do lado Oriental. Um estudo feito há poucos anos, pelo entâo senador uruguaio, Wilson Ferreira Aldunate, mostrou que a existên. cia de grandes propriedades na faixa de fronteira, do lado de lá, acarreta o despovoamento, o isolamento das estâncias e a impossibilidade de vigilância da fronteira. Ferreira Aldunate citou famílias inteiras de contrabandistas que são, ao mesmo tempo, grandes proprietários rurais na faixa fronteirista.

Nos anos em que o gado uruguaio permanecia em baixa, o contrabando para o Brasil era um fato real e incontestável.

\section{O TRÁFICO DE GUIAS FALSAS}

A necessidade do charque nacional ter de ser exportado por Montevidéu ou Buenos Aires, o que aconteceu por muitos anos, criou outra modalidade de contrabando: o tráfico de guias falsas.

O nosso produto era acompanhado por guias fiscais durante sua passagem pelo estrangeiro. Nesses palses, o charque correspondente às guias era trocado por produto platino, de melhor qualidade, ficando o nosso produto para ser vendido depois, como artigo de categoria inferior. Remetia-se, para o mercado brasileiro, o charque de maior teor de gordura, enquanto o mais magro ia para Cuba. Muitas vezes, vendiam-se só as guias brasileiras, sem a mercadoria, para serem ajuntadas ao charque platino, nosso concorrente.

Os prejuízos para a economia brasileira eram incalculáveis.

O problema do tráfico de guias só foi resolvido com a lei federal que passou a considerar como estrangeiro todo o charque que transitasse fora do território nacional, a chamada "Lei de Nacionalização do Charque". Naquela época, em 1928, grande parcela do charque produzido 


\section{SISTEMAS DE VENDA DE GADO}

No livro "Episódios do Ciclo do Charque" (Edigal, Porto Alegre, 1987), no capítulo dedicado a Rosário do Sul, referimo-nos ao sistema de venda de gado gordo mediante pesagem antes do abate, pelo chamado peso vivo e a rendimento ou seja, pelo peso das carcaças.

Antes das charqueadas de empresas estrangeiras, não era costume a venda de gado a peso, embora já houvesse balança na tablada de Pelotas. A grande maioria das transações era feita no rodeio, a vulto, como se dizia. O comprador pagava uma quantia únida, por cabeça de animal apartado no ato do faturamento da tropa.

-O plano do Gen. Flores da Cunha era, no futuro, enviar carnes congeladas para 0 Rio, em navios frigorfficos. 
Doc 71 - s/n (Alvarino da Fontoura Marques - A Economia do Charque. O charque nas artes. Culinária do charque)

\section{A FABRICAÇÃO de CONSERVAS NAS CHARQUEADAS}

O fabrico de conservas junto às charqueadas começou mais cedo que a introdução da indústria frigorífica. Nasceu com a necessidade das charqueadas aproveitarem melhor os produtos da matança.

Os avanços científicos aplicados na indústria, especialmente as descobertas da época de Pasteur sobre o emprego da esterilizaçāo pelo calor como recurso para evitar a proliferaçāo de micróbios, agentes da decomposiāo dos alimentos, levaram ao desenvolvimento das técnicas de fabricação de conservas enlatadas.

Em nosso meio, a Charqueada do Paredāo, quando passou para os ingleses, a partir de 1887, começou a fabricar extrato de carne, línguas e rabadas. Estas duas últimas representavam, certamente, dois tipos de conservas enlatadas de grande difusão mundial.

Em breve, muitas charqueadas começaram a produzir extrato de carne, bem como conservas de lingua, rabada e outras. A Mc. Coll \& Co., fabricante de Ifnguas enlatadas, abriu uma fábrica em Pelotas, em 1909.

Já fizemos referéncias à produção de gorduras comestíveis, de adubo orgânico, de farinhas de ossos e de carne, como indústrias que foram- $ঙ$ acrescentando às charqueadas modernizadas, com a finalidade de melhor aproveitamento de tudo o que podia resultar da matança do boi.

Em algumas charqueadas, o emprego da gordura chegou a ser completo. Além da separaçāo entre gorduras comestíveis e industriais, foi-se ao nível do desdobramento destas últimas para fabricação de sabōes, velas de estearina e glicerina. Os três principais componentes da gordura animal, os ácidos graxos: alêico, palmítico e esteárico foram separados da glicerina, à qual estão combinados, dando os produtos que enumeramos acima.

Já citamos, igualmente, os processos industriais aplicados no aproveitamento de pêlos, ossos e substância córnea de chifres e cascos.

Todos esses recursos industriais adotados pelas charqueadas modernas, representavam uma fonte de lucros muitas vezes superior à do charque, dos couros e do sebo, das charqueadas tradicionais. 
Doc 72 - s/n (Alvarino da Fontoura Marques - A Economia do Charque. O charque nas artes. Culinária do charque)

A atuação do Sindicato trouxe elevação de preço do produto e aumento das exportaçóes, conseguindo, pela primeira vez, remessas diretas para Cuba.

As divergências já existentes entre pecuaristas e charqueadores foram agravadas pela atuação do Sindicato, devido aos preços impostos pelo mesmo nas compras de gado. Alguns fazendeiros chegaram a definir a entidade como um verdadeiro "trust".

Os pecuaristas sentiam-se duplamente prejudicados, pelos charqueadores e pelos frigorificos estrangeiros. Ao entrarem os anos 30 , a classe dos pecuaristas, dominante no Estado, estava dividida em criadores e charqueadores, ambos reunidos em associaçōes que defendiam interesses especificos: a FARSUL e o SINDICATO DOS CHARQUEADORES.

O Sindicato foi muito favorecido por medidas oficiais: criaçāo do Banco do Rio Grande do Sul, Lei de Desnacionalizaçāo do Charque e redução de $50 \%$ nos fretes ferroviários.

Indiretamente, o Sindicato foi o estimulador do espírito cooperativista no meio pastoril, como sendo uma forma de reação dos fazendeiros que se sentiam prejudicados pelos frigoríficos estrangeiros e pelo Sindicato dos Charqueadores. Agravava o descontentamento, o acúmulo das crises sofridas pelo charque no decorrer do século.

O Sindicato dos Charqueadores significava entendimento entre os produtores de charque para o estabelecimento de preços, a limitação da produção, a partilha do mercado e a criação de um aparelho comercial comum, de venda dos produtos e compra das matérias-primas.

\section{O COOPERATIVISMO}

O movimento cooperativista entre criadores, invernadores e charqueadores data de 1914, quando João Mascarenhas lançou a idéia das "charqueadas regionais" para que os fazendeiros pudessem abater seus próprios gados e se beneficiassem diretamente dos lucros provindos da atividade.

A proposta de João Mascarenhas baseava-se nas "packing houses" norte-americanas muito em evidência naquela época, principalmente depois que o Dr. Joaquim Francisco de Assis Brasil, em 1901, havia publica. do na "Revista Agrícola do Rio Grande do Sul" um relatório sobre a "Exposiçāo Pecuária de Chicago", que tinha visitado oficialmente, como representante de nosso Ministério do Exterior. (J. F. de Assis Brasil. In "Revista Agrícola do Rio Grande do Sul". Números de 31/12/1901 e 31/1/1902. Pelotas). 
Doc 73 - s/n (Alvarino da Fontoura Marques - A Economia do Charque. O charque nas artes. Culinária do charque)

\section{DIETÉTICA E CULINÁRIA DO CHARQUE}

\section{O charque na cozinha}

A culinária brasileira do charque é muito rica. Há grande número de pratos em que ele ocupa o lugar de qualquer outro tipo de carne. Cada regiáo possui suas maneiras próprias de preparar esses pratos, variando, ora o tipo de carne-seca, ora sua maneira de cozinhar e ora o outro alimento que Ihe faz companhia.

Muitos não passam de ligeiras variantes regionais de um mesmo prato, comum em todo território nacional.

Todos têm, como finalidade prática, tornar mais saborosa uma carne que perdeu suas caracteristicas originais e se transformou num alimento seco, com mau aspecto e com excesso de sal, "uma estopa", como achava J. F. de Assis Brasil.

Uma parte muito importante do charque é sua gordura própria - destacadamente abundante nos tipos platino e rio-grandense - que confere a esses produtos qualidades muito especiais e apreciadas, de aparência, consistência, cheiro e paladar. A gordura era tâo importante que, na classificação oficial do charque, o critério principal era seu teor em partes gordas. Os dois primeiros lugares cabiam aos tipos: "AA" e "XX", que correspondiam aos charques: "Gordo" e de "Boa Gordura".

De fato, a gordura bovina, considerada pelo "Larousse Gastronomique", a mais nobre de todas, coloca o charque gordo entre as iguarias finas, com ar oma e sabor comparáveis aos dos mais famosos ing redientes da culinária mundial.

O emprego de óleos vegetais, de banha de porco e de outras gorduras, durante os processos culinários, pode influir desfavoravelmente sobre o rico sabor original do charque gordo, deturpando-o em grande parte.

Além disso, o charque gordo tornava-se mais económico por dispensar o uso de outras gorduras, de custo elevado. No interior do Brasil, o charque do Rio Grande do Sul e o platino sempre foram muito aprecia- 
dos por serem ricos em gordura. As donas-de-casa sertanejas, depois de fritarem bem o charque picado, acrescentavam o arroz, o aipim, a abóbora ou a simples farinha de mandioca e tinham o prato pronto para ir à mesa, sem o acréscimo de gordura alguma.

Quem comprava charque do sul, adquiria dois tipos de alimento: carne e gordura num só, o que representava grande vantagem sob o aspecto econômico e compensava o preço um pouco mais elevado dessé charque, sobre o da carne-seca local. 
Doc 75 - s/n (Alvarino da Fontoura Marques - A Economia do Charque. O charque nas artes. Culinária do charque)

\section{PRATOS FEITOS COM CHARQUE}

\section{Aboboras recheadas com charque (Receita do Dr. Armando Fonticella)}

- 4 abóboras pequenas e verdes;

- $700 \mathrm{~g}$ de charque

- temperos: 1 cebola grande, 4 dentes de alho, 1 molho de manjerona e 2 tomates bem maduros.

Cortar o charque em fatias finas e desfiar. Refogar em óleo a cebola e 0 alho bem picados. Juntar o charque e deixar refogando cerca de 15 minutos. Acrescentar os tomates e a manjerona. Manter no fogo até os tomates desmancharem.

Cortar a parte de cima das abóboras e retirar-lhes as sementes. Rechear as abóboras com o charque e colocar as tampinhas. Pôr as abóboras em uma panela grande, com dois dedos de água. Levar ao fogo médio, com a panela tampada, até cozinharem.

\section{Arroz de carreteiro}

O arroz de carreteiro é, sem dúvida, a mais popular de todas as apresentaçōes culinárias à base de charque.

Ele nasceu, como o próprio nome está dizendo, da necessidade do condutor de carretas de bois de preparar, ele mesmo, suas refeiçōes.

As viagens eram longas e feitas a passo de boi. A jornada era cumprida em duas etapas, de 10 a $15 \mathrm{~km}$ cada uma, separadas pelo almoço e a sesta do meio-dia, indispensáveis à alimentação e ao descanso de homens e animais.

O carreteiro, com pouco tempo para soltar os bois, desencilhar - cavalo e atá-lo à soga, fazer fogo, cevar o mate e cozinhar sua refeição, tinha que se limitar a preparar um prato rápido que fosse satisfatório sob o ponto de vista nutritivo e que agradasse ao seu paladar simples. 
Doc 76 - s/n (Alvarino da Fontoura Marques - A Economia do Charque. O charque nas artes. Culinária do charque)

\begin{abstract}
Arroz de tropeiro
É uma variante do arroz de carreteiro, difundida em algumas regiões brasileiras, como no sul da Bahia. Corresponde ao "Arroz de Boiadeiro", do Brasil Central, geralmente feito com carne fresca e temperado com muito alho.
\end{abstract}

\title{
Camboeiro
}

Tem este nome uma variedade de farnel usado no Norte; comida de "camboeiro", pessoa encarregada de conduzir filas de mulas ou jumentos (almocreve, tropeiro).

Não passa de uma carne-de-sol em pedaços, bem frita e misturada com farinha de mandioca seca. 


\section{Cangica com charque}

É um dos pratos únicos que exige muito pouco, apenas uma salada, um legume ou um fruta, para constituir uma refeição completa e substanciosa.

Por ser de cozimento demorado, é prato caseiro que não pode ser preparado nos fogões a gás da cidade e nem por viajantes.

A tualmente ainda se consome cangica com charque ou com carne de ovelha nas fazendas do interior, cozida nos tradicionais fogões a lenha.

O fiel e minucioso cronista dos costumes das nossas estâncias dos últimos 50 anos, Raul Annes Gonçalves ("Mala de Garupa". Martins Livreiro Ed., Porto Alegre, 1984) tem um capítulo dedicado à cangica, tão assídua em nosso cardápio campeiro. Descreve o preparo da cangica feita em casa, no pilão, mais rica e mais gostosa que a atual, feita nas cangiqueiras de beira de cidade. Fala na cangica temperada com charque $e$ a preparada com espinhaço de ovelha, a melhor. Cita também as sobremesas feitas com cangica, tão deliciosas quanto nutritivas. 
Doc 78 - s/n (Alvarino da Fontoura Marques - A Economia do Charque. O charque nas artes. Culinária do charque)

\section{Charque grelhado}

Não é um prato campeiro e tradicional. É uma maneira povoeira e mais requintada de se apresentar o charque.

\section{RECEITA:}

Corta-se o charque em pedaços grandes, de 10 a $15 \mathrm{~cm}$.

A ferventa-se-os bem, com temperos, durante 2 a 3 horas, ou até que resultem em estado pastoso.

Deixa-se escorrer a água.

Pica-se o charque em pedaços menores que são untados com manteiga e grelhados em assadeira.

Servir com arroz branco, com pirão comum ou com pirê de batatas.

\section{Chatasca ou Xatasca}

\section{RECEITA PARA 4 PESSOAS:}

- 1/2 kg de charque magro;

- 1 colher de sopa de óleo ou banha;

- 1 cebola picada;

- Farinha de mandioca, de preferência proveniente de Santa Catarina, mais rica em amido;

- Temperos verdes diversos;

- Pimenta da terra.

Cortar o charque em pedaços grandes.

Aferventá-los bem até que fiquem moles e fáceis de desfiar. temperos.

Pôr o charque desfiado a refogar com a gordura, a cebola e os

Engrossar com a farinha de mandioca.

\section{Churrasco de charque}

É um dos pratos mais saborosos da culinária gaúcha, com a condição de que se utilize um charque especial para ser assado no espeto ou na grelha, macio, com pouco sal e relativamente gordo. Os chamados 
Doc 79 - s/n (Alvarino da Fontoura Marques - A Economia do Charque. O charque nas artes. Culinária do charque)

\section{Engasga-gato}

É o nome tradicional e pitoresco de um guisadão de charque (ou também de carne fresca ou de sobras de carne da refeição anterior), bem refogado com azeite ou banha e temperos à vontade.

Serve-se acompanhado de pirão, arroz ou pirê.

\section{Feijão com charque}

Outro prato tradicional em todo o País. Trata-se de uma feijoada, na qual não figuram tantos ingredientes como nas tradicionais do Centro do Brasil, mas apenas pedaços de bom charque gordo. 
Doc 80 - s/n (Alvarino da Fontoura Marques - A Economia do Charque. O charque nas artes. Culinária do charque)

\section{Fervido ou aferventado de charque}

Consiste numa variante do "puchero", em que a carne fresca é substituída pelo charque.

\section{RECEITA PARA 4 PESSOAS:}

- $1 / 2 \mathrm{~kg}$ de charque gordo;

- Couve, repolho, milho verde, nabos, cenouras, pedaços de moranga, pedaços de aipim, batatas, etc.;

- Cebola, tomate picado, pimenta da terra, alho, vinagre, etc.

Cortar o charque em pedaços de tamanho médio e pô-los a ferver em bastante água nova.

Quando estiverem bem cozidos, acrescentar os temperos e os outros ingredientes.

Voltar a ferver até que tudo esteja bem cozido.

Servir no próprio caldo.

Fazer um pirão com o caldo.

\section{Guisado de charque com abóbora}

ou moranga; com couve ou repolho

Apresentações caseiras, mais populares, do charque. 
Doc 81 - s/n (Alvarino da Fontoura Marques - A Economia do Charque. O charque nas artes. Culinária do charque)

\section{Mandioca ou aipim com charque}

Igual aos outros guisados de charque, porém com pedaços de aipim, mandioca ou macacheira.

\section{Maria Izabel}

Em Goiás e Piauf, é popular uma variante do arroz de carreteiro em que o charque é cortado mais miúdo e frito até torrar. Luís da Câmara Cascudo ("Dicionário do Folclore Brasileiro". Editora Itatiaia, Belo Horizonte, 1984) enumera Maria-Zabé, prato semelhante, comum entre os garimpeiros do Baixo Amazonas, do Rio das Mortes e do Araguaia.

\section{Paçoca}

A popularíssima paçoca é, na verdade, o componente básico de variadas apresentações. No Rio Grande do Sul, resume-se o charque desfiado e misturado com farinha de mandioca.

O charque magro é aferventado e desfiado (antigamente era socado em pilão), depois posto a fritar, temperado e misturado com farinha.

O charque preparado dessa maneira pode durar muitos dias, sendo por isso usado como farnel nas viagens longas.

Em Minas Gerais, a farinha de milho substitui a de mandioca.

Nas estâncias antigas, a paçoca de charque servia para o recheio de pastelões feitos com massa de farinha de trigo ou de batatas e, igualmente, para a confecção de omeletes e tortas com ovos batidos.

No Norte, a paçoca pode vir misturada com bananas. No Amazonas, faz-se uma paçoca sem carne, misturando-se farinha de castanhas com farinha de mandioca e rapadura. Há outras variantes em que o amendoim substitui as castanhas. Na região serrana do Rio Grande do Sul, mistura-se pinhão cozido e moído à paçoca (Carlos Castillo. "Fogão Campeiro". Martins Livreiro, Porto Alegre, 1984). 
Doc 82 - s/n (Alvarino da Fontoura Marques - A Economia do Charque. O charque nas artes. Culinária do charque)

\section{Roupa-velha} de Charque".

Também leva os nomes de "Marimbondo de Charque" ou "Desfiado

Para Apolinário Porto Alegre, Roque Calage e os trmãos Zeno e Rui Cardoso Nunes, dicionaristas de termos gaúchos, paçoca e Roupavelha são quase a mesma coisa.

A única diferença importante é que a paçoca é para ser levada em viagem, e a Roupa-velha é uma comida quente e temperada.

Há semelhança também com a Chatasca.

Em Santa Catarina há uma variedade de Roupa-velha, bem diferente das demais, em que são empregados pedaços de charque que sobraram da feijoada. Tais pedaços são desfiados e fritos, depois engrossados com farinha de mandioca, fazendo-se um mexido que toma a cor escura do feijão preto.

A Roupa-velha catarinense come-se, geralmente, com couve.

\section{Socotroco}

É um guisado com pouco molho, engrossado com farinha de mandioca.

\section{Tira-gosto de carne-de-sol}

\section{RECEITA USADA NO INTERIOR DO PIAUÍ:}

No preparo desse prato popular do Norte, não se usa o charque, propriamente, e sim a carne-de-sol que são mantas de carne magra, com pouco sal e bastante pimenta do reino moida, oreadas ao sol durante dois ou três dias.

A carne-de-sol é picada em pedaços de 2 a $3 \mathrm{~cm}$ e posta a fritar em azeite de soja, sem temperos.

Serve-se com farofa preparada com farinha grossa de mandioca, colorau ( $p \delta$ de urucum) e, às vezes, um pouco de manteiga, margarina ou gordura da própria fritura. Junto, acompanham rodelas de tomate e de cebola.

$$
\text { É usado como aperitivo, com cerveja ou outras bebidas.* }
$$

"Informaçoes do Sr. Atila K. Marques, captadas em Floreano, PI. 


\section{OCHARQUE}

0 mercado da carne e sua produção no sul do Brasil permanecem estacionários há longos anos: tal é a conclusão que creio poder deduzir de minhas observa. çöes. Para estabelecê-la, insistirei, primeiramente, sobre 0 estudo das charqueadas e dos "saladeiros": pois, no Brasil como nos países vizinhos, estes estabelecimentos consituem, atualmente, o modo de utilização mais importante; e a "carne seca" ou "tasajo" é um alimento utillzado em diversas regiöes muito vastas da América do Sul, não somente pelos escravos, como se disse, mas por toda a população, mesmo a mais abastada.

\section{AS CARNES SECAS}

$O$ centro de fabricação mais importante da carne seca, tanto para o Brasil como para toda a América do Sul, é, ainda hoje como antigamente, Pelotas, pequena cidade ativa e industriosa da província do Rio Grande. Ai existem, atualmente, trinta e duas charqueadas ou saladeiros em plena atividade: há dez anos seu número não variou sensivelmente. Há, também, cifras de bois mortos cada ano, durante o período de matança ou safra: sabese que este periodo estende-se de outubro a fim de junho. De acordo com as cifras que o Sr. Secretário da Câmara de Comércio teve a bondade de comunicar-me, deve-se estimar em cerca de 400.000 bois por ano a produção de Pelotas. Ela era de 381.000 em 1863, de 383.000 em 1875, de 385.000 em 1866, de 414.000 em 1887; mas ela pode despencar em certos anos excepci- onais, 326.000 em 1862-63, 307.000 em 1876-77. Os começos da safra deste ano têm, eles também, sido muito pouco ricos em gado.

É preciso acrescentar que existiam outrora, na província do Rio Grande, diversas outras charqueadas: fora uma exceção, a de Cachoeira, estas charqueadas desapareceram, ou diminuiram consideravelmente de importância: e assim o estado estacionário da produção do Rio Grande acha-se ainda melhor estabelecido.

Além disso, não se poderia negar que existe, para este mercado da carne seca no Brasil, um verdadeiro obstáculo, que se revela por numerosos sintomas. Citare apenas dois deles. $\ddot{E}$, primeiramente, este "convênio" que, no começo da safra, os charqueadores de Pelotas redigiram e assinaram para tentar pôr um fim à alta dos preços, e limitar eles próprios sua própria concorrência. Esta lei do "maximum" com comissão de compra dos bois, comissão de supervisão e de medidas probitivas, teve porém, por resultado, como todas as medidas análogas, 0 agravamento da crise que ela devia prevenir. 0 convênio, ao fim de algumas semanas, caiu no esquecimento; mas raramente 0 gado tinha atingido um preço tão elevado como durante a safra atual; e entre as cau. sas múltiplas da escassez das tropas sobre o mercado de venda ou "tablada" é preciso, evidentemente, colocar esta tentativa de regulamento. Não podendo mais contar com uma livre discussão dos preços, os estancieiros ou os tropeiros encaminhavam seus bois para outro mercado; e, com efeito, tardiamente, nos meses de março $\theta$ abril, após o fracasso do convênio, a tablada tornou-se de novo bastante povoada.

É preciso reconhecer, entretanto, que os charqueadores têm, aparentemente, razăo em preocupar-se com seu mercado de compra: pois seu mercado de venda 
está longe de ser próspero. Apesar dos direitos proteto. res elevados, pois que atingem perto de $10 \%$, a carne seca de Pelotas luta dificilmente com as carnes do Sul, que a cada ano invadem mais os mercados do Brasil. Sabe-se que a carne seca é, sobretudo, vendida nas provincias do Brasil, da Bahia, de Pernambuco e do Rio de Janeiro, en na itha de Cuba: os outros mercados, $\mathrm{Ce}$ ará, O Pará, como Porto Rico ou a Venezuela são com. pletamente acessórios. Até os últimos anos, este mercado era bastante dividido, as charqueadas de Pelotas abasteciam o Brasil, os "saladeiros" do Sul abasteciam Havana, e enviavam a Pernambuco, sobretudo, uma parte de sua melhor carne. Hoje, a situação já é bem diferente, e seria tácil assegurar-se, ${ }^{13}$ pelo exame dos registros de alfândegas do Rio Grande ou de Pernam. buco, sobretudo, do Rio de Janeiro, da progressão rápida da venda das carnes do Rio da Prata.

Quer dizer que seria preciso exagerar, e considerar como já, comprometida a produção de Pelotas? É preciso dar crédito às indicações dos saladeiristas do Sul, como o deviam fazer os correspondentes de revistas célebres, ou diversos escritores viajantes; e negar toda importância ao mercado do Rio Grande ou parecer ignorá-10. É preciso, mesmo, crer sobre este ponto que os próprios charqueadores de Pelotas, entre os vários que eu poderia citar, acreditam que esta indústria está destinada a desaparecer num futuro mais ou menos dis. tante? Eu serei menos pessimista que os interessados: e, depois de ter visitado os lugares de produção, depois de ter examinado com cuidado, e alguns por várias veZes, nove "saladeiros" em Pelotas, dois na República

\footnotetext{
3 Ey repetirei ainda para nom

grande pesar, obter a sara nåo mais voltar ao assunto, que não pude, com para basear eslas conclusbes.
}

Argentina, cinco na República Oriental, depois de ter co letado múltiplas informaçōes no sul do Brasil.

Não somente Pelotas é o lugar de produção mais antigo e mais importante; mas creio que certas condições, tais como as qualidades do gado, a existência de um mercado, de uma tablada já regularmente abaste. cida, são especialmente favoráveis. Em todo caso, as razões das dificuldades atuais do mercado do Rio Grande me parecem muito diferentes das que, comumente, se ouvem dizer.

Estas coclusões, eu as deduzi do exame de di. versos fatores que vou, agora, passar em revista.

\section{A - Preparação da carne seca}

Esta carne seca, produto complexo, muito impro. priamente denominada, como veremos, é o resultado de uma série de preparações complicadas, e que eu só posso descrever aqui muito rapidamente.

a) Matança dos bois - Uma tropa de gado, depois de 5 a 20 dias de viagem em média, chega ao saladeiro: encerram-na nos espaços fechados, ou "mangueiras", muito variáveis em número e em disposição. № dia seguinte de sua chegada, geralmente, fazem-na passar por pequenos grupos de 20 a 60 mais ou menos em um espaço fechado menor, cercada de muralhas resistentes $e$ bastante elevadas: é a "mangueira de matança" que co.

\footnotetext{
${ }^{14}$ Eu direi, uma vez por todas, que evitei toda indicaçáo de palavra técrica ou toda descrição demasiado precisa. Além disso, sob pena de estender-me demais, pude supor conhecias diversas operaçóes que nåo săo especlicas dos saladeiros. Muitas vezes, também, encontrar-se-ăo duas palavras para indicar a mesma coisa, p. ex., charqueada e saladeiro: uma $\theta$ a denominaçåo brasileira $\theta$ a outra, a do Rio da Prata.
} 


\begin{tabular}{|c|c|}
\hline $\begin{array}{l}96 \\
\text { munica com as outras por um caminho estreito mais ou } \\
\text { menos longo, o "curro" ou "brete". Esta última mangueira } \\
\text { tem um chäo inclinado, e geralmente deslizante, maca- } \\
\text { damizado, em grandes tijolos ou às vezes em pranchas. } \\
\text { A mangueira figura, com bastante exatidão, o plano de } \\
\text { dois troncos de cone encostados por sua larga base: um } \\
\text { dos vértices corresponde ao curro ou brete: } 0 \text { outro mais } \\
\text { importante é aquele onde os bois vão ser sucessiva- } \\
\text { mente mortos. Neste lugar, o chão da mangueira conti- } \\
\text { nua com uma vagoneta móvel sobre trilhos. } \\
\text { Estando tudo assim disposto, um homem colo- } \\
\text { cado sobre uma plataforma que guarnece exteriormente } \\
\text { a parede da mangueira de matança, atira um laço sobre } \\
\text { um dos bois que estão lá reunidos: o animal é preso pe- } \\
\text { los chifres, ou mais raramente pela cabeça e o pescoço. } \\
\text { A mesma corda do laço muito longa, enrola-se em torno } \\
\text { de um molinete vertical ou transversal, ou simplesmente } \\
\text { em torno de uma polia, e por sua extremidade oposta ao } \\
\text { lado que laça, ela é fixada aos arreios de dois animais de } \\
\text { carga, cavalos ou bois. } \\
\text { Uma vez o animal laçado, é suficiente fazer puxar } \\
\text { a corda para que o boi seja arrastado por alguns metros, } \\
\text { sobre este chão deslizante, e venha colocar-se direta- } \\
\text { mente sob a mão de um segundo operário (às vezes, é o } \\
\text { mesmo)o matador ou "desnucador". Este desnucador, é } \\
\text { colocado, ele também, sobre a plataforma exterior, ao } \\
\text { nivel da abertura inferior e da vagoneta, e, por causa da } \\
\text { altura da plataforma, ele fica mais elevado que o boi. } \\
\text { Este, quaisquer que sejam seus esforços e sua resistên-. } \\
\text { cia, vem bater sua cabeça e é fixado contra o molinete } \\
\text { pela tração da corda e dos animais da carga; e o desnu- } \\
\text { cador só tem enterrar de alto a baixo um longo facão, } \\
\text { muito resistente e mal afiado entre o atlas e o occipital } \\
\text { para o bulbo. }\end{array}$ & 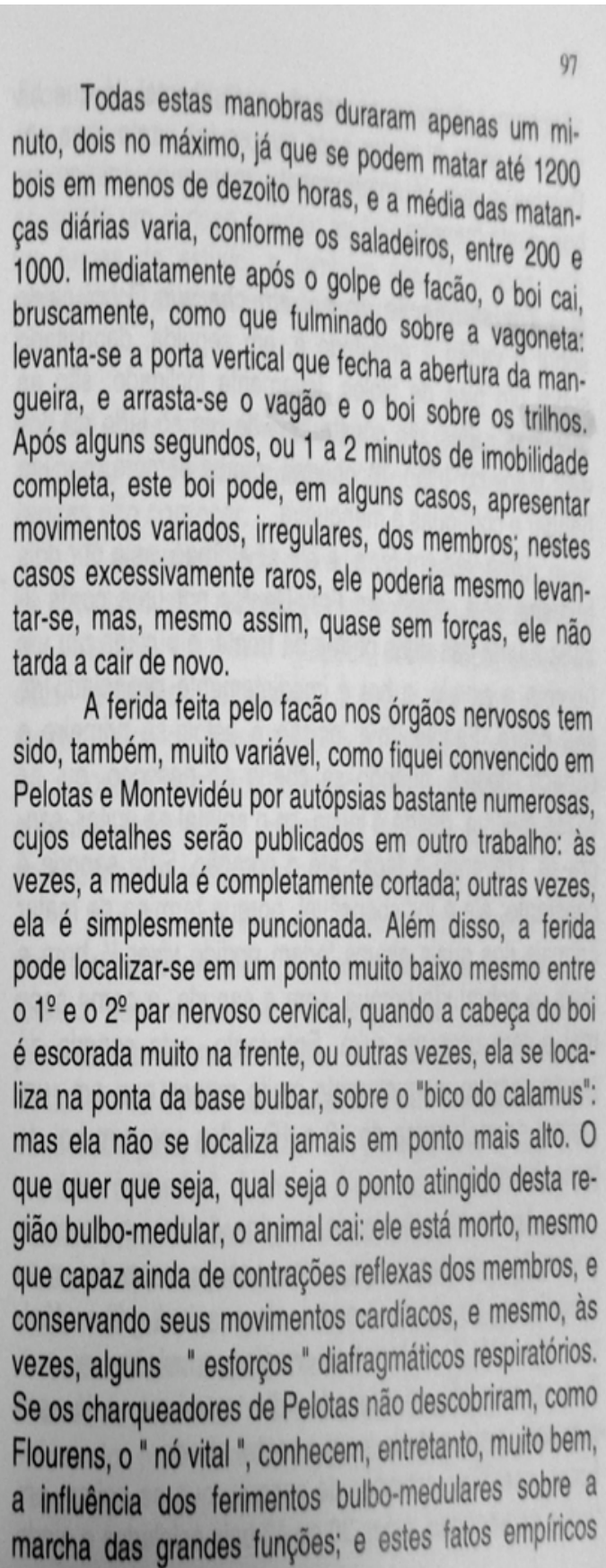 \\
\hline
\end{tabular}


são bem anteriores ao estudo experimental, já que há mais de vinte e quatro anos que se faz carne seca em Pelotas, e que, já anteriormente, matava-se, parece, os bois desta maneira.

$B$ - Transformação do boi em charque 0 boi caído sobre o vagão e arrastado é, em seguida, depositado sobre um piso de tijolos, levemente inclinado: são as "canchas". Elas são construidas de um só lado ou dos dois lados do trilho, recobertas, quase sempre, por um hangar e contiguas à mangueira.

Uma vez em terra, e ele ai é tirado, seja por dois homens, seja, como em Fray-Bentos por uma corda fixada a uma das duas partes da frente, e puxada por um homem a cavalo, 0 boi é imediatamente despojado de seu couro. Faz-se uma incisão e esfola-se primeiro a cabeça; depois, quando se chega ao pescoço, ou, às vezes mesmo, desde 0 inicio, se 0 animal se agitar, sangra-se, cravando o tacão até 0 coração. Esta sangria é constante; ela é indispensável, porque termina de matar animais dos quais alguns teriam podido viver $1 / 2$ hora $e$ mais, e sobretudo porque, sem a sangria, a carne seca mạl e tem uma cor ruim. Entretanto, esta sangria dá pouco sangue, seguramente muito menos que em um animal normal, cerca de 12 a 15 quilos para um boi de tamanho médio.

Acaba-se em alguns minutos de tirar o couro: 0 animal tem, muitas vezes, reflexos muito marcados, mas irregulares, às vezes, mesmo, ele ensaiará gritos afônicos: ele terá, durante a hemorragia, convulsōes, ou methor, abalos não-coordenados dos membros, e já será cameado pela metade, com o ventre aberto.

Estes operários cobertos de sangue, que se agitam em todos os sentidos, estes 30 ou 40 bois esfolados e ainda vivos, sentindo o facão e não podendo reagir, mugindo $\mathrm{e}$ não podendo se fazer ouvir, procurando levantar-se e so conseguindo executar safanões desordenados, oferecem ao artista um curioso quadro; ao fisiologista, interessantes temas de estudo, e também aos filantropos que preferem os animais ao homem, uma reforma para tentar.

\section{C - Até aí, as operações têm sido, em toda a parte, as mesmas, em Pelotas como no Rio da Prata; as dife- renças vão começar.}

0 animal esfolado é dividido em pedaços: os qua. tro membros são retirados, transportados e suspensos em uma sala vizinha, o "galpão", sobre suportes especiais, "tendidas" Destaca-se, a seguir, em um só frag. mento, todos os músculos cévico-faciais, dorso-lomba. res e costo-abdominais do mesmo lado: cada um desses enormes fragmentos unilaterais constitui a "manta", a porção mais apreciada pelos consumidores.

Somente no Rio da Prata, cada manta compreende também, além dos músculos pré-vertebrais e torácico-abdominais, os músculos "carré" dos lombos e psoa-ilíacos do mesmo lado; ao contrário, em Pelotas, destacam-se à parte os músculos lombo-líacos direitos e esquerdos para deles fazer um pedaço único, supranumerário: o "lombo". Além do mais, no Rio da Prata, as mantas compreendem também os músculos intercostais, fáceis de destacar, enquanto que, em Pelotas, deixam-se estes músculos aderentes nas costelas; e estas fileiras de costelas com a carne intermediária formarão o que se chama as "costelas". Estas costelas serão utilizadas, sobretudo, para a alimentação dos empregados $\theta$ dos escravos. 
100

A manta $e$ os membros são levados ao galpão: ficam a cabeça, o tronco $e$ as visceras: todas estas partes serão rapidamente separadas, jogadas de lado para fora das canchas $\theta$ carregadas: um boi toma o lugar do precedente; a operação durou de 5 a 6 minutos.

D - É no galpão que começam as operações verdadejramente originais. A carne dos membros é separada dos ossos; fazendo uma série de furos na carne com a ajuda de um facão e a separando por estes orifícios com dois dedos, o "carneador", em alguns instantes, deixa apenas ossos e articulações completamente intactos. Ainda aí uma nova diferença: em Pelotas, cada membro fornece dois pedaços de carne, um anterior e outro posterior, no Rio da Prata, a carne do membro anterior será separada dos ossos em um só pedaço. Ter-se-ão, assim, para os membros, oito pedaços (porções) em Pelotas, e somente seis no Rio da Prata.

Então, tendo-se conta da diferença já assimilada, cada animal fornece em Pelotas, onze fragmentos (tiras) de carne; o "lombo" ou músculos sacro-lombares bilaterais', as duas "mantas", o "colchão" ou "chicsuela", músculos anteriores do membro posterior; o "tatu" ou "pato", músculos posteriores do mesmo membro: e, finalmente, as duas paletas, "paleta de dentro " ou músculos ânterointernos do membro anterior, "paleta de fora" ou músculos póstero-externos. Ao contrário, em Montevidéu ou Buenos Aires, falta o lombo, unido às mantas pela metade; $\theta$ uma das paletas: perfaz ao todo, oito pedaços.

Estas diferenças são, como se verá, úteis do ponto de vista do rendimento.

E - O boi é trazido em tiras de carne desprovidas de os. sos, exceto a rótula conservada no colchão e um frag. mento de omoplata unido à paleta. Resta a operação mais delicada, pois ela tem por objeto fazer passar estes pedaços de carne irregulares em forma e espessura ao estado de retalhos, igualmente espessos em toda a parte e cujos contornos não terão forma definida; é a "char. queagem": e, ainda que complicada é feita, também, muito rapidamente.

Os pedaços de carne são estendidos sobre uma mesa no Rio da Prata, e um só operário os maneja; em Pelotas, eles são estendidos sobre barras de madeira, que sustentam sua parte mediana, e dois charqueadores os trabalham, cada um por um lado. Em todos os casos, a carne, ficando sempre estendida sobre a mesa ou so. bre 0 suporte por uma de suas faces, é sobre a outra talhada rapidamente por golpes de facão dados sucessivamente, desbastando, partindo do meio do pedaço, isto é, de sua parte mais grossa. Só as mantas são, sobretudo, "charqueadas" em suas partes laterais que corres. pondem uma, aos músculos abdominais e a outra, mais importante, aos dorso-lombares. A parte mediana intermediária muito aponeurótica é mal tocada pelo facão.

Esta operação tem como consequiência dar ao fragmento uma espessura regular, e de tornar muito maiores as superfícies de dessecamento e de salga: mas há, sob o ponto de vista dos resultados últimos, diferenças muito grandes entre 0 Rio da Prata $\mathrm{e}$ Pelotas.

Em Pelotas, a carne é charqueada muito fina, cerca de $1 \frac{1}{2} \mathrm{~cm}$, ainda que seja bem difícil medir estar superficies irregulares: no Sul, a carne é seguramente charqueada muito mais grossa, metade a mais, pelo menos. Tentei apreciar as diferenças pela mensuração dos mesmos pedaços antes e depois da "charqueagem": mas a coisa está longe de ser tácil, por causa das difierenças extremas dos pedaços. Assim, as mantas au- 
102

mentam somente a metade de sua superficie e, em lugar de 1 metro, média variável, elas têm, uma vez charqueadas, 1 metro 50 de maior largura: ao contrário, um colchẫo de $40 \mathrm{~cm}$ terá, a seguir, 90 centímetros e mais; um lombo será ainda mais aumentado. Estas cifras são as de Pelotas, elas tem sido menores em Montevidéu, mas sem que se possa deduzir nenhuma proporção precisa de sua comparação.

0 que quer que seja, a carne charqueada em Pelotas é mais fina que no Rio da Prata: e, além do mais, differença enorme mais importante, na charqueagem, acrescenta-se, em Pelotas, uma operação acessória, que não existe absolutamente em outro lugar, a "lanhagem". Fazem-se sobre diversas partes deste fragmento, incisões paralelas umas às outras, de 5 a 14 $\mathrm{cm}$, mais ou menos, bastante profundas, já que quase 0 atravessam, e em diversas direções segundo os pontos lanhados. A superficie exposta ao ar e também à salga será assim tornada mais considerável ainda; mas ela se tornará, também, mais irregular.

F - A carne é preparada: ela tem que sofrer apenas mais duas operaçōes últimas: a da salga e do dessecamento; estas duas operaçōes apresentarão também, conforme os lugares, muito grandes differenças.

Salga - E, primeiramente, a salga: ela é direta em Pelotas, precedida da passagem na salmoura no Rio da Prata. Esta passagem pela salmoura é, porém, rápida: dura de 10 a 20 minutos: os pedaços charqueados caem da mesa na cavidade de salmoura contigua: esta cavidade, bastante considerável, é preenchida com o líquido que foi fornecido pelas pilhas de carnes salgadas dos dias precedentes: depois tirados dali com a ajud, os pedaços impregnados são Esta colocaräo ganchos pelos empilhadores. Sul pelos mesmos proces pina se faz em Pelotas e no precedida também por usomente em Pelotas, ela é diferente da coló uma operação acessória, muito charqueados são ļa na salmoura. Todos os pedaços de sal, onde operários para mesas côncavas, cheias impregnam de sal, esf especiais, os "salgadores", os dos pontos lanhados.

A carne passada na salmoura, no Rio da Prata, ou esfregada com sal em Pelotas, é, finalmente, empilhada, isto é, disposta em montes verticais, de base quadrangular muito larga, mas menos altos. Uma pilha podendo conter a carne de 100 bois, e uma outra a de 1200, com. preende-se que suas dimensões possam ser bastante variáveis. Eis, por exemplo, as proporções de uma pilha de 200 bois, observadas em casa do Sr. Rasgado em Pelotas: $5 \mathrm{~m} 50$ de comprimento, $3 \mathrm{~m} 50$ de largura, 80 $\mathrm{cm}$ de altura sobre os bordos, $1 \mathrm{~m} 30$ no meio.

A pilha tinha, neste caso, a forma de uma cúpula: muito freqüentemente, elas são completamente regulares, em forma de um grande quadrado, e, sobretudo no Sul, onde a cifra de matança é mais elevada, elas podem atingir 2 e 3 metros de altura.

Para empilhar a carne, dispõem-na simplesmente em camadas sucessivas. Uma primeira e larga camada de sal estando estendida sobre o solo, faz-se uma primeira camada de carne: em Pelotas, esta primeira camada é feita com os pedaços menos bons, os "lombos". Acima dessa primeira camada, nova camada de sal, de. pois nova camada de carne $\theta$ assim sucessivamente. Para formar as camadas, não se deve tomar outra precaução a não ser estender cada pedaço de carne, no 
104

sentido de sua maior largura, de modo a que não faça nem monte nem dobra de nenhuma espécie. Quatro ou cinco operários de pé sobre a pilha obtêm facilmente este resultado, estendendo os fragmentos com suas mâos, ou melhor, com ganchos de ferro.

A colocação e a permanência na pilha apresentam, ainda, grandes diferenças em Pelotas e no Rio da Prata.

E, primeiramente, diferenças na quantidade de sal: a carne é muito menos salgada em Pelotas; e as camadas de sal intermediárias às camadas de carne são muito menos espessas, menos completas.

Ainda que, coisa curiosa e que infelizmente, nós encontraremos, não tenha sido feita em nenhuma parte, nas charqueadas que eu vi, pesagens precisas, pode-se estimar de 10 a 12 quilos a quantidade de sal empregada em Pelotas para a carne de um único animal, enquanto que, em Buenos Aires ou Montevidéu, esta quantidade se elevaria a um pouco mais, cerca de 15 quilos.

Além disso, o sal, que vem geralmente de Cádis para quase todos os saladeiros, é bastante refinado pela raspagem em Pelotas, e é, muitas vezes, conservado muito grosso no Sul.

Esta diferença muito importante da quantidade de sal não é a única. Em Pelotas, a carne é empilhada somente uma única vez; no Rio da Prata, ela passa sempre por duas pilhas de salga sucessivas. Depois de 12 a 20 horas, conforme 0 saladeiro, a mesma carne que havia sido empilhada na véspera, é refeita em uma segunda pilha ao lado do lugar da primeira; e a carne que, na véspera, formava as camadas superiores será na segunda pilha a parte mais inferior.

Este segundo empilhamento tem com efeito, principalmente, o objetivo de comprimir, de maneira muito

\section{5}

igual, toda a carne, para espremer a salmoura; e este fator compressão desempenha, no Sul, um papel maior que no Rio Grande. Compreendendo uma pilha toda a Ihas são muito maiores, mortos no mesmo dia, as pionde a matança é mais mais elevadas no Rio da Prata não somente mais igual por caravel, e a compressão $e$ ela é também muito mais fausa da dupla pilha; mas matou 300 ou 400 bo me serte. Se 0 saladeirista do Sul ficion 300 ou 400 bois e se ele julga a compressão insuficiente, ele recobre a primeira e também a segunda pilha de pranchas de madeira bastante pesadas: e esta compressão acessória jamais é utilizada em Pelotas. Entretanto, a compressão é importante mesmo em Pelotas, $e$ a quantidade de salmoura escorrida é, em toda a parte considerável; assim, uma pilha de 200 bois fornece, em Pelotas, cerca de 4 metros cúbicos de salmoura.

0 empilhamento pode ainda variar por um outro fator, sua duração: geralmente, a carne é exposta ao sol, em Pelotas, no fim de sua primeira pilha que durou 1 ou 2 dias; no Rio da Prata, depois de suas duas pilhas, que terão durado dois dias.

Mas, segundo as condições do tempo, a duração da pilha pode ser consideravelmente modificada; $e$, quando chegam os meses mais frios e mais irregulares de abril, maio, junho, torna-se, muitas vezes, impossivel fazer secar a carne.

Em Pelotas, deixam-na, então, na primeira pilha que, durante estas épocas irregulares, será carregada de mais sal: e esta carne assim empilhada pode-se conservar sem alterar-se por 30,40 dias, e mesmo mais, tempo se ela tiver sido suficientemente salgada. Esta pequena pilha, que contém somente de 200 a 300 bois, só dura, porém, o tempo suficiente para impedir o dessecamento; 
106

e, nos anos favoráveis, pode acontecer que a carne não fique empilhada mais de 6 a 8 dias.

Ao contrário, no Rio da Prata, para esta operação, também tudo é mais completamente regularizado; e se fazem cada ano pilhas especiais, relativamente enormes, pois elas contém de 1200 a 1800 bois: chamam-nas de "pilhas de inverno". Estas pilhas, feitas ao ar livre e não sob hangares como as precedentes, são circulares em vez de quadrangulares. Estabelecem-se sobre uma base especial, circular também, quase sempre em alvenaria: pois ela deve ser sólida para suportar um peso tão enorme. A pilha de inverno tem, geralmente, de 16 a 26 metros de diâmetro na sua base, e ela vai se estreitando levemente para seu cume: ela representa, então, um tronco de cone: sua altura é variável com o número dos animais, comumente de 3 a 4 metros.

Estas pilhas de inverno têm uma duração fixa; começadas em abril, no fim, geralmente, elas estão completas no fim de maio ou junho; e, então, depois de ter sido recobertas com um tecido espesso sobre sua parte superior, elas permanecerão ali, de três a quatro meses, até o inicio do bom tempo, em fim de setembro ou outubro. E, entretanto, esta carne, para se conservar assim, não foi submetida a nenhuma preparação nova. A carne de cada matança, após ter passado por duas pithas de inverno, e acumulada em cima das matanças precedentes. Nós veremos, porém, que, por razões diversas e principalmente econômicas, a pilha de inverno. de vencimento por demais distante, tende a ser abando. nada.

G - Dessecamento - Depois de ter passado pela pilha simples, de duração irregular em Pelotas, pela dupla pi-
Iha, ou mesmo pela pilha de inverno no Rio da Prata, a carne vai ser, finalmente, dessecada.

Este dessecamento é precedido, no Rio da Prata, por uma operação acessória: a carne, saindo da pilha, é repassada na salmoura, mas sem demorar; esta passagem terá simplesmente por objetivo lavá-la, tirando as grandes partículas de sal que ficaram aderentes. Nesse ponto de vista ainda, esta diferença é importante: pois a presença dos fragmentos de sal é uma das maiores cau. sas do mau aspecto das carnes do Rio Grande.

A carne é, finalmente, levada para as "varas", ou secadores: são simples barras de madeira, bastante longas, estendidas transversalmente a $1 \mathrm{~m} 50$ do solo, mais ou menos, e dispostas muito variadamente. Assim, muitas vezes, principalmente no Sul, instalar-se-ão sobre os mesmos suportes verticais duas séries de varas, umas acima das outras; as superiores receberão as mantas, as inferiores, os pedaços menos importantes. Estas varas, geralmente afastadas de $2 \mathrm{~m}$ a $2 \mathrm{~m} 20$, são às vezes de tal forma próximas, que os fragmentos de carne fazem sombra uns sobre os outros. A direção das varas é, geralmente, de oeste a leste, de maneira que a exposição seja Norte-Sul: mas esta direção é, outras vezes, bastante ruim. Enfim, a disposição do conjunto de varas é muito variável e os espaços largos ou caminhos que se deixam entre elas para facilitar o transporte $\theta$ as mano. bras são, muitas vezes, insuficientes. Estas varas são muito extensas; podendo receber a carne de 1000 a 3000 bois conforme os saladeiros, elas cobrem necessariamente um espaço bastante vasto.

As carnes são carregadas e estendidas sobre estas barras de madeira transversais: 0 , estando a cavalo $\dot{e}$, então, exposto ao ar somente por uma das faces. 
108

Em Pelotas, a carne permanecerá sobre as varas muitos dias seguidos e até que ela esteja seca. Se o tempo for favorável, 5 ou 6 dias serão suficientes: mas, durante o inverno, é preciso muito mais, 15 dias e mais. De onde a necessidade, em Pelotas, de varas muito extensas. Durante todo este tempo, limitar-se-á a fazer, cada noite, pequenos montes, ou "burras", acumulando diversas tiras de carne sobre certos pontos das varas: reunir-se-ẫo, por exemplo, 10 mantas umas por cima das outras sobre uma parte mais resistente da barra de apoio, e se recobrirá este monte, seja de couros secos, seja de um tecido fortemente alcatroado. Estas precauçōes não têm outro objetivo a não ser preservar a carne dos serenos da noite que, sabe-se, são muito abundantes: na manhã do dia seguinte, estendem-se de novo as tiras de carne, mas expondo ao sol a face que, na véspera, era a mais inferior.

As coisas se passarão de uma forma muito diferente no Rio da Prata: a dessecação da carne ai dura um tempo mais longo, e ela é, pelo menos na aparência, mais complicada.

A carne estendida sobre as varas, depois de ter sido lavada na segunda salmoura, permanecerá apenas um único dia sobre estas varas: depois, ela será recolo. cada na pilha, cada pilha correspondendo ainda à matança de um dia. A carne permanecerá na pilha de 3 a 5 dias; depois, ela será recolocada um dia sobre as varas. Refar-se-á, ainda, uma nova pilha, que durará de 5 a 7 dias, depois uma nova exposição de um dia ao sol, e assimn sucessivamente, até que a carne esteja comple. tamente seca. 0 conjunto das operações terá durado sempre cerca de 1 mês: a carne permanecerá empilhada de 20 a 25 dias; $\theta$ terá havido de quatro a sete exposi-
pôes sobre as varas.
Estas pilhas intermediárias de desecamento do Rio da Prata fazem-se ao ar livre no mesecamento do varas, em espaços reservados: elas têm mesmo das tros de comprimento, de 4 a 8 de têm de 8 a $10 \mathrm{me}$. variável, de cerca de 2 metros, largura, $\theta$ uma altura gundo o número de animais.

Elas têm por objetivo completar a compressão da carne que, assim empilhada quatro ou cinco vezes su. cessivamente, amontoa-se de uma maneira mais com. pleta. Para melhor assegurar a compressão, quase sem. pre se recobre, seja com madeira, seja com pedras, a primeira e segunda pilha de dessecamento; e assim eu vi, em Enseada, pilhas recobertas de uma camada de pedras de "gneiss" muito pesadas, de cerca de $60 \mathrm{~cm}$ de espessura.

Apesar dessa compressão excessiva, geralmente, a carne, nestas pilhas de dessecamento, não perdem mais salmoura; mas, dizem os saladeiristas, ela toma corpo e aroma e, sobretudo, ela se habitua, por estas mutações sucessivas, a não mais ser exposta ao ar. Além do mais, esta compressão repetida e prolongada empilhando os pedaços, faz desaparecer suas irregularidades, e thes dá uma superficie uniforme.

Após este dessecamento, contínuo em Pelotas, descontínuo e separado por pilhas de compressão no Sul, a carne é, finalmente, empilhada definitivamente; $\theta$ somente então separa-se em qualidades differentes. Fazem-se, em geral, duas qualidades em Pelotas, e três no Rio da Prata: esta diferença provém, principalmente, de que o Rio da Prata somente vende a Cuba, para onde são expedidas as piores carnes; também se dá o nome de "havaneira" às qualidades mais inferiores.

As carnes separadas ficaram ainda empithadas por um tempo variável: às vezes mesmo, se o tempo for 
110

ruim, úmido, ou se o dessecamento for incompleto, será necessário fazê-las repassar ainda sobre as varas antes de embarcá-las. Finalmente, de quinze dias a dois me. ses após a matança, ou ao fim de um tempo mais longo nos casos das pilhas de inverno, tudo está terminado e os pedaços de carne seca são amontoados sem nenhum invólucro no porão dos navios que os transportarão. Es. tes navios, quase todos espanhóis ou brasileiros, carre. gam de 3000 a 8000 quintais: mas, com exceção de ra. ros saladeiros, como Fray-Bentos, é impossível que 0 carregamento possa ser feito diretamente; e o transporte por barcas intermediárias é necessário. É muito curto em Montevidéu, é mais longo em Pelotas, que expede ao Rio Grande, e é ainda mais longo para certos saladeiros do Sul, o de Tuyu por exemplo. Esta carne será, em seguida, encaminhada para os mercados de venda, entregue aos comerciantes e vendida aos consumidores de 6 a 12 meses após o animal ter sido morto.

\section{B- Natureza da " carne seca "}

Nós seguimos a carne desde o momento em que ela entrou na mangueira, sob a forma de boi, até 0 momento em que ela foi empilhada nos navios de transporte. Evitei acrescentar uma série de detalhes relativos à retirada dos couros, à charqueagem, ao sal e a suas qualidades, etc. Também não insisti sobre os nomes especiais dados aos diversos operários $e$ às diversas operaçöes: pois eu desejava ser compreendido antes que exaustivo, e eu queria fazer conhecer os pontos importantes $e_{1}$ sobretudo, os detalhes diferenciais.

Com eleito, muitos deste detalhes são, relativa. mente, pouco conhecidos pelos interessados. 0 saladei- rista do Sul ignora os procedimentos de Pelotas, $\theta$ as informações que eu pedia aos charqueadores brasileiros sobre seus concorrentes do Sul eram-me raramente fornecidas de uma maneira satisfatória. A comparação precedente, neste ponto de vista, era então útil: e ela vai, além do mais, permitir-nos apreciar melhor 0 estado do
mercado deste produto.

$E$, primeiramente, o que é verdadeiramente a carne seca? Este nome, já o disse, parece-me ruim, e é bem certo que 0 dessecamento no sol tal como se compreende, desempenha, o que quer que se tenha escrito, um papel acessório.

É bem verdade que a carne perdeu uma parte muito grande de sua umidade; mas ela a perdeu pela compressão nas pilhas muito mais que pela exposição ao sol. A quantidade de salmoura fornecida pelas pilhas é considerável, nós vimos, em Pelotas: ela é maior ainda no Sul e se dão conta de que a exposição ao sol, durante algumas horas, em intervalos espaçados, não deveria ter importância capital. 0 calor, nestas regiōes, é, porém, pouco considerável; 0 tempo é, muitas vezes, nublado, e os saladeiristas preferem mesmo o tempo nublado com um pouco de brisa. Finalmente, os fragmentos de carne expostos ao ar e ao sol não se aquecem muito, eu o constatei muitas vezes. Teria sido curioso estudar por pesagens estas perdas de peso, e de comparar estas perdas pelas pilhas: mas, infelizmente, neste ponto como em outros ainda mais fáceis, fui surpreendido por dificuldades que eu não havia previsto.

A ponto, entretanto, estas experiências a serem feitas: elas provarão, creio, que a carne seca é, sobretudo, seca por compressão. 
112

Mas esta carne seca é, além do mais, uma carne salgada; e é o sal que me parece desempenhar, na conservação efetiva, o papel principal.

Com efeito, fragmentos de carne charqueados, expostos ao sol sem ser salgados, alteram-se e apodrecem em Pelotas como no Sul; e deterioram-se, mesmo se foram comprimidos. Ao contrário, carne salgada podese conservar indefinidamente, se ela tiver bastante sal: assim, os charqueadores de Pelotas acrescentam mais sal durante os tempos úmidos, e conservam, então, sua pilha 50 ou 60 dias; os saladeiristas do Sul fazem melhor ainda com as pilhas de inverno, que duram de 3 a 4 meses e, muitas vezes mais. Do mesmo modo, a carne do Sul permanece relativamente menos tempo exposta ao ar e, entretanto, ela seria um pouco mais conservável: ela é, com efeito, mais salgada.

0 sal desempenharia, então, um papel predominante: e eu creio, mesmo, que este papel é relativamente complexo, e que esta carne, tanto pelo sal como pelo ar, sofre uma espécie de transformação.

A carne seca difere levemente quanto ao aroma e quanto ao gosto dos chamados charques de vento, so. bre a preparação dos quais nós teremos de falar novamente: estas diferenças só podem ser devidas à adição ao sal.

A carne seca ou "tasajo" tem uma cor cinza amarelada mais ou menos uniforme, pálida, que lhe dá, em grande parte, seu aspecto desagradável. Esta cor parece-me devida à ação do sal e do ar; e à sua ação conjunta. As carnes salgadas em "barril" permanecem vermelhas: a presença do ar é então, necessária. Do mesmo modo, se se observa uma primeira pilha de salga, constata-se que, sobre toda sua superficie exterior, as carnes são acinzentadas, enquanto que, se se abre a pilha, em qualquer lugar no interior, elas perma. neceram vermelhas, ou pouco modificadas. Mas, se es. tas carnes tiverem sido expostas sobre varas, elas se tornarão cinzentas sobre toda sua superficie, e a cor cinza aumentará com a duração da exposição ao ar e se
tornará amarelada.

Esta transformação de cor é mais limitada às ca. madas mais externas; e, se se cortam as tiras de carne, sobretudo nos primeiros dias, encontra-se entre as duas superficies amareladas, uma carne amolecida, vermelho escura, ou violácea. Esta carne intermediária é bastante semelhante às nossas carnes de salsichas ou outras conservas, e ela pode mesmo ser comida tal como aquelas. A coloração cinzenta superficial é muito menos uniforme na carne de Pelotas, menos salgada, e existem, em certos lugares, espaços quase vermelhos que, infelizmente, contribuem para a irregularidade do aspecto.

A coloração amarelada é ainda menos marcada nos charques de vento; ela é menos escura e mais cinza esbranquiçada e não amarelada: e se pode, mesmo, nós 0 veremos, fazê-la desaparecer. Esta transformação da carne em um produto diferente de aspecto, cinza amarelado, seria então, mesmo, devida ao ar e ao sal.

A prova de que a "carne seca" difere em muitos pontos da carne é demonstrada ainda por outros fatos, $e$ especialmente pelas modificações de higrometricidade.

Sabe-se que as carnes normais são facilmente conserváveis num tempo frio, no inverno, sendo a geada um fator favorável. Ao contrário, a carne seca se altera muito mais rapidamente no inverno do que no verão: ela embolora, reduz-se a particulas finas, pulveriza-se etc. $e$ carnes enviadas para a Europa no inverno ai teriam chegado, afirmaram-me os senhores Ymenes e Pla, e outros ainda, em estado muito ruim. 
114

Do mesmo modo, a carne seca é excessivamente sensivel às variaçōes de umidade, principalmente quando está dessecada incompletamente. Ela pode, em seguida, ao contrário, conservar-se por longos meses nos portos, e os charqueadores reconhecem bem a carne que nẫo se altera: amarelada, antes que acinzentada, ela é aromática, de um odor forte e não desagradável. Entretanto, mesmo para esta carne bem dessecada e conservável por longo tempo, é ainda a umidade que limitará a conservação de 6 a 10 meses, e acarretará, mais tarde, a alteração do produto.

Ai estão fatos bem interessantes, ainda que isola. dos: eles têm uma grande importância no ponto de vista, principalmente, de uma exportação possível, e seria então, útil demonstrar, por meio de pesquisas precisas, como a carne dessecada se comporta em presença do frio, notadamente. Estas experiências, conduzidas regularmente, sobre as condições do dessecamento atual, permitiriam, provavelmente, encontrar um novo modo de dessecamento mais rápido, mais regular e mais completo.

0 que quer que seja, e antes de chegar a este último ponto muito importante, é preciso que discutamos um outro: procurar nas diferenças da preparação, ou do rendimento, ou da mão-de-obra, as razões do estado de luta e de mal-estar que atravessa, hoje, o mercado do Rio Grande.

\section{C - " Carne seca " de Pelotas e do Rio da Prata}

Preparação - Creio que as diferenças da preparação têm uma certa influência, e estas diferenças podem-se resumir em uma palavra: a carne de Pelotas é irregular no aspecto. Menos salgada, e dessecada mais rapida. mente, ela conserva partes avermelhadas, em lugar de ser quase uniformemente cinza; menos comprimida, me. nos achatada, ela forma uma lâmina menos igual; não tendo sido passada na salmoura, ela conserva, muitas vezes, fragmentos de sal aderentes em certos lugares: finalmente, e sobretudo, estando "lanhada", ela apresenta, ao nivel das incisões, espécies de saliências em degraus bastante irregulares.

É que, com efeito, a carne, ao secar, contrai-se, como 0 provam as mensurações: uma manta char. queada perdeu, uma vez seca, cerca de $1 / 3$ de seu comprimento; e os pedaços pequenos, lombo, colchão, paleta, perdem mais ainda, como me certifiquei por numerosas mensurações. Ora, esta contração, devida pro. vavelmente ao tecido célulo-aponevrótico, é, em todos os casos, efetuada de modo muito desigual, pelo fato de que a secção dos músculos, durante a charqueagem, alcança alturas muito diferentes: um músculo é cortado muito perto do outro, muito longe de seu ponto de liga. mento. Ela será mais desigual em Pelotas, onde a charqueagem é mais fina, isto é, as secções de músculos são mais numerosas: enfim, ainda em Pelotas esta retração torna-se mais irregular, compreende-se, após a "lanhagem", que rompe, em diversos pontos, a continuidade das fibras. Se se acrescenta que a compressão intensa e prolongada tende a suprimir estas irregularida. des por uma prensagem completa no Rio da Prata, enquanto que elas persistem em Pelotas, dar-se-á conta das grandes diferenças de aspecto das carnes do Sul e das do Rio Grande.

Ai estão, dir-se-á, questões acessórias; e que importa 0 aspecto, se o produto é bom ? Infelizmente, na prática, vê-se, para outros produtos, o quanto 0 aspecto a aparência são coisas importantes; $\theta$ seria longa a lista 
116

das substâncias ditas alimentícias que, apesar de seu pouco valor, são, a cada dia, vendidas graças a qualida. des visuais ou mesmo a rótulos mais ou menos mentiro. sos.

Năo hesito mesmo em dizer, e eu retornarei a este ponto, que 0 aspecto atual das carnes secas é o principal obstáculo para sua importação pela Europa.

Rendimento em peso - Creio também que estas diferenças da preparação de Pelotas e do Rio da Prata forçamnos a colocar uma outra questão: e esta questão, infelizmente ainda, não podemos resolvê-la.

A carne de Pelotas é charqueada mais fina também; ela apresenta, no dessecamento, superfícies mais largas; ela é, além do mais, "lanhada " e fica exposta ao sol de 5 a 6 dias seguidos e, muitas vezes, bem mais tempo, em lugar da exposição descontínua do Rio da Prata: enfim, ela recebe menos sal. Devia-se, então, perguntar se esta carne não perde mais de seu peso; e esta questão só podia, evidentemente, ser resolvida por pesagens.

Seria preciso comparar o peso de diversos bois charqueados e frescos, e os mesmos tornados secos: seria preciso, também, para comparar com as cifras da Europa e ter uma relação nos preços da carne, pesar os mesmos bois inteiros depois de despojados das visceras e da cabeça, mas com os ossos. Tentei fazer executar estas pesagens tão simples, nas primeiras charqueadas que visitei; e devo confessar que, não tendo obtido êxito, apesar dos pedidos múltiplos e repetidos, acreditei ser inútil fazer, no Rio da Prata, as mesmas tentativas, já que me faltava termo de comparação.

É preciso, então, ater-se às generalidades: estima-se o rendimento em carne seca de um boi médio de
4 arrobas ou 60 quilos, mais ou menos em Pelotas, de 150 libras espanholas ou 70 quilos no Rio da Prata. Mas estas cifras não podem fornecer-nos nenhuma conclusão comparativa, já que a qualidade dos bois é, como 0 veremos, bastante diferente. Seja como for, elas demonstram que a carne seca corresponde a uma pequena parte do peso da carne fresca. Ainda que todos os bois do Sul sejam pequenos e pouco gordos, e isso ainda mais no Rio da Prata que em Pelotas, esta cifra de rendimento, 60 quilos, é relativamente mínima. Segundo a opinião de todos os saladeiristas, ela representa apenas a metade do peso da carne fresca charqueada, e prova. velmente um pouco menos: os diversos açougueiros es. timam, com efeito, de 180 a 210 quilos o peso da carne com osso dos mesmos bois que fornecem 60 quilos de carne seca: e, por outro lado, esta cifra de rendimento de $50 \%$ é considerada demasiado elevada por vários saladeiristas.

Sabe-se, além disso, que o rendimento varia com diversos fatores: sabe-se que os bois mais gordos perdem relativamente menos peso que os bois magros e, principalmente que os bois estafados; sabe-se que as porções magras, isto é, os membros, perdem mais peso que as mantas; e nós veremos este detalhe ser utilizado em Fray-Bentos, onde se faz carne seca com as mantas e alguns outros pedaços gordos e extrato de carne com as partes magras. Sabe-se, também, que os animais demasiado jovens destilam mais salmoura e perdem mais peso que os animais mais desenvolvidos: donde, afora mesmo 0 couro, a mais valia dos bois de trela ou dos bois mansos mais velhos.

Finalmente, é certo que a quantidade da carne produzida varia com o modo de preparaçâo. Assim, pareceria que a carne abatida num tempo muito úmido per- 
118 deria menos salmoura; mas, também, ela seca mal. Do mesmo modo, os bois não sangrados forneceriam, tal. vez, um pouco mais de carne: mas a carne demasiado vermelha tem cor ruim e seca mal. Dois fatores, a duração da compressão e a do dessecamento são, sobre. tudo, importantes: e, assim, em certos saladeiros bem cuidados que eu poderia citar, prepara-se rapidamente uma carne pouco dessecada, tendo-se talvez, perdido de 30 a 40\%. Excelente, porém, se ela é rapidamente vendida, esta carne continua a perder ainda seu peso, uma vez embarcada; o fato é mesmo tão conhecido, que os compradores o levam em conta para estes estabelecimentos, como me afirmaram ainda os senhores Faria Cunha, os comerciantes bem conhecidos do Rio de Janeiro.

Seja como for, compreende-se a importância que há para um saladeirista em diminuir, mesmo de 5 a $10 \%$, a perda de peso que ele sofre. Sobretudo em uma fabricação onde tudo se calcula por quantidades enormes, e onde os beneficios são, relativamente, muito restritos, há, evidentemente, vantagem considerável em aumentar a cifra do rendimento; $e$, se fosse provado, como me parece provável, que os procedimentos de Pelotas secam mais a carne que os do Rio da Prata, haveria, evidentemente aí, uma causa séria de inferioridade econômica, que não compensaria mesmo um valor substancial maior, e real talvez, nós o veremos, dos produtos. Neste ponto de vista ainda, haveria então que tentar pesquisas metódicas diretas e precisas, e deve-se admirar que os saladeiristas, tão diretamente interessados, não tenham ainda tentado resolver todos estes pontos por pesagens e experiências fáceis; e que eles não sabiam, mesmo, na maioria, a proporção exata do rendimento de seus processos de fabricação completamente empíricos.

Utilização das diversas partes - Nós passamos a um outro fator que é considerado por quase todos os char. queadores como o mais importante; e nós vamos ver que ele não desempenha, certamente, nenhum papel. Em Pelotas, quase todo o mundo considera a utilização de todos os produtos dos bois muito mais completa no Rio da Prata: os charqueadores concordam em lamentar a cifra pouco elevada dos animais que eles matam, e que não thes permite instalações muito vastas, e de fábricas acessórias para a transformação do sangue em gelatina, das vísceras em guano, das línguas em conservas, etc. É perfeitamente exato que a differença das cifras de ma. tança é um dos elementos de inferioridade; mas é, nós 0 veremos, em consequêencia de causas bem diversas.

Em todo caso, devo dizê-lo, após ter recebido to. das estas queixas, eu fiquei bastante admirado quando, chegando ao Rio da Prata, e visitando estabelecimentos modelos como os do Sr. Cibilis, do Sr. Paulet em Montevidéu, ou do Sr. Cambaceres em Ensenada, ou ainda o de Fray-Bentos, eu não encontrei aí a utilização das partes acessórias mais perfeita que em Pelotas.

Nestes estabelecimentos, tanto quanto no Rio Grande, não se utilizam as vísceras; e os pulmões, os rins, o fígado são completamente abandonados. Não se utiliza, também, 0 sangue, que é abandonado por toda a parte e desviado para o rio, seja a matança de 140.000 cabeças ou de 14.000 por ano. Eu vi uma única exceção no saladeiro do Sr. Repeto em Ensenada: e ainda a utilização do sangue era feita por um empresário especial, $\theta$ em construçôes independentes.

Este industrial pagava, para adquirir este sangue, uma taxa insignificante, não devendo ultrapassar 5.000 francos num saladeiro cuja matança é de cerca de 
120

30.000 a 40.000 animais. Além disso, a quantidade de sangue recolhido e, sobretudo, a quantidade de produtos fabricados, guano e gelatina, me pareceram, relativamente, muito pouco consideráveis: 500 bois forneceriam somente 250 baldes de sangue, os quais, filtrados, preparados etc, dariam em definitivo $1 \frac{1}{2}$ toneladas de gordura animal e 45 baldes de gelatina. $E$, entretanto, a instalação dos filtros, das cubas, dos secadores etc. etc. é relativamente onerosa, e as manobras complicadas, se bem que evito descrevê-las aqui.

Se em lugar de considerar estas partes acessó. rias, sangue e visceras, mais ou menos abandonadas por toda a parte, comparar-se a utilização das outras partes do animal, chega-se, ainda, às mesmas conclusões: e a situação de Pelotas, não é de modo algum inferior neste ponto de vista, à do Rio da Prata.

Depois das vísceras e do sangue, os produtos menos importantes são os tendões, as crinas, os chifres, os Ossos, etc.: sua utilização se faz, por toda a parte, pelos mesmos processos. Fabrica-se, muitas vezes, com as patas, um óleo especial; mas este óleo, chamado de "mocotó", prepara-se também em algumas charqueadas de Pelotas. Do mesmo modo, em Ensenada, em FrayBentos notadamente, conservas especiais são feitas com as línguas; mas existe também uma fábrica de conservas de línguas em Pelotas, e ela utiliza os produtos de diversas charqueadas. O Sr. João de Rezende tentou mesmo, na casa do Sr. d'Almeida em Pelotas, conservar os rins; $\theta$ eu vi estas tentativas. Os chifres são, por toda a parte, tratados e vendidos da mesma maneira: o invólucro córneo externo, que tem mais valor, é separado facilmente de seu conteúdo ósseo, se se bate com um golpe seco num certo sentido, ao fim de 3 a 6 semanas. Estes chi-
121

fres são, além disso, vendidos mais freqüentemente com os couros, cujo carregamento eles facilitam.

Ao lado destes produtos diversos, deve-se colocar um outro um pouco mais importante: são os OSSOS, ou melhor, suas cinzas de seus detritos calcinados. Por toda a parte também, no Sul como no Rio Grande, depois de terem sido despojados de sua gordura mais ou menos completamente, estes ossos, ainda munidos de seus ligamentos, de fragmentos de tendões etc., servem para aquecer caldeiras a vapor: só depois de ter sido completamente queimados, que eles fornecem frag. mentos muito frágeis, bastante volumosos a maioria das vezes, ainda que conhecidos sob o nome de "cinzas" ou poeira. Estas cinzas serão geralmente vendidas na Europa, e vendidas como adubo; e elas representam um certo produto, suponhamos cerca de 5 toneladas para 400 cabeças: a tonelada vale, mais ou menos, 100 francos.

Estes ossos fornecem, entretanto, um aquecimento irregular: também na casa do Sr. Cibilis, acrescentam-Ihes carvão mineral; em Fray-Bentos, aquecemse as caldeiras unicamente com o carvão, e não se transformam os ossos em fosfatos terrosos; mas, ao sair das cubas de gordura, esmagam-nos, ainda úmidos, com seus princípios azotados, com a ajuda de mós verticais muito potentes, e se vende seu pó.

Não insistirei mais sobre todos estes produtos acessórios, que representam uma parte muito pequena do preço do animal, suponhamos cerca de 5 a 6 francos; e não me deterei nos detalhes da preparaçẫo dos óleos de mocotó ou da pata de boi, nem na utilização especial de certos ossos mais longos chamados "caracus", fêmures, tibias, nem na dos tendões. 
122

Eu insistirei, ao contrário, um pouco mais sobre dois outros produtos muito mais importantes: quero falar das gorduras e do couro. Na Europa, onde o gado é caro, estes produtos podem ser considerados como acessórios: mas, nestes paises de criação livre e sem despesas, onde um boi pode ser vendido barato, 0 couro $e$ as gorduras tornam-se muito importantes por causa da sua facilidade relativa de conservação e de transporte.

Seus preços variam menos que os da carne; $e$, enquanto que esta venderá cinco vezes menos que na Europa, um couro salgado terá quase um valor comparável. Também o couro e as gorduras representam para 0 saladeirista cerca da metade do preço, isto é, tanto quanto a própria carne, ou muito pouco menos.

Além disso, a prova da importância do couro e das gorduras é fornecida por um outro fato bem conhecido: no Rio da Prata, os saladeiristas matam, freqüentemente, tropas muito grandes de jumentos, que um preconceito muito curioso impede, como se sabe, de utilizar como montarias. Ora, estes jumentos são mortos unicamente pelas gorduras e por seu couro, que é menos caro, entretanto, que o de boi; e, quanto às carnes, são deixadas e queimadas com os ossos, ao sair da "graxaria", para aquecer as caldeiras.

As gorduras - A preparação das gorduras é, sobretudo, complicada; e é justo reconhecer que esta preparação é mais completa, mais perfeita em Pelotas que na maioria dos saladeiros do Sul.

Em Pelotas, em quase todos os saladeiros, e em todos os que visitei, fazem-se duas espécies de gordura: ou melhor, os ossos, a cabeça e o encéfalo, certas visceras-estômago, coração, fornecerão gordura; e os intestinos bem lavados, os invólucros renais, o peritônio darão um excelente sebo etc. Ao contrário, no Rio da Prata, faz-se um único produto gorduroso cozinhando tudo junto: ossos, visceras e intestinos.

Eu não saberia entrar nos detalhes complicados desta preparação. Direi somente que estas gorduras ou estes sebos são preparados em cubas pela cocção sob vapor a uma pressão bastante forte; $e$ as caldeiras aquecidas pelos ossos não têm outro objetivo a não ser for. necer este vapor, que deve ser de duas ou três atmosfe. ras. Eu digo que deve; pois em nenhum ponto, no Rio da Prata como no Rio Grande, pude ter a indicação certa.

As grandes cubas onde se fará 0 cozimento são dispostas de cada lado das caldeiras: há muito grandes, de 4 a 5 metros de altura, para as gorduras. Elas contêm os ossos e as visceras de 150 a 200 animais. As cubas de sebo são menores. Estas cubas são de madeira dura e muito espessa, circuladas de ferro. Elas se abrem para baixo sobre o lado; e é por esta porta lateral que se co. meça a enchê-las, como também é por ela que se as es. vaziará. É também por baixo que escoam as gorduras com a ajuda de condutos especiais. A cocção sob vapor dura de 36 a 50 horas para as grandes cubas de gordura de ossos e de vísceras: ela é muito mais rápida para as pequenas cubas de "sebum". Toda esta fabricação foi imaginada em 1828 por um químico francês, 0 Sr. Cambaceres, que a instalou em Buenos Aires; mas ela é, há muito tempo, adotada por toda a parte em Pelotas.

Em Pelotas, não somente o sebo é fabricado à parte nas cubas menores: mas, além do mais, adotou-se em certas charqueadas um verdadeiro luxo de precauções. Assim, na casa do Sr. De Cunha, tiram-se os intestinos, que se juntam às gorduras, e $s e$ faz 0 sebo somente com os invólucros peritoniais; na casa do $\mathrm{Sr}$. d'Almeida, os intestinos são também separados, $\theta$ Se 
124

fabrica um sebo especial acinzentado e impuro: na casa de muitos outros, enfim, após ter fabricado separada. mente a gordura e 0 sebo, purificam-nos, em seguida por um novo cozimento lento, na totalidade ou em parte. Obtém-se, assim, um sebo amarelo-laranja, duro, untuoso, verdadeiramente muito perfeito. Do mesmo modo, em lugar de colocar em barris toda a gordura comum ou refinada, alguns charqueadores de Pelotas derramam a mais perfeita em bexigas de bois especialmente preparadas; e esta gordura será vendida mais caro para 0 consumo alimentar: ela é, com efeito, fina, branca e sem odor.

Não insistirei muito nesta preparação das gorduras. Devo, entretanto, notar que, na casa do Sr. Cibilis e também em Fray-Bentos, já se instalou um sistema de preparação bastante diferente: as cubas, em número de 8 a 10, são de ferro; muito mais longas, cilíndricas, ou melhor, ovóides, elas recebem o vapor sob uma pressão mais forte, e cozinham a gordura muito mais depressa.

Esta gordura, que se fará escoar pelo alto da cuba impelindo a água sob pressão por uma abertura inferior, será também extraída muito mais completamente; enfim, 0 enchimento das cubas faz-se lançando-se os ossos $\theta$ as visceras pela abertura superior, e as manobras diver. sas são certamente mais rápidas. Infelizmente, estas "graxarias" assim aperfeiçoadas custam muito caro, cerca de 100.000 francos, e só podem ser instaladas em saladeiros importantes.

Do mesmo modo, não pude insistir sobre a quantidade de gordura muito pouco constante fornecida por cada animal: pode-se tornar, como média, de 8 a 12 quilos de gordura $\theta$ de 4 a 9 de sebo. Este sebo é, além disso, o mais variável, ele diminui enormemente no gado fatigado e estafado e torna-se mais abundante nos bois gordos; e, como é um pouco mais caro que a gordura, este fato deve ser considerado.

Nada mais farei que apontar as gorduras especiais preparadas com as tibias e os fêmures, ou "caracus" ; ou ainda diversas particularidades, a não utilização das vértebras cervicais no Rio da Prata, que são diretamente queimadas porque elas não forneceriam gorduras; a ablação da parte carnuda do coração, sua base e 0 pericárdio sendo unicamente lançados nas cubas; 0 uso inconstante de prensas diversas para efetuar a extração de gordura sempre incompleta, etc.

Couros - Passo, finalmente, ao produto que, depois da carne, é seguramente o mais importante: quero falar dos couros.

Sabe-se que estes couros são transportados para a Europa ainda verdes, ou melhor, consenvados pela salga; e eles são principalmente, vendidos a Antuérpia, ao Havre ou à Inglaterra. Mas, durante este transporte e antes, eles passaram por uma preparação que é exata. mente a mesma em Pelotas ou no Rio da Prata.

Uma vez retirados, os couros passam entre as mãos de dois operários especiais, que os limparão completamente dos fragmentos de gordura ou de carne que ficaram aderentes, e regularizarão certos pontos. Depois, eles serão lançados em um fosso de salmoura, cheio da salmoura que já senviu para lavar a carne dos dias precedentes no Rio da Prata para impregnar, durante 24 horas, as "costelas" (costelas e músculos intermediários) em Pelotas.

Os couros permanecem no fosso de salmoura durante 24 horas em Pelotas, menos no Sul. Fartamente salpicados de sal na saida, eles săo em seguida, dobrados em dois, de maneira que os pêlos fiquem no exterior, 
126

e dispostos em camadas uns ao lado dos outros. Por cima de cada camada de couros, joga-se uma camada espessa de sal, e instalam-se assim, numa construção especial ou "barraca", pilhas muito grandes, quadrangulares, geralmente pouco elevadas, e formadas de $10 \mathrm{a}$ 15 camadas superpostas. Utiliza-se, para a salga, 0 sal acinzentado e sujo que serviu às pilhas de carne; mas, como seria insuficiente, é preciso acrescentar outro. Em resumo, calcula-se que o couro utiliza um pouco menos de sal que a carne em Pelotas, e muito menos no Rio da Prata.

0 couro, uma vez salgado e empilhado, pode ser conservado por um tempo indefinido, ou bastante longo. Em Pelotas, ao fim de 5 ou 6 dias, ele já é transportável; no Rio da Prata, deixa-se empilhado por um tempo maior, talvez por causa da permanência menos longa na salmoura, Seja como for, num caso ou noutro, os couros, uma vez embarcados, são de novo empilhados, salgados e preparados no porão do navio.

Além disso, eles foram pesados ainda impregnados de sal, que apenas foi sacudido; pois eles são vendidos a peso, por um preço variável, mas bastante elevado. Estes couros são, geralmente, de muito boa qualidade, e têm na Europa um verdadeiro renome. Seu preço é relativamente elevado para os melhores, os mais espessos. Os de vaca são vendidos de 20 a $30 \%$ menos que os de boi ou "novilho", em igualdade de peso. Nós veremos também que há para os bois diferenças muito grandes no valor de seu couro: mas não é o lugar aqui de insistir sobre isso.

Basta-nos ter mostrado que o estado atual do mercado de Pelotas não se poderia explicar, como se crê geralmente, por uma utilização menos perfeita dos produtos. Não se vendem as visceras e o sangue nem de um lado nem do outro; os ossos, os pés, as crinas, os chifres, as línguas, as "miudezas", como se chama, são tratados da mesma maneira, e servem mais ou menos na mesma medida ao Rio Grande $\theta$ ao Rio da Prata: do mesmo modo, os couros; $\theta$, quanto às gorduras, é em Pelotas que eu considero sua preparação a mais perfeita.

Disposição, importância dos saladeiros - Resta um outro fator ao qual se atribui também importância; é a presumida inferioridade da instalação dos saladeiros no Brasil. Foram sobretudo os saladeiros do Rio da Prata, mais ao alcance das vias de comunicação, que foram visitados e descritos por diversos viajantes: alguns citam as charqueadas de Pelotas, mas sem suspeitar a sua importân. cia; e outros pereceram ignorar-the completamente a existência. Um deles, mesmo, escreveu ${ }^{15}$ que o Brasil não podia engordar seu próprio gado, e era obrigado a vendê-lo magro à República Oriental; e ele limita à província de Mato Grosso a zona de pastagens utilizadas neste país. Verdadeiramente, não vale a pena atravessar os mares para chegar a tais observações, ou melhor, a tais informações. $E$, entretanto, é verdade dizer que a má opinião, um pouco aceita em toda a parte, sobre as charqueadas de Pelotas atribui-se, em parte, aos próprios charqueadores. Eles também crêem, e alguns deles que quiseram acolher-me e informar-me, indicaramme que seus estabelecimentos eram menores, mas mal

\footnotetext{
${ }^{15}$ Revista cientifica de 19 de julho de 1879. Ver também Revista dos Dois Mundos T. LXIII,1876 - pág. 319. Eu repito que me abstive de toda bibliografia tanto quanto discussōes que teriam ido longe demais: creí dever, entretanto, assinalar esses dois artigos, tanto por causa da notoriedade das revistas que os publicaram, como pelas numerosas inexatidōes que eles contêm.
} 
146

momento em que o preço dos escravos aumenta rapi. damente por causa da supressão deste triste tráfico e da
lei emancipadora de 1871 .

Enfim, se, apesar da existência da tablada, mer. cado direto abundantemente abastecido, o gado é caro em Pelotas, e se os charqueadores fazem neste mercado uma ativa concorrência, é ainda aos escravos que se deve atribuí-10. Por causa dos gastos enormes e constantes de mão-de-obra assegurada e paga adianta. damente, o charqueador de Pelotas tem necessidade de trabalhar mesmo assim; também a menor diminuição nas chegadas produz um aumento de preço considerável, e isso tanto mais que estas 32 charqueadas são, apesar de tudo, por causa de seu número, fora de proporção com a cifra média das tropas vendidas a cada dia. Este último fator, ainda que desfavorável, prova, entretanto, a vitalidade desta indústria na província do Rio Grande.

Terei de insistir ainda sobre numerosas outras diferenças desfavoráveis devidas à presença dos escravos. Assim, não somente o saladeirista do Sul não tem de se preocupar com o desemprego de seus operários além disso, ele meses se ele diminuir seu abate, mas, lizá-los a cada dia; e poucora, de maneira nenhuma, utidois dias em três, ou três lhe importa que, se ele abate seus operários não seies dias em cinco, uma parte de do mesmo modo, um cha utilizada. Ao contrário, não há, de-obra paga adiantadamente, procure, tendo sua mãopre; também certos trabalte, procure empregá-la semchifres, e mesmo do empilhos como os dos couros, dos às vezes, executados tardiamento ou do embarque são, cia nos dias de inatividade e por demais, de preferênuma palavra, não há especializ todos os escravos. Em se procura economizar a mão-de-obra.
A menor especialização do trabalho em Pelotas tem ainda uma outra causa: é a necessidade de uma vigilância ao escravo. Esse operário, não tendo nenhum interesse em trabalhar muito, produz, nós o vimos, bem menos que 0 operário livre. Mas, mesmo para obter este menor resultado, é preciso submeter o escravo a uma tarefa mínima, vigiar para que ele a cumpra e puni-lo se ele não a atinge. Assim, em Pelotas, o mesmo animal será esfolado, dividido, depois sua carne separada dos ossos, e, finalmente, charqueada e "lanhada" por um único operário, sobretudo porque é necessário saber quantos bois terá produzido este operário. Ele deverá ter consigo, no fim de sua jornada, um certo número de orelhas que indicarão o número dos animais que ele tiver preparado, e couros que ele tiver tirado; todos os pedaços que ele tiver "lanhado" serão marcados de uma maneira especial e poderão ser reconhecidos. Infelizmente, este sistema necessita, vê-se, de uma vigilância muito ativa, de onde um pessoal muito numeroso: gerentes, feitores, etc. Esse pessoal, certamente, mais importante, por seu custo e seu número, nas pequenas charqueadas de Pelotas, de pouco abate, que nos saladeiros do Sul, cuja produção é três e seis vezes superior. aí está, também, uma causa de inferioridade.

Como, porém, comparar estes bandos de escravos, presos a sua tarefa, às equipes de operários do Sul, trabalhando para eles (mesmos) e interessados nos beneficios do patrão, pois que os seus também aumentam proporcionalmente. Eu disse "equipes": á que, com efeito, a responsabilidade individual existe, em todos seus graus, nos saladeiros do Rio da Prata; cada série de operários tem um operário chefe, só em relaçấo com o patrão: os homens da vagoneta formam uma equipe, os esfoladores uma outra, os charqueadores, os "passa. 
160

imóveis e suas máquinas, e também

muitas vezes feitas com um ano de antecos compras, engordar os bois demasiado jovens; e entecedência, para assegurá-la com a ajuda deste jogo de bó chegam a extrato e a carne seca, jogo evidentementança entre o sório.

Não insistirei muito sobre este produto por demais elogiado: não nego que não se possa fazer um bom ex. trato sacrificando bastante carne; e eu comi, por exem. plo, um de gosto muito agradável na casa do Sr. Chaves, em Pelotas; tenho, porém, a intenção, no decorrer de meus estudos sobre os alimentos da América do Sul, de experimentar 0 extrato Liebig e de investigar seu valor nutritivo: será, então, o momento de abordar outros
pontos.

Charques de vento - Passo, agora, a carnes em conserva mais importantes, ainda que, na maioria, elas não ocasionem grandes transações. Quero falar das carnes chamadas "charques de vento" e, especialmente, do
charque do Chile.

Esse charque, assim chamado porque se vende principalmente no Chile, é preparado sem sal, pela expo. sição ao ar: ele constitui então, verdadeiramente, uma necessário múltipl, para chegar a conservar sem sal, é meiro lugar, escolher pedaçoşōes. É preciso, em priem seguida, dividi-los em fragmeio magros; é preciso preciso charquear esses fragmentos muito pequenos: é que eles se tornem translígmentos de tal maneira finos, car desde o dia seguinte aúcos, e é preciso fazê-los sevilhados de sal, eles não do abate pois, apenas polsecam se o tempo está úmido conservariam; e eles não
100

é favorável, eles estão prontos ao fim de 5 a 6 dias; mas charqueados finos, virados diversas vezes sobre as varas, eles demandam muita mão-de-obra; uma vez prontos e secos, eles perderam muito de seu peso, pelo menos $3 / 5$, afirmaram-me, ou seja, um rendimento muito fraco. Enfim, secando-os ao ar, eles se tornaram, não cinza esbranquiçado ou amarelado como a carne seca, mas quase cinza enegrecido: e é necessário batê-los para fazê-los retornar uma cor vermelha pouco escura, verdadeiramente agradável. $A$ batida se faz por um meio bastante simples, colocando a carne dessecada, entre couros secos, e correndo ou saltando em cima, por um tempo bastante longo.

Sejam quais forem esses meios de preparação, sempre primitivos, essa carne não é sem futuro: a que eu vi na casa do Sr. Cibils, e da qual ele me quis dar amostras que eu experimentarei, tinha bom aspecto e bom aroma; e, segundo a opinião de todas as pessoas que a comeram, ela é superior a carne seca, pois que, uma vez cozida, ela se aproxima muito, por seu sabor e seu odor, da carne fresca. É no sentido dessa preparação que se deverá, creio, dirigir para tentar uma transformação industrial regularizada; é também essa carne que, modificada, me parece ter mais futuro na Europa; e eu pretendo fazê-la experimentar na França, conjuntamente com a carne de Pelotas bem escolhida, como eu o digo mais adiante.

Mas, ao lado do charque já preparado regularmente, e vendido ao Chile por alguns saladeiros do Rio da Prata, existem, sobretudo no Brasil, inumeráveis charques de vento, de tal forma numerosos, que formam quase todas as transiçōes de aspecto entre a came verde $\theta$ a verdadeira carne seca; $\theta$ eles podem conservar-se de 10 dias a 3 meses. 
162

Esses charques de vento, pouco ou nada se ven. dem; mas eles servem, em uma escala muito grande,
para a alimentação das regiōes de criação, ou mais exatamente, eles formam, em quase todas as regiões do
Sul, a base da alimentação.

No sul do Brasil, ou no estado de Buenos Aires ou de Montevidéu, todo o mundo come carne em quantida. des enormes. Os habitantes das cidades e os operários dos saladeiros consomem carne fresca; mas é bem dificil para um estancieiro isolado, e a "fortiori" a um campo. nês, "campeiro" ou "gaúcho", de ter sempre um boi re. centemente abatido. Também, para assegurar a alimentação, trazem-no em todas essas regiões, para salgar e secar levemente a carne, pois que o isolamento das pro. priedades e a ausência de rápidas vias de comunicação torna impossivel as trocas e as compras. Um estancieiro que abater um boi a cada oito dias para a alimentação de 20 pessoas de sua casa, escravos ou servidores, e parentes, poderá salgar e secar pouca carne: um estancieiro que matar um boi a cada quinze dias, secará mais tempo; e, enfim, o camponês que, por meios diversos e, muitas vezes, pelo roubo, obtiver um boi, o charqueará em pedaços mais finos, e o fará secar, porque esse animal deve assegurar sua alimentação durante várias se-
manas.

Esse charque de vento, com suas formas diversas, fabrica-se em todas as regiões que eu visitei; e em Moda a parte, no Paraná como no Rio Grande ou em trêstevidéu, encontram-se, ao lado da estância, duas ou três varas ou barras transversais pouco extensas, destiParaná por exemplo, que se macanteñão mesmo, no versos bois para transformá-los ara, muitas vezes, diem seguida vendido e debitado; e, do mesmo modo que eu comi, diversas vezes, carne seca viajando para o Rio Grande, nós usamos, meu companheiro e eu, diversas vezes, no Paraná, charques de vento. Mas aqui não é o lugar de insistir (sobre isso).

Do mesmo modo, não tenho de discutir aqui a quantidade consumida na América do Sul, sob estas diversas formas, carne seca, charque de vento ou carne fresca. Basta saber que este consumo é verdadeira. mente enorme. Para as três regiöes do Rio Grande, Montevidéu e Buenos Aires, deve-se estimar, pelo menos em 2 milhões de bois, senão mais, a quantidade de animais abatidos para uso local: vendem-se, com efeito, mais de um milhão de couros secos; e é preciso acrescentar a esses couros vendidos e exportados os que são utilizados para fazer cordas, arreios, coberturas diversas, de carroça, de "surrões" etc. É preciso acrescentar tam. bém os couros dos matadouros da cidade: esses couros, sabe-se, são vendidos como os de saladeiros, verdes e salgados. Em uma palavra, comparando as populações, o consumo da carne nessas regiōes é, pelo menos, 18 vezes maior que na França, por exemplo; e esse alimento, para todas as classes, forma a base da alimentação.

Eu não saberia salientar aqui tudo o que foi escrito sobre a carne seca ou seus sucedâneos, os charques de vento. Muitos viajantes se comprazem em considerá-los como uma alimentação completamente inferior e destinada aos escravos. É evidente que, antes de escrever, eles não pensaram em comer, eles próprios e diversas vezes, carne seca bem preparada, em "feijoada", por exemplo; eles se basearam em informaçöes incompletas, fornecidas por europeus ou por nativos europeizados; $\theta$ estes, com efeito, puseram-se a desprezar esse alimento 
vida social do gado. Do mesmo modo, eu direi mais adi citaçōes exteriores, e especialmente sua grande as ex. moral: o medo, medo que se transforma, muitas doen fa em verdadeiro furor.

A vida social não é, porém, específica das espé. cies bovinas; os cavalos, por exemplo, eles também, se separam em tropas menores, chamadas "manadas", em que diversas éguas e seus filhotes aceitam por assim dizer, a supremacia de um só garanhão, que dirigirá o conjunto Inversamente, existem, também, "tropilhas", formadas de diversos cavalos castrados e de uma ou duas éguas: essas tropilhas, ainda que muito harmoniosas uma vez formadas, são mais artificiais e organiza. das, sobretudo, tendo em vista a venda. Sabe-se que sempre se compra uma tropilha inteira; e nada é mais curioso em uma diligência, por exemplo, quando sua tro. pilha é bem formada, que ver, além dos dez cavalos atrelados, dois ou três outros de reposiçãa e uma ou duas éguas seguir a galope, durante todo o revezamento, através dos campos povoados de bois e de cavalos, sem jamais se separar da parte atrelada.

Não somente esse gado vive, mas elo.

vremente; $\theta$, ainda aí as gado vive, mas ele se criará li. Europa ou pelo que esto pessoas que julgassem pela das relaçōes desse gado.

Percorrendo gado.

pastagerm era excolente 0 araná numa época em que a més de janeiro, eu vi todos gado em bom estado, no rem lado a lado com as esses touros vigorosos vive. possivel. É que, com efeito vacas o mais tranqüilamente cho quando a têmea está dispóná aproximação do ma. abordagem encontra-se, assim, disposta $\theta$ preparada; $\theta$ essa nada pelo estado da nutriçăa. É metetamente determi. Iutas entre touros, como se escreveu, baseando-se, po. rém, em fatos exatos. Entretanto, no Paraná, o número de touros é bastante considerável, de 1 para 20 a 1 para 60 vacas, conforme o caso. No Sul, onde a cópula é feita por todos os jovens bois de 3 anos não castrados, e por alguns touros melhores deixados de propósitio, cada vaca no cio é, sempre e por toda a parte, seguida por um touro vigoroso que não tem mesmo que se defender contra os numerosos competidores mais jovens ou menos fortes. Somente em circunstâncias excepcionais que a vaca é fatigada pelos touros; e, por exemplo, se uma vaquilhona entra no cio, no meio de uma tropa de venda de 500 a 600 novilhos, não castrados, acontece, muitas vezes, que ela será verdadeiramente estalliada e morta ao fim de algumas horas. Inversamente, sabe-se também que touros chegados da Europa são, muitas vezes, inábeis com as vacas do campo; não podem nem al. cançá-las nem abordá-las uma vez alcançadas, se bem que se é obrigado, muitas vezes, a ajudá-los, e de encerrar, para esta cópula especial, as vacas em um recinto estreito.

Intervenção do homem - Vamos voltar (a falar) sobre a época e a proporção de criação, muito variáveis de acordo com as províncias consideradas, e nós passamos a um outro ponto: aos cuidados prestados a esse gado. Esses cuidados, ainda que muito restritios, não são absolutamente nulos, como se escreveu; em toda a parte, no Norte como no Sul, no Paraná como na Repúbica Oriental, faz-se o "rodeio", isto é, a reuniâa em um so ponto de diversas tropas de animais, em épocas determinadas. 
170

Para as estâncias menos extensas, a reunião po. derá fazer-se perto das edificações da estância e, muitas vezes mesmo, em um espaço fechado, bastante largo, chamado "mangueira"; para as estâncias extensas, ricas em gado, como seria quase impossivel reunir em um único lugar 10.000 a 20.000 cabeças, por exemplo, fa. zem-se diversos rodeios em diversos pontos do campo, escolhidos com antecedência e sempre os mesmos. Em outras estâncias ainda, no Paraná notadamente, fazem. se um ou dois rodeios na mangueira, a cada ano, e diversos outros pequenos rodeios em diversos intervalos.

Essa reunião se faz sempre pelos mesmos pro. cessos: homens a cavalo, peões, campeiros, gaúchos, às vezes ajudados por cães especiais em Montevidéu, sempre munidos de um laço destinado a apanhar e trazer de volta os animais mais desgarrados, percorrem 0 campo, tocando diante deles o gado, ou melhor, suas diversas tropas. Essas tropas são, porém, fáceis de conduzir; elas se abalam e correm em massa, e se dirigem elas próprias para o ponto habitual do rodeio, tendo geralmente os touros à sua frente.

Mantêm-se esses animais reunidos durante um tempo mais ou menos longo e, às vezes, durante horas; os peöes correm ao redor das tropas gritando ou, simplesmente, postam-se em diversos pontos. Habitua-se, assim, esse gado muito medroso ao contato do homem e também a esse modo de reunião.

Aproveita-se o rodeio para julgar o estado do gado, da época $\theta$ da proporção de venda; $\theta$, principalmente em certas épocas, para dar-hhe cuidados especiais: sal no Paraná, cuidados médicos em uma região mais vasta. É também no rodeio, $\theta$ outras vezes nas mangueiras, que se praticam as operaf̧ōes de marcação $\theta$ da castração.
171

A marcação é importante, pois que só ela estabelece 0 direito de propriedade, cada estância tendo sua marca e, muitas vezes, várias. Encontram-se, sobretudo no Paraná, estâncias em que todos os filhos têm sua parte de gado, e como se autoriza também, muito freqüentemente, alguns escravos a possuí-10, compreendese a confusão que dai poderia resultar, mas que o hábito impede muito facilmente. A marcação se faz em épocas e por procedimentos variáveis; mas sempre ela é colo. cada sobre os filhotes do ano, os "terneiros" , cuja cifra é indicada pelas marcas colocadas. Reprova-se, principalmente, a marcação por estragar o couro; é feita a ferro em brasa e sobre um ponto muito mal escolhido: 0 flanco do lado esquerdo geralmente, pouco adiante do osso iliaco. Seria bem fácil mudar a marca de lugar, pois que todos, charqueadores e compradores de couros, queixam-se; e, entretanto, a reforma não foi feita ainda.

Na mesma época da marcação, e habitualmente nos mesmos rodeios, faz-se a castração, quase em toda a parte, senão por toda a parte, pelo processo de retirada. A "bistournage" não é mais empregada a não ser em raras regiões, do Paraná notadamente, em pequena escala, e para os velhos touros. Esta ablação dos testículos é, porém, muito rápida; o touro laçado nem bem foi laçado por terra, que o peão já, com sua faca comum longa e forte, fez uma incisão nas bolsas, cortou os cordões e tirou os testículos: muitas vezes, mesmo, trava-se uma espécie de luta para saber quem castrará o maior número de animais. Não somente a época da castraçăo, mas também a idade dos animais é variável, como veremos, segundo as regiöes; entretanto, essa castração é sempre tardia, pois que ela se faz entre 2 a 4 anos.

Não insisto mais sobre esses procedimentos gerais de criação: vê-se que esse gado não é absoluta- 
Doc 106 - 1988 (Antenor Peixoto de Castro - Xarqueadas de Danúbio Gonçalves Um resgate para história ${ }^{16}$ )

Meu pai foi chamado para administrar o estabelecimento e em 1931 transferimos residência para a casa grande da Charqueada, com cerca de $1.000 \mathrm{~m}^{2}$ de construção e áreas de quartos que eqüivaliam a um excelente salão de festas. Ali nos instalamos e permanecemos até 1941, acompanhando as safras que se sucediam e que movimentavam os trabalhadores do Areal, da Várzea e do Passo, de $1^{\circ}$ de janeiro até 30 de junho de cada ano, data fixada para o encerramento da safra. Em 1934, formado Perito Contador, fui admitido como Auxiliar de Escritório da Charqueada, com a incumbência, entre outras, de acompanhar o andamento de todas as matanças. No primeiro dia útil de cada ano a safra era iniciada, encerrando-se, impreterivelmente, em 30 de junho, com a duração, portanto, de seis meses. ${ }^{4}$

\footnotetext{
${ }^{16}$ Vale ressaltar que o autor da obra é José Antônio Mazza Leite, Antenor Peixoto de Castro é somente o autor da carta apresentada pelo autor da obra.
} 
Doc 107 - 1988 (Antenor Peixoto de Castro - Xarqueadas de Danúbio Gonçalves Um resgate para história)

deve ter ocorrido entre os anos de 1938 e 1939, não recordo bem, quando durante a safra foram abatidas cerca de 38.000 reses. Tratava-se da firma Vva. Pedro Osorio Cia. Ltda., cuja Charqueada estava localizada no Passo dos Negros, contígua ao Engenho São Gonçalo, às margens do Canal do São Gonçalo. ${ }^{3}$ 
Doc 108 - 1988 (Antenor Peixoto de Castro - Xarqueadas de Danúbio Gonçalves Um resgate para história)

As matanças iniciavam entre meia-noite e uma hora da madrugada, quando deveriam estar a postos todos os empregados, o chamado de... "boi... boi... boi", ecoava num raio de 5 quilômetros, convocando os operários. A tropa que deveria ser abatida, de propriedade da firma ou de custeio, de 300, 500 ou mesmo de 800 bois, já estava distribuída nos mangueirões interligados, que davam para um pequeno com capacidade para cerca de 20 bois. Aí, os animais encostados uns aos outros, aguardavam o laçador-matador, em geral um castelhano de boa cepa, com coragem bastante para desnucar as reses com um pequeno punhal de dois gumes, numa operação que muitas vezes entrava noite a dentro. Quinze minutos antes do início da matança, com o livro ponto debaixo do braço, recorria todos os setores do galpão para anotar a presença dos operários em seus postos, já distribuídos pelo "Capataz da Cancha". Ali estavam alinhados, esperando o primeiro boi, zorreiros, camboneiros, coleiros, carneadores, charqueadores, aguateiros, salgadores, matambreiros, foguistas, mergulhadores de carne e de couros, balanceiros, porteiros, guincheiros, carregadores de ossadas e buchadas, serradores de caracu, resfriadores, graxeiros, eletrecistas, tripeiros, etc e etc. ${ }^{5}$ 
Doc 109 - 1988 (Antenor Peixoto de Castro - Xarqueadas de Danúbio Gonçalves Um resgate para história)

Os tanques, com mais ou menos 6 metros de comprimento, por 1,50 $\mathrm{m}$ de largura e 1,20 $\mathrm{m}$ de altura, já estavam cheios de salmoura, com os medidores de salinidade boiando em seus interiores, um destinado à salga da carne e outro à dos couros. As fornalhas, com as bocas vermelhas escancaradas, iam pouco a pouco transmitindo aos manômetros a pressão das 4 caldeiras destinadas ao preparo da graxa amarelinha, acondicionadas em bordalesas ou em bexigas, que enchiam os olhos pela qualidade. Montanhas de sal grosso, completamente branco, trazidas por barcos que atracavam nos trapiches da Charqueada, completavam o interior do enorme galpão, que se mantinha absolutamente limpo, aguardando a salga da carne e do couro, para formarem as "pilhas de inverno" que, ao fim da safra, beiravam as telhas, com quase 5 metros de altura. Pela tarde, véspera da matança, as tropas que vinham trazidas pelos tropeiros, passavam pela Balança Municipal (imediações do Parque Tênis Clube) e em grupo de 50 animais eram pesados, fazendo-se ao final a média de peso da tropa. A seguir eram levados para a Charqueada pela Estrada das Tropas (hoje Avenida São Francisco de Paula) para serem encerrados nos mangueirões. ${ }^{6}$ 
Aí, o Capataz da Cancha e mais eu, empoleirados cada um de um lado do portão da mangueira, com algumas pedrinhas no bolso, fazíamos a contagem dos animais componentes da tropa. Os tropeiros, para facilitar a contagem, faziam alas para a passagem do gado, em pequenos lotes. Não era fácil a tarefa e ao final da contagem, antes que os tropeiros falassem, nós já tínhamos o resultado que em geral conferia, havendo algumas vezes pequenas divergências decorrentes do extravio de alguma rês ou sacrifício de alguns novilhos para a alimentação dos boiadeiros que vinham de fazendas muito distantes. O pequeno brete, uma vez abatida as reses nele encerradas, era imediatamente reabastecido. Os rodeios crioulos nos mostram seguidamente a perícia de um laçador perseguindo a rês em seu cavalo para, num arremesso certo, laçá-la ou derrubá-la ao solo num pialo. É maravilhoso! Não menos maravilhosa, no entanto, é a perícia de um laçador de brete! Ali estão 20 animais apertados uns contra os outros, chifre a chifre, não restando mais de $5 \mathrm{~cm}$ separando as guampas dos animais!? 
Doc 111 - 1988 (Antenor Peixoto de Castro - Xarqueadas de Danúbio Gonçalves Um resgate para história)

O animal caia sobre uma zorra colocada sobre trilhos e o zorreiro abrindo uma portinhola puxava a zorra e, juntamente com o coleiro e o camboneiro, derrubavam o animal e o colocavam ao longo da cancha (local de carneamento), onde os carneadores esperavam para o início dos trabalhos. O cambaneiro era o operário que passava uma grossa corrente pelos chifres do boi e o coleiro o que puxava pela cola para, num esforço conjunto, derrubar a rês, colocando-a na devida posição. ${ }^{9}$ 
O laçador preparava, então, sua laçada, quase exatamente da medida do afastamento dos chifres do animal que pretendia laçar. Mostrava o animal e dizia: É aquele mestiço de zebu! $\mathrm{O}$ animal estava apertado entre os outros! Será que dava? Distante mais ou menos $4 \mathrm{~m}$, o animal estava parado. Aí, então, a laçada voava sem reboleiro e caía exatamente sobre os 2 chifres do animal indicado. Uma façanha de craque! Fácil? Eu experimentei e em 50 tiros tive a nota zero... O velho castelhano João Taborda não era mole! Laçado o boi, ele gritava: Ala... Ala... Ala... E o laço enrolado ao guincho (máquina à vapor), puxava o boi até encostar sua cabeça a um moirão colocado horizontalmente, onde era desnucado com o punhal de 2 gumes. ${ }^{8}$ 
Doc 113 - 1988 (Antenor Peixoto de Castro - Xarqueadas de Danúbio Gonçalves Um resgate para história)

O local onde haviam carneado já estava completamente limpo. Por ali já haviam passado, devidamente montados em petiços, os carregadores de ossadas e buchadas, que, com ganchos fixados aos arreios faziam o serviço, levando a buchada para o monturo e a ossada para a graxeira para a elaboração da graxa, colocada, como disse, em bordalesas e bexigas. Também haviam colaborado com o carneador 2 matambreiros que, com um instrumento especial, soltavam o matambre, parte mais difícil de ser trabalhada com a faca. ${ }^{11}$ 
Doc 114 - 1988 (Antenor Peixoto de Castro - Xarqueadas de Danúbio Gonçalves Um resgate para história)

Tal serviço era repetido 20 a 30 vezes seguindo, conforme a capacidade da cancha, distribuindo-se o trabalho entre igual número de carneadores. Quando o último carneador era servido, os primeiros já haviam carneado os seus animais e aguardavam novas peças. ${ }^{10}$ 
Doc 115 - 1988 (Antenor Peixoto de Castro - Xarqueadas de Danúbio Gonçalves Um resgate para história)

O trabalho do carneador era dos mais importantes na matança. Ao receber o boi ele o sangrava e todo o sangue era aparado dentro de uma espécie de forma de lata, colocada sob o pescoço do animal e posteriormente levado a tonéis, para depois de coagulado e seco, ser misturado com farinha de ossos para fabricação de adubo (guano). Ao final do trabalho do carneador, sobrava na cancha apenas o couro da rês, já que o aguateiro fazia a limpeza do local. Vinha, então, o "capatazes da cancha" que examinava o couro. Qualquer furo em local importante que o desvalorizava, era motivo para o carneador não receber a ficha correspondente ao seu trabalho. Durante a matança o carneador recebia uma média de 25 fichas, que valiam, cada uma "um mil e quinhentos réis". Este serviço, assim como o dos carneadores salgadores, eram os mais bem pagos. A carne tirada pelos carneadores era levada para os charqueadores, em números de três ou quatro, que faziam o seu corte em mantas e outros pedaços que compunham propriamente o "charque", como produto final. Colocada a carne nos varais em setor contíguo à cancha, para resfriamento ${ }^{12}$, era ela, pouco tempo depois devidamente pesada, para se conhecer a média de carne da tropa, sendo lançada após no tanque da salga. Ali dois homens, munidos de paus com uma rodela numa extremidade, mergulhavam a carne durante algum tempo até que ela estivesse completamente salgada. ${ }^{13}$ 
Feito esse trabalho, retiravam a carne do tanque e a depositavam a sua borda, para que os salgadores efetuassem o seu trabalho. Os salgadores, em pequeno número, cobriam de sal grosso uma área de mais ou menos $8 \times 5 \mathrm{~m}$ e ali iam depositando, devidamente aberta, a carne retirada do tanque. Coberta a área com carne, espalhavam nova camada de sal, agora sobre a carne e, alternadamente, iam colocando carne e sal até que o charque de toda a tropa ali estivesse depositado. Colocavam, após o término, uma espécie de rede de cordas sobre a pilha, para separá-la da próxima tropa que para ali viria. As anotações feitas: $1^{\mathrm{a}}$ tropa, fulano; $2^{\mathrm{a}}$ tropa, sicrano e assim por diante, até que aquela imensa pilha quase encostava no teto do galpão. Eram pilhas de inverno. Matanças que somente meses depois seriam transformadas em charque e colocadas no mercado. ${ }^{14}$ 
Doc 117 - 1988 (Antenor Peixoto de Castro - Xarqueadas de Danúbio Gonçalves Um resgate para história)

Outras matanças, por interesse dos proprietários das tropas, eram rapidamente tratadas para consumo. Sobre o preparo do charque falaremos oportunamente. Estávamos, ainda, em plena "cancha". A ocorrência de matanças de grande número de reses, obrigava os 
trabalhadores a um regime de esforço fora do comum, pois muitas delas, iniciadas à primeira hora da manhã, prolongavam-se até pela tardinha, reiniciando os trabalhos novamente pela madrugada. Nesse contínuo emendar de matanças, os operários andavam quase dormindo pelos cantos. Nessas ocasiões o meu pai, para acordar o pessoal, mandava soltar na cancha um animal que não fosse muito brabo. O bicho, mediante um descuido propositado, passava pelo buraco da zorra e enfrentava todo mundo que estava na cancha. Corre pra cá, foge pra lá, esconde aqui, esconde acolá, todo mundo acordava..15 
Doc 119 - 1988 (Antenor Peixoto de Castro - Xarqueadas de Danúbio Gonçalves Um resgate para história)

Aí entrava em cena o Bernardino Gritão, um preto da zona do Areal, meio surdo, que puxando a faca da cintura com a mão esquerda, segurava o rabo do animal com a direita, e com dois rápidos movimentos da faca desgarronava o dito cujo, que ficava se arrastando pela cancha. Sua morte acontecia logo após. ${ }^{16}$ 
Acontecia, às vezes, que o Bernardino não estava por perto e o animal percorria toda a cancha ameaçando uns e outros e, postava-se, afinal, em um dos cantos do galpão. Aí, então, era acionado o ronda Baltazar, o seu Balta, que se encaminhava para o animal e cerca de uns 20 metros, levantando o 38 com a mão esquerda, colocava uma bala na testa da vítima que arriava para o chão, sendo carneado ali mesmo, sob grande salva de palmas. Agora sim! Todo o mundo estava acordado e pronto para recomeçar o trabalho! Entrementes, o produto de algumas matanças ia ser preparado para consumo. Orientação do escritório central mandava preparar determinada matança. Aí, então, entrava em ação o "Capataz de Rua". ${ }^{17}$ 
Doc 121 - 1988 (Antenor Peixoto de Castro - Xarqueadas de Danúbio Gonçalves Um resgate para história)

O competente João Doralino, um preto que tinha em bondade e respeito, tanto como os seus 120 quilos, botava em forma cerca de 30 operários, cada um com o seu carrinho de mão, para retirar o charque ainda pingando e depositá-lo sobre os varais que ocupavam mais de um hectare. Dia de sol, bonito, as peças iam perdendo a umidade e antes do cair da tarde já estavam novamente no galpão, agora em nova pilha. Durante alguns dias era repetida a operação até que, completamente seco e mostrando uma gordura dourada, o charque apresentava um aspecto excelente. ${ }^{18}$ 
Doc 122 - 1988 (Antenor Peixoto de Castro - Xarqueadas de Danúbio Gonçalves Um resgate para história)

Em cerca de 10 anos, apenas em duas oportunidades houve corrida para o recolhimento dos varais. A experiência do meu pai sobre o assunto fazia com que mesmo em alguns dias de sol não se fizesse o trabalho, pois, conforme previsão, o tempo mudava e passava a chover. Pronto o charque, os operários passavam a se ocupar de uma nova tarefa. Os sacos de aniagem eram devidamente carimbados com o nome da firma, o peso, o local de destino e a classificação do produto. O peso era determinado pela média da tropa, acusada por ocasião da matança, e variava entre 80 e 100 quilos. Finalizando o tratamento do charque, ele estava incluído dentro de uma das seguintes classificações: AA - SS - XX - BB - GG e MM. Considerava-se com o AA o charque especial, com uma camada de gordura dourada sobre as mantas, destacando-se dos demais; como SS, o mesmo tipo, com um pouco menos de gordura; como XX o charque um pouco gordo, muito parelho, e, como os anteriores, tipo exportação; a seguir vinham os tipos BB e GG, de pouca gordura e, finalmente o pelancudo MM. Era feito um amarrado com cordas finas e a carne devidamente ensacada. Cosido o saco, estava pronto para embarque. Os principais mercados eram do Norte e Nordeste, com Pernambuco e Bahia como as maiores expressões. ${ }^{19}$ 
Doc 123 - 1988 (Antenor Peixoto de Castro - Xarqueadas de Danúbio Gonçalves Um resgate para história)

Muitas singularidades acompanhavam as matanças. A firma mantinha um regular número de pequenas casas onde em geral moravam, permanentemente, os operários mais categorizados, como charqueadores, carneadores, rondas e salgadores e o agrupamento chamava-se "quadra", e um outro conjunto de quartos, para os empregados solteiros que se chamava 'turma'..$^{20}$ 
Ao final da cada matança todos os portões do galpão eram fechados, e exceção de um, onde eu me postava, sentado a uma mesa, frete a um pequeno bloco. A fila ia se formando e cada empregado, portando um saco branco, ia dizendo: 'Um valezinho para uma agulha e um par de rins'; o outro falava: Tô lavando uma bexiguinha de graxa e uns miúdos; um terceiro pedia: Só um terneirinho, um coração e uma agulha. E eles, após um exaustivo dia de trabalho, entregavam os vales no porteira e, em casa, iam salgando aqueles pedaços de carne que representavam parte de seu sustento na safra seca. E isso se repetia durante os seis meses da safra. E os que não conheceram esse tempo, por certo haverão de perguntar: Será que isso acontecia? Tudo de graça mesmo? ${ }^{21}$ 
Ao término da safra, o operário poupador abria a sua grande caixa de madeira e lá estavam, devidamente salgadas, algumas arrobas de uma carne muito especial. Outra particularidade era o acerto de contas ao final de safra. Muitos empregados iam retirando pequenos vales nos fins de semana e deixavam o grosso, se é assim que se poderia chamar, para o final. Acertado o saldo credor, portanto um envelope, lá se ia o trabalhador, que passava pela "turma" para apreciar o "jogo do osso". Sorte e culo, culo e sorte, passavam a ser responsáveis pela felicidade de uns e tristeza de outros. Ás vezes, em um único "tiro", lá se ia o conteúdo do envelope e adeus saldo credor! ${ }^{22}$ 
Percebe-se logo que Porto Alegre é uma cidade muito nova. Todas as casas em construção. Mas, depois do Rio de Janeiro não vi cidade tão suja, talvez mesmo mais suja que a metrópole.

João Rodrigues, comprador de couros nesta Capitania, dera-me uma carta de recomendação para seu sócio o Capitâo José Antônio de Azevedo, e eu tive o cuidado de avisá-lo, antes de minha chegada, a fim de conseguir alugar uma casa

Acompanhado do pai de meu guia tomei a dianteira de meus camaradas, a cerca de uma légua daqui. Apresentei-me em casa do Capitão, sendo muito bem acolhido e após conduzido à casa que ele me alugara, muito grande e confortável.

À primeira vista o Capitão José Antônio pareceu-me secarrão, mas logo notei que sua frieza de tratamento não passava de timidez e falta de convívio.

Recebi aqui uma correspondência dos Srs. Bourdon et Fry, contendo várìas cartas de minha família, felizmente portadoras de boas notícias. Admirei-me, entretanto, de não receber nenhuma carta de João Rodrigues.

Esta tarde fui visitar o sargento-mór João Pedro, ajudante de campo do General, que residia no Rio de Janeiro. Fui bem recebido e combinamos ir juntos, amanhã, à casa do General e de outras pessoas a que estou recomendado.

Ao entrar nesta Capitania verifiquei logo os hábitos carnívoros de seus habi. tantes. Em todas as estâncias vêem-se muitos ossos de bois, espalhados por todos os cantos, e ao entrar nas casas das fazendas sente-se logo o cheiro de carne e de gordura.

Em toda parte onde parávamos na estrada, meu guia perguntava se era possível adquirir uma manta. A manta nada mais é que uma grande faixa de carne seca e nunca foi vendida ao meu guia, pois todos o presenteavam com franqueza. Ele e seus companheiros improvisaram então espetos de pau, com os quais assavam ligeiramente pedaços de carne, sendo a manta logo devorada.

Porto Alegre, 22 de junho. - Acompanhado pelo major João Pedro ${ }^{1}$ dirigi-me ao Palácio para apresentar meu passaporte ao General e entregar-lhe as cartas de recomendação que trazia.

Após subirmos uma escadaria penetramos em uma saleta, onde fui condignamente recebido por um ajudante de campo, que levou ao conhecimento do General a finalidade de minha visita. Este, após examinar meus documentos, faloume com grande cavalheirismo e ofereceu-me cavalos, criados e hospedagem no Palácio. Agradeci e retirei-me instantes depois.

O Conde de Figueira (tal o título do General) pertence a uma das principais casas de Portugal. Antes de sua nomeação era o que se chama "um gozador da vida", tendo dissipado muitos haveres, passando assim por um estróina.

Sua escolha causou estupefação, sendo lamentada a sorte da Capitania que ia ser por ele governada.

Aqui chegado, todavia, pôs-se em brios e quis provar que merecia melhor reputação, mudando de conduta, tornando-se sóbrio e consagrando-se de corpo e alma ao seu cargo.

Todo mundo elogia sua probidade e seu amor à justiça, apesar dos altos fun. cionários e pessoas abastadas não o reconhecerem como tal.

Mostra entretanto ser amigo do povo, envidando esforç aliviar os impostos, no sentido de

Aos olhos de neus jurida das possibilidades da Capitania. é que sabe atirar o leus jurisdicionados ele possui outro mérito de alta valia vendo-se com a rapidez e cavalgar tão bem quanto os naturais do lugar, locomompago de um ponto a outro da Capitania. 
Doc 127 - 1820/21 (Auguste de Saint-Hilaire - Viagem ao Rio Grande do Sul)

alguém aí residente há 17 anos informa-me que sua população aumentou nesse lapso de tempo em mais dois terços. Pode ser considerada como principal empório da Capitania e mormente da zona nordeste do Estado.

Os negociantes adquirem quase todas as mercadorias no Rio de Janeiro e as distribuem nos arredores da cidade. Em troca exportam principalmente couros, trigo e carne seca; é também de Porto Alegre que saem todas as conservas expedidas da província.

O rápido aumento da população fez com que os terrenos se tornassem mais valorizados aqui que nas cidades do interior. Poucas casas possuem jardim e muitas não tem mesmo pátio, redundando isso no grave inconveniente de serem atiradas à rua todas as imundícies, tornando-as de uma extrema sujeira. As encruzilhadas, os terrenos baldios e principalmente as margens do lago são entulhadas de lixo. Apesar de ser o lago o único manancial de água potável, utilizado pela população, consentem que nele se faça o despejo das residências. 
Doc 128 - 1820/21 (Auguste de Saint-Hilaire - Viagem ao Rio Grande do Sul)

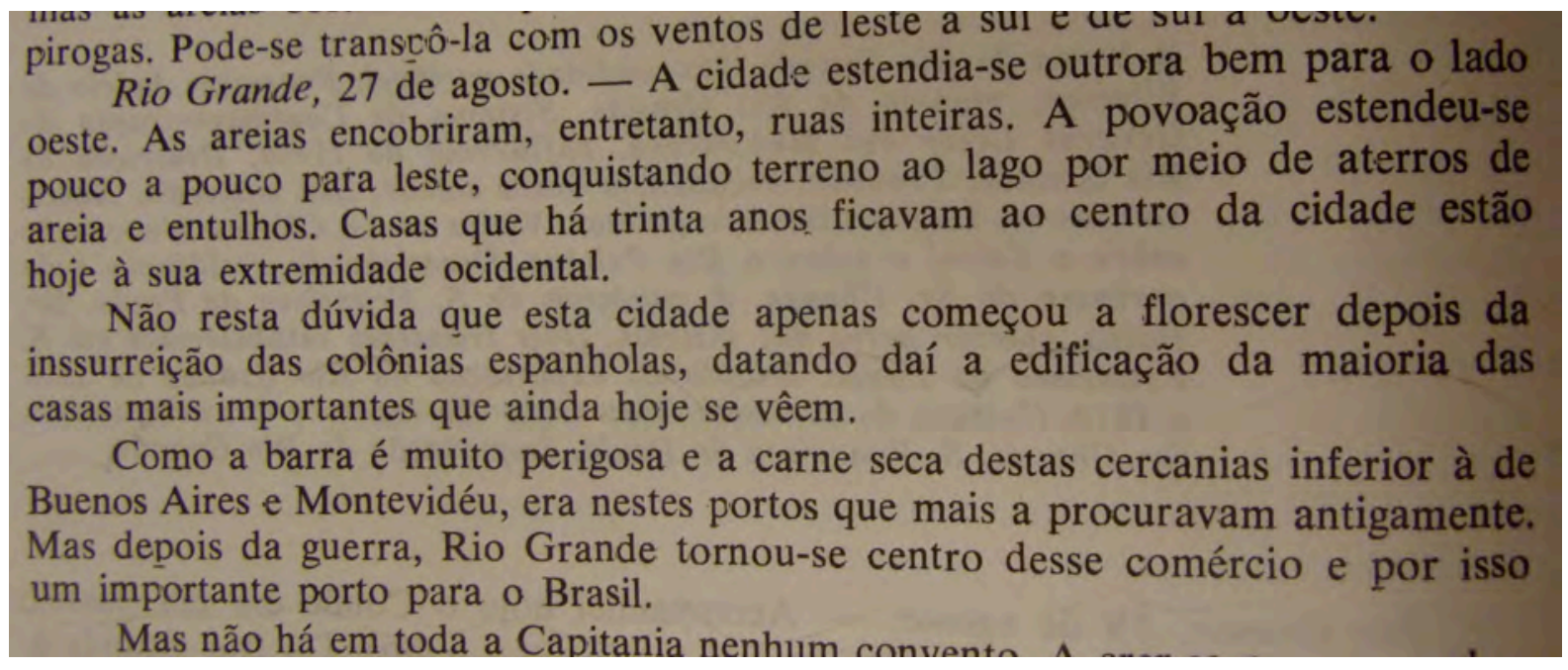


Entretanto uma chuva forte obrigou-nos a descer no iate, privando-nos do vrazer de ver os sítios por onde passávamos. Somente à entrada do Rio de Stâo Gonçalo, que não é verdadeiramente um rio, mas um canal estreito ligando as Lagoas dos Patos e Mirim, subi à coberta do iate. Disse-me o Sr. Chaves que a corrente do Rio São Gonçalo se dirige, segundo os ventos, tanto na direção da Lagoa dos Patos quando na da Mirim, mas nas enchentes é na direção da primeira que ela corre. À embocadura do Rio São Gonçalo, dizem, a Lagoa dos Patos tem 2 léguas.

Aí deixamos o roteiro de Porto Alegre e entramos no rio, que pode ter a largura do Loire diante de Orleans. As margens, muito planas, são cobertas de pastagens salpicadas de algumas árvores. A noite em breve surpreendeu-nos, sendo-me impossivel distinguir as cousas.

De Porto Alegre à entrada do Rio São Gonçalo vão 7 léguas e estamos somente com duas de trajeto. Em seguida passamos a um outro rio chamado $\mathrm{Pe}$ lotas, na margem do qual se situa a residência do $\mathrm{Sr}$. Chaves, onde chegamos após meia légua de viagem.

O Rio Pelotas, disseram-me, tem 12 léguas de curso e somente é navegável em cerca de meia légua. No resto de seu curso é obstruído por troncos e galhos de árvores.

A viagem de hoje foi muito agradável. O Sr. Chaves é um homem culto, sabendo o latim, o francês, com leituras de história natural, conversando muito bem. Pertence à classe dos xarqueadores ou fabricantes de carne seca.

Os xarqueadores compram o gado dos estancieiros, abatem-no, retalham-no e preparam o xarque que vendem aos negociantes.

As marés fazem-se sentir no Rio Grande, porém com irregularidade. Os ventos têm sobre ela uma grande influência.

Margem do Rio Pelotas, 6 de setembro de 1820. - Dada a hora avançada de nossa chegada ontem à morada do $\mathrm{Sr}$. Chaves nada pude dizer ainda a respeito.

A casa está situada do modo o mais favorável, pois que os iates podem chegar até bem junto dela. A residência do proprietário é de um pavimento apenas, porém, grande, coberta de telhas e um pouco elevada sobre o solo. Interiormente é dividida em grandes peças que se comunicam umas com as outras e que ao mesmo tempo se abrem para fora.

Hospedaram-me em um quarto pouco iluminado, dando para uma sala de refeições, gênero de distribuição comum em todo o Brasil.

Mesas, cadeiras e canapés compõem o mobiliário do Sr. Chaves. As cômodas e as secretárias são móveis completamente modernos no Brasil e somente encontradiços em um número exiguo de casas.

O Rio Pelotas, que tem quase a largura do Essonne em Pithiviers, passa ao lađu da habitação, serpenteando em uma vasta planície, tendo ao lado oposto uma pequiena encosta onde se vêem algumas casas cobertas de telhas.

Diante da residência do $\mathrm{Sr}$. Chaves estende-se belo gramado e além vêem-se várias fileiras, compridas, de grossos paus fincados nà terra. Têm cerca de 4 pés, sendo cada um terminado por pequena forquilha. Essas forquilhas recebem varões transversais destinados a estender a carne a secar, no tempo das xarqueadas. Ao lado desses secadouros existe o edifício onde se salga a carne e onde é construído o reservatório, denominado tanque.

Quando o animal é abatido, retalham-no, salgam os pedaços e colocam no tanque onde se impregnam de salmoura. Ao fim de 24 horas vão para os seca. douros, onde ficam durante 8 dias, quando há bom temp̣o. A carne seca não se conserva mais de um ano. E exportada principalmente para o Rio de Janeiro, Bahia e Havana, onde serve de alimento para os negros. 
reunidos em casa do coletor geral. Entre eles estava um velho residente na região, há vinte anos, e que foi o primeiro habitante do lugar. Então às margens do canal eram cobertas de matas e de pântanos; ele devastou-as e drenou as terras. vendendo retalhadamente uma grande parte de sua propriedade.

A região, há pouco descrita, que se estende entre o Rio Pelotas, o Rio São Gonçalo e a paróquia de S. Francisco pertence a xarqueadores e as casas mencionadas são as respectivas residências. Não podiam escolher melhor local pois aí recebem, sem a mínima dificuldade, o gado criado nas gordas pastagens situadas ao sul do Jacuí e facilmente exportam a carne seca e os couros através dos rios Pelotas e São Gonçalo. Há entre eles homens muito ricos. O Sr. Chaves, por exemplo, que começou como caixeiro, dispõe hoje de fortuna avaliada em 600 mil francos.

A localização dos xarqueadores à margem do Rio São Gonçalo deu lugar à formação da Paróquia de S. Francisco.

Após deixarmos a casa do Sr. Paiva, o coletor geral dos dízimos, seguimos para a aldeia, distante, já dito, meio quarto de légua do Rio São Gonçalo e situada em vasta planície. É sede da paróquia e conta para mais de 100 casas, construídas segundo um plano regular de edificação da aldeia. As ruas são largas e retas. A praça em que fica a igreja é pequena porém muito bonita. A frente da maioria das casas é asseada. Não se vê em S. Francisco de Paula uma palhoça siquer e tudo aqui anuncia abastança. Na verdade as casas são todas de um só pavimento mas são bem construídas, cobertas de telhas e guarnecidas de janelas envidraçadas. 
Vou transcrever aqui o extrato dos dados de exportação do Rio Grande, durante vários anos, fornecidos pelo $\mathrm{Sr}$. Chaves:

ANO 1816 - Carne seca - Para o Rio de Janeiro, 169.879 arrobas; Bahia, 236.371; Pernambuco, 215.136; Santa Catarina, 950; Campos, 2.000; Havana, 74,230; Total, 707.116 a $\$ 700^{6}$ igual a $494: 981 \$ 200$. Sêbo - Para o Rio de Janeiro, 36.698 arrobas; Bahia, 14.242; Pernambuco, 4.836; Santa Catarina, 640; Campos, 159; Havana, 480; Total, 57.055 a $1 \$ 200$ igual a $68: 466 \$ 000$. Graxa Para o Rio de Janeiro, 4.836; Santa Catarina, 390; Nova York, 56; Total, 5.282 a $1 \$ 200$ igual a $6: 338 \$ 400$. Crinas - Para o Rio de Janeiro, 657,5 arrobas a $\$ 700$ igual a $460 \$ 250$. Barris de carne salgada - Para o Rio de Janeiro, 250 a $9 \$ 600$ igual a 2:400\$000. Couros de boi - Para o Rio de Janeiro, 153.866; Bahia, 26.244; Pernambuco, 7.555; Santa Catarina, 300; Campos, 32; Guernesey, 4.407; Porto, 11.452; Nova York, 13.675; Havana, 1.311; Alexandria, 6.816; Total, 225.638 a $1 \$ 200$ igual a 270:765\$600. Couros de éguas - Para o Rio de Janeiro, 1.746; Guernesey, 63; Nova York, 320; Total, 2.129 a $\$ 400$ igual a $851 \$ 600$. Trigo (alqueires) - Para o Rio de Janeiro, 224.9581/2; Santa Catarina, 2.023; Total, 226.9811/2 a $1 \$ 600$ igual a 363:070\$400. Chifres - Para o Rio de Janeiro, 365.700; Bahia, 500; Pernambuco, 21.100; Guernesey, 700: Porto, 4.800; Nova York. 96.800; Havana, 24.350; Alexandria, 14.500. Total, 528.450 a $1 \$ 000$ iguala $5: 284 \$ 500^{7}$ - Total das exportações, $1.212: 617 \$ 950$.

ANO 1817 - Carne seca - Para o Rio de Janeiro, 164.180 arrobas; Bahia, 234.103; Pernambuco, 61.260; Santa Catarina, 2.771; Laguna, 800; Maranhão, 12.075; Campos, 3.500; Montevidéu, 8.800; Havana, 72.796. Total, 560.285 a

6 No original francês os números referentes a moeda shio acompanhados de um sinal que

7 Náo se sabe qual a unidade de venda. 
1\$360 igual a 761:987\$600, - Sêbo - Para o Rio de Janeiro, 25.5841/2; Bahia, Salem (sic) 15. Total, 34.0231/2 a 1 S920 igual Maranhão, 125; Campos, 110; Rio de Janeiro, 5.268; Bahia, 30; Santa Catarina, 114; Lagraxa - Para o Montevidéu, 2.772. Total, 8.204 a $1 \$ 920$ igual a 15:751\$68, 50; Campos, 20; Rio de Janeiro, 478; Bahia, 38; Salem, 81. Total, 597 a $24 \$ 560$. Crinas - Para o Barris de carne salgada - Para o Rio de Janeiro, 100; Montevidé, 644. 744 a $12 \$ 800$ igual a 9:523\$200. Couros de boi - Para o Rio de Janei. Total, 138.754; Bahia, 15.890; Pernambuco, 5.063; Maranhão, 85, Havana, 59; . ... 3.190; Anvers, 6.193. Total, 169.234 a $1 \$ 440$ igual a $243: 696 \$ 960$. Couros, égua - Para o Rio de Janeiro, 3.389; Salem, 4.000. Total, 7.389 a \$400 a 2:955\$600. Trigo (em alqueires) — Para o Rio de Janeiro, 10 141; Pernambuco. 4.093; Santa Catarina, 1.053; Campos, 100; Montevidé; Bahia, Total, 109.446 a $2 \$ 000$ igual a 218:892\$. Chifres - Para o Rio 172.489; Bahia, 8.000; Pernambuco, 16.800; Havana, Total, 247.789 a $2 \$ 000$ igual a $4: 955 \$ 780$. Total dias $1.324: 616 \$ 260$. 
Nas xarqueadas os negros são tratados com rudeza. O Sr. Chaves, tido como um dos xarqueadores mais humanos, só fala aos seus escravos com exagerada severidade, no que é imitado por sua mulher; os escravos parecem tremer diante de seus donos.

Há sempre na sala um pequeno negro de 10 a 12 anos, cuja função é ir chamar os outros escravos, servir água e prestar pequenos serviços caseiros. Não conheco criatura mais infeliz que essa criança. Nunca se assenta, jamais sorri, em tempo algum brinca! Passa a vida tristemente encostado à parede e é freqüientemente maltratado pelos filhos do dono. À noite chega-lhe o sono, e, quando não há ninguém na sala, cai de joelhos para poder dormir. Não é esta casa a única que usa esse impiedoso sistema: ele é freqüiente em outras.

Afirmei que nesta Capitania os negros são tratados com bondade e que os brancos com eles se familiarizam, mais que em outros pontos do País. Referia-me aos escravos đas estâncias, que são em pequeno número; nas xarqueadas a coisa muda de figura, porque sendo os negros em grande número e cheios de vícios, trazidos da Capital, torna-se necessário tratálos com mais energia.

Hoje vieram me acordar e em boa hora avisaram-me que podíamos partir porque cessara o vento. Embarquei no iate do Sr. Chaves, com um de seus amigos, seguindo o mesmo caminho da vinda. Pouco terei de acrescentar a respeito da região.

As margens dos rios S. Gonçalo e Pelotas são muito chatas, o campo é alegre e coberto de bosquetes e de pastagens. Chegados a Norte passamos para uma sumaca, também pertencente ao $\mathrm{Sr}$. Chaves, donde nos transportamos a uma lancha que nos levou ao Rio Grande. 
de atividade, espírito militar e aum sentmincin Francisco de Paula é a aldeia do Rio Rio Grande, 14 de setembro. - São Franciscó tualmente 18 nesta paróquia Grande onde existe maior número de ano é de cerca de $20 \mathrm{mil}$. A paróquia é limitada ao norte pelo Rio Camaquam, ao sul pelo Arroio das Pedras e o Rio Piratiní; a leste pela Lagoa dos Patos e Rio São Gonçalo; a oeste pela Serra dos Tapes.

Apesar de ter cessado há meses a matança nas xarqueadas sente-se ainda nos arredores um forte cheiro de açougue, donde se pode fazer idéia do que não será esse odor no tempo da matança. Nessa época, dizem, não se pode aproximar das xarqueadas sem ser logo coberto pelas moscas. Ao imaginar essa multidão de animais decapitados, o sangue a correr em borbotões, a prodigiosa quantidade de carne exposta nos secadouros, vejo que tais lugares devem inspirar contrariedade e pavor.

Tenho já observado, muitas vezes, que os mineiros não são arraigados à terra natal. Com efeito nenhum hábito particular os retém e eles não têm pesar em sair à procura de melhores situações, por isso que sua inteligência, peculiar, Thes garante meios fáceis de subsistência em qualquer parte. Os habitantes desta Capitania, ao contrário, nunca emigram porque sabem que fora dela serão obriga- 
e do Rio Grande nos lugares onde não existe outro meio de atravessar o rio. A pelota, este o nome dado a tais pirogas, é simplesmente um couro crú em que se ligam as quatro pontas, tomando desse modo a forma de um barco, com feitio aproximado de sacolas de papel onde se embrulham biscoitos. Enche-se a pelota de objetos, amarra-se numa corda ou uma tira de couro a uma de suas extremidades e um homem, a nado, fá-la passar o rio, tendo a ponta da corda presa aos dentes.

Para facilitar o trabalho meus homens estenderam uma corda de um lado a outro do rio com o fito de diminuir o esforço da natação, apoiando-se nela para descansar. Eu mesmo passei o rio sentado numa pelota chegando sem novidade à outra margem, bem como as bagagens e carroças. Matias, José Mariano e Firmiano alternaram-se na passagem da pelota. 
nas margens.

Da Estância dos Dourados passamos durante algum tempo, na Xarqueada do Curral Alto de S. João da Fortaleza, onde o patrão devia embarcar uma partida de carne-seca. Antes de chegarmos sua situação foi-nos anunciada por nuvens de urubús, que escureciam o céu.

A fase da matança terminara, havia muito tempo; contudo havia ainda muita carne no chão e vísceras de bois, putrefatas espalhavam forte mau cheiro ao redor da casa.

Essa fica em situação encantadora. A colina sobre a qual foi construída domina uma vasta extensão de terras; a espessa mata que margina o Jacuí borda o campo e esse rio deixa ver, intervalos, grandes trechos de seu curso, assemelhando-se a lagos.

Antes de chegarmos a Curral Alto passamos diante da embocadura do riacho Francisquinho, que corre à direita do Jacuí. Vimos, em seguida, a foz do Arroio do Carajá, à mesma margem do anterior e um pouco antes de anoitecer passamos diante da Aldeia de Santo Amaro sede de uma paróquia. A localidade oxde está essa aldeia é descampada, mas à direita e à esquerda da povoação vêem-se pequenos grupos de casas, sobre o cimo de uma colina e, na vertente, aldeia não seria grande cousa, se entremeados de laranjeiras e gramados. Tal do rio, mas afirmaram-me que se constasse somente dessa parte que se avista mos por Santo Amaro deixamos, ainda oposta há muitas casas. Após passardo Conde. 
Doc 137 - 1820/21 (Auguste de Saint-Hilaire - Viagem ao Rio Grande do Sul)

çado e sarmentoso, n. $^{\circ} 1853$ bis.

Rio Grande, 11 de agosto. - Em 1818 a quantidade de carne seca exportada para Cuba e Estados Unidos subiu a 100 mil arrobas. Taxaram em 600 réis o imposto de cada arroba, o que até essa ocasião era de 200 réis apenas. Em 1819 a exportação desceu a 40 mil arrobas e espera-se seja ainda menor este ano. As embarcações de mais de 40 palmos de calado não podem transpor a 
Doc 138 - 1820/21 (Auguste de Saint-Hilaire - Viagem ao Rio Grande do Sul)

de 38 brancos, 25 brancas, 2 inalas escravos, 44 negros e 27 negras escravas. negras livres, 4 mulatos elotas, 5 de setembro de 1820. - Estive ontem à tarde Margens do Rio Pelotas me disse tencionar partir esta manhã. Efetivamente em casa do Sr. Cha horas em uma lancha que nos levou ao iate do Sr. Chaves, ancorado a pouca distância de Rio Grande.

Trouxe comigo Firmiano, deixando Laruotte na cidade. Quanto a José Mariano passou todo o tempo em que estive em Rio Grande na estância da Mangueira, situada entre o saco do mesmo nome e o lago, tendo conseguido arranjar úma linda coleção de pássaros. Essa estância pertence a um amigo de Mateus da Cunha Teles, o tenente Vieira, o qual tratou cavalheirescamente o meu empregado. 


\section{Capítulo 2 - O GLOSSÁRIO}

\subsection{Aporte teórico metodológico da composição do glossário}

Como pré-requisito para o desenvolvimento do Glossário, faz-se necessário delinear o aporte das ciências que envolvem a descrição de um vocabulário - a Lexicologia e a Lexicografia - para que a terminologia empregada nas discussões esteja de acordo com as bases teóricas, como também sejam aplicados os conceitos adequados.

A Lexicologia, segundo Cabré (1993), descreve o conhecimento linguístico do falante de uma língua sob o ponto de vista do léxico, sendo uma ciência que estuda as palavras que ele conhece e utiliza em situações variadas de seu cotidiano, concentrando-se e embasando-se, portanto, na análise e na descrição da competência linguística desse falante.

As explicações de Biderman (2001, p. 16) complementam a abrangência da lexicologia, definindo "como objetos básicos de estudo e análise a palavra, a categorização lexical e a estruturação do léxico". Entretanto, considerando as afirmações do autor de que "o léxico de qualquer língua constitui um vasto universo de limites imprecisos e indefinidos", a prática da lexicologia apresenta, por vezes, problemas teóricos que acarretam graves consequências às análises linguísticas neste campo.

A outra disciplina afim, a Lexicografia, pode ser definida como a ciência que se ocupa dos dicionários. Segundo Verdelho (1990), a lexicografia começou a se configurar e se estruturar como disciplina a partir do século XVI, motivada pelo ensino do latim, não mais caracterizado como língua materna.

Nas origens renascentistas da lexicografia portuguesa, o autor cita as obras de Jerônimo Cardoso (1592) como marcadoras do início da dicionarização da língua portuguesa, e destaca os ortografistas Duarte Nunes de Leão (1576), Amaro Reboredo (1619) e Agostinho Barbosa (1652) como figuras engenhadoras desse processo. Considerando a contribuição dos jesuítas, cita a Prosódia de Bento Pereira (1634) como a obra dicionarística mais importante e representativa dessa ordem religiosa.

A mesma ordem de importância o autor confere ao dicionaristas/enciclopedista, Raphael Bluteau (1712), afirmando que "entre os vocabulários bilingues de origem renascentista e os dicionários monolingues modernos, situa-se a obra mais monumental da lexicografia portuguesa, o Vocabulário Portuguez e Latino" (VERDELHO apud NUNES, 2002, p.22). O abundante corpus lexical, as referências semânticas e as reflexões teóricas 
constantes em seu Vocabulário fazem de Bluteau um dos autores mais importantes da lexicografia.

Verdelho (1990) também informa que a lexicografia moderna bilingue portuguesa surgiu depois da segunda metade do século XVIII, com as publicações de Bernardo Barcelar, em 1783 e de António de Moraes Silva, em 1789.

Então, foi somente por meio de dicionaristas como Francisco Júlio de Caldas Aulete, Cândido Figueiredo e Moraes Silva que os dicionários se estabeleceram com a função de decodificar e escolarizar a aprendizagem de uma língua, permeando o propósito de ativar a comunicação e, atualmente, sendo considerados peças fundamentais com outra finalidade: o acesso à significação das palavras.

Também as considerações de Biderman (1989, p.75) reafirmam a importância do dicionário como "instrumento indispensável e imprescindível na fixação do léxico de uma língua e ferramenta fundamental na consolidação de uma língua escrita e literária”.

No Brasil, ainda no final do século XIX, integrantes da Academia Brasileira de Letras apontaram a necessidade de elaboração de um dicionário que abarcasse o português falado e que elencasse as diferenças entre o português brasileiro e o português europeu. Em 1924, Laudelino Freire apresentou um projeto com essas ideias, consolidado anos mais tarde, sob o nome Grande e Novíssimo Dicionário da Língua Portuguesa (1939-1944). Nessa mesma época, a Academia encomendou de Antenor Nascentes uma obra de semelhante tipologia, que deveria seguir o modelo do Dicionário da Real Academia Espanhola (Drae).

Ambas as obras não foram adiante e, segundo Biderman, foi somente o Novo Dicionário da Língua Portuguesa, de Aurélio Buarque de Holanda, em 1975, que a lacuna deixada pelos outros dicionários inclusive o PDBLP, (Pequeno Dicionário de Língua Portuguesa) de 1938, foi preenchida.

Entretanto, segundo a autora, nem o Michaelis e a obra de Houaiss, nem mesmo o dicionário do próprio Aurélio, foram, até hoje, elaborados segundo sólidos critérios lexicográficos científicos.

Sobre o glossário, segundo Guerra (2003), na Idade Média eram assim denominados os catálogos independentes de anotações léxicas que eram julgadas como de difícil compreensão para o leitor de uma dada obra.

A menção a ele é antiga, mas seu reconhecimento científico começou a ter espaço em meados do século XVIII. E foi somente no século XIX que o emprego moderno do termo foi reconhecido a William Whenwell, que o definiu, em 1837 como "système des termes 
employés dans la description des objects de l'histoire naturelle ${ }^{17}$ " (WHENWELL apud REY, 1979, p.6).

Tal função permanece atualmente, e os glossários são "concebidos en general como inventarios léxicos que se proponen aclarar el sentido de ciertos vocabulos oscuros o poco familiares a los receptores de una obra." ${ }^{\prime 18}$. (GUERRA, 2003, p. 55).

A autora também define vocabulário, que pode ser entendido como um catálogo de palavras pertencentes a uma região, atividade ou campo semântico definido.

Quando se estuda as ciências lexicográfica e lexicológica, conceituar os termos a serem empregados demanda não só um esforço intelectual como também uma laboriosa pesquisa bibliográfica. Considerando que os dicionários linguísticos nem sempre apresentam similaridade entre os termos e conceitos, como menciona Biderman (2001, p. 169) "Termos como palavra e vocábulo da linguagem comum se prestam a equívocos e imprecisões", e, como forma de justificar a escolha das conceituações adotadas para a pesquisa, faz-se necessária a definição de alguns desses termos ${ }^{19}$.

Assim, verbete corresponde a cada uma das entradas do glossário com as acepções, abonações, tabelas, análises e meios extraguísticos; lexia se refere a cada item lexical, sinônimo de palavra e vocábulo; e léxico e vocabulário são entendidos como o conjunto de lexias ou vocábulos, e são considerados nesta pesquisa como sinônimos. Por fim, glossário é empregado como o conjunto de termos, uma compilação de lexias organizadas em ordem alfabética, que fornece definições de palavras e expressões usuais ou não e que, neste estudo, engloba termos relacionados ao charque.

\subsection{As pesquisas nos dicionários de Língua Portuguesa}

O léxico, como conjunto de de vocábulos de uma língua, não é um produto estático, porque está em constante modificação segundo o uso que os falantes fazem das lexias. Por isso, o estudo da significação das do vocabulário do charque foi ampliado nesta pesquisa para além do corpus. Tal ampliação possibilita a realização de um estudo diacrônico das lexias, observando as mudanças e relações dicionarizadas que o vocabulário do charque

\footnotetext{
${ }^{17}$ Tradução nossa: "sistema de termos empregados na descrição de objetos da história natural"

${ }^{18}$ Tradução nossa: "concebido em geral como inventários léxicos que se propõem a esclarecer o significado de certas palavras obsvuras ou desconhecidas para os destinatários de uma obra"

19 Estas definições não apresentam citação dos autores por terem sido conceituadas através da leitura de diferentes obras, durante o cumprimento da disciplina de Lexicografia e Terminologia em Língua Portuguesa e através de debates no exame de qualificação.
} 
experimentou ao longo de quatro séculos - XVIII, XIX, XX e XXI - e que influenciaram na formação e expansão da variedade do português brasileiro.

Analogamente ao que acontece com as terminologias que envolvem o estudo do léxico, também as compilações vocabulares apresentam diferentes denominações. Os dicionários, os glossários, os thesaurus, dentre outros, por vezes se mesclam e/ou se confundem, deixando aos pesquisadores a difícil tarefa de determinar as propriedades e limites de cada um destes repertórios lexicográficos.

O dicionário pode ser entendido como um tipo de obra que, além de apresentar finalidade didática, foi concebida, em sentido purista, como instrumento de consulta para sanar dúvidas de significação das palavras. Ao longo de sua história, foi elaborado para resolver problemas relativos ao léxico, qualquer fosse a área ou a natureza da dúvida. Guerra (2003, p.58) assim o define: “...em puridad, el diccionario vendría a ser um conjunto organizado de estudios parciales y con criterio homogéneo del léxico de una lengua” ${ }^{20}$.

Considerando tais funcionalidades conferidas aos dicionários, optou-se pela realização deste estudo diacrônico através da coleta e análise das acepções apresentadas em dez (10) dicionários, sendo estes oito (8) gerais e dois (2) regionalistas - dadas às 211 lexias previamente selecionadas dos documentos e dispostas no glossário. A escolha dos autores, obras e edições seguiu os seguintes critérios ${ }^{21}$ :

1. as obras abrangem o mesmo período de datação dos documentos do corpus utilizado para a seleção das lexias;

2. os dicionários são monolíngues, em Língua Portuguesa;

3. as obras selecionadas comtemplam exemplares produzidos em território português e brasileiro; dada a nacionalidade dos autores dos documentos do corpus;

4. ao menos uma das obras escolhidas possui ênfase no uso do léxico;

5. o material inclui exemplares de cunho regionalista, dada a especificidade regional da tese.

\footnotetext{
${ }^{20}$ Tradução nossa: "puramente falando, o dicionário se tornaria um conjunto organizado de estudos parciais e com critérios homogêneos do léxico de uma língua."

${ }^{21}$ A título de consulta, foi realizado um resumo pormenorizado dos dez dicionários mencionados, descrevendo sua organização e expondo a composição estrutural das introduções de cada uma das obras. Porém, considerando a extensão desses dicionários, e, por conseguinte, dos resumos, optou-se por apresentá-los como apêndices, precedendo as referências bibliográficas desta tese.
} 
Além da datação e nacionalidade como premissa de escolha dos dez dicionários, foram também consideradas, como critério de seleção, características peculiares dessas obras, que se apresentavam relevantes ao estudo proposto nesta pesquisa:

1. Vocabulario Portuguez e Latino, de Raphael Bluteau (1712), além da datação e nacionalidade da obra, foi escolhido por ser considerado um marco nos estudos do léxico da Língua Portuguesa;

2. Diccionario da Língua Portugueza, de Antonio de Moraes Silva - $2^{\text {a. edição }}$ (1813), este dicionário foi escolhido além da datação e nacionalidade da obra, como afirma o próprio autor, porque procurou elaborar uma obra mais enxuta que a obra de Bluteau, apresentando maior facilidade de manuseio e idéias mais claras e exatas do que comumente se acha nos livros desse assunto;

3. Grande Diccionario Portuguez ou Thesouro da Língua Portugueza, de Domingos Vieira (1873), escolhida por ser "a obra mais volumosa, de mais trabalho original e mais especificamente linguística, entre a lexicografia portuguesa do séc. XIX”. (Verdelho,1990, p. 253);

4. Grande e Novíssimo Dicionário da Língua Portuguesa, de Laudelino Freire (1940), escolhido por ser o primeiro grande dicionário brasileiro, além de apresentar acepções inéditas, de acordo com os modernos preceitos da lexicografia;

5. Dicionário Contemporâneo da Língua Portuguêsa, de Caldas Aulete - edição brasileira (1958), selecionada por ser a edição brasileira atualizada, revista e aumentada com a introdução dos vocábulos em uso no Brasil;

6. Novo Dicionário da Língua Portuguesa, de Aurélio Buarque de Holanda Ferreira - $2^{\text {a. }}$ edição (1986), a escolha deu-se pela consagração da obra como um todo, inclusive traz a metonímia Aurélio como sinônimo de dicionário;

7. Dicionário Houaiss da Língua Portuguesa, de Antônio Houaiss e Mauro de Salles Villar - $1^{\text {a. }}$ edição (2001), também amplamente reconhecida pelo público brasileiro, registra a universalidade lusofônica, ressaltando as variantes regionais;

8. Dicionário de usos do português do Brasil, de Francisco da Silva Borba $-1^{\text {a. }}$ edição (2002), escolhida por ser uma obra que realiza um retrato da língua escrita no Brasil na segunda metade do século XX. 
9. Dicionário de Regionalismos do Rio Grande do Sul, de Zeno e Rui Cardoso Nunes $-7^{\text {a. }}$ edição (1996), obra que fornece uma visão do panorama dialetal gaúcho, e seus autores considerados expoentes da estrutura literária dessa região.

10. Dicionário Gaúcho Brasileiro, de Batista Bossle - $1^{\text {a. }}$ edição (2003), considerada uma obra sistemática e criteriosa e possivelmente a mais completa e rigorosa do gênero.

Os dicionários serão apresentados em dois momentos. $\mathrm{O}$ primeiro momento é parte constituinte do verbete do glossário, onde estarão tabuladas as ocorrências das lexias e a correspondência entre as acepções fornecidas pelos autores das obras lexicográficas e as acepções fornecidas no glossário elaborado na tese. No segundo momento do estudo realizado com os dicionários, configura-se uma análise quantitativa e qualitativa das ocorrências e correspondências lexicais apresentadas nas tabelas dos verbetes. Estas análises estão no subcapítulo 2.8, logo após o glossário.

Com a finalidade de sistematização e facilitação da leitura, os dicionários serão referenciados por meio das iniciais propostas na tabela abaixo:

Tabela 1 - Legenda dos dicionários estudados

\begin{tabular}{|c|c|}
\hline Sigla & Autor e obra que representa \\
\hline $\mathbf{R B}$ & Vocabulario Portuguez e Latino - Raphael Bluteau \\
\hline AMS & Diccionario da Língua Portugueza - Antonio de Moraes Silva \\
\hline DV & $\begin{array}{l}\text { Grande Diccionario Portuguez ou Thesouro da Língua Portugueza - } \\
\text { Domingos Vieira }\end{array}$ \\
\hline $\mathbf{L F}$ & $\begin{array}{l}\text { Grande e Novíssimo Dicionário da Língua Portuguesa - Laudelino } \\
\text { Freire }\end{array}$ \\
\hline $\mathbf{C A}$ & Dicionário Contemporâneo da Língua Portuguêsa - Caldas Aulete \\
\hline ABHF & $\begin{array}{l}\text { Novo Dicionário da Língua Portuguesa - Antônio Buarque de Holanda } \\
\text { Ferreira }\end{array}$ \\
\hline AH/MSV & $\begin{array}{l}\text { Dicionário Houaiss da Língua Portuguesa - Antônio Houaiss e Mauro } \\
\text { de Salles Villar }\end{array}$ \\
\hline FSB & Dicionário de usos do português do Brasil - Francisco da Silva Borba \\
\hline ZCN/RCN & $\begin{array}{l}\text { Dicionário de Regionalismos do Rio Grande do Sul, de Zeno Cardoso } \\
\text { Nunes e Rui Cardoso Nunes }\end{array}$ \\
\hline BB & Dicionário Gaúcho Brasileiro - Batista Bossle \\
\hline
\end{tabular}




\subsection{Aspectos adotados definição do glossário}

Um dos entraves para o desenvolvimento do glossário é a não existência de critérios rígidos que sistematizem sua confecção e que consigam abranger todos os trabalhos lexicográficos e terminológicos existentes. Por isso, a primeira medida adotada para a definiçãa do glossário foi a elaboração de uma organização estrutural.

Buscou-se adotar na definição do léxico selecionado os seguintes aspectos:
a) a compreensão de forma concisa;
b) a não circularidade e redundância;
c) o desuso de metalinguagem;
d) o uso de estrutura lexical e sintática uniformes;
e) o uso de meios extralinguísticos (imagens) quando possível;
f) amostragem do léxico representativa e não exaustiva;

Optou-se por não incluir no glossário o uso de marcas diacrônicas (indicações de vigência da palavra), diatrópicas (indicações que marcam o tipo geográfico do uso de uma palavra) ou marcas diafásicas e diastráticas (marcadores de restrição com relação ao estilo, nível da língua ou intenção).

Este trabalho é dirigido a leitores especializados ou não, onde se buscam, dentro do próprio corpus, as referências para as acepções, já que as referências para as acepções são encontradas no próprio corpus. O uso de abonações ${ }^{22}$ é um dos recursos utilizado em praticamente todos os verbetes.

(...) proveer de contorno sintáctico al vocablo en cuestión, ofreciendo, ya sea explícita o implícitamente, información sobre sua colocaciones posibles; reintroducir el vocablo al uso del fue abstraído, facilitando así el regreso de la mirada reflexiva a la actividad verbal de su lector, es servir de vehículo para la transmissión indirecta de datos culturales y sociales. ${ }^{23}$. (LARA, 1997, p. 10)

Em um primeiro momento, a disposição do glossário teve como base a obra Vocabulaire quadrilangue du café $=$ Quadrilingual Coffe Vocabulary $=$ Vocabulario Quadringüe del caffè =Vocabulário Quadringue do café, organizado em conjunto pelo Office québécois de la langue française, pela Università di Bologna, Laboratorio di Ricerca Terminologica e pela Universidade de São Paulo, Departamento de Letras Clássicas e

\footnotetext{
${ }^{22}$ Abonação: Citação de trecho de obra como exemplo do uso da palavra, expressão, etc. (BECHARA, 2009, p.04)

${ }^{23}$ Tradução nossa: "fornecer limite sintático ao vocábulo em questão, oferecendo, ainda que seja explícita ou implicitamente, informação sobre seus posicionamentos possíveis, reintroduzir o vocábulo ao uso do qual foi abstraído, facilitando assim o retorno da visão reflexiva para a atividade verbal de seu leitor, é servir de veículo para a transmissão indireta de dados culturais e sociais."
} 
Vernáculas. Com a decisão de incluir os estudos das acepções dos 10 dicionários, a disposição dos verbetes acabou se alterando, no entanto, procurou-se manter, sempre que possível, a estrutura de base.

\subsection{Detalhamento dos verbetes e outras informações sobre a composição do glossário}

Verbete

Os verbetes são apresentados usando o critério semasiológico ${ }^{24}$ - ordem alfabética, iniciando com um número cardinal, sendo compostos, na grande maioria, pela entrada, acepção, abonação, tabela, análise e meio extraguístico ${ }^{25}$.

\section{Entrada}

A entrada, objeto da definição, é a palavra ou lexia que abre o verbete. Apresentam-se grafadas em negrito, letra inicial maiúscula, em cor preta. As lexias que são homônimas ${ }^{26}$ e homógrafas ${ }^{27}$ serão marcadas com o numeral após a lexia de entrada. Ex.: verbete número 06 - Armazém 1; verbete número 07 - Armazém 2. Os substantivos e adjetivos são apresentados no masculino singular- com exceção dos substantivos ou adjetivos no gênero feminino, que implicam mudança de significado - e os verbos estão no infinitivo.

\section{Classificação gramatical}

Apresenta-se sempre abreviada, separada da lexia de entrada por uma barra vertical (|), em cor preta. No caso dos verbos, não serão apresentados, neste glossário, a marcação de regência.

\footnotetext{
${ }^{24}$ Semasiológico: que corresponde à semasiologia. Semasiologia: o estudo das relações entre sinais e símbolos, e daquilo que eles representam, marca, significação. (CUNHA, 2010, p. 588)

${ }^{25}$ Entende-se por meio extra linguístico a foto e respectiva legenda. As referências completas destas figuras estarão dispostas emu ma lista que antecede a Lista Geral de Redução. No corpo do verbete, abaixo da figura, constará somente algumas informações resumidas.

${ }^{26}$ Homônima: diz-se de ou a palavra que tem a mesma grafia e/ou pronúncia de outra(s), mas significado distinto. (BECHARA, 2009, p. 474)

${ }^{27}$ Homógrafa: diz-se de ou a palavra que tem a mesma grafia de outra(s), mas significados diferentes. (BECHARA, 2009, p. 474)
} 


\section{Acepção}

Entende-se por acepção o significado de cada lexia. Nesse glossário, foram elaboradas a partir de informações retiradas dos documentos do corpus, sem pesquisa prévia em obras lexicográficas. As acepções são apresentadas logo abaixo da entrada, em letra minúscula, padrão negrito e cor verde escura. Quando houver a ocorrência de diferentes acepções em uma mesma entrada, elas são separadas pelo uso de duas barras verticais $(\|)$, iniciando em letra minúscula e sem ponto final.

\section{Abonação}

Usada na maioria dos verbetes apresentados no glossário, com exceção às lexias provenientes das pesquisas nos atlas linguísticos ou da pesquisa de campo. É identificada pela palavra Abonação entre aspas (“") na cor preta, estando localizada abaixo da acepção, com letra inicial maiúscula e sublinhada. Quando o trecho da obra ou documento for retirado do meio de frase, o início da citação é marcado com o uso de reticências (...). Este mesmo recurso é usado caso o trecho não esteja transcrito até o ponto final da frase. Ao término da abonação, entre parênteses, apresenta-se número do documento que foi extraído o trecho, o nome do autor e o ano do documento. Ex. (Doc 115 - A.P.C. 1988). Quando a abonação for extraída dos documentos pesquisados nos arquivos, indica-se, após o número do documento, a cidade em que foi feita a pesquisa. Ex. (Doc 54 - Poa 1871). Nos casos em que não foi possível especificar o ano de escrita do documento, usa-se a abreviatura s/n (sem data). Optou-se por não apresentar uma abonação que correspondesse a cada acepção apresentada por dois fatores: o primeiro é a extensão dos verbetes, pois em alguns casos há um número elevado de acepções para uma entrada e, segundo, porque, em alguns casos, a acepção não foi retirada de forma direta dos documentos do corpus, sendo elaborada a partir do entendimento de seu contexto. As abonações estão em ordem cronológica.

\section{Remissão}

Procurou-se evitar, sempre que possível o uso de remissão, que é indicada pela palavra ver, em padrão negrito e cor verde. 


\section{Variantes}

As variações ortográficas, fonéticas, linguísticas etc. originárias dos documentos estão posicionadas abaixo da abonação, antecedidas pela palavra Variante, sem o apontamento dos respectivos documentos a que pertencem originalmente. Já as variantes provenientes das obras lexicográficas apresentam-se após as análises descritivas e, neste caso, há referência à obra da qual foram extraídas.

\subsection{Estudos dos dicionários}

Convencionou-se apresentar os estudos realizados nos 10 dicionários, citados no capítulo anterior, dentro dos verbetes do glossário.

A disposição física que sistematiza o estudo é a seguinte: abaixo da abonação ou da variante, precedendo a tabela, há a indicação: Ocorrência nos dicionários. Esta marcação está grafada em letra preta, sublinhada. Abaixo da indicação, apresenta-se a tabela, em cor branca, verde escura e verde clara. Na primeira coluna estão contidas as siglas contendo as letras inicias do nome de cada autor da obra; nos casos em que a obra apresenta mais de um autor, usa-se o recurso de separação dos nomes com uma barra simples inclinada $(/)^{28}$. As siglas estão em padrão negrito, em caixa alta, recurso que se utiliza não só nas tabelas, mas também no corpo das descrições. Na segunda coluna são expostos o ano das obras, em cor preta, ao lado de cada autor a que corresponde. A terceira coluna exibe em seu cabeçalho a palavra Lexia, que indica a presença ou não da lexia de entrada do glossário em cada obra. Para esta marcação, utiliza-se o recurso do sinal de soma (+),caso haja lexia ou o sinal negativo (-) caso não haja ${ }^{29}$. Já a quarta coluna, que fornece a indicação de Acepção corresponde ao glossário, indica-se com o sinal de (+), a acepção fornecida na obra consultada tenha o mesmo sentido de definição da acepção elaborada para o glossário. Nos casos em que, além da correspondência entre as acepções, o autor mencionar a palavra charque, faz-se o uso do sinal positivo duplo (++); e quando não houver correspondência, usa-se o sinal negativo (-).

\section{Análise descritiva}

Abaixo das tabelas encontra-se um pequeno texto em que são resumidas, de forma simples e concisa, as acepções encontradas nas obras. Esta descrição pode, ou não, apresentar: os sinônimos fornecidos pelos autores, as acepções divergentes às

\footnotetext{
${ }^{28}$ Conforme observa-se na Tabela 1 apresentada no item 2.2, contendo nome do autor e obra.

${ }^{29}$ As lexias presentes nos dicionários não precisam ser, necessariamente, lexias de entrada. Caso o autor da obra tenha fornecido a palavra dentro do verbete, considerou-se com o sinal de positivo (+).
} 
do glossário e as hipóteses levantadas ao longo da leitura dos verbetes. Permeando as análises descritivas estão apontamentos e comentários, indicados como Observação e/ou Notas. Quando não houver ocorrência da lexia do glossário em nenhuma obra lexicográfica, opta-se por não apresentar a tabela. Esses casos estão identificados com a expressão Não consta em nenhuma obra ocorrência da lexia em questão.

\section{Lista de redução}

O glossário apresenta uma lista de redução, onde estão contidas, em ordem alfabética, as abreviaturas utilizadas.

\subsection{Lista de figuras do Glossário}

\section{Figura 1 Vista do arroio Pelotas a partir da Charqueada Santa Rita \\ Foto: Cátia Schreiner, 2011

Figura 2 Arroz Carreteiro \\ Fonte: Site MS Karate \\ Disponível em: www.karatems.com/news/arroz-carreteiro}

Acesso em: 12 de abril de 2012

Figura 3 Balança de época da Charqueada Santa Rita

Fonte: Cátia Schreiner, 2011

Figura 4 Casa de Comércio de Charque

Aquarela "Loja di Carne Secca," Jean-Baptiste Debret

In: Revista Pesquisa FAPESP, Edição 191/ Janeiro de 2012

Disponível em: http://revistapesquisa.fapesp.br/2012/01/18/voce-tem-fome-deque; acesso em : 12 de abril de 2012

Figura 5 Casa Grande da Charqueada Santa Rita

Fonte: Cátia Schreiner, 2010

Figura $6 \quad$ Charque com sal grosso

Fonte: Site Assador gaúcho

Disponível em: http://assadorgaucho.blogspot.com.br/2011/05/uma-lista-decosas-com-charque-charque.html; acesso em: 12 de abril de 2012

Figura $7 \quad$ Charqueada Santa Rita

Fonte: Cátia Schreiner, 2011 
Figura 8 Empilhadores de charque

Fonte: Site luisafonsocosta.blogspot.com

Disponível em: http://luisafonsocostatupan.blogspot.com.br/2011/01/fatos-e-

fotos-da-historia-de.html; acesso em 04 de maio de 2012

Figura 9 Mangueira de Matança

Fonte: Foto de Maquete de uma mMangueira de Matança

Museu do Charque, Pelotas, RS

Cátia Schreiner, 2011

Figura $10 \quad$ Matambreiros

Xilogravura de Danúbio Gonçalves, acervo do

Museu do Charque, Pelotas

Foto: Cátia Schreiner, 2011

Figura $11 \quad$ Pelota

Fonte: Fotografia de uma Reprodução de uma pelota em tamanho natural, acervo do Museu do Charque, Pelotas, RS

Foto: Cátia Schreiner, 2011

Figura 12 Pilha de charque

Fonte: Fotografia da Maquete de uma Charqueada, acervo do Museu do Charque, Pelotas, RS

Foto: Cátia Schreiner, 2011

Figura 13 Secadouro de charque

Fonte: Site terra-australis-br.blogspot.com.br

Disponível em: http://terra-australis-br.blogspot.com.br/2011/10/no-tempo-dascharqueadas-parte-1.html; acesso em: 07 de abril de 2012

Figura 14 Tinas

Xilogravura de Danúbio Gonçalves, acervo do

Museu do Charque, Pelotas, RS

Foto: Cátia Schreiner, 2011

Figura 15 Trapiche

Margens do arroio Pelotas, Charqueada Santa Rita

Foto: Cátia Schreiner, 2011

Figura $16 \quad$ Varas

Fonte: Fotografia da Maquete de uma Charqueada, acervo do Museu do 


\begin{tabular}{ll}
\hline & Charque, Pelotas, RS \\
& Foto: Cátia Schreiner, 2011 \\
\hline Figura $17 \quad$ Varal com Mantas de Charque \\
& Fonte: Site lucianoandanças.blogspot.com.br \\
& Disponível em: http://lucianoandancas.blogspot.com.br/2011/04/historia-do- \\
& charque.html/; acesso em: 12 de abril de 2012 \\
\hline Figura 18 & Zorra \\
& Xilogravura de Danúbio Gonçalves, acervo \\
& Museu Nacional de Belas Artes, Rio de Janeiro RJ \\
& In: GUTIERREZ, E. J. B. Sítio Charqueador Pelotense. Porto Alegre: \\
& Paisagem do Sul, 2010. \\
\hline
\end{tabular}

\subsection{Lista geral de reduções do Glossário}

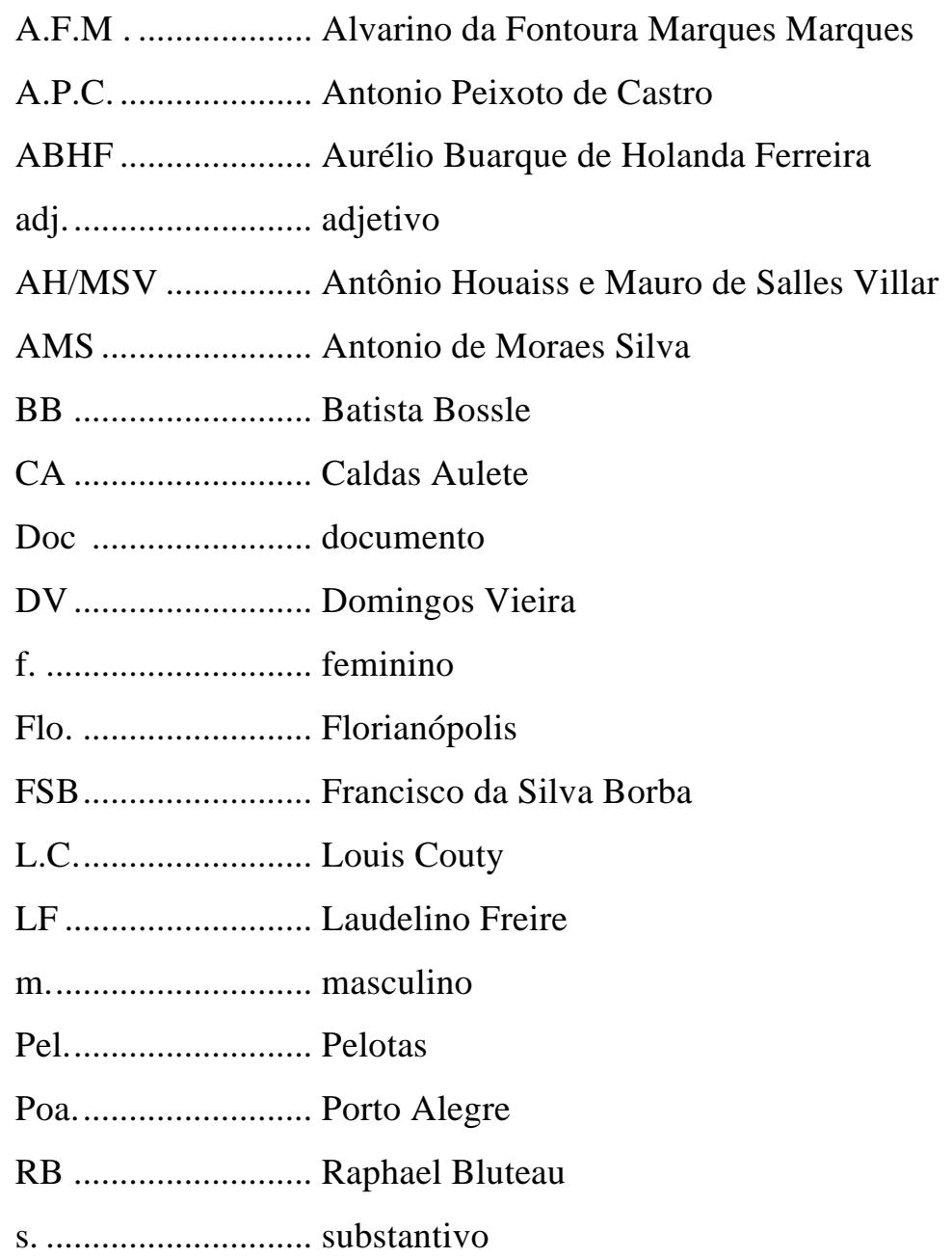


A.S.H..................... Auguste de Saint-Hilaire

$\mathrm{s} / \mathrm{n}$........................... sem data

$\mathrm{v}$.............................. verso

V............................. verbo

ZCN/RCN .............. Zeno Cardoso Nunes /Rui Cardoso Nunes 


\subsection{Glossário}

Abate | s.m.

carneação do boi para o preparo do charque || esquartejamento

Abonação: “... e é preciso fazê-lo secar desde o dia seguinte ao do abate pois, apenas poivilhados de sal, eles não se conservariam...” (Doc 102 - L.C. 1880)

“...a atividade da charqueada consistia, basicamente, do abate do gado e da salga da carne, que era estendida em varais para ficar exposta ao sol.” (Doc 44 - Pel. 2007)

Ocorrência nos dicionários:

\begin{tabular}{|c|c|c|c|}
\hline Autor & Ano obra & Lexia & $\begin{array}{c}\text { Acepção correspondente } \\
\text { ao glossário }\end{array}$ \\
\hline RB & 1712 & + & - \\
\hline AMS & 1813 & + & - \\
\hline DV & 1873 & + & - \\
\hline LF & 1940 & + & + \\
\hline CA & 1958 & + & + \\
\hline ABHF & 1986 & + & - \\
\hline ZCN/RCN & 1996 & - & + \\
\hline AH/MSV & 2001 & + & + \\
\hline FSB & 2002 & + & - \\
\hline BB & 2003 & - & + \\
\hline
\end{tabular}

Análise descritiva dos dicionários gerais:

Os autores RB, AMS e DV apresentam a entrada abate com o sentido de diminuição, principalmente associada a preço, desconto. Em LF, CA e AH/MSV abate aparece como matança de gado. Já ABHF e FB não apresentam abate no sentido de diminuição, informando unicamente como efeito ou ato de abater para consumo.

Análise descritiva dos dicionários regionalistas:

Não consta a lexia nas referidas obras.

Abatido $\mid$ adj.

relativo ao abate || rês que já sofreu o processo de abate

Abonação: "Este imposto, que é de 200 reis, recae sobre cada cabeça de gado abatido para exportação nas xarqueadas e em outros estabelecimentos congeneres." (Doc 17 Pel. 1869)

Ocorrência nos dicionários: 


\begin{tabular}{|c|c|c|c|}
\hline Autor & Ano obra & Lexia & $\begin{array}{c}\text { Acepção correspondente } \\
\text { ao glossário }\end{array}$ \\
\hline RB & 1712 & + & - \\
\hline AMS & 1813 & - & - \\
\hline DV & 1873 & + & - \\
\hline LF & 1940 & + & + \\
\hline CA & 1958 & + & - \\
\hline ABHF & 1986 & + & - \\
\hline ZCN/RCN & 1996 & - & - \\
\hline AH/MSV & 2001 & + & + \\
\hline FSB & 2002 & + & - \\
\hline BB & 2003 & - & - \\
\hline
\end{tabular}

Análise descritiva dos dicionários gerais:

RB expõe um grande número de abonações e acepções para esta entrada, mas somente menciona o sentido de abatimento, humilhação, enfraquecido. DV compartilha de RB e fornece um sentido náutico para a lexia, que aparece em CA. Em LF, das 10 acepções, consta a nona como morto: gado abatido, mas também dá ênfase no sentido de derrubado, franco, humilhado, diminuído. AH/MSV apresenta o sentido de morte, informando, entre parênteses, que este sentido é especialmente usado com animais.

Análise descritiva dos dicionários regionalistas:

Não consta a lexia nas referidas obras.

Açougue | s.m.

local onde se abate e comercializa carne || matadouro

Abonação: “Apesar de ter cessado há meses a matança, nas xarqueadas sente-se ainda nos arredores um forte cheiro de açougue, donde se pode fazer idéia do que nāo será esse odor no tempo da matança". (Doc 134 - A.S.H. 1820/21)

“Artigo 74. -E' prohibido: §1o --Receber carne nos açougues do mercado depois das 6 horas da tarde, salvo caso de força maior. $\$ 20-$ Vender carne depois das 3 horas da tarde, no verão.... ...\$7o -Comprar, vender ou depositar nos açougues qualquer genero alem da carne verde, ou salgar esta nos açougues." (Doc 02 - Flo. 1896/1901)

Ocorrência nos dicionários:

\begin{tabular}{|l|c|c|c|}
\hline Autor & Ano obra & Lexia & $\begin{array}{c}\text { Acepção correspondente } \\
\text { ao glossário }\end{array}$ \\
\hline RB & 1712 & + & + \\
\hline AMS & 1813 & + & + \\
\hline DV & 1873 & + & + \\
\hline LF & 1940 & + & + \\
\hline
\end{tabular}




\begin{tabular}{|l|c|c|c|}
\hline CA & 1958 & + & + \\
\hline ABHF & 1986 & + & + \\
\hline ZCN/RCN & 1996 & - & - \\
\hline AH/MSV & 2001 & + & + \\
\hline FSB & 2002 & + & + \\
\hline BB & 2003 & - & - \\
\hline
\end{tabular}

Análise descritiva dos dicionários gerais:

Os autores RB e AMS indicam açougue como local de gritaria, baderna, de insultos. DV apresenta a locução de manha de açougue, definindo-a como local para brigas. A lexia açougue segundo estes autores poderia ser usada tanto para o local que se abate quanto para o local onde só se comercializam as carnes. LF fornece a lexia matadouro, assim como ABHF e AH/MSV. As obras mencionam um sentido figurado de açougue como local para mortes violentas e sinônimo de prostíbulo. Em FSB encontra-se a entrada casa de carnes como sinônimo.

Nota: Nos documentos do corpus, geralmente o açougue era um local onde costumava-se praticar atos imorais. Em documentos encontrados em Florianópolis, era proibido, por lei, "fazer alarido, proferir ou praticar atos, gestos e termos deshonestos" , assim como proibia-se o abate de animais.

Análise descritiva dos dicionários regionalistas:

Não consta a lexia nas referidas obras.

Aguateiro | s.m.

empregado da charqueada encarregado da limpeza das instalações

Abonação: "Ali estavam alinhados, esperando o primeiro boi, zorreiros, camboneiros, coleiros, carneadores, charqueadores, aguateiros, salgadeiros, matambreiros..." (Doc 108 - A.P.C. 1988)

“Ao final do trabalho do carneador, sobrava na cancha apenas o couro da rês, já que o aguateiro fazia a limpeza do local.” (Doc 115 - A.P.C. 1988)

Ocorrência nos dicionários:

\begin{tabular}{|c|c|c|c|}
\hline Autor & Ano obra & Lexia & $\begin{array}{c}\text { Acepção correspondente } \\
\text { ao glossário }\end{array}$ \\
\hline RB & 1712 & - & - \\
\hline AMS & 1813 & - & - \\
\hline DV & 1873 & - & - \\
\hline LF & 1940 & + & - \\
\hline CA & 1958 & + & - \\
\hline
\end{tabular}




\begin{tabular}{|c|c|c|c|}
\hline ABHF & 1986 & - & - \\
\hline ZCN/RCN & 1996 & + & - \\
\hline AH/MSV & 2001 & + & - \\
\hline FSB & 2002 & - & - \\
\hline BB & 2003 & + & - \\
\hline
\end{tabular}

Análise descritiva dos dicionários gerais:

Nenhuma das obras define aguateiro para pessoas, e sim para animais encarregados de puxar/carregar água, ou até mesmo no sentido figurado de cavalo ruim. Quando tratase de alguém que vende e/ou distribui água é chamado de aguadeiro. A definição usada para pessoas foi empregado por LF e AH/MSV sendo este definido como aquele que fica encostado por condescendência do proprietário e se ocupa de serviços leves, como recados etc.

Variantes: aguadeiro (LF, CA, AH/MSV); aguatero (CA, ZCN/RCN, BB)

Análise descritiva dos dicionários regionalistas:

A acepção de BB corresponde a de LF e AH/MS.

Alcatroado $\mid$ adj.

tecido untado com alcatrão usado para cobrir a manta de carne no varal durante a noite afim de protegê-la do tempo

Abonação: “...10 mantas umas por cima das outras sobre uma parte mais resistente da barra de apoio, e se recobrirá este monte, seja de couros secos, seja de um tecido fortemente alcatroado." (Doc 91 - L.C. 1880)

Ocorrência nos dicionários:

\begin{tabular}{|c|c|c|c|}
\hline Autor & Ano obra & Lexia & $\begin{array}{c}\text { Acepção correspondente } \\
\text { ao glossário }\end{array}$ \\
\hline RB & 1712 & - & - \\
\hline AMS & 1813 & + & + \\
\hline DV & 1873 & + & + \\
\hline LF & 1940 & + & + \\
\hline CA & 1958 & + & + \\
\hline ABHF & 1986 & + & + \\
\hline ZCN/RCN & 1996 & - & + \\
\hline AH/MSV & 2001 & + & - \\
\hline FSB & 2002 & - & - \\
\hline BB & 2003 & - & + \\
\hline
\end{tabular}

Análise descritiva dos dicionários gerais: 
A obra de RB somente apresenta o verbo alcatroar. As obras que apresentam a entrada mencionam este tipo de tecido para cobrir materiais diversos, mas não citam seu uso nas charqueadas.

Análise descritiva dos dicionários regionalistas:

Não consta a lexia nas referidas obras.

Armazém 1 | s.m.

edifício onde se guarda objetos da charqueada

Abonação: "Huma charqueada denomináda do Catovello, comprehendendo o terreno e todas as benfeitorias, galpões, barraca de couros, graixeira, armazens..." (Doc 54 Poa 1871)

Variante: armasem

Ocorrência nos dicionários:

\begin{tabular}{|c|c|c|c|}
\hline Autor & Ano obra & Lexia & $\begin{array}{c}\text { Acepção correspondente } \\
\text { ao glossário }\end{array}$ \\
\hline RB & 1712 & - & - \\
\hline AMS & 1813 & + & + \\
\hline DV & 1873 & + & + \\
\hline LF & 1940 & + & + \\
\hline CA & 1958 & + & + \\
\hline ABHF & 1986 & + & + \\
\hline ZCN/RCN & 1996 & - & - \\
\hline AH/MSV & 2001 & + & + \\
\hline FSB & 2002 & - & - \\
\hline BB & 2003 & - & - \\
\hline
\end{tabular}

Análise descritiva dos dicionários gerais:

Tanto DV quanto AMS apresentam armazém somente no sentido bélico, como local para guardar objetos de guerra. Os outros autores que indicam a lexia, além do sentido dado por DV e AMS, expõe outros tipos de produtos armazenados, em nenhuma obra é mencionado algum artigo relacionado ao charque.

Variante: almazem (AMS, DV, AH/MSV)

Análise descritiva dos dicionários regionalistas:

BB somente indica a lexia armazeneiro como aquele que armazena. 
local onde se comercializa produtos || casa de comércio de charque

Abonação: “...me obriga agora a mudar de parecer o mizeravel estado, em que chegarão os Barriz, e Barrica que remeteo o Governador Sebastião Xavier, pois de 23 Barriz, e huma Barrica, que por estes Armazens se receberão, só se aproveitarão 13..." (Doc 13 - Flo. 1798 )

"Huma charqueada denomináda do Catovello, comprehendendo o terreno e todas as benfeitorias, galpões, barraca de couros, graixeira, armazens...” (Doc 54 - Poa 1871) "Hum armasem na rua vinte e quatro de Outubro desta cidade, esquina da de Paysandú, com nove braças mais ou menos de fundo..." (Doc 56 - Poa 1871)

Variante: armasem

Ocorrência nos dicionários:

\begin{tabular}{|c|c|c|c|}
\hline Autor & Ano obra & Lexia & $\begin{array}{c}\text { Acepção correspondente } \\
\text { ao glossário }\end{array}$ \\
\hline RB & 1712 & - & - \\
\hline AMS & 1813 & - & - \\
\hline DV & 1873 & + & + \\
\hline LF & 1940 & + & + \\
\hline CA & 1958 & + & + \\
\hline ABHF & 1986 & + & - \\
\hline ZCN/RCN & 1996 & - & - \\
\hline AH/MSV & 2001 & - & - \\
\hline FSB & 2002 & - & - \\
\hline BB & 2003 & - & + \\
\hline
\end{tabular}

Análise descritiva dos dicionários gerais:

DV apresenta a entrada armazém afirmando que modernamente emprega-se o sentido de se comercializar ou se dar "a chave do armazém". LF, CA e ABHF fornecem como sinônimo de armazém a lexia mercearia. Geralmente os autores denominam o armazém de produtos alimentícios como armazém de secos e molhados. AH/MSV é a obra que apresenta maior número de tipos de armazéns, considerando-os grandes ou pequenas instalações de compra e venda de produtos. FSB vai além, apresentando para esta lexia um sentido concreto e outro abstrato.

Variantes: almazem (DV, AH/MSV); almazem de comerciante (AMS)

Análise descritiva dos dicionários regionalistas:

BB apresenta as lexias venda, como o estabelecimento comercial onde se compram e vendem os produtos da terra e se adquirem os produtos, bodega, como um pequeno armazém e negócio, como casa de comércio, estabelecimento comercial. 
Arreada $\mid$ s.f.

incursão em campo para roubo de gado || atividade ilícita de captação de gado para evitar o pagamento de imposto

Abonação: “...homens separados de comunicação para estarem mais aptos a poderem sair ao campo fazer os roubos de gado (a que chamavam de arreadas), sendo estes havidos por desembaraçados e resolutos campistas..." (Doc 67 - A.F.M. s/n)

Ocorrência nos dicionários:

\begin{tabular}{|c|c|c|c|}
\hline Autor & Ano obra & Lexia & $\begin{array}{c}\text { Acepção correspondente } \\
\text { ao glossário }\end{array}$ \\
\hline RB & 1712 & - & - \\
\hline AMS & 1813 & - & - \\
\hline DV & 1873 & - & - \\
\hline LF & 1940 & + & + \\
\hline CA & 1958 & - & - \\
\hline ABHF & 1986 & - & - \\
\hline ZCN/RCN & 1996 & + & + \\
\hline AH/MSV & 2001 & - & - \\
\hline FSB & 2002 & - & - \\
\hline BB & 2003 & + & + \\
\hline
\end{tabular}

Análise descritiva dos dicionários gerais:

LF define a lexia como apressamento do gado alçado.

Análise descritiva dos dicionários regionalistas:

ZCN/RCN informa que, no Rio Grande do Sul, considerava-se arreada como apressamento de gado inimigo, sendo o indivíduo encarregado deste serviço chamado de arreador ou, segundo BB usa-se tanto arreador como também arreiador. BB também conceitua arreada como roubo de gado, apresenta a lexia arrear no sentido de apressar gado, arrebanhar e expõe a expressão: andar em reculuta, que significa andar à procura de gado, arrebanhando-o.

Observação: Segundo Alvarino da Fontoura, Rubens Reys de Barcelos e outros autores, esta atividade era, de certa forma, consentida ou tolerada por autoridades e charqueadores. Esta atividade servia, indiretamente, como um meio de afastar os homens de índole duvidosa da sociedade, pois, para a sua realização, era necessário o deslocamento - por longos períodos - para os campos mais isolados dos estados. Os autores afirmam que muitos homens enriqueceram com as arreadas. 
medida de peso usada para comercializar produtos produzidos na charqueada Abonação: “ Carne = Cada raçam a tres quartas sem Osso mil quinhentas, e dez arrobas, e vinte cinco arrates.” (Doc 10 - Flo. 1797)

Ocorrência nos dicionários:

\begin{tabular}{|c|c|c|c|}
\hline Autor & Ano obra & Lexia & $\begin{array}{c}\text { Acepção correspondente } \\
\text { ao glossário }\end{array}$ \\
\hline RB & 1712 & - & - \\
\hline AMS & 1813 & - & - \\
\hline DV & 1873 & - & - \\
\hline LF & 1940 & + & + \\
\hline CA & 1958 & + & + \\
\hline ABHF & 1986 & - & - \\
\hline ZCN/RCN & 1996 & - & - \\
\hline AH/MSV & 2001 & - & - \\
\hline FSB & 2002 & - & - \\
\hline BB & 2003 & - & - \\
\hline
\end{tabular}

Análise descritiva dos dicionários gerais:

A obra de LF e CA apresentam a lexia arrate conforme grafia apresentada nos documentos do corpus. Ambos os dicionaristas indicam ao consulente que arrate é a forma antiga para arratel, informando que 1 arratel é equivalente a 16 onças. Já RB indica que os portugueses consideravam esta medida, mas, outros povos consideravam o arratel como o equivalente a 12 onças. DV fornece a informação de que 1 arroba equivale a 32 arratéis. CA e AH/MSV informam a quantidade de 1 arrate para 459 gramas.

Variante: arratel (RB, AMS, DV LF, CA, AH/MSV)

Análise descritiva dos dicionários regionalistas:

Não consta a lexia nas referidas obras.

Arroba $\mid$ s.f.

medida de peso usada na comercialização de produtos fabricados na charqueada Abonação: “... beneficio das Carnes, e fretes de Embarcações, a fim de saber-se se fará conta á Fazenda Real o preço em que por este modo ficará valendo a arroba de Carne." (Doc 15 - Flo. 1795) 
“...estima-se que o rendimento em carne seca de um boi médio de 4 arrobas ou 60 quilos, mais ou menos em Pelotas, de 150 libras espanholas..." (Doc 96 - L.C. 1880)

Ocorrência nos dicionários:

\begin{tabular}{|c|c|c|c|}
\hline Autor & Ano obra & Lexia & $\begin{array}{c}\text { Acepção correspondente } \\
\text { ao glossário }\end{array}$ \\
\hline RB & 1712 & + & + \\
\hline AMS & 1813 & + & + \\
\hline DV & 1873 & + & + \\
\hline LF & 1940 & + & + \\
\hline CA & 1958 & + & + \\
\hline ABHF & 1986 & + & - \\
\hline ZCN/RCN & 1996 & - & + \\
\hline AH/MSV & 2001 & + & + \\
\hline FSB & 2002 & + & + \\
\hline BB & 2003 & + & + \\
\hline
\end{tabular}

Análise descritiva dos dicionários gerais:

Todos os dicionários que apresentam esta unidade de peso informam a equivalência de 1 arroba para 32 arratéis. CA ainda informa a equivalência de 1 arroba para o antigo almude (16,8 litros). ABHF e AH/MSV fornecem aos consulentes que a arroba é a unidade usada no Brasil como medida de peso em produtos agropecuários, equivalendo a 15 kilogramas. FSB utiliza a carne bovina como produto pesado em arrobas em uma das abonações.

Variantes: arrôba (RB); arrouba (ABHF, AH/MSV)

Análise descritiva dos dicionários regionalistas:

BB apresenta esta lexia de entrada como termo regionalista.

Arroio | s.m.

canal de água geralmente estreito e pequeno usado na charqueada para escoar as mercadorias || local em que se localiza o trapiche || regato

Abonação: "Declaramos mais que no supra-citado terreno, e entre a estrada de baixo e o Arroio de Pelotas; existem edificadas as Cazas de Moradia..." (Doc 57 - Poa 1870) “...charqueada do Cotovello, que váe sahir á porteira da charqueada do mesmo Braga, com quatrocentas braças de fundo até encontrar o arroio de Pelotas..." (Doc 55 - Poa 1871)

"Três anos e 4.653 quilômetros depois, chega ao arroio Pelotas, com o firme propósito de instalar, ali, uma charqueada." (Doc 40 - Pel. 2007) 
Ocorrência nos dicionários:

\begin{tabular}{|c|c|c|c|}
\hline Autor & Ano obra & Lexia & $\begin{array}{c}\text { Acepção correspondente } \\
\text { ao glossário }\end{array}$ \\
\hline RB & 1712 & + & + \\
\hline AMS & 1813 & + & + \\
\hline DV & 1873 & + & + \\
\hline LF & 1940 & + & + \\
\hline CA & 1958 & + & + \\
\hline ABHF & 1986 & + & + \\
\hline ZCN/RCN & 1996 & - & + \\
\hline AH/MSV & 2001 & + & + \\
\hline FSB & 2002 & + & - \\
\hline BB & 2003 & - & + \\
\hline
\end{tabular}

Análise descritiva dos dicionários gerais:

DV informa que arroio é proveniente da locução arrojo, o que suporta a afirmação de RB que esta palavra é mais castelhana que portuguesa.

Variantes: arrôio (RB); arroyo (RB, $\mathrm{AH} / \mathrm{MSV})$; aroio (AH/MSV)

Análise descritiva dos dicionários regionalistas:

ZCN/RCN e BB não apresentam esta lexia.

Nota: No Rio Grande do Sul, seis municípios têm o nome associado a esta lexia, como Arroio do Sal, Arroio do Meio e Arroio do Padre. O Estado de Santa Catarina tem somente 2 e o Estado do Paraná nenhum município, o que levanta a hipótese que esta lexia é mais utilizada no Rio Grande do Sul que em outros estados do sul do Brasil.

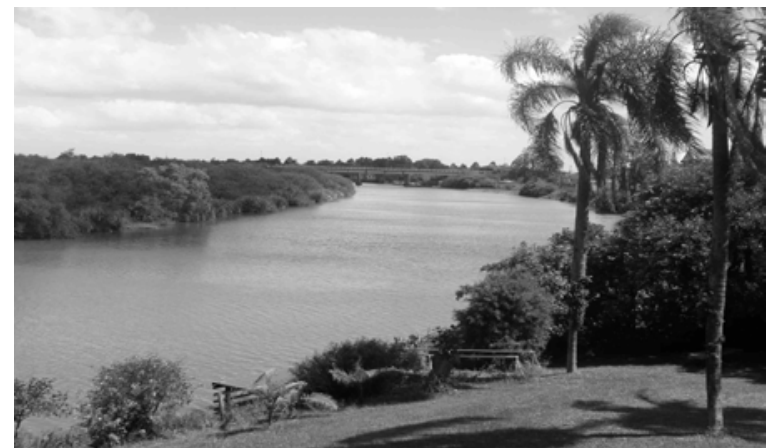

Fig. 1 Vista do arroio Pelotas a partir da Charqueada Santa Rita Foto: Cátia Schreiner, 2011

Arroz carreteiro | s.m.

prato feito com charque e arroz || pedaço de charque frito, refogado com cebola, tempero e cozidos com arroz 
Abonação: "O arroz carreteiro é, sem dúvida, a mais popular de todas as apresentações culinárias à base de charque." (Doc 75 - A.F.M. s/n)

Ocorrência nos dicionários:

\begin{tabular}{|c|c|c|c|}
\hline Autor & Ano obra & Lexia & $\begin{array}{c}\text { Acepção correspondente } \\
\text { ao glossário }\end{array}$ \\
\hline RB & 1712 & - & - \\
\hline AMS & 1813 & - & - \\
\hline DV & 1873 & - & - \\
\hline LF & 1940 & - & - \\
\hline CA & 1958 & - & - \\
\hline ABHF & 1986 & + & + \\
\hline ZCN/RCN & 1996 & + & + \\
\hline AH/MSV & 2001 & + & + \\
\hline FSB & 2002 & + & + \\
\hline BB & 2003 & + & + \\
\hline
\end{tabular}

Análise descritiva dos dicionários gerais:

Os dicionários RB, AMS, DV, LF e CA apenas apresentam a entrada arroz. A entrada do verbete conforme o glossário consta somente em ABHF como prato da culinária típico do sul do Brasil. O autor, ao especificar o modo de preparo, cita como ingredientes no preparo a carne seca e a carne-de-sol ao invés do charque. AH/MSV apresenta como ingredientes do preparo do prato o charque ou a carne-de-sol. FSB cita como um prato típico do sul preparado com carne seca ou carne-de-sol.

Nota: O que se verifica nos outros dicionários é que a entrada consta como arroz-decarreteiro. A entrada, correspondente ao glossário, a dizer, arroz-carreteiro aparece somente em BB. Optou-se, porém, em incluir na tabela todas as entradas de verbete das obras, grafadas com ou sem o conectivo, julgando tratar-se da mesma lexia.

Variantes: arroz-de-carreteiro (ABHF, ZCN/RCN, AH/MSV), carreteiro (ZCN/RCN, AH/MSV)

Análise descritiva dos dicionários regionalistas:

Em ZCN/RCN e BB a acepção dos autores é que este prato é feito com arroz cozido com guisado de charque. 


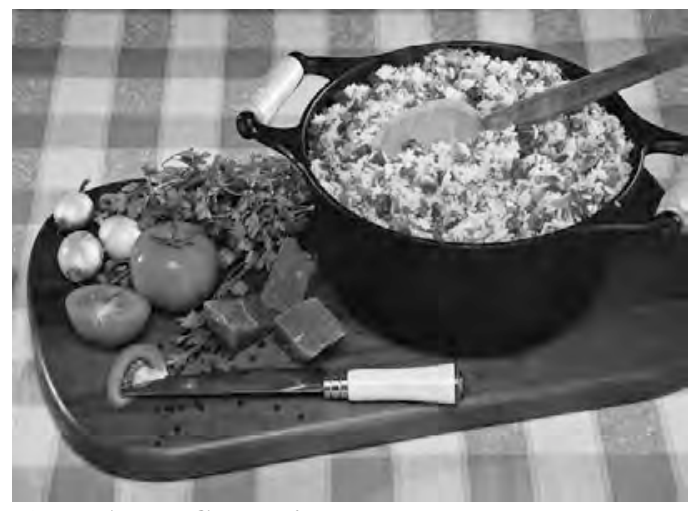

Fig. 2: Arroz Carreteiro

Fonte: Site MS Karate

Atestador| s.m.

aparelho que confere pesos e medidas na charqueada

Abonação: "Relação da Charqueada, objectos pertencentes á mesma... ... 2 Baldiadeiras Escumadeiras 4 Candieiros, comprado pela sociedade 1 Attestador..." (Doc 51 - Poa 1870)

Variante: attestador

Ocorrência nos dicionários:

\begin{tabular}{|c|c|c|c|}
\hline Autor & Ano obra & Lexia & $\begin{array}{c}\text { Acepção correspondente } \\
\text { ao glossário }\end{array}$ \\
\hline RB & 1712 & - & - \\
\hline AMS & 1813 & - & - \\
\hline DV & 1873 & - & - \\
\hline LF & 1940 & + & + \\
\hline CA & 1958 & + & + \\
\hline ABHF & 1986 & + & - \\
\hline ZCN/RCN & 1996 & - & - \\
\hline AH/MSV & 2001 & + & - \\
\hline FSB & 2002 & - & - \\
\hline BB & 2003 & - & - \\
\hline
\end{tabular}

Análise descritiva dos dicionários gerais:

As obras RB, AMS e DV apresentam somente o verbo atestar. A acepção desta lexia assemelha-se com a do glossário no sentido de atestar com uma vasilha ou um instrumento que atesta pipas, tonéis etc. Este verbo aparece em FSB e ABHF não mais com esta acepção. AH/MSV retorna a acepção de vasilha ou instrumento para atestar associando-a somente com vinho ou outra bebida.

Análise descritiva dos dicionários regionalistas:

Não consta a lexia nas referidas obras. 
Balança | s.f.

instrumento utilizado para pesar os produtos como gado em pé, carne verde, carne salgada, couro etc. || objeto utilizado em tabladas para pesar tropas de animais

Abonação: “... Tres carroças da charqueada. Huma balança grande de pesar couros quatro (4) peneiras grandes para salga...” (Doc 49 - Poa 1870)

"Pela tarde, véspera da matanca, as tropas que vinham trazidas pelos tropeiros, passavam pela balança municipal (imediações do Parque Tênis Clube) e em grupo de 50 animais eram pesados, fazendo-se ao final a média de peso da tropa." (Doc 109 A.P.C. 1988)

Ocorrência nos dicionários:

\begin{tabular}{|c|c|c|c|}
\hline Autor & Ano obra & Lexia & $\begin{array}{c}\text { Acepção correspondente } \\
\text { ao glossário }\end{array}$ \\
\hline RB & 1712 & + & + \\
\hline AMS & 1813 & + & + \\
\hline DV & 1873 & + & + \\
\hline LF & 1940 & + & + \\
\hline CA & 1958 & + & + \\
\hline ABHF & 1986 & + & - \\
\hline ZCN/RCN & 1996 & - & + \\
\hline AH/MSV & 2001 & + & + \\
\hline FSB & 2002 & + & - \\
\hline BB & 2003 & - & + \\
\hline
\end{tabular}

Análise descritiva dos dicionários gerais:

Todos os outros dicionários apresentam a acepção de balança correspondente a do glossário, fornecendo inúmeras tipologias em seus verbetes. Nenhuma obra, porém, apresenta esta lexia no sentido agrícola ou pecuário, contrariamente ao corpus do trabalho.

Análise descritiva dos dicionários regionalistas:

Não consta a lexia nas referidas obras. 


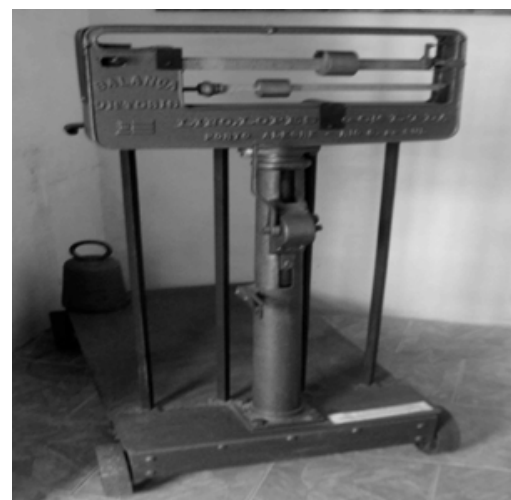

Fig. 3 Balança de época da Charqueada Santa Rita Fonte: Cátia Schreiner, 2011

Balanceiro | s.m.

empregado da charqueada encarregado de pesar os produtos

Abonação: "Ali estavam alinhados, esperando o primeiro boi... ... mergulhadores de carne e de couros, balanceiros, porteiros, guincheiros, carregadores de ossadas e buchadas, serradores de caracu, resfriadores..." (Doc 107 - A.P.C. 1988)

Ocorrência nos dicionários:

\begin{tabular}{|c|c|c|c|}
\hline Autor & Ano obra & Lexia & $\begin{array}{c}\text { Acepção correspondente } \\
\text { ao glossário }\end{array}$ \\
\hline RB & 1712 & - & - \\
\hline AMS & 1813 & - & - \\
\hline DV & 1873 & + & - \\
\hline LF & 1940 & + & + \\
\hline CA & 1958 & + & + \\
\hline ABHF & 1986 & + & - \\
\hline ZCN/RCN & 1996 & - & + \\
\hline AH/MSV & 2001 & + & - \\
\hline FSB & 2002 & + & - \\
\hline BB & 2003 & - & + \\
\hline
\end{tabular}

Análise descritiva dos dicionários gerais:

ABHF e AH/MSV relacionam o balanceiro com o trabalho nos engenhos de cana-deaçúcar e não nas fábricas de charque.

Análise descritiva dos dicionários regionalistas:

Não consta a lexia nas referidas obras.

Barão | s.m.

título de nobreza conferido ao charqueador 
Abonação: "Coube a Domingos de Castro Antiqueira, proprietário da charqueada de cascalho - localizada na margem direita do arroio Pelotas - ostentar um título nobiliário em Pelotas: o de Barão de Jaguari.” (Doc 37 - Pel. 2007)

Ocorrência nos dicionários:

\begin{tabular}{|c|c|c|c|}
\hline Autor & Ano obra & Lexia & $\begin{array}{c}\text { Acepção correspondente } \\
\text { ao glossário }\end{array}$ \\
\hline RB & 1712 & + & + \\
\hline AMS & 1813 & + & + \\
\hline DV & 1873 & - & - \\
\hline LF & 1940 & + & + \\
\hline CA & 1958 & + & + \\
\hline ABHF & 1986 & + & - \\
\hline ZCN/RCN & 1996 & - & + \\
\hline AH/MSV & 2001 & + & + \\
\hline FSB & 2002 & + & - \\
\hline BB & 2003 & - & + \\
\hline
\end{tabular}

Análise descritiva dos dicionários gerais:

ABHF e AH/MSV informam que o barão é homem poderoso pelo valor, posição e/ou riqueza.

Nota: Todas as obras que apresentam a entrada barão definem a acepção informando que o baronato é a graduação imediata a de visconde, o que corrobora com as informações do corpus. Segundo historiadores pelotenses, somente dois dos barões do charque conseguiram o título de visconde, acredita-se que os títulos de baronato concedidos aos charqueadores eram muito mais devido à sua riqueza e possíveis favores políticos que valor social.

Variantes: baram (RB); baron (AH/MSV); barom (AH/MSV)

Análise descritiva dos dicionários regionalistas:

Não consta a lexia nas referidas obras.

Barca $\mid$ s.f.

embarcação usada no transporte de mercadorias || barco a vapor || barcaça

Abonação: "Dez anos depois, associou-se a outros dois charqueadores - Domingos José de Almeida e José Vieira Viana - em um projeto inédito: construir o primeiro barco a vapor do Rio Grande do Sul. A barca, batizada de Liberal - em uma alusão aos ideais políticos pelos quais se norteava..." (Doc 43 - Pel. 2007) 
"Do Rio Grande. - Barca Social 3.000 arrobas, patacho Palheiro 3.000, patacho Marinhas 13.000, barca Pombinha 5,500, barca Andrade Neves...” (Doc 31 - Pel. 1869)

"Para Pernambuco com escalla, a barca nacional - Norma - de 224 toneladas manifestou 10084 arrobas de xarque, 50 couros vaccuns seccos de refugo, 356 arrobas de graixa. 400 restias de sebolas..." (Doc 28 - Pel. 1869)

Ocorrência nos dicionários:

\begin{tabular}{|c|c|c|c|}
\hline Autor & Ano obra & Lexia & $\begin{array}{c}\text { Acepção correspondente } \\
\text { ao glossário }\end{array}$ \\
\hline RB & 1712 & + & + \\
\hline AMS & 1813 & + & + \\
\hline DV & 1873 & - & - \\
\hline LF & 1940 & + & + \\
\hline CA & 1958 & + & + \\
\hline ABHF & 1986 & + & + \\
\hline ZCN/RCN & 1996 & - & + \\
\hline AH/MSV & 2001 & + & + \\
\hline FSB & 2002 & + & - \\
\hline BB & 2003 & - & + \\
\hline
\end{tabular}

Análise descritiva dos dicionários gerais:

Ao analisar as acepções dadas pelos autores, percebem-se discrepâncias no que se refere ao tamanho de uma barca. Em RB e AMS a lexia é definida como uma embarcação maior que um barco. Em LF, a barca é considerada um navio mercantil semelhante à galera. CA, entretanto, afirma que barca é uma embarcação pequena, destinada a carga e transportes. ABHF e AH/MSV generalizam as acepções designando-a como grande variedade de embarcações marítimas ou fluviais, este lexicógrafo descreve, ainda barca como uma embarcação miúda de apenas um mastro, que antigamente possuía três mastros. FSB não faz alusão ao tamanho.

Observação: Durante a seleção das lexias do corpus estudado, não foi possível evidenciar o tamanho das barcas.

Variante: bárca (AMS)

Análise descritiva dos dicionários regionalistas:

Não consta a lexia nas referidas obras. 
Abonação: “À medida que as barcaças e iates partiam de Pelotas rumo ao porto de Rio Grande ou ao Rio de Janeiro, uma nova e poderosa elite começou a surgir em Pelotas." (Doc 36 - Pel. 2007)

Ocorrência nos dicionários:

\begin{tabular}{|c|c|c|c|}
\hline Autor & Ano obra & Lexia & $\begin{array}{c}\text { Acepção correspondente } \\
\text { ao glossário }\end{array}$ \\
\hline RB & 1712 & + & + \\
\hline AMS & 1813 & + & + \\
\hline DV & 1873 & - & - \\
\hline LF & 1940 & + & + \\
\hline CA & 1958 & + & + \\
\hline ABHF & 1986 & + & - \\
\hline ZCN/RCN & 1996 & - & + \\
\hline AH/MSV & 2001 & + & + \\
\hline FSB & 2002 & + & - \\
\hline BB & 2003 & - & + \\
\hline
\end{tabular}

Análise descritiva dos dicionários gerais:

Todos os dicionaristas que apresentam a lexia mencionam a barcaça como barco grande.

Nota: Não foi encontrado no corpus refer6encias ao tamanho destas embarcações.

Variantes: barcâça (RB); barcáça (AMS)

Análise descritiva dos dicionários regionalistas:

Não consta a lexia nas referidas obras.

Barco a vapor| s.m.

embarcação com o apoio de motor

Abonação: “...construir o primeiro barco à vapor do Rio Grande do Sul. A barca, batizada de Liberal - em uma alusão aos ideais políticos pelos quais se norteava singrou as águas da Lagoa dos Patos impulsionada por um motor importado dos Estados Unidos até ser confiscada pelo governo imperial durante a Revolução Farroupilha." (Doc 43 - Pel. 2007)

Ocorrência nos dicionários:

\begin{tabular}{|c|c|c|c|}
\hline Autor & Ano obra & Lexia & $\begin{array}{c}\text { Acepção correspondente } \\
\text { ao glossário }\end{array}$ \\
\hline RB & 1712 & - & - \\
\hline AMS & 1813 & - & - \\
\hline DV & 1873 & - & - \\
\hline LF & 1940 & - & - \\
\hline
\end{tabular}




\begin{tabular}{|c|c|c|c|}
\hline CA & 1958 & + & + \\
\hline ABHF & 1986 & - & - \\
\hline ZCN/RCN & 1996 & - & - \\
\hline AH/MSV & 2001 & + & + \\
\hline FSB & 2002 & - & - \\
\hline BB & 2003 & - & - \\
\hline
\end{tabular}

Análise descritiva dos dicionários gerais:

RB somente apresenta somente a lexia barco de pesca. CA cita o barco à vapor (sic) em sua abonação, sendo considerado como correspondente ao glossário. Este dicionarista não associa, entretanto, o uso dos barcos a vapor com os charqueadores. AH/MSV apresenta a lexia vapor como variante para barco, juntamente com lancha, nau, navio etc.

Análise descritiva dos dicionários regionalistas:

Não consta a lexia nas referidas obras.

Barra de madeira $\mid$ s.f.

pedaço de madeira usado para apoiar a carne durante a charqueação || tábua de madeira colocada por cima de uma pilha que serve de peso na compressão da carne salgada || espécie de prancha

Abonação: “...em Pelotas, eles são estendidos sobre barras de madeira que sustentam sua parte mediana, e dois charqueadores os trabalham, cada um por um lado. Em todos os casos, a carne, ficando sempre estendida sobre a mesa ou sobre o suporte por uma de suas faces..." (Doc 87 - L.C. 1880)

Ocorrência nos dicionários:

Não consta a lexia nas referidas obras.

Análise descritiva dos dicionários gerais:

CA faz menção do uso de barra no sentido de apertar. Entretanto, o exemplo dado por este autor é de uso tipográfico e a barra, neste caso, é somente de ferro. Em outra acepção, CA vincula o uso da barra de madeira restritamente como peça usada na cabeceira de leitos. ABHF, AH/MSV e FSB citam a lexia de forma generalizada, como uma peça longa, estreita, rígida, que pode ser de metal, madeira ou outro material.

Análise descritiva dos dicionários regionalistas: 
ZCN/RCN e BB apresentam a entrada barra como jogo infantil, não especificando nada acerca das barras utilizadas nas charqueadas.

Barraca 1 | s.f.

espécie de tenda || estrutura feita sobre mantas de charque, geralmente de couro, que cobre a pilha de carne salgada

Abonação: " Por cima de cada camada de couros, joga-se uma camada espessa de sal, e instalam-se assim, numa construção especial ou "barraca" pilhas muito grandes..." (Doc 100 - L.C. 1880)

Ocorrência nos dicionários:

\begin{tabular}{|c|c|c|c|}
\hline Autor & Ano obra & Lexia & $\begin{array}{c}\text { Acepção correspondente } \\
\text { ao glossário }\end{array}$ \\
\hline RB & 1712 & + & + \\
\hline AMS & 1813 & + & + \\
\hline DV & 1873 & + & + \\
\hline LF & 1940 & + & + \\
\hline CA & 1958 & + & + \\
\hline ABHF & 1986 & + & - \\
\hline ZCN/RCN & 1996 & + & + \\
\hline AH/MSV & 2001 & + & + \\
\hline FSB & 2002 & + & - \\
\hline BB & 2003 & + & \\
\hline
\end{tabular}

Análise descritiva dos dicionários gerais:

RB classifica barraca como espécie de tenda, mas a define como pequena tenda armada no campo. AMS é sucinto em sua descrição, definindo-a como tenda militar de campo ou casa rústica mal lavada. DV apresenta barraca como sinônimo de cabana, tenda militar ou casas cobertas de rama. Alguns autores definem barraca como espécie de guarda-chuva usado nas campanhas. CA e FSB definem barraca como construção feita de pano, palha de madeira, não citando o couro como possível material empregado nestas construções.

Nota: Nos saladeiros, as barracas preveniam que as intempéries do tempo, como chuvas e o sereno atingissem diretamente as carnes que se encontravam embaixo destas construções.

Variante: barrâca $(\mathrm{RB})$

Análise descritiva dos dicionários regionalistas:

Não consta a lexia nas referidas obras. 
BB apresenta somente a lexia barraqueiro, significando o mesmo que dono da barraca.

Barraca 2 | s.f.

local onde se comercializa os produtos da charqueada

Abonação: "Huma charqueada denomináda do Catovello, comprehendendo o terreno e todas as benfeitorias, galpões, barraca de couros, graixeira, armazens..." (Doc 54 Poa 1871)

Ocorrência nos dicionários:

\begin{tabular}{|c|c|c|c|}
\hline Autor & Ano obra & Lexia & $\begin{array}{c}\text { Acepção correspondente } \\
\text { ao glossário }\end{array}$ \\
\hline RB & 1712 & + & - \\
\hline AMS & 1813 & + & - \\
\hline DV & 1873 & + & - \\
\hline LF & 1940 & + & + \\
\hline CA & 1958 & + & + \\
\hline ABHF & 1986 & + & + \\
\hline ZCN/RCN & 1996 & + & + \\
\hline AH/MSV & 2001 & + & - \\
\hline FSB & 2002 & + & + \\
\hline BB & 2003 & + & + \\
\hline
\end{tabular}

Análise descritiva dos dicionários gerais:

RB classifica diferentes tipos de barracas, como de madeira, de soldados, de pescadores, mas não faz referência às barracas como estabelecimento comercial. LF, AH/MSV mencionam na definição do verbete a barraca como casa comercial onde comercializam couros, lãs etc. CA apresenta a locução barraca de couro como sendo brasileira do sul do país, dando acepção de estabelecimento que negocia produtos da indústria pastoril. ABHF, por sua vez, assemelha a definição de LF e AH/MSV, classificando a lexia sendo tipicamente brasileira do sul.

Análise descritiva dos dicionários regionalistas:

ZCN/RCN e BB apresentam entrada barraca com acepção correspondente, informando que, no RS, em geral, significa uma espécie de estabelecimento de comércio de produtos agropastoris. 
Abonação: “... me obriga agora a mudar de parecer o mizeravel estado, em que chegarão os Barriz, e Barrica que remeteo o Governador Sebastião Xavier, pois de 23 Barriz, e huma Barrica, que por estes Armazens se receberão, só se aproveitarão 13..." (Doc 13v - Flo. 1798)

Ocorrência nos dicionários:

\begin{tabular}{|c|c|c|c|}
\hline Autor & Ano obra & Lexia & $\begin{array}{c}\text { Acepção correspondente } \\
\text { ao glossário }\end{array}$ \\
\hline RB & 1712 & + & + \\
\hline AMS & 1813 & + & + \\
\hline DV & 1873 & + & + \\
\hline LF & 1940 & + & + \\
\hline CA & 1958 & + & + \\
\hline ABHF & 1986 & + & - \\
\hline ZCN/RCN & 1996 & - & + \\
\hline AH/MSV & 2001 & + & + \\
\hline FSB & 2002 & + & - \\
\hline BB & 2003 & - & + \\
\hline
\end{tabular}

Análise descritiva dos dicionários gerais:

Os dicionários apresentam barrica como diminutivo de barril. Em nenhuma delas, entretanto, foram usados como exemplo os produtos carne,charque, sal etc.

Variante: barríca (DV)

Análise descritiva dos dicionários regionalistas:

Não consta a lexia nas referidas obras.

24 Barril | s.m.

objeto de madeira para carregar ou armazenar carne salgada, charque ou outro produto || espécie de pipa utilizada no transporte ou armazenamento de líquidos Abonação: “... me obriga agora a mudar de parecer o mizeravel estado, em que chegarão os Barriz, e Barrica que remeteo o Governador Sebastião Xavier, pois de 23 Barriz, e huma Barrica, que por estes Armazens se receberão, só se aproveitarão 13..." (Doc 13v - Flo. 1798)

“As carnes salgadas em "barril” permanecem vermelhas; a presença do ar é então necessária” (Doc 93 - L.C. 1880)

“...Para o Rio de Janeiro, 657,5 arrobas a $\$ 700$ igual a 460\$250. Barris de carne salgada - Para o Rio de Janeiro, 250 a 9\$600...” (Doc 131 - A.S.H. 1820/21)

Ocorrência nos dicionários: 


\begin{tabular}{|c|c|c|c|}
\hline Autor & Ano obra & Lexia & $\begin{array}{c}\text { Acepção correspondente } \\
\text { ao glossário }\end{array}$ \\
\hline RB & 1712 & + & + \\
\hline AMS & 1813 & + & + \\
\hline DV & 1873 & + & + \\
\hline LF & 1940 & + & + \\
\hline CA & 1958 & + & + \\
\hline ABHF & 1986 & + & + \\
\hline ZCN/RCN & 1996 & - & - \\
\hline AH/MSV & 2001 & + & + \\
\hline FSB & 2002 & + & - \\
\hline BB & 2003 & - & - \\
\hline
\end{tabular}

Análise descritiva dos dicionários gerais:

A grande maioria dos autores que apresentam a entrada barril mencionando seu uso como transporte de água e vinho. Somente AH/MSV abrange a definição, afirmando que o barril serve para transportar/armazenar alimentos especialmente líquidos. Em nenhum momento usa-se carne ou até mesmo sal como possíveis produtos transportados em barris.

Variantes: barrîl (RB); barríl (AMS, DV)

Análise descritiva dos dicionários regionalistas:

Não consta a lexia nas referidas obras.

Beneficiar | v.

manufaturar || preparar a carne para consumo || salgar a carne

Abonação: “...ficaõ pertencendo a Vossa Merce em cuja Repartiçaõ se devem conservar os gados, que do Continente vierem remettidos para aquelle fim, como tambem salgar e beneficiar as Carnes, de modo que deste partido rezultem as vantagens que se manifestaõ..." (Doc 08 - Flo. 1797)

“... segurando-lhe a remessa de Sal, e de homens praticos no modo de beneficiar as Carnes; pois desta sorte se poderá desde já ocorrer aos gravissimos damnos..." (Doc 09 - Flo. 1797)

Ocorrência nos dicionários:

\begin{tabular}{|c|c|c|c|}
\hline Autor & Ano obra & Lexia & $\begin{array}{c}\text { Acepção correspondente } \\
\text { ao glossário }\end{array}$ \\
\hline RB & 1712 & + & - \\
\hline AMS & 1813 & + & - \\
\hline DV & 1873 & - & - \\
\hline
\end{tabular}




\begin{tabular}{|c|c|c|c|}
\hline LF & 1940 & + & - \\
\hline CA & 1958 & + & - \\
\hline ABHF & 1986 & - & - \\
\hline ZCN/RCN & 1996 & + & - \\
\hline AH/MSV & 2001 & + & - \\
\hline FSB & 2002 & + & - \\
\hline BB & 2003 & - & - \\
\hline
\end{tabular}

Análise descritiva dos dicionários gerais:

Todos os autores que apresentam esta lexia, indicam em suas acepções o sentido de aumentar, melhorar, aproveitar. RB, AMS, DV e FSB fornecem nas acepções o exemplo de beneficiamento de terras ou metais, não de animais ou seus produtos. Já LF, CA e AH/MSV, além do sentido apresentado pelos outros autores, agregam à lexia a acepção sinônimos como ferrar, marcar, castrar etc. Observa-se que CA traz o substantivo beneficiação enquanto o corpus apresenta beneficiamento.

Análise descritiva dos dicionários regionalistas:

A obra de ZCN/RCN e BB trazem a entrada beneficiar com uma única acepção: castrar. BB ainda apresenta a lexia beneficiado, para animal castrado.

Observação: Durante a composição do glossário, surgiram dúvidas na definição da acepção, pois o corpus somente apresenta esta lexia no sentido de preparar, manufaturar. Dado que o uso deste verbo só foi encontrado nos documentos catarinenses, não há como afirmar que no Rio Grande do Sul é uso exclusivo de castração, ou que emprega-se também no sentido apresentado nos outros documentos editados na pesquisa.

\section{Benfeitoria $\mid$ s.f.}

conjunto de obras e edificações que promovem a melhoria da charqueada

Abonação: “... e entre a estrada de baixo e o Arroio de Pelotas; existem edificadas as Cazas de Moradia, Galpões, Graixeiras, e todas as mais benfeitorias que formão o Estabelecimento de Charqueada..." (Doc 57 - Poa 1870)

"Bens de raiz - Huma charqueada denomináda do Catovello, comprehendendo o terreno e todas as benfeitorias, galpões, barraca de couros, graixeira, armazens, mangueiras, varies, casas de moradia, pomár..." (Doc 54 - Poa 1871)

Ocorrência nos dicionários:

\begin{tabular}{|l|l|l|l|} 
Autor & Ano obra & Lexia & Acepção correspondente \\
\hline
\end{tabular}




\begin{tabular}{|c|c|c|c|}
\hline & & & ao glossário \\
\hline RB & 1712 & - & - \\
\hline AMS & 1813 & + & + \\
\hline DV & 1873 & - & - \\
\hline LF & 1940 & + & + \\
\hline CA & 1958 & + & + \\
\hline ABHF & 1986 & + & - \\
\hline ZCN/RCN & 1996 & - & + \\
\hline AH/MSV & 2001 & + & - \\
\hline FSB & 2002 & - & + \\
\hline BB & 2003 & + & \\
\hline
\end{tabular}

Análise descritiva dos dicionários gerais:

LF apresenta em sua acepção três tipos de benfeitorias, são elas: necessária, útil e voluptuária.AH/MSV apresenta, além destas três, outra classificação que denomina de proveitosa (variação sutil da voluptuária).

Nota: De acordo com o corpus, acredita-se que, nas charqueadas, as benfeitorias eram divididas entre as três, pois algumas obras e edificações eram, de fato, necessárias, outras úteis ao melhor preparo e conservação dos produtos lá fabricados, e, provavelmente, poucas delas eram construídas para tornar estabelecimento saladeril mais agradável ou para recreação. Este termo foi encontrado inúmeras vezes em testamentos de charqueadores, o que corrobora com a acepção de que era uma lexia empregada com o significado de melhorias.

Variante: bemfeitoria (AMS, LF, AH/MSV)

Análise descritiva dos dicionários regionalistas:

Não consta a lexia nas referidas obras.

Bexiga $\mid$ s.f.

órgão interno da rês que após ser retirado do animal, serve como bolsa para acondicionar gordura

Abonação: “ Do mesmo modo, em lugar de colocar em barris toda a gordura comum ou refinada, alguns charqueadores de Pelotas derramam a mais perfeita em bexigas de bois especialmente preparadas..." (Doc 99 - L.C. 1880)

“...16 de Janeiro. - Graxa em pipas, 320 a 330 kilos, dita em bexigas, 400 a 420; lingoas de fumeiro, $28 \$$ a $29 \$$ cento; ditas communs, $16 \$$ a $20 \$$; em salmoura, $26 \$$ a 30\$...”(Doc 31 - Pel. 1869) 
“...levando a buchada para o monturo e a ossada para a graxeira para a elaboração da graxa, colocada, como disse, em bordalesas e bexigas." (Doc 113 - A.P.C. 1988)

Ocorrência nos dicionários:

\begin{tabular}{|c|c|c|c|}
\hline Autor & Ano obra & Lexia & $\begin{array}{c}\text { Acepção correspondente } \\
\text { ao glossário }\end{array}$ \\
\hline RB & 1712 & + & + \\
\hline AMS & 1813 & + & - \\
\hline DV & 1873 & + & - \\
\hline LF & 1940 & + & - \\
\hline CA & 1958 & + & - \\
\hline ABHF & 1986 & + & - \\
\hline ZCN/RCN & 1996 & - & - \\
\hline AH/MSV & 2001 & + & - \\
\hline FSB & 2002 & + & - \\
\hline BB & 2003 & - & - \\
\hline
\end{tabular}

Análise descritiva dos dicionários gerais:

RB apresenta a bexiga como uma espécie de bolsa depois do cozimento, definindo esta lexia como pertencente ao processo digestivo, sinônimo de vesícula. DV, LF, CA e FSB apresentam outras acepções ligadas à patologia, história natural etc. ABHF e AH/MSV apresentam bexiga como um reservatório que, depois de seco e cheio de ar, serve para fins de brincadeiras infantis ou carnavalescas.

Variantes: bexîga (RB); bexigua (AH/MSV); bixigua (AH/MSV)

Análise descritiva dos dicionários regionalistas:

Não consta a lexia nas referidas obras.

Boi | s.m.

animal da espécie bovina || matéria prima na fabricação do charque || rês

Abonação: “... sabe-se que os bois mais gordos perdem relativamente menos peso que os bois magros e, principalmente que os bois estafados; sabe-se que as porções magras..." (Doc 95 - L.C. 1880)

Ocorrência nos dicionários:

\begin{tabular}{|c|c|c|c|}
\hline Autor & Ano obra & Lexia & $\begin{array}{c}\text { Acepção correspondente } \\
\text { ao glossário }\end{array}$ \\
\hline RB & 1712 & + & + \\
\hline AMS & 1813 & + & + \\
\hline DV & 1873 & + & + \\
\hline LF & 1940 & + & + \\
\hline CA & 1958 & + & + \\
\hline
\end{tabular}




\begin{tabular}{|c|c|c|c|}
\hline ABHF & 1986 & + & + \\
\hline ZCN/RCN & 1996 & - & - \\
\hline AH/MSV & 2001 & + & + \\
\hline FSB & 2002 & + & + \\
\hline BB & 2003 & + & + \\
\hline
\end{tabular}

Análise descritiva dos dicionários gerais:

RB classifca como boi toda a espécie de gado que tem corno. AMS classifica como o macho da espécime vacum.

Variantes: boy (RB); bôy (RB); bôi (RB); bòi (AMS); bói (DV, LF)

Nota: Ao longo da seleção das lexias componentes do glossário, os autores dos documentos apresentavam tipos e classificações diferentes de bois. Os bois denominados magros, por exemplo, eram animais considerados pouco lucrativos nas charqueadas dado sua condição, eram reses com pouca gordura corporal. Os bois estafados eram, por exemplo, proibidos, por lei, de serem abatidos. Os bois mansos, eram usados no serviço das charqueadas.

Análise descritiva dos dicionários regionalistas:

BB define o boi como o macho bovídeo castrado. Uma segunda acepção apresentada pelo autor define a lexia como um tipo de dança.

Boi de trela| s.m.

boi usado na charqueada

Abonação: “ "..e perdem mais peso que os animais mais desenvolvidos: donde, afora mesmo o couro, a mais valia dos bois de trela ou dos bois..." (Doc 95 - L.C. 1880)

Ocorrência nos dicionários:

Não consta a lexia nas referidas obras.

Boi em pé | s.m.

boi vivo || bovino não abatido

Abonação: “... quando o governo farroupilha proibiu a atividade de produção do charque por entender que o boi em pé era um produto mais fácil de ser controlado." (Doc 38 - Pel. 2007)

Ocorrência nos dicionários: 


\begin{tabular}{|c|c|c|c|}
\hline Autor & Ano obra & Lexia & $\begin{array}{c}\text { Acepção correspondente } \\
\text { ao glossário }\end{array}$ \\
\hline RB & 1712 & - & - \\
\hline AMS & 1813 & - & - \\
\hline DV & 1873 & - & - \\
\hline LF & 1940 & - & - \\
\hline CA & 1958 & - & - \\
\hline ABHF & 1986 & + & + \\
\hline ZCN/RCN & 1996 & - & - \\
\hline AH/MSV & 2001 & + & - \\
\hline FSB & 2002 & - & - \\
\hline BB & 2003 & - & + \\
\hline
\end{tabular}

Análise descritiva dos dicionários gerais:

ABHF e AH/MSV indicam que o boi em pé é o boi de corte que ainda se encontra nas invernadas.

Análise descritiva dos dicionários regionalistas:

Não consta a lexia nas referidas obras.

Boiada $\mid$ s.f.

conjunto de bois || tropa

Abonação: “ ...ou nas suas vizinhanças há pastos, ou logradouros em que possão descançar, e engordar as Boyadas que vierem successivamente do Rio Grande..." (Doc 15v - Flo. 1795)

"A despeza que se deveria fazer com a gente, e cavalos para conduzirem as boiadas: O frete de Sal até a Ilha de Santa Catharina: Vazilhame: Tanoeiros; que os não há na mesma..." (Doc 11 - Flo. 1798)

Variante: boyada

Ocorrência nos dicionários:

\begin{tabular}{|c|c|c|c|}
\hline Autor & Ano obra & Lexia & $\begin{array}{c}\text { Acepção correspondente ao } \\
\text { glossário }\end{array}$ \\
\hline RB & 1712 & - & - \\
\hline AMS & 1813 & + & + \\
\hline DV & 1873 & + & + \\
\hline LF & 1940 & + & + \\
\hline CA & 1958 & + & + \\
\hline ABHF & 1986 & + & + \\
\hline ZCN/RCN & 1996 & + & + \\
\hline AH/MSV & 2001 & + & + \\
\hline FSB & 2002 & + & + \\
\hline BB & 2003 & + & + \\
\hline
\end{tabular}


Análise descritiva dos dicionários gerais:

ABHF apresenta a lexia boiama como sinônimo. AH/MSV além de boiama, apresenta outras lexias como boizama, manada e rebanho.

Variante: boiáda (DV)

Análise descritiva dos dicionários regionalistas:

ZCN/RCN e BB informam que a tropa, ou boiada são lexias usadas para os conjuntos de bois mansos.

Bordalesa $\mid$ s.f.

recipiente que acondiciona graxa || objeto da charqueada que armazena a graxa e a gordura

Abonação: “...caldeiras destinadas ao preparo da graxa amarelinha, acondicionadas em bordalesas ou em bexigas, que enchiam os olhos pela qualidade." (Doc 109 A.P.C. 1988)

Ocorrência nos dicionários:

\begin{tabular}{|c|c|c|c|}
\hline Autor & Ano obra & Lexia & $\begin{array}{c}\text { Acepção correspondente } \\
\text { ao glossário }\end{array}$ \\
\hline RB & 1712 & - & - \\
\hline AMS & 1813 & - & - \\
\hline DV & 1873 & - & - \\
\hline LF & 1940 & + & - \\
\hline CA & 1958 & + & - \\
\hline ABHF & 1986 & + & - \\
\hline ZCN/RCN & 1996 & - & - \\
\hline AH/MSV & 2001 & + & - \\
\hline FSB & 2002 & - & - \\
\hline BB & 2003 & - & - \\
\hline
\end{tabular}

Análise descritiva dos dicionários gerais:

LF fornece a acepção de bordalesa como sinônimo de barril, com capacidade de 225 litros. CA, ABHF e AH/MSV repetem a acepção dada por $\mathbf{L F}$, acrescentando a informação de que a bordalesa serve para acondicionar vinho. Nenhuma das obras refere-se ao armazenamento de graxa ou gordura.

Variantes: bordaleza (LF); bordelesa (AH/MSV)

Análise descritiva dos dicionários regionalistas:

Não consta a lexia nas referidas obras. 
medida de comprimento || medida comumente usada pelos charqueadores

Abonação: "Hum terreno na rua do Riachuello desta Cidade, de quina da rua de Paysandú com quatro e meia braças de frente ao Norte, mais ou menos..." (Doc 55 Poa 1871)

“...charqueada do Catovello, que váe sahir á porteira da charqueada do mesmo Braga, com quatrocentas braças de fundo até encontrar o arroio de Pelotas..." (Doc 55 - Poa 1871)

Ocorrência nos dicionários:

\begin{tabular}{|c|c|c|c|}
\hline Autor & Ano obra & Lexia & $\begin{array}{c}\text { Acepção correspondente } \\
\text { ao glossário }\end{array}$ \\
\hline RB & 1712 & + & + \\
\hline AMS & 1813 & + & + \\
\hline DV & 1873 & + & + \\
\hline LF & 1940 & + & + \\
\hline CA & 1958 & + & + \\
\hline ABHF & 1986 & + & + \\
\hline ZCN/RCN & 1996 & + & + \\
\hline AH/MSV & 2001 & + & - \\
\hline FSB & 2002 & - & + \\
\hline BB & 2003 & + & + \\
\hline
\end{tabular}

Análise descritiva dos dicionários gerais:

Os autores apresentam medidas equivalentes da braça. Segundo estes autores, 1 braça equivale a 7 pés geométricos ou 10 palmos de craveira. CA e ABHF informam que a lexia é uma medida antiga. AH/MSV informa que, mesmo se tratando de uma medida antiga, ainda se usa no Brasil e que suas dimensões variam de país para país.

Observação: De acordo com alguns lexicógrafos, o nome desta medida originou-se da medida que se toma quando estende-se dois braços abertos, medindo de punho a punho.

Análise descritiva dos dicionários regionalistas:

Ambos os dicionaristas sul rio-grandenses são unânimes em afirmar que esta unidade de medida é bastante usada no Rio Grande do Sul e classificam outros dois tipos de braças, a dizer, braça-de-sesmaria (antiga medida de superfície) e braça-de-sol (medida antiga de medir o tempo: distância aparente que falta para o sol desaparecer no horizonte). Outra medida de apresentada por BB é a denonimada légua, que é uma medida itinerária equivalente a 3.000 braças. 
Brete | s.m.

pequeno curral estreito localizado ao final da mangueira de matança onde de coloca o boi para o abate $\|$ caminho estreito mais ou menos longo que interliga as mangueiras de matança || curro

Abonação: "...é a "mangueira de matança" que comunica com as outras por um caminho estreito mais ou menos longo, o "curro"ou "brete". Esta última mangueira tem um chão inclinado, e geralmente deslizante, macadamizado, em grandes tijolos ou às vezes em pranchas. A mangueira figura, com bastante exatidão, o plano de dois troncos de cone encostados por sua larga base: um dos vértices corresponde ao curro ou brete..." (Doc 85 - L.C. 1880)

"O pequeno brete, uma vez abatida as reses nele encerradas, era imediatamente reabastecido." (Doc 110 - A.P.C. 1988)

Ocorrência nos dicionários:

\begin{tabular}{|c|c|c|c|}
\hline Autor & $\begin{array}{c}\text { Ano } \\
\text { obra }\end{array}$ & Lexia & $\begin{array}{c}\text { Acepção correspondente } \\
\text { ao glossário }\end{array}$ \\
\hline RB & 1712 & + & + \\
\hline AMS & 1813 & + & - \\
\hline DV & 1873 & + & - \\
\hline LF & 1940 & + & ++ \\
\hline CA & 1958 & - & - \\
\hline ABHF & 1986 & + & ++ \\
\hline ZCN/RCN & 1996 & + & ++ \\
\hline AH/MSV & 2001 & + & ++ \\
\hline FSB & 2002 & + & + \\
\hline BB & 2003 & + & ++ \\
\hline
\end{tabular}

Análise descritiva dos dicionários gerais:

Segundo RB, AMS e DV a lexia brete era usada como espécie de armadilha para aves e não para gado. LF, ABHF e AH/MSV, não só apresentam a acepção conforme os autores anteriores, mas acabam por citar o uso de bretes para o abate de gado e tosa, complementando a definição quanto ao seu uso nas charqueadas. CA somente informa de que brete era usado no Rio Grande do Sul.

Variante: brête (DV, AMS, LF, CA)

Análise descritiva dos dicionários regionalistas:

Os autores regionalistas também citam as charqueadas como local de uso de bretes para o abate, local de confinamento para tolher os movimentos do animal a ser abatido 
e, também, como corredor estreito que conduz o gado à charqueada. Os dicionaristas mencionam embretamento, que é o ato de colocar no brete e embretado, que é o animal que foi colocado no brete. BB complementa o verbete atribuindo um sentido figurado para a lexia, definindo-a como uma cilada para surpreender uma pessoa.

Brigue | s.m.

meio de transporte fluvial usado para transportar a mercadoria produzida na charqueada

Abonação: "Rio de Janeiro, no brigue nacional -Norma- Eufrazio Lopes de Araujo 50 barricas com 323 arrobas de sebo coado.” (Doc 28 - Pel. 1869)

Ocorrência nos dicionários:

\begin{tabular}{|c|c|c|c|}
\hline Autor & Ano obra & Lexia & $\begin{array}{c}\text { Acepção correspondente } \\
\text { ao glossário }\end{array}$ \\
\hline RB & 1712 & - & - \\
\hline AMS & 1813 & - & - \\
\hline DV & 1873 & + & + \\
\hline LF & 1940 & + & + \\
\hline CA & 1958 & + & - \\
\hline ABHF & 1986 & + & - \\
\hline ZCN/RCN & 1996 & - & - \\
\hline AH/MSV & 2001 & + & - \\
\hline FSB & 2002 & + & - \\
\hline BB & 2003 & - & - \\
\hline
\end{tabular}

Análise descritiva dos dicionários gerais:

CA, AH/MSV e FSB definem brigue como embarcação de guerra. ABHF e AH/MSV apresentam outras duas entradas: brigue-barca e brigue-escuna. A partir destas duas lexias apresentadas pelos dicionaristas, levanta-se a hipótese de que brigue pode ser usado não somente para fins bélicos, como também para transportar mercadorias, conforme apresentou-se no corpus da pesquisa.

Variante: brígue (DV)

Análise descritiva dos dicionários regionalistas:

Não consta a lexia nas referidas obras. 
parte do intestino e demais órgãos internos do animal || víscera || parte descartada do animal abatido na charqueada

Abonação: “O local onde haviam carneado já estava completamente limpo. Por ali já haviam passado, devidamente montados em petiços, os carregadores de ossadas e buchadas, que, com ganchos fixados aos arreios faziam o serviço, levando a buchada para o monturo e a ossada para a graxeira para a elaboração da graxa..." (Doc 113 A.P.C. 1988)

Ocorrência nos dicionários:

\begin{tabular}{|c|c|c|c|}
\hline Autor & Ano obra & Lexia & Acepção correspondente \\
\hline RB & 1712 & - & - \\
\hline AMS & 1813 & - & - \\
\hline DV & 1873 & + & + \\
\hline LF & 1940 & + & + \\
\hline CA & 1958 & + & + \\
\hline ABHF & 1986 & + & + \\
\hline ZCN/RCN & 1996 & + & + \\
\hline AH/MSV & 2001 & + & + \\
\hline FSB & 2002 & + & + \\
\hline BB & 2003 & + & + \\
\hline
\end{tabular}

Análise descritiva dos dicionários gerais:

CA e ABHF apresentam na acepção a buchada como um prato de culinária que se pode preparar geralmente com as vísceras de caprinos. FSB informa em seu verbete que este prato culinário é muito preparado no norte do Brasil.

Variante: bucháda (DV)

Análise descritiva dos dicionários regionalistas:

Não consta a lexia nas referidas obras.

Burra $\mid$ s.f.

pilha de charque amontoada sobre o secador, coberto de couro ou tecido afim de proteger do tempo à noite

Abonação: "Durante todo este tempo, limitar-se-á a fazer, cada noite, pequenos montes, ou "burras", acumulando diversas tiras de carne sobre certos pontos das varas..." (Doc 91 - L.C. 1880)

Ocorrência nos dicionários:

\begin{tabular}{|c|c|c|c|}
\hline Autor & Ano obra & Lexia & $\begin{array}{c}\text { Acepção correspondente } \\
\text { ao glossário }\end{array}$ \\
\hline
\end{tabular}




\begin{tabular}{|c|c|c|c|}
\hline RB & 1712 & - & - \\
\hline AMS & 1813 & + & - \\
\hline DV & 1873 & + & - \\
\hline LF & 1940 & + & - \\
\hline CA & 1958 & + & - \\
\hline ABHF & 1986 & + & - \\
\hline ZCN/RCN & 1996 & - & - \\
\hline AH/MSV & 2001 & + & - \\
\hline FSB & 2002 & + & - \\
\hline BB & 2003 & - & - \\
\hline
\end{tabular}

Análise descritiva dos dicionários gerais:

Das obras que apresentam a lexia, em nenhuma delas houve a correspondência da acepção encontrada no corpus com a exposta no glossário.

Análise descritiva dos dicionários regionalistas:

Não consta a lexia nas referidas obras.

Caldeira $\mid$ s.f.

recipiente destinado ao preparo da graxa || objeto usado na charqueada no preparo de subprodutos

Abonação: “As grandes cubas onde se fará o cozimento são dispostas de cada lado das caldeiras: há muito grandes, de 4 a 5 metros de altura, para as gorduras..." (Doc 98 L.C. 1880)

"As fornalhas, com as bocas vermelhas escancaradas, iam pouco a pouco transmitindo aos manômetros a pressão das 4 caldeiras destinadas ao preparo da graxa amarelinha, (Doc 109 - A.C.P. 1988)

Ocorrência nos dicionários:

\begin{tabular}{|c|c|c|c|}
\hline Autor & $\begin{array}{c}\text { Ano } \\
\text { obra }\end{array}$ & Lexia & $\begin{array}{c}\text { Acepção correspondente ao } \\
\text { glossário }\end{array}$ \\
\hline RB & 1712 & + & + \\
\hline AMS & 1813 & + & + \\
\hline DV & 1873 & + & + \\
\hline LF & 1940 & + & + \\
\hline CA & 1958 & + & + \\
\hline ABHF & 1986 & + & - \\
\hline ZCN/RCN & 1996 & - & + \\
\hline AH/MSV & 2001 & + & + \\
\hline FSB & 2002 & + & - \\
\hline BB & 2003 & - & + \\
\hline
\end{tabular}


Análise descritiva dos dicionários gerais:

Todas as obras apresentam nos verbetes o uso das caldeiras principalmente para a fabricação de vapor. AMS enfatiza o seu uso nos engenhos de cana de açúcar. LF exemplifica inúmeras utilidades para as caldeiras, em nenhuma delas, porém, menciona a cocção de partes de animais.

Variante: caldeyra (AH/MSV)

Análise descritiva dos dicionários regionalistas:

Não consta a lexia nas referidas obras.

Camboneiro| s.m.

empregado da charqueada que posiciona o animal para o abate passando uma corrente pelos chifres do animal para derrubá-lo

Abonação: "Ali estavam alinhados, esperando o primeiro boi, zorreiros, camboneiros, coleiros, carneadores, charqueadores, aguateiros, salgadeiros..." (Doc 108 - A.P.C. 1988)

"O cambaneiro era o operário que passava uma grossa corrente pelos chifres do boi e o coleiro o que puxava pela cola para, num esforço conjunto, derrubar a rês, colocando-a na devida posição”. (Doc 111 - A.P.C. 1988)

Variante: cambaneiro, caboleiro

Ocorrência nos dicionários:

Não consta a lexia nas referidas obras.

Análise descritiva dos dicionários gerais:

Nenhum dos dicionários pesquisados menciona alguma lexia que possa servir como sinônimo ou mesmo como comprovação do uso desta palavra. No corpus composto para o glossário, esta lexia repete-se várias vezes, mas por apenas em um único autor. Observação: Não foi possível realizar o cotejo entre o documento original e a edição selecionada. Levanta-se, então, a hipótese de uma possível gralha na edição.

Cancha $\mid$ s.f.

local onde se prepara o charque || construção geralmente feita com piso de tijolo, levemente inclinada || espécie de tablado onde o animal é abatido e carneado || parte contígua à mangueira 
Abonação: “... A manta e os membros são levados ao galpão: ficam a cabeça, o tronco e as vísceras: todas estas partes serão rapidamente separadas, jogadas de lado para fora das canchas e carregadas...” (Doc 87 - L.C. 1880)

"Nesse contínuo emendar de matanças, os operários andavam quase dormindo pelos cantos. Nessas ocasiões o meu pai, para acordar o pessoal, mandava soltar na cancha um animal que não fosse muito brabo. O bicho, mediante um descuido propositado, passava pelo buraco da zorra e enfrentava todo mundo que estava na cancha..." (Doc 118 - A.P.C. 1988)

Ocorrência nos dicionários:

\begin{tabular}{|c|c|c|c|}
\hline Autor & Ano obra & Lexia & $\begin{array}{c}\text { Acepção correspondente ao } \\
\text { glossário }\end{array}$ \\
\hline RB & 1712 & - & - \\
\hline AMS & 1813 & - & - \\
\hline DV & 1873 & - & - \\
\hline LF & 1940 & + & ++ \\
\hline CA & 1958 & + & - \\
\hline ABHF & 1986 & + & ++ \\
\hline ZCN/RCN & 1996 & + & ++ \\
\hline AH/MSV & 2001 & + & ++ \\
\hline FSB & 2002 & + & - \\
\hline BB & 2003 & + & ++ \\
\hline
\end{tabular}

Análise descritiva dos dicionários gerais:

LF apresenta, dentre outras utilidades para a cancha, a acepção ligada diretamente ao vocabulário do charque, informando que cancha é o local em que se abatem os bois nas charqueadas. A maioria dos autores que apresentam a lexia faz referência ao preparo de erva mate, ou como construção comum em olarias, sem menção ao abate de gado ou ao preparo de charque. ABHF e AH/MSV apresentam no verbete outra subentrada denominada cancha de charqueada, sendo esta citada como regionalista do RS, definida como local onde se coloca a rês a ser arrastada, esfolada e morta.

Análise descritiva dos dicionários regionalistas:

ZCN/RCN define a cancha como local de abate nas charqueadas, enquanto que BB, assim como ABHF e AH/MSV desassociam a cancha de charqueada como o local onde se prepara erva, tijolos ou se realizam jogos. Os dois autores apresentam a lexia praia como sinônimo de cancha e mencionam a expressão: na cancha, usada para designar que há qualquer coisa atrapalhando a execução de um determinado plano. 


\section{Capataz da cancha $\mid$ s.m.}

empregado da charqueada encarregado da distribuição do empregado dos postos de trabalho dentro do galpão e demais instalações, de acordo com suas funções \| empregado da charqueada que ajuda na contagem dos animais da tropa || aquele que inspeciona o couro retirado do animal pelo carneador

Abonação: "Quinze minutos antes do início da matança, com o livro ponto debaixo do braço, recorria todos os setores do galpão para anotar a presença dos operários em seus postos, já distribuídos pelo “capataz da cancha”. (Doc 108 - A.P.C. 1988)

"Ao final do trabalho do carneador, sobrava na cancha apenas o couro da rês, já que o aguateiro fazia a limpeza do local. Vinha, então, o "capatazes da cancha" que examinava o couro. Qualquer furo em local importante que o desvalorizava, era motivo para o carneador não receber a ficha correspondente ao seu trabalho" (Doc 116 - A.P.C. 1988)

Ocorrência nos dicionários:

Não consta a lexia nas referidas obras.

Observação: Mesmo tendo citado o capataz como administrador ou empregado de charqueada, nenhum dicionarista especifica ou classifica tipos distintos de capatazes. Análise descritiva dos dicionários regionalistas:

ZCN/RCN e BB apresentam o verbo capatezar, ou capatezear, como ação de exercer a profissão de capataz; o substantivo capatezeação, como o ato de exercer o serviço do capataz. BB ainda menciona a lexia maioral, como sendo o capataz da estância ou da tropa.

Capataz de rua | s.m.

empregado da charqueada encarregado da distribuição dos trabalhadores nos postos de trabalho ao lado de fora do galpão da charqueada

Abonação: “Aí, então, entrava em ação o “capataz de rua”. O competente João Doralino, um preto que tinha em bondade e respeito, tanto como seus 120 quilos, botava em forma cerca de 30 operários, cada um com seu carrinho de mão, para retirar o charque ainda pingando e depositá-lo sobre os varais que ocupavam mais de um hectare." (Doc 120/121 A.P.C. 1988)

Ocorrência nos dicionários: 
Não consta a lexia nas referidas obras.

BB apresenta as lexias moirdomo (uso comum na fronteira do Estado) como capataz, administrador; e sota-capataz como pessoas que exercem autoridade imediatamente inferior à do capataz, com capacidade de substituí-lo.

\section{Carne de feijão $\mid$ s.m.}

carne salgada usada para temperar feijão || charque || carne seca

Não consta a lexia nas referidas obras.

Observação: Não foi encontrada nenhuma referência ao uso de carne de feijão nos documentos do corpus selecionado. Esta lexia foi incluída no glossário por ter sido mencionada na pesquisa oral e não nos documentos escritos.

Carne de sol | s.m.

carne preparada com pouco sal, pimenta e seca ao sol || carne seca

Abonação: "No preparo desse prato popular do norte, não se usa o charque, propriamente, e sim a carne-de-sol que são mantas de carne magra, com pouco sal e bastante pimenta do reino moída, oreadas ao sol durante dois ou três dias." (Doc 82 A.F.M. $s / n)$

Ocorrência nos dicionários:

\begin{tabular}{|c|c|c|c|}
\hline Autor & Ano obra & Lexia & $\begin{array}{c}\text { Acepção correspondente } \\
\text { ao glossário }\end{array}$ \\
\hline RB & 1712 & - & - \\
\hline AMS & 1813 & - & - \\
\hline DV & 1873 & - & - \\
\hline LF & 1940 & + & + \\
\hline CA & 1958 & + & + \\
\hline ABHF & 1986 & + & - \\
\hline ZCN/RCN & 1996 & - & + \\
\hline AH/MSV & 2001 & + & + \\
\hline FSB & 2002 & + & - \\
\hline BB & 2003 & - & + \\
\hline
\end{tabular}

Análise descritiva dos dicionários gerais:

AMS apresenta a carne seca ao sol como tassalho. Este autor não fornece a lexia carne-de-sol, somente menciona que algumas carnes como a carne de fumo é seca ao sol. LF apresenta a lexia como sinônimo de carne-do-ceará, carne de vento e carne do 
sertão. CA e ABHF apresentam carne-de-sol como sinônimo de carne-de-vento e carne-do-sertão. AH/MSV dá como sinônimo de carne-de-sol a carne fresca conservada em sal. Segundo este autor, a carne fresca é, então, posteriormente, posta ao sol para secar.

Análise descritiva dos dicionários regionalistas:

Não consta a lexia nas referidas obras.

Carne de vaca | s.m.

carne proveniente do abate de vacas || carne bovina em geral

Abonação: "O diario, e grande consumo, que se faz nesta Cidade de carne de vaca, naõ só com o Sustento dos Moradores, como tambem da Esquadra, que prezentemente se conserva neste Porto..." (Doc 15 - Flo. 1795)

Ocorrência nos dicionários:

\begin{tabular}{|c|c|c|c|}
\hline Autor & Ano obra & Lexia & $\begin{array}{c}\text { Acepção correspondente } \\
\text { ao glossário }\end{array}$ \\
\hline RB & 1712 & + & + \\
\hline AMS & 1813 & - & - \\
\hline DV & 1873 & - & - \\
\hline LF & 1940 & + & - \\
\hline CA & 1958 & + & - \\
\hline ABHF & 1986 & + & - \\
\hline ZCN/RCN & 1996 & - & - \\
\hline AH/MSV & 2001 & - & - \\
\hline FSB & 2002 & + & - \\
\hline BB & 2003 & - & - \\
\hline
\end{tabular}

Análise descritiva dos dicionários gerais:

LF, CA, ABHF e FSB apresentam carne de vaca como sendo um tipo de planta e não a carne proveniente do abate de vacas.

Nota: Nos documentos do corpus, comprovou-se que gado e carne de vaca eram usados como sinônimos, portanto, a denominação carne de vaca não se refere ao abate exclusivo das fêmeas do gado vacum.

Análise descritiva dos dicionários regionalistas:

Não consta a lexia nas referidas obras. 
tipo de charque produzido no estado do Ceará || carne salgada com pouco sal e seca ao sol

Ocorrência nos dicionários:

\begin{tabular}{|c|c|c|c|}
\hline Autor & Ano obra & Lexia & $\begin{array}{c}\text { Acepção correspondente } \\
\text { ao glossário }\end{array}$ \\
\hline RB & 1712 & - & - \\
\hline AMS & 1813 & - & - \\
\hline DV & 1873 & - & - \\
\hline LF & 1940 & + & + \\
\hline CA & 1958 & + & ++ \\
\hline ABHF & 1986 & + & ++ \\
\hline ZCN/RCN & 1996 & - & + \\
\hline AH/MSV & 2001 & + & - \\
\hline FSB & 2002 & - & - \\
\hline BB & 2003 & - & + \\
\hline
\end{tabular}

Análise descritiva dos dicionários gerais:

LF apresenta esta lexia como sinônimo de carne-de-sol. CA e AH/MSV apresentam a carne-do-ceará como sinônimo de charque, sem especificar o modo de preparo. CA e ABHF apresentam a variante carne-do-sertão como lexia usada no nordeste, em oposição à carne-do-ceará, que, segundo o autor é usada no Brasil.

Nota: Não há abonação no verbete, pois esta lexia foi selecionada a partir dos estudos dos atlas linguísticos, mas especificamente da obra: Bases para Elaboração do Atlas Linguístico do Brasil.

Análise descritiva dos dicionários regionalistas:

Não consta a lexia nas referidas obras.

Carne fresca | s.m.

carne de boi abatido sem nenhum processo de conservação || carne própria para consumo imediato || carne não charqueada

Abonação: " Seja como for, elas demonstram que a carne seca corresponde a uma pequena parte do peso da carne fresca." (Doc 102 - L.C. 1880)

“ É o nome tradicional e pitoresco de um guisadão de charque (ou também de carne fresca ou de sobras de carne ..." (Doc 79 - A.F.M. s/n )

Ocorrência nos dicionários: 


\begin{tabular}{|c|c|c|c|}
\hline Autor & Ano obra & Lexia & $\begin{array}{c}\text { Acepção correspondente } \\
\text { ao glossário }\end{array}$ \\
\hline RB & 1712 & + & + \\
\hline AMS & 1813 & - & - \\
\hline DV & 1873 & + & - \\
\hline LF & 1940 & + & - \\
\hline CA & 1958 & - & - \\
\hline ABHF & 1986 & + & + \\
\hline ZCN/RCN & 1996 & - & - \\
\hline AH/MSV & 2001 & + & + \\
\hline FSB & 2002 & - & - \\
\hline BB & 2003 & - & - \\
\hline
\end{tabular}

Análise descritiva dos dicionários gerais:

RB indica que a carne fresca é a carne do animal morto há pouco tempo. LF apresenta uma acepção classificada como popular para carne fresca definindo-a como a carne de uma pessoa recém falecida. DV cita a carne fresca, sem fornecer acepção e AH/MSV apresenta a carne fresca como sinônimo de carne verde.

Análise descritiva dos dicionários regionalistas:

Não consta a lexia nas referidas obras.

Carne salgada | s.m.

carne preparada com sal, geralmente guardada em barril || carne cortada em pedaço, passada na salmoura, empilhada e prensada para secar || carne comumente transportada em barril

Abonação: “... pois não podia esperar acontecesse em hum Paiz, em que incessantemente estão fazendo facturas de Carnes Salgadas, que se exportão para varios Portos da America, mas como tudo seja falivez, se remetteo ao Governador Sebastião Xavier huma Receita, ou hû preservativo aos prejuizos das Carnes Salgadas que continua a mandar..." (Doc 13v - Flo. 1798)

Ocorrência nos dicionários:

\begin{tabular}{|c|c|c|c|}
\hline Autor & Ano obra & Lexia & $\begin{array}{c}\text { Acepção correspondente } \\
\text { ao glossário }\end{array}$ \\
\hline RB & 1712 & - & - \\
\hline AMS & 1813 & - & - \\
\hline DV & 1873 & + & - \\
\hline LF & 1940 & - & - \\
\hline CA & 1958 & - & - \\
\hline ABHF & 1986 & - & - \\
\hline ZCN/RCN & 1996 & - & - \\
\hline
\end{tabular}




\begin{tabular}{|c|c|c|c|}
\hline AH/MSV & 2001 & - & - \\
\hline FSB & 2002 & - & - \\
\hline BB & 2003 & - & - \\
\hline
\end{tabular}

Análise descritiva dos dicionários gerais:

DV somente cita a carne salgada, sem fornecer a acepção.

Análise descritiva dos dicionários regionalistas:

Não consta a lexia nas referidas obras.

Carne seca | s.m.

carne produzida principalmente no nordeste || carne salgada e posta para secar || charque || carne de cor cinza amarelada, de aspecto desagradável, sensível às variações de umidade || tajano

Abonação: "Em 1818 a quantidade de carne seca exportada para Cuba e Estados Unidos subiu a 100 mil arrobas". (Doc 137 - A.S.H. 1820/21)

“A carne seca nāo se conserva mais de um ano. É exportada principalmente para o Rio de Janeiro, Bahia e Havana, onde serve de alimento para os negros”. (Doc 129 A.S.H. 1820/21)

“... estudo experimental, já que há mais de vinte e quatro anos que se faz carne seca em Pelotas, e que, já anteriormente, matava-se, parece, os bois dessa maneira.”. (Doc 86 - L.C. 1880)

“ ...sob o aspecto econômico e compensava o preço mais elevado desse charque, sobre o da carne-seca local." (Doc 74 - A.F.M. s/n)

Ocorrência nos dicionários:

\begin{tabular}{|c|c|c|c|}
\hline Autor & Ano obra & Lexia & $\begin{array}{c}\text { Acepção correspondente } \\
\text { ao glossário }\end{array}$ \\
\hline RB & 1712 & - & - \\
\hline AMS & 1813 & - & - \\
\hline DV & 1873 & - & - \\
\hline LF & 1940 & + & ++ \\
\hline CA & 1958 & - & - \\
\hline ABHF & 1986 & - & - \\
\hline ZCN/RCN & 1996 & - & - \\
\hline AH/MSV & 2001 & - & - \\
\hline FSB & 2002 & + & ++ \\
\hline BB & 2003 & - & - \\
\hline
\end{tabular}

Análise descritiva dos dicionários gerais: 
LF menciona a carne seca como uma carne salgada e posta ao sol para secar, apresentando a carne seca como sinônimo de charque. FSB apenas exibe no verbete a lexia carne seca como sinônimo de charque.

Nota: Louis Couty em sua obra: A Erva Mate e o Charque, critica a nomenclatura carne seca, como se pode observar na citação a seguir: "E, primeiramente, o que é verdadeiramente a carne seca? Este nome, já o disse, parece-me ruim, e é bem certo que o dessecamento, o que quer que se tenha escrito, um papel acessório... ... Mas esta carne seca é, além do mais, uma carne salgada; e é o sal que me parece desempenhar, na conservação efetiva, o papel principal."

Análise descritiva dos dicionários regionalistas:

Não consta a lexia nas referidas obras.

BB apresenta a expressão estar por cima da carne seca, definindo-a como estar bem financeiramente.

carne fresca

Abonação: “Artigo 71. - As carnes verdes serão conduzidas do matadouro para os açougues cobertas de panno de brim limpo.” (Doc 02 - Flo. 1896/1901)

“...Comprar, vender ou depositar nos açougues qualquer genero alem da carne verde, ou salgar esta nos açougues" (Doc 02 - Flo. 1896/1901)

"Fora do Rio Grande do Sul, os produtores de charque geralmente não abatiam os melhores novilhos, que eram reservados para os frigoríficos e destinavam-se ao consumo de carne verde ou à exportação.” (Doc 66 - A.F.M. s/n)

Ocorrência nos dicionários:

\begin{tabular}{|c|c|c|c|}
\hline Autor & Ano obra & Lexia & $\begin{array}{c}\text { Acepção correspondente } \\
\text { ao glossário }\end{array}$ \\
\hline RB & 1712 & - & - \\
\hline AMS & 1813 & - & - \\
\hline DV & 1873 & - & - \\
\hline LF & 1940 & + & + \\
\hline CA & 1958 & + & + \\
\hline ABHF & 1986 & + & + \\
\hline ZCN/RCN & 1996 & - & + \\
\hline AH/MSV & 2001 & + & - \\
\hline FSB & 2002 & - & - \\
\hline BB & 2003 & - & + \\
\hline
\end{tabular}


Análise descritiva dos dicionários gerais:

ABHF e AH/MSV apresentam as lexias carne fresca e carne verde como sinônimas. AH/MSV define a carne verde como a carne que se compra em açougues. CA e ABHF definem carne verde como a carne ainda não salgada.

Análise descritiva dos dicionários regionalistas:

Não consta a lexia nas referidas obras.

\section{$51 \quad$ Carneador $\mid$ s.m.}

empregado de charqueada responsável por sangrar o boi || operário que carneia o boi, retira o couro e separa a carne do osso

Abonação: "A carne dos membros é separada dos ossos; fazendo uma série de furos na carne com a ajuda de um facão e a separando por estes orifícios com dois dedos, o "carneador", em alguns instantes, deixa apenas ossos e articulações completamente intactos." (Doc 87 - L.C. 1880)

"Tal serviço era repetido 20 a 30 vezes seguidos, conforme a capacidade da cancha, distribuindo-se o trabalho entre igual número de carneadores. Quando o último carneador era servido, os primeiros já haviam carneado os seus animais e aguardavam novas peças." (Doc 114 - A.P.C. 1988)

"Ha dias fugio da xarqueada da Alfredo Gonçalves Moreira, o mulato Damasio, carneador, baixo, grosso de corpo, sem barba, de 18 a 20 annos, e bem claro. Ha noticias que anda pelas xarqueadas do Rio São Gonçalo, offerecendo-se para carnear e intitula-se livre." (Doc 33 - Pel. 1869)

Ocorrência nos dicionários:

\begin{tabular}{|c|c|c|c|}
\hline Autor & Ano obra & Lexia & $\begin{array}{c}\text { Acepção correspondente } \\
\text { ao glossário }\end{array}$ \\
\hline RB & 1712 & - & - \\
\hline AMS & 1813 & - & - \\
\hline DV & 1873 & - & - \\
\hline LF & 1940 & + & + \\
\hline CA & 1958 & - & - \\
\hline ABHF & 1986 & + & + \\
\hline ZCN/RCN & 1996 & + & ++ \\
\hline AH/MSV & 2001 & + & + \\
\hline FSB & 2002 & - & + \\
\hline BB & 2003 & + & ++ \\
\hline
\end{tabular}

Análise descritiva dos dicionários gerais: 
ABHF apresenta carneador como lexia regionalista sinônimo de magarefe. Este sinônimo é também usado por AH/MSVe LF.

Nota: O trabalhado do carneador era considerado um dos, senão, o mais importante em uma charqueada. Nos documentos do final do século XIX e XX, quando o trabalhador era assalariado e não mais escravizado, há informações de que o trabalho do carneador era um dos mais bem pagos dentro de um estabelecimento saladeril. Em documentos anteriores a esse período, pôde-se observar que o trabalho do carneador era realizado por um escravo com capacidade de trabalho superior aos demais.

Análise descritiva dos dicionários regionalistas:

As obras de ZCN/RCN e BB definem o carneador como indivíduo empregado nas charqueadas responsável por desmanchar a rês. BB ainda dá como sinônimo, a lexia carniceiro e apresenta ao consulente a entrada carneadeira, que é a faca especial usada pelo carneador. Ambos apresentam a lexia magarefe como sinônimo de carneador.

operário que, além de carnear o boi, também é responsável por impregnar o pedaço de carne com sal

Abonação: "Durante a matança o carneador recebia uma média de 25 fichas, que valiam, cada uma "um mil e quinhentos réis". Este serviço, assim como o dos carneadores salgadores, eram os mais bem pagos." (Doc 115 - A.P.C. 1988)

Ocorrência nos dicionários:

Não consta a lexia nas referidas obras.

\section{Carnear | v.}

abater o boi || retirar a carne da rês para consumo || esquartejar o animal

Abonação: "Ha noticias que anda pelas xarqueadas do Rio São Gonçalo, offerecendose para carnear e intitula-se livre. Quem o apprehender e levar a seu senhor será gratificado." (Doc 33 - Pel. 1869)

Ocorrência nos dicionários:

\begin{tabular}{|c|c|c|c|}
\hline Autor & Ano obra & Lexia & $\begin{array}{c}\text { Acepção correspondente } \\
\text { ao glossário }\end{array}$ \\
\hline RB & 1712 & - & - \\
\hline AMS & 1813 & - & - \\
\hline DV & 1873 & - & - \\
\hline
\end{tabular}




\begin{tabular}{|c|c|c|c|}
\hline LF & 1940 & + & ++ \\
\hline CA & 1958 & - & - \\
\hline ABHF & 1986 & + & ++ \\
\hline ZCN/RCN & 1996 & + & ++ \\
\hline AH/MSV & 2001 & + & ++ \\
\hline FSB & 2002 & + & + \\
\hline BB & 2003 & + & ++ \\
\hline
\end{tabular}

Análise descritiva dos dicionários gerais:

Somente na obra de $\mathbf{L F}$ é que a lexia carnear começa a ser dicionarizada. Este autor, assim como ABHF e AH/MSV apresenta, além da acepção correspondente ao glossário, a lexia carnear como sinônimo de charquear. CA não exibe a entrada, mas apresenta a lexia carneeiro como adjetivo do verbo carnear.

Análise descritiva dos dicionários regionalistas:

Ambas as obras regionalistas apresentam a acepção de carnear como matar, esfolar, esquartejar a rês para consumo ou preparo do charque. ZCN/RCN e BB apresentam a entrada carneação como substantivo derivado do verbo carnear. BB ainda revela a lexia carneadeira definida como uma faca especial para carnear, e o substantivo carneio apresentado como o ato de carnear.

Carregador de ossada e buchada $\mid$ s.m.

empregado da charqueada encarregado de transportar a buchada e a ossada para a graixeira

Abonação: "Ali estavam alinhados, esperando o primeiro boi, zorreiros, camboneiros... ... balanceiros, porteiros, guincheiros, carregadores de ossadas e buchadas..." (Doc 108 - A.P.C. 1988)

Ocorrência nos dicionários:

Não consta a lexia nas referidas obras.

Análise descritiva dos dicionários gerais:

RB apresenta o carregador como sendo somente aquele que carrega pessoas. AMS e DV apresentam o carregador como aquele que carrega navios. ABHF, AH/MSV e FSB definem a lexia como aquele que conduz bagagens, mercadoria etc. Nenhum dos autores apresenta a lexia mencionando o carregador como trabalhador de charqueada.

Análise descritiva dos dicionários regionalistas:

Não consta a lexia nas referidas obras. 


\section{Carreteiro| s.m.}

abreviatura de arroz-de-carreteiro

Abonação: "O carreteiro, com pouco tempo para soltar os bois, desencilhar o cavalo e atá-lo à soga, fazer fogo, cear o mate e cozinhar sua refeição, tinha que se limitar a preparar um prato rápido..."(Doc 75 - A.F.M. s/n)

Ocorrência nos dicionários:

\begin{tabular}{|c|c|c|c|}
\hline Autor & Ano obra & Lexia & $\begin{array}{c}\text { Acepção correspondente } \\
\text { ao glossário }\end{array}$ \\
\hline RB & 1712 & + & - \\
\hline AMS & 1813 & + & - \\
\hline DV & 1873 & + & - \\
\hline LF & 1940 & + & - \\
\hline CA & 1958 & + & - \\
\hline ABHF & 1986 & + & + \\
\hline ZCN/RCN & 1996 & + & ++ \\
\hline AH/MSV & 2001 & + & - \\
\hline FSB & 2002 & - & - \\
\hline BB & 2003 & + & ++ \\
\hline
\end{tabular}

Análise descritiva dos dicionários gerais:

RB, AMS, DV, LF, CA apresentam somente a acepção de carreteiro como aquele que governa, dirige a carreta. ABHF é o primeiro a introduzir a acepção de acordo com o glossário, indicando como sinônimo de arroz-de-carreteiro. Este autor é seguido por AH/MSV, que também informa a forma reduzida de arroz-de-carreteiro.

Análise descritiva dos dicionários regionalistas:

ZCN/RCN e BB primeiramente colocam carreteiro como variante na entrada arrozde-carreteiro ou arroz-carreteiro. $\mathrm{Na}$ entrada com a lexia carreteiro, os autores apresentam como prato campeiro feito com guisado de charque.

Carrinho-de-mão | s.m.

carro pequeno de três rodas utilizado na charqueada para transportar produtos em curtas distâncias

Abonação: “...Tres carrinhos de mão e uma carroça do serviço da olaria e chacara. Trinta e tantos carrinhos de mão do serviço da charqueada..." (Doc 49 - Poa 1870) 
"O competente João Doralino, um preto que tinha em bondade e respeito, tanto como seus 120 quilos, botava em forma cerca de 30 operários, cada um com seu carrinho de mão, para retirar o charque ainda pingando e depositá-lo sobre os varais que ocupavam mais de um hectare.” (Doc 121 - A.P.C. 1988)

Ocorrência nos dicionários:

\begin{tabular}{|c|c|c|c|}
\hline Autor & Ano obra & Lexia & $\begin{array}{c}\text { Acepção correspondente } \\
\text { ao glossário }\end{array}$ \\
\hline $\mathbf{R B}$ & 1712 & - & + \\
\hline AMS & 1813 & - & + \\
\hline DV & 1873 & + & + \\
\hline $\mathbf{L F}$ & 1940 & + & + \\
\hline CA & 1958 & + & + \\
\hline ABHF & 1986 & + & + \\
\hline ZCN/RCN & 1996 & - & - \\
\hline AH/MSV & 2001 & + & + \\
\hline FSB & 2002 & - & + \\
\hline BB & 2003 & - & - \\
\hline
\end{tabular}

Análise descritiva dos dicionários gerais:

RB, AMS e FSB apresentam a acepção correspondente ao do glossário, mas não denominam o tipo de carrinho como sendo de mão. Os demais dicionaristas apresentam a mesma acepção do glossário, apresentando no verbete a lexia carrinhode-mão. Em nenhuma obra, porém, se faz a menção do uso em charqueadas.

Análise descritiva dos dicionários regionalistas:

Não consta a lexia nas referidas obras.

Carroça s.f.

veículo puxado por boi ou cavalo utilizado na charqueada para o transporte dos produtos ou pessoas

Abonação: "Eu mesmo passei o rio sentado numa pelota chegando sem novidade à outra margem, bem como as bagagens e carroças." (Doc 135 - A.S.H. 1820/21)

“...Trinta e tantos carrinhos de mão do serviço da charqueada. Tres carroças da charqueada. Huma balança grande de pesar couros..." (Doc 49 - Poa 1870)

Ocorrência nos dicionários:

\begin{tabular}{|c|c|c|c|}
\hline Autor & Ano obra & Lexia & $\begin{array}{c}\text { Acepção correspondente } \\
\text { ao glossário }\end{array}$ \\
\hline RB & 1712 & + & - \\
\hline AMS & 1813 & + & - \\
\hline
\end{tabular}




\begin{tabular}{|c|c|c|c|}
\hline DV & 1873 & + & - \\
\hline LF & 1940 & + & + \\
\hline CA & 1958 & + & + \\
\hline ABHF & 1986 & + & + \\
\hline ZCN/RCN & 1996 & - & - \\
\hline AH/MSV & 2001 & + & + \\
\hline FSB & 2002 & + & + \\
\hline BB & 2003 & - & - \\
\hline
\end{tabular}

Análise descritiva dos dicionários gerais:

RB, AMS e DV apresentam na acepção carroça como carro comprido. A partir de LF as acepções dos dicionários passam a corresponder a do glossário. ABHF e AH/MSV fazem referência a lexia carrocim, definida como diminutivo de carroça.

Variantes: carrôça $(\mathrm{RB})$; carróça $(\mathrm{DV})$

Análise descritiva dos dicionários regionalistas:

BB apresenta carrocita como lexia de entrada com a mesma acepção, e menciona a lexia gaiota como diminutivo de carroça.

Casa de comércio de charque $\mid$ s.f.

estabelecimento onde se comercializa charque || armazém

Abonação: “... Senhor José Ignacio da Cunha, Cidadão Brasileiro, domiciliado com sua casa de commercio de Xarque na cidade de Pelotas Provincia do Rio Grande do Sul; e constando pelos documentos que apresentou, e diligencias a que se procedeu, que tem capacidade legal para poder commerciar..." (Doc 20 - Pel. 1854)

Variante: casa de commercio de xarque

Ocorrência nos dicionários:

\begin{tabular}{|c|c|c|c|}
\hline Autor & Ano obra & Lexia & $\begin{array}{c}\text { Acepção correspondente } \\
\text { ao glossário }\end{array}$ \\
\hline RB & 1712 & - & - \\
\hline AMS & 1813 & - & - \\
\hline DV & 1873 & - & + \\
\hline LF & 1940 & - & + \\
\hline CA & 1958 & - & - \\
\hline ABHF & 1986 & - & - \\
\hline ZCN/RCN & 1996 & - & - \\
\hline AH/MSV & 2001 & - & - \\
\hline FSB & 2002 & - & - \\
\hline BB & 2003 & - & - \\
\hline
\end{tabular}


Análise descritiva dos dicionários gerais:

RB apresenta a entrada casa de comércio, generalizando na acepção os produtos que são comercializados neste local. LF menciona em um tipos de casa a lexia casa da courama, definida como a casa onde se salga e empilha peles. Outra lexia também mencionada por LF é casa de negócios, como o local onde se compra e vende qualquer artigo. ABHF apresenta duas entradas para casa comercial, porém a acepção dada é como sinônimo de casa bancária ou de comércio de mercadorias em geral. Esta última acepção de ABHF também se encontra em AH/MSV.

Análise descritiva dos dicionários regionalistas:

Não consta a lexia nas referidas obras.

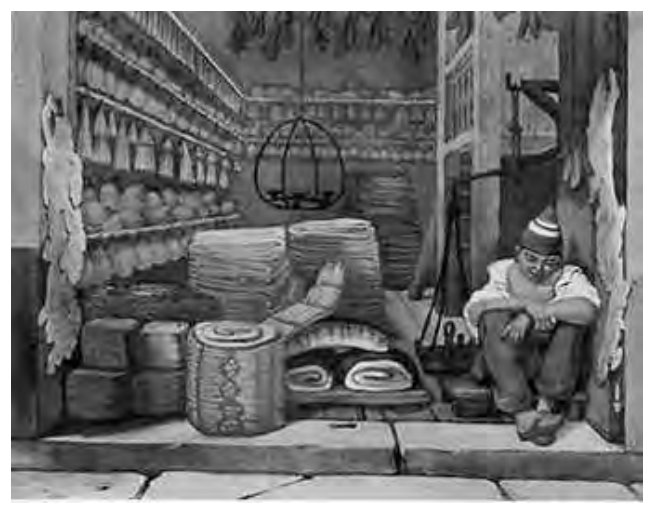

Fig. 4 Casa de comércio de Charque Aquarela "Loja di Carne Secca", de Jean-Baptiste Drebet

Casa de moradia $\mid$ s.f.

construção da charqueada usada para habitação || casa grande dividida em cômodos geralmente construída com um só pavimento || benfeitoria do estabelecimento saladeril

Abonação: "Um estabelecimento de xarqueada completamente montado prompto a trabalhar com todos seus acessorios casa de moradia chacara, potreiro, um terreno junto a ribeira..." (Doc 65 - Poa 1873)

Ocorrência nos dicionários:

\begin{tabular}{|c|c|c|c|}
\hline Autor & Ano obra & Lexia & $\begin{array}{c}\text { Acepção correspondente } \\
\text { ao glossário }\end{array}$ \\
\hline RB & 1712 & - & - \\
\hline AMS & 1813 & - & - \\
\hline DV & 1873 & - & - \\
\hline LF & 1940 & + & + \\
\hline CA & 1958 & - & - \\
\hline ABHF & 1986 & + & + \\
\hline
\end{tabular}




\begin{tabular}{|c|c|c|c|}
\hline ZCN/RCN & 1996 & - & - \\
\hline AH/MSV & 2001 & - & - \\
\hline FSB & 2002 & + & + \\
\hline BB & 2003 & - & - \\
\hline
\end{tabular}

Análise descritiva dos dicionários gerais:

LF e ABHF apresentam somente a lexia moradia como sinônimo de casa e não apresentam a locução casa de moradia conforme os documentos do corpus. AH/MSV apresenta morada como sinônimo de casa de moradia.

Nota: Geralmente a casa de moradia era ocupada pelos funcionários de posto mais elevado ou pelos proprietários da charqueada.

Análise descritiva dos dicionários regionalistas:

Não consta a lexia nas referidas obras.

Casa grande $\mid$ s.f.

construção dentro da charqueada habitada pela família do charqueador || casa destinada ao funcionário de alto escalão || casa de moradia

Abonação: "Meu pai foi chamado para administrar o estabelecimento e em 1931 transferimos residência para a casa grande da charqueada, com cerca de $1.000 \mathrm{~m} 2 \mathrm{de}$ construção e áreas de quartos que eqüivaliam a um excelente salão de festas" (Doc 106 - A.P.C. 1988)

Ocorrência nos dicionários:

\begin{tabular}{|c|c|c|c|}
\hline Autor & Ano obra & Lexia & $\begin{array}{c}\text { Acepção correspondente } \\
\text { ao glossário }\end{array}$ \\
\hline RB & 1712 & - & - \\
\hline AMS & 1813 & - & - \\
\hline DV & 1873 & - & - \\
\hline LF & 1940 & + & + \\
\hline CA & 1958 & - & - \\
\hline ABHF & 1986 & + & + \\
\hline ZCN/RCN & 1996 & + & + \\
\hline AH/MSV & 2001 & - & + \\
\hline FSB & 2002 & + & + \\
\hline BB & 2003 & + & + \\
\hline
\end{tabular}

Análise descritiva dos dicionários gerais: 
LF define a lexia como o local onde mora o proprietário da fazenda ou do engenho, não mencionando o charqueador ou estancieiro. ABHF apresenta casa grande como denominação usada nos tempos coloniais do Brasil. Assim como LF e FSB, este autor também exemplifica casa como moradia de fazendeiro ou proprietário de engenho de açúcar.

Análise descritiva dos dicionários regionalistas:

As obras de ZCN/RCN e BB não apresentam como exemplo de casa grande a propriedade de um charqueador, estes autores somente informam nas acepções (que são idênticas) que casa grande é a morada de fazendeiro. BB apresenta a lexia casas no plural, como a sede de uma estância.

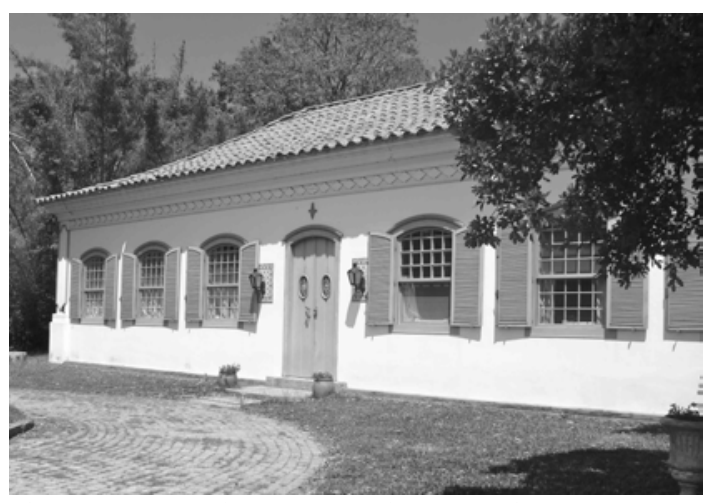

Fig 5 Casa Grande, Charqueada Santa Rita

Fonte: Cátia Schreiner, 2011

Chácara | s.f.

pequena fazenda || estabelecimento rural

Abonação: "Um estabelecimento de xarqueada completamente montado prompto a trabalhar com todos seus acessorios casa de moradia chacara, potreiro, um terreno junto a ribera ate na estrada que vai para a Boa Vista..." (Doc 65 - poa 1873)

“Artigo 134. - O proprietario, que encontrar em seus terrenos, quintaes ou chacaras, animaes á solta, de qualquer ...” (Doc 03 - Flo. 1889)

Ocorrência nos dicionários:

\begin{tabular}{|c|c|c|c|}
\hline Autor & Ano obra & Lexia & $\begin{array}{c}\text { Acepção correspondente } \\
\text { ao glossário }\end{array}$ \\
\hline RB & 1712 & + & - \\
\hline AMS & 1813 & + & + \\
\hline DV & 1873 & + & + \\
\hline LF & 1940 & + & + \\
\hline CA & 1958 & + & + \\
\hline ABHF & 1986 & + & + \\
\hline ZCN/RCN & 1996 & + & + \\
\hline
\end{tabular}




\begin{tabular}{|c|c|c|c|}
\hline AH/MSV & 2001 & + & + \\
\hline FSB & 2002 & + & + \\
\hline BB & 2003 & + & + \\
\hline
\end{tabular}

Análise descritiva dos dicionários gerais:

AMS apresenta chácara como sinônimo de sítio, quinta, roça, classificadas de acordo com a região a que pertencem. Outro lexicógrafo que classifica chácara como termo brasílico e de acordo com regiões é DV. A maioria dos autores informa nas acepções a lexia chácara como sinônimo de casa de detenção.

Variantes: xacara (RB); xácara (CA, ABHF, AH/MSV); chacra (ZCN/RCN, $\mathrm{AH} / \mathrm{MSV}, \mathrm{BB})$

Análise descritiva dos dicionários regionalistas:

BB apresenta a entrada chacareiro como dono, administrador de chácara, ou pequeno criador de gado. $\mathrm{O}$ autor menciona as lexias sítio, e sitiante, definindo como pequena propriedade rural, e morador, proprietário do sítio, respectivamente.

Variante: chacra $(\mathrm{ZCN} / \mathrm{RCN}, \mathrm{BB})$

Charque | s.m.

carne salgada e seca, bastante utilizada na alimentação por viajantes, escravos e pelas tropas do exército || carne salgada || jabá || carne seca || carne que perdeu suas características originais e foi transformada em alimento seco, de mau aspecto e com excesso de sal || tajano charque AA charque com alto teor de gordura dourado sobre as mantas || charque brasileiro de qualidade superior, que dispensa o uso de outras gorduras em seu preparo culinário || iguaria fina charque BB || charque de qualidade mediana, com baixo teor de gordura || charque GG charque gordo charque AA || charque de qualidade superior e alto teor de gordura charque MM charque considerado de qualidade ruim || charque magro e pelancudo charque magro charque com baixo teor de gordura charque SS charque com qualidade relativamente inferior que o AA || charque regular charque superior charque com qualidade superior aos demais produzidos em território nacional charque $\mathbf{X X}$ charque uniforme com pouca gordura, considerado tipo exportação 
Abonação: “...aumentaram ainda mais a demanda por charque. Barata e relativamente duradoura a carne salgada e seca era a base da alimentação de soldados e escravos. Sendo assim, quanto mais guerras e escravos, maior a procura por charque." (Doc 36 - Pel. 2007)

“ A gordura era tão importante que, na classificação oficial do charque, o critério principal era seu teor em partes gordas." (Doc 73 - A.F.M. s/n)

"O desenvolvimento da pecuária por todo o Brasil possibilitou a fabricação de charque em muitas regiões que antes eram consumidores de charque..." Doc 66 A.F s/n)

"Considerava-se com o AA o charque especial, com uma camada de gordura dourada sobre as mantas, destacando-se dos demais; como SS, o mesmo tipo, com um pouco menos de gordura; como o $\mathbf{X X}$ o charque um pouco gordo, muito parelho, e, como os anteriores, tipo exportação; a seguir vinham os tipos BB e GG, de pouca gordura..." (Doc 122 - A.P.C. 1988)

“... coloca o charque gordo entre as iguarias finas, com aroma sabor comparáveis aos dos mais famosos ingredientes da culinária mundial.” (Doc 73 - A.F.M. s/n )

"O charque magro é aferventado e desfiado (antigamente era socado em pilão), depois posto a fritar, temperado e misturado com farinha." (Doc 81 - A.F.M. s/n)

Variantes: xarque superior, xarque suprior

Ocorrência nos dicionários:

\begin{tabular}{|c|c|c|c|}
\hline Autor & Ano obra & Lexia & $\begin{array}{c}\text { Acepção correspondente } \\
\text { ao glossário }\end{array}$ \\
\hline RB & 1712 & - & - \\
\hline AMS & 1813 & + & + \\
\hline DV & 1873 & + & + \\
\hline LF & 1940 & + & + \\
\hline CA & 1958 & + & + \\
\hline ABHF & 1986 & + & + \\
\hline ZCN/RCN & 1996 & + & + \\
\hline AH/MSV & 2001 & + & + \\
\hline FSB & 2002 & + & + \\
\hline BB & 2003 & + & + \\
\hline
\end{tabular}

Análise descritiva dos dicionários gerais:

AMS menciona o charque como uma lexia empregada no sul do Brasil. Os dicionários pesquisados apresentam sinônimos e variantes para esta lexia, e, em alguns casos, especificam a região onde esta se emprega. DV curiosamente apresenta duas vezes esta entrada charque na obra, uma delas grafada com ch e a outra com $\mathrm{x}$, ambas como 
sendo do sul do Brasil. LF e AH/MSV, além da acepção, informam que este é um tipo de carne preparada para exportação.

Observação: AMS e DV levantam uma hipótese de que é possível que as palavras enxercar, enxercado e enxerqueira, tenham derivado da lexia xarque. CA apresenta somente verbo enxercar como derivado de xarque. AH/MSV indica em seu verbete que, segundo outros autores, estas lexias supostamente derivadas de xarque, são usadas em Portugal.

Nota: Os documentos do corpus apresentaram vários tipos diferentes de charque, classificados conforme a qualidade e o teor de gordura.

Variantes: xarque (AMS, DV); xárque (AH/MSV)

Análise descritiva dos dicionários regionalistas:

ZCN/RCN e BB definem o charque como tipo de carne salgada, feita com gado bovino. ZCN/RCN considera que a carne de sol produzida da Bahia ao Maranhão é muito mais saborosa que a produzida no sul do Brasil, no Uruguai e Argentina. Estes dicionaristas apresentam as lexias charquear, como sinônimo de preparar o charque e mencionam um tipo de charque, denominado de charque salgado, com a classificação de denominar um charque tipo exportação. BB ainda apresenta a lexia, charqueio, como o ato de charquear e colocar o charque fresco para secar.

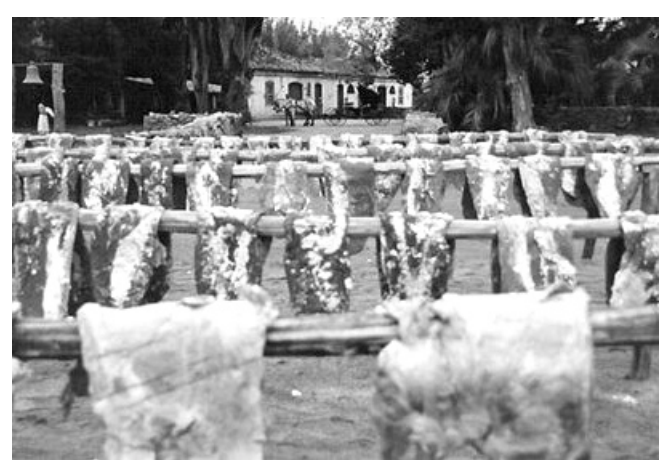

Fig. 6 Charque com sal grosso

Fonte: Site Assador gaúcho

Charque de vento $\mid$ s.m.

charque produzido com pouco sal || pedaço magro de carne charqueado e exposto ao sol e ao vento para secar

Abonação: “ A carne seca difere levemente quanto ao aroma e quanto ao gosto dos chamado charque de vento, sobre a preparação dos quais nos teremos de falar..." (Doc 93 - L.C. 1880) 
"Charques de vento - Passo, agora, a carnes em conserva mais importantes, ainda que, na maioria, elas não ocasionem grandes transações.” (Doc 102 - L.C. 1880)

Ocorrência nos dicionários:

\begin{tabular}{|c|c|c|c|}
\hline Autor & Ano obra & Lexia & $\begin{array}{c}\text { Acepção correspondente } \\
\text { ao glossário }\end{array}$ \\
\hline RB & 1712 & - & - \\
\hline AMS & 1813 & - & - \\
\hline DV & 1873 & - & - \\
\hline LF & 1940 & - & - \\
\hline CA & 1958 & + & + \\
\hline ABHF & 1986 & + & + \\
\hline ZCN/RCN & 1996 & + & + \\
\hline AH/MSV & 2001 & + & - \\
\hline FSB & 2002 & - & + \\
\hline BB & 2003 & + & + \\
\hline
\end{tabular}

Análise descritiva dos dicionários gerais:

CA, ABHF e AH/MSV definem charque-de-vento como um tipo de carne preparada para o consumo imediato, cortado em mantas finas, com pouco sal, secado ao vento. Em CA, na entrada do verbete, a lexia encontra-se grafada com ch, e, dentro do verbete, na acepção, encontra-se grafado com x.

Nota: Segundo alguns autores, o charque de vento supera o charque salgado em se tratando do odor e sabor. Depois de cozido o charque de vento tem a característica de quase retornar ao odor e sabor da carne fresca. Ao comparar a durabilidade do charque de vento ao salgado, este supera o anterior, pois o sal auxilia em sua conservação. Os autores informam que o charque de vento é usado no sul do país, em áreas rurais, como um meio de preservação de carne e não meio econômico de produção em massa, pois este é produzido somente em pequenas escalas. Nas áreas do país onde o tempo é mais seco, quente e onde venta mais, como no nordeste, este tipo de charque é bastante empregado.

Análise descritiva dos dicionários regionalistas:

ZCN/RCN e BB apresentam charque-de-vento como um tipo de charque preparado para o consumo nas estâncias, bastante saboroso, mas de pouca durabilidade. BB indica que este tipo de charque pode ser seco ao sol ou à sombra. 
Abonação: "O desenvolvimento da pecuária por todo o Brasil possibilitou a fabricação de charque em muitas regiões que antes eram consumidoras de charque rio-grandense e mesmo de charque platino." (Doc 66 - A.F.M. s/n)

"Muitas vezes vendiam-se só as guias brasileiras, sem a mercadoria, para serem ajuntadas ao charque platino, nosso concorrente." (Doc 69 - A.F.M. s/n)

Variantes: xarque superior, xarque suprior, xarque do Rio da Prata

Ocorrência nos dicionários:

Não consta a lexia nas referidas obras.

Nota: Nos documentos do corpus encontram-se referências de que o charque do Rio da Prata, ou charque platino era de qualidade superior ao produzido no sul do Brasil. Os fatores atribuídos a isso eram a qualidade dos bois e das pastagens. O charque platino e do sul eram preparados de maneira diferente. Louis Couty é o autor que discorre de forma bastante minuciosa sobre estas diferenças, comparando os processos, os rendimentos e a qualidade do charque produzido o Rio da Prata e em Pelotas.

Charqueada 1 | s.f.

estabelecimento onde se charqueia a carne || local onde se abate, salga e prepara a carne charqueada || estabelecimento saladeril || saladeiro

Abonação: “... da charqueada; tirados ou separados estes utencis e objectos deixa de existir a fabrica de charquear, ficando unicamente os galpões e [ca]zas que não valem o preço porque foi a[va]liada a charqueada toda." (Doc 50 - Poa 1870)

“... Em Pelotas, há registros de charqueadas instaladas na margens dos arroio Pelotas, fragata e Santa Bárbara e no canal São Gonçalo.” (Doc 35 - Pel. 2007)

Ocorrência nos dicionários:

\begin{tabular}{|c|c|c|c|}
\hline Autor & Ano obra & Lexia & $\begin{array}{c}\text { Acepção correspondente } \\
\text { ao glossário }\end{array}$ \\
\hline RB & 1712 & - & - \\
\hline AMS & 1813 & - & - \\
\hline DV & 1873 & + & ++ \\
\hline LF & 1940 & + & ++ \\
\hline CA & 1958 & + & ++ \\
\hline ABHF & 1986 & + & ++ \\
\hline ZCN/RCN & 1996 & + & ++ \\
\hline AH/MSV & 2001 & + & ++ \\
\hline FSB & 2002 & + & ++ \\
\hline
\end{tabular}




\begin{tabular}{|l|l|l|l|} 
BB & 2003 & + & ++ \\
\hline
\end{tabular}

Análise descritiva dos dicionários gerais:

AH/MSV e ABHF apresentam como sinônimo de charqueada a lexia tablada e, em sentido figurado, mencionam que charqueada é o mesmo que vencer o jogo.

Variante: charqueáda (DV)

Análise descritiva dos dicionários regionalistas:

ZCN/RCN e BB informam que, no Rio Grande do Sul, a expressão fazer charqueada é vencer no jogo, tomando todo o dinheiro dos adversários. BB também relata no verbete uma breve contextualização sobre a primeira charqueada instalada no RS.

Nota: As charqueadas eram compostos, geralmente, de diversas edificações, como: mangueiras, canchas, galpões, tanques de salga, um local especial para o preparo das gorduras, as barracas de couro, os depósitos, as casas de moradia, e grandes espaços ao ar livre onde estendiam-se os varais para secar as carnes ao sol.

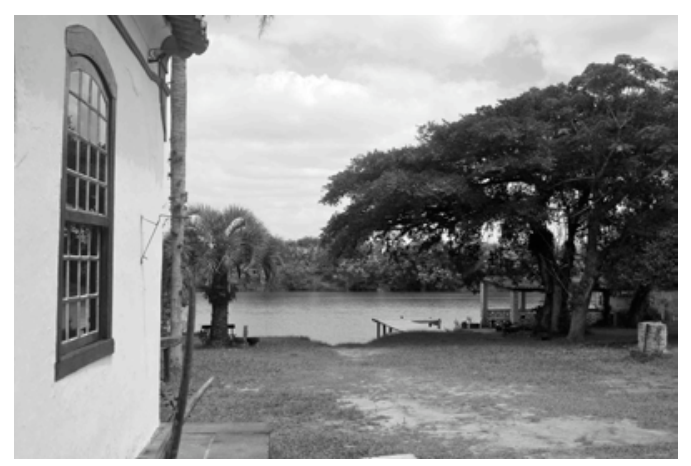

Fig.7 Charqueada Santa Rita

Fonte: Cátia Schreiner, 2010

\section{Charqueada 2 s.f.}

carne que sofreu o processo de salga e dessecamento

Abonação: "Assim, as mantas aumentam somente a metade de sua superfície e, em lugar de 1 metro, média variável, elas têm, uma vez charqueadas, 1 metro de 50 de maior largura...” (Doc 87/88 L.C. 1880)

"O que quer que seja, a carne charqueada em Pelotas é mais fina que no Rio da Prata..." (Doc 88 - L.C. 1880)

Ocorrência nos dicionários:

Não consta a lexia nas referidas obras. 
proprietário da charqueada || senhorio de produção de charque || fabricante de carne seca || aquele que compra gado, abate, retalha e comercializa o charque e os subprodutos fabricados na charqueada

Abonação: "O Senhor Chaves é um homem culto, sabendo o latim, o francês, com leituras de história natural, conversando muito bem. Pertence à classe dos xarqueadores ou fabricantes de carne seca...” (Doc 129 - A.S.H. 1820/21)

"Se nos campos, os charqueadores se entregavam à rude e violenta rotina de suas propriedades sem maiores pesares, na cidade - que crescia impulsionada por suas fortunas - se esforçavam para manter um estilo de vida refinado..." (Doc 34 - Pel. 2007)

“... O poder dos charqueadores pelotenses foi oficialmente consolidado a partir de 1829, quando o imperador dom Pedro I outorgou o primeiro título de nobreza a um fazendeiro do ramo.” (Doc 37 - Pel. 2007)

" O charqueador era um burguês bronco, cujo objetivo era ganhar dinheiro, a cultura era apenas um símbolo de status..." (Doc 34 - Pel. 2007)

Variante: xarqueador

Ocorrência nos dicionários:

\begin{tabular}{|c|c|c|c|}
\hline Autor & Ano obra & Lexia & $\begin{array}{c}\text { Acepção correspondente } \\
\text { ao glossário }\end{array}$ \\
\hline RB & 1712 & - & - \\
\hline AMS & 1813 & + & + \\
\hline DV & 1873 & + & + \\
\hline LF & 1940 & + & + \\
\hline CA & 1958 & + & + \\
\hline ABHF & 1986 & + & ++ \\
\hline ZCN/RCN & 1996 & + & ++ \\
\hline AH/MSV & 2001 & + & ++ \\
\hline FSB & 2002 & + & ++ \\
\hline BB & 2003 & + & ++ \\
\hline
\end{tabular}

Análise descritiva dos dicionários gerais:

Todas as obras, com exceção de RB, apresentam a lexia e a acepção correspondente ao glossário, inclusive mencionando a lexia charque em seus verbetes.

Nota: Os charqueadores, segundo historiadores, eram pessoas muito simples, que trabalhavam duramente, pois não era considerado fácil a tarefa de manter uma fábrica de charquear. Entretanto, esta classe tentava manter um padrão mais elevado, 
disfarçando a rudeza, buscando reconhecimento social em forma de títulos de nobreza ou mandando os filhos estudarem no exterior.

Análise descritiva dos dicionários regionalistas:

As obras regionalistas não trazem informações adicionais, apenas apresentam no verbete a variante saladerista, que não foi encontrada nas outras obras consultadas.

Charqueador 2 | s.m.

empregado de charqueada encarregado de charquear a carne || aquele que prepara a carne a ser charqueada

Abonação: “... em Pelotas, eles são estendidos sobre barras de madeira que sustentam sua parte mediana, e dois charqueadores os trabalham, cada um por um lado. Em todos os casos, a carne, ficando sempre estendida sobre a mesa ou sobre o suporte ..." ( Doc 87 - L.C. 1880)

"No numero dos escravos cujo aluguel eu desejo saber, comprehenden-se Xarqueadores, ximangos, salgadores, e descarneadores. Desejo saber se o preço do aluguel tem sido invariavel durante alguns annos atráz." (Doc 60 - Poa 1883)

"A carne tirada pelos carneadores era levada para os charqueadores, em números de três ou quatro, que faziam o seu corte em mantas e outros pedaços que compunham propriamente o "charque", como produto final.” (Doc 115 - A.P.C. 1988)

Variante: xarqueador

Ocorrência nos dicionários:

\begin{tabular}{|c|c|c|c|}
\hline Autor & Ano obra & Lexia & $\begin{array}{c}\text { Acepção correspondente } \\
\text { ao glossário }\end{array}$ \\
\hline RB & 1712 & - & - \\
\hline AMS & 1813 & - & - \\
\hline DV & 1873 & - & - \\
\hline LF & 1940 & + & ++ \\
\hline CA & 1958 & + & ++ \\
\hline ABHF & 1986 & + & ++ \\
\hline ZCN/RCN & 1996 & - & - \\
\hline AH/MSV & 2001 & + & ++ \\
\hline FSB & 2002 & + & ++ \\
\hline BB & 2003 & + & ++ \\
\hline
\end{tabular}

Análise descritiva dos dicionários gerais:

$\mathrm{Na}$ grande maioria dos dicionários pesquisados, os autores usam o substantivo fabricante para distinguir o charqueador empregado do charqueador proprietário. 
Análise descritiva dos dicionários regionalistas:

ZCN/RCN apresenta a lexia charqueador somente com a definição de proprietário. Já BB apresenta ambas, indicando o charqueador também como a pessoa que fabrica o charque.

\section{Charqueagem | s.f.}

processo de uniformização do pedaço de carne a ser salgado || ação de cortar a parte mais espessa da manta de carne afim de regularizar a superfície de dessecamento e de salga

Abonação: "Resta a operação mais delicada, pois ela tem por objeto fazer passar estes pedaços de carne irregulares em forma e espessura ao estado de retalhos, igualmente espessos em toda a parte e cujos contornos não terão forma definida; é a "charqueagem" e, ainda que complicada é feita, também, muito rapidamente." (Doc 87 - L.C. 1880)

Ocorrência nos dicionários:

Não consta a lexia nas referidas obras.

\section{$70 \quad$ Chatasca $\mid$ s.f.}

prato preparado com charque temperado, desfiado, fervido e engrossado com farinha de mandioca

Abonação: “Chatasca ou Xatasca Receita para 4 pessoas” (Doc 78 - A.F.M. s/n)

Variante: xatasca

Ocorrência nos dicionários:

Não consta em nenhuma obra ocorrência da lexia em questão.

71 Chifre| s.m.

parte externa óssea da cabeça do animal || subproduto de charqueada || guampa || corno

Abonação: “ Os chifres são, por toda a parte, tratados e vendidos da mesma maneira: o invólucro córneo externo, que tem mais valor, é separado...” (Doc 97 - L.C. 1880) 
"O laçador preparava, então, sua laçada, quase exatamente da medida do afastamento dos chifres do animal que pretendia laçar.” (Doc 110 A.P.C. 1988)

Ocorrência nos dicionários:

\begin{tabular}{|c|c|c|c|}
\hline Autor & Ano obra & Lexia & $\begin{array}{c}\text { Acepção correspondente } \\
\text { ao glossário }\end{array}$ \\
\hline RB & 1712 & + & - \\
\hline AMS & 1813 & - & - \\
\hline DV & 1873 & + & + \\
\hline LF & 1940 & + & + \\
\hline CA & 1958 & + & + \\
\hline ABHF & 1986 & + & - \\
\hline ZCN/RCN & 1996 & - & + \\
\hline AH/MSV & 2001 & + & + \\
\hline FSB & 2002 & + & - \\
\hline BB & 2003 & - & + \\
\hline
\end{tabular}

Análise descritiva dos dicionários gerais:

A maioria dos autores apresenta uma remissão desta entrada para a lexia corno, que concorda com a acepção do glossário.

Variante: chifro (RB, AH/MSV)

Análise descritiva dos dicionários regionalistas:

BB apresenta a entrada corno, com a mesma acepção do glossário para chifre. Ambos os dicionaristas apresentam nas obras a lexias chifraço, definindo-a como golpe com chifres; mocho, como uma raça de gado sem chifre.

Chimango | s.m.

trabalhador de charqueada

Abonação: "No numero dos escravos cujo aluguel eu desejo saber, comprehenden-se Xarqueadores, ximangos, salgadores, e descarneadores.” (Doc 60 - Poa 1883)

“... Guilherme carneador, Adriano Carneador, Firmino carneador, Sergio carneador, Mathias salgador, Salviano, salgador, Saturnino chimango, Benedicto, chimango, Paulo carpinteiro, Antonio cozinheiro..." (Doc 62 - Poa 1873)

Variante: ximango

Ocorrência nos dicionários:

\begin{tabular}{|c|c|c|c|}
\hline Autor & Ano obra & Lexia & $\begin{array}{c}\text { Acepção correspondente } \\
\text { ao glossário }\end{array}$ \\
\hline RB & 1712 & - & - \\
\hline AMS & 1813 & - & - \\
\hline DV & 1873 & - & - \\
\hline LF & 1940 & + & - \\
\hline
\end{tabular}




\begin{tabular}{|c|c|c|c|}
\hline CA & 1958 & + & - \\
\hline ABHF & 1986 & + & - \\
\hline ZCN/RCN & 1996 & + & - \\
\hline AH/MSV & 2001 & + & - \\
\hline FSB & 2002 & + & - \\
\hline BB & 2003 & + & - \\
\hline
\end{tabular}

Análise descritiva dos dicionários gerais:

Nas obras encontraram-se diferentes acepções, sem que nenhuma delas fizesse referência a qualquer tipo de trabalho manual. Entre a nomenclatura de aves e a alcunha dada aos federalistas pelos governistas durante a Revolução Farroupilha, autores como $\mathbf{C A}$ e $\mathbf{A B H F}$, informaram que, principalmente no RS, é denominado de chimango um tipo tenaz de arame destinado a retirar brasas dos fogões.

Variante: ximango (LF, CA, ABHF, AH/MSV, BB)

Análise descritiva dos dicionários regionalistas:

Assim como CA e ABHF, as obras regionalistas também citam chimango como um tipo tenaz de arame destinado a retirar brasas dos fogões. ZCN/RCN apresenta outras duas lexias relacionadas a chimango, a dizer, chimangada, definida como grupo de chimangos e chimanguice, que é a ação própria de chimangos.

Churrasco $\mid$ s.m.

pedaço de carne assado na grelha ou no espeto || carne assada que pode ser feita com charque especial macio

Abonação: “ Churrasco de charque É um dos pratos mais saborosos da culinária gaúcha, com a condição de que se utilize um charque especial para ser assado..." (Doc 78 - A.F.M. s/n)

Ocorrência nos dicionários:

\begin{tabular}{|c|c|c|c|}
\hline Autor & Ano obra & Lexia & $\begin{array}{c}\text { Acepção correspondente } \\
\text { ao glossário }\end{array}$ \\
\hline RB & 1712 & - & - \\
\hline AMS & 1813 & - & - \\
\hline DV & 1873 & - & - \\
\hline LF & 1940 & + & + \\
\hline CA & 1958 & + & - \\
\hline ABHF & 1986 & + & + \\
\hline ZCN/RCN & 1996 & + & + \\
\hline AH/MSV & 2001 & + & + \\
\hline FSB & 2002 & + & + \\
\hline
\end{tabular}




\section{BB}

2003

$+$

$+$

Análise descritiva dos dicionários gerais:

Todos os autores que apresentam a lexia somente exemplificam o uso de carne de rês crua, podendo ser usados outros tipos de animais, como carneiro, ovelha, porco etc.

Análise descritiva dos dicionários regionalistas:

Nem mesmo as obras regionalistas apresentaram o churrasco sendo preparado com um pedaço de charque. O churrasco de charque, contudo, foi um prato apresentado em uma das bibliografias componentes do corpus do trabalho. Outra lexia que pode ser considerada sinônimo de churrasco é assado. Esta lexia é mencionada nas obras de BB e ZCN/RCN, que apresentam a palavra assador, como aquele que assa o churrasco, ou assado.

Ciclo do charque | s.m.

período compreendido entre o final do século XVIII e início do século XX que marca o surgimento, apogeu e fim do período mais produtivo da fabricação de charque

Abonação: “... a missão de redigir o curto texto que selará para sempre o destino do

Ciclo do Charque: a Lei Áurea. Os dois artigos redigidos por Vianna e lidos pela princesa Isabel, em 13 de maio de 1888...” (Doc 35 - Pel. 2007)

“Ao contrário de seus contemporâneos, Osório não se imobilizou quando o Ciclo do Charque deu os primeiros sinais de esgotamento e passou a investir na produção de arroz.” (Doc 47 - Pel. 2007)

“... "Episódios do Ciclo do Charque”... ...no capítulo dedicado a Rosário do Sul, referimo-nos ao sistema de venda de gado mediante pesagem antes do abate..." (Doc 70 - A.F.M. s/n)

Ocorrência nos dicionários:

\begin{tabular}{|c|c|c|c|}
\hline Autor & Ano obra & Lexia & $\begin{array}{c}\text { Acepção correspondente } \\
\text { ao glossário }\end{array}$ \\
\hline RB & 1712 & - & - \\
\hline AMS & 1813 & + & - \\
\hline DV & 1873 & - & - \\
\hline LF & 1940 & + & - \\
\hline CA & 1958 & + & - \\
\hline ABHF & 1986 & + & - \\
\hline ZCN/RCN & 1996 & - & - \\
\hline
\end{tabular}




\begin{tabular}{|c|c|c|c|}
\hline AH/MSV & 2001 & + & - \\
\hline FSB & 2002 & + & - \\
\hline BB & 2003 & - & - \\
\hline
\end{tabular}

Análise descritiva dos dicionários gerais:

Inúmeros historiadores e autores definem ciclo como uma época ou período de tempo. Os dicionaristas expõem nas acepções o ciclo como certa ordem de fatores que devem se repetir da mesma maneira, formando um círculo. Entretanto, lexicógrafos como CA, ABHF e AH/MSV, definem ciclo o período histórico em que ocorrem fatos importantes a partir de um acontecimento, ou uma fase em que predomina determinado fato político, econômico etc. Entre estes autores, nenhum deles menciona o ciclo do charque, e sim, somente o ciclo do ouro ou das navegações.

Análise descritiva dos dicionários regionalistas:

Não consta a lexia nas referidas obras.

BB somente apresenta a Idade do Couro, fazendo referência aos primórdios da história do Rio Grande, quando o gado alçado existia em quantidade e era abatido somente para o aproveitamento do couro.

Coleiro| s.m.

empregado da charqueada encarregado de derrubar a rês na zorra || aquele que pega 0 animal pela cola (rabo) afim de posicionar o animal para 0 abate

Abonação: "Ali estavam alinhados, esperando o primeiro boi, zorreiros, camboneiros, coleiros, carneadores, charqueadores, aguateiros, salgadeiros, matambreiros..." (Doc 108 - A.P.C. 1988)

Ocorrência nos dicionários:

\begin{tabular}{|c|c|c|c|}
\hline Autor & Ano obra & Lexia & $\begin{array}{c}\text { Acepção correspondente } \\
\text { ao glossário }\end{array}$ \\
\hline RB & 1712 & - & - \\
\hline AMS & 1813 & - & - \\
\hline DV & 1873 & - & - \\
\hline LF & 1940 & + & - \\
\hline CA & 1958 & + & - \\
\hline ABHF & 1986 & + & - \\
\hline ZCN/RCN & 1996 & - & - \\
\hline AH/MSV & 2001 & + & - \\
\hline FSB & 2002 & - & - \\
\hline BB & 2003 & - & - \\
\hline
\end{tabular}


Análise descritiva dos dicionários gerais:

Acredita-se que o nome originou do castelhano cola: rabo, e por isso, a denominação coleiro não tem a acepção nos dicionários portugueses estudados. Este tipo de trabalho era provavelmente específico do sul do país, onde houve mais influência castelhana na fala sul rio-grandense.

Variante: colleiro (LF)

Análise descritiva dos dicionários regionalistas:

Os autores $\mathbf{Z C N} / \mathbf{R C N}$ e BB apresentam a lexia de entrada colear, definindo-a como o ato de fazer tombar, cair a rês puxando pela cola ou cauda.

Combalido | adj.

pedaço de carne estragado, putrefato || em mau estado de conservação Abonação: “... que se venderão por muito diminuto peço por se achar já combalida a Carne, lansando-se ao Mar o resto: Não sei se o efeito procedeo da qualidade das Rezes, se da Madeira dos Barriz se da impropriedade da Estação, ou da ignorancia de quem fez as Salgas..." (Doc 13v - Flo. 1798)

Ocorrência nos dicionários:

\begin{tabular}{|c|c|c|c|}
\hline Autor & Ano obra & Lexia & $\begin{array}{c}\text { Acepção correspondente } \\
\text { ao glossário }\end{array}$ \\
\hline RB & 1712 & + & - \\
\hline AMS & 1813 & + & - \\
\hline DV & 1873 & + & + \\
\hline LF & 1940 & + & + \\
\hline CA & 1958 & + & + \\
\hline ABHF & 1986 & + & - \\
\hline ZCN/RCN & 1996 & - & + \\
\hline AH/MSV & 2001 & + & - \\
\hline FSB & 2002 & + & - \\
\hline BB & 2003 & - & + \\
\hline
\end{tabular}

Análise descritiva dos dicionários gerais:

Considerou-se como acepção correspondente as lexias que apresentaram a definição de combalido como podre para qualquer tipo de alimento, mesmo que não tenham citado especificamente a carne. As obras consultadas apresentam principalmente a acepção de combalido como abatido, enfraquecido.

Nota: Nos documentos do corpus, observou-se que toda e qualquer carne denominada combalida era imediatamente considerada imprópria para o consumo. 
Variante: combalîdo (RB)

Análise descritiva dos dicionários regionalistas:

Não consta a lexia nas referidas obras.

Conserva $\mid$ s.f.

produto fabricado na charqueada || subproduto geralmente feito com a língua do animal

Abonação: “... transformação do sangue em gelatina, das vísceras em guano, das línguas em conservas etc." (Doc 96 - L.C. 1880)

“... conservas especiais são feitas com as línguas, mas existe também uma fábrica de conservas de língua em Pelotas...” (Doc 97 - L.C. 1880)

Ocorrência nos dicionários:

\begin{tabular}{|c|c|c|c|}
\hline Autor & Ano obra & Lexia & $\begin{array}{c}\text { Acepção correspondente } \\
\text { ao glossário }\end{array}$ \\
\hline RB & 1712 & + & + \\
\hline AMS & 1813 & + & + \\
\hline DV & 1873 & + & + \\
\hline LF & 1940 & + & + \\
\hline CA & 1958 & + & + \\
\hline ABHF & 1986 & + & + \\
\hline ZCN/RCN & 1996 & - & - \\
\hline AH/MSV & 2001 & + & + \\
\hline FSB & 2002 & + & + \\
\hline BB & 2003 & - & - \\
\hline
\end{tabular}

Análise descritiva dos dicionários gerais:

RB cita doces e líquidos como exemplos de conservas. AMS e CA definem a conserva como caldas ou líquidos que livram da corrupção o corpo metido nela. Este último autor apresenta como sinônimo a lexia salmoira.

Análise descritiva dos dicionários regionalistas:

Não consta a lexia nas referidas obras.

\section{Conserva enlatada $\mid$ s.f.}

produto produzido na charqueada embalado em lata || recurso industrial utilizado na charqueada para melhor aproveitamento do animal abatido 
Abonação: " O fabrico de conservas enlatadas às charqueadas começou mais cedo que a introdução da indústria frigorífica." (Doc 71 - A.F.M. s/n)

Ocorrência nos dicionários:

\begin{tabular}{|c|c|c|c|}
\hline Autor & Ano obra & Lexia & $\begin{array}{c}\text { Acepção correspondente } \\
\text { ao glossário }\end{array}$ \\
\hline RB & 1712 & - & - \\
\hline AMS & 1813 & - & - \\
\hline DV & 1873 & - & - \\
\hline LF & 1940 & - & - \\
\hline CA & 1958 & - & - \\
\hline ABHF & 1986 & - & - \\
\hline ZCN/RCN & 1996 & - & - \\
\hline AH/MSV & 2001 & + & + \\
\hline FSB & 2002 & - & + \\
\hline BB & 2003 & - & - \\
\hline
\end{tabular}

Análise descritiva dos dicionários gerais:

CA e ABHF apresentam a entrada conserva como líquido ou calda que se conserva gêneros alimentícios, mas não mencionam sobre a conserva enlatada destes alimentos. AH/MSV menciona no verbete a conserva enlatada. FSB, por sua vez, apresenta na acepção a definição de conserva enlatada, indicando-a como líquido que está hermeticamente fechado em lata.

Nota: De acordo com Alvarino da Fontoura Marques, este recurso industrial adotado pelas charqueadas modernas, muitas vezes, gerava lucro superior ao dos produtos principais das charqueadas tradicionais.

Análise descritiva dos dicionários regionalistas:

Não consta a lexia nas referidas obras.

Contrabando de charque $\mid$ s.m.

comércio de charque sem o controle fiscal do Estado

Abonação: “... Contrabando de xarque O remedio verdadeiramente efficaz para evita-lo, que reverteria em extraordinarias vantagens para o Estado, sob multiplos sentidos, seria, sem duvida nenhuma, o já apontado por outros e também por nós..." (Doc 24 - Pel. 1927)

"O contrabando, tanto o de gado como o de charque, trazia grandes lucros às charqueadas e frigoríficos da fronteira, a ponto de muitos deverem sua propriedade, 
exclusivamente ao fato de estarem localizados junto à linha divisória..." (Doc 69 A.F.M. s/n)

Variante: contrabando de xarque

Ocorrência nos dicionários:

Não consta a lexia nas referidas obras.

Análise descritiva dos dicionários regionalistas:

BB apresenta as lexias chibeiro ou muambeiro como aquele que realiza o contrabando. Nota: As grandes propriedades rurais, ou latifúndios, acabavam facilitando este tipo de prática, pois era inviável uma fiscalização eficiente nas grandes propriedades particulares. No início do século XX, a preocupação com o contrabando de charque aumentava consideravelmente, uma vez que Estados como Mato Grosso e São Paulo também estavam produzindo o produto. A concorrência, somada ao contrabando existente há anos, aumentava o prejuízo do dos charqueadores gaúchos.

\section{Contrabando de gado $\mid$ s.m.}

comercialização de gado sem controle fiscal || ação praticada por alguns proprietários de gado para evitar o pagamento de imposto

Abonação: "No que fica exposto - deixamos exaradas as suggestões que nos ocorrem com referencia ao contrabando do gado de córte, para consumo." (Doc 24 - Pel. 1927)

"O contrabando, tanto o de gado como o de charque, trazia grandes lucros às charqueadas e frigoríficos da fronteira, a ponto de muitos deverem sua propriedade, exclusivamente ao fato de estarem localizados junto à linha divisória..." (Doc 69 A.F.M. s/n)

Ocorrência nos dicionários:

Não consta a lexia nas referidas obras.

Nota: As grandes propriedades rurais, ou latifúndios, faziam com que o contrabando de gado fosse intensificado devido à localização destas propriedades em regiões fronteiriças. No Rio Grande do Sul o contrabando de gado era realizado nas divisas com os países vizinhos onde o gado, além de ser de era de melhor qualidade, poderia ser comercializado sem o pagamento do imposto, baixando o preço e aumentando o lucro dos charqueadores. 
parte externa do animal bovino || pele limpa de fragmentos de gordura ou carne || parte do animal usada em barracas, montarias, vestuário, meio de transporte etc Abonação: "Nāo podiam escolher melhor local pois aí recebem, sem a mínima dificuldade, o gado criado nas gordas pastagens situadas ao sul do Jacuí e facilmente exportam a carne seca e os couros através dos rios Pelotas e Sāo Gonçalo.” (Doc 130 - A.S.H. 1820/21)

“... o boi é imediatamente despojado de seu couro. Faz-se uma incisão e esfola-se primeiro a cabeça; depois, quando se chega ao pescoço...” (Doc 86 - L.C. 1880)

“... Couros de boi - Para o Rio de Janeiro, 153.866; Bahia, 26.244; Pernambuco..." (Doc 131 - A.S.H. 1820/21)

“... Couros de éguas - Para o Rio de Janeiro, 1.746; Guernesey, 63; Nova York, 320; total.". (Doc 131 - A.S.H. 1820/21)

“ Estes couros são, geralmente, de muito boa qualidade, e têm na Europa um verdadeiro renome. Seu preço é relativamente elevado para os melhores, os mais espessos. Os de vaca são vendidos de 20 a 30 \% menos que os de boi..." (Doc 100 L.C. 1880)

Ocorrência nos dicionários:

\begin{tabular}{|c|c|c|c|}
\hline Autor & Ano obra & Lexia & $\begin{array}{c}\text { Acepção correspondente } \\
\text { ao glossário }\end{array}$ \\
\hline RB & 1712 & + & + \\
\hline AMS & 1813 & + & + \\
\hline DV & 1873 & + & + \\
\hline LF & 1940 & + & + \\
\hline CA & 1958 & + & + \\
\hline ABHF & 1986 & + & - \\
\hline ZCN/RCN & 1996 & + & + \\
\hline AH/MSV & 2001 & + & + \\
\hline FSB & 2002 & + & - \\
\hline BB & 2003 & + & \\
\hline
\end{tabular}

Análise descritiva dos dicionários gerais:

RB define couro como pele, despojo do animal. Sobre seu uso, RB menciona uma vasta nomenclatura de couros, dada a variedade de animais, terras e usos. AMS apresenta a acepção como "a pele dos animais". DV apresenta alguns tipos de couros fornecendo definição detalhada do que são compostos e onde são preparados. CA 
apresenta inúmeras acepções para couro em sentido figurado. Essa tendência de é seguida por AH/MSV, ABHF e FSB, que apresentam um grande número de expressões.

Nota: Foram encontradas, nas obras, referência aos couros especificamente de bois, éguas e vacas. Estes tipos não serão apresentados em verbetes individuais neste glossário.

Variantes: còuro (DV); còiro (DV); coiro (ABHF, AH/MSV)

Análise descritiva dos dicionários regionalistas:

As obras regionalistas de ZCN/RCN e BB não apresentam couro como lexia de entrada, entretanto apresentam as lexias couro cru e couro nonato. Não há referência sobre a fabricação de couro nas charqueadas ou em período anterior aos estabelecimentos saladeris. Os dicionaristas fornecem o verbo courear, como ação de tirar o couro do animal; o substantivo coureada, ação de courear e o substantivo coureador ou coireador, definindo-o como o indíviduo que de coureia.

\section{Couro salgado $\mid$ s.m.}

couro mergulhado na salmoura || couro que passou pelo processo de salga no tanque de água

Abonação: “Seus preços variam menos que os da carne; e, enquanto que esta venderá cinco vezes menos que na Europa, um couro salgado terá quase um valor comparável." (Doc 98 - L.C. 1880)

Ocorrência nos dicionários:

Não consta a lexia nas referidas obras.

Nota: Segundo Louis Couty alguns estabelecimentos saladeris pelotenses deixavam o couro mergulhado em salmoura por mais de 24 horas e, após a retirada, estes couros recebiam uma camada extra de sal antes de serem dobrados.

Couro vacum seco $\mid$ s.m.

espécie de couro preparado a partir de gado tipo vaccum

Abonação: “Para Pernambuco com escalla, a barra nacional - Norma-de 224 toneladas manifestou 10084 arrobas de xarque, 50 couros vaccuns seccos de refugo, 
356 arrobas de graixa. 400 restea de sebolas, 805 arrobas de sebo..." (Doc 28 - Pel. 1863)

“... Hampton Roads, no patacho americano -H.C. Brock - Carlos Raynsford 500 couros vaccuns seccos." (Doc 28 - Pel. 1869)

Variante: couro vaccum secco

Ocorrência nos dicionários:

\begin{tabular}{|c|c|c|c|}
\hline Autor & Ano obra & Lexia & $\begin{array}{c}\text { Acepção correspondente } \\
\text { ao glossário }\end{array}$ \\
\hline RB & 1712 & - & + \\
\hline AMS & 1813 & - & - \\
\hline DV & 1873 & - & - \\
\hline LF & 1940 & + & + \\
\hline CA & 1958 & - & - \\
\hline ABHF & 1986 & - & - \\
\hline ZCN/RCN & 1996 & - & - \\
\hline AH/MSV & 2001 & - & - \\
\hline FSB & 2002 & - & - \\
\hline BB & 2003 & - & - \\
\hline
\end{tabular}

Análise descritiva dos dicionários gerais:

RB apenas cita o couro vacum seco, sem definir a acepção. LF cita o couro seco, sem especificação, definindo-a como pele apenas salgada, mas já seca.

Análise descritiva dos dicionários regionalistas:

Não consta a lexia nas referidas obras.

Couro verde $\mid$ s.m.

couro que passou pelo processo de salga, mas não foi seco

Abonação: "Sabe-se que estes couros são transportados para a Europa ainda verdes, ou melhor, conservados pela salga..." (Doc 99 - L.C. 1880)

Variante: couro vaccum secco

Ocorrência nos dicionários:

\begin{tabular}{|c|c|c|c|}
\hline Autor & Ano obra & Lexia & $\begin{array}{c}\text { Acepção correspondente } \\
\text { ao glossário }\end{array}$ \\
\hline RB & 1712 & - & - \\
\hline AMS & 1813 & - & - \\
\hline DV & 1873 & + & + \\
\hline LF & 1940 & + & + \\
\hline CA & 1958 & + & + \\
\hline ABHF & 1986 & - & - \\
\hline ZCN/RCN & 1996 & - & - \\
\hline
\end{tabular}




\begin{tabular}{|c|c|c|c|}
\hline AH/MSV & 2001 & - & - \\
\hline FSB & 2002 & - & - \\
\hline BB & 2003 & - & - \\
\hline
\end{tabular}

Análise descritiva dos dicionários gerais:

DV e CA apresenta o couro cru como sinônimo de couro verde. LF e AH/MSV definem este tipo de couro como a pele que vem diretamente do matadouro ainda mole e fresca, ou apenas salgada. Para LF, CA, AH/MSV, couro fresco e cru são sinônimos de couro verde.

Análise descritiva dos dicionários regionalistas:

Não consta a lexia nas referidas obras.

Cuba $\mid$ s.f.

espécie de tina usada no preparo de gordura e sebo || objeto côncavo de madeira, circundado de ferro, usado na caldeira para fabricação da graxa

Abonação: “ A cocção sob vapor dura de 36 a 50 horas para as grandes cubas de gordura de ossos e de vísceras: ela é muito mais rápida para as pequenas cubas de "sebum"." (Doc 98 - 1.C. 1880)

"Direi somente que estas gorduras ou estes sebos são preparados em cubas pela cocção sob vapor a uma pressão bastante forte..." (Doc 98 - L.C. 1880)

Ocorrência nos dicionários:

\begin{tabular}{|c|c|c|c|}
\hline Autor & Ano obra & Lexia & $\begin{array}{c}\text { Acepção correspondente } \\
\text { ao glossário }\end{array}$ \\
\hline RB & 1712 & + & - \\
\hline AMS & 1813 & + & - \\
\hline DV & 1873 & + & - \\
\hline LF & 1940 & + & - \\
\hline CA & 1958 & + & - \\
\hline ABHF & 1986 & + & - \\
\hline ZCN/RCN & 1996 & - & - \\
\hline AH/MSV & 2001 & + & - \\
\hline FSB & 2002 & + & - \\
\hline BB & 2003 & - & - \\
\hline
\end{tabular}

Análise descritiva dos dicionários gerais:

RB, AMS e DV apresentam a lexia cuba definindo-a como vaso grande para guardar líquidos, principalmente vinho. ABHF e LF generalizam a acepção informando aos consulentes que as cubas podem ter vários usos nas indústrias. 
Variante: cùba (RB)

Análise descritiva dos dicionários regionalistas:

Não consta a lexia nas referidas obras.

Depósito | s.m.

local utilizado para guardar mantimentos e utensílios de charqueada || armazém Abonação: “ ... Madeiras e outros materiaes de construção Deposito de sal, Deposito de xarque Deposito de outros gêneros..." (Doc 04 - Flo. 1896/98)

"Em Pernambuco o deposito de xarque, até o dia 9, era o seguinte: do Rio Grande. Barca Social 3.000 arrobas, patacho Palheiro 3.000, patacho Marinhas 13.000, barca Pombinha 5,500, barca Andrade..." (Doc 31 - Pel. 1869)

"Deposito de sal 20\$. Deposito de xarque 50\$. Deposito de outros generos 20\$ a 160\$..." (Doc 04 - Flo. 1896/98)

Variantes : depozito, deposito

Ocorrência nos dicionários:

\begin{tabular}{|c|c|c|c|}
\hline Autor & Ano obra & Lexia & $\begin{array}{c}\text { Acepção correspondente } \\
\text { ao glossário }\end{array}$ \\
\hline RB & 1712 & + & - \\
\hline AMS & 1813 & - & - \\
\hline DV & 1873 & + & + \\
\hline LF & 1940 & + & + \\
\hline CA & 1958 & + & + \\
\hline ABHF & 1986 & + & + \\
\hline ZCN/RCN & 1996 & + & - \\
\hline AH/MSV & 2001 & + & + \\
\hline FSB & 2002 & + & + \\
\hline BB & 2003 & + & - \\
\hline
\end{tabular}

Análise descritiva dos dicionários gerais:

DV e LF, definem depósito como ação de depositar, confiar, guardar algo. CA, é a primeira obra que apresenta a acepção correspondente ao glossário. Este autor é seguido por ABHF, AH/MSV e FSB, levantando-se a hipótese de que depósito com sentido de armazém tornou-se corrente a partir da metade do século XX.

Variantes: depôsito (RB); deposito (RB, DV)

Análise descritiva dos dicionários regionalistas:

As obras regionalistas apresentam a lexia depósito somente no sentido de multa a ser paga pelo carreirista em caso de desistência de corrida de animais. 
Descarneador $\mid$ s.m.

empregado de charqueada encarregado de esfolar e separar a carne dos ossos

Abonação: "No numero dos escravos cujo aluguel eu desejo saber, comprehenden-se Xarqueadores, ximangos, salgadores, e descarneadores.” (Doc 61 - Poa 1883)

Variantes: descarnador

Ocorrência nos dicionários:

\begin{tabular}{|c|c|c|c|}
\hline Autor & Ano obra & Lexia & $\begin{array}{c}\text { Acepção correspondente } \\
\text { ao glossário }\end{array}$ \\
\hline RB & 1712 & - & - \\
\hline AMS & 1813 & + & + \\
\hline DV & 1873 & + & - \\
\hline LF & 1940 & + & - \\
\hline CA & 1958 & + & - \\
\hline ABHF & 1986 & + & - \\
\hline ZCN/RCN & 1996 & - & - \\
\hline AH/MSV & 2001 & + & + \\
\hline FSB & 2002 & + & + \\
\hline BB & 2003 & - & - \\
\hline
\end{tabular}

Análise descritiva dos dicionários gerais:

AMS, DV e CA apresentam a entrada descarnador, porém como um instrumento para retirar carne dos dentes. RB e AMS exibem a entrada descarnar, no sentido de tirar carne, diminuir a gordura e carne de um corpo bem nutrido. $\mathrm{O}$ verbo descarnar também aparece como lexia de entrada em ABHF, como a ação de tirar a carne dos ossos e emagrecer.

Variantes: descarnador (DV); descarnár (AMS)

Análise descritiva dos dicionários regionalistas:

ZCN/RCN e BB exibem somente a lexia descarnado, adjetivo que indica muito magro, sem carne.

Desnucador | s.m.

operário da charqueada encarregado de matar o boi || aquele que enterra a faca ou o punhal na cabeça ou coração do animal com a finalidade de matá-lo \| matador 
Abonação: "Uma vez que o animal laçado, é suficiente fazer puxar a corda para que o boi seja arrastado por alguns metros, sobre este chão delizante, e venha colocar-se diretamente sob a mão de um segundo operário (às vezes, é o mesmo) o matador ou “desnucador". (Doc 85 - L.C. 1880)

“... e o desnucador só tem enterrar de alto a baixo um longo facão, muito resistente e mal afiado entre o atlas e o occipital para o bulbo. (Doc 85 - L.C. 1880)

Ocorrência nos dicionários:

Não consta em nenhuma obra ocorrência da lexia em questão.

Análise descritiva dos dicionários gerais:

RB, AMS, DV e LF, apresentam o verbo desnucar e a variante desnocar. ABHF e AH/MSV apresentam o verbo desnucar, definido como matar a rês. A acepção do verbo dada pelos autores corresponde com a ação do desnucador encontrada no glossário.

Análise descritiva dos dicionários regionalistas:

BB e ZCN/RCN apresentam também somente o verbo desnucar, com a mesma acepção dos últimos dois autores citados acima.

\section{Dessecamento | s.m.}

operação de secagem da carne realizado pelo uso de um varal comprido onde a carne é estendida

Abonação: “ Dessecamento - Depois de ter passado pela pilha simples, de duração irregular em Pelotas, pela dupla pilha, ou mesmo pela pilha de inverno no Rio da Prata, a carne vai ser, finalmente dessecada". (Doc 90 - L.C. 1880)

Ocorrência nos dicionários:

\begin{tabular}{|c|c|c|c|}
\hline Autor & Ano obra & Lexia & $\begin{array}{c}\text { Acepção correspondente } \\
\text { ao glossário }\end{array}$ \\
\hline RB & 1712 & - & - \\
\hline AMS & 1813 & + & - \\
\hline DV & 1873 & - & - \\
\hline LF & 1940 & + & + \\
\hline CA & 1958 & + & + \\
\hline ABHF & 1986 & + & + \\
\hline ZCN/RCN & 1996 & - & + \\
\hline AH/MSV & 2001 & + & + \\
\hline FSB & 2002 & - & - \\
\hline BB & 2003 & - & + \\
\hline
\end{tabular}


Análise descritiva dos dicionários gerais:

AMS não apresenta acepção para a lexia, sendo encontrado no verbete somente a remissão para o verbo desecar. LF, CA, ABHF e AH/MSV apresentam esta lexia como sinônimo de dessecação, lexia encontrad em FSB.

Observação: Segundo Louis Couty, no Rio da Prata, a carne ainda passava rapidamente pela salmoura antes de realizar esta operação. No sul do Brasil a carne era retirada das pilhas e era imediatamente levada aos varais para seu dessecamento.

Variante: deseccamento (LF)

Análise descritiva dos dicionários regionalistas:

Não consta a lexia nas referidas obras.

Eletricista | s.m.

empregado de charqueada responsável pela parte elétrica

Abonação: “Ali estavam alinhados, esperando o primeiro boi, zorreiros, camboneiros... ... serradores de caracu, resfriadores, graxeiros, eletrecistas, tripeiros, etc e etc." (Doc 108 - A.P.C. 1988)

Variante: eletrecista

Ocorrência nos dicionários:

\begin{tabular}{|c|c|c|c|}
\hline Autor & Ano obra & Lexia & $\begin{array}{c}\text { Acepção correspondente } \\
\text { ao glossário }\end{array}$ \\
\hline RB & 1712 & - & - \\
\hline AMS & 1813 & - & - \\
\hline DV & 1873 & - & - \\
\hline LF & 1940 & + & + \\
\hline CA & 1958 & + & + \\
\hline ABHF & 1986 & + & + \\
\hline ZCN/RCN & 1996 & - & + \\
\hline AH/MSV & 2001 & + & + \\
\hline FSB & 2002 & + & - \\
\hline BB & 2003 & - & + \\
\hline
\end{tabular}

Análise descritiva dos dicionários gerais:

Nota: Não era esperado a referência de eletricista como empregado de charqueada. Nos documentos do corpus não é evidente quais eram as atribuições de um eletricista dentro de um estabelecimento saladeril e nem há comprovação de que este indivíduo realizava exclusivamente este tipo de serviço ou se também mantinha outras atribuições. 
Observação: Uma vez que a energia elétrica não havia sido introduzida no Rio Grande do Sul até meados do século XIX, esta atividade é somente encontrada nas charqueadas mais modernas. Nos documentos mais antigos, há indicações do uso de lampiões, lamparinas, candieiros etc.

Variante: electicista (LF)

Análise descritiva dos dicionários regionalistas:

Não consta a lexia nas referidas obras.

\section{Embarcação | s.m.}

meio de locomoção fluvial usado para transporte de pessoas e mercadorias || navio || nau || fragata || iate || lancha || sumaca

Abonação: “... o Sal precizo por conta da Fazenda Real, como para a exportação d[as] mesmas carnes em Embarcações que para esse fim de devaõ expedir mas naõ me parecendo acertado dar neste Negocio os primeiros passos..." (Doc 15 - Flo. 1795)

Ocorrência nos dicionários:

\begin{tabular}{|c|c|c|c|}
\hline Autor & Ano obra & Lexia & $\begin{array}{c}\text { Acepção correspondente } \\
\text { ao glossário }\end{array}$ \\
\hline RB & 1712 & + & + \\
\hline AMS & 1813 & + & + \\
\hline DV & 1873 & + & + \\
\hline LF & 1940 & + & + \\
\hline CA & 1958 & + & + \\
\hline ABHF & 1986 & + & + \\
\hline ZCN/RCN & 1996 & - & + \\
\hline AH/MSV & 2001 & + & + \\
\hline FSB & 2002 & + & - \\
\hline BB & 2003 & - & + \\
\hline
\end{tabular}

Análise descritiva dos dicionários gerais:

As obras apresentam a acepção correspondente principalmente no que concerne a generalização desta lexia como qualquer tipo de construção destinada a navegar.

Variante: embarcaçam (RB)

Análise descritiva dos dicionários regionalistas:

BB apresenta chalana como exemplo de embarcação pequena de fundo achatado. 
colocar em barrica

Abonação: “...onde estará trez dias escorrendo; e depois deste tempo, que já estiver bem escorrida e enxuta, se embarrica com camadas de novo Sal, ficando intermiado por toda a carne até o lugar, em que se funda a vazilha..." (Doc 14 - Flo. 1798)

Ocorrência nos dicionários:

\begin{tabular}{|c|c|c|c|}
\hline Autor & Ano obra & Lexia & $\begin{array}{c}\text { Acepção correspondente } \\
\text { ao glossário }\end{array}$ \\
\hline RB & 1712 & - & - \\
\hline AMS & 1813 & + & + \\
\hline DV & 1873 & - & - \\
\hline LF & 1940 & + & + \\
\hline CA & 1958 & + & + \\
\hline ABHF & 1986 & + & + \\
\hline ZCN/RCN & 1996 & - & - \\
\hline AH/MSV & 2001 & + & + \\
\hline FSB & 2002 & - & - \\
\hline BB & 2003 & - & - \\
\hline
\end{tabular}

Análise descritiva dos dicionários gerais:

AMS, LF e CA apresentam como exemplo de alimento embarricado o peixe salgado. Observação: Em um dos documentos do corpus, que trata de um receituário de como preparar a carne salgada, o autor do documento ressalta que a carne a ser embarricada não poderia ser colocada em barricas que já tivessem transportado aguardente, vinho e água, podendo somente reaproveitar as que tivessem transportado sal, azeite ou que fossem novas.

Análise descritiva dos dicionários regionalistas:

Não consta a lexia nas referidas obras.

Empilhador | s.m.

Empregado de charqueada encarregado de colocar o charque na pilha || aquele que empilha o charque

Abonação: “... carnes salgadas dos dias precedentes: depois, os pedaços impregnados são tirados dali com a ajuda de ganchos pelos empilhadores...” (Doc 88 - L.C. 1880) Ocorrência nos dicionários:

Não consta a lexia nas referidas obras. 
Análise descritiva dos dicionários gerais:

AMS apresenta somente o verbo empilhar, mas não faz referência ao indivíduo que executa este tipo de serviço. CA menciona a lexia empilhamento, como a ação de empilhar. ABHF apresenta tanto verbo empilhar, como o substantivo empilhamento. AH/MSV apresenta, além das citadas por ABHF, outras lexias derivadas do mesmo radical, a dizer, o substantivo empilhadeira e o adjetivo empilhado. FSB é o único autor que traz a lexia empilhador, definindo-a como o trabalhador que opera a máquina empilhadeira.

Análise descritiva dos dicionários regionalistas:

Não consta a lexia nas referidas obras.

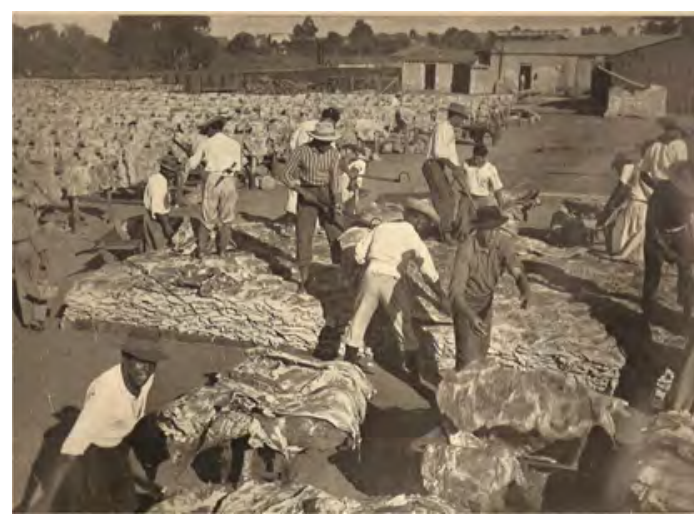

Fig.8 Empilhadores de charque

Fonte: Site luisafonsocosta.blogspot.com

Engasga gato $\mid$ s.m.

espécie de guisado de charque || sobra de charque refogada com gordura e tempero

Abonação: “Engasga-gato É o nome tradicional e pitoresco de um guisadão de charque..." (Doc 79 - A.F.M. s/n)

Ocorrência nos dicionários:

\begin{tabular}{|c|c|c|c|}
\hline Autor & Ano obra & Lexia & $\begin{array}{c}\text { Acepção correspondente } \\
\text { ao glossário }\end{array}$ \\
\hline RB & 1712 & - & - \\
\hline AMS & 1813 & - & - \\
\hline DV & 1873 & - & - \\
\hline LF & 1940 & - & - \\
\hline CA & 1958 & + & ++ \\
\hline ABHF & 1986 & + & ++ \\
\hline ZCN/RCN & 1996 & - & - \\
\hline AH/MSV & 2001 & + & - \\
\hline FSB & 2002 & - & - \\
\hline
\end{tabular}




\section{BB}

Análise descritiva dos dicionários gerais:

CA e ABHF informam que esta lexia é brasileira, usada no sul, definida como uma espécie de farofa de carne ou charque guisados em pedaços graúdos.

Análise descritiva dos dicionários regionalistas:

BB apresenta a significação de engasga-gato como uma espécie de ensopado com charque, especificando que o tipo de charque usado neste prato é o da manta da barrigueira. ZCN/RCN não apresenta a lexia em sua obra.

Escuna $\mid$ s.f.

embarcação usada para transportar produtos da charqueada

Abonação: “ $\mathrm{Na}$ escuna dinamarquesa - Maria - Thomsom, Loessel e land, 700 couros vaccuns salgados..." (Doc 28 - Pel. 1869)

"Lisboa com escalla pelo Porto, na escuna portuguesa -Angelica1. —José Luiz da Fonseca e C 416 couros vaccuns seccos, 121 dittos avariados, 205 dittos de terneiro seccos, 18 dittos de refugo." (Doc 28 - Pel. 1869)

Ocorrência nos dicionários:

\begin{tabular}{|c|c|c|c|}
\hline Autor & Ano obra & Lexia & $\begin{array}{c}\text { Acepção correspondente } \\
\text { ao glossário }\end{array}$ \\
\hline RB & 1712 & - & - \\
\hline AMS & 1813 & - & - \\
\hline DV & 1873 & + & + \\
\hline LF & 1940 & + & + \\
\hline CA & 1958 & + & + \\
\hline ABHF & 1986 & + & - \\
\hline ZCN/RCN & 1996 & - & + \\
\hline AH/MSV & 2001 & + & + \\
\hline FSB & 2002 & + & - \\
\hline BB & 2003 & - & + \\
\hline
\end{tabular}

Análise descritiva dos dicionários gerais:

DV indica em sua obra que escuna pode ser uma embarcação usada tanto para fins bélicos como para fins mercantes, que corrobora com a acepção do glossário, sendo encontrada no corpus inúmeros exemplos de escunas como o tipo de embarcação de que se serviam os mercadores de charque e outros produtos. LF e ABHF apresentam como tipo de embarcação ligeira de velas latinas. 
Análise descritiva dos dicionários regionalistas:

Não consta a lexia nas referidas obras.

Escravo de charqueada $\mid$ s.m.

escravo que trabalha dentro da charqueada || trabalhador em regime de escravidão que realiza todo tipo de serviço na charqueada, principalmente o mais pesado || consumidor de charque || negro

Abonação: "Se é ou não verdade que grande parte dessa divida era proveniente de alugues de grande numero de escravos de Xarqueadas" (Doc 63 - Poa 1883)

"Peço-lhe o favor de informar-me ao pé desta, para fins convenientes, qual o preço do aluguel annual dos escravos destinados ao serviço de Xarqueada, isto é, do anno corrido, obrigando-se o Xarqueador a dar-lhe alimentação, vestiario e botica. No numero dos escravos cujo aluguel eu desejo saber, comprehenden-se xarqueadores, ximangos, salgadores, e descarneadores." (Doc 61 - Poa 1883)

“... o escravo assinava um contrato pelo qual se comprometia em continuara prestar serviços ao seu senhor por mais sete anos como forma de pagar a "dívida" de casa e comida contraída ao longo da vida. Desse modo permaneceriam cativos até 1891, ou seja, três anos após a abolição.” (Doc 35 - Pel. 2007)

"A atividade não existiria sem o escravo, pois era muito penosa e rude e os brancos não se dignavam a fazê-la, pois naquela época era indigno ao homem branco fazer esforço físico" (Doc 48 - Pel. 2007)

Ocorrência nos dicionários:

\begin{tabular}{|c|c|c|c|}
\hline Autor & Ano obra & Lexia & $\begin{array}{c}\text { Acepção correspondente } \\
\text { ao glossário }\end{array}$ \\
\hline RB & 1712 & + & - \\
\hline AMS & 1813 & + & - \\
\hline DV & 1873 & + & - \\
\hline LF & 1940 & + & - \\
\hline CA & 1958 & + & - \\
\hline ABHF & 1986 & + & - \\
\hline ZCN/RCN & 1996 & - & - \\
\hline AH/MSV & 2001 & + & - \\
\hline FSB & 2002 & + & - \\
\hline BB & 2003 & - & - \\
\hline
\end{tabular}

Análise descritiva dos dicionários gerais: 
Não houve nas obras referência de escravos nas charqueadas. Esta lexia apresenta, em alguns dicionários, definições em sentido figurado, como por exemplo: escravo do amor, escravo de confissão etc. Sinônimos de escravo são colocados como: servo, criado, cativo etc.

Nota: Segundo os documentos do corpus, o sistema escravagista nas charqueadas é conhecido como um dos mais cruéis e rudes. O escravo era obrigado a fazer o trabalho mais pesado e, após o término do período de escravidão, os charqueadores não conseguiam encontrar quem se dispusesse a fazer o serviço, além de perder uma parcela importante dos consumidores do produto. A média de vida de um escravo de charqueada era inferior aos escravos que trabalhavam nos engenhos de cana-deaçúcar.

Análise descritiva dos dicionários regionalistas:

Não consta a lexia nas referidas obras.

Estabelecimento de charqueada | s.m.

propriedade rural que compreende uma charqueada || conjunto de construções onde se produz charque || conjunto de obras como galpão, curral, casa de moradia, terreno de varal, potreiro, mangueira de matança etc || estabelecimento saladeril || saladeiro

Abonação: "Outro sim terá a bondade de diser-me se é ou não verdade ter o abaixoassignado o seo Estabelecimento de Xarqueada sito no $2^{\circ}$. districto ha muitos annos arrendado a seo genro Manoel Rodrigues Vieira da Cunha..." (Doc 64 - Poa 1873)

“... que divide pela parte de Éste como citado arrôio, pelo Sul com o terrêno de Jose Antonio Moreira até a estrada que passa junto ao Estabelecimento da Charqueada e segue desta estrada..." (Doc 57 - Poa 1870)

"Meu pai foi chamado para administrar o estabelecimento e em 1931 transferimos residência para a casa grande da charqueada..." (Doc 106 - A.P.C. 1988)

Variante: estabelecimento de xarqueada

Ocorrência nos dicionários:

Não consta a lexia nas referidas obras.

Análise descritiva dos dicionários regionalistas: 
Nas obras regionalistas de $\mathbf{Z C N} / \mathbf{R C N}$ e BB foi encontrada a definição para estabelecimento de charqueada no verbete charqueada. A acepção de ambos os autores é que a charqueada é um estabelecimento onde se abate o gado.

Nota: A lexia estabelecimento de charqueada foi encontrada, no corpus, principalmente nos inventários dos charqueadores, o que leva a cer que era o termo empregado para descrever a propriedade de maneira geral.

Estância $\mid$ s.f.

\section{propriedade rural de criação de gado}

Abonação: “ Consta-me que Sua Magestade; tem nessa Ilha huã Estância, naõ sei o seu tamanho, nem a sua fertilidade, e parece-me que até ignoro se faz algum rendimento á Fazenda Real...” (Doc 12 - Flo. 1797)

"Em todas as estâncias vêem-se muitos ossos de bois, espalhados por todos os cantos, e ao entrar nas casas das fazendas sente-se logo o cheiro de carne e de gordura" (Doc 126 - A.S.H. 1820/21)

"Ao contrário das estâncias, onde o gado era criado, as charqueadas não eram grandes propriedades rurais..." (Doc 44 - Pel. 2007)

Ocorrência nos dicionários:

\begin{tabular}{|c|c|c|c|}
\hline Autor & Ano obra & Lexia & $\begin{array}{c}\text { Acepção correspondente } \\
\text { ao glossário }\end{array}$ \\
\hline RB & 1712 & + & - \\
\hline AMS & 1813 & + & - \\
\hline DV & 1873 & + & + \\
\hline LF & 1940 & + & + \\
\hline CA & 1958 & + & + \\
\hline ABHF & 1986 & + & + \\
\hline ZCN/RCN & 1996 & + & + \\
\hline AH/MSV & 2001 & + & + \\
\hline FSB & 2002 & + & + \\
\hline BB & 2003 & + & + \\
\hline
\end{tabular}

Análise descritiva dos dicionários gerais:

RB considera a estância somente como morada. AMS também não indica estância como local de criação de gado e sim como local de parada, de descanso apresentando a lexia rancho como sinônimo. DV denomina que estância, na América do Sul, é o local de educação e conservação de gado. LF, CA e AH/MSV definem a lexia como 
estabelecimento rural, fazenda de criação de gado. ABHF, CA e FSB fazem referência desta lexia como usual no RS.

Análise descritiva dos dicionários regionalistas:

ZCN/RCN e BB apresentam a estância como grandes propriedades rurais de criação de gado compostas também por campos, mangueiras, casas do proprietário, lavouras, galpões e outras instalações. Os dicionaristas mencionam a lexia estanciola como diminutivo irregular de estância; criação, como o conjunto de animais de uma estância e a lexia bocona, como estância grande.

\section{Estancieiro | s.m.}

produtor de gado || charqueador || criador de animais || aquele que vende gado ao charqueador $\|$ fazendeiro

Abonação: "Um estancieiro que abater um boi a cada oito dias para a alimentaçãoo de 20 pessoas de sua casa, escravos ou servidores, e parentes, poderá secar e salgar pouca carne....”(Doc 103 - L.C. 1880)

“... a partir da independência da República do Uruguai estabeleceu-se um conflito de interesses entre charqueadores e estancieiros. Os produtores de gado insistiam em ter livre acesso às terras compradas no país vizinho antes da independência, enquanto os charqueadores de Pelotas eram contrários ao envio de gado gaúcho para o Uruguai..." (Doc 38 - Pel. 2007)

Ocorrência nos dicionários:

\begin{tabular}{|c|c|c|c|}
\hline Autor & Ano obra & Lexia & $\begin{array}{c}\text { Acepção correspondente } \\
\text { ao glossário }\end{array}$ \\
\hline RB & 1712 & - & - \\
\hline AMS & 1813 & - & - \\
\hline DV & 1873 & + & + \\
\hline LF & 1940 & + & + \\
\hline CA & 1958 & + & + \\
\hline ABHF & 1986 & + & + \\
\hline ZCN/RCN & 1996 & + & + \\
\hline AH/MSV & 2001 & + & + \\
\hline FSB & 2002 & + & + \\
\hline BB & 2003 & + & + \\
\hline
\end{tabular}

Análise descritiva dos dicionários gerais:

As acepções não diferem da fornecida do glossário. 
Observação: Em vários documentos, os estancieiros são apresentados como "parceiros" dos charqueadores, em outros, como duas classes de proprietários rurais divergentes, sobretudo nas questões tributárias de seus produtos.

Variante: estanceiro (DV, LF, CA, ABHF)

Análise descritiva dos dicionários regionalistas:

BB menciona que os estancieiros, no passado, usavam os seus peões como soldados, e, desempenhando o papel chefes militares, formavam exércitos eficientes nas guerras dos pampas.

Fatura $\mid$ s.f.

preparo || manufatura da carne || beneficiamento de charque

Abonação: "Eu espero conciderar agora como huã admiravel providencia ao novo Systema da factura das Carnes para as Esquadras de Sua Magestade, mas destituido de todos os conhecimentos da extenção dos seus Campos, da sua Natureza, das qualidades dos seus pastos, das distancias de Aguas..." (Doc 12 - Flo. 1797)

Variante: facture

Ocorrência nos dicionários:

\begin{tabular}{|c|c|c|c|}
\hline Autor & Ano obra & Lexia & $\begin{array}{c}\text { Acepção correspondente } \\
\text { ao glossário }\end{array}$ \\
\hline RB & 1712 & - & - \\
\hline AMS & 1813 & - & - \\
\hline DV & 1873 & - & - \\
\hline LF & 1940 & + & + \\
\hline CA & 1958 & + & + \\
\hline ABHF & 1986 & + & + \\
\hline ZCN/RCN & 1996 & - & + \\
\hline AH/MSV & 2001 & + & + \\
\hline FSB & 2002 & + & - \\
\hline BB & 2003 & - & + \\
\hline
\end{tabular}

Análise descritiva dos dicionários gerais:

LF, CA, ABHF e AH/MSV apresentam a lexia como o substantivo que designa o feitio, a elaboração, a ação de fazer. Nenhum autor, entretanto, dá como exemplo carne e/ou charque como possíveis produtos faturados.

Variante: factura (LF, CA)

Análise descritiva dos dicionários regionalistas:

Não consta a lexia nas referidas obras. 
Feijoada $\mid$ s.f.

feijão temperado com pedaços de charque || prato típico da culinária brasileira preparado com feijão, carne suína e/ou bovina e outras partes do animal

Abonação: "É evidente que, antes de escrever, eles não pensaram em comer, eles próprios e diversas vezes, carne seca bem preparada, em "feijoada", por exemplo..." (Doc 103 - L.C. 1880)

“ Trata-se de uma feijoada, na qual não figuram tantos ingredientes como nas tradicionais do centro do Brasil, mas apenas pedaços de bom charque gordo." (Doc 79 - A.F.M. s/n)

Ocorrência nos dicionários:

\begin{tabular}{|c|c|c|c|}
\hline Autor & Ano obra & Lexia & $\begin{array}{c}\text { Acepção correspondente } \\
\text { ao glossário }\end{array}$ \\
\hline RB & 1712 & - & - \\
\hline AMS & 1813 & + & + \\
\hline DV & 1873 & + & + \\
\hline LF & 1940 & + & + \\
\hline CA & 1958 & + & + \\
\hline ABHF & 1986 & + & - \\
\hline ZCN/RCN & 1996 & - & ++ \\
\hline AH/MSV & 2001 & + & + \\
\hline FSB & 2002 & + & - \\
\hline BB & 2003 & - & + \\
\hline
\end{tabular}

Análise descritiva dos dicionários gerais:

AMS e DV consideram em suas acepções a feijoada como o cozimento de feijões e não acrescentam nenhuma outra informação adicional sobre o modo de preparo e/ou ingredientes. CA indica que no sul do Brasil é comum a adição de partes de animais, e que, no norte, são adicionados legumes. LF, CA, ABHF e FSB indicam como ingrediente utilizado na feijoada a carne seca. Já AH/MSV cita a lexia charque como produto usado em seu preparo, considerando-o como prato nacional.

Variante: feijoáda (AMS)

Análise descritiva dos dicionários regionalistas:

Não consta a lexia nas referidas obras. 
Foguista $\mid$ s.m.

empregado da charqueada encarregado de produzir e manter o fogo aceso durante a produção de charque e demais subprodutos

Abonação: “Ali estavam alinhados, esperando o primeiro boi, zorreiros, camboneiros, coleiros, carneadores, charqueadores, aguateiros, salgadeiros, matambreiros, foguistas, mergulhadores de carne e de couros..." (Doc 108 - A.P.C. 1988)

Ocorrência nos dicionários:

\begin{tabular}{|c|c|c|c|}
\hline Autor & Ano obra & Lexia & $\begin{array}{c}\text { Acepção correspondente } \\
\text { ao glossário }\end{array}$ \\
\hline RB & 1712 & - & - \\
\hline AMS & 1813 & - & - \\
\hline DV & 1873 & - & - \\
\hline LF & 1940 & + & + \\
\hline CA & 1958 & - & - \\
\hline ABHF & 1986 & + & + \\
\hline ZCN/RCN & 1996 & + & + \\
\hline AH/MSV & 2001 & + & + \\
\hline FSB & 2002 & - & - \\
\hline BB & 2003 & + & + \\
\hline
\end{tabular}

Análise descritiva dos dicionários gerais:

LF, ABHF e AH/MSV indicam na entrada foguista a remissão fogueiro. ABHF e AH/MSV conceituam fornalheiro como sinônimo de foguista e fogueiro, apresentando semelhante acepção à do glossário.

Análise descritiva dos dicionários regionalistas:

ZCN/RCN e BB apresentam a entrada foguista indicando para a remissão fogueiro, mas não fornecem sua acepção.

Forquilha $\mid$ s.f.

terminação de um pedaço de madeira em forma de "v" que serve de apoio para o varão transversal onde se estende a carne salgada para secar

Abonação: "Essas forquilhas recebem varões transversais destinados a estender a carne a secar, no tempo das xarqueadas..." (Doc 129 - A.S.H. 1820/21)

Ocorrência nos dicionários:

\begin{tabular}{|c|c|c|c|}
\hline Autor & Ano obra & Lexia & $\begin{array}{c}\text { Acepção correspondente } \\
\text { ao glossário }\end{array}$ \\
\hline RB & 1712 & + & - \\
\hline
\end{tabular}




\begin{tabular}{|c|c|c|c|}
\hline AMS & 1813 & + & - \\
\hline DV & 1873 & + & + \\
\hline LF & 1940 & + & + \\
\hline CA & 1958 & + & - \\
\hline ABHF & 1986 & + & + \\
\hline ZCN/RCN & 1996 & + & - \\
\hline AH/MSV & 2001 & + & + \\
\hline FSB & 2002 & + & + \\
\hline BB & 2003 & + & - \\
\hline
\end{tabular}

Análise descritiva dos dicionários gerais:

RB e AMS apresentam a lexia forquilha como pau com três pontas para apartar trigo, erva miúda etc. DV e FSB a definem como uma vara comprida com dois ganchos. LF, CA, ABHF e AH/MSV acrescentam que esta vara pode servir como varal, cabide, de modo a estender qualquer coisa. CA menciona que, no Rio Grande do Sul, é usado como meio de indicar gado recortando a ponta de uma das orelhas do animal.

Variante: fórquilha (RB)

Análise descritiva dos dicionários regionalistas:

ZCN/RCN e BB não mencionam forquilha no preparo da carne salgada. Ambos os dicionaristas fornecem a lexia estaleiro como paus suspensos em forquilhas altas onde se coloca carne para secar. Os autores regionalistas também apresentam as palavras enforquilhado - preso em forquilha, enforquilhar - prender na forquilha e enforquilhar-se - sentido figurado para montar a cavalo de forma deselegante. ZCN/RCN acrescenta a informação de que forquilha é o nome dado a um tipo de grama de boa qualidade para a alimentação do gado ou também a define como sinal para identificar animais que não o gado.

Fornalha $\mid$ s.f.

espécie de forno onde se produz calor para a caldeira durante o preparo da graxa na charqueada

Abonação: “As fornalhas, com as bocas vermelhas escancaradas, iam pouco a pouco transmitindo aos manômetros a pressão das 4 caldeiras destinadas ao preparo da graxa amarelinha..." (Doc 109 - A.P.C. 1988)

Ocorrência nos dicionários:

\begin{tabular}{|c|c|c|c|}
\hline Autor & Ano obra & Lexia & $\begin{array}{c}\text { Acepção correspondente } \\
\text { ao glossário }\end{array}$ \\
\hline
\end{tabular}




\begin{tabular}{|c|c|c|c|}
\hline RB & 1712 & + & - \\
\hline AMS & 1813 & + & + \\
\hline DV & 1873 & + & + \\
\hline LF & 1940 & + & + \\
\hline CA & 1958 & + & + \\
\hline ABHF & 1986 & + & + \\
\hline ZCN/RCN & 1996 & - & - \\
\hline AH/MSV & 2001 & + & + \\
\hline FSB & 2002 & + & + \\
\hline BB & 2003 & - & - \\
\hline
\end{tabular}

Análise descritiva dos dicionários gerais:

RB não define a lexia, apresentando no verbete somente a indicação de fornalha pequena - fornacula. AMS menciona produtos o melado, o ferro etc. como materiais preparados em tachos assentados em fornalha.

Análise descritiva dos dicionários regionalistas:

Não consta a lexia nas referidas obras.

Fragata $\mid$ s.f.

meio de transporte de produtos da charqueada

Abonação: "Methodo de se fazerem as Carnes no Armazens da Ribeira, para a Equipagem das Naos, e Fragatas de Sua Magestade.” (Doc 14 - Flo. 1798)

Ocorrência nos dicionários:

\begin{tabular}{|c|c|c|c|}
\hline Autor & Ano obra & Lexia & $\begin{array}{c}\text { Acepção correspondente } \\
\text { ao glossário }\end{array}$ \\
\hline RB & 1712 & + & + \\
\hline AMS & 1813 & + & + \\
\hline DV & 1873 & + & + \\
\hline LF & 1940 & + & + \\
\hline CA & 1958 & + & + \\
\hline ABHF & 1986 & + & - \\
\hline ZCN/RCN & 1996 & - & + \\
\hline AH/MSV & 2001 & + & - \\
\hline FSB & 2002 & + & - \\
\hline BB & 2003 & - & + \\
\hline
\end{tabular}

Análise descritiva dos dicionários gerais:

Todos os lexicógrafos mencionam a constituição da fragata em seus verbetes: quantos remos, se é de vela, se serve para artilharia etc. Estes autores apresentam inúmeros 
sinônimos para este tipo de embarcação. LF, CA e ABHF também definem fragata no sentido figurado, como mulher alta, corpulenta e bem resolvida em sua ações.

Variante: fragáta (RB, AMS, DV)

Análise descritiva dos dicionários regionalistas:

Não consta a lexia nas referidas obras.

Gado $\mid$ s.m.

conjunto de animais que servem para o consumo

Abonação: “A abundância de gado no Rio Grande do Sul facilitava a exploração comercial da carne..." (Doc 40 - Pel. 2007)

"Nāo podiam escolher melhor local pois aí recebem, sem a mínima dificuldade, o gado criado nas gordas pastagens situadas ao sul do Jacuí e facilmente exportam a carne seca e os couros através dos rios Pelotas e Sāo Gonçalo". (Doc 130 - A.S.H. $1820 / 21)$

“Artigo 68. - E prohibido: $\S 1^{\text {o. }}$ - Matar gado magríssimo, doente, cançado, ou estropeado; bem como esquartejar o que for encontrado morto." (Doc 01 - Flo. $1896 / 1901)$

Ocorrência nos dicionários:

\begin{tabular}{|c|c|c|c|}
\hline Autor & Ano obra & Lexia & $\begin{array}{c}\text { Acepção correspondente } \\
\text { ao glossário }\end{array}$ \\
\hline RB & 1712 & + & + \\
\hline AMS & 1813 & + & + \\
\hline DV & 1873 & + & + \\
\hline LF & 1940 & + & + \\
\hline CA & 1958 & + & + \\
\hline ABHF & 1986 & + & + \\
\hline ZCN/RCN & 1996 & + & + \\
\hline AH/MSV & 2001 & + & + \\
\hline FSB & 2002 & + & + \\
\hline BB & 2003 & + & + \\
\hline
\end{tabular}

Análise descritiva dos dicionários gerais:

RB define gado como todo animal que é doméstico e que se põe para pastar. As acepções de AMS, DV, LF e CA assemelham-se às de RB. Os autores, entretanto, acrescentam que gado são os animais que pastam e servem para lavoura, serviço e sustento. ABHF define gado como reses em geral. AH/MSV e FSB apresentam gado como sinônimo de rebanho. 
Nota: Sabe-se que a lexia gado pode se referir a outros tipos de animais que não somente o bovino, uma vez que engloba criação de animais em geral. Portanto, gado cavalar, ovino, lagineiro, caprino, dentre outros, encontrado no corpus, não serão especificados, pois não são animais usados na fabricação de charque gaúcho. Em muitos documentos foram encontradas referências ao gado cansado (gado que percorreu longas distâncias), doente (gado que não apresenta boa saúde, impróprio para o consumo) e estropeado (gado machucado).

Análise descritiva dos dicionários regionalistas:

ZCN/RCN e BB mencionam de que, no Rio Grande do Sul, quando se faz referência a outro gado além do vacum, identifica-se qual é. Portanto, para os autores regionalistas, a acepção de gado é gado vacum. Estes autores apresentam outros tipos de gado comuns no sul do país, como o gado de porta, gado de corte, gado de cria, gado de invernar, gado chimarrão. Também apresentam as lexias gadão, como gado em bom estado, gadaria, como porção de gado, gadeiro, definido como relativo ao gado. A expressão choro de gado é definida nos dicionários como lamento de gado, local onde a rês é morta. BB ainda menciona a lexia marrano como gado ruim e a expressão flor de gado, indicando que é o gado em bom estado, gado de excelente qualidade.

Gado gaúcho | s.m.

gado criado no Estado do Rio Grande do Sul

Abonação: “... os charqueadores de Pelotas eram contrários ao envio de gado gaúcho para o Uruguai e defendiam um controle mais rígido das fronteiras..." (Doc 38 - Pel. 2007)

Ocorrência nos dicionários:

Não consta a lexia nas referidas obras.

Gado gordo $\mid$ s.m.

gado de peso maior || próprio para o consumo || gado bastante lucrativo na charqueada

Abonação: “... sistema de venda de gado gordo mediante pesagem antes do abate, pelo chamado peso vivo e a rendimento, ou seja, pelo peso das carcaças." (Doc 70 A.F.M. $s / n)$ 
Ocorrência nos dicionários:

\begin{tabular}{|c|c|c|c|}
\hline Autor & Ano obra & Lexia & $\begin{array}{c}\text { Acepção correspondente } \\
\text { ao glossário }\end{array}$ \\
\hline RB & 1712 & - & - \\
\hline AMS & 1813 & - & - \\
\hline DV & 1873 & - & - \\
\hline LF & 1940 & - & - \\
\hline CA & 1958 & - & - \\
\hline ABHF & 1986 & - & - \\
\hline ZCN/RCN & 1996 & - & + \\
\hline AH/MSV & 2001 & - & - \\
\hline FSB & 2002 & - & - \\
\hline BB & 2003 & - & ++ \\
\hline
\end{tabular}

Análise descritiva dos dicionários gerais:

Não consta a lexia nas referidas obras.

Análise descritiva dos dicionários regionalistas:

ZCN/RCN e BB definem gado gordo como aquele que é destinado a ser abatido, entretanto, gado gordo encontra-se na entrada gado de corte. BB ainda informa que o gado gordo ou em bom estado, pode ser vendido a charqueadas, frigoríficos etc. Não se inclui, entretanto, as vacas de cria e animais novos.

Gado magro | s.m.

gado considerado abaixo do peso recomendado para 0 abate || boi magríssimo Abonação: “... Matar gado magríssimo, doente, cançado, ou estropeado; bem como esquartejar o que fôr encontrado morto." (Doc 01 - Flo. 1896/1901)

Ocorrência nos dicionários:

Não consta a lexia nas referidas obras.

Análise descritiva dos dicionários gerais:

Nota: Nos documentos selecionados em Florianópolis, foram encontradas leis que proibiam o abate do gado magro ou magríssimo, sob pena de multa.

Análise descritiva dos dicionários regionalistas:

Segundo ZCN/RCN e BB o gado magro é aquele que se compra para invernar e vender mais tarde, depois da engorda. O gado magro é definido na lexia de entrada gado de invernar. 
Gado uruguaio | s.m.

gado proveniente do Uruguai || gado considerado de melhor qualidade que o gado gaúcho

Abonação: "A entrada do gado uruguaio era indispensável para a manutenção de suas indústrias e a taxa de importação cobrada, aumentava significativamente os custos do négocio." (Doc 38 - Pel. 2007)

"Nos anos em que o gado uruguaio permanecia em baixa, o contrabando para o Brasil era um fato real e incontestável.” (Doc 69 - A.F.M. s/n)

Ocorrência nos dicionários:

Não consta a lexia nas referidas obras.

\section{Gado vacum | s.m.}

gado bovino

Abonação: "A taxa de 3\$000, $1 \$ 500$ e $10 \$ 000$ por cabeça de gado vaccum só será cobrada sobre o gado á de 30\$000." (Doc 16 - Pel. s/n)

Variante: vaccum

Ocorrência nos dicionários:

\begin{tabular}{|c|c|c|c|}
\hline Autor & Ano obra & Lexia & $\begin{array}{c}\text { Acepção correspondente } \\
\text { ao glossário }\end{array}$ \\
\hline RB & 1712 & - & - \\
\hline AMS & 1813 & - & - \\
\hline DV & 1873 & - & - \\
\hline LF & 1940 & - & - \\
\hline CA & 1958 & + & + \\
\hline ABHF & 1986 & - & - \\
\hline ZCN/RCN & 1996 & - & + \\
\hline AH/MSV & 2001 & + & + \\
\hline FSB & 2002 & - & - \\
\hline BB & 2003 & + & + \\
\hline
\end{tabular}

Análise descritiva dos dicionários gerais:

CA apresenta a lexia de gado vacum na legenda da foto apresentada no verbete. AH/MSV menciona a lexia como conjunto de animais formado de vacas, bois e ovelhas.

Análise descritiva dos dicionários regionalistas: 
ZCN/RCN e BB definem o gado vacum como gado em geral. Os dicionários regionalistas informam ao consulente que, quando uma pessoa nascida no Rio Grande do Sul se refere a outro gado que não seja o vacum, ele o especifica, denominando-o de gado cavalar, gado lanígero, gado muar etc.

Gado xucro | s.m.

gado não domesticado || gado criado solto || gado chimarrão

Abonação: “... atividade semelhante, praticada anteriormente, nas vacarias, por faeneros e changadores, para a caça ao gado xucro e retirada do couro e do sebo." (Doc 68 - A.F.M. s/n)

Ocorrência nos dicionários:

\begin{tabular}{|c|c|c|c|}
\hline Autor & Ano obra & Lexia & $\begin{array}{c}\text { Acepção correspondente } \\
\text { ao glossário }\end{array}$ \\
\hline RB & 1712 & - & - \\
\hline AMS & 1813 & - & - \\
\hline DV & 1873 & - & - \\
\hline LF & 1940 & - & - \\
\hline CA & 1958 & + & + \\
\hline ABHF & 1986 & - & - \\
\hline ZCN/RCN & 1996 & - & - \\
\hline AH/MSV & 2001 & - & - \\
\hline FSB & 2002 & - & + \\
\hline BB & 2003 & - & + \\
\hline
\end{tabular}

Análise descritiva dos dicionários gerais:

CA define a lexia gado xucro indicando no verbete que trata-se de um tipo de gado do Brasil, especificamente Rio Grande do Sul.

Análise descritiva dos dicionários regionalistas:

A definição de gado xucro nas obras de ZCN/RCN e BB encontram-se na entrada de gado chimarrão. A acepção do gado chimarrão em ZCN/RCN é definida como um tipo de gado bovino que foge ao custeio e passa a viver em estado selvagem, sinônimo de gado xucro. A expressão não dar rodeio é definida nas obras regionalistas como ser como o gado xucro. Em sentido figurado, usa-se a lexia para a pessoa grosseira e mal educada.

Variante: chucro $(\mathrm{ZCN} / \mathrm{RCN})$ 
Galiota | s.f.

embarcação utilizada no transporte de mercadorias || espécie de barco utilizado no transporte das exportações dos produtos da charqueada

Abonação: "EXPORTAÇÃO. DIA 23. Falmouth. na galiota olde burguesa -Adele Claussem e Bertram 1291 couros vaccuns salgados..." (Doc 28 - Pel. 1869)

Ocorrência nos dicionários:

\begin{tabular}{|c|c|c|c|}
\hline Autor & Ano obra & Lexia & $\begin{array}{c}\text { Acepção correspondente } \\
\text { ao glossário }\end{array}$ \\
\hline RB & 1712 & - & - \\
\hline AMS & 1813 & + & + \\
\hline DV & 1873 & + & + \\
\hline LF & 1940 & + & + \\
\hline CA & 1958 & + & + \\
\hline ABHF & 1986 & + & - \\
\hline ZCN/RCN & 1996 & - & + \\
\hline AH/MSV & 2001 & + & + \\
\hline FSB & 2002 & + & - \\
\hline BB & 2003 & - & + \\
\hline
\end{tabular}

Análise descritiva dos dicionários gerais:

Todas as obras que apresentam a lexia galiota, apresentam a grafia galeota, $\operatorname{com} e$ e não com $i$, como aparece no documentos do corpus. Por se tratar de um anúncio de jornal da cidade de Pelotas no século XVIII, levanta-se a hipótese que, ou o impressor do jornal cometeu um erro ortográfico ou no Sul do Brasil, grafava-se a lexia com $e$ e não $i$.

Variante: galeóta (AMS)

Análise descritiva dos dicionários regionalistas:

Não consta a lexia nas referidas obras.

Galpão | s.m.

edifício na charqueada onde se guarda a pilha de inverno || grande construção onde se realiza o serviço da charqueada || salão geralmente vizinho à cancha onde se prepara a manta de carne || benfeitoria

Abonação: "O animal esfolado é dividido em pedaços: os quatro membros são retirados, transportados e suspensos em uma sala vizinha, o "galpão", sobre suportes especiais" (Doc 86 - L.C. 1880) 
"A manta e os membros são levados ao galpão: ficam a cabeça, o tronco e as víceras: todas estas partes serão rapidamente separadas, jogadas de lado para fora das canchas e carregadas..” (Doc 87 - L.C. 1880)

"É no galpão que começam as operações verdadeiramente originais. A carne dos membros é separada dos ossos...” (Doc 87 - L.C. 1880)

“... completavam o interior do enorme galpão, que se mantinha absolutamente limpo, aguardando a salga da carne e do couro, para formarem as "pilhas de inverno"que, ao fim da safra, beiravam as telhas, com quase 5 metros de altura." (Doc 109 - A.P.C. 1988)

Ocorrência nos dicionários:

\begin{tabular}{|c|c|c|c|}
\hline Autor & Ano obra & Lexia & $\begin{array}{c}\text { Acepção correspondente } \\
\text { ao glossário }\end{array}$ \\
\hline RB & 1712 & - & - \\
\hline AMS & 1813 & - & - \\
\hline DV & 1873 & - & - \\
\hline LF & 1940 & + & - \\
\hline CA & 1958 & + & - \\
\hline ABHF & 1986 & + & - \\
\hline ZCN/RCN & 1996 & + & - \\
\hline AH/MSV & 2001 & + & - \\
\hline FSB & 2002 & + & - \\
\hline BB & 2003 & + & - \\
\hline
\end{tabular}

Análise descritiva dos dicionários gerais:

LF, CA, ABHF, AH/MSV e FSB definem a lexia galpão como uma construção que serve basicamente para dois fins: o de guardar os utensílios de lavoura e como varanda, alpendre ou habitação para os peões da estância. As acepções são mencionadas como regionalistas do sul do Brasil.

Observação: Para alguns autores dos documentos, considera-se o galpão toda a construção onde se realizava as operações do feitio do charque, para outros, era só uma parte anexa, uma espécie de sala onde se guardavam as carnes.

Análise descritiva dos dicionários regionalistas:

As obras de ZCN/RCN e BB, além das definições das obras citadas anteriormente, ainda especificam o galpão como sendo local para guardar utensílios, ração etc. Segundo os dicionaristas, o galpão é uma construção de uso exclusivamente masculino, em que faz churrasco, toma-se chimarrão, bebe-se cachaça e serve de pouso para tropeiros ou carreteiros que necessitem de apenas um local para dormir. Os animais também podem dormir no galpão. Os autores apresentam as lexias 
galponeada, como reunião realizada no galpão e galponeiro definida como a pessoa acostumada ao galpão.

Gancho | s.m.

peça de metal usada para içar o gado durante a matança afim de posicioná-lo para o abate || objeto de metal usado no açougue ou na charqueada para pendurar carne

Abonação: "...conservar a carne sem ser pendurada nos ganchos para isso destinados." (Doc 02 - Flo. 1896/1901)

"Quatro ou cinco operários de pé sobre a pilha obtém facilmente este resultado, estendendo os fragmentos com suas mãos, ou melhor, com ganchos de ferro." (Doc 89 - L.C. 1880)

Ocorrência nos dicionários:

\begin{tabular}{|c|c|c|c|}
\hline Autor & Ano obra & Lexia & $\begin{array}{c}\text { Acepção correspondente } \\
\text { ao glossário }\end{array}$ \\
\hline RB & 1712 & + & - \\
\hline AMS & 1813 & + & - \\
\hline DV & 1873 & + & - \\
\hline LF & 1940 & + & - \\
\hline CA & 1958 & + & - \\
\hline ABHF & 1986 & + & - \\
\hline ZCN/RCN & 1996 & - & - \\
\hline AH/MSV & 2001 & + & - \\
\hline FSB & 2002 & + & - \\
\hline BB & 2003 & - & - \\
\hline
\end{tabular}

Análise descritiva dos dicionários gerais:

RB e AMS não definem claramente a lexia gancho, somente especificam o seu formato e material. DV, LF e CA apresentam a lexia gancho como peça curva de metal que serve para suspender pesos, não mencionando carne ou outro tipo de alimento. As definições são extensas, referindo-se ao vestuário, anzol, lucro escusos etc. ABHF e AH/MSV definem como peça para suspender qualquer peso, sem citar açougues ou carnes. Já FSB apresenta o gancho como peça de metal que serve para suspender bois nos açougues.

Variante: gàncho (AMS)

Análise descritiva dos dicionários regionalistas:

Não consta a lexia nas referidas obras. 
Gordura comestível | s.f.

produto de charqueada preparado através da fervura dos ossos, cabeça, coração e víscera do animal || gordura própria para consumo humano || produto usado na culinária

Abonação: “A preparação das gorduras é, sobretudo, complicada; e é justo reconhecer que esta preparação é mais completa, mais perfeita em Pelotas que na maioria dos saladeiros do sul.” (Doc 98 - L.C. 1880)

"Considerava-se com o AA o charque especial, com uma camada de gordura dourada sobre as mantas, destacando-se dos demais; como SS, o mesmo tipo, com um pouco menos de gordura..." (Doc 122 - A.P.C. 1988)

Ocorrência nos dicionários:

\begin{tabular}{|c|c|c|c|}
\hline Autor & Ano obra & Lexia & $\begin{array}{c}\text { Acepção correspondente } \\
\text { ao glossário }\end{array}$ \\
\hline RB & 1712 & - & - \\
\hline AMS & 1813 & - & + \\
\hline DV & 1873 & - & + \\
\hline LF & 1940 & - & + \\
\hline CA & 1958 & - & - \\
\hline ABHF & 1986 & - & - \\
\hline ZCN/RCN & 1996 & - & + \\
\hline AH/MSV & 2001 & - & + \\
\hline FSB & 2002 & - & - \\
\hline BB & 2003 & - & - \\
\hline
\end{tabular}

Análise descritiva dos dicionários gerais:

AMS apresenta alguns exemplos de gorduras comestíveis, o toucinho, a banha etc. A única referência mencionada por $\mathbf{D V}$ é que certas gorduras servem para a nutrição. $\mathbf{L F}$ apresenta no verbete alguns tipos de gordura apenas listando as lexias. CA, por sua vez, repete algumas informações já apresentadas nas obras anteriormente citadas, mencionando a lexia jabá em sua abonação sobre gorduras e óleos de cozinha. AH/MSV apresenta a lexia sem fazer separação tipológica, mas discorre sobre diferentes usos para a gordura, como banha etc. FSB assemelha-se a AH/MSV, mencionando o uso culinário da gordura.

Nota: A quantidade e qualidade da gordura dos pedaços de charque são fatores que definem sua classificação. Era considerado o melhor charque o que tivesse um alto teor de gordura dourada. 
Análise descritiva dos dicionários regionalistas:

Não consta a lexia nas referidas obras.

Gordura industrial | s.f.

gordura considerada imprópria para consumo humano || graxa utilizada na produção de sabão, vela etc

Abonação: "A preparação das gorduras é, sobretudo, complicada; e é justo reconhecer que esta preparação é mais completa, mais perfeita em Pelotas que na maioria dos saladeiros do sul.” (Doc 98 - L.C. 1880)

"Além da separação entre gorduras comestíveis e industriais, foi-se ao nível do desdobramento destas últimas para a fabricação de sabões, velas de estearina e glicerina." (Doc 71 - A.F.M. s/n)

Ocorrência nos dicionários:

\begin{tabular}{|c|c|c|c|}
\hline Autor & Ano obra & Lexia & $\begin{array}{c}\text { Acepção correspondente } \\
\text { ao glossário }\end{array}$ \\
\hline RB & 1712 & - & - \\
\hline AMS & 1813 & - & - \\
\hline DV & 1873 & - & - \\
\hline LF & 1940 & - & - \\
\hline CA & 1958 & - & - \\
\hline ABHF & 1986 & - & - \\
\hline ZCN/RCN & 1996 & - & - \\
\hline AH/MSV & 2001 & - & - \\
\hline FSB & 2002 & - & + \\
\hline BB & 2003 & - & - \\
\hline
\end{tabular}

Análise descritiva dos dicionários gerais:

Nenhum autor, com exceção de FSB, menciona a existência ou do uso de gorduras industrialmente. Este lexicógrafo apresenta o uso industrial de gorduras e, em sua abonação, menciona a aplicabilidade desta sustância no preparo de sabões e velas.

Análise descritiva dos dicionários regionalistas:

Não consta a lexia nas referidas obras.

Graxa | s.f.

gordura extraída do animal || produto produzido na charqueada para o melhor aproveitamento do gado abatido 
Abonação: “...transmitindo aos manômetros a pressão das 4 caldeiras destinadas ao preparo da graxa amarelinha, acondicionadas em bordalesas ou em bexigas, que enchiam os olhos pela qualidade.” (Doc 109 - A.P.C. 1988)

“...16 de Janeiro. - Graxa em pipas, 320 a 330 kilos, dita em bexigas, 400 a 420; lingoas de fumeiro, $28 \$$ a $29 \$$ cento; ditas communs, $16 \$$ a $20 \$$; em salmoura, $26 \$$ a 30\$; sebo coado, 420 a 440 rs. kilos; soccado 300 a 330; xarque superior do Rio..." (Doc 31 - Pel. 1869)

Variante: graixa

Ocorrência nos dicionários:

\begin{tabular}{|c|c|c|c|}
\hline Autor & Ano obra & Lexia & $\begin{array}{c}\text { Acepção correspondente } \\
\text { ao glossário }\end{array}$ \\
\hline RB & 1712 & + & - \\
\hline AMS & 1813 & + & - \\
\hline DV & 1873 & + & - \\
\hline LF & 1940 & + & + \\
\hline CA & 1958 & + & + \\
\hline ABHF & 1986 & + & - \\
\hline ZCN/RCN & 1996 & - & + \\
\hline AH/MSV & 2001 & + & + \\
\hline FSB & 2002 & + & - \\
\hline BB & 2003 & - & - \\
\hline
\end{tabular}

Análise descritiva dos dicionários gerais:

RB, AMS e DV apresentam nas lexias acepções associadas à graxa de sapato, produto de lubrificação de rodas ou doença de cavalos. LF, CA, AH/MSV e FSB apresentam graxa como sinônimo de gordura, banha, mencionando-a como produto animal. ABHF somente define a lexia como lubrificante e óleo para conservação de couro. Variantes: graixa (RB, DV, LF, AH/MSV); gráxa (AMS)

Análise descritiva dos dicionários regionalistas:

ZCN/RCN revela o verbo graxear como sinônimo de namorar. Ambos os autores mencionam as lexias graxento e graxudo como animal que tem muita graxa, gorduroso etc. BB apresenta a expressão graxa em focinho de cachorro, que significa algo de pouca duração.

Graxeiro| s.m.

empregado da charqueada que prepara a graxa 
Abonação: "Ali estavam alinhados, esperando o primeiro boi, zorreiros, camboneiros... ...serradores de caracu, resfriadores, graxeiros, eletrecistas, tripeiros, etc e etc." (Doc 108 - A.P.C. 1988)

Ocorrência nos dicionários:

\begin{tabular}{|c|c|c|c|}
\hline Autor & Ano obra & Lexia & $\begin{array}{c}\text { Acepção correspondente } \\
\text { ao glossário }\end{array}$ \\
\hline RB & 1712 & - & - \\
\hline AMS & 1813 & - & - \\
\hline DV & 1873 & - & - \\
\hline LF & 1940 & + & - \\
\hline CA & 1958 & + & - \\
\hline ABHF & 1986 & + & - \\
\hline ZCN/RCN & 1996 & - & - \\
\hline AH/MSV & 2001 & + & - \\
\hline FSB & 2002 & + & - \\
\hline BB & 2003 & - & - \\
\hline
\end{tabular}

Análise descritiva dos dicionários gerais:

LF, CA, ABHF, AH/MSV e FSB apresentam a lexia de entrada, mas a acepção dos verbetes refere-se somente ao indivíduo que passa a graxa em lugares como trilhos de trem etc. Estes autores não definem graixeiro como aquele que fabrica ou prepara graxa, como apresentou-se no corpus do trabalho.

Análise descritiva dos dicionários regionalistas:

Não consta a lexia nas referidas obras.

Graxaria | s.f.

construção onde se prepara a graxa || local onde se produz gordura e sebo || local da instalação da caldeira

Abonação: “...todas as benfeitorias, galpões, barraca de couro, graixeira, armazéns, mangueiras, varáes...”(Doc 54 - Poa 1871)

"Infelizmente, estas "graxarias" assim aperfeiçoadas custam muito caro..." (Doc 97 L.C. 1880)

“...e quanto às carnes, são deixadas e queimadas com os ossos, ao sair da "graxaria", para aquecer as caldeiras" (Doc 98 - L.C. 1880)

Variante: graixeira

Ocorrência nos dicionários:

\begin{tabular}{|l|l|l|l|}
\hline Autor & Ano obra & Lexia & Acepção correspondente \\
\hline
\end{tabular}




\begin{tabular}{|c|c|c|c|}
\hline & & & ao glossário \\
\hline RB & 1712 & - & - \\
\hline AMS & 1813 & - & - \\
\hline DV & 1873 & - & - \\
\hline LF & 1940 & + & + \\
\hline CA & 1958 & + & + \\
\hline ABHF & 1986 & + & ++ \\
\hline ZCN/RCN & 1996 & + & + \\
\hline AH/MSV & 2001 & + & - \\
\hline FSB & 2002 & + & ++ \\
\hline BB & 2003 & + & + \\
\hline
\end{tabular}

Análise descritiva dos dicionários gerais:

CA menciona o Rio Grande do Sul como o estado em que emprega esta lexia. ABHF refere-se diretamente às charqueadas em sua acepção.

Variante: graxeira $(\mathrm{LF}, \mathrm{ZCN} / \mathrm{RCN}, \mathrm{BB})$

Análise descritiva dos dicionários regionalistas:

ZCN/RCN e BB definem a graxeira ou graxaria como o local onde se coloca a caldeira, citando as charqueadas como o local em que se prepara as graxas derretendo os ossos e gorduras das reses a fim de fabricar a gordura.

Guampa $\mid$ s.f.

ver chifre

Abonação: "Não menos maravilhosa, no entanto, é a perícia de um laçador de brete! Ali estão 20 animais apertados uns contra os outros, chifre a chifre, não restando mais de $5 \mathrm{~cm}$ separando as guampas dos animais.” (Doc 110 - A.P.C. 1988)

Ocorrência nos dicionários:

\begin{tabular}{|l|c|c|c|}
\hline \multicolumn{1}{|c|}{ Autor } & Ano obra & Lexia & $\begin{array}{c}\text { Acepção correspondente } \\
\text { ao glossário }\end{array}$ \\
\hline RB & 1712 & - & - \\
\hline AMS & 1813 & - & - \\
\hline DV & 1873 & - & - \\
\hline LF & 1940 & + & + \\
\hline CA & 1958 & + & + \\
\hline ABHF & 1986 & + & + \\
\hline ZCN/RCN & 1996 & + & + \\
\hline AH/MSV & 2001 & + & + \\
\hline FSB & 2002 & + & + \\
\hline BB & 2003 & + & + \\
\hline
\end{tabular}

Análise descritiva dos dicionários gerais: 
As obras de LF, CA, ABHF, AH/MSV e FSB apresentam guampa com a remissão para chifre, o que se pode inferir é que, no resto do país, as lexias chifre e corno são mais usuais do que guampa.

Nota: No Rio Grande do Sul, esta parte do animal é considerada não só um subproduto de charqueada, mas utensílio para guardar bebida.

Análise descritiva dos dicionários regionalistas:

ZCN/RCN e BB apresentam as lexias: guampaço definida como golpe de guampa; guampada como golpe ou líquido contido na guampa; guampa-torta como o homem valente, destemido; guampear definido como agredir o indivíduo com as guampas. Este verbo também apresenta a acepção em sentido figurado, usado como sinônimo de trair, ser infiel. Ainda são mencionadas as lexias guampinha definida como pequena guampa; guampudo, como aquele que têm grandes chifres (diz-se do homem que tem uma mulher infiel). BB fornece as lexias: guampa do apojo, que é uma espécie de caixinha coletada nos Centros de Tradição Gaúchas (CTGs), usadas para pagamento de pequenas despesas; guampeador no sentido de corneador, e, por último, a expressão: a meia guampa usada no sentido de ligeiramente embriagado.

Guano | s.m.

espécie de adubo preparado com farinha de osso, sangue coagulado e víscera de animal || subproduto fabricado na charqueada

Abonação: “... sangue era aparado dentro de uma espécie de forma de lata, colocada sob o pescoço do animal e posteriormente levado a tonéis, para depois de coagulado e seco, ser misturado com farinha de ossos para a fabricação de adubo (guano)." (Doc 115 - A.P.C. 1988)

Ocorrência nos dicionários:

\begin{tabular}{|c|c|c|c|}
\hline Autor & Ano obra & Lexia & $\begin{array}{c}\text { Acepção correspondente } \\
\text { ao glossário }\end{array}$ \\
\hline RB & 1712 & - & - \\
\hline AMS & 1813 & - & - \\
\hline DV & 1873 & + & - \\
\hline LF & 1940 & + & + \\
\hline CA & 1958 & + & + \\
\hline ABHF & 1986 & + & + \\
\hline ZCN/RCN & 1996 & - & + \\
\hline AH/MSV & 2001 & + & - \\
\hline FSB & 2002 & - & - \\
\hline
\end{tabular}




\section{\begin{tabular}{l|l} 
BB & 2003
\end{tabular}}

Análise descritiva dos dicionários gerais:

DV apresenta a lexia definindo-a como uma substância produzida pelo excremento das aves marinhas. LF, CA e ABHF denominam o guano produzido com carnes de animais e outras sustâncias orgânicas, como guano artificial. Em nenhum documento do corpus foi encontrada esta referência, pois os autores que mencionam este produto não diferenciam seus tipos. AH/MSV ainda acrescenta o nome genérico - adubo.

Análise descritiva dos dicionários regionalistas:

Não consta a lexia nas referidas obras.

Guincheiro | s.m.

empregado de charqueada encarregado do manuseio do guincho ou máquina a vapor

Abonação: “Ali estavam alinhados, esperando o primeiro boi, zorreiros, camboneiros... ... balanceiros, porteiros, guincheiros, carregadores de ossadas e buchadas...” (Doc 108 - A.P.C. 1988)

Ocorrência nos dicionários:

\begin{tabular}{|c|c|c|c|}
\hline Autor & Ano obra & Lexia & $\begin{array}{c}\text { Acepção correspondente } \\
\text { ao glossário }\end{array}$ \\
\hline RB & 1712 & - & - \\
\hline AMS & 1813 & - & - \\
\hline DV & 1873 & - & - \\
\hline LF & 1940 & + & - \\
\hline CA & 1958 & + & + \\
\hline ABHF & 1986 & + & + \\
\hline ZCN/RCN & 1996 & - & - \\
\hline AH/MSV & 2001 & + & + \\
\hline FSB & 2002 & - & - \\
\hline BB & 2003 & - & - \\
\hline
\end{tabular}

Análise descritiva dos dicionários gerais:

Enquanto LF apresenta guincheiro como galho de árvore, CA, ABHF e AH/MSV apresentam uma acepção correspondente ao glossário, a dizer, aquele que opera o guincho. CA fornece no verbete a lexia guindasteiro como sinônimo.

Análise descritiva dos dicionários regionalistas:

Não consta a lexia nas referidas obras. 
Guincho $\mid$ s.m.

objeto curvo geralmente de metal usado para pendurar o boi durante o abate \| utensílio usado para puxar o boi a ser desnucado

Abonação: "Laçado o boi, ele gritava: Ala...Ala...Ala...E o laço enrolado o guincho (máquina à vapor), puxava o boi até encostar sua cabeça a um moirão colocado horizontalmente, onde era desnucado com o punhal de 2 gumes". (Doc 112 - A.P.C. 1988)

Ocorrência nos dicionários:

\begin{tabular}{|c|c|c|c|}
\hline Autor & Ano obra & Lexia & $\begin{array}{c}\text { Acepção correspondente } \\
\text { ao glossário }\end{array}$ \\
\hline RB & 1712 & - & - \\
\hline AMS & 1813 & + & - \\
\hline DV & 1873 & + & - \\
\hline LF & 1940 & + & + \\
\hline CA & 1958 & + & + \\
\hline ABHF & 1986 & + & - \\
\hline ZCN/RCN & 1996 & - & + \\
\hline AH/MSV & 2001 & + & + \\
\hline FSB & 2002 & + & - \\
\hline BB & 2003 & - & + \\
\hline
\end{tabular}

Análise descritiva dos dicionários gerais:

AMS e DV apresentam a lexia guincho definindo-a como ave ou grito que não se pronuncia. LF, CA e FSB apresentam além destas definições como objeto pequeno que eleva pesos. Somente ABHF e AH/MSV indicam que guincho é uma máquina a vapor.

Análise descritiva dos dicionários regionalistas:

Não consta a lexia nas referidas obras.

Guisado | s.m.

prato da culinária brasileira feito com pedaços de charque picados

Abonação: "Igual aos outros guisados de charque, porém com pedaços de aipim, mandioca ou macaxeira."(Doc 81 - A.F.M. s/n)

Ocorrência nos dicionários:

\begin{tabular}{|l|l|l|l|}
\hline Autor & Ano obra & Lexia & Acepção correspondente \\
\hline
\end{tabular}




\begin{tabular}{|c|c|c|c|}
\hline & & & ao glossário \\
\hline RB & 1712 & - & - \\
\hline AMS & 1813 & - & - \\
\hline DV & 1873 & - & - \\
\hline LF & 1940 & - & - \\
\hline CA & 1958 & + & ++ \\
\hline ABHF & 1986 & + & ++ \\
\hline ZCN/RCN & 1996 & + & ++ \\
\hline AH/MSV & 2001 & + & + \\
\hline FSB & 2002 & + & ++ \\
\hline BB & 2003 & + & ++ \\
\hline
\end{tabular}

Análise descritiva dos dicionários gerais:

CA é o primeiro autor a fazer referência a guisado como carne fresca picada, e, também, apresenta aos consulentes o guisado como um picadinho de charque. AH/MSV somente apresenta guisado como picadinho de carne fresca ou salgada, não mencionando a lexia charque. Esta mesma acepção foi encontrada em ABHF e FSB.

Observação: Os guisados de charque, segundo Alvarino da Fontoura Marques, podem ser acompanhados de banana da terra, batatas inglesas, pêssegos verdes, abóbora, massa cozida à parte, dentre outros acompanhamentos.

Análise descritiva dos dicionários regionalistas:

ZCN/RCN e BB apresentam como acepção picadinho de carne fresca ou charque. BB ainda menciona guisado como sinônimo de carne moída ou boi ralado, indicando que estas lexias são usadas no estado de Santa Catarina.

Havaneira | s.f.

charque de qualidade inferior || carne salgada de qualidade ruim exportada para Cuba

Abonação: “... que o Rio da Prata somente vende a Cuba, para onde são expedidas as piores carnes; também se dá o nome de "havaneira" às qualidades mais inferiores." (Doc 91 - L.C. 1880)

Ocorrência nos dicionários:

\begin{tabular}{|c|c|c|c|}
\hline Autor & Ano obra & Lexia & $\begin{array}{c}\text { Acepção correspondente } \\
\text { ao glossário }\end{array}$ \\
\hline RB & 1712 & - & - \\
\hline AMS & 1813 & - & - \\
\hline DV & 1873 & - & - \\
\hline LF & 1940 & + & - \\
\hline
\end{tabular}




\begin{tabular}{|c|c|c|c|}
\hline CA & 1958 & - & - \\
\hline ABHF & 1986 & - & - \\
\hline ZCN/RCN & 1996 & - & - \\
\hline AH/MSV & 2001 & + & - \\
\hline FSB & 2002 & - & - \\
\hline BB & 2003 & + & - \\
\hline
\end{tabular}

Análise descritiva dos dicionários gerais:

Os dicionaristas que apresentam a lexia não a definem como um tipo de carne e sim um tipo de dança.

Nota: Saint-Hilaire cita o envio das carnes para Havana, de onde originou-se o nome havaneira, mas em nenhum momento discorre sobre esta qualificação. Louis Couty também menciona, mesmo que rapidamente, sobre o envio de carne ruim para Cuba.

Análise descritiva dos dicionários regionalistas:

Não consta a lexia nas referidas obras.

Iate $\mid$ s.m.

embarcação usada para transportar pessoas em curtas distâncias | meio de transporte bastante utilizado por charqueadores

Abonação: "Embarquei no iate do Senhor Chaves, com um de seus amigos, seguindo o mesmo caminho da vinda." (Doc 133 - A.S.H. 1820/21)

"A casa está situada do modo o mais favorável, pois que os iates podem chegar até bem junto dela. A residência do proprietário é de um pavimento..." (Doc 129 - A.S.H. $1820 / 21)$

"À medida que as barcaças e iates partiam de pelotas rumo ao porto de Rio Grande ou ao Rio de Janeiro, uma nova e poderosa elite começou a surgir em Pelotas." (Doc 36 - Pel. 2007)

Variantes: hiate

Ocorrência nos dicionários:

\begin{tabular}{|c|c|c|c|}
\hline Autor & Ano obra & Lexia & $\begin{array}{c}\text { Acepção correspondente } \\
\text { ao glossário }\end{array}$ \\
\hline RB & 1712 & + & + \\
\hline AMS & 1813 & + & + \\
\hline DV & 1873 & + & + \\
\hline LF & 1940 & + & + \\
\hline CA & 1958 & + & + \\
\hline ABHF & 1986 & + & + \\
\hline
\end{tabular}




\begin{tabular}{|c|c|c|c|}
\hline ZCN/RCN & 1996 & - & - \\
\hline AH/MSV & 2001 & + & + \\
\hline FSB & 2002 & + & + \\
\hline BB & 2003 & - & - \\
\hline
\end{tabular}

Análise descritiva dos dicionários gerais:

DV e AMS em suas descrições indicam que os iates eram comuns na Inglaterra, Holanda e costa de Portugal. LF é o primeiro dicionarista a grafar iate sem o uso da inicial h. Este autor é seguido pelos outros autores e, assim como ele, CA classifica dois os tipos de iate. A primeira acepção é definida como navio de pequena lotação e a segunda, denominada de iate de recreio, que é definido como navio elegante, ligeiro. Hoje em dia, observa-se que os iates são embarcações luxuosas, rápidas e usadas para recreação. Esta observação é comprovada por ABHF e AH/MSV que, a partir do século XX, apresentam iate como antigo navio de vela, descrevendo iate como embarcação luxuosa que transporta pessoas "de distinção". FSB somente define esta lexia como embarcação de recreio.

Observação: Há indícios de que os charqueadores mais abastados possuiam iates para seu uso pessoal. Saint-Hilaire, em seu diário, relata o uso do iate como meio de transporte intermediário, transportando os passageiros de seu estabelecimento de charqueada até as embarcações maiores.

Variantes: hiate (RB, AH/MSV); hiáte (AMS)

Análise descritiva dos dicionários regionalistas:

Não consta a lexia nas referidas obras.

128 Imposto | s.m.

quantia paga por imposição governamental

Abonação: “Imposto sobre gado abatido - Este imposto, que é de 200 reis, recae sobre cada cabeça de gado abatido para exportação nas xarqueadas e em outros estabelecimentos congeneres." (Doc 17 - Pel. s/n)

“... tenho a dizer a Vossa Merces que approvo que seja administrada pelo respectivo Procurador, a arrecadação do imposto de 20 reis por cabeça de gado que se matar nas charqueadas desse municipio..." (Doc 19 - Pel. 1844) 
"Em 1818 a quantidade de carne seca exportada para Cuba e Estados Unidos subiu a 100 mil arrobas. Taxaram em 600 réis o imposto de cada arroba, o que até essa ocasiāo era de 200 réis..." (Doc 137 - A.S.H. 1820/21)

Ocorrência nos dicionários:

\begin{tabular}{|c|c|c|c|}
\hline Autor & Ano obra & Lexia & $\begin{array}{c}\text { Acepção correspondente } \\
\text { ao glossário }\end{array}$ \\
\hline RB & 1712 & + & + \\
\hline AMS & 1813 & + & + \\
\hline DV & 1873 & + & + \\
\hline LF & 1940 & + & + \\
\hline CA & 1958 & + & + \\
\hline ABHF & 1986 & + & + \\
\hline ZCN/RCN & 1996 & - & + \\
\hline AH/MSV & 2001 & + & + \\
\hline FSB & 2002 & + & - \\
\hline BB & 2003 & - & + \\
\hline
\end{tabular}

Análise descritiva dos dicionários gerais:

DV é o primeiro lexicógrafo a classificar alguns tipos de impostos em sua obra, como imposto direto, indireto etc. LF, CA, ABHF e AH/MSV apresentam uma lista de impostos, enquanto FSB apresenta apenas dois. Mesmo com as acepções correspondentes ao glossário, nenhuma das obras menciona impostos sobre animais, como aparece no corpus.

Observação: Os impostos cobrados aos produtores e comprados de gado ou charque e seus produtos, aparecem em inúmeros documentos do corpus. Cobravam-se impostos sobre o gado verde, o gado abatido, o gado exportado, importado, por cabeça de gado, por tropa de gado etc. Há documentos elaborados pelos criadores de gado do Rio Grande do Sul em uma tentativa de proteger estes contribuintes dos problemas de contrabando, pois, vários comerciantes encontravam meio de burlar as leis e aumentar seus lucro, sonegando impostos. Segundo historiadores pelotenses, as altas taxas, a quantidade de impostos e a insatisfação generalizada perante o governo, foram os principais desencadeadores da Revolução Farroupilha.

Análise descritiva dos dicionários regionalistas:

Não consta a lexia nas referidas obras. 
Jabá | s.m.

charque || carne seca || tajano || carne-do-ceará

Ocorrência nos dicionários:

\begin{tabular}{|c|c|c|c|}
\hline Autor & Ano obra & Lexia & $\begin{array}{c}\text { Acepção correspondente } \\
\text { ao glossário }\end{array}$ \\
\hline RB & 1712 & - & - \\
\hline AMS & 1813 & - & - \\
\hline DV & 1873 & - & - \\
\hline LF & 1940 & + & ++ \\
\hline CA & 1958 & + & ++ \\
\hline ABHF & 1986 & + & ++ \\
\hline ZCN/RCN & 1996 & - & - \\
\hline AH/MSV & 2001 & + & ++ \\
\hline FSB & 2002 & + & ++ \\
\hline BB & 2003 & - & - \\
\hline
\end{tabular}

Análise descritiva dos dicionários gerais:

LF e FSB apresentam jabá, como sinônimo de carne seca e charque. CA e ABHF fornecem no verbete jabá uma remissão para charque. AH/MSV define jabá como o mesmo que charque e levanta a hipótese de que jabá é derivado do tupi yabá, que significa fugir, esconder-se - dada a ausência dos viajantes de seus lares.

Observação: Em nenhum documento do corpus foi encontrada a lexia jabá, esta lexia, por sua vez, compõe o códice por ter sido mencionada nas pesquisas de campo.

Análise descritiva dos dicionários regionalistas:

Não consta a lexia nas referidas obras.

Laçador de brete $\mid$ s.m.

empregado da charqueada encarregado de laçar o gado dentro do brete

Abonação: "Não menos maravilhosa, no entanto, é a perícia de um laçador de brete! Ali estão 20 animais apertados uns conta os outros, chifre a chifre, não restando mais de 5 centímetros separando as guampas dos animais!"(Doc 110 - A.P.C. 1988)

Ocorrência nos dicionários:

Não consta a lexia nas referidas obras.

Análise descritiva dos dicionários gerais: 
LF apresenta que o laçador é homem destro no exercício de laçar. ABHF e AH/MSV fornecem a mesma acepção de $\mathbf{L F}$, indicando a lexia como regionalista do Rio Grande do Sul.

Análise descritiva dos dicionários regionalistas:

Não consta a lexia nas referidas obras.

ZCN/RCN e BB apresentam, em suas obras, as seguintes lexias: emlaçar, definida como jogar o laço; enlaçador, como sinônimo de laçador; laçaço definida como pancada com um laço. As expressões, afrouxar o laço significando atirar o laço para laçar a rês e, por fim, dar um laçaço, expressão apresentada como golpear, puxar o laço com violência.

Laçador matador $\mid$ s.m.

empregado da charqueada que, além de laçar o boi para o abate, também se encarrega de desnucar a rês

Abonação: "Não menos maravilhosa, no entanto, é a perícia de um laçador de brete! Ali estão 20 animais apertados uns conta os outros, chifre a chifre, não restando mais de 5 centímetros separando as guampas dos animais!”(Doc 110 - A.P.C. 1988)

“Aí, os animais encostados uns nos outros, aguardavam o laçador-matador, em geral um castelhano de boa cepa, com coragem bastante para denucar as reses com um pequeno punham de dois gumes." (Doc 108 - A.P.C. 1988)

Ocorrência nos dicionários:

Não consta a lexia nas referidas obras.

Análise descritiva dos dicionários gerais:

Não consta a lexia nas referidas obras.

Análise descritiva dos dicionários regionalistas:

Na obra de ZCN/RCN o verbete laçador tem acepção de homem destro no manejo do laço. O autor apresenta como sinônimo de laçador, a lexia campeiro, informando que este é encarregado de laçar as reses. BB apresenta acepção semelhante a $\mathbf{Z C N} / \mathbf{R C N}$, indicando que o campeiro é responsável por laçar o gado.

Lancha $\mid$ s.f. 
embarcação utilizada para transporte de pessoas e mercadorias produzidas na charqueada

Abonação: “As margens dos rios Sāo Gonçalo e Pelotas sāo muito chatas, o campo é alegre e coberto de bosquetes e de pastagens. Chegados a norte passamos para uma sumaca, também pertencente ao Senhor Chaves, donde nos transportamos a uma lancha que nos levou ao Rio Grande". (Doc 133 - A.S.H. 1820/21)

Ocorrência nos dicionários:

\begin{tabular}{|c|c|c|c|}
\hline Autor & Ano obra & Lexia & $\begin{array}{c}\text { Acepção correspondente } \\
\text { ao glossário }\end{array}$ \\
\hline RB & 1712 & + & + \\
\hline AMS & 1813 & + & + \\
\hline DV & 1873 & + & + \\
\hline LF & 1940 & + & - \\
\hline CA & 1958 & + & + \\
\hline ABHF & 1986 & + & + \\
\hline ZCN/RCN & 1996 & + & + \\
\hline AH/MSV & 2001 & + & + \\
\hline FSB & 2002 & + & - \\
\hline BB & 2003 & + & + \\
\hline
\end{tabular}

Análise descritiva dos dicionários gerais:

RB e CA indicam que lancha é um barco pequeno, utilizado por navios para locomoção. AMS e FSB apresentam lancha como embarcação pequena. DV define lancha como embarcação grande, usada em transporte de mercadorias e para salvamentos de acidentes com navios.

Observação: Não há citação de lancha como meio transporte de carne, charque ou outro tipo de mercadoria conforme se apresentou nos documentos do trabalho.

Análise descritiva dos dicionários regionalistas:

Os autores regionalistas apenas indicam a lexia lancha como sinônimo de pé grande.

Lanhagem $\mid$ s.f.

processo usado durante a charqueagem da carne || espécie de incisão paralela e profunda feita na manta de carne || cortes em diversas direções feitos na carne para aumentar a superfície de contato com o sal e o ar || retalhação

Abonação: “... na charqueagem, acrescenta-se, em Pelotas, uma operação acessória, que não existe absolutamente em outro lugar, a" lanhagem". (Doc 88 - L.C. 1880)

Ocorrência nos dicionários: 
Não consta a lexia nas referidas obras.

Análise descritiva dos dicionários gerais:

CA apresenta o verbo lanhar, definindo-o como ferir, modificar, golpear, associando a lexia ao castigo a negros. ABHF e AH/MSV também mencionam o verbo lanhar, definindo como golpear para salgar o peixe.

Nota: Na obra de Louis Couty, o autor discorre sobre a lanhagem de maneira detalhada. Segundo este autor, esta operação era exclusivamente realizada em Pelotas. Análise descritiva dos dicionários regionalistas:

Não consta a lexia nas referidas obras.

Magarefe | s.m.

trabalhador de açougue || açougueiro || aquele que corta a carne

Abonação: "Artigo 70. -Os magarefes são obrigados a conservarem sempre em estado de asseio os balcões, balanças, pesos e todos utencilios empregados no córte e venda da carne; bem como a varrer, lavar os açougues todos os dias depois de finda a venda." (Doc 02 - Flo. 1896/1901)

Ocorrência nos dicionários:

\begin{tabular}{|c|c|c|c|}
\hline Autor & Ano obra & Lexia & $\begin{array}{c}\text { Acepção correspondente } \\
\text { ao glossário }\end{array}$ \\
\hline RB & 1712 & + & + \\
\hline AMS & 1813 & + & + \\
\hline DV & 1873 & + & + \\
\hline LF & 1940 & - & - \\
\hline CA & 1958 & + & + \\
\hline ABHF & 1986 & + & - \\
\hline ZCN/RCN & 1996 & - & + \\
\hline AH/MSV & 2001 & + & + \\
\hline FSB & 2002 & + & - \\
\hline BB & 2003 & - & + \\
\hline
\end{tabular}

Análise descritiva dos dicionários gerais:

RB, DV e CA apresentam a lexia magarefe como sinônimo daquele que mata e esfola as reses para o açougue. AMS apresenta-o como aquele que esfola as carniças nos açougues. AH/MSV é o primeiro dicionarista a indicar magarefe como sinônimo de açougueiro. FSB define a acepção da lexia como aquele que abate as reses nos matadouros.

Análise descritiva dos dicionários regionalistas: 
Não consta a lexia nas referidas obras.

Mangueira | s.f.

espaço fechado onde se encerra o boi recém chegado ao estabelecimento saladeril || espécie de cercado usado para guardar bois

Abonação: "Uma tropa de gado, depois de 5 a 20 dias de viagem em média, chega ao saladeiro: encerram-na nos espaços fechados, ou "mangueiras", muito variáveis em número e em disposição. (Doc 84 - L.C. 1880)

Ocorrência nos dicionários:

\begin{tabular}{|c|c|c|c|}
\hline Autor & Ano obra & Lexia & $\begin{array}{c}\text { Acepção correspondente } \\
\text { ao glossário }\end{array}$ \\
\hline RB & 1712 & - & - \\
\hline AMS & 1813 & - & - \\
\hline DV & 1873 & - & - \\
\hline LF & 1940 & - & - \\
\hline CA & 1958 & + & + \\
\hline ABHF & 1986 & + & + \\
\hline ZCN/RCN & 1996 & + & + \\
\hline AH/MSV & 2001 & + & + \\
\hline FSB & 2002 & + & + \\
\hline BB & 2003 & + & + \\
\hline
\end{tabular}

Análise descritiva dos dicionários gerais:

RB, AMS e DV apresentam mangueira como termo náutico, composto de panos alcatroados. CA, ABHF e FSB apresentam como lexia regionalista rio-grandense, definindo-a como grande curral de gado. AH/MSV fornece a mesma acepção dos dicionaristas anteriores, mencionando o uso no RS, em GO e SP.

Análise descritiva dos dicionários regionalistas:

ZCN/RCN e BB apresentam a lexia mangueira como um grande curral construído de pedras, arame ou madeira que serve para para encerrar o gado para castração, curar bicheiras, marcação etc. Ambos os lexicógrafos indicam que as mangueiras são construídas junto às casas das estâncias. Não há indicação de mangueira em um estabelecimento de charqueada. ZCN/RCN menciona as lexias curralão como sinônimo de mangueira, e manguear, definida como ação de encerrar, prender o gado na mangueira. 
Mangueira de matança $\mid$ s.f.

cercado usado para confinar o boi antes do abate \|| pequeno espaço cercado de muros altos e resistentes || espaço de confinamento de gado

Abonação: "No dia seguinte de sua chegada, geralmente, fazem-na passar por pequenos grupos de 20 a 60 mais ou menos em um espaço fechado menos, cercada de muralhas resistentes e bastante elevadas: é a "mangueira de matança" que comunica com as outras por um caminho estreito mais ou menos longo, o "curro"ou "brete". (Doc 84 - L.C. 1880)

Ocorrência nos dicionários:

Não consta a lexia nas referidas obras.

BB apresenta em sua obra o verbo emangueirar, definido como ação de colocar na mangueira.

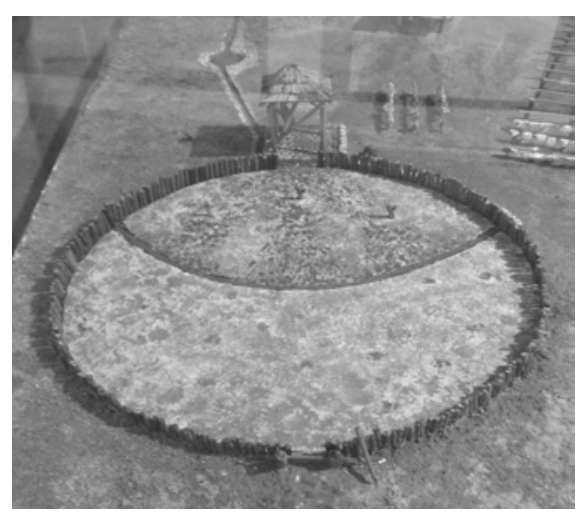

Fig.9 Mangueira de Matança

Fonte: Maquete do Museu do Charque, Pelotas

Foto: Cátia Schreiner, 2011

Mangueirão | s.m.

grande mangueira de matança destinada ao confinamento de gado

Abonação: "A seguir eram levados para a Charqueada pela Estrada das Tropas (hoje Avenida São Francisco de Paula) para serem encerrados nos mangueirões.” (Doc 109 - A.P.C. 1988)

Ocorrência nos dicionários:

\begin{tabular}{|c|c|c|c|}
\hline Autor & Ano obra & Lexia & $\begin{array}{c}\text { Acepção correspondente } \\
\text { ao glossário }\end{array}$ \\
\hline RB & 1712 & - & - \\
\hline AMS & 1813 & - & - \\
\hline DV & 1873 & - & - \\
\hline LF & 1940 & + & + \\
\hline
\end{tabular}




\begin{tabular}{|c|c|c|c|}
\hline CA & 1958 & + & + \\
\hline ABHF & 1986 & + & + \\
\hline ZCN/RCN & 1996 & + & + \\
\hline AH/MSV & 2001 & + & + \\
\hline FSB & 2002 & - & - \\
\hline BB & 2003 & + & + \\
\hline
\end{tabular}

Análise descritiva dos dicionários gerais:

LF e CA apresentam mangueirão como curral muito extenso. ABHF e AH/MSV mencionam mangueirão como de um curral muito extenso destinado a tropas de animais.

Análise descritiva dos dicionários regionalistas:

ZCN/RCN e BB apresentam mangueirão como uma mangueira grande para encerrar tropas de animais e mencionam a lexia transcurral, definida como curral pequeno ao lado da mangueira.

Manta $\mid$ s.f.

pedaço de carne salgada || grande fragmento unilateral de carne || porção grande de charque

Abonação: "Em toda a parte onde parávamos na estrada, meu guia perguntava se era possível adquirir uma manta. A manta nada mais é que uma grande faixa de carne seca e nunca foi vendida ao meu guia, pois todos o presenteavam com franqueza. Ele e seus companheiros improvisaram então espetos de pau, com os quais assavam ligeiramente pedaços de carne, sendo a manta logo devorada". (Doc 126 - A.S.H. $1820 / 21)$

"Destaca-se, a seguir, em um só fragmento, todos os músculos cérvico-faciais, dorsolombares e costo-abdominais do mesmo lado: cada um desses

enormes fragmentos unilaterais constitui a "manta", a porção mais apreciada pelos consumidores." (Doc 86 - L.C. 1880)

Ocorrência nos dicionários:

\begin{tabular}{|c|c|c|c|}
\hline Autor & Ano obra & Lexia & $\begin{array}{c}\text { Acepção correspondente } \\
\text { ao glossário }\end{array}$ \\
\hline RB & 1712 & - & - \\
\hline AMS & 1813 & - & - \\
\hline DV & 1873 & - & - \\
\hline LF & 1940 & - & - \\
\hline CA & 1958 & + & + \\
\hline
\end{tabular}




\begin{tabular}{|c|c|c|c|}
\hline ABHF & 1986 & + & + \\
\hline ZCN/RCN & 1996 & + & + \\
\hline AH/MSV & 2001 & + & + \\
\hline FSB & 2002 & + & + \\
\hline BB & 2003 & + & + \\
\hline
\end{tabular}

Análise descritiva dos dicionários gerais:

RB e AMS apresentam a lexia manta de toucinho, definida como metade de um porco aberto. LF apresenta inúmeros tipos de mantas e, assim como as obras anteriormente citadas, somente apresenta a lexia manta de toucinho. CA, ABHF e AH/MSV definem a manta como pedaços de carne ou peixe expostos ao sol, e esclarecem que, no sul do Brasil, manta é pedaço de peito e costela de rês. FSB apenas generaliza como peixe ou carne secos ao sol.

Análise descritiva dos dicionários regionalistas:

ZCN/RCN e BB apresentam a lexia manta como grandes pedaços de rês secos ao sol. Ambos indicam o verbo mantear, como ação de partir a carne em mantas. BB ainda menciona um tipo de manta denominada manta da barrigueira. Neste verbete, o autor indica uma remissão para a lexia barrigueira. No verbete barrigueira apresenta a acepção definida como pedaço de charque de rês.

Matadouro | s.m.

local onde se abate gado || açougue || local público para abater gado

Abonação: "É preciso acrescentar também os couros dos matadouros da cidade: esses couros, sabe-se, são vendidos como os de saladeiros...” (Doc 99 - L.C. 1880)

“...essa Camara pede que pelos Cofres Provinciaes se lhe empreste quarto contos de reis, para tratar do provimento de agoa para essa Cidade, e de oitocentos mil reis para a construcção de hum canal e utensilios do matadouro publico..." (Doc 18 - Pel. 1845)

“... as vaccas velhas, ainda que em estado de gestação, abatidas nos matadouros públicos..." (Doc 17 - Pel. s/n)

Ocorrência nos dicionários:

\begin{tabular}{|c|c|c|c|}
\hline Autor & Ano obra & Lexia & $\begin{array}{c}\text { Acepção correspondente } \\
\text { ao glossário }\end{array}$ \\
\hline RB & 1712 & - & + \\
\hline AMS & 1813 & - & + \\
\hline DV & 1873 & - & - \\
\hline
\end{tabular}




\begin{tabular}{|c|c|c|c|}
\hline LF & 1940 & + & + \\
\hline CA & 1958 & + & + \\
\hline ABHF & 1986 & + & + \\
\hline ZCN/RCN & 1996 & - & - \\
\hline AH/MSV & 2001 & + & + \\
\hline FSB & 2002 & + & + \\
\hline BB & 2003 & - & - \\
\hline
\end{tabular}

Análise descritiva dos dicionários gerais:

RB e AMS não apresentam a lexia matadouro, mas sim, matadeiro, com acepção correspondente ao glossário. LF, CA, ABHF e AH/MSV apresentam, além da acepção do glossário, a informação de que o matadouro é um lugar insalubre, de carnificina. CA expõe ao consulente que ir para matadouro é expor-se a perigo iminente de perder a vida. FSB somente indica que o matadouro é local para o abate de reses.

Variantes: matadeiro (RB, AMS); matadoiro (ABHF, AH/MSV)

Análise descritiva dos dicionários regionalistas:

Não consta a lexia nas referidas obras.

As obras regionalistas apresentam a lexia abatedouro, com a variante abatedoiro, definida como lugar onde as reses são abatidas.

Matambre | s.m.

parte do animal localizada entre a carne e os ossos || parte difícil de ser extraída durante a carneação

Abonação: “...Também haviam colaborado com o carneador 2 matambreiros que, com um instrumento especial, soltavam o matambre, parte mais difícil de ser trabalhada com a faca." (Doc 113 - A.P.C. 1988)

Ocorrência nos dicionários:

\begin{tabular}{|c|c|c|c|}
\hline Autor & Ano obra & Lexia & $\begin{array}{c}\text { Acepção correspondente } \\
\text { ao glossário }\end{array}$ \\
\hline RB & 1712 & - & - \\
\hline AMS & 1813 & - & - \\
\hline DV & 1873 & - & - \\
\hline LF & 1940 & + & - \\
\hline CA & 1958 & + & + \\
\hline ABHF & 1986 & + & + \\
\hline ZCN/RCN & 1996 & + & + \\
\hline AH/MSV & 2001 & + & + \\
\hline
\end{tabular}




\begin{tabular}{|c|c|c|c|}
\hline FSB & 2002 & + & + \\
\hline BB & 2003 & + & + \\
\hline
\end{tabular}

Análise descritiva dos dicionários gerais:

LF, CA, ABHF e AH/MSV apresentam matambre como o mesmo que mata hambre, do espanhol: matar a fome. CA, ABHF e AH/MSV indicam também matambre como lexia usada no RS, definindo-a como a primeira carne que se retira da rês depois do couro. FSB apresenta matambre como assado de carne que cobre as costelas do boi. Análise descritiva dos dicionários regionalistas:

ZCN/RCN e BB também apresentam a lexia matambre como o mesmo que mata hambre, como também a carne entre as costelas e o couro da rês. Os dicionaristas esclarecem ao consulente que é a primeira carne a ser retirada depois da extração do couro do animal e que esta carne fornece um assado muito saboroso. A expressão, agachar-se no matambre definida como comer o matambre; a lexia vaqueira, como sinônimo de matambre, são mencionados pelos autores. BB fornece a expressão repontar o matambre, definindo-a como aparecer o matambre da rês. Segundo este autor, o matambre reponta por baixo do couro, quando ela se movimenta, por ser muito gorda.

\section{Matambreiro| s.m.}

empregado da charqueada encarregado de retirar o matambre do animal

Abonação: “Ali estavam alinhados, esperando o primeiro boi, zorreiros, camboneiros... ...matambreiros, foguistas, mergulhadores de carne e de couros, balanceiros..." ( Doc 108 - A.P.C. 1988)

"Também haviam colaborado com o carneador 2 matambreiros que, com um instrumento especial, soltavam o matambre, parte mais difícil de ser trabalhada com a faca" (Doc 113 - A.P.C. 1988)

Ocorrência nos dicionários:

Não consta a lexia nas referidas obras.

Análise descritiva dos dicionários gerais:

Não consta a lexia nas referidas obras. 
Nota: Segundo os documentos do corpus, o matambreiro era um tipo especial de trabalhador nas charqueadas. Retirar o matambre era, além de difícil, um trabalho que exigia muita habilidade para ser executado de forma rápida e eficaz.

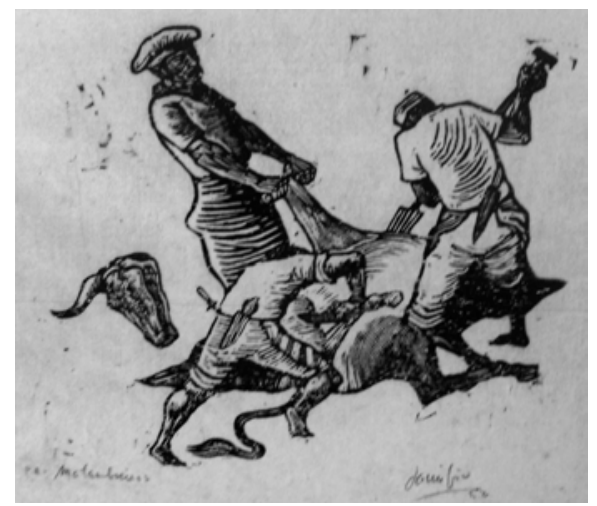

Fig 10 Matambreiros

Xilogravura de Danúbio Gonçalves, acervo do

Museu do Charque, Pelotas, RS

Matança | s.f.

carneação do animal || conjunto de ações com a finalidade de abater um número grande de gado || safra

Abonação: "As matanças iniciavam-se entre meia-noite e uma hora da madrugada, quando deveriam estar a postos todos os empregados, o chamado de... "boi...boi...boi", ecoava num raio de 5 quilômetros, convocando os operários. A tropa que deveria ser abatida, de propriedade da firma ou de custeio, de 300, 500 ou mesmo de 800 bois, já estava distribuída nos mangueirões interligados..." (Doc 108 - A.C.P. 1988)

“...Artigo 67. - A matança do gado serà feita regularmente das 2 horas ás 4 horas da tarde no inverno, e das 3 ás 5 no verão, excepto em èpocas reconhecidamente anormaes..." (Doc 01 - Flo. 1896/1901)

"A fase da matança terminara, havia muito tempo; contudo havia ainda muita carne no chão e vísceras de bois, putrefatas espalhavam forte mau cheiro..." Doc 136 A.S.H. 1820/21)

Ocorrência nos dicionários:

\begin{tabular}{|c|c|c|c|}
\hline Autor & Ano obra & Lexia & $\begin{array}{c}\text { Acepção correspondente } \\
\text { ao glossário }\end{array}$ \\
\hline RB & 1712 & + & - \\
\hline AMS & 1813 & + & + \\
\hline DV & 1873 & + & - \\
\hline LF & 1940 & + & + \\
\hline
\end{tabular}




\begin{tabular}{|c|c|c|c|}
\hline CA & 1958 & + & + \\
\hline ABHF & 1986 & + & + \\
\hline ZCN/RCN & 1996 & - & - \\
\hline AH/MSV & 2001 & + & + \\
\hline FSB & 2002 & + & + \\
\hline BB & 2003 & - & - \\
\hline
\end{tabular}

Análise descritiva dos dicionários gerais:

RB e DV classificam matança relacionando-a com pessoas e não animais. AMS apresenta matança como morte de gado para sustento. LF é o primeiro autor a apresentar ambas acepções: matança como abate de animais e de pessoas. As acepções de LF são também apresentadas nas obras de CA, ABHF, AH/MSV e FSB.

Análise descritiva dos dicionários regionalistas:

Não consta a lexia nas referidas obras.

$\operatorname{Matar} \mid v$.

abater || carnear

Abonação: “Artigo 68. - E prohibido: $\S 1^{\text {o. }}$ - Matar gado magríssimo, doente, cançado, ou estropeado; bem como esquartejar o que for encontrado morto." (Doc 01 - Flo. 1896/1901)

"Esta sangria é constante; ela é indispensável, porque termina de matar animais dos quais alguns teriam podido viver..." (Doc 86 - L.C. 1880)

Ocorrência nos dicionários:

\begin{tabular}{|c|c|c|c|}
\hline Autor & Ano obra & Lexia & $\begin{array}{c}\text { Acepção correspondente } \\
\text { ao glossário }\end{array}$ \\
\hline RB & 1712 & + & - \\
\hline AMS & 1813 & + & - \\
\hline DV & 1873 & + & - \\
\hline LF & 1940 & + & + \\
\hline CA & 1958 & + & + \\
\hline ABHF & 1986 & + & + \\
\hline ZCN/RCN & 1996 & + & + \\
\hline AH/MSV & 2001 & + & + \\
\hline FSB & 2002 & + & - \\
\hline BB & 2003 & + & + \\
\hline
\end{tabular}

Análise descritiva dos dicionários gerais: 
RB, AMS e DV definem o verbo como tirar, desprover a vida. A partir de LF, todos os autores apresentam a acepção correspondente ao glossário, no sentido de carnear, abater.

Análise descritiva dos dicionários regionalistas:

Tanto BB quanto $\mathbf{Z C N} / \mathbf{R C N}$ definem a lexia matar como causar esgotamento de animais pelo excesso de serviço.

Medidor de sanilidade $\mid$ s.m.

instrumento utilizado dentro do tanque de salmoura para medir o nível de sanilidade da água

Abonação: “Os tanques, com mais ou menos 6 metros de comprimento, por 1,50 metro de largura e 1,20 metro de altura, já estavam cheios de salmoura, com os medidores de sanilidade boiando em seus interiores, um destinado à salga da carne e outro à dos couros." (Doc 109 - A.P.C. 1988)

Ocorrência nos dicionários:

\begin{tabular}{|c|c|c|c|}
\hline Autor & Ano obra & Lexia & $\begin{array}{c}\text { Acepção correspondente } \\
\text { ao glossário }\end{array}$ \\
\hline RB & 1712 & + & - \\
\hline AMS & 1813 & + & - \\
\hline DV & 1873 & + & - \\
\hline LF & 1940 & + & - \\
\hline CA & 1958 & + & - \\
\hline ABHF & 1986 & + & - \\
\hline ZCN/RCN & 1996 & - & - \\
\hline AH/MSV & 2001 & + & - \\
\hline FSB & 2002 & + & - \\
\hline BB & 2003 & - & - \\
\hline
\end{tabular}

Análise descritiva dos dicionários gerais:

Os dicionaristas apenas apresentam a lexia medidor como instrumento de medida. LF, ABHF, AH/MSV e FSB exemplificam alguns tipos, mas em nenhuma das acepções é mencionado o medidor de sanilidade.

Análise descritiva dos dicionários regionalistas:

Não consta a lexia nas referidas obras. 
Mergulhador | s.m.

empregado da charqueada que mergulha a carne ou couro no tanque de salmoura

Abonação: "Ali estavam alinhados, esperando o primeiro boi, zorreiros, camboneiros, coleiros, carneadores, charqueadores, aguateiros, salgadeiros, matambreiros, foguistas, mergulhadores de carne e de couros..." (Doc 108 - A.P.C. 1988)

Ocorrência nos dicionários:

\begin{tabular}{|c|c|c|c|}
\hline Autor & Ano obra & Lexia & $\begin{array}{c}\text { Acepção correspondente } \\
\text { ao glossário }\end{array}$ \\
\hline RB & 1712 & - & - \\
\hline AMS & 1813 & + & - \\
\hline DV & 1873 & + & - \\
\hline LF & 1940 & + & - \\
\hline CA & 1958 & + & - \\
\hline ABHF & 1986 & + & - \\
\hline ZCN/RCN & 1996 & - & - \\
\hline AH/MSV & 2001 & + & - \\
\hline FSB & 2002 & + & - \\
\hline BB & 2003 & - & - \\
\hline
\end{tabular}

Análise descritiva dos dicionários gerais:

Os dicionaristas que apresentam a lexia definem mergulhador como aquele que vai ao fundo do mar para pegar o que precisa, aquele que trabalha no fundo do mar. Observação: O trabalho do mergulhador, nas charqueadas era de mergulhar o couro ou as carnes nos tanques de salmoura. Em alguns estabelecimentos, este processo era repetido. O mergulhador imergia novamente o couro e/ou a carne para retirar o excesso de sal no processo de dessecamento.

Mocotó | s.m.

espécie de óleo produzido com a pata do animal || subproduto de charqueada Abonação: "Fabrica-se muitas vezes, com as patas, um óleo especial; mas este óleo, chamado de "mocotó", prepara-se também em algumas charqueadas de Pelotas." (Doc 97 - L.C. 1880)

Ocorrência nos dicionários:

\begin{tabular}{|c|c|c|c|}
\hline Autor & Ano obra & Lexia & $\begin{array}{c}\text { Acepção correspondente } \\
\text { ao glossário }\end{array}$ \\
\hline RB & 1712 & - & - \\
\hline
\end{tabular}




\begin{tabular}{|c|c|c|c|}
\hline AMS & 1813 & - & - \\
\hline DV & 1873 & + & - \\
\hline LF & 1940 & + & - \\
\hline CA & 1958 & + & - \\
\hline ABHF & 1986 & + & - \\
\hline ZCN/RCN & 1996 & + & - \\
\hline AH/MSV & 2001 & + & - \\
\hline FSB & 2002 & + & - \\
\hline BB & 2003 & + & - \\
\hline
\end{tabular}

Análise descritiva dos dicionários gerais:

DV apresenta mocotó como termo usado no Brasil para designar mãos de boi, cruas ou guisadas. LF apresenta como extremidade dos membros desprovidos dos cascos que serve de alimento. Nenhuma das obras que apresentam a lexia indicam em sua acepção mocotó como óleo.

Análise descritiva dos dicionários regionalistas:

BB e ZCN/RCN apresentam acepções semelhantes às obras anteriores. Ambos também apresentam a lexia mocotozada, como um prato servido com mocotó. BB aproxima sua acepção com a do glossário, definindo o mocotó como as patas dos bovinos, destituídas de casco, usadas como alimento.

Monturo| s.m.

local na charqueada onde se coloca os restos do animal abatido || lixeira

Abonação: “...os carregadores de ossadas e buchadas, que, com guanchos fixados aos arreios faziam o serviço, levando a buchada para o monturo e a ossada para a graxeira para a elaboração da graxa, colocada, como disse, em bordalesas e bexigas." (Doc 113

- A.P.C. 1988)

Ocorrência nos dicionários:

\begin{tabular}{|c|c|c|c|}
\hline Autor & Ano obra & Lexia & $\begin{array}{c}\text { Acepção correspondente } \\
\text { ao glossário }\end{array}$ \\
\hline RB & 1712 & + & - \\
\hline AMS & 1813 & + & - \\
\hline DV & 1873 & + & - \\
\hline LF & 1940 & + & - \\
\hline CA & 1958 & + & - \\
\hline ABHF & 1986 & + & - \\
\hline ZCN/RCN & 1996 & - & - \\
\hline AH/MSV & 2001 & + & - \\
\hline FSB & 2002 & + & \\
\hline
\end{tabular}


Análise descritiva dos dicionários gerais:

RB, AMS, DV, LF e CA fornecem a acepção de monte de esterco, imundícies para monturo, que não corresponde ao glossário, pois, de acordo com os documentos do corpus, o monturo era formado dentro das instalações da charqueada onde os animais já haviam sido abatidos. ABHF e AH/MSV apresentam acepções generalizadas de monturo, definindo-a como um depósito de coisas velhas, dejetos, coisas sujas.

Observação: Em alguns documentos pode-se comprovar que o monturo era formado das vísceras e restos dos animais depois da descarnação.

Análise descritiva dos dicionários regionalistas:

Não consta a lexia nas referidas obras.

148 Moira|s.f.

abreviação para salmoura || líquido obtido com mistura de água e sal usado no preparo da salga da carne

Abonação: “...e depois de bem rebatida as vazilhas, e bem estancadas, enchem- se de moira, que deve ser feita de agua doce com sal bom em ponto..." (Doc 14 - Flo. 1798)

Ocorrência nos dicionários:

Não consta a lexia nas referidas obras.

Análise descritiva dos dicionários gerais:

Na obra de RB, a lexia moira é apresentada ao consulente como um termo antiquado por morra. A lexia moira é, na verdade, usada na conjugação do verbo morrer no presente do indicativo. Na obra de $\mathbf{L F}$ a abreviação de moira é apresentada com a variante moura.

Análise descritiva dos dicionários regionalistas:

Não consta a lexia nas referidas obras.

149 Moirão| s.m.

espécie de grade || local cerrado onde se guarda o boi para o abate 
Abonação: “E o laço enrolado ao guincho (máquina à vapor), puxava o boi até encostar sua cabeça a um moirão colocado horizontalmente, onde era desnucado com punhal de 2 gumes.” (Doc 112 - A.P.C. 1988)

Ocorrência nos dicionários:

\begin{tabular}{|c|c|c|c|}
\hline Autor & Ano obra & Lexia & $\begin{array}{c}\text { Acepção correspondente } \\
\text { ao glossário }\end{array}$ \\
\hline RB & 1712 & + & - \\
\hline AMS & 1813 & + & - \\
\hline DV & 1873 & - & - \\
\hline LF & 1940 & - & - \\
\hline CA & 1958 & + & + \\
\hline ABHF & 1986 & + & - \\
\hline ZCN/RCN & 1996 & - & - \\
\hline AH/MSV & 2001 & + & - \\
\hline FSB & 2002 & - & - \\
\hline BB & 2003 & - & - \\
\hline
\end{tabular}

Análise descritiva dos dicionários gerais:

RB apresenta moirão como jogo de canas. AMS fornece outras acepções como estacas, poste, jogo. CA, por sua vez, é a primeira obra a apresenta a lexia moirão como varas que servem como grade, cerca. Este autor informa que no Rio Grande do Sul mourão é designação para pau de aramado. ABHF e AH/MSV indicam uma série de acepções como estaca, vara para segurar canoas, pau para sustentar videiras, dentre outras.

Análise descritiva dos dicionários regionalistas:

Não consta a lexia nas referidas obras. A única referência é dada em BB em que o lexicógrafo apresenta a lexia mourama como um conjunto de mourões.

Nau | s.m.

espécie de navio usado no transporte de mercadorias || embarcação

Abonação: “A Relação incluza serve para se regular o gado necessario para dous mezes ás Tripulaçoens e guarniçoens das Naus, e Fragatas, e neste mesmo Orsamento feito pelo estado efectivo das praças..." (Doc 11 - Flo. 1798)

Variante: nao

Ocorrência nos dicionários:

\begin{tabular}{|c|c|c|c|}
\hline Autor & Ano obra & Lexia & $\begin{array}{c}\text { Acepção correspondente } \\
\text { ao glossário }\end{array}$ \\
\hline
\end{tabular}




\begin{tabular}{|c|c|c|c|}
\hline RB & 1712 & + & + \\
\hline AMS & 1813 & + & - \\
\hline DV & 1873 & + & - \\
\hline LF & 1940 & + & + \\
\hline CA & 1958 & + & + \\
\hline ABHF & 1986 & + & + \\
\hline ZCN/RCN & 1996 & - & - \\
\hline AH/MSV & 2001 & + & + \\
\hline FSB & 2002 & + & + \\
\hline BB & 2003 & - & - \\
\hline
\end{tabular}

Análise descritiva dos dicionários gerais:

Segundo RB a nau é uma embarcação grande e não deve ser usado como sinônimo de navio, que é o genérico de embarcação menor. AMS apresenta nau como embarcação maior que navios e fragatas. LF é o primeiro dicionarista a apresentar a nau como navio mercante e é seguido por CA, ABHF e AH/MSV (que mencionam em suas acepções o uso de transporte do quinto da mineração do ouro). Nos documentos do corpus não há indicação de como os autores classificavam o tamanho das naus, somente eram citadas como meio de transporte de mercadorias.

Variantes: nao (RB, AMS); náo (DV)

Análise descritiva dos dicionários regionalistas:

Não consta a lexia nas referidas obras.

Navio | s.m.

embarcação || meio de transporte fluvial usado para transporte de mercadoria Abonação: “...a reducção dos fretes nos navios do Lloyd Brasileiro e companhias subvencionadas..." (Doc 31 - Pel. 1869 )

“ Nós seguimos a carne desde o momento em que ela entrou na mangueira, sob a forma de boi, até o momento em que ela foi empilhada nos navios de transporte." (Doc 92 - L.C. 1880)

Ocorrência nos dicionários:

\begin{tabular}{|c|c|c|c|}
\hline Autor & Ano obra & Lexia & $\begin{array}{c}\text { Acepção correspondente } \\
\text { ao glossário }\end{array}$ \\
\hline RB & 1712 & + & - \\
\hline AMS & 1813 & + & - \\
\hline DV & 1873 & + & - \\
\hline LF & 1940 & + & + \\
\hline CA & 1958 & + & + \\
\hline
\end{tabular}




\begin{tabular}{|c|c|c|c|}
\hline ABHF & 1986 & + & + \\
\hline ZCN/RCN & 1996 & - & - \\
\hline AH/MSV & 2001 & + & + \\
\hline FSB & 2002 & + & + \\
\hline BB & 2003 & - & - \\
\hline
\end{tabular}

Análise descritiva dos dicionários gerais:

A maioria das obras fornece na acepção da lexia navio referências sobre o tamanho, capacidade etc. Em alguns casos, aparece a indicação de navio mercante. LF é a primeira obra que menciona várias classificações para navio, como o navio de transporte, o navio cargueiro etc. As obras de CA, ABHF e AH/MSV assemelham-se à obra anterior, exemplificando e aumentando as classificações dos navios. FSB é bastante suscinto em seu verbete, informando que o navio transporta mercadorias.

Análise descritiva dos dicionários regionalistas:

Não consta a lexia nas referidas obras.

Ossada $\mid$ s.f.

conjunto de ossos retirados do animal usado na charqueada par a queima e produção de vapor

Abonação: “ ...levando a buchada para o monturo e a ossada para a graxeira para a elaboração da graxa, colocada, como disse, em bordalesas e bexigas." (Doc. 113 A.P.C. 1988)

Ocorrência nos dicionários:

\begin{tabular}{|c|c|c|c|}
\hline Autor & Ano obra & Lexia & $\begin{array}{c}\text { Acepção correspondente } \\
\text { ao glossário }\end{array}$ \\
\hline RB & 1712 & + & - \\
\hline AMS & 1813 & - & - \\
\hline DV & 1873 & - & - \\
\hline LF & 1940 & + & + \\
\hline CA & 1958 & + & + \\
\hline ABHF & 1986 & + & + \\
\hline ZCN/RCN & 1996 & - & + \\
\hline AH/MSV & 2001 & + & + \\
\hline FSB & 2002 & + & - \\
\hline BB & 2003 & - & + \\
\hline
\end{tabular}

Análise descritiva dos dicionários gerais: 
As obras que apresentam a lexia ossada não apresentam divergências com relação à acepção apresentada no glossário. Somente RB menciona que a ossada é um conjunto de ossos do corpo humano. FSB menciona uma pequena citação a respeito da ossada de restos de animais.

Análise descritiva dos dicionários regionalistas:

Não consta a lexia nas referidas obras.

Os autores BB e $\mathbf{Z C N} / \mathbf{R C N}$ apresentam a entrada ossama mencionando a lexia ossada em sua acepção.

Paçoca $\mid$ s.f.

prato feito com charque desfiado e farinha de mandioca || comida usada como farnel em viagem longa

Abonação: “ Nas estâncias antigas, a paçoca de charque servia para o recheio de pastelões feitos com massa de farinha de trigo ou de batatas..." (Doc 81 - A.F.M. s/n) Ocorrência nos dicionários:

\begin{tabular}{|c|c|c|c|}
\hline Autor & Ano obra & Lexia & $\begin{array}{c}\text { Acepção correspondente } \\
\text { ao glossário }\end{array}$ \\
\hline RB & 1712 & - & - \\
\hline AMS & 1813 & - & - \\
\hline DV & 1873 & - & - \\
\hline LF & 1940 & + & - \\
\hline CA & 1958 & - & - \\
\hline ABHF & 1986 & + & + \\
\hline ZCN/RCN & 1996 & + & ++ \\
\hline AH/MSV & 2001 & + & - \\
\hline FSB & 2002 & - & - \\
\hline BB & 2003 & + & ++ \\
\hline
\end{tabular}

Análise descritiva dos dicionários gerais:

LF e CA somente indicam paçoca como carne pilada com farinha. ABHF e FSB apresentam como ingredientes do prato a carne fresca, seca ou a carne-de-sol. AH/MSV generaliza a definição de paçoca como uma farinha resultante da mistura de vários ingredientes.

Análise descritiva dos dicionários regionalistas:

ZCN/RCN e BB apresentam a acepção de paçoca como comida campeira, feita com charque. ZCN/RCN ainda informa que esta comida dura muitos dias, sendo 
apropriada para longas viagens. Ambos os autores fornecem um sentido figurado para a lexia, apresentando-a como coisa complicada, confusão.

Observação: Somente os dicionários regionalistas apresentam o charque como ingrediente da paçoca.

Partida $\mid$ s.f.

carga comercializada || quantidade de mercadoria

Abonação: “... Da Estância dos Dourados passamos durante algum tempo, na Xarqueada do Curral Alto de Sāo João da Fortaleza, onde o patrão devia embarcar uma partida de carne seca. (Doc 136 - A.S.H. 1820/21)

Ocorrência nos dicionários:

\begin{tabular}{|c|c|c|c|}
\hline Autor & Ano obra & Lexia & $\begin{array}{c}\text { Acepção correspondente } \\
\text { ao glossário }\end{array}$ \\
\hline RB & 1712 & + & - \\
\hline AMS & 1813 & + & - \\
\hline DV & 1873 & - & - \\
\hline LF & 1940 & + & + \\
\hline CA & 1958 & + & + \\
\hline ABHF & 1986 & + & + \\
\hline ZCN/RCN & 1996 & + & + \\
\hline AH/MSV & 2001 & + & + \\
\hline FSB & 2002 & + & - \\
\hline BB & 2003 & + & + \\
\hline
\end{tabular}

Análise descritiva dos dicionários gerais:

LF e CA apresentam a acepção informando partida como quantidade de mercadorias enviadas, remessa. ABHF cita como exemplo as partidas e remessas de café e não de carne e indica que, no RS, a lexia é usada como sinônimo de corrida de cavalo. Esta acepção é partilhada dos autores ZCN/RCN e BB.

Análise descritiva dos dicionários regionalistas:

Nota: Observa-se que, das obras que apresentam a lexia, somente as regionalistas não correspondem ao glossário. O que se pode inferir é que, no RS, partida como remessa caiu em desuso.

Patacho | s.m.

tipo de embarcação || navio 
Abonação: “ New-york no patacho americano -Yung America-Thompsen, Loessel e Lind, 753 couros vaccuus seccos, 34 dittos avariados, 20 dittos de terneiro, 118 dittos vaccuns salgados, 62 fardos com 940 arrobas de [ 1]ã.." (Doc 28 - Pel. 1869)

"Pernambuco com escalla no patacho nacional -Oriente -Belxior e Cardia 23 couros vaccuns de refugo" (Doc 28 - Pel. 1869)

Ocorrência nos dicionários:

\begin{tabular}{|c|c|c|c|}
\hline Autor & Ano obra & Lexia & $\begin{array}{c}\text { Acepção correspondente } \\
\text { ao glossário }\end{array}$ \\
\hline RB & 1712 & - & - \\
\hline AMS & 1813 & - & - \\
\hline DV & 1873 & + & + \\
\hline LF & 1940 & + & + \\
\hline CA & 1958 & - & - \\
\hline ABHF & 1986 & + & - \\
\hline ZCN/RCN & 1996 & - & + \\
\hline AH/MSV & 2001 & + & + \\
\hline FSB & 2002 & + & - \\
\hline BB & 2003 & - & + \\
\hline
\end{tabular}

Análise descritiva dos dicionários gerais:

DV apresenta patacho como embarcação, porém associada à embarcação de guerra. Os autores apresentam patacho geralmente como embarcação ligeira, não indicando, entretanto, que era de uso no transporte de mercadorias, como se apresentou nos documentos do corpus. FSB apresenta em sua abonação do verbete um trecho de documento que se refere a um patacho enviado à província de Rio Grande, o que corrobora com o uso deste tipo de embarcação no sul do país.

Variante: pataxo (DV)

Análise descritiva dos dicionários regionalistas:

Não consta a lexia nas referidas obras.

Pelota $\mid$ s.f.

embarcação primitiva feita de vara e couro para travessia de pequena extensão || espécie de bote de madeira e couro

Abonação: “A pelota, este nome dado a tais pirogas, é simplesmente um couro crú em que se ligam as quatro pontas, tomando desse modo a forma de um barco, com feitio aproximado de sacolas de papel onde se embrulham biscoitos." (Doc 135 - A.S.H. 1820/21) 
"Eu mesmo passei o rio sentado numa pelota chegando sem novidade à outra margem, bem como as bagagens e carroças. Matias, José Mariano e Firmiano alternaram-se na passagem da pelota.” (Doc 135 - A.S.H. 1820/21)

Ocorrência nos dicionários:

\begin{tabular}{|c|c|c|c|}
\hline Autor & Ano obra & Lexia & $\begin{array}{c}\text { Acepção correspondente } \\
\text { ao glossário }\end{array}$ \\
\hline RB & 1712 & + & - \\
\hline AMS & 1813 & - & - \\
\hline DV & 1873 & - & - \\
\hline LF & 1940 & + & + \\
\hline CA & 1958 & + & + \\
\hline ABHF & 1986 & + & + \\
\hline ZCN/RCN & 1996 & + & + \\
\hline AH/MSV & 2001 & + & - \\
\hline FSB & 2002 & + & + \\
\hline BB & 2003 & + & + \\
\hline
\end{tabular}

Análise descritiva dos dicionários gerais:

CA e AH/MSV acrescentam nos verbetes a informação de que o uso da pelota como meio de transporte para pequenas travessias é usado no Mato Grosso e no Rio Grande do Sul. ABHF e FSB, por outro lado, sequer apresentam pelota como meio de transporte, restringindo a acepção de pelota como bola.

Nota: A cidade de Pelotas recebeu este nome por influência do uso deste meio de transporte.

Variantes: pelôta (DV); pellota (LF)

Análise descritiva dos dicionários regionalistas:

Os autores regionalistas esclarecem que a pelota pode ser puxada por um animal ou por um indivíduo a nado. BB apresenta as lexias peloteiro, como o indivíduo que realiza este serviço e menciona a lexia balsa como sinônimo de pelota.

Nota: Em conversa com moradores antigos da cidade de Pelotas, um dos relatos feitos por uma senhora bisneta de charqueador foi que, quando criança, ao brincar perto do Arroio Pelotas, sempre via passar em um homem vendendo charque. Este vendedor fazia uso da pelota como meio de transporte. Hoje em dia poderíamos dizer que esta prática aproxima-se de um comerciante ambulante. 


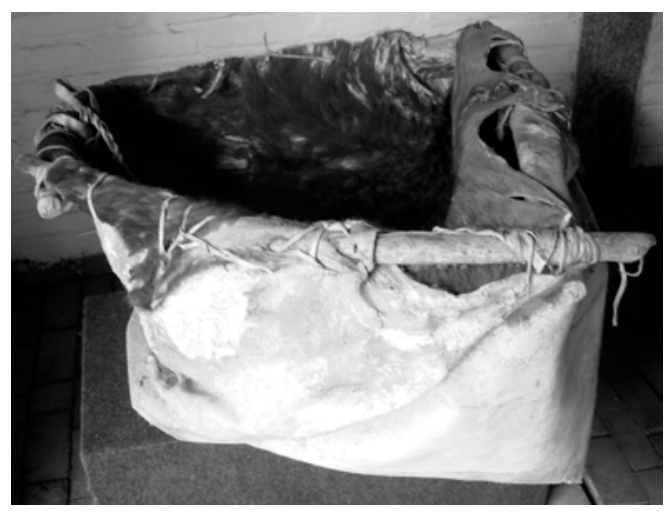

Fig.11 Pelota

Museu do Charque, Pelotas, RS

Foto: Cátia Schreiner, 2011

Peneira $\mid$ s.f.

objeto usado na charqueada para retirar o excesso de espuma que se forma na salmoura e/ou na graxa

Abonação: "Huma balança grande de pesar couros Quatro (4) peneiras grandes para sal utensis da graxeira..." (Doc 49 - Poa 1870)

Ocorrência nos dicionários:

\begin{tabular}{|c|c|c|c|}
\hline Autor & Ano obra & Lexia & $\begin{array}{c}\text { Acepção correspondente } \\
\text { ao glossário }\end{array}$ \\
\hline RB & 1712 & - & - \\
\hline AMS & 1813 & + & + \\
\hline DV & 1873 & + & + \\
\hline LF & 1940 & + & + \\
\hline CA & 1958 & + & + \\
\hline ABHF & 1986 & + & + \\
\hline ZCN/RCN & 1996 & + & + \\
\hline AH/MSV & 2001 & + & + \\
\hline FSB & 2002 & + & - \\
\hline BB & 2003 & + & \\
\hline
\end{tabular}

Análise descritiva dos dicionários gerais:

As acepções mais antigas de peneira, descrevem a lexia como objeto feito de crina ou de seda. Já as obras mais recentes indicam a peneira como feita de metal, plástico etc. Não esperava-se encontrar referência a este objeto especificamente usado nas charqueadas, entretanto, considerou-se a correspondência ao glossário, dada sua utilização nos estabelecimentos saladeris.

Análise descritiva dos dicionários regionalistas: 
ZCN/RCN e BB fornecem a acepção de peneira como chapéu de palha, portanto, sem nenhuma correspondência à acepção do glossário.

Pilha de inverno $\mid$ s.f.

pilha de carne salgada guardada durante o inverno para ser comercializada em outro período || monte de carne de até 5 metros de altura feito com mantas de charque || pilha circular ou retangular de couro ou carne guardada dentro do galpão da charqueada

Abonação: “...completavam o interior do enorme galpão, que se mantinha absolutamente limpo, aguardando a salga da carne e do couro, para formarem as “pilhas de inverno"que, ao fim da safra, beiravam as telhas, com quase 5 metros de altura.”(Doc 109 - A.P.C. 1988)

“...pilhas especiais, relativamente enormes, pois elas contém de 1200 a 1800 bois: chamam-nas de "pilhas de inverno". (Doc 90 - L.C. 1880)

Ocorrência nos dicionários:

Não consta a lexia nas referidas obras

Análise descritiva dos dicionários gerais:

RB apresenta além da lexia pilha, a denominada pilha de sal. Lexicógrafos como LF, CA e AH/MSV apresentam uma série de exemplos de diversos tipos de pilhas, sem referências à pilha de inverno.

Análise descritiva dos dicionários regionalistas:

Os lexicógrafos regionalistas apenas apresentam a entrada pilha volta, definida como pilha feita de carne quando retirada do tanque de salmoura. Em nenhum documento do corpus, entretanto, teve a ocorrência da lexia pilha volta.

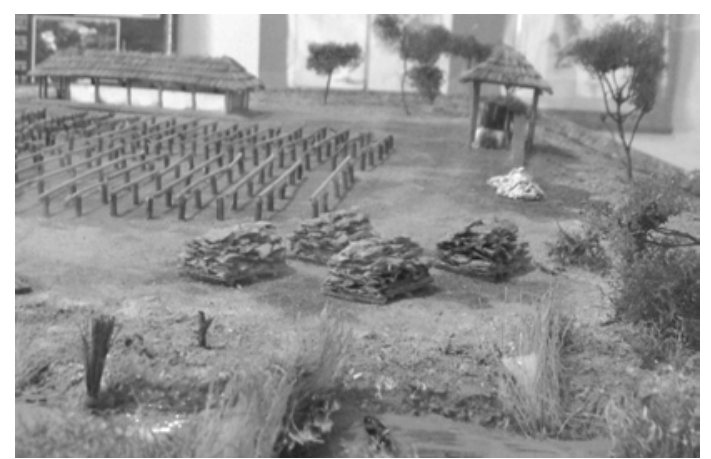

Fig 12 Pilha de charque

Fonte: Maquete do Museu do Charque, Pelotas, RS

Foto: Cátia Schreiner, 2011 
Pipa $\mid$ s.f.

barril de madeira || objeto usado no transporte de líquidos ou carne || meio de armazenamento, conservação e transporte de carne salgada

Abonação: " vai para a Boa Vista e entre deste lugar até encontrar terrenos do Major Antonio Pereira com as quaes da Devida 200 Bazilas vazias 46 Pipas e 100 Alqueires de Sal para carnes)..." (Doc 65 - Poa. 1873)

Ocorrência nos dicionários:

\begin{tabular}{|c|c|c|c|}
\hline Autor & Ano obra & Lexia & $\begin{array}{c}\text { Acepção correspondente } \\
\text { ao glossário }\end{array}$ \\
\hline RB & 1712 & + & + \\
\hline AMS & 1813 & - & - \\
\hline DV & 1873 & - & - \\
\hline LF & 1940 & + & + \\
\hline CA & 1958 & + & + \\
\hline ABHF & 1986 & + & + \\
\hline ZCN/RCN & 1996 & - & - \\
\hline AH/MSV & 2001 & + & + \\
\hline FSB & 2002 & + & + \\
\hline BB & 2003 & - & - \\
\hline
\end{tabular}

Análise descritiva dos dicionários gerais:

RB menciona o uso exclusivo de pipa para armazenar vinho e azeite. LF generaliza o armazenamento de líquidos em pipas, sem especificação. Em nenhuma obra houve referência ao uso de pipas para armazenar carne salgada, salmoura ou qualquer produto citado nos documentos do corpus.

Análise descritiva dos dicionários regionalistas:

Não consta a lexia nas referidas obras.

Porteira $\mid$ s.f.

portão que delimita a entrada da charqueada || porta geralmente retangular de madeira que se localiza na entrada da propriedade rural

Abonação: “... fasendo frente á estrada que sahe da mesma charqueada do Cotovello, que váe sahir á porteira da charqueada do mesmo Braga, com quartocentas braças de fundo até encontrar o arroio de Pelotas...” (Doc 55 - Poa 1871)

Ocorrência nos dicionários:

\begin{tabular}{l|l|l|l|} 
Autor & Ano obra & Lexia & Acepção correspondente
\end{tabular}




\begin{tabular}{|c|c|c|c|}
\hline & & & ao glossário \\
\hline RB & 1712 & + & - \\
\hline AMS & 1813 & + & - \\
\hline DV & 1873 & - & - \\
\hline LF & 1940 & + & - \\
\hline CA & 1958 & + & + \\
\hline ABHF & 1986 & - & - \\
\hline ZCN/RCN & 1996 & + & + \\
\hline AH/MSV & 2001 & - & - \\
\hline FSB & 2002 & + & + \\
\hline BB & 2003 & + & + \\
\hline
\end{tabular}

Análise descritiva dos dicionários gerais:

RB, AMS e ABHF apenas indicam a lexia porteira como feminino de porteiro, aquela que tem o cuidado com a porta. CA apresenta a acepção correspondente ao glossário, definindo-a como portão grande de propriedades rurais. FSB, por sua vez somente apresenta como portão de entrada, abandonando a acepção de mulher que guarda a porta.

Análise descritiva dos dicionários regionalistas:

ZCN/RCN e BB são unânimes em apresentar a acepção como portão de entrada para propriedades rurais e ambos citam as mangueiras como exemplos de cercados que possuem porteiras em sua estrutura. Nenhuma das obras menciona o tipo de propriedade rural que se utiliza de porteira.

Porteiro| s.m.

empregado de charqueada encarregado de abrir e fechar a porteira do estabelecimento || trabalhador que se encarrega de fechar e abrir a portinhola da zorra durante o abate

Abonação: "Ali estavam alinhados, esperando o primeiro boi, zorreiros, camboneiros, coleiros, carneadores, charqueadores, aguateiros, salgadeiros, matambreiros, foguistas, mergulhadores de carne e de couros, balanceiros, porteiros..." (Doc 108 - A.P.C. 1988)

Ocorrência nos dicionários:

\begin{tabular}{|c|c|c|c|}
\hline Autor & Ano obra & Lexia & $\begin{array}{c}\text { Acepção correspondente } \\
\text { ao glossário }\end{array}$ \\
\hline RB & 1712 & + & - \\
\hline AMS & 1813 & + & - \\
\hline DV & 1873 & - & - \\
\hline
\end{tabular}




\begin{tabular}{|c|c|c|c|}
\hline LF & 1940 & + & - \\
\hline CA & 1958 & - & - \\
\hline ABHF & 1986 & + & - \\
\hline ZCN/RCN & 1996 & - & - \\
\hline AH/MSV & 2001 & + & - \\
\hline FSB & 2002 & + & - \\
\hline BB & 2003 & - & - \\
\hline
\end{tabular}

Análise descritiva dos dicionários gerais:

Considerou-se aqui como lexia correspondente ao glossário somente a definida como aquele que se encarrega de abrir e fechar a porteira. ABHF apresenta na lexia porteiro-mor como lugar cercado nas estâncias onde se guardam animais empregados nos trabalhos cotidianos, indicando o uso no sul do Brasil.

Análise descritiva dos dicionários regionalistas:

Não consta a lexia nas referidas obras.

Potreiro | s.m.

pequeno curral cercado onde se coloca o animal para pastar e/ou descansar

Abonação: “ Um estabelecimento de xarqueada completamente montado prompto a trabalhar com todos seus acessorios Casa de moradia Chacara, potreiro, um terreno junto a ribera te na estrada que vai para a Boa Vista..." (Doc 65 - Poa - 1873)

Ocorrência nos dicionários:

\begin{tabular}{|c|c|c|c|}
\hline Autor & Ano obra & Lexia & $\begin{array}{c}\text { Acepção correspondente } \\
\text { ao glossário }\end{array}$ \\
\hline RB & 1712 & - & - \\
\hline AMS & 1813 & - & - \\
\hline DV & 1873 & + & + \\
\hline LF & 1940 & - & - \\
\hline CA & 1958 & + & + \\
\hline ABHF & 1986 & - & + \\
\hline ZCN/RCN & 1996 & + & + \\
\hline AH/MSV & 2001 & + & - \\
\hline FSB & 2002 & - & + \\
\hline BB & 2003 & + & + \\
\hline
\end{tabular}

Análise descritiva dos dicionários gerais:

LF fornece definições da lexia potreiro como negociante de potros, piquete. CA também refere-se a potreiro como negociante de animais e indica como regionalista do sul do país a acepção correspondente ao glossário. 
Análise descritiva dos dicionários regionalistas:

As obras de ZCN/RCN e BB definem a lexia potreiro como o local próximo às estâncias onde se guardam os animais utilizados na lida diárias das propriedades rurais.

Prensa $\mid$ s.f.

instrumento usado para escorrer a salmoura ou o líquido natural da carne salgada || objeto pesado usado para deixar a carne salgada enxuta

Abonação: “...e feita a pilha, que deve ser sobre taboas, poem-se outras taboas por cima da dita pilha, bem unidas, a maneira de huma imprensa, e carrega-se bem de pezo, ou pedras, ou paos, ou outro qualquer pezo, que a faça espremer bem, onde estará trez dias escorrendo..." (Doc 14 - Flo. 1798)

Variantes: imprensa

Ocorrência nos dicionários:

\begin{tabular}{|c|c|c|c|}
\hline Autor & Ano obra & Lexia & $\begin{array}{c}\text { Acepção correspondente } \\
\text { ao glossário }\end{array}$ \\
\hline RB & 1712 & + & - \\
\hline AMS & 1813 & + & - \\
\hline DV & 1873 & + & - \\
\hline LF & 1940 & - & - \\
\hline CA & 1958 & + & + \\
\hline ABHF & 1986 & + & + \\
\hline ZCN/RCN & 1996 & - & - \\
\hline AH/MSV & 2001 & + & - \\
\hline FSB & 2002 & + & - \\
\hline BB & 2003 & - & + \\
\hline
\end{tabular}

Análise descritiva dos dicionários gerais:

Algumas obras definem a lexia prensa como duas tábuas de madeiras que servem para espremer alguma coisa. CA, ABHF, AH/MSV e FSB fornecem como exemplo de produto prensado a mandioca, para a fabricação de farinha.

Análise descritiva dos dicionários regionalistas:

Não consta a lexia nas referidas obras.

Prontificação | s.m.

criação || preparação do gado para abate 
Abonação: “... me ocorreo recomendar a Vossa Excelencia a prontificação dos gados, e sua condução até a Ilha de Santa Catharina, a cujo Governador encarregava da Salga das Carnes, remettendo-lhe o sal que fosse necessario, e o vazilhame precizo para a sua conduçaõ..." (Doc 11 - Flo. 1798)

Ocorrência nos dicionários:

\begin{tabular}{|c|c|c|c|}
\hline Autor & Ano obra & Lexia & $\begin{array}{c}\text { Acepção correspondente } \\
\text { ao glossário }\end{array}$ \\
\hline RB & 1712 & - & - \\
\hline AMS & 1813 & - & - \\
\hline DV & 1873 & - & - \\
\hline LF & 1940 & + & - \\
\hline CA & 1958 & + & - \\
\hline ABHF & 1986 & + & - \\
\hline ZCN/RCN & 1996 & - & - \\
\hline AH/MSV & 2001 & + & - \\
\hline FSB & 2002 & + & - \\
\hline BB & 2003 & - & - \\
\hline
\end{tabular}

Análise descritiva dos dicionários gerais:

LF, CA e ABHF indicam a lexia prontificação como o ato de prontificar. Ao consultar o verbete do verbo prontificar, a acepção mencionada pelos autores é definida como oferecer, ministrar, executar uma tarefa.

Análise descritiva dos dicionários regionalistas:

Não consta a lexia nas referidas obras.

Punhal | s.m.

objeto pontiagudo, de corte preciso, geralmente de dois gumes, usado para abater a rês || faca que se usa para desnucar o gado

Abonação: “... puxava o boi até encostar sua cabeça a um moirão colocado horizontalmente, onde era desnucado com o punhal de 2 gumes..." (Doc 112 A.P.C. 1988)

Ocorrência nos dicionários:

\begin{tabular}{|c|c|c|c|}
\hline Autor & Ano obra & Lexia & $\begin{array}{c}\text { Acepção correspondente } \\
\text { ao glossário }\end{array}$ \\
\hline RB & 1712 & + & - \\
\hline AMS & 1813 & + & - \\
\hline DV & 1873 & + & - \\
\hline LF & 1940 & + & - \\
\hline CA & 1958 & + & - \\
\hline
\end{tabular}




\begin{tabular}{|c|c|c|c|}
\hline ABHF & 1986 & + & - \\
\hline ZCN/RCN & 1996 & - & - \\
\hline AH/MSV & 2001 & + & - \\
\hline FSB & 2002 & + & - \\
\hline BB & 2003 & - & - \\
\hline
\end{tabular}

Análise descritiva dos dicionários gerais:

Todas as obras que apresentaram a lexia somente fornecem a indicação de que o punhal é um objeto cortante ou que fere mortalmente alguém. Em nenhum dos dicionários utilizou-se como definição o uso de punhal para abate de animais.

Análise descritiva dos dicionários regionalistas:

Não consta a lexia nas referidas obras.

Putrefato $\mid$ adj.

relativo à carne podre $\|$ impróprio para o consumo humano

Abonação: "A fase da matança terminara, havia muito tempo; contudo havia ainda muita carne no chão e vísceras de bois, putrefatas espalhavam forte mau cheiro..." Doc 136 - A.S.H. 1820/21)

Ocorrência nos dicionários:

\begin{tabular}{|c|c|c|c|}
\hline Autor & Ano obra & Lexia & $\begin{array}{c}\text { Acepção correspondente } \\
\text { ao glossário }\end{array}$ \\
\hline RB & 1712 & - & - \\
\hline AMS & 1813 & - & - \\
\hline DV & 1873 & - & - \\
\hline LF & 1940 & + & + \\
\hline CA & 1958 & + & + \\
\hline ABHF & 1986 & + & + \\
\hline ZCN/RCN & 1996 & - & + \\
\hline AH/MSV & 2001 & + & + \\
\hline FSB & 2002 & + & - \\
\hline BB & 2003 & - & + \\
\hline
\end{tabular}

Análise descritiva dos dicionários gerais:

As obras anteriores a LF apenas apresentam o substantivo putrefação. LF é a primeira obra que apresenta a lexia correspondente ao glossário. Este autor é seguido por $\mathbf{C A}$, ABHF, AH/MSV e FSB, que fornecem como exemplo o cheiro forte, a podridão e a decomposição de corpos.

Análise descritiva dos dicionários regionalistas:

Não consta a lexia nas referidas obras. 
Quadra | s.f.

conjunto de empregados da charqueada

Abonação: “A firma mantinha um regular número de pequenas casas onde em geral moravam, permanentemente, os operários mais categorizados, como charqueadores, carneadores, rondas e salgadores e o agrupamento chamava-se “quadra”...” (Doc 123 - A.P.C. 1988)

Ocorrência nos dicionários:

\begin{tabular}{|c|c|c|c|}
\hline Autor & Ano obra & Lexia & $\begin{array}{c}\text { Acepção correspondente } \\
\text { ao glossário }\end{array}$ \\
\hline RB & 1712 & - & - \\
\hline AMS & 1813 & - & - \\
\hline DV & 1873 & + & - \\
\hline LF & 1940 & + & - \\
\hline CA & 1958 & + & - \\
\hline ABHF & 1986 & + & - \\
\hline ZCN/RCN & 1996 & + & - \\
\hline AH/MSV & 2001 & + & - \\
\hline FSB & 2002 & + & - \\
\hline BB & 2003 & + & \\
\hline
\end{tabular}

Análise descritiva dos dicionários gerais:

A partir de DV todas as obras apresentam a lexia. Em nenhuma delas há correspondência entre a acepção apresentada e a acepção encontrada nos documentos. Levanta-se a hipótese de que esta denominação era de uso restrito em algumas charqueadas, como é o caso da estabelecimento em que trabalhava Antenor Peixoto de Castro, autor dos documentos em que foi selecionada a lexia.

Análise descritiva dos dicionários regionalistas:

As obras de ZCN/RCN e BB apresentam a lexia quadra como medida de distância, como espaço entre duas esquinas e corridas de cavalo. Os autores apresentam outros tipos de quadra como a de sesmaria, a de carreira e a quadra quadrada.

Réis | s.m.

medida monetária || moeda usada na comercialização do produto fabricado na charqueada até o século XIX 
Abonação: “... tenho a dizer a Vossa Merces que approvo que seja administrada pelo respectivo Procurador, a arrecadação do imposto de 20 reis por cabeça de gado que se matar nas charqueadas desse Municipio...” (Doc 19 - Pel. 1844)

“Taxaram em 600 réis o imposto de cada arroba, o que, até essa ocasião era de 200 réis apenas." (Doc 137 - A.S.H. 1820/21)

“... entregue na Laguna, para onde pode Vossa Senhoria remeter os 8:000\$000 de reis que deverá receber...” (Doc 06 - Flo. 1816)

Variantes: reis

Ocorrência nos dicionários:

\begin{tabular}{|c|c|c|c|}
\hline Autor & Ano obra & Lexia & $\begin{array}{c}\text { Acepção correspondente } \\
\text { ao glossário }\end{array}$ \\
\hline RB & 1712 & + & + \\
\hline AMS & 1813 & + & + \\
\hline DV & 1873 & + & + \\
\hline LF & 1940 & + & + \\
\hline CA & 1958 & + & + \\
\hline ABHF & 1986 & + & - \\
\hline ZCN/RCN & 1996 & - & + \\
\hline AH/MSV & 2001 & + & - \\
\hline FSB & 2002 & - & + \\
\hline BB & 2003 & + & + \\
\hline
\end{tabular}

Análise descritiva dos dicionários gerais:

Todas as obras que apresentaram a lexia as acepções corresponderam ao glossário. Levanta-se a hipótese de que FSB, por ser um dicionarista de uso, acaba por apresentar a lexia réis somente como plural de real, referindo-se à moeda corrente do Brasil.

Variante: reis (RB)

Análise descritiva dos dicionários regionalistas:

Não consta a lexia nas referidas obras.

BB apresenta a lexia balastraca, como a antiga moeda de 400 réis.

Rês | s.m.

boi || gado bovino

Abonação: “ Não sei se o efeito procedeo da qualidade das Rezes, se da Madeira dos Barriz se da impropriedade da Estação, ou da ignorancia de quem fez as Salgas..." (Doc 13 - Flo. 1798) 
“...não recordo bem, quando durante a safra foram abatidas cerca de 38.000 reses. Tratava-se da firma..." (Doc 107 - A.P.C. 1988)

“... havendo algumas vezes pequenas divergências decorrentes do extravio de alguma rês ou sacrifício de alguns novilhos para a alimentação dos boiadeiros..." (Doc 110 A.P.C. 1988)

Variantes: res, rêz

Ocorrência nos dicionários:

\begin{tabular}{|c|c|c|c|}
\hline Autor & Ano obra & Lexia & $\begin{array}{c}\text { Acepção correspondente } \\
\text { ao glossário }\end{array}$ \\
\hline RB & 1712 & + & + \\
\hline AMS & 1813 & + & + \\
\hline DV & 1873 & + & + \\
\hline LF & 1940 & + & + \\
\hline CA & 1958 & + & + \\
\hline ABHF & 1986 & + & + \\
\hline ZCN/RCN & 1996 & + & + \\
\hline AH/MSV & 2001 & + & + \\
\hline FSB & 2002 & + & + \\
\hline BB & 2003 & + & + \\
\hline
\end{tabular}

Análise descritiva dos dicionários gerais:

Segundo RB, AMS e LF a lexia rês deriva de cabeça e serve para indicar qualquer gado. CA define como qualquer animal quadrúpede que se abate para a alimentação do homem. Esta acepção é apresentada por todos os outros autores. Em nenhuma obra a rês é citada como matéria prima do charque.

Variantes: rez (RB); res (RB, AMS); rés (ABHF)

Análise descritiva dos dicionários regionalistas:

As obras regionalistas mostraram-se bastante sucintos na acepção de rês. Ambas apresentam somente a indicação de rês como animal vacum.

Resfriador | s.m.

empregado da charqueada responsável por resfriar a carne

Abonação: "Ali estavam alinhados, esperando o primeiro boi, zorreiros, camboneiros... ... serradores de caracu, resfriadores, graxeiros, eletrecistas, tripeiros, etc e etc." (Doc 108 - A.P.C. 1988)

Ocorrência nos dicionários:

\begin{tabular}{|l|l|l|l|}
\hline Autor & Ano obra & Lexia & Acepção correspondente \\
\hline
\end{tabular}




\begin{tabular}{|c|c|c|c|}
\hline & & & ao glossário \\
\hline RB & 1712 & - & - \\
\hline AMS & 1813 & + & - \\
\hline DV & 1873 & + & - \\
\hline LF & 1940 & + & - \\
\hline CA & 1958 & + & - \\
\hline ABHF & 1986 & + & - \\
\hline ZCN/RCN & 1996 & - & - \\
\hline AH/MSV & 2001 & + & - \\
\hline FSB & 2002 & + & - \\
\hline BB & 2003 & + & \\
\hline
\end{tabular}

Análise descritiva dos dicionários gerais:

AMS, DV, CA, ABHF e AH/MSV apresentam duas acepções para a lexia. Uma trata de um instrumento que serve para resfriar bebidas, a outra é indicada pelo adjetivo de resfriar + dor.

Nota: Os documentos do corpus não esclarecem como era realizada a atividade do resfriador nas charqueadas, ou seja, não há como precisar em que momento da charqueação era necessário o uso de seu trabalho.

Análise descritiva dos dicionários regionalistas:

Não consta a lexia na obra de ZCN/RCN. BB usa a remissão passador na lexia resfriador. A entrada passador, por sua vez, é definida como peça utilizada nas bombas de chimarrão.

Retalhar $\mid \mathrm{v}$.

cortar em pedaços || talhar novamente a carne ou couro || lanhar

Abonação: "Separa-se toda a carne dos ossos, e fazendo-se em pedaços, ratalha-se bem, de modo que fique aberta sem grossura..." (Doc 14 - Flo. 1798)

Variante: ratalhar

Ocorrência nos dicionários:

\begin{tabular}{|c|c|c|c|}
\hline Autor & Ano obra & Lexia & $\begin{array}{c}\text { Acepção correspondente } \\
\text { ao glossário }\end{array}$ \\
\hline RB & 1712 & + & + \\
\hline AMS & 1813 & + & + \\
\hline DV & 1873 & + & + \\
\hline LF & 1940 & + & + \\
\hline CA & 1958 & + & + \\
\hline ABHF & 1986 & + & - \\
\hline ZCN/RCN & 1996 & + & - \\
\hline AH/MSV & 2001 & + & + \\
\hline FSB & 2002 & + & + \\
\hline
\end{tabular}


Análise descritiva dos dicionários gerais:

Além da acepção exposta no glossário, LF apresenta retalhar como matar aos golpes. CA, ABHF e AH/MSV fornecem nos verbetes as mesmas acepções encontradas nas obras regionalistas. Estes autores marcam o uso desta lexia como no sul do Brasil, corroborando com as obras de ZCN/RCN e BB.

Análise descritiva dos dicionários regionalistas:

As obras de ZCN/RCN e BB definem a acepção de retalhar também como a esterilização de cavalos.

Rodeio | s.m.

reunião de tropas de animais em épocas determinadas || ponto de encontro de estanceiros, peões e charqueadores para comercializar gado

Abonação: “ '.. em toda a parte, no Norte como no Sul, no Paraná como na República Oriental, fa-se o "rodeio"..." (Doc 104 - L.C. 1880)

“Aproveita-se o rodeio para julgar o estado do gado, da época e da proporção de venda..." (Doc 105 - L.C. 1880)

“...por falta de humanidade dos Pastores com as mesmas Rezes, que de Ordinario á força de crueldades fazem os rodeyos aos gados, vindos a ter parte..." (Doc 12 - Flo. 1797)

"A grande maioria das transações era feita no rodeio, a vulto, como se dizia." (Doc 70 - A.F.M. s/n)

Variantes: rodeyo

Ocorrência nos dicionários:

\begin{tabular}{|c|c|c|c|}
\hline Autor & Ano obra & Lexia & $\begin{array}{c}\text { Acepção correspondente } \\
\text { ao glossário }\end{array}$ \\
\hline RB & 1712 & - & - \\
\hline AMS & 1813 & + & - \\
\hline DV & 1873 & + & - \\
\hline LF & 1940 & + & + \\
\hline CA & 1958 & + & + \\
\hline ABHF & 1986 & + & + \\
\hline ZCN/RCN & 1996 & + & + \\
\hline AH/MSV & 2001 & + & - \\
\hline FSB & 2002 & + & + \\
\hline BB & 2003 & + & \\
\hline
\end{tabular}


Análise descritiva dos dicionários gerais:

AMS apresenta a acepção de rodeio como dar uma volta no caminho. LF ainda menciona rodeio como dança gauchesca realizada nas festas do gado. AH/MSV apresenta a expressão pedir rodeio, definida como solicitar ao proprietário rural vizinho ajuda para procurar gado extraviado. FSB apresenta a definição de rodeio como modalidade esportiva.

Variantes: rodèyo (AMS); rodeo (AMS); rodêo (DV)

Análise descritiva dos dicionários regionalistas:

ZCN/RCN e BB definem a lexia rodeio como local dentro de uma estância que se reúne o gado para contar, castrar, examinar, curar bicheiras, etc. Em sentido figurado, os autores apresentam a acepção: conjunto, grupo. BB ainda apresenta uma terceira acepção, mencionada como festa campeira onde há competição de laço, declamações de poesias gauchescas, dentre outras atividades. ZCN/RCN e BB fornecem aos consulentes a expressão parar rodeio, que, segundo eles, é definida como reunir o gado no rodeio. Esta expressão encontra-se em ABHF e AH/MSV.

Saco de aniagem | s.m.

sacola feita com pano que armazena o charque para o transporte || saco bastante usado nos transportes de mercadorias da charqueadas nas exportações dos produtos || local onde se estampa a categoria de qualidade do charque

Abonação: "Os sacos de aniagem eram devidamente carimbados com o nome da firma, o peso, o local de destino e a classificação do produto. O peso era determinado pela média da tropa, acusada por ocasião da matança, e variava entre 80 e 100 quilos. (Doc 122 - A.P.C. 1988)

Ocorrência nos dicionários:

Não consta a lexia nas referidas obras.

Observação: De acordo com documentos do corpus, o saco de aniagem depois de enfadado, era marcado em um dos lados indicando a procedência e o tipo de charque contido nele.

BB apresenta a lexia bolsa como sinônimo de saco. 
Safra $\mid$ s.f.

período que compreende o preparo e venda do charque || matança

Abonação: "No primeiro dia útil de cada ano a safra era iniciada, encerrando-se, impreterivelmente, em 30 de junho, com a duração, portanto, de seis meses." (Doc 106 - A.P.C. 1988)

"É, primeiramente, este "convênio" que, no começo da safra, os charqueadores de Pelotas redigiram e assinaram para tentar pôr um fim à alta dos preços..." (Doc 83 L.C. 1880)

"Há, também, cifras de bois mortos cada ano, durante o período da matança ou safra..." (Doc 83 - L.C. 1880)

Ocorrência nos dicionários:

\begin{tabular}{|c|c|c|c|}
\hline Autor & Ano obra & Lexia & $\begin{array}{c}\text { Acepção correspondente } \\
\text { ao glossário }\end{array}$ \\
\hline RB & 1712 & - & - \\
\hline AMS & 1813 & - & - \\
\hline DV & 1873 & + & - \\
\hline LF & 1940 & + & - \\
\hline CA & 1958 & + & - \\
\hline ABHF & 1986 & + & + \\
\hline ZCN/RCN & 1996 & + & -+ \\
\hline AH/MSV & 2001 & + & - \\
\hline FSB & 2002 & + & - \\
\hline BB & 2003 & + & -+ \\
\hline
\end{tabular}

Análise descritiva dos dicionários gerais:

RB, DV, LF e AH/MSV apresentam a lexia safra como o período de colheita ou venda. CA indica que safra é termo regionalista do Rio Grande do Sul usado para definir este período na venda de produtos agropastoris.

ABHF e BB informam que a safra é período de produção, trabalho agrícola. ABHF, na quarta acepção, acaba informando como usual no RS a acepção de safra como venda de mercadorias, citando diretamente o charque como um dos produtos a ser comercializado.

Nota: Nos documentos de Antenor Peixoto de Castro, o autor relata que, muitas vezes, os trabalhadores das charqueadas pegavam alguns pedaços de carne para charqueá-los em suas residências, e, assim, garantir a provisão de carne para o período de entresafras, denominado por ele de safra seca.

Análise descritiva dos dicionários regionalistas: 
Zeno e BB definem a safra como o período de venda dos produtos agropastoris, inclusive citando o charque como um dos produtos comercializados durante a safra.

Sal | s.m.

Substância usada no preparo e conservação do charque

Abonação: “... 200 Bazilas vazias 46 Pipas e 100 alqueires de Sal para carnes” (Doc 65 - Poa 1873)

“O sal desempenharia, então, um papel predominante: e eu creio, mesmo, que papel é relativamente complexo, e que esta carne, tanto pelo sal como pelo ar, sofre uma espécie de transformação" (Doc 93 - L.C. 1880)

Ocorrência nos dicionários:

\begin{tabular}{|c|c|c|c|}
\hline Autor & Ano obra & Lexia & $\begin{array}{c}\text { Acepção correspondente } \\
\text { ao glossário }\end{array}$ \\
\hline RB & 1712 & + & + \\
\hline AMS & 1813 & + & - \\
\hline DV & 1873 & + & - \\
\hline LF & 1940 & + & - \\
\hline CA & 1958 & + & - \\
\hline ABHF & 1986 & + & - \\
\hline ZCN/RCN & 1996 & - & - \\
\hline AH/MSV & 2001 & - & - \\
\hline FSB & 2002 & - & - \\
\hline BB & 2003 & - & - \\
\hline
\end{tabular}

Análise descritiva dos dicionários gerais:

RB apresenta a acepção de acordo com o glossário, definindo o sal como produto usado para a conservação, além de dar tempero aos sabores. AMS e DV apresentam o sal somente como produto de tempero, que dá bom sabor. LF e ABHF apresentam inúmeros tipos de sal em suas obras.

Análise descritiva dos dicionários regionalistas:

Não consta a lexia nas referidas obras.

Sal bom $\mid$ s.m.

sal limpo e em bom estado para uso || sal de boa qualidade para ser usado na salmoura 
Abonação: “...depois de bem rebatida as vazilhas, e bem estancadas, enchem-se de moira, que deve ser feita de agua doce com sal bom em ponto..." (Doc 14 - Flo. 1798)

Variante: salbom

Ocorrência nos dicionários:

Não consta a lexia nas referidas obras.

Sal grosso $\mid$ s.m.

sal mantido em pequenas pedras utilizado na salga das carnes e no preparo da salmoura

Abonação: "Montanhas de sal grosso, completamente branco, trazidas por barcos que atracavam nos trapiches da Charqueada, completavam o interior do enorme galpão, que se mantinha absolutamente limpo, aguardando a salga da carne" (Doc 109 A.P.C. 1988)

Ocorrência nos dicionários:

\begin{tabular}{|c|c|c|c|}
\hline Autor & Ano obra & Lexia & $\begin{array}{c}\text { Acepção correspondente } \\
\text { ao glossário }\end{array}$ \\
\hline RB & 1712 & - & - \\
\hline AMS & 1813 & - & - \\
\hline DV & 1873 & - & - \\
\hline LF & 1940 & - & - \\
\hline CA & 1958 & + & + \\
\hline ABHF & 1986 & + & + \\
\hline ZCN/RCN & 1996 & - & - \\
\hline AH/MSV & 2001 & - & - \\
\hline FSB & 2002 & + & - \\
\hline BB & 2003 & - & - \\
\hline
\end{tabular}

Análise descritiva dos dicionários gerais:

CA, ABHF e AH/MSV fornecem no verbete das obras o sal grosso definindo-o como sal comum que se encontra da maneira como saiu da salina. FSB apenas cita o sal grosso, sem definí-lo.

Análise descritiva dos dicionários regionalistas:

Não consta a lexia nas referidas obras.

Sal pisado $\mid$ s.m.

sal já usado na prensa || sal apertado contra a carne 
Abonação: “... e salga-se com Sal pizado; que fique bem penetrada do Sal; e logo se poem em pilha, sendo a camada com novo Sal..." (Doc 14 - Flo. 1798)

Variantes: salpizado, sal pizado

Ocorrência nos dicionários:

RB cita o sal pisado em seu verbete, mas não apresenta a definição da lexia.

Análise descritiva dos dicionários regionalistas:

Não consta a lexia nas referidas obras.

Saladeiro $\mid$ s.m.

local onde se salga carne || lugar de produção de charque || charqueada

Abonação: “ "... depois de ter examinado com cuidado, e alguns por várias vezes, nove "saladeiros" em Pelotas, dois na República Argentina, cinco na República Oriental..." (Doc 84 - L.C. 1880)

“a) Matança dos bois - Uma tropa de gado, depois de 5 a 20 dias de viagem em média, chega ao saladeiro..." (Doc 84 - L.C. 1880)

Ocorrência nos dicionários:

\begin{tabular}{|c|c|c|c|}
\hline Autor & Ano obra & Lexia & $\begin{array}{c}\text { Acepção correspondente } \\
\text { ao glossário }\end{array}$ \\
\hline RB & 1712 & - & - \\
\hline AMS & 1813 & - & - \\
\hline DV & 1873 & - & - \\
\hline LF & 1940 & + & + \\
\hline CA & 1958 & + & + \\
\hline ABHF & 1986 & + & + \\
\hline ZCN/RCN & 1996 & + & + \\
\hline AH/MSV & 2001 & + & - \\
\hline FSB & 2002 & - & + \\
\hline BB & 2003 & + & + \\
\hline
\end{tabular}

Análise descritiva dos dicionários gerais:

CA e ABHF apresentam saladeiro como lexia empregada no Rio Grande do Sul. Análise descritiva dos dicionários regionalistas:

BB informa que saladeiro é o charqueador platino que concorria com o charque gaúcho, ocasionando a Guerra dos Farrapos. ZCN/RCN apresenta a lexia saladerista como sinônimo de charqueador. 
Saladeril $\mid$ adj.

relativo ao saldeiro

Abonação: “... para produzir carne seca e praticamente extingue a produção saladeril nordestina." (Doc 40 - Pel. 2007)

Ocorrência nos dicionários:

\begin{tabular}{|c|c|c|c|}
\hline Autor & Ano obra & Lexia & $\begin{array}{c}\text { Acepção correspondente } \\
\text { ao glossário }\end{array}$ \\
\hline RB & 1712 & - & - \\
\hline AMS & 1813 & - & - \\
\hline DV & 1873 & - & - \\
\hline LF & 1940 & + & + \\
\hline CA & 1958 & + & + \\
\hline ABHF & 1986 & - & + \\
\hline ZCN/RCN & 1996 & + & - \\
\hline AH/MSV & 2001 & - & - \\
\hline FSB & 2002 & - & - \\
\hline BB & 2003 & - & - \\
\hline
\end{tabular}

Análise descritiva dos dicionários gerais:

Segundo CA, ABHF e AH/MSV saladeiril é um adjetivo usado no Rio Grande do Sul.

Análise descritiva dos dicionários regionalistas:

BB informa que saladeiril é aquele que se dedica à produção do charque.

Salga $\mid$ s.f.

operação que consiste em colocar a manta de carne e impregná-la com sal || ação de preencher a carne com sal

Abonação: “E, primeiramente, a salga: ela é direta em Pelotas, precedida da passagem na salmoura no Rio da Prata." (Doc 88 - L.C. 1880)

Ocorrência nos dicionários:

\begin{tabular}{|c|c|c|c|}
\hline Autor & Ano obra & Lexia & $\begin{array}{c}\text { Acepção correspondente } \\
\text { ao glossário }\end{array}$ \\
\hline RB & 1712 & - & - \\
\hline AMS & 1813 & - & - \\
\hline DV & 1873 & + & + \\
\hline LF & 1940 & + & + \\
\hline CA & 1958 & + & + \\
\hline ABHF & 1986 & - & - \\
\hline ZCN/RCN & 1996 & + & - \\
\hline
\end{tabular}




\begin{tabular}{|c|c|c|c|}
\hline AH/MSV & 2001 & + & + \\
\hline FSB & 2002 & + & - \\
\hline BB & 2003 & + & - \\
\hline
\end{tabular}

Análise descritiva dos dicionários gerais:

DV e LF mencionam o peixe como o tipo de carne que sofre o processo da salga. CA, ABHF e AH/MSV fazem a distinção na acepção, informando que o processo de impregnar de sal o peixe ou a carne é denominado de salga e que, no RS a salga é definida como lugar onde se impregna de sal as carnes. FSB apresenta para a lexia salga as definições: líquido que escorre da carne salgada para conserva, vasilha com salmoura e sal e, por fim, a administração de sal para conservar.

Análise descritiva dos dicionários regionalistas:

A salga, segundo ZCN/RCN e BB é o local na charqueada onde se aplica o sal na carne e não a operação, o ato de salgar as mantas de carne.

Salgador $\mid$ s.m.

empregado de charqueada encarregado de intermear de sal a carne já passada na salmoura || trabalhador que enche a carne de sal

Abonação: “... numero dos escravos cujo aluguel eu desejo saber, comprehendem-se os Xarqueadores, ximangos, salgadores, descarneadores”. (Doc 60 - Poa 1883)

"Todos os pedaços charqueados são levados para mesas côncavas, cheias de sal, onde operários especiais, o "salgadores", os impregnam de sal, esfregando-os, sobre tudo, no nível dos pontos lanhados." (Doc 88 - L.C. 1880)

"Feito esse trabalho, retiravam a carne do tanque e a depositavam a sua borda, para que os salgadores efetuassem o seu trabalho. Os salgadores, em pequeno número, cobriam de sal grosso..." (Doc 116 - A.P.C. 1988)

Ocorrência nos dicionários:

\begin{tabular}{|c|c|c|c|}
\hline Autor & Ano obra & Lexia & $\begin{array}{c}\text { Acepção correspondente } \\
\text { ao glossário }\end{array}$ \\
\hline RB & 1712 & - & - \\
\hline AMS & 1813 & - & - \\
\hline DV & 1873 & - & - \\
\hline LF & 1940 & + & + \\
\hline CA & 1958 & + & + \\
\hline ABHF & 1986 & - & - \\
\hline ZCN/RCN & 1996 & - & + \\
\hline AH/MSV & 2001 & + & + \\
\hline
\end{tabular}




\begin{tabular}{|c|c|c|c|}
\hline FSB & 2002 & - & - \\
\hline BB & 2003 & - & - \\
\hline
\end{tabular}

Análise descritiva dos dicionários gerais:

As obras que apresentam a lexia salgador fornecem acepções correspondentes a do glossário.

Análise descritiva dos dicionários regionalistas:

Não consta a lexia nas referidas obras.

Salgar $\mid v$.

ação de adicionar sal || ato de impregnar de sal a manta de carne para transformá-la em charque || colocar a carne ou o couro na salmoura tornando-a salgada

Abonação: “...Comprar, vender ou depositar nos açougues qualquer genero alem da carne verde, ou salgar esta nos açougues" (Doc 02 - Flo. 1896/1901)

“...Vossa Merce em cuja Repartição se devem conservar os gados, que do Continente vierem remettidos para aquelle fim, como tambem salgar e beneficiar as Carnes..." (Doc 08 - Flo. 1797)

“Também para assegurar a alimentação, trazem-no em todas as regiões, para salgar e secar levemente a carne..." (Doc 103 - L.C. 1880)

Ocorrência nos dicionários:

\begin{tabular}{|c|c|c|c|}
\hline Autor & Ano obra & Lexia & $\begin{array}{c}\text { Acepção correspondente } \\
\text { ao glossário }\end{array}$ \\
\hline RB & 1712 & + & + \\
\hline AMS & 1813 & + & + \\
\hline DV & 1873 & + & + \\
\hline LF & 1940 & + & + \\
\hline CA & 1958 & + & + \\
\hline ABHF & 1986 & + & - \\
\hline ZCN/RCN & 1996 & - & + \\
\hline AH/MSV & 2001 & + & + \\
\hline FSB & 2002 & + & - \\
\hline BB & 2003 & - & + \\
\hline
\end{tabular}

Análise descritiva dos dicionários gerais: 
AMS, DV e LF mencionam nas acepções que salgar é colocar em sal as carnes e peixes para conservar sem putrefação. As outras obras que apresentam a lexia, definem o verbo como ato de temperar com sal.

Análise descritiva dos dicionários regionalistas:

Não consta a lexia nas referidas obras.

Salmoura $\mid$ s.f.

líquido preparado com água e sal usado nas charqueadas para mergulhar a carne e os couros || moira

Abonação: “...16 de Janeiro. - Graxa em pipas, 320 a 330 kilos, dita em bexigas, 400 a 420 ; lingoas de fumeiro, $28 \$$ a $29 \$$ cento; ditas communs, $16 \$$ a $20 \$$; em salmoura, $26 \$$ a 30\$; sebo coado, 420 a 440 rs. kilos; soccado 300 a 330; xarque superior do Rio..."(Doc 31 - Pel. 1869)

"Quando o animal é abatido, retalham-no, salgam os pedaços e colocam no tanque onde se impregnam de salmoura.” (Doc 129 - A.S.H. 1820/21)

"A carne passada na salmoura, no Rio da Prata, ou esfregada com sal em Pelotas, é, finalmente, empilhada, isto é, disposta em montes verticais..." (Doc 88 - L.C. 1880)

Ocorrência nos dicionários:

\begin{tabular}{|c|c|c|c|}
\hline Autor & Ano obra & Lexia & $\begin{array}{c}\text { Acepção correspondente } \\
\text { ao glossário }\end{array}$ \\
\hline RB & 1712 & + & - \\
\hline AMS & 1813 & - & + \\
\hline DV & 1873 & - & - \\
\hline LF & 1940 & + & + \\
\hline CA & 1958 & + & + \\
\hline ABHF & 1986 & + & - \\
\hline ZCN/RCN & 1996 & - & - \\
\hline AH/MSV & 2001 & - & - \\
\hline FSB & 2002 & - & - \\
\hline BB & 2003 & - & + \\
\hline
\end{tabular}

Análise descritiva dos dicionários gerais:

RB apresenta salmoura como molho posto em sal. AMS apresenta a variante salmoira como água muito salgada em que se conserva peixe ou carne. DV apresenta a lexia salgadeira como tina que o peixe e a carne ficam na salmoura. CA e RB apresentam o verbo salmourar definido como pôr em salmoura. AH/MSV fornece as lexias salmoirar e salmoeirar, com a mesma acepção de salmourar; salmoeira, definida como 
mesmo que salmoura. FSB apresenta também a lexia salmouragem, definindo-a como o banho em salmoura.

Variante: salmoira (LF)

Análise descritiva dos dicionários regionalistas:

A lexia não consta nas obras regionalistas.

Sangria $\mid$ s.f.

extração de sangue feito durante a carneação do boi || retirada lenta e constante do sangue do animal em processo de abate

Abonação: “... desde o início, se o animal se agitar, sangra-se, cravando o facão até o coração. Esta sangria é constante; ela é indispensável, porque termina de matar animais dos quais alguns teriam podido viver $1 / 2$ hora e mais..." (Doc 86 - L.C. 1880) Ocorrência nos dicionários:

\begin{tabular}{|c|c|c|c|}
\hline Autor & Ano obra & Lexia & $\begin{array}{c}\text { Acepção correspondente } \\
\text { ao glossário }\end{array}$ \\
\hline RB & 1712 & - & - \\
\hline AMS & 1813 & + & + \\
\hline DV & 1873 & + & + \\
\hline LF & 1940 & + & + \\
\hline CA & 1958 & + & + \\
\hline ABHF & 1986 & + & + \\
\hline ZCN/RCN & 1996 & - & - \\
\hline AH/MSV & 2001 & + & + \\
\hline FSB & 2002 & - & - \\
\hline BB & 2003 & - & - \\
\hline
\end{tabular}

Análise descritiva dos dicionários gerais:

AMS somente apresenta em sua obra o processo da sangria, descrevendo como a incisão é feita na veia ou artéria para soltar o sangue do corpo. LF e CA apresentam ao consulente, além da acepção correspondente ao glossário, tipos diferentes de sangria, como a capilar, desatada, dentre outras. AH/MSV é o único autor que menciona a sangria como sangue que extravia do animal quando é abatido para consumo.

Análise descritiva dos dicionários regionalistas:

Não consta a lexia nas referidas obras.

BB e ZCN/RCN apresentam lexias relacionadas à sangria, como: sangrar, sendo a acepção correspondente a do glossário; sangrador, definida como o indivíduo que 
realiza a sangria; sangradouro, que é o lugar na rês onde o sangrador introduz a faca ou punhal para realizar a sangria e também a expressão aventar em sangria, usada no sentido de corrigir a sangria mal feita.

Sebo $\mid$ s.m.

espécie de gordura produzida pela cocção do intestino, os invólucros renais e peritônio do animal || subproduto fabricado na charqueada

Abonação: "Vou transcrever aqui o extrato dos dados de exportaçāo do Rio Grande, durante vários anos, fornecidos pelo Senhor Chaves: ANO 1816 - Carne seca - Para o Rio de Janeiro, 169.879 arrobas; Bahia... ... Sêbo - Para o Rio de Janeiro, 36.698 arrobas... (Doc 131 - A.S.H. 1820/21)

“Em Pelotas, não somente o sebo é fabricado à parte nas cubas menores: mas, além do mais, adotou-se em certas charqueadas um verdadeiro luxo de precauções." (Doc 98 - L.C. 1880)

"Rio de Janeiro, no brigue nacional -Norma- Eufrazio Lopes de Araujo 50 barricas com 323 arrobas de sebo coado." (Doc 28 - Pel. 1869)

Variante: sêbo

Ocorrência nos dicionários:

\begin{tabular}{|c|c|c|c|}
\hline Autor & Ano obra & Lexia & $\begin{array}{c}\text { Acepção correspondente } \\
\text { ao glossário }\end{array}$ \\
\hline RB & 1712 & + & + \\
\hline AMS & 1813 & + & + \\
\hline DV & 1873 & + & + \\
\hline LF & 1940 & + & + \\
\hline CA & 1958 & + & + \\
\hline ABHF & 1986 & + & - \\
\hline ZCN/RCN & 1996 & - & + \\
\hline AH/MSV & 2001 & + & + \\
\hline FSB & 2002 & + & - \\
\hline BB & 2003 & - & + \\
\hline
\end{tabular}

Análise descritiva dos dicionários gerais:

LF classifica outros tipos de sebo, como o mineral, de grilo, vegetal etc. As demais lexias apresentadas nas obras, apresentam a acepção semelhante a do glossário.

Observação: A produção de sebo, nas charqueadas, mostrava-se, de certa forma, lucrativa. Em um dado momento, quando o Ciclo do Charque iniciou seu declínio, há 
indícios nos documentos de que a soma da venda dos subprodutos mostrava-se tanto ou mais lucrativa que a venda da carne salgada.

Variante: cebo (RB, AH/MSV)

Análise descritiva dos dicionários regionalistas:

Não consta a lexia nas referidas obras.

Secadouro | s.m

local onde se encontra o varal de secar carne $\|$ secador

Abonação: "Essas forquilhas recebem varões transversais destinados a estender a carne a secar, no tempo das xarqueadas. Ao lado desses secadouros existe o edifício onde se salga a carne e onde é construído o reservatório, denominado tanque". (Doc 129 - A.S.H. 1820/21)

"Ao imaginar essa multidāo de animais decapitados, o sangue a correr em borbotões, a prodigiosa quantidade de carne exposta nos secadouros, vejo que tais lugares devem inspirar contrariedade e pavor". (Doc 134 - A.S.H. 1820/21)

Ocorrência nos dicionários:

\begin{tabular}{|c|c|c|c|}
\hline Autor & Ano obra & Lexia & $\begin{array}{c}\text { Acepção correspondente } \\
\text { ao glossário }\end{array}$ \\
\hline RB & 1712 & - & - \\
\hline AMS & 1813 & - & - \\
\hline DV & 1873 & - & - \\
\hline LF & 1940 & + & + \\
\hline CA & 1958 & - & - \\
\hline ABHF & 1986 & - & - \\
\hline ZCN/RCN & 1996 & - & - \\
\hline AH/MSV & 2001 & - & - \\
\hline FSB & 2002 & - & - \\
\hline BB & 2003 & - & - \\
\hline
\end{tabular}

Análise descritiva dos dicionários gerais:

LF generaliza a acepção da lexia secadouro como local onde se seca alguma coisa.

CA e AH/MSV apresentam como sinônimo para secadouro a lexia enxugadouro.

Variantes: seccadouro (LF); secadoiro (ABHF, AH/MSV)

Análise descritiva dos dicionários regionalistas:

Não consta a lexia nas referidas obras.

ZCN/RCN fornece a lexia estaleiro como nome dado a paus suspensos em forquilhas altas onde se colocava a carne para secar. 


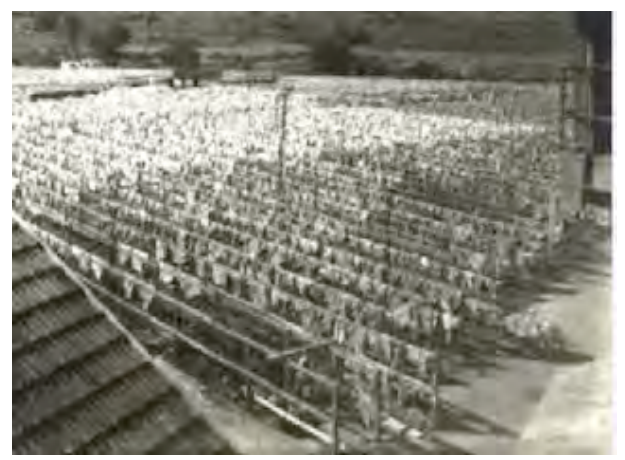

Fig. 13 Secadouro de charque

Fonte: Site terra-australis-br.blogspot.com.br

Serrador $\mid$ s.m.

empregado da charqueada encarregado de serrar os ossos para a extração do tutano

Abonação: "Ali estavam alinhados, esperando o primeiro boi, zorreiros, camboneiros... ... serradores de caracu, resfriadores, graxeiros, eletrecistas, tripeiros, etc e etc." (Doc 108 - A.P.C. 1988)

Ocorrência nos dicionários:

\begin{tabular}{|c|c|c|c|}
\hline Autor & Ano obra & Lexia & $\begin{array}{c}\text { Acepção correspondente } \\
\text { ao glossário }\end{array}$ \\
\hline RB & 1712 & + & - \\
\hline AMS & 1813 & + & - \\
\hline DV & 1873 & + & - \\
\hline LF & 1940 & + & - \\
\hline CA & 1958 & + & + \\
\hline ABHF & 1986 & + & + \\
\hline ZCN/RCN & 1996 & - & - \\
\hline AH/MSV & 2001 & + & + \\
\hline FSB & 2002 & + & + \\
\hline BB & 2003 & - & - \\
\hline
\end{tabular}

Análise descritiva dos dicionários gerais:

RB, AMS, DV e LF, somente apresentam serrador como oficial que serra madeiras. Não foi encontrado em nenhum dicionário nenhuma referência ao serrador de ossos.

Análise descritiva dos dicionários regionalistas:

Não consta a lexia nas referidas obras.

Sumaca $\mid$ s.m.

embarcação usada para transporte de carga e de pessoas || barca || navio 
Abonação: "As margens dos rios Sāo Gonçalo e Pelotas sāo muito chatas, campo é alegre e coberto de bosquetes e de pastagens. Chegados a Norte passamos para uma sumaca, também pertencente ao Senhor Chaves, donde nos transportamos a uma lancha que nos levou ao Rio Grande”. (Doc 133 - A.S.H. 1820/21)

“... do frete da Sumaca entre muito em conta e tambem a alguma avaria dos mesmos generos, como tudo quanto se compra no Rio de Janeiro tem chegado a hû excesso de que não há exemplo, virá finalmente a ficar a Receita pela despeza. As providencias da Carne Salgada do Rio Grande do Sul...” (Doc 13 - Flo. 1798)

Ocorrência nos dicionários:

\begin{tabular}{|c|c|c|c|}
\hline Autor & Ano obra & Lexia & $\begin{array}{c}\text { Acepção correspondente } \\
\text { ao glossário }\end{array}$ \\
\hline RB & 1712 & - & - \\
\hline AMS & 1813 & - & - \\
\hline DV & 1873 & + & + \\
\hline LF & 1940 & + & + \\
\hline CA & 1958 & + & + \\
\hline ABHF & 1986 & + & + \\
\hline ZCN/RCN & 1996 & - & - \\
\hline AH/MSV & 2001 & - & - \\
\hline FSB & 2002 & - & - \\
\hline BB & 2003 & - & \\
\hline
\end{tabular}

Análise descritiva dos dicionários gerais:

Segundo DV sumaca é um barco de navegação comercial da costeira do Brasil, ou uma embarcação ligeira que serve de transporte. LF, CA, ABHF e AH/MSV mencionam o uso corrente da sumaca principalmente na América do Sul. ABHF e AH/MSV apresentam sumaca como sinonímia para charque.

Análise descritiva dos dicionários regionalistas:

Não consta a lexia nas referidas obras.

Observação: BB menciona a lexia charque como sinonímia de sumaca. A obra de ZCN/RCN não consta esta referência.

Tablada $\mid$ s.f.

espécie de feira de compra e venda de gado \| mercado abundante e direto de gado 
Abonação: “... e entre as causas múltiplas da escassez das tropas sobre o mercado de venda ou "tablada" é preciso, evidentemente, colocar esta tentativa de regulamento." (Doc 83 - L.C. 1880)

“...embora já houvesse na balança na tablada de Pelotas. A grande maioria das transações..." (Doc 70 - A.F.M. s/n)

Ocorrência nos dicionários:

\begin{tabular}{|c|c|c|c|}
\hline Autor & Ano obra & Lexia & $\begin{array}{c}\text { Acepção correspondente } \\
\text { ao glossário }\end{array}$ \\
\hline RB & 1712 & - & - \\
\hline AMS & 1813 & - & - \\
\hline DV & 1873 & - & - \\
\hline LF & 1940 & - & - \\
\hline CA & 1958 & + & ++ \\
\hline ABHF & 1986 & + & ++ \\
\hline ZCN/RCN & 1996 & + & ++ \\
\hline AH/MSV & 2001 & + & ++ \\
\hline FSB & 2002 & - & - \\
\hline BB & 2003 & + & ++ \\
\hline
\end{tabular}

Análise descritiva dos dicionários gerais:

CA é o primeiro autor a mencionar a lexia tablada no dicionário, seguido por LF, ABHF e AH/MSV. Segundo estes lexicógrafos, tablada é um termo usado no Rio Grande do Sul que designa feira de gado e pode ser empregado como sinônimo de charqueada.

Análise descritiva dos dicionários regionalistas:

ZCN/RCN apresenta a lexia tablada como espécie de feira de gado, local onde se reúnem estancieiros, tropeiros e charqueadores. O autor também indica como sinônimo de charqueada. BB apresenta a mesma acepção de ZCN/RCN e emprega a expressão centro comercial ao invés de feira de gado.

Observação: O uso de charqueada como sinônimo de tablada não foi encontrado nos do corpus.

Tábua $\mid$ s.f.

pedaço de madeira usado como peso sobre a pilha de carne salgada || tora de madeira usada para fazer prensar e escorrer o excesso de água e sal da carne em processo de charqueação 
Abonação: “...e logo se poem em pilha, sendo a camada com novo Sal : e feita a pilha, que deve ser sobre taboas, poem-se outras taboas por cima da dita pilha, bem unidas..." (Doc 14 - Flo. 1798)

Variantes: táboa, taboa

Ocorrência nos dicionários:

\begin{tabular}{|c|c|c|c|}
\hline Autor & Ano obra & Lexia & $\begin{array}{c}\text { Acepção correspondente } \\
\text { ao glossário }\end{array}$ \\
\hline RB & 1712 & + & - \\
\hline AMS & 1813 & + & - \\
\hline DV & 1873 & + & - \\
\hline LF & 1940 & + & - \\
\hline CA & 1958 & - & - \\
\hline ABHF & 1986 & - & - \\
\hline ZCN/RCN & 1996 & + & - \\
\hline AH/MSV & 2001 & + & - \\
\hline FSB & 2002 & + & - \\
\hline BB & 2003 & + & - \\
\hline
\end{tabular}

Análise descritiva dos dicionários gerais:

AMS, DV, LF, ABHF e AH/MSV fornecem, em seus verbetes, diversos tipos de tábuas como a rasa, de pescoço, de geografia, mas não definem a lexia como suporte ou peso.

Variantes: taboa (RB, DV, FSB); táboa (AMS); tabua (DV)

Análise descritiva dos dicionários regionalistas:

Os lexicógrafos apresentam acepções bastante divergentes às do glossário. Segundo ZCN/RCN, tábua é cada um dos lados do pescoço do animal e também uma das rapaduras de um maço de dois. BB menciona, além das acepções fornecidas por ZCN/RCN, outras definições no sentido figurado: recusa de moça para dançar em um baile e mulher sem peitos.

Tajano | s.m

charque || carne seca

Abonação: “ ...e a "carne seca" ou "tajano" é um alimento utilizado em regiões muito vastas da América do Sul, não somente pelos escravos, como disse, mas por toda a população, mesmo a mais abastada." (Doc 83 - L.C. 1880)

"A carne seca ou "tajano" tem uma cor cinza amarelada mais ou menos uniforme, pálida, que lhe dá, em grande parte, seu aspecto desagradável.” (Doc 93 - L.C. 1880) 
Ocorrência nos dicionários:

Não consta a lexia nas referidas obras, o que comprova a hipótese de que esta lexia é usada principalmente no Uruguai e Argentina. Esta hipótese foi levantada por ter sido encontrada a lexia tajano somente nas obras de Louis Couty. Este autor, por sua vez, utiliza-se do método comparativo do preparo do charque nas charqueadas do sul do Brasil com as do Rio da Prata. Portanto, acredita-se que o uso da lexia tajano seja diretamente influenciada pela língua espanhola, e, provavelmente, não tenha ultrapassado os limites da fronteira ao ponto de tornar-se corrente na fala e uso dos habitantes do sul do Brasil.

Tanque $\mid$ s.m.

espécie de reservatório onde é mergulhado um pedaço de carne ou couro na salmoura || reservatório com cerca de 9 metros cúbicos de volume preenchido com água salgada || salmoeira

Abonação: "Ao lado desses secadouros existe o edifício onde se salga a carne e onde é construído o reservatório, denominado tanque.” (Doc 129 - A.S.H. 1820/21)

"Os tanques, com mais ou menos 6 metros de comprimento, por 1,50 metro de largura e 1,20 metro de altura, já estavam cheios de salmoura, com os medidores de sanilidade boiando em seus interiores...” (Doc 109 - A.P.C. 1988)

"Ali dois homens, munidos de paus com uma rodela numa extremidade, mergulhavam a carne durante algum tempo até que ela estivesse completamente salgada. Feito este trabalho, retiravam a carne do tanque e a depositavam a sua borda, para que os salgadores efetuassem seu trabalho" (Doc 115 - A.P.C. 1988)

Ocorrência nos dicionários:

\begin{tabular}{|c|c|c|c|}
\hline Autor & Ano obra & Lexia & $\begin{array}{c}\text { Acepção correspondente } \\
\text { ao glossário }\end{array}$ \\
\hline RB & 1712 & - & - \\
\hline AMS & 1813 & + & - \\
\hline DV & 1873 & + & - \\
\hline LF & 1940 & + & + \\
\hline CA & 1958 & + & - \\
\hline ABHF & 1986 & + & - \\
\hline ZCN/RCN & 1996 & - & + \\
\hline AH/MSV & 2001 & + & - \\
\hline FSB & 2002 & + & - \\
\hline BB & 2003 & - & - \\
\hline
\end{tabular}


Análise descritiva dos dicionários gerais:

AMS e DV definem tanque como reservatório onde se coloca água e menciona o uso de um reservatório nos engenhos de cana de açúcar. Os lexicógrafos LF, ABHF e FSB apresentam alguns tipos de tanques e definem a lexia de forma genérica: reservatório para qualquer líquido. AH/MSV, entretanto, apresenta no verbete da obra que tanque pode ser o reservatório de água que serve para colocar peixe ou carne na salmoura.

Análise descritiva dos dicionários regionalistas:

Não consta a lexia nas referidas obras.

Nota: Observando-se as abonações no verbete, percebe-se que autores como Antenor Peixoto de Castro, Auguste de Saint-Hilaire, dentre outros, informam que os pedaços de carne retirados dos animais recém abatidos eram colocados na salmoura. Esta salmoura ficava depositada dentro de um reservatório grande, que poderia ser denominado de salmoeira ou tanque. O que se observou, entretanto, é que as obras regionalistas de $\mathbf{Z C N} / \mathbf{R C N}$ e BB apresentam a lexia tangui e não tanque, para denominar este reservatório. A questão poderia ser simplesmente sanada denominando as lexias como sinônimos. O problema que envolve as lexias tangui e tanque é que, tanto ZCN/RCN quanto o glossário informam que as lexias foram extraídas da obra de Saint-Hilaire. Neste caso, hipotetiza-se de que algumas edições da obra de SaintHilaire apresentem a grafia tangui e a versão utilizada para a pesquisa apresenta a grafia tanque para designar o reservatório de água salgada. Optou-se, indicar a grafia tangui como uma variante.

Variante: tangui (ZCN/RCN, BB)

BB apresenta a acepção da lexia como salmoeira nas charqueadas.

194 Tanoeiro| s.m.

o que fabrica tonel || pessoa encarregada de fazer o tonel para armazenar a carne salgada

Abonação: "O frete do Sal até a Ilha de Santa Catharina: Vazilhame: Tanoeiros; que os não há na mesma Ilha, e pessoas inteligentes que ensinem a salgar as mesmas carnes, e metelas nas Vazilhas..." (Doc 11 - Flo. 1798)

Ocorrência nos dicionários: 


\begin{tabular}{|c|c|c|c|}
\hline Autor & Ano obra & Lexia & $\begin{array}{c}\text { Acepção correspondente } \\
\text { ao glossário }\end{array}$ \\
\hline RB & 1712 & + & + \\
\hline AMS & 1813 & + & + \\
\hline DV & 1873 & - & - \\
\hline LF & 1940 & + & + \\
\hline CA & 1958 & + & + \\
\hline ABHF & 1986 & + & + \\
\hline ZCN/RCN & 1996 & - & + \\
\hline AH/MSV & 2001 & + & + \\
\hline FSB & 2002 & + & - \\
\hline BB & 2003 & - & \\
\hline
\end{tabular}

Análise descritiva dos dicionários gerais:

As obras que apresentam a lexia tanoeiro não apresentam nenhum dado que se diferencie dos apresentados no glossário, com exceção de AH/MSVque fornece a lexia toneleiro como sinônimo de tanoeiro.

Análise descritiva dos dicionários regionalistas:

Não consta a lexia nas referidas obras.

BB fornece a lexia raspe, definida como instrumento de tanoeiro para raspar aduelas, raspilha.

Tina $\mid$ s.f.

objeto usado na charqueada para ferver sebo e graxa || espécie de panela usada na fabricação de alguns subprodutos da charqueada || vasilha

Abonação: “... tinas para sebo e graixa, ferros para a fornalha e pra descarregar as tinas, espumadeiras..." (Doc 49 - Poa 1870)

Ocorrência nos dicionários:

\begin{tabular}{|c|c|c|c|}
\hline Autor & Ano obra & Lexia & $\begin{array}{c}\text { Acepção correspondente } \\
\text { ao glossário }\end{array}$ \\
\hline RB & 1712 & + & - \\
\hline AMS & 1813 & + & - \\
\hline DV & 1873 & + & - \\
\hline LF & 1940 & + & - \\
\hline CA & 1958 & + & - \\
\hline ABHF & 1986 & + & - \\
\hline ZCN/RCN & 1996 & - & - \\
\hline AH/MSV & 2001 & + & - \\
\hline FSB & 2002 & - & - \\
\hline BB & 2003 & - & - \\
\hline
\end{tabular}


Análise descritiva dos dicionários gerais:

As obras que fornecem a lexia tina assemelham-se em definí-la como uma espécie de vasilha ou tonel para guardar água, banhar-se, carregar líquidos, guardar licores. Em nenhuma das obras foi encontrada referência de tina como recipiente para ferver líquidos.

Análise descritiva dos dicionários regionalistas:

Não consta a lexia nas referidas obras.

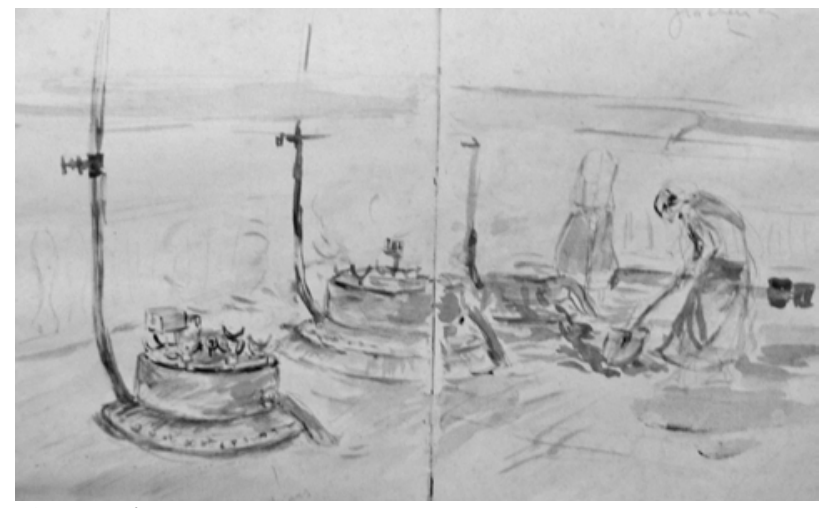

Fig. 14 Tinas

Xilogravura de Danúbio Gonçalves, acervo do

Museu do Charque, Pelotas, RS

Tina digeridora $\mid$ s.f.

equipamento que separa a graxa dos ossos || instrumento de fabricação de sabão e vela

Abonação: "Dono de um gênio inventivo, Domingos de Almeida dedicou tempo e dinheiro na construção de equipamentos capazes de modernizar sua charqueada e facilitar o trabalho. Foi o caso das tinas digeridoras..." (Doc 43 - Pel 2007)

Ocorrência nos dicionários:

Não consta a lexia nas referidas obras.

Nota: A tina digeridora, ao que parece, foi utilizada principalmente no estabelecimento do charqueador Domingos de Almeida, que, de acodo com o documentos do corpus, foi o inventor destas tinas. Não foi possível comprovar o uso destas tinas em outros estabelecimentos saladeris. 
espécie de porto pequeno, geralmente de madeira, onde a embarcação fica atracada || construção usada para trânsito de pessoas e mercadorias da embarcação, ligando a margem do arroio à charqueada

Abonação: "Montanhas de sal groso, completamente branco, trazidas por barcos que atracavam nos trapiches da Charqueada..." (Doc 109 - A.P.C. 1988)

Ocorrência nos dicionários:

\begin{tabular}{|c|c|c|c|}
\hline Autor & Ano obra & Lexia & $\begin{array}{c}\text { Acepção correspondente } \\
\text { ao glossário }\end{array}$ \\
\hline RB & 1712 & - & - \\
\hline AMS & 1813 & + & - \\
\hline DV & 1873 & + & - \\
\hline LF & 1940 & + & - \\
\hline CA & 1958 & + & - \\
\hline ABHF & 1986 & + & - \\
\hline ZCN/RCN & 1996 & - & - \\
\hline AH/MSV & 2001 & + & - \\
\hline FSB & 2002 & + & - \\
\hline BB & 2003 & - & - \\
\hline
\end{tabular}

Análise descritiva dos dicionários gerais:

Todos os lexicógrafos que apresenta a lexia definem como trapiche uma casa de guardar gêneros de embarque, uma espécie de armazém de mercadorias importadas.

Análise descritiva dos dicionários regionalistas:

Não consta a lexia nas referidas obras.

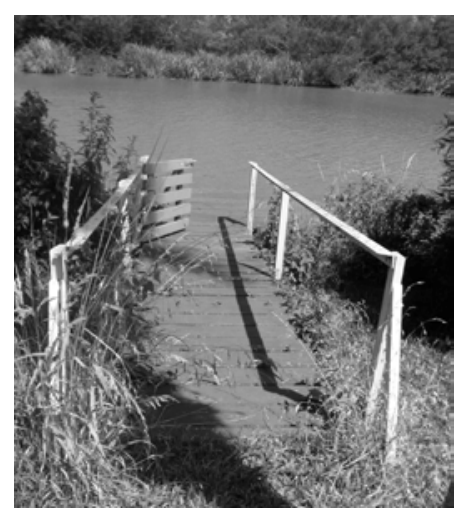

Fig. 15 Trapiche, Margens do

Arroio Pelotas, Charqueada Santa Rita,

Foto: Cátia Schreiner, 2011

Traste | s.m

objeto sem valor || conjunto de utensílios que são pouco utilizados em uma charqueada 
Abonação: “ 2 Cavallos 20 Ovelhas 500 Couros para o varal Trastes da Casa da Xarqueada" (Doc 65 - Poa 1873)

Ocorrência nos dicionários:

\begin{tabular}{|c|c|c|c|}
\hline Autor & Ano obra & Lexia & $\begin{array}{c}\text { Acepção correspondente } \\
\text { ao glossário }\end{array}$ \\
\hline RB & 1712 & + & + \\
\hline AMS & 1813 & + & - \\
\hline DV & 1873 & + & - \\
\hline LF & 1940 & + & - \\
\hline CA & 1958 & + & - \\
\hline ABHF & 1986 & + & + \\
\hline ZCN/RCN & 1996 & + & + \\
\hline AH/MSV & 2001 & - & - \\
\hline FSB & 2002 & - & + \\
\hline BB & 2003 & + & + \\
\hline
\end{tabular}

Análise descritiva dos dicionários gerais:

AMS define traste como corda de viola ou peças de uso e serviço. Esta acepção é encontrada também em DV, LF e CA, que apresentam a lexia traste para designar pessoas, com o sentido de pessoa sem valor, inútil.

Análise descritiva dos dicionários regionalistas:

As obras de ZCN/RCN e BB correspondem ao glossário e corroboram com as ocorrências nos documentos do corpus, estes autores fornecem a lexia badulaque como sinônimo de traste. BB ainda menciona as lexias cacaria e trastaria para designar grande açumulo de traste.

Nota: Esta lexia é empregada em documentos considerados oficiais, como é o caso dos inventários dos charqueadores, em que, para não listar todos os objetos de pouco valor deixados aos herdeiros, usavam a lexia traste para o conjunto destes utensílios, móveis etc.

Tripeiro | s.m.

empregado da charqueada responsável pelas tripas do animal depois do abate Abonação: “Ali estavam alinhados, esperando o primeiro boi, zorreiros, camboneiros... ... serradores de caracu, resfriadores, graxeiros, eletrecistas, tripeiros, etc e etc." (Doc 108 - A.P.C. 1988)

Ocorrência nos dicionários:

\begin{tabular}{|l|l|l|l|}
\hline Autor & Ano obra & Lexia & Acepção correspondente \\
\hline
\end{tabular}




\begin{tabular}{|c|c|c|c|}
\hline & & & ao glossário \\
\hline RB & 1712 & + & - \\
\hline AMS & 1813 & + & - \\
\hline DV & 1873 & + & - \\
\hline LF & 1940 & + & + \\
\hline CA & 1958 & + & + \\
\hline ABHF & 1986 & + & - \\
\hline ZCN/RCN & 1996 & - & - \\
\hline AH/MSV & 2001 & + & - \\
\hline FSB & 2002 & + & - \\
\hline BB & 2003 & - & - \\
\hline
\end{tabular}

Análise descritiva dos dicionários gerais:

RB, AMS, AH/MSV e FSB definem tripeiro como o homem que vende tripas. AH/MSV e FSB apresentam a lexia bucheiro como sinônimo de tripeiro. Alguns autores como CA e LF designam tripeiro como aquele que se utiliza de tripa para seu sustento, ou aquele que se alimenta delas. Uma vez que não há indicação da finalidade das tripas dos animais abatidos na charqueada, considera-se correspondente ao glossário as acepções dadas pelos autores que apresentam-o como aquele que se utiliza das tripas para sustento.

Análise descritiva dos dicionários regionalistas:

Não consta a lexia nas referidas obras.

Tropa | s.f.

conjunto de animais bovinos || grupo de animais levados de um lugar ao outro Abonação: "Pela tarde, véspera da matanca, as tropas que vinham trazidas pelos tropeiros, passavam pela balança Municipal (imediações do Parque Tênis Clube) e em grupo de 50 animais eram pesados, fazendo-se ao final a média de peso da tropa." (Doc 109 - A.P.C. 1988)

"Deixar que as tropas de gado em sua passagem damnifiquem as plantações."

(Doc 03 - Flo. 1896/1901)

Ocorrência nos dicionários:

\begin{tabular}{|c|c|c|c|}
\hline Autor & Ano obra & Lexia & $\begin{array}{c}\text { Acepção correspondente } \\
\text { ao glossário }\end{array}$ \\
\hline RB & 1712 & + & - \\
\hline AMS & 1813 & - & - \\
\hline DV & 1873 & - & - \\
\hline LF & 1940 & + & + \\
\hline
\end{tabular}




\begin{tabular}{|c|c|c|c|}
\hline CA & 1958 & + & + \\
\hline ABHF & 1986 & + & ++ \\
\hline ZCN/RCN & 1996 & + & + \\
\hline AH/MSV & 2001 & + & + \\
\hline FSB & 2002 & + & + \\
\hline BB & 2003 & + & + \\
\hline
\end{tabular}

Análise descritiva dos dicionários gerais:

RB, AMS e DV definem tropa somente como um conjunto de soldados de cavalaria. LF apresenta tropa como grande porção de gado. CA, ABHF e AH/MSV acabam por meniconá-la como lexia regionalista do Rio Grande do Sul, definida como um conjunto de gado vacum que desloca-se de um lugar ao outro. ABHF ainda apresenta a informação de que este conjunto de gado geralmente desloca-se para as charqueadas. Análise descritiva dos dicionários regionalistas:

ZCN/RCN e BB apresentam diferentes tipos de tropas, como as tropas de gado, de mulas, de éguas, de cargueiros etc. Ainda apresentam as lexias tropão como uma tropa numerosa de gado e o substantivo tropeada, definido como o ato de tropear. ZCN/RCN ainda menciona a lexia arrengueira como tropa difícil de conduzir e tropear como ação de conduzir tropa; tropilha, tropita ou tropinha, como tropa pequena; tropona como tropa grande.

Tropeiro | s.m.

viajante que transporta gado || camboeiro || condutor de tropas || viruçu

Abonação: “...José Domingos de Almeida aportou em Pelotas em 1819, como tropeiro em busca de mulas para revender nas Minas Gerais. Entre e idas e vindas, três anos depois, decidiu fixar residência na jovem freguesia." (Doc 43 - Pel. 2007)

“...Os tropeiros, para facilitar a contagem, faziam alas para a passagem do gado, em pequenos lotes. Não era fácil a tarefa e ao final da contagem, antes que os tropeiros falassem, nós já tínhamos o resultado que me geral conferia, havendo algumas vezes pequenas divergências... (Doc 110 - A.P.C. 1988)

Ocorrência nos dicionários:

\begin{tabular}{|c|c|c|c|}
\hline Autor & Ano obra & Lexia & $\begin{array}{c}\text { Acepção correspondente } \\
\text { ao glossário }\end{array}$ \\
\hline RB & 1712 & - & - \\
\hline AMS & 1813 & - & - \\
\hline DV & 1873 & + & + \\
\hline
\end{tabular}




\begin{tabular}{|c|c|c|c|}
\hline LF & 1940 & + & + \\
\hline CA & 1958 & + & + \\
\hline ABHF & 1986 & + & + \\
\hline ZCN/RCN & 1996 & + & + \\
\hline AH/MSV & 2001 & + & + \\
\hline FSB & 2002 & + & + \\
\hline BB & 2003 & + & + \\
\hline
\end{tabular}

Análise descritiva dos dicionários gerais:

LF expõe em seu dicionário que o tropeiro é o empresário dos transportes, e pode ser considerado aquele que trabalha nos cafezais, milharais e na cultura de cana-deaçúcar. Não há citação de regionalismo ou menção de tropeiros trabalhando nas charqueadas. LF, CA e AH/MSV apresentam a lexia como sinônimo de recouveiro. AH/MSV indica como uso no RS para aquele que vende e compra gado.

Nota: A lexia viruçu foi encontrada como sinônimo na obra Bases para Elaboração do Atlas Linguístico do Brasil (1961).

Análise descritiva dos dicionários regionalistas:

ZCN/RCN e BB acrescentam à acepção fornecida no glossário que o tropeiro é o peão que se encarrega da venda, transporte, e condução das tropas. Ambos lexicógrafos apresentam as lexias: beriba definindo-a como nome dado aos tropeiros paulistas. ZCN/RCN menciona a expressão calçar a ponta, usada quando se coloca um tropeiro na ponta da tropa para andar mais devagar; sendo este indivíduo denominado chamador. BB apresenta a lexia estradeiro como sinônimo de tropeiro, além das lexias: tropeirada ou tropeirama como conjunto de tropeiros e, por fim, topeirito, diminutivo de tropeiro.

Nota: ZCN/RCN encerra seu verbete mencionando aos consulentes as intempéries que o tropeiro precisa lidar em seu árduo trabalho, afirmando que o trabalho deste homem é um dos mais ásperos e que exige muita dedicação.

Turma $\mid$ s.f

agrupamento formado por empregados da charqueada || empregados solteiros ou menos categorizados da charqueada

Abonação: “A firma mantinha um regular número de pequenas casas onde em geral moravam, permanentemente, os operários mais categorizados, como charqueadores, carneadores, rondas e salgadores e o agrupamento chamava-se "quadra", e um outro 
conjunto de quartos, para os empregados solteiros que se chamava 'turma'." (Doc 123 - A.P.C 1988)

Ocorrência nos dicionários:

\begin{tabular}{|c|c|c|c|}
\hline Autor & Ano obra & Lexia & $\begin{array}{c}\text { Acepção correspondente } \\
\text { ao glossário }\end{array}$ \\
\hline RB & 1712 & - & - \\
\hline AMS & 1813 & + & - \\
\hline DV & 1873 & - & - \\
\hline LF & 1940 & + & - \\
\hline CA & 1958 & + & - \\
\hline ABHF & 1986 & + & - \\
\hline ZCN/RCN & 1996 & - & - \\
\hline AH/MSV & 2001 & + & - \\
\hline FSB & 2002 & + & - \\
\hline BB & 2003 & - & + \\
\hline
\end{tabular}

Análise descritiva dos dicionários gerais:

A única obra que forneceu acepção semelhante a do glossário foi FSB, que fornece a acepção de turma como um conjunto de trabalhadores braçais.

Nota: Acredita-se que a denominação dada por Antenor Peixoto de Castro para o grupo de trabalhadores solteiros da charqueada era de uso informal, possivelmente em contexto familiar.

Análise descritiva dos dicionários regionalistas:

Não consta a lexia nas referidas obras.

BB apresenta a lexia turmeiro, definida como operário integrante de uma turma de trabalhadores de estrada ou de obras rurais.

Vagoneta $\mid$ s.f.

espécie de plataforma onde o boi é imobilizado e abatido || vagão pequeno que transporta 0 animal abatido para o galpão

Abonação: "Imediatamente após o golpe de facão, o boi cai, levanta-se bruscamente, como que fulminado sobre a vagoneta..." (Doc 85 - L.C. 1880)

Ocorrência nos dicionários:

\begin{tabular}{|c|c|c|c|}
\hline Autor & Ano obra & Lexia & $\begin{array}{c}\text { Acepção correspondente } \\
\text { ao glossário }\end{array}$ \\
\hline RB & 1712 & - & - \\
\hline AMS & 1813 & - & - \\
\hline DV & 1873 & - & - \\
\hline LF & 1940 & + & + \\
\hline
\end{tabular}




\begin{tabular}{|c|c|c|c|}
\hline CA & 1958 & + & + \\
\hline ABHF & 1986 & + & + \\
\hline ZCN/RCN & 1996 & - & - \\
\hline AH/MSV & 2001 & + & + \\
\hline FSB & 2002 & + & + \\
\hline BB & 2003 & - & - \\
\hline
\end{tabular}

Análise descritiva dos dicionários gerais:

LF apresenta a acepção de vagoneta como vaso em forma de pirâmide invertida, montado sobre rodas usadas nas linhas férreas para conduzir entulho. CA faz uso de figura para ilustrar a vagoneta, indicando que esta e usada para transportar materiais e trabalhadores. ABHF e FSB apresentam a variante vagonete, definida como pequeno vagão.

Análise descritiva dos dicionários regionalistas:

Não consta a lexia nas referidas obras.

Vara $\mid$ s.f.

barra de madeira longa onde se pendura a carne para secar || secador

Abonação: “A carne é, finalmente, levada para as "varas", ou secadores: são simples barras de madeira, bastante longas, estendidas transversalmente a 1 metro 50 do solo..." (Doc 90 - L.C. 1880)

"A direção das varas é, geralmente, de oeste a leste, de maneira que a exposição seja Norte-Sul..." (Doc 90 - L.C. 1880)

Ocorrência nos dicionários:

\begin{tabular}{|c|c|c|c|}
\hline Autor & Ano obra & Lexia & $\begin{array}{c}\text { Acepção correspondente } \\
\text { ao glossário }\end{array}$ \\
\hline RB & 1712 & + & - \\
\hline AMS & 1813 & + & - \\
\hline DV & 1873 & + & - \\
\hline LF & 1940 & + & - \\
\hline CA & 1958 & + & - \\
\hline ABHF & 1986 & + & - \\
\hline ZCN/RCN & 1996 & + & - \\
\hline AH/MSV & 2001 & + & + \\
\hline FSB & 2002 & + & - \\
\hline BB & 2003 & + & - \\
\hline
\end{tabular}

Análise descritiva dos dicionários gerais: 
Somente AH/MSV apresenta a lexia vara como uma barra de madeira usada em matadouros para suspender animais. Todos os autores, entretanto, fornecem inúmeras utilidades e tipo de varas, nenhuma correspondente ao glossário.

Análise descritiva dos dicionários regionalistas:

Segundo $\mathbf{Z C N} / \mathbf{R C N}$ e BB, a vara é um espeto improvisado ou a haste de madeira usada para fechar a porteira.

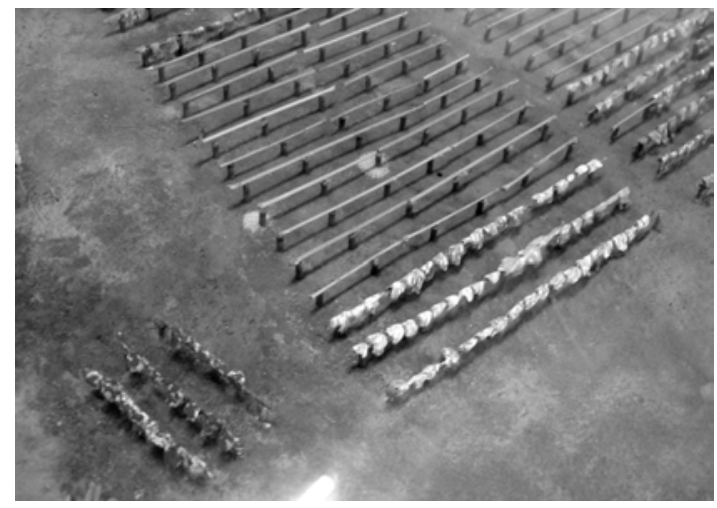

Fig. 16 Varas

Fonte: Maquete do Museu do Charque, Pelotas, RS

Foto: Cátia Schreiner, 2011

Varal | s.m.

conjunto de varas transversais usado para pendurar as mantas de charque \| local onde a carne salgada é colocada para escorrer e secar || varão || lugar onde se seca o charque || setor contíguo ao galpão onde se pendura a carne para resfriar antes de levá-la ao tanque de salga

Abonação: “... botava em forma cerca de 30 operários, cada um com seu carrinho de mão, para retirar o charque ainda pingando e depositá-lo sobre os varais que ocupavam mais de um hectare. Dia de sol, bonito, as peças iam perdendo a umidade e antes do cair da tarde já estavam novamente no galpão...” (Doc 121 - A.P.C. 1988)

"Em cerca de 10 anos, apenas em duas oportunidades houve corrida para o recolhimento dos varais. A experiência do meu pai sobre o assunto fazia com que mesmo em alguns dias de sol não se fizesse o trabalho, pois, conforme previsão, o tempo mudava e passava a chover." (Doc 122 - A.P.C. 1988)

“... 2 Cavallos, 20 Ovelhas, 500 Couros para o Varal. Trastes da Casa da Xarqueada..." (Doc 55 - Poa 1873)

Ocorrência nos dicionários:

\begin{tabular}{|c|c|c|c|}
\hline Autor & Ano obra & Lexia & $\begin{array}{c}\text { Acepção correspondente } \\
\text { ao glossário }\end{array}$ \\
\hline
\end{tabular}




\begin{tabular}{|c|c|c|c|}
\hline RB & 1712 & + & - \\
\hline AMS & 1813 & - & - \\
\hline DV & 1873 & - & - \\
\hline LF & 1940 & + & - \\
\hline CA & 1958 & + & ++ \\
\hline ABHF & 1986 & + & ++ \\
\hline ZCN/RCN & 1996 & + & ++ \\
\hline AH/MSV & 2001 & + & ++ \\
\hline FSB & 2002 & + & - \\
\hline BB & 2003 & + & ++ \\
\hline
\end{tabular}

Análise descritiva dos dicionários gerais:

RB apenas define varal como pau comprido por onde entram os correões dos filhões. AMS apresenta varal como local para se estenderem redes. LF define a lexia como local para pendurar roupa, ou barra que liga as carroças. CA, ABHF e AH/MSV apresentam as mesmas acepções de $\mathbf{L F}$ e revelando a lexia varais, no plural, usado no $\mathrm{RS}$, como grandes varas de pendurar charque.

Variante: varál (AMS)

Análise descritiva dos dicionários regionalistas:

As obras regionalistas definem varal como varas onde o charque é exposto para secar. Nas obras também encontra-se a lexia varais, definida como grandes varas para secar o charque. Segundo $\mathbf{Z C N} / \mathbf{R C N}$, a lexia varal quase não se usa no singular; informação também mencionada nos dicionários de CA, ABHF e AH/MSV. BB apresenta a lexia tendal, definida como varal onde se expõe o charque para secar.

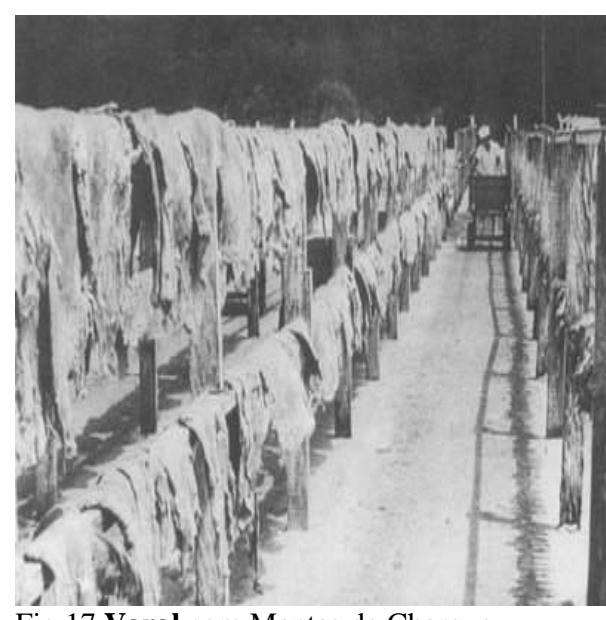

Fig.17 Varal com Mantas de Charque

Fonte: Site lucianoandanças.blogspot.com.br

Vasilha $\mid$ s.f. 
objeto utilizado para armazenar carne, sal ou salmoura || espécie de barrica usada no transporte de carne salgada

Abonação: “... se embarrica com camadas de novo Sal, ficando intermiado por toda a carne até o lugar, em que se funda a vazilha, pezando-se primeiramente para se saber quanto leva cada vazilha; e depois de bem rebatida as vazilhas, e bem estancadas, enchem-se de moira..." (Doc 14 - Flo. 1798)

Variantes: vazilha, bazila

Ocorrência nos dicionários:

\begin{tabular}{|c|c|c|c|}
\hline Autor & Ano obra & Lexia & $\begin{array}{c}\text { Acepção correspondente } \\
\text { ao glossário }\end{array}$ \\
\hline RB & 1712 & + & - \\
\hline AMS & 1813 & + & - \\
\hline DV & 1873 & + & - \\
\hline LF & 1940 & + & + \\
\hline CA & 1958 & + & + \\
\hline ABHF & 1986 & + & + \\
\hline ZCN/RCN & 1996 & + & + \\
\hline AH/MSV & 2001 & + & - \\
\hline FSB & 2002 & + & - \\
\hline BB & 2003 & + & - \\
\hline
\end{tabular}

Análise descritiva dos dicionários gerais:

RB apresenta a lexia vasilha como sinônimo de embarcação. AMS e DV definem como navio ou vaso do serviço da casa. LF fornece a acepção correspondente ao glossário, definindo a vasilha como recipiente para armazenar líquidos tanto de uso doméstico quanto em armazéns ou depósitos. FSB é sucinto em sua acepção, generalizando o uso de vasilha para recipiente que se guarda qualquer substância. Nenhuma obra, porém, forneceu como exemplo de conteúdo a ser guardado em vasilha, a salmoura, carne, charque etc.

Variante: vasílha (AMS)

Análise descritiva dos dicionários regionalistas:

As obras de ZCN/RCN e BB somente definem vasilha em sentido figurado, como indivíduo ruim, desprezível.

Vasilhame | s.m.

conjunto de vasilhas usado no transporte de sal, líquido, salmoura, carne ou outro gênero alimentício 
Abonação: "Lembrando-me de todas estas providencias não me esquece tambem a remessa de Vazilhame para a acomodação das carnes, que deve ser remetidas, confiando muito do zello de Vossa Merce mais esta prova do particular interesse com que se emprega no Real Serviço.” (Doc 8v - Flo. 1797)

Variantes: vazilhame

Ocorrência nos dicionários:

\begin{tabular}{|c|c|c|c|}
\hline Autor & Ano obra & Lexia & $\begin{array}{c}\text { Acepção correspondente } \\
\text { ao glossário }\end{array}$ \\
\hline RB & 1712 & - & - \\
\hline AMS & 1813 & - & - \\
\hline DV & 1873 & + & + \\
\hline LF & 1940 & + & - \\
\hline CA & 1958 & + & - \\
\hline ABHF & 1986 & + & - \\
\hline ZCN/RCN & 1996 & - & - \\
\hline AH/MSV & 2001 & + & - \\
\hline FSB & 2002 & - & - \\
\hline BB & 2003 & - & - \\
\hline
\end{tabular}

Análise descritiva dos dicionários gerais:

Considerou-se a acepção dada por DV como correspondente, uma vez que o autor define vasilhame como conjunto de vasilhas de uma adega ou nau. LF, CA, ABHF, AH/MSV e FSB somente indicam vasilhame como o conjunto de vasilhas, mas não especificam o uso.

Análise descritiva dos dicionários regionalistas:

Não consta a lexia nas referidas obras.

Víscera $\mid$ s.f.

órgão interno do animail || matéria prima para a fabricação de adubo/guano || buchada

Abonação: "A fase da matança terminara, havia muito tempo; contudo havia ainda muita carne no chão e vísceras de bois, putrefatas espalhavam forte mau cheiro..." (Doc 136 - A.S.H. 1820/21)

“...transformação do sangue em gelatina, das vísceras em guano, das línguas em conservas etc." (Doc 96 - L.C. 1880)

Ocorrência nos dicionários:

\begin{tabular}{|l|l|l|l|}
\hline Autor & Ano obra & Lexia & Acepção correspondente \\
\hline
\end{tabular}




\begin{tabular}{|c|c|c|c|}
\hline & & & ao glossário \\
\hline RB & 1712 & + & - \\
\hline AMS & 1813 & + & + \\
\hline DV & 1873 & + & + \\
\hline LF & 1940 & + & + \\
\hline CA & 1958 & + & - \\
\hline ABHF & 1986 & + & - \\
\hline ZCN/RCN & 1996 & - & - \\
\hline AH/MSV & 2001 & + & - \\
\hline FSB & 2002 & + & - \\
\hline BB & 2003 & - & \\
\hline
\end{tabular}

Análise descritiva dos dicionários gerais:

DV define víscera como os órgãos internos somente dos humanos e não dos animais, como apresentado nos documentos do corpus. DV, LF, CA, AH/MSV e FSB apresentam a acepção definindo-a como entranhas, órgãos internos etc. Nestes casos, considerou-se as acepções correspondente ao glossário.

Variantes: viscera (AH/MSV); vîscera (AH/MSV)

Análise descritiva dos dicionários regionalistas:

Não consta a lexia nas referidas obras.

ZCN/RCN e BB fornecem em suas obras a lexia buchada como conjunto de intestino e estômago da rês carneada. BB apresenta ainda as lexias achurras, definidas como víscera do animal e miúdos como pequenas vísceras.

Visconde $\mid$ s.m.

título concedido a alguns barões do charque

Abonação: “Além de Antiqueira, apenas João Simões Lopes ascendeu à condição de visconde e passou para a história como o Visconde da Graça, em uma referência direta a sua propriedade a Charqueada da Graça, localizada na margem esquerda do arroio Pelotas.” (Doc 37 - Pel. 2007)

“...Domingos de Castro Antiqueira, Barão de Jaguari (1829) e Visconde de Jaguari (1846) João Simões Lopes, Barão da Graça (1872) e Visconde da Graça (1876) ...”

(Doc 37 - Pel. 2007)

Ocorrência nos dicionários:

\begin{tabular}{|c|c|c|c|}
\hline Autor & Ano obra & Lexia & $\begin{array}{c}\text { Acepção correspondente } \\
\text { ao glossário }\end{array}$ \\
\hline RB & 1712 & + & + \\
\hline
\end{tabular}




\begin{tabular}{|c|c|c|c|}
\hline AMS & 1813 & + & + \\
\hline DV & 1873 & + & + \\
\hline LF & 1940 & + & + \\
\hline CA & 1958 & + & + \\
\hline ABHF & 1986 & + & + \\
\hline ZCN/RCN & 1996 & - & - \\
\hline AH/MSV & 2001 & + & + \\
\hline FSB & 2002 & + & + \\
\hline BB & 2003 & - & - \\
\hline
\end{tabular}

Análise descritiva dos dicionários gerais:

Nenhuma obra usou o charqueador como exemplo de proprietário de terra com o título concedido.

Análise descritiva dos dicionários regionalistas:

Não consta a lexia nas referidas obras.

Zorra $\mid$ s.f

espécie de plataforma puxada por trabalhadores onde se transporta o animal para o abate.

Abonação:"O animal caía sobre uma zorra colocada sobre trilhos e o zorreiro abrindo uma portinhola...” (Doc 111 - A.P.C. 1988)

Ocorrência nos dicionários:

\begin{tabular}{|c|c|c|c|}
\hline Autor & Ano obra & Lexia & $\begin{array}{c}\text { Acepção correspondente } \\
\text { ao glossário }\end{array}$ \\
\hline RB & 1712 & - & - \\
\hline AMS & 1813 & + & + \\
\hline DV & 1873 & + & + \\
\hline LF & 1940 & + & + \\
\hline CA & 1958 & + & + \\
\hline ABHF & 1986 & + & - \\
\hline ZCN/RCN & 1996 & - & - \\
\hline AH/MSV & 2001 & + & - \\
\hline FSB & 2002 & - & - \\
\hline BB & 2003 & - & + \\
\hline
\end{tabular}

Análise descritiva dos dicionários gerais:

AMS, DV, LF, CA e ABHF definem a lexia zorra como meio de transporte de pesos, madeiras etc. A acepção dada por AH/MSV não foi considerada correspondente, pois o dicionarista define a zorra como carro baixo puxado por tração animal.

Análise descritiva dos dicionários regionalistas: 
Não consta a lexia nas referidas obras.

ZCN/RCN apenas fornece a lexia arrasto, definida como transporte feito em zorra.

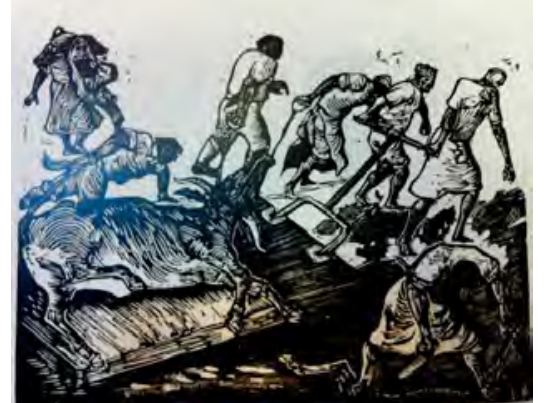

Fig. 18 Zorra

Xilogravura de Danúbio Gonçalves, Acervo

Museu Nacional de Belas Artes, RJ

Detalhe: Zorreiros e Coleiros

Zorreiro $\mid$ s.m.

empregado da charqueada encarregado de puxar a zorra no transporte do animal abatido || aquele que trabalha na zorra

Abonação:"Ali estavam alinhados, esperando o primeiro boi, zorreiros, camboneiros, coleiros, carneadores, charqueadores..." (Doc 108 - A.P.C. 1988)

Ocorrência nos dicionários:

\begin{tabular}{|c|c|c|c|}
\hline Autor & Ano obra & Lexia & $\begin{array}{c}\text { Acepção correspondente } \\
\text { ao glossário }\end{array}$ \\
\hline RB & 1712 & + & - \\
\hline AMS & 1813 & - & - \\
\hline DV & 1873 & + & - \\
\hline LF & 1940 & + & - \\
\hline CA & 1958 & - & - \\
\hline ABHF & 1986 & - & - \\
\hline ZCN/RCN & 1996 & - & - \\
\hline AH/MSV & 2001 & - & - \\
\hline FSB & 2002 & - & - \\
\hline BB & 2003 & - & - \\
\hline
\end{tabular}

Análise descritiva dos dicionários gerais:

RB, DV e LF, definem o zorreiro como tipo de embarcação lenta e o homem zorreiro como indivíduo que tem pouca atividade, vagaroso. Esta segunda acepção é compartilhada por $\mathbf{C A}, \mathbf{A B H F}$ e AH/MSV.

Análise descritiva dos dicionários regionalistas:

Não consta a lexia nas referidas obras. 


\subsection{Descrição das lexias do glossário encontradas nos dicionários}

A transcrição das consultas realizadas nas obras lexicográficas estão dispostas em tabelas nos verbetes dos glossário apresentado acima e têm por objetivo contribuir com a pesquisa na medida em que ilustra a discussão sobre as influências e contribuições do vocabulário do charque na formação e expansão da variedade do português brasileiro.

Após apresentar as tabelas e as ocorrências das lexias, suas acepções, correspondentes ao glossário ou não, julgou-se necessário fornecer um quadro geral com a descrição dos resultados obtidos. $\mathrm{O}$ que se espera encontrar, nos levantamentos qualitativo e quantitativo das ocorrências observadas, subsídios que propiciem algum tipo de resposta para as questões levantadas na tese.

As exposições feitas consideram a completude das informações e concedem um panorama geral das ocorrências, as tendências observadas e possíveis comentários adicionais. Os resultados e conclusões são apresentados nas considerações finais deste trabalho.

Conforme observado nas tabelas do glossário, explicitados no subitem 2.4 detalhamento dos verbetes e outras informações sobre a composição do glossário considerou-se um total de sete possíveis combinações de resultados, que englobam ter ou não a lexia de entrada do glossário nas obras pesquisas, e a acepção fornecida pelos autores corresponder ou não à apresentada no trabalho. Optou-se por reapresentar as combinações utilizadas nas tabelas, para auxiliar na compreensão dos dados descritos neste capítulo:

Tabela 2 - Combinações das lexias e correspondências das obras no Glossário

\begin{tabular}{|c|c|}
\hline Símbolo & Descrição \\
\hline-- & a obra não apresenta a lexia, tampouco a acepção correspondente a do glossário \\
\hline-+ & a obra não apresenta a lexia, mas a acepção correspondente é fornecida dentro do verbete \\
\hline-++ & $\begin{array}{l}\text { a obra não apresenta a lexia, mas a acepção é fornecida dentro do verbete e menciona a lexia charque } \\
\text { no verbete }\end{array}$ \\
\hline+- & a obra apresenta a lexia, mas a acepção não corresponde à acepção do glossário \\
\hline+-+ & $\begin{array}{l}\text { a obra apresenta a lexia, a acepção não corresponde a do glossário, mas menciona a lexia charque no } \\
\text { verbete }\end{array}$ \\
\hline++ & a obra apresenta a lexia e a acepção corresponde à do glossário \\
\hline+++ & a obra apresenta a lexia, a acepção corresponde à do glossário e menciona a lexia charque no verbete \\
\hline
\end{tabular}

A tabela abaixo apresenta um panorama geral detalhado dessas ocorrências nas dez obras. As siglas representativas dos dicionários estão dispostas horizontalmente no cabeçalho 
da tabela, e os símbolos correspondentes à presença/ausência de lexia, à semelhança de acepções entre dicionário e glossário e à presença de lexia charque estão dispostos horizontalmente como conteúdo.

Tabela 3 - Lista geral das lexias e acepções correspondentes

\begin{tabular}{|c|c|c|c|c|c|c|c|c|c|c|c|}
\hline & & $\begin{array}{c}\text { RB } \\
1712\end{array}$ & $\begin{array}{l}\text { AMS } \\
1813\end{array}$ & $\begin{array}{c}\text { DV } \\
1873\end{array}$ & $\begin{array}{c}\text { LF } \\
1940\end{array}$ & $\begin{array}{c}\text { CA } \\
1958\end{array}$ & $\begin{array}{c}\text { ABHF } \\
1986\end{array}$ & $\begin{array}{c}\text { AH/ } \\
\text { MSV } \\
2001\end{array}$ & $\begin{array}{l}\text { FSB } \\
2002\end{array}$ & $\begin{array}{l}\mathrm{ZCN} / \\
\mathrm{RCN} \\
1996\end{array}$ & $\begin{array}{c}\text { BB } \\
2003\end{array}$ \\
\hline 1 & Abate & +- & +- & +- & ++ & ++ & ++ & ++ & ++ & -- & -- \\
\hline 2 & Abatido & +- & -- & +- & ++ & +- & +- & ++ & +- & -- & -- \\
\hline 3 & Açougue & ++ & ++ & ++ & ++ & ++ & ++ & ++ & ++ & -- & -- \\
\hline 4 & Aguateiro & -- & -- & -- & +- & +- & -- & +- & -- & +- & +- \\
\hline 5 & Alcatroado & -- & ++ & ++ & ++ & ++ & ++ & ++ & -- & -- & -- \\
\hline 6 & Armazém 1 & -- & ++ & ++ & ++ & ++ & ++ & ++ & -- & -- & -- \\
\hline 7 & Armazém 2 & -- & -- & ++ & ++ & ++ & ++ & -- & -- & -- & -- \\
\hline 8 & Arreada & -- & -- & -- & ++ & -- & -- & -- & -- & ++ & ++ \\
\hline 9 & Arrate & -- & -- & -- & ++ & ++ & -- & -- & -- & -- & -- \\
\hline 10 & Arroba & ++ & ++ & ++ & ++ & ++ & ++ & ++ & ++ & -- & ++ \\
\hline 11 & Arroio & ++ & ++ & ++ & ++ & ++ & ++ & ++ & ++ & -- & -- \\
\hline 12 & Arroz carreteiro & -- & -- & -- & -- & -- & ++ & ++ & ++ & ++ & ++ \\
\hline 13 & Atestador & -- & -- & -- & ++ & ++ & +- & +- & -- & -- & -- \\
\hline 14 & Balança & ++ & ++ & ++ & ++ & ++ & ++ & ++ & ++ & -- & -- \\
\hline 15 & Balanceiro & -- & -- & +- & ++ & ++ & ++ & ++ & +- & -- & -- \\
\hline 16 & Barão & ++ & ++ & -- & ++ & ++ & ++ & ++ & ++ & -- & -- \\
\hline 17 & Barca & ++ & ++ & -- & ++ & ++ & ++ & ++ & ++ & -- & -- \\
\hline 18 & Barcaça & ++ & ++ & -- & ++ & ++ & ++ & ++ & ++ & -- & -- \\
\hline 19 & Barco a vapor & -- & -- & -- & -- & ++ & -- & ++ & -- & -- & -- \\
\hline 20 & $\begin{array}{l}\text { Barra de } \\
\text { madeira }\end{array}$ & -- & -- & -- & -- & -- & -- & -- & -- & -- & -- \\
\hline 21 & Barraca 1 & ++ & ++ & ++ & ++ & ++ & ++ & ++ & ++ & +- & +- \\
\hline 22 & Barraca 2 & +- & +- & +- & ++ & ++ & ++ & ++ & +- & ++ & ++ \\
\hline 23 & Barrica & ++ & ++ & ++ & ++ & ++ & ++ & ++ & ++ & -- & -- \\
\hline 24 & Barril & ++ & ++ & ++ & ++ & ++ & ++ & ++ & ++ & -- & -- \\
\hline 25 & Beneficiar & +- & +- & -- & +- & +- & -- & +- & +- & +- & -- \\
\hline 26 & Benfeitoria & -- & ++ & -- & ++ & ++ & ++ & ++ & -- & -- & ++ \\
\hline 27 & Bexiga & ++ & +- & +- & +- & +- & +- & +- & +- & -- & -- \\
\hline 28 & Boi & ++ & ++ & ++ & ++ & ++ & ++ & ++ & ++ & -- & ++ \\
\hline 29 & Boi de trela & -- & -- & -- & -- & -- & -- & -- & -- & -- & -- \\
\hline 30 & Boi em pé & -- & -- & -- & -- & -- & ++ & ++ & -- & -- & -- \\
\hline
\end{tabular}




\begin{tabular}{|c|c|c|c|c|c|c|c|c|c|c|c|}
\hline & & $\begin{array}{c}\text { RB } \\
1712\end{array}$ & $\begin{array}{l}\text { AMS } \\
1813\end{array}$ & $\begin{array}{c}\text { DV } \\
1873\end{array}$ & $\begin{array}{c}\text { LF } \\
1940\end{array}$ & $\begin{array}{c}\text { CA } \\
1958\end{array}$ & $\begin{array}{c}\text { ABHF } \\
1986\end{array}$ & $\begin{array}{c}\mathrm{AH} / \\
\mathrm{MSV} \\
2001\end{array}$ & $\begin{array}{l}\text { FSB } \\
2002\end{array}$ & $\begin{array}{l}\mathrm{ZCN} / \\
\mathrm{RCN} \\
1996\end{array}$ & $\begin{array}{c}\text { BB } \\
2003\end{array}$ \\
\hline 31 & Boiada & -- & ++ & ++ & ++ & ++ & ++ & ++ & ++ & ++ & ++ \\
\hline 32 & Bordalesa & -- & -- & -- & +- & +- & +- & +- & -- & -- & -- \\
\hline 33 & Braça & ++ & ++ & ++ & ++ & ++ & ++ & ++ & -- & ++ & ++ \\
\hline 34 & Brete & ++ & +- & +- & +++ & -- & +++ & +++ & ++ & +++ & +++ \\
\hline 35 & Brigue & -- & -- & ++ & ++ & +- & +- & +- & +- & -- & -- \\
\hline 36 & Buchada & -- & -- & ++ & ++ & ++ & ++ & ++ & ++ & ++ & ++ \\
\hline 37 & Burra & -- & +- & +- & +- & +- & +- & +- & +- & -- & -- \\
\hline 38 & Caldeira & ++ & ++ & ++ & ++ & ++ & ++ & ++ & ++ & -- & -- \\
\hline 39 & camboneiro & -- & -- & -- & -- & -- & -- & -- & -- & -- & -- \\
\hline 40 & Cancha & -- & -- & -- & +++ & +- & +++ & +++ & +- & +++ & +++ \\
\hline 41 & $\begin{array}{l}\text { Capataz da } \\
\text { cancha }\end{array}$ & -- & -- & -- & -- & -- & -- & -- & -- & -- & -- \\
\hline 42 & Capataz de rua & -- & -- & -- & -- & -- & -- & -- & -- & -- & -- \\
\hline 43 & Carne de feijão & -- & -- & -- & -- & -- & -- & -- & -- & -- & -- \\
\hline 44 & Carne de sol & -- & -- & -- & ++ & ++ & ++ & ++ & ++ & -- & -- \\
\hline 45 & Carne de vaca & ++ & -- & -- & +- & +- & +- & -- & +- & -- & -- \\
\hline 46 & Carne-do-ceará & -- & -- & -- & ++ & +++ & +++ & +++ & -- & -- & -- \\
\hline 47 & Carne fresca & ++ & -- & +- & +- & -- & ++ & ++ & -- & -- & -- \\
\hline 48 & Carne salgada. & -- & -- & +- & -- & -- & -- & -- & -- & -- & -- \\
\hline 49 & Carne seca & -- & -- & -- & +++ & -- & -- & -- & +++ & -- & -- \\
\hline 50 & Carne verde & -- & -- & -- & ++ & ++ & ++ & ++ & -- & -- & -- \\
\hline 51 & Carneador & -- & -- & -- & ++ & -- & ++ & ++ & -- & +++ & +++ \\
\hline 52 & $\begin{array}{l}\text { Carneador } \\
\text { salgador }\end{array}$ & -- & -- & -- & -- & -- & -- & -- & -- & -- & -- \\
\hline 53 & Carnear & -- & -- & -- & +++ & -- & +++ & +++ & ++ & +++ & +++ \\
\hline 54 & $\begin{array}{l}\text { Carregador de } \\
\text { ossada e } \\
\text { buchada }\end{array}$ & -- & -- & -- & -- & -- & -- & -- & -- & -- & -- \\
\hline 55 & Carreteiro & +- & +- & +- & +- & +- & ++ & +- & -- & +++ & +++ \\
\hline 56 & $\begin{array}{l}\text { Carrinho-de- } \\
\text { mão }\end{array}$ & -+ & -+ & ++ & ++ & ++ & ++ & ++ & -+ & -- & -- \\
\hline 57 & Carroça & +- & +- & +- & ++ & ++ & ++ & ++ & ++ & -- & -- \\
\hline 58 & $\begin{array}{l}\text { Casa de } \\
\text { comércio de } \\
\text { charque }\end{array}$ & -- & -- & -+ & -+ & -- & -- & -- & -- & -- & -- \\
\hline 59 & Casa de moradia & -- & -- & -- & ++ & -- & ++ & -- & ++ & -- & -- \\
\hline 60 & Casa grande & -- & -- & -- & ++ & -- & ++ & -- & ++ & ++ & ++ \\
\hline 61 & Chácara & +- & ++ & ++ & ++ & ++ & ++ & ++ & ++ & ++ & ++ \\
\hline
\end{tabular}




\begin{tabular}{|c|c|c|c|c|c|c|c|c|c|c|c|}
\hline & & $\begin{array}{c}\text { RB } \\
1712\end{array}$ & $\begin{array}{l}\text { AMS } \\
1813\end{array}$ & $\begin{array}{c}\text { DV } \\
1873\end{array}$ & $\begin{array}{c}\text { LF } \\
1940\end{array}$ & $\begin{array}{c}\text { CA } \\
1958\end{array}$ & $\begin{array}{l}\text { ABHF } \\
1986\end{array}$ & $\begin{array}{c}\mathrm{AH} / \\
\mathrm{MSV} \\
2001\end{array}$ & $\begin{array}{l}\text { FSB } \\
2002\end{array}$ & $\begin{array}{l}\mathrm{ZCN} / \\
\mathrm{RCN} \\
1996\end{array}$ & $\begin{array}{c}\text { BB } \\
2003\end{array}$ \\
\hline 62 & Charque & -- & ++ & ++ & ++ & ++ & ++ & ++ & ++ & ++ & ++ \\
\hline 63 & $\begin{array}{l}\text { Charque de } \\
\text { vento }\end{array}$ & -- & -- & -- & -- & ++ & ++ & ++ & -- & ++ & ++ \\
\hline 64 & Charque platino & -- & -- & +++ & +++ & +++ & +++ & +++ & +++ & +++ & +++ \\
\hline 65 & Charqueada 1 & -- & -- & -- & -- & -- & -- & -- & -- & -- & -- \\
\hline 66 & Charqueada 2 & -- & -- & -- & -- & -- & -- & -- & -- & -- & -- \\
\hline 67 & Charqueador 1 & -- & ++ & ++ & ++ & ++ & +++ & +++ & +++ & +++ & +++ \\
\hline 68 & Charqueador 2 & -- & -- & -- & +++ & +++ & +++ & +++ & +++ & -- & +++ \\
\hline 69 & Charqueagem & -- & -- & -- & -- & -- & -- & -- & -- & -- & -- \\
\hline 70 & Chatasca & -- & -- & -- & -- & -- & -- & -- & -- & -- & -- \\
\hline 71 & Chifre & +- & -- & ++ & ++ & ++ & ++ & ++ & ++ & -- & -- \\
\hline 72 & Chimango & -- & -- & -- & +- & +- & +- & +- & +- & +- & +- \\
\hline 73 & Churrasco & -- & -- & -- & ++ & +- & ++ & ++ & ++ & ++ & ++ \\
\hline 74 & $\begin{array}{l}\text { Ciclo do } \\
\text { charque }\end{array}$ & -- & +- & -- & +- & +- & +- & +- & +- & -- & -- \\
\hline 75 & Coleiro & -- & -- & -- & +- & +- & +- & +- & -- & -- & -- \\
\hline 76 & Combalido & +- & +- & ++ & ++ & ++ & +- & ++ & +- & -- & -- \\
\hline 77 & Conserva & ++ & ++ & ++ & ++ & ++ & ++ & ++ & ++ & -- & -- \\
\hline 78 & $\begin{array}{l}\text { Conserva } \\
\text { enlatada }\end{array}$ & -- & -- & -- & -- & -- & -- & ++ & -+ & -- & -- \\
\hline 79 & $\begin{array}{l}\text { Contrabando de } \\
\text { charque }\end{array}$ & -- & -- & -- & -- & -- & -- & -- & -- & -- & -- \\
\hline 80 & $\begin{array}{l}\text { Contrabando de } \\
\text { gado }\end{array}$ & -- & -- & -- & -- & -- & -- & -- & -- & -- & -- \\
\hline 81 & Couro & ++ & ++ & ++ & ++ & ++ & ++ & ++ & ++ & +- & +- \\
\hline 82 & Couro salgado & -- & -- & -- & -- & -- & -- & -- & -- & -- & -- \\
\hline 83 & $\begin{array}{l}\text { Couro vacum } \\
\text { seco }\end{array}$ & -+ & -- & -- & ++ & -- & -- & -- & -- & -- & -- \\
\hline 84 & Couro verde & -- & -- & ++ & ++ & ++ & -- & -- & -- & -- & -- \\
\hline 85 & Cuba & +- & +- & +- & +- & +- & +- & +- & +- & -- & -- \\
\hline 86 & Depósito & +- & -- & ++ & ++ & ++ & ++ & ++ & ++ & +- & +- \\
\hline 87 & Descarneador & -- & ++ & +- & +- & +- & +- & ++ & ++ & -- & -- \\
\hline 88 & Desnucador & -- & -- & -- & -- & -- & -- & -- & -- & -- & -- \\
\hline 89 & Dessecamento & -- & +- & -- & ++ & ++ & ++ & ++ & -+ & -- & -- \\
\hline 90 & Eletricista & -- & -- & -- & ++ & ++ & ++ & ++ & ++ & -- & -- \\
\hline 91 & Embarcação & ++ & ++ & ++ & ++ & ++ & ++ & ++ & ++ & -- & -- \\
\hline 92 & Embarricar & -- & ++ & -- & ++ & ++ & ++ & ++ & -- & -- & -- \\
\hline 93 & Empilhador & -- & -- & -- & -- & -- & -- & -- & -- & -- & -- \\
\hline
\end{tabular}




\begin{tabular}{|c|c|c|c|c|c|c|c|c|c|c|c|}
\hline & & $\begin{array}{c}\text { RB } \\
1712\end{array}$ & $\begin{array}{l}\text { AMS } \\
1813\end{array}$ & $\begin{array}{c}\text { DV } \\
1873\end{array}$ & $\begin{array}{c}\text { LF } \\
1940\end{array}$ & $\begin{array}{c}\mathrm{CA} \\
\mathbf{1 9 5 8}\end{array}$ & $\begin{array}{c}\text { ABHF } \\
1986\end{array}$ & $\begin{array}{l}\text { AH/ } \\
\text { MSV } \\
2001\end{array}$ & $\begin{array}{l}\text { FSB } \\
2002\end{array}$ & $\begin{array}{l}\mathrm{ZCN} / \\
\mathrm{RCN} \\
1996\end{array}$ & $\begin{array}{c}\text { BB } \\
2003\end{array}$ \\
\hline 94 & Engasga gato & -- & -- & -- & -- & +++ & +++ & +- & -- & -- & +++ \\
\hline 95 & Escuna & -- & -- & ++ & ++ & ++ & ++ & ++ & ++ & -- & -- \\
\hline 96 & $\begin{array}{l}\text { Escravo de } \\
\text { charqueada }\end{array}$ & +- & +- & +- & +- & +- & +- & +- & +- & -- & -- \\
\hline 97 & $\begin{array}{l}\text { Estabelecimento } \\
\text { de charqueada }\end{array}$ & -- & -- & -- & -- & -- & -- & -- & -- & -- & -- \\
\hline 98 & Estância & +- & +- & ++ & ++ & ++ & ++ & ++ & ++ & ++ & ++ \\
\hline 99 & Estancieiro & -- & -- & ++ & ++ & ++ & ++ & ++ & ++ & ++ & ++ \\
\hline 100 & Fatura & -- & -- & -- & ++ & ++ & ++ & ++ & ++ & -- & -- \\
\hline 101 & Feijoada & -- & ++ & ++ & ++ & ++ & ++ & +++ & ++ & -- & -- \\
\hline 102 & Foguista & -- & -- & -- & ++ & -- & ++ & ++ & -- & ++ & ++ \\
\hline 103 & Forquilha & +- & +- & ++ & ++ & +- & ++ & ++ & ++ & +- & +- \\
\hline 104 & Fornalha & +- & ++ & ++ & ++ & ++ & ++ & ++ & ++ & -- & -- \\
\hline 105 & Fragata & ++ & ++ & ++ & ++ & ++ & ++ & ++ & +- & -- & -- \\
\hline 106 & Gado & ++ & ++ & ++ & ++ & ++ & ++ & ++ & ++ & ++ & ++ \\
\hline 107 & Gado gaúcho & -- & -- & -- & -- & -- & -- & -- & -- & -- & -- \\
\hline 108 & Gado gordo & -- & -- & -- & -- & -- & -- & -- & -- & -+ & -++ \\
\hline 109 & Gado magro & -- & -- & -- & -- & -- & -- & -- & -- & -- & -- \\
\hline 110 & Gado uruguaio & -- & -- & -- & -- & -- & -- & -- & -- & -- & -- \\
\hline 111 & Gado vacum & -- & -- & -- & -- & ++ & -- & ++ & -- & -+ & ++ \\
\hline 112 & Gado xucro & -- & -- & -- & -- & ++ & -- & -- & -- & -+ & -+ \\
\hline 113 & Galiota & -- & ++ & ++ & ++ & ++ & ++ & ++ & ++ & -- & -- \\
\hline 114 & Galpão & -- & -- & -- & +- & +- & +- & +- & +- & +- & +- \\
\hline 115 & Gancho & +- & +- & +- & +- & +- & +- & +- & ++ & -- & -- \\
\hline 116 & $\begin{array}{l}\text { Gordura } \\
\text { comestível }\end{array}$ & -- & -+ & -+ & -+ & -- & -- & -+ & -+ & -- & -- \\
\hline 117 & $\begin{array}{l}\text { Gordura } \\
\text { industrial }\end{array}$ & -- & -- & -- & -- & -- & -- & -- & -+ & -- & -- \\
\hline 118 & Graxa & +- & +- & +- & ++ & ++ & +- & ++ & ++ & -- & -- \\
\hline 119 & Graixeiro & -- & -- & -- & +- & +- & +- & +- & +- & -- & -- \\
\hline 120 & Graxaria & -- & -- & -- & ++ & ++ & +++ & ++ & +- & +++ & +++ \\
\hline 121 & Guampa & -- & -- & -- & ++ & ++ & ++ & ++ & ++ & ++ & ++ \\
\hline 122 & Guano & -- & -- & +- & ++ & ++ & ++ & ++ & -- & -- & -- \\
\hline 123 & Guincheiro & -- & -- & -- & +- & ++ & ++ & ++ & -- & -- & -- \\
\hline 124 & Guincho & -- & +- & +- & ++ & ++ & ++ & ++ & ++ & -- & -- \\
\hline 125 & Guisado & -- & -- & -- & -- & +++ & +++ & ++ & +++ & +++ & +++ \\
\hline 126 & Havaneira & -- & -- & -- & +- & -- & -- & +- & -- & -- & +- \\
\hline
\end{tabular}




\begin{tabular}{|c|c|c|c|c|c|c|c|c|c|c|c|}
\hline & & $\begin{array}{c}\text { RB } \\
1712\end{array}$ & $\begin{array}{l}\text { AMS } \\
1813\end{array}$ & $\begin{array}{c}\text { DV } \\
1873\end{array}$ & $\begin{array}{c}\text { LF } \\
1940\end{array}$ & $\begin{array}{c}\mathrm{CA} \\
1958\end{array}$ & $\begin{array}{c}\text { ABHF } \\
1986\end{array}$ & $\begin{array}{c}\text { AH/ } \\
\text { MSV } \\
2001\end{array}$ & $\begin{array}{l}\text { FSB } \\
2002\end{array}$ & $\begin{array}{l}\mathrm{ZCN} / \\
\mathrm{RCN} \\
1996\end{array}$ & $\begin{array}{c}\text { BB } \\
2003\end{array}$ \\
\hline 127 & Iate & ++ & ++ & ++ & ++ & ++ & ++ & ++ & ++ & -- & -- \\
\hline 128 & Imposto & ++ & ++ & ++ & ++ & ++ & ++ & ++ & ++ & -- & -- \\
\hline 129 & Jabá & -- & -- & -- & +++ & +++ & +++ & +++ & +++ & -- & -- \\
\hline 130 & Laçador de brete & -- & -- & -- & -- & -- & -- & -- & -- & -- & -- \\
\hline 131 & $\begin{array}{l}\text { Laçador } \\
\text { matador }\end{array}$ & -- & -- & -- & -- & -- & -- & -- & -- & -- & -- \\
\hline 132 & Lancha & ++ & ++ & ++ & +- & ++ & ++ & ++ & ++ & +- & +- \\
\hline 133 & Lanhagem & -- & -- & -- & -- & -- & -- & -- & -- & -- & -- \\
\hline 134 & Magarefe & ++ & ++ & ++ & -- & ++ & ++ & ++ & ++ & -- & -- \\
\hline 135 & Mangueira & -- & -- & -- & -- & ++ & ++ & ++ & ++ & ++ & ++ \\
\hline 136 & $\begin{array}{l}\text { Mangueira de } \\
\text { matança }\end{array}$ & -- & -- & -- & -- & -- & -- & -- & -- & -- & -- \\
\hline 137 & Mangueirão & -- & -- & -- & ++ & ++ & ++ & ++ & -- & ++ & ++ \\
\hline 138 & Manta & -- & -- & -- & -- & ++ & ++ & ++ & ++ & ++ & ++ \\
\hline 139 & Matadouro & -+ & -+ & -- & ++ & ++ & ++ & ++ & ++ & -- & -- \\
\hline 140 & Matambre & -- & -- & -- & +- & ++ & ++ & ++ & ++ & ++ & ++ \\
\hline 141 & Matambreiro & -- & -- & -- & -- & -- & -- & -- & -- & -- & -- \\
\hline 142 & Matança & +- & ++ & +- & ++ & ++ & ++ & ++ & ++ & -- & -- \\
\hline 143 & Matar & +- & +- & +- & ++ & ++ & ++ & ++ & ++ & +- & +- \\
\hline 144 & $\begin{array}{l}\text { Medidor de } \\
\text { sanilidade }\end{array}$ & +- & +- & +- & +- & +- & +- & +- & +- & -- & -- \\
\hline 145 & Mergulhador & -- & +- & +- & +- & +- & +- & +- & +- & -- & -- \\
\hline 146 & Mocotó & -- & -- & +- & +- & +- & +- & +- & +- & +- & +- \\
\hline 147 & Monturo & +- & +- & +- & +- & +- & +- & +- & +- & -- & -- \\
\hline 148 & Moira & -- & -- & -- & -- & -- & -- & -- & -- & -- & -- \\
\hline 149 & Moirão & +- & +- & -- & -- & ++ & +- & +- & -- & -- & -- \\
\hline 150 & $\mathrm{Nau}$ & ++ & +- & +- & ++ & ++ & ++ & ++ & ++ & -- & -- \\
\hline 151 & Navio & +- & +- & +- & ++ & ++ & ++ & ++ & ++ & -- & -- \\
\hline 152 & Ossada & +- & -- & -- & ++ & ++ & ++ & ++ & ++ & -- & -- \\
\hline 153 & Paçoca & -- & -- & -- & +- & -- & ++ & +- & -- & +++ & +++ \\
\hline 154 & Partida & +- & +- & -- & ++ & ++ & ++ & ++ & ++ & +- & +- \\
\hline 155 & Patacho & -- & -- & ++ & ++ & -- & ++ & ++ & ++ & -- & -- \\
\hline 156 & Pelota & +- & -- & -- & ++ & ++ & +- & ++ & +- & ++ & ++ \\
\hline 157 & Peneira & -- & ++ & ++ & ++ & ++ & ++ & ++ & ++ & +- & +- \\
\hline 158 & Pilha de inverno & -- & -- & -- & -- & -- & -- & -- & -- & -- & -- \\
\hline 159 & Pipa & ++ & -- & -- & ++ & ++ & ++ & ++ & ++ & -- & -- \\
\hline 160 & Porteira & +- & +- & -- & +- & ++ & -- & -- & ++ & ++ & ++ \\
\hline
\end{tabular}




\begin{tabular}{|c|c|c|c|c|c|c|c|c|c|c|c|}
\hline & & $\begin{array}{c}\text { RB } \\
1712\end{array}$ & $\begin{array}{l}\text { AMS } \\
1813\end{array}$ & $\begin{array}{c}\text { DV } \\
1873\end{array}$ & $\begin{array}{c}\text { LF } \\
1940\end{array}$ & $\begin{array}{c}\text { CA } \\
1958\end{array}$ & $\begin{array}{c}\text { ABHF } \\
1986\end{array}$ & $\begin{array}{c}\text { AH/ } \\
\text { MSV } \\
2001\end{array}$ & $\begin{array}{l}\text { FSB } \\
2002\end{array}$ & $\begin{array}{l}\mathrm{ZCN} / \\
\mathrm{RCN} \\
1996\end{array}$ & $\begin{array}{c}\text { BB } \\
2003\end{array}$ \\
\hline 161 & Porteiro & +- & +- & -- & +- & -- & +- & +- & +- & -- & -- \\
\hline 162 & Potreiro & -- & -- & ++ & -- & ++ & -- & ++ & -- & ++ & ++ \\
\hline 163 & Prensa & +- & +- & +- & -- & ++ & ++ & ++ & +- & -- & -- \\
\hline 164 & Prontificação & -- & -- & -- & +- & +- & +- & +- & +- & -- & -- \\
\hline 165 & Punhal & +- & +- & +- & +- & +- & +- & +- & +- & -- & -- \\
\hline 166 & Putrefato & -- & -- & -- & ++ & ++ & ++ & ++ & ++ & -- & -- \\
\hline 167 & Quadra & -- & -- & +- & +- & +- & +- & +- & +- & +- & +- \\
\hline 168 & Réis & ++ & ++ & ++ & ++ & ++ & ++ & ++ & -- & -- & ++ \\
\hline 169 & Rês & ++ & ++ & ++ & ++ & +- & ++ & ++ & ++ & ++ & ++ \\
\hline 170 & Resfriador & -- & +- & +- & +- & +- & +- & +- & +- & -- & +- \\
\hline 171 & Retalhar & ++ & ++ & ++ & ++ & ++ & ++ & +- & ++ & +- & +- \\
\hline 172 & Rodeio & -- & +- & +- & ++ & ++ & ++ & ++ & +- & ++ & ++ \\
\hline 173 & $\begin{array}{l}\text { Saco de } \\
\text { aniagem }\end{array}$ & -- & -- & -- & -- & -- & -- & -- & -- & -- & -- \\
\hline 174 & Safra & -- & -- & +- & +- & +- & ++ & +- & +- & +-+ & +-+ \\
\hline 175 & Sal & ++ & +- & +- & +- & +- & +- & -- & -- & -- & -- \\
\hline 176 & Sal bom & -- & -- & -- & -- & -- & -- & -- & -- & -- & -- \\
\hline 177 & Sal grosso & -- & -- & -- & -- & ++ & ++ & -- & +- & -- & -- \\
\hline 178 & Sal pisado & -- & -- & -- & -- & -- & -- & -- & -- & -- & -- \\
\hline 179 & Saladeiro & -- & -- & -- & ++ & ++ & ++ & ++ & -- & ++ & ++ \\
\hline 180 & Saladeril & -- & -- & -- & ++ & ++ & -- & -- & -- & ++ & -- \\
\hline 181 & Salga & -- & -- & ++ & ++ & ++ & -- & ++ & +- & +- & +- \\
\hline 182 & Salgador & -- & -- & -- & ++ & ++ & -- & ++ & -- & -- & -- \\
\hline 183 & Salgar & ++ & ++ & ++ & ++ & ++ & ++ & ++ & ++ & -- & -- \\
\hline 184 & Salmoura & +- & -+ & -- & ++ & ++ & ++ & -- & -- & -- & -- \\
\hline 185 & Sangria & -- & ++ & ++ & ++ & ++ & ++ & ++ & -- & -- & -- \\
\hline 186 & Sebo & ++ & ++ & ++ & ++ & ++ & ++ & ++ & ++ & -- & -- \\
\hline 187 & Secadouro & -- & -- & -- & ++ & -- & -- & -- & -- & -- & -- \\
\hline 188 & Serrador & +- & +- & +- & +- & ++ & ++ & ++ & ++ & -- & -- \\
\hline 189 & Sumaca & -- & -- & ++ & ++ & ++ & +++ & -- & -- & -- & -- \\
\hline 190 & Tablada & -- & -- & -- & -- & +++ & +++ & +++ & -- & +++ & +++ \\
\hline 191 & Tábua & +- & +- & +- & +- & -- & -- & +- & +- & +- & +- \\
\hline 192 & Tajano & -- & -- & -- & -- & -- & -- & -- & -- & -- & -- \\
\hline 193 & Tanque & -- & +- & +- & ++ & +- & +- & ++ & +- & -- & -- \\
\hline 194 & Tanoeiro & ++ & ++ & -- & ++ & ++ & ++ & ++ & ++ & -- & -- \\
\hline 195 & Tina & +- & +- & +- & +- & +- & +- & +- & -- & -- & -- \\
\hline
\end{tabular}




\begin{tabular}{|c|c|c|c|c|c|c|c|c|c|c|c|}
\hline & & $\begin{array}{c}\text { RB } \\
1712\end{array}$ & $\begin{array}{l}\text { AMS } \\
1813\end{array}$ & $\begin{array}{c}\text { DV } \\
1873\end{array}$ & $\begin{array}{c}\text { LF } \\
1940\end{array}$ & $\begin{array}{c}\text { CA } \\
1958\end{array}$ & $\begin{array}{c}\text { ABHF } \\
1986\end{array}$ & $\begin{array}{c}\text { AH/ } \\
\text { MSV } \\
2001\end{array}$ & $\begin{array}{l}\text { FSB } \\
2002\end{array}$ & $\begin{array}{l}\mathrm{ZCN} / \\
\mathrm{RCN} \\
1996\end{array}$ & $\begin{array}{c}\text { BB } \\
2003\end{array}$ \\
\hline 196 & Tina digeridora & -- & -- & -- & -- & -- & -- & -- & -- & -- & -- \\
\hline 197 & Trapiche & -- & +- & +- & +- & +- & +- & +- & +- & -- & -- \\
\hline 198 & Traste & ++ & +- & +- & +- & +- & ++ & -- & -- & ++ & ++ \\
\hline 199 & Tripeiro & +- & +- & +- & ++ & ++ & +- & +- & +- & -- & -- \\
\hline 200 & Tropa & +- & -- & -- & ++ & ++ & +++ & ++ & ++ & ++ & ++ \\
\hline 201 & Tropeiro & -- & -- & ++ & ++ & ++ & ++ & ++ & ++ & ++ & ++ \\
\hline 202 & Turma & -- & +- & -- & +- & +- & +- & +- & ++ & -- & -- \\
\hline 203 & Vagoneta & -- & -- & -- & ++ & ++ & ++ & ++ & ++ & -- & -- \\
\hline 204 & Vara & +- & +- & +- & +- & +- & +- & ++ & +- & +- & +- \\
\hline 205 & Varal & +- & -- & -- & +- & +++ & +++ & +++ & +- & +++ & +++ \\
\hline 206 & Vasilha & +- & +- & +- & ++ & ++ & ++ & ++ & +- & +- & +- \\
\hline 207 & Vasilhame & -- & -- & ++ & +- & +- & +- & +- & -- & -- & -- \\
\hline 208 & Víscera & +- & ++ & ++ & ++ & +- & +- & +- & +- & -- & -- \\
\hline 209 & Visconde & ++ & ++ & ++ & ++ & ++ & ++ & ++ & ++ & -- & -- \\
\hline 210 & Zorra & -- & ++ & ++ & ++ & ++ & ++ & +- & -- & -- & -- \\
\hline 211 & Zorreiro & +- & -- & +- & +- & -- & -- & -- & -- & -- & +- \\
\hline
\end{tabular}

Afim de facilitar o entendimento, simplificando as ocorrências e correspondências acima fornecidas, a tabela a seguir apresenta o panorama geral em números relativos, e, logo a seguir, em percentual.

Tabela 4 - Lista geral das lexias e acepções correspondentes em número relativo

\begin{tabular}{c|cccccccccc}
\hline Obras & RB & AMS & DV & LF & CA & ABHF & $\begin{array}{c}\text { AH/ } \\
\text { MSV }\end{array}$ & FSB & $\begin{array}{c}\text { ZCN/ } \\
\text { RCN }\end{array}$ & BB \\
\hline Ano & 1712 & 1813 & 1873 & 1940 & 1958 & 1986 & 2001 & 2002 & 1996 & 2003 \\
\hline-- & 130 & 118 & 109 & 53 & 58 & 58 & 56 & 84 & 146 & 139 \\
-+ & 3 & 4 & 2 & 2 & 0 & 0 & 1 & 5 & 3 & 1 \\
-++ & 0 & 0 & 0 & 0 & 0 & 0 & 0 & 0 & 0 & 1 \\
+- & 41 & 43 & 43 & 44 & 40 & 38 & 39 & 41 & 19 & 21 \\
+-+ & 0 & 0 & 0 & 0 & 0 & 0 & 0 & 0 & 1 & 1 \\
++ & 37 & 46 & 56 & 105 & 105 & 100 & 104 & 75 & 30 & 34 \\
+++ & 0 & 0 & 1 & 7 & 8 & 15 & 11 & 6 & 12 & 14 \\
\hline $\begin{array}{c}\text { Total de } \\
\text { ocorrências }\end{array}$ & 211 & 211 & 211 & 211 & 211 & 211 & 211 & 211 & 211 & 211 \\
\hline
\end{tabular}


O que se observa, analisando os números fornecidos na tabela 2, é que no total das 211 lexias do glossário, as obras regionalistas são as que fornecem o menor número de lexias e acepções correspondentes. As obras de LF e CA, por outro lado, são as que fornecem o maior número destas ocorrências. Acredita-se que as obras regionalistas apresentam este número menor de correspondência por considerarem a maioria das lexias do vocabulário do charque pertencentes ao vocabulário brasileiro e não só riograndense.

Tabela 5 - Lista geral das lexias e acepções correspondentes em percentual

\begin{tabular}{l|cccccccccc}
\hline & RB & AMS & DV & LF & CA & ABHF & $\begin{array}{c}\text { AH/ } \\
\text { MSV }\end{array}$ & FSB & $\begin{array}{c}\text { ZCN/ } \\
\text { RCN }\end{array}$ & BB \\
\hline Ano & 1712 & 1813 & 1873 & 1940 & 1958 & 1986 & 2001 & 2002 & 1996 & 2003 \\
-- & $62 \%$ & $56 \%$ & $52 \%$ & $25 \%$ & $27 \%$ & $27 \%$ & $27 \%$ & $40 \%$ & $69 \%$ & $66 \%$ \\
-+ & $1 \%$ & $2 \%$ & $1 \%$ & $1 \%$ & $0 \%$ & $0 \%$ & $0 \%$ & $2 \%$ & $1 \%$ & $0 \%$ \\
-++ & $0 \%$ & $0 \%$ & $0 \%$ & $0 \%$ & $0 \%$ & $0 \%$ & $0 \%$ & $0 \%$ & $0 \%$ & $0 \%$ \\
+- & $19 \%$ & $20 \%$ & $20 \%$ & $21 \%$ & $19 \%$ & $18 \%$ & $18 \%$ & $19 \%$ & $9 \%$ & $10 \%$ \\
++ & $0 \%$ & $0 \%$ & $0 \%$ & $0 \%$ & $0 \%$ & $0 \%$ & $0 \%$ & $0 \%$ & $0 \%$ & $0 \%$ \\
++ & $18 \%$ & $22 \%$ & $27 \%$ & $50 \%$ & $50 \%$ & $47 \%$ & $49 \%$ & $36 \%$ & $14 \%$ & $16 \%$ \\
\hline+++ & $0 \%$ & $0 \%$ & $0 \%$ & $3 \%$ & $4 \%$ & $7 \%$ & $5 \%$ & $3 \%$ & $6 \%$ & $7 \%$ \\
\hline
\end{tabular}

A partir do comentário acima, decidiu-se, por ora, analisar as obras denominadas de dicionários gerais, a dizer, os oitos dicionários de Língua Portuguesa separando as obras regionalistas. Mantendo este recorte, indica-se a obra de RB, com 62\%, como o dicionário que menos revela as lexias do vocabulário do charque. Em contrapartida, encontra-se, nas obras de LF, CA, ABHF e AH/MSV, um maior índice de lexias e correspondências $(++)$, com $50 \%, 50 \%, 47 \%$ e $49 \%$ respectivamente.

Considerando o ano das edições, pode-se afirmar que as lexias e as acepções correspondentes às do glossário encontram-se em menos número nos séculos XVIII e XIX. A partir do século XX, o número de ocorrências e correspondências cresce de $22 \%$ (média entre as obras so século XVIII e XIX) para 46,5\% (média das cinco obras editadas nos séculos XX e XXI).

Observa-se, na tabela, que não há esta diferença ao analisarmos a combinação (+ -), ou seja, os casos em que as obras apresentam a lexia, mas a acepção não corresponde. Neste cenário, as obras apresentam similaridades que variam entre 18 e $21 \%$, indicando que, uma vez encontrada a lexia, a não correnpondência entre as acepções é possível em qualquer período histórico da língua. Ressalta-se, que, na maioria destes casos, não há correspondência 
entre as acepções nas obras selecionadas, o que corrobora com a hipótese de que a mesma palavra varia o sentido e a definição ao longo dos séculos tornando-a independente de ser ou não só destoante com a acepção do vocabulário do charque. Toma-se como exemplo a lexia monturo, em que AMS, DV e RB fornecem a acepção como esterco, imundícies já em ABHF e AH/MSV, monturo apresenta a acepção de depósito de coisas velhas.

A ocorrência $(-+)$, em que os autores não apresentam a entrada, mas há a correspondência da acepção, ou até mesmo o uso da palavra charque na definição $(-++)$, é bastante raro, observando-se, inclusive, um caso de nulidade em número percentual. As lexias que apresentam estes casos, como por exemplo a entrada casa de comércio de charque, me que DV e LF não apresentam esta lexia, mas, ao longo do verbete, fornecem como exemplo as casas de comércio em que comercializam produtos como o couro e peles.

Outro exemplo é o caso da lexia gado xucro, em que ambas as obras regionalistas apresentam somente a entrada de gado chimarrão, e, em suas acepções, definem este gado como um gado xucro, criado solto, de forma selvagem. Em BB, por exemplo, não há a ocorrência da lexia gado gordo e sim gado de corte, o que indica a ocorrência (-), entretanto, no verbete gado de corte, o autor define a lexia de acordo com a acepção encontrada no glossário para gado gordo, e, menciona o uso deste gado como apropriado para a fabricaçãoo de charque $(-++)$. Estes casos, como ocorrem somente em um ou duas lexias, apresentam o percentual nulo, entretanto, considerado nas análises.

\section{Agrupamento das obras}

De modo a facilitar as análises e apresentar uma descrição mais objetiva, optou-se por dividir as obras em grupos distintos ${ }^{30}$. Esta divisão deu-se da seguinte maneira: Os dicionários de Raphael Bluteau, Antônio Moraes e Silva e Domingos Vieira foram agrupados e denominados portugueses. As obras de Laudelino Freire, Caldas Aulete ${ }^{31}$, Antônio Buarque de Holanda Ferreira e Antônio Houaiss/Mauro de Salles Villar formam o segundo grupo, denominados de brasileiros. A obra de Francisco da Silva Borba constitui uma das divisões e é denominada de usos e, por último, a obra de Zeno e Rui Cardoso Nunes, juntamente com o dicionário de Batista Bossle, formam o conjunto denominado de regionalistas.

\footnotetext{
${ }^{30}$ Esta decisão também foi tomada em razão das descrições acima fornecidas, pois percebe-se, desde o início do capítulo, uma tendência natural em analisar as dez obras pesquisadas em conjuntos separados.

31 Caldas Aulete é lexicógrafo português, sendo as edições anteriores a estas consideradas portuguesas, entretanto, sua obra foi classificada como brasileira, por se tratar, conforme já citado anteriormente, da edição brasileira atualizada, revista e aumentada com a introdução dos vocábulos em uso no Brasil.
} 
A tabela a seguir fornece os números das ocorrências de lexias e as correspondências entre as acepções em cada um dos grupos formados. Estes números de lexias foram somadas entre as obras de cada grupo.

Tabela 6 - Ocorrências por grupo de dicionários

\begin{tabular}{l|cccc}
\hline & Portugueses & Brasileiros & Usos & Regionalistas \\
\hline-- & 357 & 225 & 84 & 285 \\
-+ & 9 & 3 & 5 & 4 \\
-++ & 0 & 0 & 0 & 1 \\
+- & 127 & 161 & 41 & 40 \\
+-+ & 0 & 0 & 0 & 2 \\
++ & 139 & 414 & 75 & 64 \\
+++ & 1 & 41 & 6 & 26 \\
\hline & 633 & 844 & 211 & 422 \\
\hline
\end{tabular}

Tabela 7 - Ocorrências por grupo de dicionários (em percentual)

\begin{tabular}{c|cccc}
\hline & Portugueses & Brasileiros & \multicolumn{1}{l}{ Usos } & Regionalistas \\
\hline-- & $56 \%$ & $27 \%$ & $40 \%$ & $68 \%$ \\
-+ & $1 \%$ & $0 \%$ & $2 \%$ & $1 \%$ \\
-++ & $0 \%$ & $0 \%$ & $0 \%$ & $0 \%$ \\
+- & $20 \%$ & $19 \%$ & $19 \%$ & $9 \%$ \\
+-+ & $0 \%$ & $0 \%$ & $0 \%$ & $0 \%$ \\
++ & $49 \%$ & $36 \%$ & $15 \%$ \\
+++ & $22 \%$ & $5 \%$ & $3 \%$ & $6 \%$ \\
\hline & $0 \%$ & $100 \%$ & $100 \%$ & $100 \%$ \\
\hline
\end{tabular}

Os resultados destes agrupamentos evidenciam algumas as descrições já fornecidas. Percebe-se uma tendência dos dicionários portugueses em não apresentar o vocabulário do charque em suas obras, representação dada na tabela por (--), mostrando que $56 \%$ das lexias que compõe o glossário não constam nessas obras. Atenta-se ao fato de que os dicionários regionalistas têm um grande percentual de não ocorrências entre as lexias e acepções, com $68 \%$ dos casos. Os dicionários brasileiros apresentam proporção bem menor para estas ocorrências, com 27\%, o que pode ser comprovado pela verificação de seu oposto, representado em $(++)$, com $49 \%$. Já o dicionário de usos não fornece $40 \%$ das lexias e acepções do glossário. 
Considerando o caso das obras apresentarem a lexia, mas não corresponder à acepção do glossário (+ -), percebe-se que, desta vez, os dicionários regionalistas apresentam um número significativamente menor que os outros, ocorrendo em $9 \%$ das vezes uma acepção diferente, contrastando com os 19 ou $20 \%$ dos outros grupos.

Essas porcentagens demonstram uma consonância entre a documentação componente do corpus e as obras editadas no Rio Grande do Sul. Entretanto, chama-se a atenção dos casos em que a lexia é fornecida e a acepção é correspondente $(++)$. O resultado desta combinação nas obras brasileiras é de praticamente a metade, (49\%). Este resultado diminui um pouco com a obra denominada de usos, e, seguindo a tendência, as obras portuguesas também parecem não concordar com o glossário, apresentando somente em $22 \%$ casos de similaridade.

\section{A lexia charque nas obras}

Para evidenciar o objeto da tese, a lexia charque, optou-se por realizar um recorte das ocorrências do uso desta palavra nas obras, a dizer, a combinação em que, além da correspondência entre as acepções, o autor menciona a palavra charque, caracterizado nas tabelas como $+/++$.

Gráfico 1 - Lexias com referência ao charque

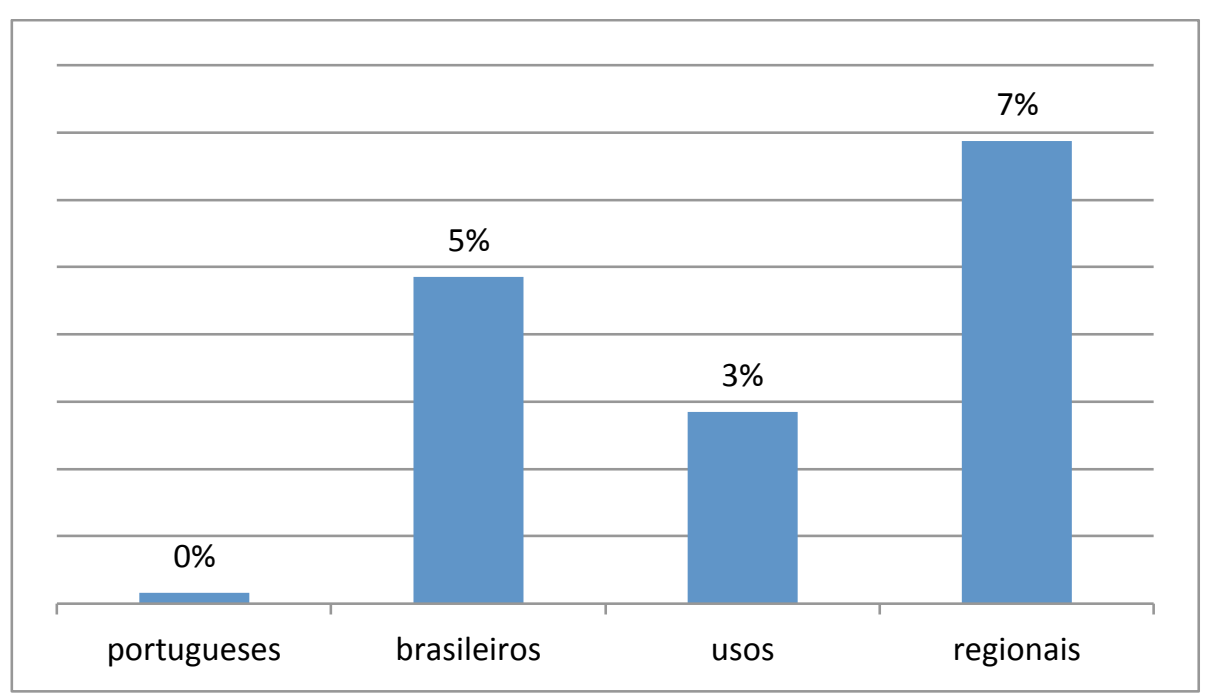

Das ocorrências em que as obras não só apresentaram correlação entre as acepções, mas mencionaram a lexia charque, podemos afirmar que estes números apresentam o resultado esperado, ou seja, há sim, nas obras de $\mathrm{ZCN} / \mathrm{RCN}$ e $\mathrm{BB}$, uma maior ocorrência do emprego da lexia charque, 7\%, que nas obras brasileiras, 5\%, caracterizando a representatividade regionalista. Este percentual diminui no dicionário de uso, e é inexistente 
nas obras portuguesas, que podem ter justificativa na cronologia, pois são os dicionários mais antigos, precisamente do século XVIII e início do XIX, ainda com bases estritamente portuguesas de composição. 


\title{
Capítulo 3 - OS ATLAS LINGUÍSTICOS
}

\author{
Nenhum verdadeiro estudioso da filologia nega o \\ valor dos atlas linguísticos nem o seu caráter de \\ indispensáveis.
}

(Antenor Nascentes)

Uma das etapas propostas do trabalho trata do estudo dos atlas linguísticos. O objetivo principal deste estudo é utilizar a base metodológica aplicada nos atlas na pesquisa de campo realizada. Outro propósito é utilizar os atlas como fonte de pesquisa na formação da listagem do vocabulário do charque, ampliando o léxico do glossário elaborado. Pode-se também, através desse estudo, fornecer aos consulentes do trabalho, um panorama geral do que tratam os atlas, apresentando um resumo sobre suas metodologias e resultados.

\subsection{Bases para Elaboração do Atlas Linguístico do Brasil -}

A obra disponível na biblioteca da Universidade de São Paulo trata do volume II. Datada de 1961, Antenor Nascentes, seu organizador, informa em curto prefácio que este questionário é o complemento do questionário geral já publicado pela Casa Rui Barbosa ${ }^{32}$.

Esta obra reconhece brevemente que há possíveis falhas mostrando-se abertos às críticas e sugestões, pois afirma ser a primeira obra desta natureza. Sem maiores explicações prévias, o atlas apresenta, em seguida, uma lista de questões e metaplasmos numerados do 1 ao 236.

No capítulo seguinte, Especificações do questionário geral, foram encontrados dentre nomes e expressões, as seguintes lexias, que podem estar relacionadas ao vocabulário do charque:

Página 30: carne-do-ceará, carne-do-sertão, carne-sêca, charque, jabá.

Página 35: novilho, terneiro, ternero, vitelo.

Página 36: tropeiro, viruçu.

\footnotetext{
${ }^{32}$ Pesquisando sobre a obra, averigou-se que a Comissão de Filologia da Casa Rui Barbosa, no Decreto 30.643 datado em 20 de março de 1952, priorizava a elaboração do Atlas Linguístico do Brasil. Como este projeto não cobriria todos os estudos dialetais no Brasil, sendo necessária uma nova visão na abordagem dos fenômenos da variação linguística brasileira, Antenor Nascentes publicou, anos mais tarde, as bases para a elaboração do atlas linguístico brasileiro e recomendava, nesta obra, os atlas regionais.
} 
Não se encontram, na obra, as questões empregadas pelo inquiridor. Sendo assim, não há como analisar quais perguntas foram feitas aos informantes na obtenção dessas respostas.

A obra de Antenor Nascentes não auxiliou como base metológica, pois acredita-se que, como é parte constituinte (volume II) de outra obra, acabou por deixar as explanações metodológicas fora deste volume. Porém, este atlas serviu para ampliação da listagem do léxico do vocabulário charque, inclusive, faz-se notar que charque, jabá, carne-de-sertão e carne-sêca são considerados um único produto, e não há separação de acordo com seu modo de preparo.

\subsection{Atlas Linguístico do Estado de São Paulo - ALESP}

Financiado pela FAPESP, o ALESP apresenta somente a elaboração do questionário ${ }^{33}$. O autor afirma que sem o ALESP não será possível conhecer e fixar adequadamente as variações da língua falada em São Paulo para entender melhor os aspectos históricos e sociais da realidade deste Estado. O autor, Pedro Caruso, finaliza suas observações sobre a obra concluindo que esta poderá servir de apoio pedagógico aos professores de Língua Portuguesa no que se refere ao domínio e conscientização das variantes do português paulista.

O índice apresenta o questionário dividido em quatro partes: (I) Terra, (II) Homem, (III) Lendas e superstições e (IV) Experiência pessoal. Em nenhuma destas partes foram encontradas lexias do vocabulário do charque. Entretanto, esta obra serviu de base metodológica no objetivo principal deste capítulo, pois tanto a ficha de localidade quanto a ficha do informante são compostas por itens relevantes a serem considerados posteriormente, quando for realizada a elaboração do questionário a sere aplicado na pesquisa de campo desta tese de doutoramento.

Seguem, na íntegra, os dados levantados nas fichas supracitadas:

FICHA DA LOCALIDADE: Nome do lugar; município; distrito; nomes anteriores; nome popular; nome dos habitantes do lugar; número de habitantes; atividades econômicas predominantes; indústrias caseiras; cidades mais próximas; vias de comunicação; emigração; imigração; data de fundação do lugar; outras informações.

FICHA DO INFORMANTE: 1- a) Dados do informante: nome; apelido; local do nascimento; sexo; estado civil; profissão; idade. b) Grau de instrução: analfabeto, mobral, primário incompleto, primário completo. c) Domicílio: morou sempre em; até aos... anos em;

\footnotetext{
${ }^{33}$ O Atlas Linguístico do Estado de São Paulo - ALESP -, segundo Pedro Caruso, seu idealizador, está com a etapa de inquérito finda, encontrando-se o material gravado em fase de transcrição fonética. O levantamento Linguístico foi realizado em cem localidades do Estado, com base no questionário publicado em 1983.
} 
dos...anos até aos....anos em. d) Viagens: no Estado de São Paulo; fora do Estado de São Paulo. e) Serviço Militar: prestou em... no ano de...; dispensado. 2- Dados dos pais e do cônjuge: naturalidade do pai; naturalidade da mãe; naturalidade do cônjuge. 3- Dados do inquérito: local; onde; data; inquiridos. 4 - Outras observações. 5- Dados de Registro: $\mathrm{n}^{\mathrm{o}}$ da fita; lado; pista; horas de gravação; transcritor; revisor; data.

\subsection{Comitê Nacional do Projeto ALiB: Atlas Linguístico do Brasil: Questionários}

No acervo da biblioteca da FFLCH, na Universidade de São Paulo, encontram-se duas obras do Comitê Nacional do Projeto ALiB. Uma consta do ano de 1998 e a outra do ano de 2001. Cotejando as duas obras, observou-se algumas diferenças no sumário, assim como também no texto da apresentação. Para não se tornar repetitivo tratar de ambas as obras, optou-se pela mais recente, datada de 2001, pois acredita-se que esta apresenta as modificações que seus autores julgaram necessárias.

O sumário deste atlas apresenta os seguintes assuntos assim divididos: Apresentação; Ficha de Localidade; Ficha do Informante; Convenções; Questionário Fonético-Fonológico; Questionário Semântico-Lexical - QSL; Questionário Morfossintático - QMS; Questões de Pragmática; Temas para Discursos Semidirigidos; Perguntas Metalingüísticas; Texto para Leitura.

Os objetivos do Projeto ALiB são citados na apresentação e podem ser resumidos sendo os seguintes: descrever a realidade linguística do Brasil; oferecer aos estudiosos de língua portuguesa, pesquisadores e pedagogos subsídios para aprimorar o ensino/aprendizagem, interpretando a multidialetividade brasileira; estabelecer e interpretar isoglossas cartografadas em mapas afim de traçar a divisão dialetal do Brasil; oferecer dados que permitam o aprimoramento dos estudos lexicográficos, gramaticais; auxiliar autores de livros didáticos e professores a aprofundar seus conhecimentos na realidade cultural brasileira; contribuir para o entendimento da língua portuguesa como instrumento social de comunicação; dentre outros.

Ainda na apresentação, no que se refere à rede de pontos, consta da informação de que foram selecionadas 250 localidades - espalhadas por todo o território nacional e os critérios das escolhas destas localidades. Quanto aos informantes, encontram-se dados sobre a faixa etária, local de inquérito, grau de escolaridade e profissão. Com referência aos questionários linguísticos, apresentam-se informações de suas categorias, divisões e suas bases 
metodológicas. Encerrando a apresentação do atlas, constam os nomes e cargos dos colaboradores, seguidos de seus respectivos locais de atuação e agências de fomento e também os agradecimentos finais.

Dando continuidade à descrição do atlas pesquisado, aparecem, de forma detalhada, as convenções usadas na aplicação do questionário. Nestas convenções há um detalhamento mais sistemático de como o questionário poderá ser apresentado, mostrando ao consulente o que significam as reticências, colchetes, caixa alta etc. Os questionários são apresentados na íntegra.

Para esta tese, somente será analisado o questionário semântico lexical - QSL. Consta deste questionário os seguintes campos: acidentes geográficos; fenômenos atmosféricos; astros e tempo; atividades agropastoris; fauna; corpo humano; ciclos da vida; convívio e comportamento social; religião e crenças; jogos e diversão infantis; habitação; alimentação e cozinha; vestuário e acessórios e vida urbana. Das duzentas e duas (202) questões componentes deste questionário, nenhuma delas está relacionada, ao vocabulário do charque.

No capítulo Temas para discursos semidirigidos, as perguntas sobre relato pessoal, comentário, descrição e relato não pessoal ${ }^{34}$ poderão servir de base para o questionário a ser desenvolvido. Finalizando o atlas encontram-se perguntas metalinguísticas e um texto (parábola) para leitura.

\subsection{Atlas Linguístico - Etnográfico da Região Sul do Brasil - ALERS}

O Atlas Linguístico da região sul do Brasil possui dois volumes, sendo o primeiro intitulado - Introdução. Este volume é composto pelos seguintes tópicos: Sistema de Símbolos Fonéticos; Sistema de Símbolos para a Cartografia; 1. Brasil Meridional: O Ordenamento Político do Espaço Social; 2. O Projeto ALERS: Origem, Objetivos e Métodos; 3. Questionários; 4. Região Sul do Brasil: Microrregiões Homogêneas; 5. Rede de Pontos; 6. Pesquisadores de Campo e Pontos de Inquérito Pesquisados; 7. Dados das Localidades e dos Informantes; 8. Referências Bibliográficas e Mapas Auxiliares.

A primeira parte, Sistema de Símbolos Fonéticos e para a Cartografia, consta de uma listagem seguido de algumas observações acerca dos símbolos empregados no atlas. $\mathrm{O}$ capítulo 1. Brasil Meridional: O Ordenamento Político do Espaço Social tem como ponto de partida as concepções geopolíticas que marcaram as disputas dos territórios entre portugueses

\footnotetext{
${ }^{34}$ Consta do Relato não pessoal: Conte um caso/ um fato de seu conhecimento (de que tenha ouvido falar, que tenha acontecido com um amigo, etc)
} 
e espanhóis desde o século XVI, descrevendo as fundações de cidades como Buenos Aires e Montevidéu, passando pelos povos jesuíticos das missões e sua destruição, descreve as guerras que se sucederam, como a Guerra Guaranítica, chegando à política de povoamento, que, segundo Moraes Paz, sobrepuseram-se às estratégias militares. O autor deste capítulo, então, cita a chegada de casais açorianos em Santa Catarina e ao Rio Grande do Sul e afirma que:

\begin{abstract}
No entanto, o que realmente garante a vinculação das terras meridionais ao patrimônio colonial português é a abertura de estradas, como o Caminho dos Conventos (1728) e o Caminho das Tropas (1731). O primeiro tem um grande significado militar, pois parte de Laguna em direção a Sacramento. Já o segundo, ligando as áreas pastoris gaúchas, sobretudo os campos de Viamão, às feiras de gado de Sorocaba e Itu, assegura o abastecimento alimentar da região das minas. Ao longo de seu traçado vão surgindo "pousos" e "currais", origem primeira de inúmeras fazendas, freguesias, vilas e cidades. (p.14)
\end{abstract}

Moraes Paz continua debatendo acerca do impacto das decisões políticas e econômicas européias no Brasil, principalmente sobre o fortalecimento da imigração a partir da segunda metade do século XIX. Finalizando seu capítulo de contextualização histórica, o autor debate sobre a migração, que fez com que os imigrantes europeus e suas famílias começassem a ocupar o interior de Santa Catarina, e mais tarde, fossem até o estado do Paraná, que vinha sofrendo influência ocupacional paulista dada a crise do café - já no século XX - após a década de 20.

O capítulo 2 trata da origem, objetivo e fundamento do projeto ALERS. Segundo descrição dos autores, o ALERS teve seu início em 1980 com um Grupo Interdepartamental para o Estudo da Variação Linguística do Rio Grande do Sul, com o intuito de retomar as pesquisas iniciadas pelo dialetólogo Heinrich A.W. Bunse. Durante o I Encontro de Estudos do Bilinguismo e da Variação Linguística da Região Sul, em 1982, foram definidos os procedimentos de concretização do projeto e, 5 anos mais tarde, a equipe coordenada por Walter Koch iniciou os estudos deste atlas compondo um grupo interestadual de trabalho, a dizer - Universidade Federal do Rio Grande do Sul (UFRGS), Universidade Federal de Santa Catarina (UFSC) e a Universidade Federal do Paraná (UFPR).

Este atlas tem como objetivos específicos: registrar e organizar as variantes geolinguísticas, fônicas, morfossintáticas e semântico-lexicais da língua portuguesa falada na area rural da Região Sul do Brasil; registrar e apresentar sob forma cartográfica e/ou descritiva, as variantes de igual natureza; fazer registro de discursos livre nos pontos de inquérito (rurais e urbanos); proceder nos pontos de inquérito (zona rural) aspectos de cultura local - como vestuário, utensílios domésticos, crenças, jogos, etc. e também objetiva a 
construção de um banco de dados linguísticos e etnográficos para servir de subsídio em futuros estudos sobre a Região Sul.

O capítulo discorre sobre os instrumentos de coleta (questionário de aproximadamente 700 questões, dividido em 3: questionário semântico lexical - QSL, morfossintático - QMS e fonético fonológico - QFF); os critérios dos pontos de sondagem (quantidade, distribuição, seleção e identificação); os requisitos de seleção dos informantes tanto da área urbana quanto a rural (grau de instrução, faixa etária, estado civil, ascendência, etc.); os registros e locais das entrevistas e inquiridores; o tratamento dos dados (tábua de símbolos fonéticos usados, graua de abstração de representação, procedimentos de digitação, etc) e o processo de cartografia.

O questionário Semântico-Lexical vem descrito logo a seguir, juntamente com os outros dois citados anteriormente, mas que serão desconsiderados dado o objetivo da pesquisa. O ALERS divide o QSL em: I. Acidentes Geográficos; II. Fenômenos Atmosféricos; III. Astros e Tempos; IV. Sistemas de Peso e Medidas; V. Flora; VI. Atividades Agro-Pastoris, VII. Fauna; VIII. Corpo Humano; IX. Cultura e Convívio; X. Ciclos da Vida; XI. Religião e Crenças; XII. Festas e Divertimentos; XIII. Habitação; XIV. Alimentação e Cozinha e XV. Vestuário.

Este questionário, por sua vez, estende-se às regiões sendo divido em: QSL específico do Paraná, composto de 12 itens; QSL específico de Santa Catarina subdividido em I. Influência Germânica - 7 itens, II. Influência Italiana - 4 itens, III. Influência Portuguesa - 4 itens, IV Outros - 10 itens e QSL específico do Rio Grande do Sul, composto por 40 itens.

Somam-se um total de 721 itens levantados nas perguntas, dentre estas, somente duas, a dizer, item 198 e 199, estão relacionadas ao vocabulário charque - pertencentes ao campo semântico Atividades Agro-Pastoris e poderão servir no glossário a ser composto na etapa posterior desta tese de doutoramento. São elas:

198. TIRAR O COURO Quando se carneia a) uma rês; b) uma ovelha, o que se faz depois de sangrar o animal?

199. MATADOURO Onde é que se carneia?

O volume 1 do ALERS apresenta após o questionário, um mapa da Região Sul no contexto dialetal de Antenor Nascentes. Em seguida apresenta uma lista das microrregiões homeogêneas da região sul, a rede de pontos listando todos os municípios, as localidades onde foram feitas as coleta de dados, os nomes dos pesquisadores envolvidos nos pontos de inquérito, os dados das localidades e dos informantes, os mapas de grupos étnicos, a segunda 
língua falada e denominação do vernáculo dos informantes. Este volume encerra-se com as referências bibliográficas e com os nomes de todas as pessoas que participaram do projeto.

O volume II (dois) é divido em duas grandes partes. A parte I, denominada Cartas Fonéticas, é composta por: sistema de símbolos para a cartografia, sistema de símbolos fonéticos; questionário fonético-fonológico - QFF; mapas auxiliares; vocalismo; consonantismo e apêndice. A parte II, denominada Cartas Morfossintéticas, apresenta o questionário morfossintático - QMS e suas divisões em gênero; número; graus; formas de tratamento; pronomes pessoais oblíquos; flexão verbal e advérbios. Por tratar somente de fonologia e morfosintaxe, o volume II não será aqui estudado detalhadamente.

Este atlas seguramente servirá como fonte metodológica, pelo próprio caráter de abrangência interestadual principalmente quando os questionários foram estendidos por estado, fazendo com que peculiaridades diatológicas pudessem constar no produto final. Entretanto, esperava-se encontrar mais subsídios para a pesquisa com relação à ampliação do léxico do vocabulário charque.

\subsection{Atlas Linguístico do Paraná - ALPR}

O atlas linguístico do Estado do Paraná de autoria de Vanderci de Andrade Aguilera é composto de dois volumes. O volume I, consta da apresentação, e o volume II apresenta as Cartas Isofônicas.

O volume I - Apresentação - é iniciado pelos agradecimentos e pela citação dos nomes da equipe de apoio. O sumário, logo a seguir, é composto por: Introdução; Esboço da História da Colonização Paranaense; Pontos Linguísticos Investigados; Características dos Informantes por Localidade; Questionário Linguístico; Notação Fonética; Apresentação das Cartas e Notas Explicativas.

No capítulo introdutório, a autora descreve que este atlas constitui-se inicialmente de sua tese de doutorado, que a sugestão de Pedro Caruso, autor do Atlas Linguístico de São Paulo - já citado neste capítulo - serviu de base metolodológica para o ALPR, assim como outros atlas existentes no momento de suas pesquisas. Aguilera também cita como seu objetivo permitir estudos comparativos de interesse para a dialetologia e história da língua portuguesa. No capítulo 2, como o próprio nome diz, a autora esboça a história da colonização do Estado do Paraná, desde o Tratado de Tordesilhas, em 1494, até o ano de 1943, dividindo a história paranaense em três ondas povoadoras: a do Paraná tradicional, Paraná moderno do norte e Paraná moderno do sudoeste e oeste. 
Após este breve capítulo de contextualização histórica, a autora descreve os 65 pontos de inquérito pesquisados, fornecendo dados como: data de criação; nomes anteriores; população; altitude; economia predominante; municípios mais próximos; distância da capital; dentre outros.

Em seguida, o atlas apresenta a metodologia aplicada para a caracterização dos informantes, que foram separados por localidade e uma lista de palavras utilizadas nos questionários separadas por campos semânticos. São eles: (I) Terra: natureza, fenômenos atmosféricos, astros, tempo, flora, plantas medicinais, fauna. (II) Homem: partes do corpo, funções, doenças, vestuário, calçados, agricultura, instrumentos agrícolas, brinquedos, jogos infantis, lendas e superstições. Também foi solicitada uma narrativa de experiência pessoal de uma situação de perigo ou um fato triste.

No capítulo 6 foi descrita a notação fonética utilizada na transcrição, logo após a autora descreve a confeccção das cartas, seguido das notas explicativas, errata e observações. Não há registro da lexia, nem palavras relacionadas ao vocabulário do charque.

\subsection{Atlas Linguístico de Mato Grosso do Sul - ALMS}

A decisão de ampliar o estudo dos atlas ao Atlas de Mato Grosso do Sul se deu em razão da migração. Sabe-se que muitos gaúchos, catarinenses e paranaenses migraram de seus Estados de origem indo habitar o Estado do Mato Grosso há algumas décadas atrás, sendo, inclusive, fato mencionado e discutido no capítulo 3 deste atlas. Segundo o organizador, Derci Pedro de Oliveira, mineiros, paulistas, goianos, gaúchos e paranaenses foram para o Mato Grosso auxiliando o estabelecimento da agricultura e da pecuária. Sendo assim, decidiu-se incluir o atlas sul matogrosense visando não somente a possível inclusão de mais vocábulos relacionados ao charque, mas também como mais uma fonte metodológica na construção do questionário e do glossário.

$\mathrm{O}$ atlas de Mato Grosso do Sul mostrou-se uma grata surpresa pela sua organização e explanação metodológica. O sumário é composto por: introdução; origem; objetivos; justificativa; pesquisadores adjuntos; inquiridores; transcritores; inquiridores/transcritores; procedimentos metodológicos; sistema de símbolos fonéticos; cartas linguísticas; considerações sobre o léxico, conclusão e referências.

Na introdução feita pelo organizador - Darci Pedro de Oliveira - há um debate sobre a dialetologia, onde este descreve o que considera o marco dos estudos dialetológicos e como a obra Atlas Prévio dos Falares Baianos de Nelson Rossi fez surgir a vontade de outras obras 
regionais, inclusive a obra citada. Seguindo em seu debate, Oliveira afirma a importância da interdisciplinaridade da sócio-linguística e a dialetologia auxiliando na criação de novas alternativas metodológicas.

Logo após a descrição dos primeiros estudos e de como se originou o trabalho como um todo, o organizador cita como objetivos principais deste atlas o propósito de conhecer as características dos falares de Mato Grosso, contribuir para o ensino/aprendizagem da língua portuguesa, sistematizar dados para futuras descrições em diversas áreas de conhecimento e a elaboração do atlas em si.

Ressaltando a diversidade cultural e as influências que a língua falada em Mato Grosso sofreu, o autor cita como a migração, as regiões fronteiriças com paraguaios e bolivianos e a forte influência indígena como principais fatores para a descrição da realidade sul matogrossense. Após a justificativa, são citados todos os nomes das pessoas envolvidas no processo de construção do atlas, assim os dados dos informantes, separados pelas localidades a qual pertencem. A coleta de dados é descrita, sendo esta realizada por meio de entrevistas utilizando o método direto e indireto. O questionário formado por 557 perguntas foi dividido em aspectos fonéticos e lexicais. A morfossintática foi estudada a partir das narrativas dos fatos que marcaram a vida dos informantes.

Em seguida o atlas apresenta o nome e a descrição das localidades escolhidas para as entrevistas, quais os temas do questionário, os sistemas de símbolos e encerra esta primeira parte descrevendo como foram elaboradas as cartas linguísticas.

O capítulo intitulado Considerações sobre o léxico, escrito por Vitória Regina Spanghero Ferreira - UFMS - foi considerado relevante para esta pesquisa, pois introduz algumas palavras selecionadas dentre as várias que compõem o Atlas Linguístico de Mato Grosso. Segundo a autora, a descrição das palavras que compõem este capítulo aponta características linguístico-culturais da língua portuguesa e especificamente do Estado do Mato Grosso do Sul, permitindo conhecer as diversas formas de nomeação dos falantes demonstrando suas cosmovisões e aspirações.

No capítulo intitulado Descrição Lexical é apresentada "uma porção do léxico sulmatogrossense", exemplificando nomes de animais, plantas, alimentos, partes do corpo, etc. A descrição da palavra Carnear, a seguir, justifica-se não só como uma lexia que irá compor o glossário desta tese de doutoramento, assim como também para demonstrar a metodologia aplicada neste atlas:

\section{Carnear}


Etimologia: do platino carnear 'retirar a carne do gado abatido'.Acepções: verbo intransitivo. Regionalismo: Brasil. Abater e esquartejar o gado, retirando suas carnes para secar. Transitivo direto. Abater, esquartejar (o gado). Regionalismo. Mato Grosso do Sul. Matar a rês gorda, para consumo da fazenda. Denominações Sul-mato-grossenses: abater, carnear, matar para comer, churrasco, matula, manteia, chaquiá a carne, churrasquiar, discarneiar, bitela, matar para despesa. (p. 264, 265).

O ALMS finaliza com agradecimentos aos informantes, seguido de uma pequena explanação de quão satisfatório este atlas se tornou ao longo dos 11 anos de sua composição, algumas fotos são apresentadas, o que auxilia na visualização do ambiente em que foi composta a obra.

\subsection{Esboço de um Atlas Línguístico de Minas Gerais}

Como última fonte de pesquisa deste capítulo, apresenta-se o esboço do atlas do Estado de Minas Gerais. A inclusão deste atlas é dado seu caráter metodológico e não sua localização geográfica ou por questões migratórias como no atlas anterior. Vale ressaltar que o uso desta fonte servirá não só como instrumento metodológico para a construção/elaboração do questionário a ser aplicado, mas também como guia na própria construção do trabalho de doutoramento. Ou seja, durante a descrição dos procedimentos adotados nas pesquisas, por exemplo, o controle das variantes; a escolha dos informantes; das localidades; etc, vários questionamentos começaram a ser levantados, e a própria descrição metodológica do atlas auxiliou na elucidação das questões.

O sumário desta obra é composto por: apresentação; plano da obra; resumo; introdução; metodologia; as localidades; as cartas; glossário e bibliografia. Para este estudo será somente comentado o capítulo intitulado - Metodologia, que se divide em: pesquisa direta; pesquisa indireta; apresentação das cartas; a gravação; pesquisa sociolinguística e transcrição fonética.

Em relação à metodologia aplicada no EALMG os próprios autores iniciam o capítulo afirmando a impossibilidade de utilizar um método que seja capaz de aglutinar todos os fenômenos linguísticos de uma área determinada. Sendo assim, informam que a metodologia por eles empregada procurava ser coerente de modo que não prejudicasse os fins propostos. Relacionada à pesquisa direta, foi feita uma pesquisa espontânea (porém dirigida e mediante questionário preparado), in loco em 116 municípios mineiros. O questionário foi composto em 8 (oito) esferas semânticas, com ordenação rigorosa e sistemática, a fim de que se tornasse um "jogo de senemas sucessivos”. Este questionário foi centralizado nas experiências diárias 
e reduzido a 415 (quatrocentas e quinze) perguntas. Há uma explanação de que a experiência ao longo do tempo levou os pesquisadores a adaptá-lo e reduzí-lo para não tornar o informante desinteressado e dispersivo.

Ainda sobre o questionário, apresentou-se um dado elucidativo, segundo os autores, as questões que dificilmente obtinham resposta foram abandonadas e, em uma ou outra área, dada a vivência do informante, as perguntas eram evitadas. Como exemplo o atlas apresenta o seguinte comentário: “... em áreas de tropeiros, onde há elevações a serem cansativamente percorridas e o carro de boi não é utilizado, variamos para aqueles o assunto.... nas zonas exclusivas de milho, não se indagava sobre o plantio de fumo.” (p. 26). O item 1.1.2 o capítulo de metodologia trata da entrevista, onde, segundo os inquiridores, procurou-se a espontaneidade do diálogo, e jamais procurou-se mencionar antes o nome do objeto a ser perguntado. Numa fase preliminar, foram adotados desenhos $\mathrm{e}$ fotografias, que, principalmente para os analfabetos, mostrou-se ineficaz, sendo substituída quando possível pelo objeto miniaturizado.

Com relação à formulação das perguntas preferiu-se um questionário pequeno a um grande, flexível e indireto. Os autores, neste ponto do atlas, tornam-se repetitivos em afirmar que a formulação correta das perguntas é de extrema importância.

A busca do informante é tratada a seguir e afirma-se ser tida de forma discreta e casual e por apresentar falhas, passou a contar com a ajuda da administração pública municipal. Os locais das entrevistas foram sempre na própria residência do entrevistado ou na Prefeitura, sempre sem a presença de estranhos ou familiares, de modo a não contaminar as respostas. Se a busca foi casual, a escolha foi rigorosa, obedecendo aos seguintes critérios: a. pessoa nascida na localidade em estudo; b. idade entre 30 e 50 anos; c. se casado, o cônjuge deveria ser da mesma localidade; d. iletrado; e. não ser viajado e não ter morado em outro município; f. não ter prestado o serviço militar; g. ter boas condições fônicas e de saúde; h. profissão variável. Os autores apresentam um fato até então não levantado nos outros atlas: a indicação de que os informantes foram pagos no valor correspondente ao salário-hora do Estado de Minas Gerais da época.

O uso de mais de um informante ao mesmo tempo é explicitado no item 1.1.7., os autores informam que sempre que possível dirigiam as conversas com vários informantes, sendo um o principal, fazendo com que fosse poupada a procura de informantes complementares para preencher as lacunas da entrevista. Frisa-se que, entretanto, o importante não era a pluralidade de informadores, mas sim a fidelidade do resultado, e, 
sempre que aparecesse alguma forma que soasse estranha, esta era imediatamente testada na comunidade. Com relação à localidade, procurou-se o equilíbrio, sendo feitas em municípios urbanos mais industrializados, municípios com comprovada importância histórica, assim como pontos afastados, chamados de pontos marginais. $\mathrm{O}$ atlas ainda apresenta o dado dos inquiridores, sendo este planejado por dois e executado por quatro professores, divididos no inquérito e transcrição.

A explanação da pesquisa indireta traz a sequência metodológica aplicada no envio das correspondências que tinham a finalidade de comprovar, no domínio do léxico, a validade das isolexias esboçadas após as 50 primeiras gravações. Esta pesquisa indireta é apresentada neste capítulo, porém dado seu rigor teórico, não será aqui tratado detalhadamente. O que se pode afirmar, entretanto, é que este tipo de pesquisa será, em menor escala de rigorismo, utilizado nesta tese de doutoramento, quando for aplicado o questionário denominado, por ora, de questionário da lexia charque. Ou seja, dada suas adaptações, esta tese de doutorado poderá também se servir do uso de correspondências para testar o uso da lexia charque.

O capítulo metodológico explicitado nesse último atlas ainda apresenta os dados técnicos das gravações, em relação ao material empregado, e informa que, sempre que o informante se mostrou incomodado com o uso do gravador, a entrevista era interrompida. Entretanto, segundo os autores, raramente o gravador tornou-se um empecilho para a conversação livre e espontânea. Essa obra encerra-se com as explanações sobre a pesquisa sociolinguística e os dados sobre a transcrição fonética empregadas nas degravações. 


\section{Capítulo 4 - A PESQUISA DE CAMPO}

Este capítulo tem por objetivo demonstrar as bases teórico-metodológicas utilizadas para o desenvolvimento do questionário utilizado na coleta de dados. Também constam desse capítulo a justificativa para a escolha do objeto de pesquisa, os dados obtidos na aplicação do questionário e as análises que abrangem essa etapa.

Tendo em vista o objetivo geral desta tese, que se configura como o estudo do vocabulário do charque no Sul do Brasil propondo discutir as influências e contribuições deste produto na formação e expansão da variedade do português brasileiro, o planejamento realizado inicialmente para a pesquisa de campo seria a elaboração de um questionário que incluísse todas as lexias componentes do glossário.

Constituído desta maneira, o questionário seria aplicado nos locais onde o charque exerce influência, com a finalidade de testar o uso do vocabulário proveniente da documentação que constitui o corpus prévio do glossário e, a partir dos dados obtidos nas entrevistas, verificar a possibilidade de incursão de outras lexias nele.

Entretanto, durante a seleção, as lexias provenientes dos documentos evidenciaram-se em elevado número, o que suscitou alguns questionamentos, sendo: o número de questões não tornaria a pesquisa cansativa? Haveria, nas cidades em que o charque exerceu influência significativa, charqueadas ainda em funcionamento? Se sim, o número de entrevistados seria insuficiente para comprovar o grau de influência de uma lexia? Se não, como encontrar informantes que pudessem colaborar com a pesquisa?

Essas questões somadas à experiência cotidiana na cidade, resultaram em outra problemática acerca do tema da pesquisa: o (des)conhecimento acerca do uso da própria lexia charque.

\footnotetext{
A diversidade lingüística (sic) sempre foi, consciente ou inconscientemente, motivo de preocupação não só dos estudiosos da linguagem como de qualquer usuário de determinada língua. Por que não falamos exatamente igual aos nossos pais? Por que sentimos estranho, ou mesmo errado, o modo de falar de um amigo que veio de outra região? (AGUILERA, 1998, p. 78)
}

Portanto, o estranhamento dos falantes paulistas com relação à lexia charque, o receio de tornar a pesquisa de campo extensa e improdutiva, acerca da influência e contribuição do charque na formação e expansão da variedade do português brasileiro, modificou os planos iniciais da pesquisa de campo. 
Assim, em vez de aplicar um questionário com mais de 200 questões, conforme idealizado inicialmente, optou-se por realizar uma pesquisa de campo simples e direta, com o objetivo de testar, primeiramente, o conhecimento elementar da lexia charque.

\subsection{Questionário da lexia charque - considerações teórico-metodológicas}

Se a concepção inicial desta pesquisa de campo partiu da observação, e, portanto baseou-se em critérios mais empíricos que científicos, não se pode dizer o mesmo sobre os critérios utilizados na formulação do questionário, na seleção sóciogeográfica dos entrevistados e na análise dos dados empregados nas pesquisas.

O rigor metodológico inicia-se com a Ficha do Informante, desenvolvida com base em estudos prévios realizados dos atlas linguísticos, tomando por modelo o instrumento desenvolvido para o Atlas Linguístico Brasileiro (ALiB).

Quanto à forma de coleta de dados, optou-se pela pesquisa direta, in loco, evitando questionários aplicados por terceiros. Isso se deve ao fato de que, à distância, não há como observar casos de direcionamento nas respostas, o que altera o resultado da pesquisa.

Para tanto, procurou-se elaborar uma pergunta baseada no preceito da onomasiologia $^{35}$, de modo que fosse possível obter como resposta a lexia desejada ou outras que se configurassem como variáveis dela. Houve atenção especial para não induzir o inquerido a empregar a lexia testada, por isso não foram utilizados recursos extras, como fotografia ou amostra do próprio objeto de análise.

Com relação à escolha dos pontos de inquérito, optou-se por selecionar localidades emergentes do próprio corpus do trabalho e da leitura da bibliografia apresentada no subcapítulo 1.1. A primeira decisão tomada foi que o questionário deveria ser aplicado em outros pontos além da cidade de Pelotas e que fosse aplicado procurando abranger outros lugares da região Sul do Brasil, possibilitando o cotejo dos dados em diferentes localidades, enriquecendo e fornecendo heterogeneidade às pesquisas.

A localidade considerada no Rio Grande do Sul foi a cidade de Pelotas, pois, durante as primeiras revisões bibliográficas, ficou evidente que este município foi a principal localidade charqueadora rio-grandense. E, em Santa Catarina, a cidade escolhida foi Florianópols em razão de sua frequência na documentação componente do corpus.

\footnotetext{
35 Segundo BERTOLDI (1935), "Por onomasiologia entende-se um aspecto particular da pesquisa linguística que, partindo de uma determinada idéia (sic), examina as várias maneiras com as quais essa idéia encontrou expressão na palavra.” Op cit. BABINI (2006).
} 
Já o Estado do Paraná não foi incluído como ponto de inquérito, pois não foi encontrada, nas pesquisas bibliográficas e na documentação coletada, referências da atividade do charque nesse local.

Decidiu-se, também, estender a aplicação do questionário a São Paulo. A escolha deste Estado deve-se a dois motivos: o primeiro, já apontado no início deste capítulo, relaciona-se a verificar o (des)conhecimento da lexia charque no local; e o segundo, e mais relevante, está ligado à possibilidade de suscitar uma discussão sobre a influência do dialeto caipira paulista no Sul do Brasil, vinculando os movimentos bandeirante, monçoeiro e tropeiro com a economia do charque. Por esta razão, esta pesquisa foi aplicada também na cidade de Sorocaba, dada sua relação histórica com o movimento tropeiro.

E para testar o conhecimento da lexia charque nas diferentes localidades selecionadas, a busca dos informantes não poderia seguir os princípios da Dialetologia tradicional ${ }^{36}$, mais sim deveria ser heterogênea, para que testasse o uso da lexia charque com variáveis sociais distintas. Assim, o questionário foi aplicado ao maior número de informantes possível, abrangendo diferentes idades, profissões, estado civis e graus de escolaridade.

Para descrever os pontos de inquérito será utilizado o modelo desenvolvido por Aguilera (1996) no Atlas Linguístico do Paraná, que identifica as cidades pesquisadas e fornece informações sobre a data de fundação, nomes anteriores que ela possa ter recebido, gentílico, área, população, PIB e PIB per capita, municípios mais próximos, economia e etnias, a saber:

SÃO PAULO: Capital do Estado de São Paulo. Fundação da cidade: 25 de janeiro de 1554. Nomes anteriores: São Paulo de Piratininga. Gentílico: paulistano. Área: 1.522,986 $\mathrm{km}^{2}$. População: 11.244 .369 habitantes ${ }^{37}$. PIB: R\$ 357.116.681,300 mil. PIB per capita: R\$ 32.493,96 $6^{38}$. Municípios mais próximos: Caieiras e Mairiporã a norte, Guarulhos a nordeste, Itaquaquecetuba, Poá e Ferraz de Vasconcelos a leste, Mauá, Santo André, São Caetano do Sul, São Bernardo do Campo, Diadema e São Bernardo a sudeste, São Vicente, Mongaguá e Itanhaém a sul, Juquitiba, Embu-Guaçu, Itapecirica da Serra, Embu, Taboão da Serra, Cotia e Osasco a oeste e Santana de Parnaíba e Cajamar a noroeste. Economia: indústria, cidade

\footnotetext{
${ }^{36}$ Os princípios da Dialetologia tradicional podem ser assim brevemente resumidos: ser nascido na localidade em estudo; ter origem ou tradição rural; e que estivesse na faixa de 30 a 55 anos.

${ }^{37}$ Dado do IBGE de 2010.

${ }^{38}$ Dados do IBGE 2008.
} 
terciária, pólo de serviços e negócios. Etnias: brancos $(68,0 \%)$, pardos $(25,0 \%)$, pretos $(5,1 \%)$, amarelos $(2,0 \%)$ e indígenas $(0,2 \%)^{39}$.

FLORIANÓPOLIS: Capital do Estado de Santa Catarina. Fundação da cidade: 23 de março de 1726. Nomes anteriores: Desterro. Gentílico: florianopolitano. Área: 433,317 $\mathrm{km}^{2}$. População: 421.203 mil habitantes ${ }^{40}$. PIB: R\$ 8.120.985,896 mil. PIB per capita: R\$ 20.184,0941. Municípios mais próximos: São José. Economia: turismo, comércio, prestação de serviços e setor de tecnologia. Etnias: brancos $(88,1 \%)$, pardos $(9 \%)$, negros $(2,7 \%)$, amarelos ou indígenas $(0,2 \%)$.

PELOTAS: A cidade de Pelotas está localizada na região sul do Estado, cerca de 250 km da capital, Porto Alegre. Fundação da cidade: 7 de julho de 1812. Nomes anteriores: A Freguesia de São Francisco de Paula. Gentílico: pelotense. Área: $1.610 \mathrm{~km}^{2}$. População: 328.275 mil habitantes ${ }^{42}$. PIB: R\$ 3.564.295,551 mil. PIB per capita: R\$ 10.386,4843. Municípios mais próximos: Morro Redondo, Canguçu, Arroio do Padre, São Lourenço do Sul, Turuçu, Capão do Leão e Rio Grande. Economia: agropecuária, indústria e serviços. Etnias: brancos $(47,8 \%)$, pardos $(4,3 \%)$, negros $(5,8 \%)$, amarelos $(0,08 \%)$, indígenas $(0,17 \%)^{44}$ e não sabem $(0,17 \%)$.

SOROCABA: A cidade de Sorocaba se localiza na região Sudoeste do Estado de São Paulo, a cerca de 90 km de distância da capital, São Paulo. Fundação da cidade: 15 de agosto de 1654. Nome anterior: Nossa Senhora da Ponte de Sorocaba. Gentílico: Sorocabano. Área: $449 \mathrm{~km}^{2}$. População: 586.625 habitantes $^{45}$. PIB: R\$ 13.072.889,430 mil. PIB per capita: $\mathrm{R} \$$ $22.683,70^{46}$. Municípios mais próximos: Porto Feliz, Votorantim, Mairinque, Itu, Araçoiaba da Serra, Salto de Pirapora, Iperó. Economia: indústria, turismo, e negócios. Etnias: brancos $(66,6 \%)$, pardos $(24,2 \%)$, pretos $(6,8 \%)$, amarelos $(2 \%)$, indígena $(0,4 \%)$.

Para identificar os dados dos informantes e registrar a pergunta-chave sobre a lexia charque, foi desenvolvido o modelo seguinte:

\footnotetext{
${ }^{39}$ Dados do IBGE 2000.

${ }^{40}$ Dado do IBGE 2010.

${ }^{41}$ Dados IBGE 2008.

${ }^{42}$ Dado do IBGE 2008.

${ }^{43}$ Dados IBGE 2008.

${ }^{44}$ Dados do IBGE 2007.

${ }^{45}$ Dado do IBGE de 2010.

${ }^{46}$ Dados do IBGE 2008.
} 


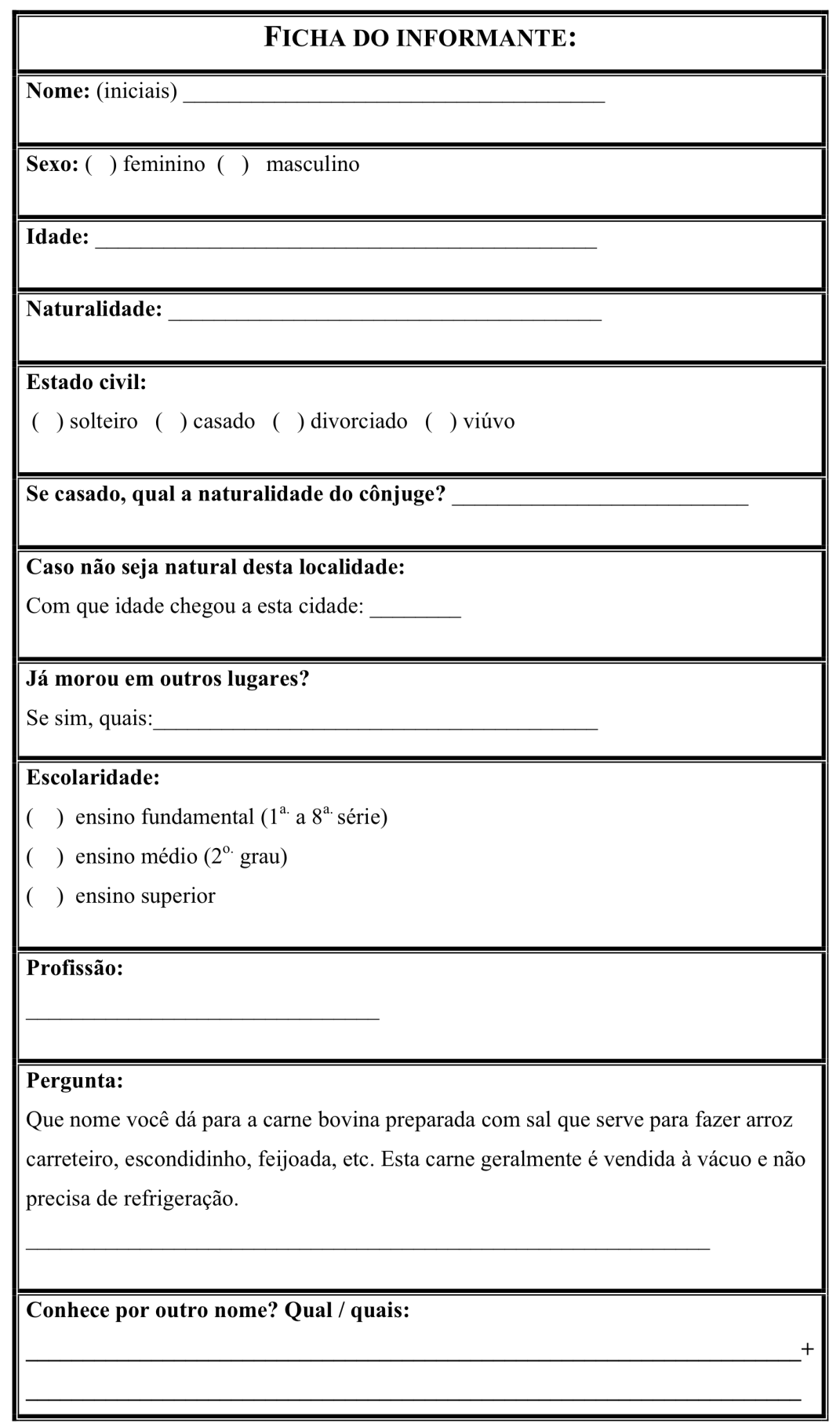


Após a aplicação desta Ficha aos primeiros 99 informantes, observou-se que alguns desses entrevistados apresentavam dificuldade no preenchimento de alguns dados e/ou apresentaram dúvidas para responder, devido à ausência de opções de resposta na Ficha que se enquadrassem em seu perfil, comprovando que, para evitar este tipo de situação, a pesquisa deveria ser aplicada e, se possível, preenchida por um mesmo inquiridor.

O primeiro problema apresentado relacionou-se à compreensão do significado de naturalidade, fato que comprometeu também as respostas subsequentes, como a que versava sobre a naturalidade do cônjuge, nos casos em que o estado civil não era solteiro, e outra que solicitava a idade do entrevistado quando chegou à cidade, no caso de ele não ser natural da localidade.

No momento dessas questões, alguns informantes confundiram naturalidade com nacionalidade dando respostas como: brasileiro ou então deixando-a em branco. Nesses casos a presença do inquiridor contornou a dificuldade, pois foi possível realizar a pergunta em forma de conversação livre e indireta, permitindo assim registrar a naturalidade correta do informante.

Quanto ao problema referente à ausência de opções que contemplassem a resposta dos informantes, a questão que suscitou tal dificuldade estava relacionada à escolaridade. Muitos informantes não sabiam qual resposta selecionar no caso de não terem concluído determinado grau escolar. Considerando estas dúvidas, optou-se por aperfeiçoar a Ficha do Informante, inserindo novas opções de resposta e modificando a maneira de questionar a naturalidade.

Faz-se necessário atentar que mesmo que a Ficha do Informante tenha sido aperfeiçoada, os 99 questionários inicialmente aplicados foram consideradas nas análises. Após a reformulação, a Ficha do Informante apresentou-se conforme consta a seguir: 


\section{FICHA DO INFORMANTE:}

Nome: (iniciais)

Sexo: ( ) feminino ( ) masculino

Idade:

Cidade em que nasceu:

Caso não tenha nascido nesta localidade:

Com que idade chegou a esta cidade:

\section{Estado civil:}

( ) solteiro ( ) casado ( ) divorciado ( ) viúvo

Se casado, qual a cidade que nasceu o esposo(a)?

\section{Já morou em outros lugares?}

Se sim, quais:

\section{Escolaridade:}

( ) ensino fundamental completo ( ) ensino fundamental incompleto

( ) ensino médio completo ( ) ensino médio incompleto

( ) ensino superior completo ( ) ensino superior incompleto

( ) pós- graduação completo ( ) pós-graduação incompleto

\section{Profissão:}

\section{Pergunta:}

Que nome você dá para a carne bovina preparada com sal que serve para fazer arroz carreteiro, escondidinho, feijoada, etc. Esta carne geralmente é vendida embalada à vácuo e não precisa de refrigeração.

Conhece por outro nome? Qual / quais: 


\subsection{Descrição dos resultados da pesquisa de campo}

Este capítulo pretende realizar uma descrição dos dados coletados após a aplicação dos questionários. As análises e conclusões da pesquisa de campo serão apresentadas nas considerações finais da tese. Nesta parte do capítulo busca-se, através destas descrições, evidências e/ou subsídios que auxiliem nas respostas aos questionamentos levantados na tese, com relação às influências e contribuições do charque na Língua Portuguesa.

De acordo com o questionário aplicado, observam-se as seguintes variáveis sociolinguísticas:

1. Cidade onde foi aplicado o questionário

2. Gênero

3. Idade

4. Naturalidade

5. Estado civil

6. Naturalidade do cônjuge

7. Escolaridade

8. Profissão

Conforme exposto no item anterior, a pesquisa de campo abarcou as cidades de São Paulo, Florianópolis, Pelotas e Sorocaba, que apresentaram a seguinte distribuição do total de 336 questionários aplicados:

Tabela 8 - Número de entrevistas - de acordo com as localidades

\begin{tabular}{lcc}
\hline & Quant. & \% \\
\hline Sorocaba & 31 & $9 \%$ \\
\hline Florianópolis & 64 & $19 \%$ \\
\hline Pelotas & 87 & $26 \%$ \\
\hline São Paulo & 154 & $46 \%$ \\
\hline Total & 336 & $100 \%$ \\
\hline
\end{tabular}

Já em relação às outras variáveis, faz-se necessário estabelecer algumas ressalvas:

1. Mesmo que o informante não fosse natural da cidade pesquisada, ele foi considerado na pesquisa, pois após uma análise detalhada das informações fornecidas nos questionários, verificou-se que os inquiridos eram nascidos em cidades vizinhas ou já residiam no município havia mais de 5 anos. Além disso, os informantes que não se enquadram nestas condições ocorreram em número muito reduzido, concluindo-se que não alterariam o resultado final da pesquisa. 
2. No que se refere à idade, foram criadas três faixas etárias para simplificar a descrição dos dados coletados, definidas da seguinte maneira: foi considerado jovem o informante com idade entre 0 a 24 anos; adulto o informante com idade entre 25 e 59 anos; e sênior o informante com idade superior a 60 anos.

3. Com relação à escolaridade, optou-se também por definir três grandes blocos: demonimou-se fundamental o informante não alfabetizado, com ensino fundamental completo ou incompleto; médio o informante com ensino médio completo ou não; e superior o informante com ensino universitário e/ou pósgraduação completo ou incompleto.

4. Não foi feita separação ou reclassificação tendo por base as profissões, pois acredita-se que elas sejam compatíveis com o grau de escolaridade informado. Entretanto, as profissões foram simplificadas e sempre infomadas no gênero masculino, independentemente do sexo do entrevistado, conforme o exemplo: Atendente de loja, Atendente de Caixa, Vendedor de Loja e Vendedor de Carro são todos considerados como Vendedores.

Tabela 9 - Lista de profissões dos informantes

\begin{tabular}{|l|l|l|l|}
\hline Adm. De Empresa & Corretor de Seguros & Impressor & Professor \\
\hline Advogado & Designer de Interiores & Jardineiro & Promotor de Justiça \\
\hline Analista de Crédito & Do Lar & Jornalista & Promotor de Vendas \\
\hline Analista de Sistemas & Doméstica & Lavrador & Publicitário \\
\hline Aposentado & Economiária Aposentada & Manicure & Repr. Comercial \\
\hline Arquiteto & Editor de texto & Marceneiro & Revisor de texto \\
\hline Ass. Jurídico & Educador & Marítimo aposentado & Secretária \\
\hline Ass.Ensino Infantil & Embarcador & Massoterapeuta & Servidor Público \\
\hline Assistente Jurídico & Encadernador & Master Black belt & Social Media \\
\hline Atendente de loja & Enfermeiro & Mecânico Industrial & Sorveteiro \\
\hline Aux. Administrativo & Engenheiro Agrônomo & Médico & Sup. Recrutamento \\
\hline Aux. Atendimento & Engenheiro Civil & Menor Aprendiz & Supervisor \\
\hline Aux. de Limpeza & Engenheiro Mecânico & Mestre de obra & Supervisor Financeiro \\
\hline Aux. Direitos Autorais & Escritor & Metroviário & Taxista \\
\hline Aux. Escritório & Estagiário & Modelo & Téc. Administrativo \\
\hline Babá & Estudante & Monitor & Téc. Arte Gráfica \\
\hline Bancário & Executivo de Contas & Montador Cinematográfico & Téc. Sistemas biomédicos \\
\hline Bibliotecário & Fiscal de Caixa & Músico & Técnico Contábil \\
\hline Biólogo & Frentista & Operador Teleatendimento & Técnico de Informática \\
\hline Cabeleleira & Funcionário Público & Operadora de Caixa & Tradutor \\
\hline Caixa & Funileiro & Pedagogo & Vagabundo \\
\hline Camareira & Gerente Comercial & Pedreiro & Vendedor \\
\hline Comerciante & Gerente de Turismo & Personal Trainer & Vigilante \\
\hline Cons. Propr. Intelectual & Gráfico & Pesquisador em Literatura & \\
\hline Corretor de Imóveis & Guia Turístico & Pintor & \\
\hline
\end{tabular}


A tabela acima, é meramente ilustrativa. Não foi realizado nenhum levantamento ou análise dos dados relacionando as profissões exercidas pelos informantes e as localidades selecionadas para a pesquisa de campo.

De acordo com o exposto, os dados e categorias acima mencionados podem ser assim tabulados:

Tabela 10 - Distribuição de Faixa Etária por Localidade

\begin{tabular}{lcccccccccc}
\hline & \multicolumn{2}{c}{ Florianópolis } & \multicolumn{2}{c}{ Pelotas } & \multicolumn{2}{c}{ São Paulo } & \multicolumn{2}{c}{ Sorocaba } & \multicolumn{2}{c}{ Total } \\
\hline Jovem & 31 & $48 \%$ & 19 & $22 \%$ & 82 & $53 \%$ & 13 & $42 \%$ & 145 & $43 \%$ \\
Adulto & 31 & $48 \%$ & 56 & $64 \%$ & 68 & $44 \%$ & 17 & $55 \%$ & 172 & $51 \%$ \\
Sênior & 2 & $3 \%$ & 12 & $14 \%$ & 4 & $3 \%$ & 1 & $3 \%$ & 19 & $6 \%$ \\
\hline Total & $\mathbf{6 4}$ & $\mathbf{1 0 0 \%}$ & $\mathbf{8 7}$ & $\mathbf{1 0 0 \%}$ & $\mathbf{1 5 0}$ & $\mathbf{1 0 0 \%}$ & $\mathbf{3 1}$ & $\mathbf{1 0 0 \%}$ & $\mathbf{3 3 2}$ & $\mathbf{1 0 0 \%}$ \\
\hline
\end{tabular}

Observa-se que o número de informantes adultos é maior em duas das quatro localidades pesquisadas, com exceção de Florianópolis, em que o número de jovens e adultos é igual. Acredita-se que o número significativamente menor de informantes, seniores nas cidades de Florianópolis, São Paulo e Sorocaba deu-se em razão da forma como foram aplicados os questionários: nestas três cidades, $90 \%$ das entrevistas ocorreram nas ruas, local onde a incidência de transeuntes com mais de 60 anos, ou mais é menor do que de adultos e jovens, devido a limitações naturais impostas pela idade. Já em Pelotas, um número considerável de entrevistas foi realizado com pessoas de convívio próximo, ou seja, algumas pessoas conhecidas se prontificaram em aplicar os questionários em casa com os pais ou avós $^{47}$, aumentando, por esta razão, o número de entrevistados com idade superior a 60 anos, em relação às outras cidades.

Tabela 11 - Distribuição do Nível de Escolaridade por Localidade

\begin{tabular}{lcccccccccc}
\hline & \multicolumn{2}{c}{ Florianópolis } & \multicolumn{2}{c}{ Pelotas } & \multicolumn{2}{c}{ São Paulo } & \multicolumn{2}{c}{ Sorocaba } & \multicolumn{2}{c}{ Total } \\
\hline Fundamental & 7 & $11 \%$ & 10 & $11 \%$ & 1 & $1 \%$ & 5 & $16 \%$ & 23 & $7 \%$ \\
Médio & 33 & $52 \%$ & 29 & $33 \%$ & 26 & $17 \%$ & 19 & $61 \%$ & 107 & $32 \%$ \\
Superior & 24 & $38 \%$ & 48 & $55 \%$ & 127 & $82 \%$ & 7 & $23 \%$ & 206 & $61 \%$ \\
\hline Total & $\mathbf{6 4}$ & $\mathbf{1 0 0 \%}$ & $\mathbf{8 7}$ & $\mathbf{1 0 0 \%}$ & $\mathbf{1 5 4}$ & $\mathbf{1 0 0 \%}$ & $\mathbf{3 1}$ & $\mathbf{1 0 0 \%}$ & $\mathbf{3 3 6}$ & $\mathbf{1 0 0 \%}$ \\
\hline
\end{tabular}

Analisando a variável escolaridade, verifica-se que na cidade de São Paulo, os informantes com nível superior é expressivamente maior que o médio e o fundamental, o que pode ser explicado pelo fato de ter sido aplicado um grande número de questionários dentro

\footnotetext{
${ }^{47}$ Neste casos, todos inquiridores foram devidamente instruídos em como deveriam aplicar o questionário, de modo que não induzir as respostas.
} 
do campus da Universidade de São Paulo ${ }^{48}$. Já em Pelotas, não há justificativa plausível para a mesma constatação.

Em Florianópolis e Sorobaca, acredita-se que o maior número de informantes com ensino médio é condinzente com a faixa etária. O número inferior de informantes com ensino fundamental provavelmente se deve ao fato da pesquisa de campo não ter sido aplicada em áreas de baixa renda dos municípios selecionados ${ }^{49}$.

Tabela 12 - Distribuição da Naturalidade em cada Localidade

\begin{tabular}{llccccccccc}
\hline & \multicolumn{2}{c}{ Florianópolis } & \multicolumn{2}{c}{ Pelotas } & \multicolumn{2}{c}{ São Paulo } & \multicolumn{2}{c}{ Sorocaba } & \multicolumn{2}{c}{ Total } \\
\hline Natural & 40 & $63 \%$ & 64 & $74 \%$ & 89 & $58 \%$ & 22 & $71 \%$ & 215 & $64 \%$ \\
$\begin{array}{l}\text { Outra } \\
\text { Localidade }\end{array}$ & 24 & $38 \%$ & 23 & $26 \%$ & 65 & $42 \%$ & 9 & $29 \%$ & 121 & $36 \%$ \\
\hline Total & $\mathbf{6 4}$ & $\mathbf{1 0 0 \%}$ & $\mathbf{8 7}$ & $\mathbf{1 0 0 \%}$ & $\mathbf{1 5 4}$ & $\mathbf{1 0 0 \%}$ & $\mathbf{3 1}$ & $\mathbf{1 0 0 \%}$ & $\mathbf{3 3 6}$ & $\mathbf{1 0 0 \%}$ \\
\hline
\end{tabular}

Conforme exposto anteriormente, optou-se por não fazer a exclusão dos informantes que não natos das cidades pesquisadas. A decisão de considerá-los é corroborada pelos dados coletados, que evidenciam, nas quatro cidades selecionadas, maioria natural do município em questão, 64\%, o que pressupõe que os questionários efetivamente representam a opinião daquelas localidades.

Observa-se que a cidade de São Paulo apresenta um número menor de informantes natos. Acredita-se que este dado está diretamente relacionado ao fato desta cidade ser uma grande capital, o que proporciona condições favoráveis aos movimentos migratórios e, portanto, a uma maior heterogeneidade dos habitantes.

Tabela 13 - Distribuição do Gênero por Localidade

\begin{tabular}{lcccccccccc}
\hline & Florianópolis & \multicolumn{2}{c}{ Pelotas } & \multicolumn{2}{c}{ São Paulo } & \multicolumn{2}{c}{ Sorocaba } & \multicolumn{2}{c}{ Total } \\
\hline Feminino & 32 & $50 \%$ & 57 & $66 \%$ & 103 & $67 \%$ & 17 & $55 \%$ & 209 & $62 \%$ \\
Masculino & 32 & $50 \%$ & 30 & $34 \%$ & 51 & $33 \%$ & 14 & $45 \%$ & 127 & $38 \%$ \\
\hline Total & 64 & $\mathbf{1 0 0 \%}$ & 87 & $\mathbf{1 0 0 \%}$ & 154 & $\mathbf{1 0 0 \%}$ & 31 & $\mathbf{1 0 0 \%}$ & 336 & $\mathbf{1 0 0 \%}$ \\
\hline
\end{tabular}

Nas cidades de Florianópolis e Sorocaba, observa-se uma semelhança no resultado da distribuição por gênero, (50\% masc.), (45\% masc.), respectivamente. Acredita-se que esta semelhança se deve ao fato de que, em ambas as localidades, a grande maioria dos questionários foi aplicada no centro da cidade com os transeuntes.

\footnotetext{
${ }^{48}$ Este local também influenciou no número elevado de informantes jovens na cidade de São Paulo, variável apresentada na tabela anterior.

${ }^{49}$ Esta afirmação tem como base os dados do IBGE SIS 2010, em que há comprovação de que o rendimento familiar é determinante no acesso ao sistema educacional. Disponível em: http://www.ibge.gov.br/home/presidencia/noticias/noticia_visualiza.php?id_noticia=1717\&id_pagina=1. Acesso em: 04 de maio de 2012.
} 
Já em São Paulo, a presença da maioria dos informantes do gênero feminino (67\%) deve-se ao fato de que grande parte dos questionários foi aplicado nas dependências da $\mathrm{FFLCH}^{50}$, no curso de Letras, onde há uma incidência maior de mulheres que homens. Em Pelotas o número menor de informantes do gênero masculino deve-se aos locais onde foram aplicados os questionários ${ }^{51}$.

\subsubsection{Descrição e análise das respostas obtidas}

Conforme pode ser observado na Ficha do Informante exibida anteriormente, a pergunta realizada para os entrevistados foi:

Que nome você dá para a carne bovina preparada com sal que serve para fazer arroz carreteiro, escondidinho, feijoada, etc. Esta carne geralmente é vendida embalada à vácuo e não precisa de refrigeração?

A finalidade desse segundo questionamento foi aumentar a variedade das respostas para verificar outras formas de denominação para o mesmo objeto, além de possibilitar a ampliação do vocabulário relacionado ao charque, posteriormente incluído no glossário, e de suscitar outras análises.

Entretanto, as respostas obtidas foram esperadas, já que tais lexias estavam presentes nos dicionários e/ou documentos do corpus. Foram elas: carne-de-sol, carne seca, jabá, tajano, carne-de-vento, entre outras.

Tabela 14 - Respostas da pergunta 1 , por Localidade

\begin{tabular}{lcccccccccc}
\hline & \multicolumn{2}{c}{ Florianópolis } & \multicolumn{2}{c}{ Pelotas } & \multicolumn{2}{c}{ São Paulo } & \multicolumn{2}{c}{ Sorocaba } & \multicolumn{2}{c}{ Total } \\
\hline Charque & 33 & $52 \%$ & 82 & $94 \%$ & 12 & $8 \%$ & 1 & $3 \%$ & 128 & $38 \%$ \\
Carne Seca & 20 & $31 \%$ & 3 & $3 \%$ & 111 & $72 \%$ & 28 & $90 \%$ & 162 & $48 \%$ \\
Carne de Sol & 4 & $6 \%$ & 0 & $0 \%$ & 14 & $9 \%$ & 0 & $0 \%$ & 18 & $5 \%$ \\
Jabá & 1 & $2 \%$ & 0 & $0 \%$ & 6 & $4 \%$ & 2 & $6 \%$ & 9 & $3 \%$ \\
Não Sabe & 3 & $5 \%$ & 0 & $0 \%$ & 10 & $6 \%$ & 0 & $0 \%$ & 13 & $4 \%$ \\
Outros & 3 & $5 \%$ & 2 & $2 \%$ & 1 & $1 \%$ & 0 & $0 \%$ & 6 & $2 \%$ \\
\hline Total & $\mathbf{6 4}$ & $\mathbf{1 0 0 \%}$ & $\mathbf{8 7}$ & $\mathbf{1 0 0 \%}$ & $\mathbf{1 5 4}$ & $\mathbf{1 0 0 \%}$ & $\mathbf{3 1}$ & $\mathbf{1 0 0 \%}$ & $\mathbf{3 3 6}$ & $\mathbf{1 0 0 \%}$ \\
\hline
\end{tabular}

De acordo com a tabela acima indica-se uma tendência de utilizar a lexia charque no sul, constatada pelo número elevado $(94 \%)$ de respostas em Pelotas, em contraposição às cidades de São Paulo (8\%) e Sorocaba (3\%) onde prevalece a lexia carne seca.

Em Pelotas ocorreu um fato curioso relacionado ao emprego da lexia charque. Um dos informantes alegou, ao devolver o questionário, que optou por responder carne seca porque

\footnotetext{
${ }^{50}$ Faculdade de Filosofia, Letras e Ciências Humanas.

${ }^{51}$ Os questionários foram aplicados em duas grandes lojas de departamento de artigos femininos, uma clínica estética e em um parque infantil, sendo este um local frequentado quase exclusivamente por mães e babás.
} 
sabia que havia na cidade uma tendência ao charque, então, quis fornecer um dado diferenciado.

Outra observação, também em Pelotas, refere-se à lexia churrasco, fornecida por dois informantes. Acredita-se que o início da pergunta: que nome você dá para a carne bovina preparada com sal, induziu a essa resposta, dada a semelhança no modo de preparo.

Em Florianópolis, observa-se que há uma diferença menor entre as respostas carne seca $(31 \%)$ e charque (52\%), mas a parte majoritária dos informantes ainda optou pela segunda lexia.

No que se refere a "outros", as lexias fornecidas foram: carne a vácuo, frescal e carne temperada. É possível que estas respostas tenham sido dadas apenas com o intuito de evitar o uso da resposta "não sei”. Em São Paulo, a única lexia diferente das apresentadas na tabela foi carne salgada.

Tabela 15 - Respostas da pergunta 2, por Localidade

\begin{tabular}{lcccccccccc}
\hline & \multicolumn{2}{c}{ Florianópolis } & \multicolumn{2}{c}{ Pelotas } & \multicolumn{2}{c}{ São Paulo } & \multicolumn{2}{c}{ Sorocaba } & \multicolumn{2}{c}{ Total } \\
\hline Charque & 9 & $14 \%$ & 2 & $2 \%$ & 39 & $25 \%$ & 6 & $19 \%$ & 56 & $17 \%$ \\
Carne Seca & 13 & $20 \%$ & 21 & $24 \%$ & 22 & $14 \%$ & 3 & $10 \%$ & 59 & $18 \%$ \\
Carne de Sol & 16 & $25 \%$ & 14 & $16 \%$ & 58 & $38 \%$ & 6 & $19 \%$ & 94 & $28 \%$ \\
Jabá & 1 & $2 \%$ & 0 & $0 \%$ & 20 & $13 \%$ & 4 & $13 \%$ & 25 & $7 \%$ \\
Outros & 4 & $6 \%$ & 2 & $2 \%$ & 6 & $4 \%$ & 0 & $0 \%$ & 12 & $4 \%$ \\
Não Respondeu & 21 & $33 \%$ & 48 & $55 \%$ & 9 & $6 \%$ & 12 & $39 \%$ & 90 & $27 \%$ \\
\hline Total & $\mathbf{6 4}$ & $\mathbf{1 0 0 \%}$ & $\mathbf{8 7}$ & $\mathbf{1 0 0 \%}$ & $\mathbf{1 5 4}$ & $\mathbf{1 0 0 \%}$ & $\mathbf{3 1}$ & $\mathbf{1 0 0 \%}$ & $\mathbf{3 3 6}$ & $\mathbf{1 0 0 \%}$ \\
\hline
\end{tabular}

Observando a tabela das respostas à segunda questão, verifica-se que em Sorocaba, dos 31 entrevistados, 19 (61\%), apresentaram uma segunda lexia, sendo em igual número as ocorrências de charque e carne seca. Em São Paulo, dos 154 entrevistados, 143 (94\%) forneceram outras respostas, sendo a lexia carne se sol (38\%) maioria, seguida por charque (25\%), e, por último, tecnicamente empatados, carne seca e jabá. Em Florianópolis, dos 64 informantes, $43(67 \%)$ responderam conhecer outra lexia, sendo carne de sol a de maior ocorrência. Já em Pelotas, dos 87 entrevistados, apenas 39 (44\%) deles mencionaram outra lexia, o que indica um desconhecimento maior de outras formas de representação para a carne salgada e seca que não o charque. Ainda assim, dentre os que forneceram lexias complementares, a maior presença foi carne seca (24\%) e carne de sol (16\%), e não houve ocorrência para jabá.

Comparativamente, observa-se uma relação entre a primeira e a segunda respostas, que pode ser verificada nas tabelas abaixo: 
Tabela 16 - Respostas das perguntas 1 e 2 - Florianópolis

\begin{tabular}{lcccc}
\hline & \multicolumn{2}{l}{ Pergunta 1 } & \multicolumn{2}{c}{ Pergunta 2 } \\
\hline Charque & 33 & $52 \%$ & 9 & $14 \%$ \\
Carne Seca & 20 & $31 \%$ & 13 & $20 \%$ \\
Carne de Sol & 4 & $6 \%$ & 16 & $25 \%$ \\
Jabá & 1 & $2 \%$ & 1 & $2 \%$ \\
Não Sabe & 3 & $5 \%$ & 0 & $0 \%$ \\
Outros & 3 & $5 \%$ & 4 & $6 \%$ \\
Não Respondeu & 0 & $0 \%$ & 21 & $33 \%$ \\
\hline Total & $\mathbf{6 4}$ & $\mathbf{1 0 0 \%}$ & $\mathbf{6 4}$ & $\mathbf{1 0 0 \%}$ \\
\hline
\end{tabular}

Observa-se que, em Florianópolis, 33 informantes (52\%), forneceram charque como resposta 1, e $9(14 \%)$ para a resposta 2. Carne seca foi mencionada por 20 (31\%) como resposta 1 e $13(20 \%)$ como resposta 2 . Carne de sol foi a lexia mais respondida como secundária $(25 \%)$.

Como respostas alternativas, em que a tabela apresenta como outros, foram apresentadas respostas como: carne

Tabela 17 - Respostas das perguntas 1 e 2 - Pelotas

\begin{tabular}{lcccc}
\hline & \multicolumn{2}{c}{ Pergunta 1 } & \multicolumn{2}{c}{ Pergunta 2 } \\
\hline Charque & 82 & $94 \%$ & 2 & $2 \%$ \\
Carne Seca & 3 & $3 \%$ & 21 & $24 \%$ \\
Carne de Sol & 0 & $0 \%$ & 14 & $16 \%$ \\
Jabá & 0 & $0 \%$ & 0 & $0 \%$ \\
Outros & 0 & $0 \%$ & 2 & $2 \%$ \\
Não Respondeu & 2 & $2 \%$ & 48 & $55 \%$ \\
\hline Total & $\mathbf{8 7}$ & $\mathbf{1 0 0 \%}$ & $\mathbf{8 7}$ & $\mathbf{1 0 0 \%}$ \\
\hline
\end{tabular}

Em Pelotas considera-se alto o número de respostas 1 para charque (94\%), e também elevado o número de informantes que não respondeu à pergunta $2(55 \%)$. Carne seca é a resposta mais conhecida para a segunda pergunta (24\%), mas carne de sol é também bastante citada, em (16\%) das respostas. É curioso observar que Pelotas foi o único município que não apresentou a lexia jabá em nenhuma das perguntas.

Tabela 18 - Respostas das perguntas 1 e 2 - São Paulo

\begin{tabular}{lcccc}
\hline & \multicolumn{2}{c}{ Pergunta 1 } & \multicolumn{2}{c}{ Pergunta 2 } \\
\hline Charque & 12 & $8 \%$ & 39 & $25 \%$ \\
Carne Seca & 111 & $72 \%$ & 22 & $14 \%$ \\
Carne de Sol & 14 & $9 \%$ & 58 & $38 \%$ \\
Jabá & 6 & $4 \%$ & 20 & $13 \%$ \\
Outros & 10 & $6 \%$ & 6 & $4 \%$ \\
Não Respondeu & 1 & $1 \%$ & 9 & $6 \%$ \\
\hline Total & $\mathbf{1 5 4}$ & $\mathbf{1 0 0 \%}$ & $\mathbf{1 5 4}$ & $\mathbf{1 0 0 \%}$ \\
\hline
\end{tabular}


São Paulo apresenta a lexia carne seca na maioria das respostas à pergunta 1 , correspondendo a $72 \%$. Já para a pergunta 2, a lexia predominante foi carne de sol, com $38 \%$ das repostas. Atenta-se ao número elevado de informantes que forneceu mais de uma resposta, o que resultou em somente $6 \%$ que não informou resposta à pergunta 2 .

Tabela 19 - Respostas das perguntas 1 e 2 - Sorocaba

\begin{tabular}{lcccc}
\hline & \multicolumn{2}{c}{ Pergunta 1 } & \multicolumn{2}{c}{ Pergunta 2 } \\
\hline Charque & 1 & $3 \%$ & 6 & $19 \%$ \\
Carne Seca & 28 & $90 \%$ & 3 & $10 \%$ \\
Carne de Sol & 0 & $0 \%$ & 6 & $19 \%$ \\
Jabá & 2 & $6 \%$ & 4 & $13 \%$ \\
Outros & 0 & $0 \%$ & 0 & $0 \%$ \\
Não Respondeu & 0 & $0 \%$ & 12 & $39 \%$ \\
\hline Total & $\mathbf{3 1}$ & $\mathbf{1 0 0 \%}$ & $\mathbf{3 1}$ & $\mathbf{1 0 0 \%}$ \\
\hline
\end{tabular}

Sorocaba apresenta a mesma tendência da cidade de São Paulo, o que pode ser explicado pelo fato de serem cidades pertencentes ao mesmo Estado.

Porém, a diferença está no número de ocorrências para resposta 1 como carne seca (90\%) em Sorocaba, contrastando com os $3 \%$ de resposta charque, diferença relativa um pouco menor quando comparada à porcentagem de São Paulo (72\% e 8\%). As respostas número 2, estão bem distribuídas, sem que haja discrepância entre as quatro lexias citadas.

Fato curioso é não ter nenhuma ocorrência para carne de sol como resposta à pergunta 1 em Sorocaba (0\%), sendo essa lexia somente mencionada na pergunta 2, representando $19 \%$ das respostas obtidas.

\subsubsection{A lexia charque}

Ao analisar as respostas, visando um estudo detalhado das ocorrências da lexia charque na pergunta número 1, observa-se os resultados obtidos:

a) Distribuição por Faixa etária

Tabela 20 - Percentual lexia 'Charque' da pergunta 1, conforme Faixa Etária

\begin{tabular}{lccccc}
\hline & Florianópolis & Pelotas & São Paulo & Sorocaba & Total \\
\hline Jovem & $35 \%$ & $100 \%$ & $7 \%$ & $0 \%$ & $25 \%$ \\
Adulto & $65 \%$ & $93 \%$ & $7 \%$ & $6 \%$ & $45 \%$ \\
Sênior & $100 \%$ & $92 \%$ & $25 \%$ & $0 \%$ & $74 \%$ \\
\hline Média total & $\mathbf{5 2 \%}$ & $\mathbf{9 4 \%}$ & $\mathbf{8 \%}$ & $\mathbf{3 \%}$ & $\mathbf{3 8 \%}$ \\
\hline
\end{tabular}

Em Florianópolis, verifica-se que a ocorrência da lexia charque é maior na medida em que aumenta a faixa etária. Já em Pelotas, a faixa etária não influencia nas respostas, o que é 
percebido pela proximidade das porcentagens. E em São Paulo, os dados apontam influência da faixa etária, pois $25 \%$ dos seniores responderam charque, enquanto somente $7 \%$ dos jovens e dos adultos forneceram essa lexia.

Por fim, em Sorocaba não parece haver influência da faixa etária à lembrança da lexia charque. Porém, um dado curioso é que, se fossem também apresentados os dados referentes à charque como segunda resposta, seria possível verificar uma tendência de emprego dessa lexia entre os seniores, que apresentaram (74\%) de ocorrências dela como alternativa para carne seca. Já entre os jovens, esta proporção caiu para $25 \%$.

b) Distribuição por Escolaridade

Tabela 21 - Percentual lexia 'Charque' da pergunta 1, conforme Escolaridade

\begin{tabular}{lccccc}
\hline & Florianópolis & Pelotas & São Paulo & Sorocaba & Total \\
\hline Fundamental & $71 \%$ & $90 \%$ & $0 \%$ & $0 \%$ & $61 \%$ \\
Médio & $55 \%$ & $93 \%$ & $15 \%$ & $5 \%$ & $47 \%$ \\
Superior & $42 \%$ & $96 \%$ & $6 \%$ & $0 \%$ & $31 \%$ \\
\hline Média total & $\mathbf{5 2 \%}$ & $\mathbf{9 4 \%}$ & $\mathbf{8 \%}$ & $\mathbf{3 \%}$ & $\mathbf{3 8 \%}$ \\
\hline
\end{tabular}

Nas cidades de Florianópolis e Pelotas, não foi possível encontrar uma correlação entre o nível de escolaridade e as respostas fornecidas pelos informantes. Em São Paulo e Sorocaba parece haver uma tendência de informantes de ensino médio mencionarem a lexia charque mais do que as de ensino fundamental e superior.

Tabela 22 - Percentual lexia 'Charque' da pergunta 1, conforme Gênero

\begin{tabular}{lccccc}
\hline & Florianópolis & Pelotas & São Paulo & Sorocaba & Total \\
\hline Feminino & $44 \%$ & $93 \%$ & $4 \%$ & $6 \%$ & $34 \%$ \\
Masculino & $59 \%$ & $97 \%$ & $16 \%$ & $0 \%$ & $44 \%$ \\
\hline Média total & $\mathbf{5 2 \%}$ & $\mathbf{9 4 \%}$ & $\mathbf{8 \%}$ & $\mathbf{3 \%}$ & $\mathbf{3 8 \%}$ \\
\hline
\end{tabular}

Considerando a variável gênero, com exceção de Sorocaba, onde 100\% dos entrevistados que responderam charque à pergunta 1 foram do sexo feminino, não foi possível encontrar dados contrastantes. O que se observou nas outras três cidades pesquisadas é que parece haver uma predominância masculina ao mencionar a lexia charque. Em Sorocaba, acredita-se ser mais um problema de amostragem que um tendência natural. 


\subsubsection{Observações gerais}

Durante a aplicação do questionário e durante a tabulação dos dados ${ }^{52}$, algumas lexias fornecidas pelos entrevistados acabaram por chamar a atenção, por sua natureza destoante da resposta ou por levantar discussões e/ou questionamentos.

O primeiro caso relaciona-se com as respostas à questão complementar obtidas na cidade de Florianópolis. Um dos entrevistados realizou jabá como primeira resposta e a lexia encharque como segunda e, sendo ele natural da Amazônia, entende-se a opção de primeira resposta. O que chama a atenção é a lexia encharque, que suscita duas possibilidades: ou o informante cometeu um equívoco ao assimilar a lexia charque ou se trata de influência do verbo encharcar, grande problemática na etimologia da lexia charque, conforme citado na introdução desta tese.

Outra questão observada é a ocorrência da resposta jaó, na cidade de São Paulo, sendo este uso explicado pelo informante como sendo um caso de metonímia, em que a entrevistada menciona a marca de carne seca/charque mais conhecida na localidade onde reside, designando o produto.

Destaca-se jerked beef como outra lexia encontrada ao longo das pesquisa, com uma única ocorrência na cidade de São Paulo. Atenta-se ao fato de que, jerked beef, hoje em dia, é a designação mais encontrada nas embalagens a vácuo vendidas nos açougues e supermercados de todo o país. Como houve apenas uma ocorrência, não se pode afirmar que a denominação identifique para os consumidores o charque ou a carne seca.

No que se refere ao segundo questionamento proposto, respostas como carne louca, carne salgada, churrasco grego, bacon ou toucinho foram mencionadas pelos entrevistados. Acredita-se que, assim como ocorreu na primeira pergunta, alguns informantes preferiram fornecer uma resposta indiscriminada a deixar em branco ou fazer uso do "não sei".

\footnotetext{
${ }^{52}$ As tabelas contendo todos os dados levantados na pesquisa de campo estão apresentados no apêndice da tese, precedendo as referências bibliográficas.
} 


\section{CONSIDERAÇÕES FINAIS}

O objetivo geral desta tese foi estudar o vocabulário do charque no Sul do Brasil e propor uma discussão sobre a sua influência e contribuição na variedade e expansão da Língua Portuguesa.

Para viabilizar esse estudo, fez-se necessário, primeiramente, a composição de um corpus que fosse capaz de representar o vocabulário do charque. Após a realização de pesquisas bibliográficas e buscas em arquivos públicos, foram reunidos 138 documentos (manuscritos e impressos) dos séculos XVIII, XIX, XX e XXI, que apresentavam o charque como assunto central. Todos os documentos foram fac-similados, e, para facilitar a leitura e minimizar as dificuldades paleográficas nos documentos manuscritos, foi fornecida a edição semidiplomática, que também viabilizou o cotejo das edições.

Após a formação do corpus documental, foi realizada uma seleção de 211 lexias pertencentes ao vocabulário do charque, que foram dispostas em um glossário cuja elaboração teve como finalidade: apresentar as lexias de forma ordenada; definir as palavras e expressões dos vocábulos relacionados ao charque; contextualizar o uso desses vocábulos por meio de abonações extraídas dos documentos editados; e, por fim, fornecer informações e observações pertinentes à significação das lexias.

Para auxiliar tanto no suporte teórico-metodológico do estudo do corpus, quanto na composição estrutural glossário, optou-se por investigar outras fontes documentais, como obras sobre a história geral brasileira, atlas linguísticos e dicionários de Língua Portuguesa.

A bibliografia sobre a história geral brasileira auxiliou no estabelecimento das regiões para a compilação do corpus, além de sanar dúvidas e ampliar o conhecimento com relação à etimologia e contextualização histórica do charque.

A utilização dos atlas linguísticos foi indispensável como base metodológica para desenvolver a pesquisa de campo e para ampliar o arcabouço das lexias pertencentes ao vocabulário do charque.

E os dicionários de Língua Portuguesa, gerais, regionais e de usos, serviram como fonte de consulta para tecer as considerações referentes a esse estudo. Para ilustrar essa etapa utilizou-se o recurso de tabelas e análises descritivas, que demonstraram o caminho percorrido por cada uma das lexias em sua evolução histórico-lexicográfica. Considerou-se satisfatórios os critérios de seleção das dez obras lexicográficas e de suas edições, que levaram em consideração a datação, a nacionalidade e algumas características particulares a cada uma. 
$\mathrm{Na}$ estrutura do glossário buscou-se - além de fazer constar o aporte da área de lexicografia e da lexicologia - abarcar informações dos documentos, que foram utilizados como fontes para estabelecimento das lexias e elaboração das entradas, das acepções e das abonações.

O resultado foi a constituição de um glossário que se configura como um catálogo original do vocabulário do charque estudado. Nele também foi apresentado, como parte integrante dos verbetes, um estudo diacrônico das 211 lexias selecionadas.

A partir das tabulações, das análises qualitativa e quantitativa das lexias selecionadas, e das acepções extraídas das obras lexicográficas, foi possível identificar alguns padrões de ocorrências das lexias do vocabulário do charque, que permitiram o levantamento de hipóteses para responder as questionamentos levantadas na tese.

Ao se buscar nas obras lexicográficas as lexias selecionadas para o glossário, percebeu-se uma tendência dos dicionários portugueses à não ocorrência do vocabulário do charque. É preciso ressaltar que a data das obras de Bluteau, Moraes e Vieira coincide com o auge do Ciclo do Charque - séculos XVIII e XIX -, quando aconteciam as charqueadas do Sul, assim como a grande produção nordestina das carnes-de-sol e das carnes-do-ceará.

Observa-se, no gráfico abaixo, a porcentagem das ocorrências das lexias no glossário e as acepções não correspondentes. As porcentagens fornecidas abaixo foram calculadas da seguinte maneira: foi feita a soma do número relativo de ocorrências de $(--)^{53}$ nas obras por grupo $^{54}$ ao qual pertencem, e fez-se a média aritmética considerando a totalidade das lexias. Por exemplo: as obras portuguesas representadas por RB, AMS e DV, apresentam, respectivamente 130, 118 e 109 ocorrências da combinação (- -), em um total de 357 . Multiplicando as 211 lexias do glossário por 3 (quantidade de obras portuguesas), tem-se um total geral de 633 lexias. O percentual de 357 ocorrências, sobre as 633 lexias totalizam os $56 \%$ indicados no gráfico.

\footnotetext{
$53(--)=$ a obra não apresenta a lexia, tampouco a acepção correspondente à do glossário.

${ }^{54}$ Os grupos dos dicionários são: portugueses, brasileiros, de usos e regionais.
} 
Gráfico 2 - Distribuição de ocorrências das lexias e acepções não correspondentes (- -)

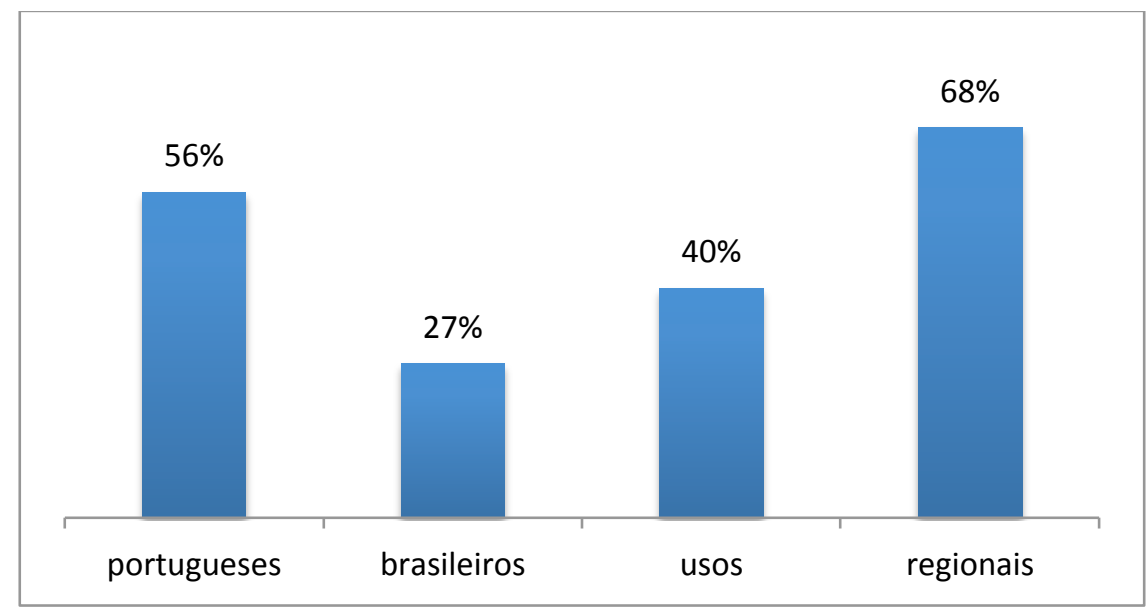

As frequências apontadas para as lexias evidenciam que as obras denominadas brasileiras - de Freire, Aulete, Ferreira e Houaiss - apresentam o índice de não correspondência mais baixo, indicando um crescimento de $29 \%$ (diferença entre $56 \%$ dos portugueses e os $27 \%$ brasileiros) de ocorrências de lexias do vocabulário do charque nos dicionários nos séculos XX e XXI.

Considerando que o Ciclo do Charque na década de 40, data da obra de Freire, estava em declínio, com um grande número de charqueadas desativadas e a indústria do charque em processo de extinção ${ }^{55}$. Pode-se inferir, portanto, que nesse período, mesmo com a diminuição na produção e consumo do charque, sua influência e seu vocabulário já havia se afirmado no uso e no léxico da língua brasileira.

O aumento de 13 pontos percentuais, obtidos da diferença entre $40 \%$ (usos) e $27 \%$ (brasileiros), levanta a hipótese de que, com a modernização da sociedade, a indústria do charque e os processos de comercialização de carne tenham sofrido mudanças significativas e, por isso, o conjunto de palavras relacionadas ao produto tenha caído em desuso.

No que se refere às obras regionalistas, o alto índice da combinação (- -) constatado mostrou-se inusitado. Esperava-se que, como a maioria dos documentos do corpus foi selecionada no Rio Grande do Sul e as obras escolhidas tratavam de assuntos diretamente ligados a esse Estado, elas apresentariam um alto índice de ocorrências das lexias componentes do glossário, e, consequentemente, um alto índice de correspondência entre as acepções.

As hipóteses para explicar os 68\% de ocorrência da combinação (- -) para as obras regionalistas partem do pressuposto de que os lexicógrafos $\mathrm{ZCN} / \mathrm{RCN}$ e $\mathrm{BB}$ não classificam

\footnotetext{
${ }^{55}$ Observa-se estas informações no documento número 45 do corpus, que trata sobre o fim do Ciclo do Charque.
} 
estas lexias como regionalistas, mas sim nacionais. Outra hipótese é que os próprios autores regionalistas não concedem ao charque e seu vocabulário um caráter relevante na história riograndense, não sendo, portanto, estabelecido como referência lexical.

Considerando a análise para o critério $(++)^{56}$ e $(+++)^{57}$, o gráfico abaixo ilustra uma situação oposta à observada anteriormente. Os critérios de elaboração são os mesmos empregados no anterior:

\section{Gráfico 3 - Distribuição de ocorrências das lexias e acepções correspondentes e/ou com a menção} à lexia charque $(++$ ou +++$)$

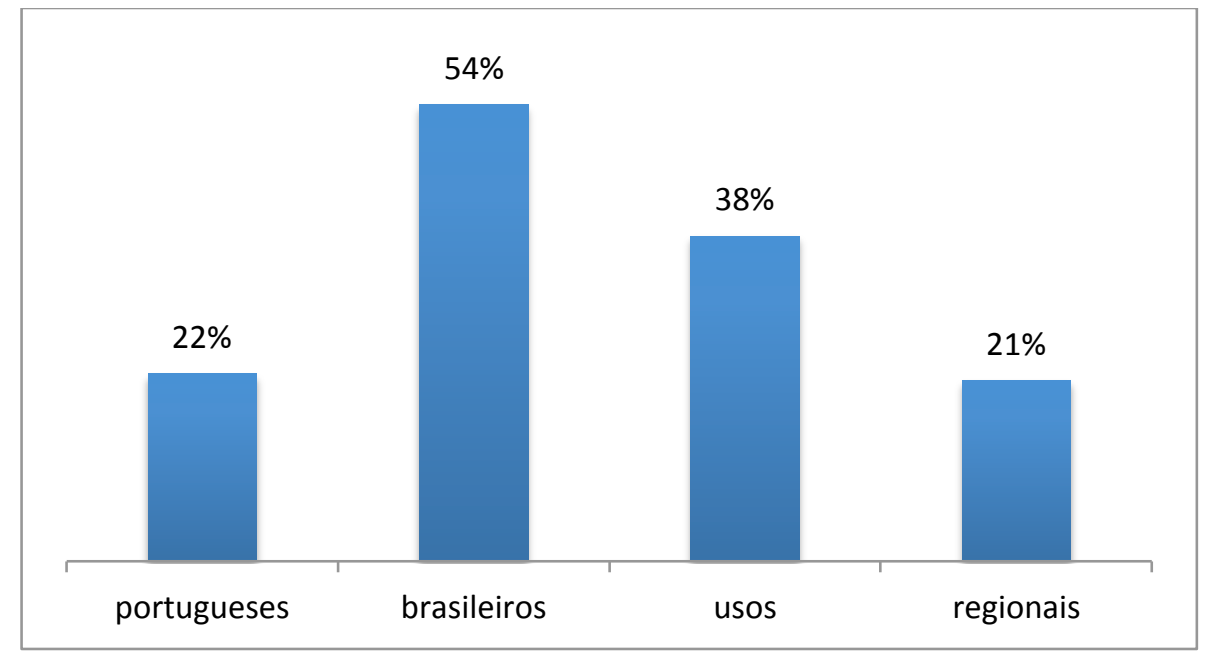

Ao analisar os percentuais acima, nota-se também baixa ocorrência de lexias e correspondências encontrada nas obras portuguesas. Observa-se que em relação a elas, as obras brasileiras apresentam um aumento de 32 pontos percentuais, o que reafirma a tendência das obras brasileiras de apresentar as palavras do vocabulário do charque e de citar a lexia charque nos verbetes. Acredita-se, também, que o número de semelhanças entre as lexias e acepções é maior nas obras brasileiras em decorrência do progresso dos estudos metodológicos lexicográficos e da inclusão de regionalismos.

A queda das ocorrências no dicionário de usos (38\%) reafirma a redução do uso das lexias na língua escrita no Brasil na segunda metade do século XX e início do século XXI, sendo, portanto, uma obra que não considera expressões mais arcaicas como os outros dicionários. O baixo percentual de ocorrências nas obras regionalistas são consoantes com as observações feitas a partir da análise do gráfico anterior, não apresentando incongruências nas análises.

\footnotetext{
${ }^{56}(++)$ = a obra apresenta a lexia e a acepção corresponde à do glossário.

$57(+++)$ = a obra apresenta a lexia, a acepção corresponde à do glossário e menciona a lexia charque no verbete.
} 
Portanto, as considerações acima observadas, aliadas ao uso de marcas diacrônicas ${ }^{58}$ e diatópicas ${ }^{59}$ nos dicionários gerais - apontam grande quantidade de lexias como em desuso ou empregadas somente no Sul do Brasil. Essa constatação é contraditória ao que se observa nas obras regionalistas: além da escassez de exemplos, nos verbetes das obras, mencionando o charque ou os estabelecimentos de charqueada ${ }^{60}$, elas apontam o charque e seu vocabulário como lexias de influência diminuta, pouco contribuindo na formação e variedade da Língua Portuguesa.

Esta tese também realiza o estudo documental e lexicológico para uma coleta e análise de material oral. A pesquisa de campo, realizada em quatro municípios de três Estados diferentes, abarcou um total de 336 informantes. Procurou-se, através das análises dos dados obtidos, evidenciar resultados que pudessem contribuir e reafirmar as considerações feitas sobre as influências do charque, principalmente no que se refere à expansão desta lexia na Língua Portuguesa.

O rigor metodológico da pesquisa de campo foi evidenciado na Ficha do Informante, desenvolvida com base nos estudos de atlas linguísticos - tomando como modelo o desenvolvido para o Atlas Linguístico Brasileiro (ALiB) - e levando em consideração critérios importantes para a seleção sociogeográfica, a forma da coleta dos dados, a escolha dos pontos de inquérito, já apresentados no desenvolvimento deste trabalho.

Com relação às oito variáveis sociolinguísticas analisadas, pode-se afirmar que o agrupamento de algumas delas, como faixa etária e grau de escolaridade, simplificaram a tabulação dos dados. Buscou-se, por meio da análise das tabelas fornecidas, promover uma conversão de informações em números absolutos e percentuais, de modo a facilitar o entendimento dos estudos.

Desta forma, ao retomar alguns dados descritos, observa-se que a pesquisa de campo, de modo geral, revelou que o gênero dos entrevistados, assim como o grau de escolaridade, não são variáveis relevantes. Ou seja, não foram encontrados nesses conjuntos quaisquer dados que pudessem ser usados para levantar hipóteses ou inferir respostas aos questionamentos iniciais da tese.

\footnotetext{
58 "São considerados diacrônicos os estudos, pesquisas, uma lingüística, na medida em que têm como ponto de vista a diacronia, i.e., a evolução dos fatos lingüísticos. São qualificados igualmente como diacrônicos todos os fatos considerados elementos ou fatores de um sistema em curso de evolução, como pertencente a estados diferentes de desenvolvimento." (DUBOIS et al., 2006, p. 182)

${ }^{59}$ Indicações que marcam o tipo geográfico do uso de uma lexia.

${ }^{60}$ Vários autores apresentam nos verbetes exemplos de uso de determinado instrumento em engenhos de açúcar. Lexias como balanceiro, caldeira, tanque etc. são apontadas como usuais neste tipo de estabelecimento, e, raramente é dado como exemplo os estabelecimentos saladeris.
} 
O questionário aplicado nas localidades, tencionou, como resposta à pergunta $1^{61}$, a lexia charque. Os resultados obtidos estão expostos a seguir.

Parte-se de Pelotas para início das análises, por ser considerada a cidade núcleo das charqueadas, onde foram tabulados os seguintes números: das 336 entrevistas, 87 foram realizadas nesse município, representando $26 \%$ do total. Destes 87 informantes, 82 responderam charque, o que representa um total de $94 \%$ das respostas. As respostas restantes dividem-se em carne seca e churrasco, sendo que para as duas ocorrências de churrasco levanta-se a hipótese de falha no entendimento da questão, já que foram proferidas pelos informantes seniores. Pode-se afirmar, portanto, que o baixíssimo número de respostas divergentes da esperada comprova a influência direta e expressiva do charque no léxico desta localidade.

Em Florianópolis, das 336 entrevistas, foram aplicados os questionários com 64 informantes, representando assim19\% do total. As respostas obtidas foram as seguintes: 33 pessoas, que equivalem a $52 \%$ dos informantes, responderam charque para a pergunta feita, sendo carne seca a segunda lexia mencionada por 20 informantes, em um total de $31 \%$. Respostas como carne de sol, jabá, carne salgada e carne de feijão também foram mencionadas. Este resultado foi satisfatório, pois como Florianópolis é a capital do Estado vizinho ao Rio Grande do Sul, esperava-se encontrar uma influência média do charque no léxico deste município.

Na cidade de São Paulo, em um total de 154 entrevistas, que representaram $46 \%$ do total de questionários aplicados, apenas $12(8 \%)$ dos informantes responderam charque. Em contrapartida, a lexia carne seca foi mencionada por 111 informantes, o que corresponde a $72 \%$ das entrevistas. O baixo percentual de ocorrência de charque era esperado, já que a experiência pessoal da pesquisadora nessa cidade apontava para um (des)conhecimento em massa da lexia charque.

Assim, os dados provenientes da pesquisa de campo nessa localidade corroboraram com as expectativas, o que comprova que a lexia charque e o vocabulário que a envolve exerce uma influência muito pequena em São Paulo. Atenta-se ao fato de que a menção à lexia charque foi expressiva nos informantes com faixa etária superior a 60 anos, representando $25 \%$ das 12 respostas obtidas. Se comparada aos $7 \%$ de ocorrências entre os jovens e $7 \%$ entre os adultos, pode-se inferir a hipótese de que o charque ainda exerça

\footnotetext{
${ }^{61}$ Pergunta número 1: Que nome você dá para a carne bovina preparada com sal que serve para fazer arroz carreteiro, escondidinho, feijoada, etc. Esta carne geralmente é vendida embalada à vácuo e não precisa de refrigeração?
} 
alguma influência em pessoas mais velhas, provavelmente por elas apresentarem algum resquício histórico de convivência com este produto.

Esperava-se que os resultados da aplicação do questionário no município de Sorocaba, quarta localidade entrevistada, fossem distribuídos de maneira igualitária. Das 336 entrevistas, 31 (9\%) foram feitas nesse município. A resposta para a lexia charque foi fornecida por apenas 1 informante (3\%), contrapondo com as $28(90 \%)$ respostas para a lexia carne seca. Levanta-se a hipótese de que este informante não forneceu a resposta carne seca em decorrência de ele ser natural da cidade de Espírito Santo do Pinhal (localidade vizinha à Sorocaba), analfabeto e, assim como em São Paulo, apresentar a influência da lexia devido à idade: 82 anos.

Considerando as leituras realizadas sobre o charque como um bem de consumo e exportação e sua forte ligação histórica e econômica com o movimento tropeiro, as feiras de gado e os rodeios durante o Ciclo do Charque, esperava-se encontrar uma maior influência do charque e do vocabulário nesta cidade.

Por fim, após analisar os dados levantados nas pesquisas de campo, nos estudos lexicográficos e históricos e nas observações gerais realizadas nesta tese, pode-se levantar que a influência do charque no Sul do Brasil, especificamente no Estado do Rio Grande do Sul foi mais expressiva do que nos estados vizinhos. Sua contribuição na variedade e expansão da Língua Portuguesa diminui consideravelmente ao longo do tempo e enfrenta embargo pelo espaço geográfico e pela história social de cada localidade, de forma que sua expansão lexical pode ser considerada, atualmente, como restrita às fronteiras dos campos sulistas.

Salienta-se que a conclusão destes estudos, para se afirmar de forma categórica o grau de influência do vocabulário do charque, necessita de uma pesquisa de campo que abranja um maior número de lexias do vocabulário estudado, percorrendo os municípios envolvidos nos caminhos das tropas e de comércio do charque em geral. Desta forma, poderia-se trazer mais elementos históricos, culturais e linguísticos, assim como mais dados que permitiriam não só o levantamento de hipóteses, mas também resultados mais conclusivos. Contudo, as pesquisas realizadas nesta tese satisfazem os objetivos propostos e abrem espaço para estudos posteriores acerca do tema. 
APÊNDICE 
RESULTADOS DAS PESQUISAS DE CAMPO 


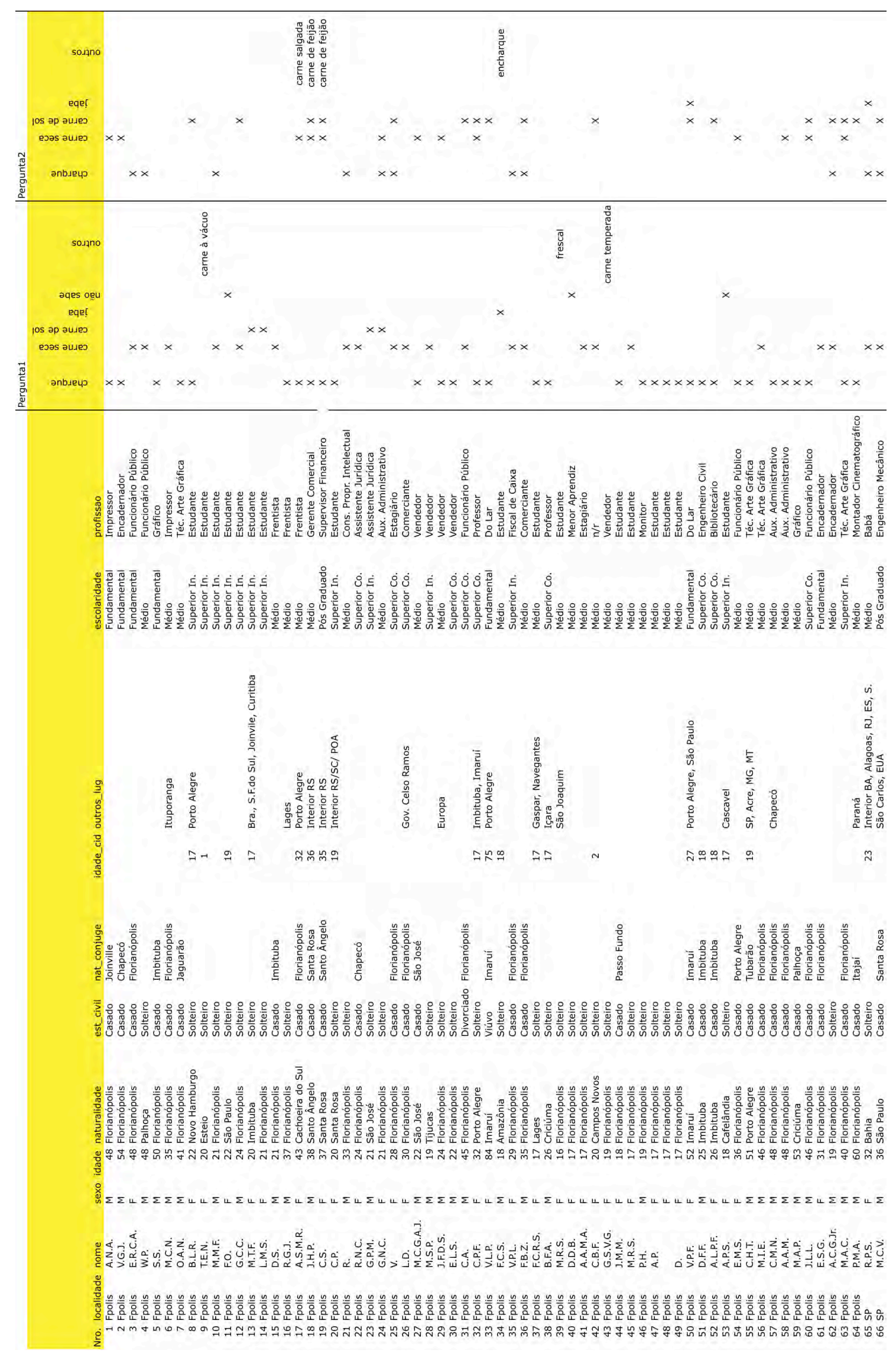




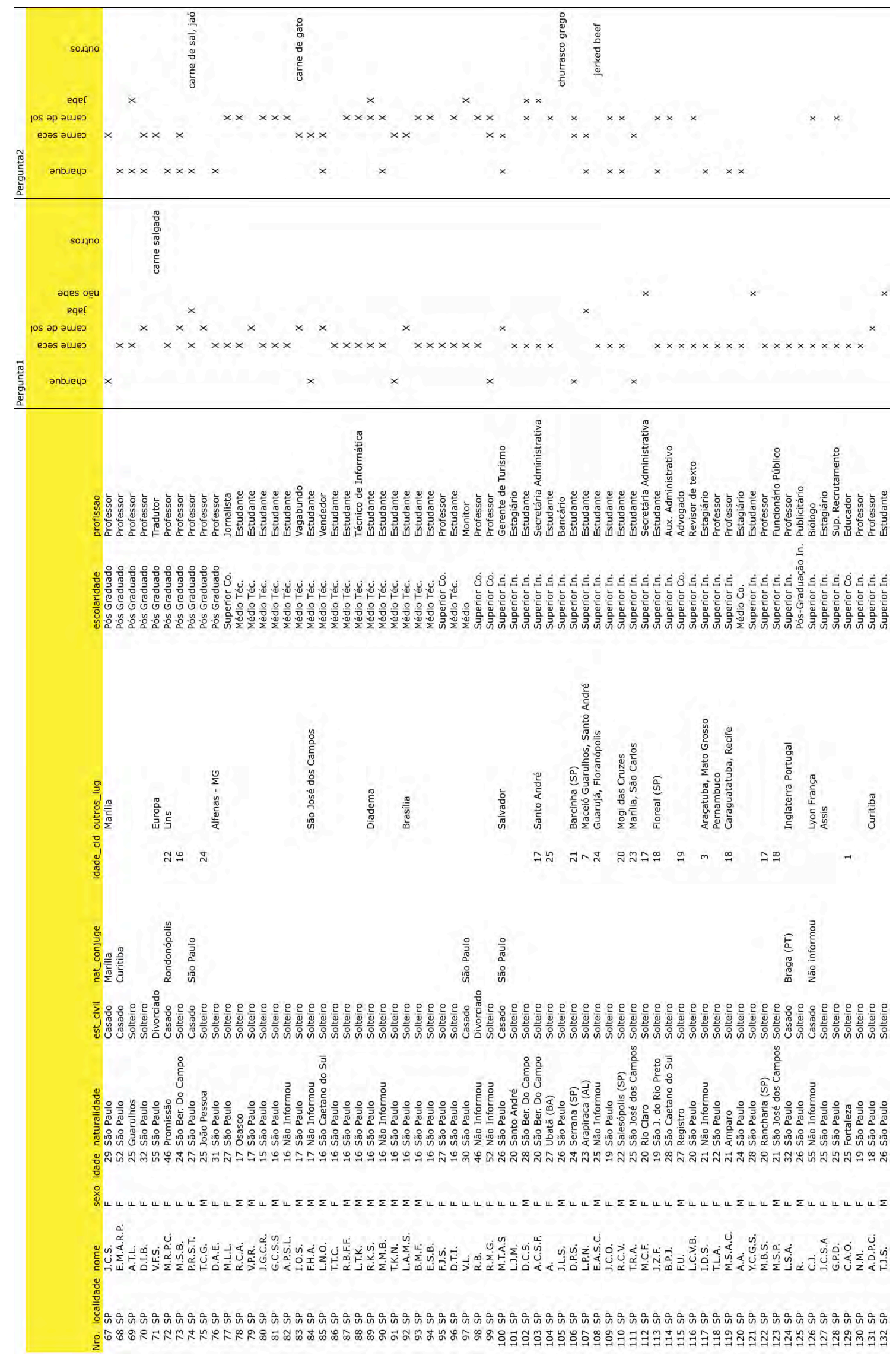



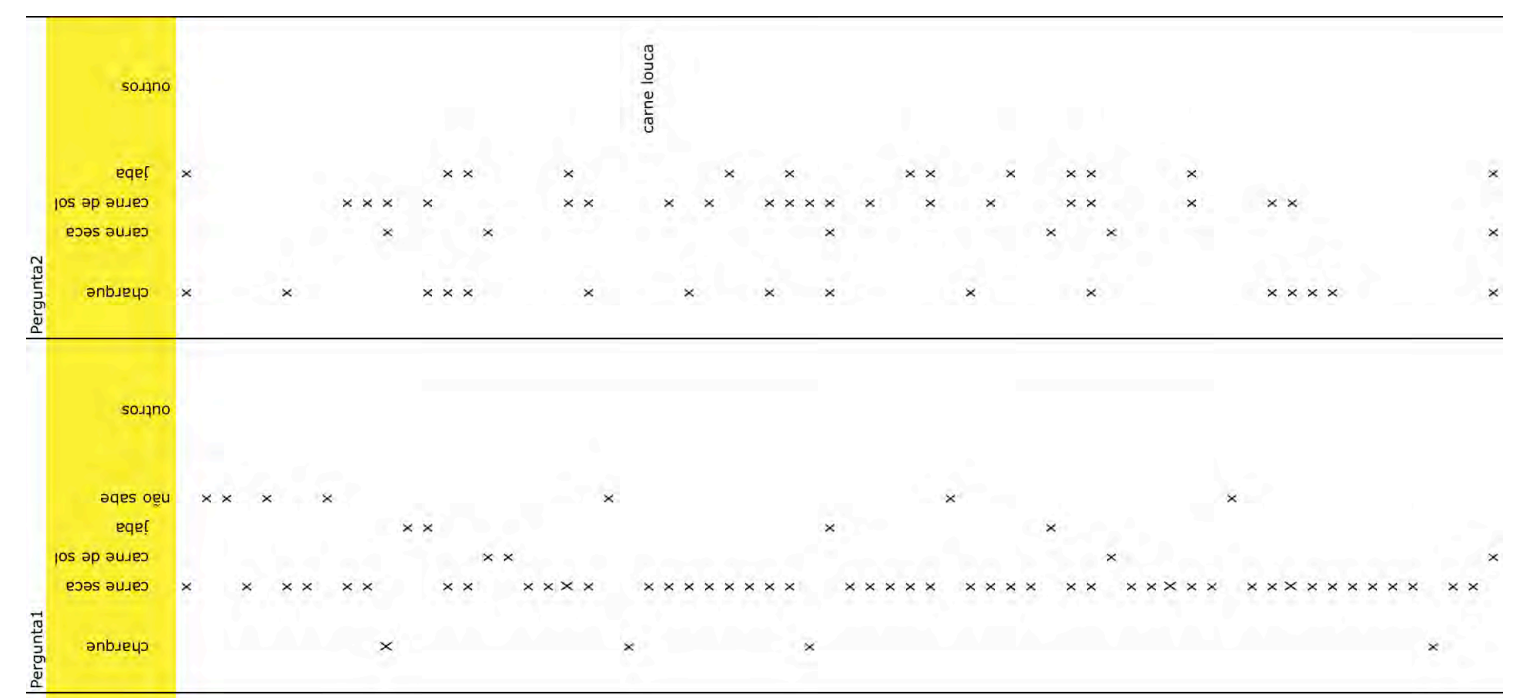

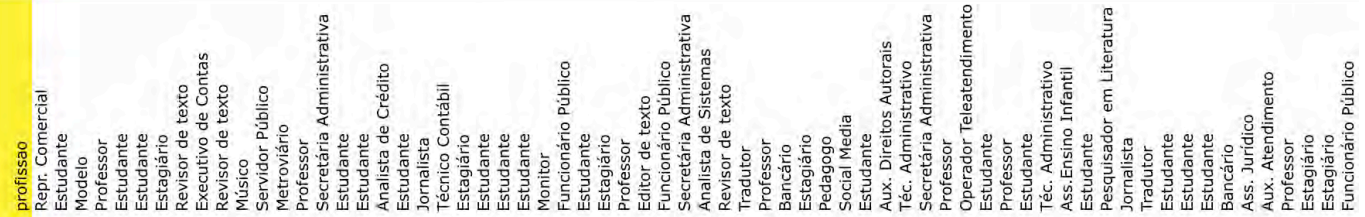

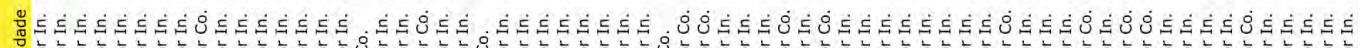

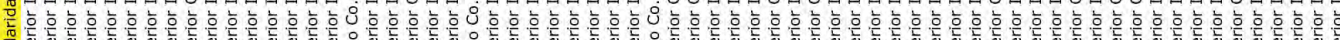

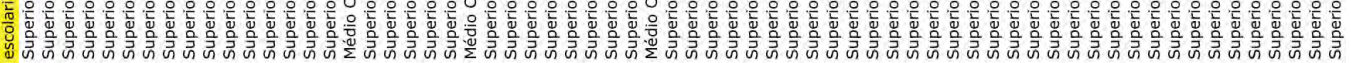

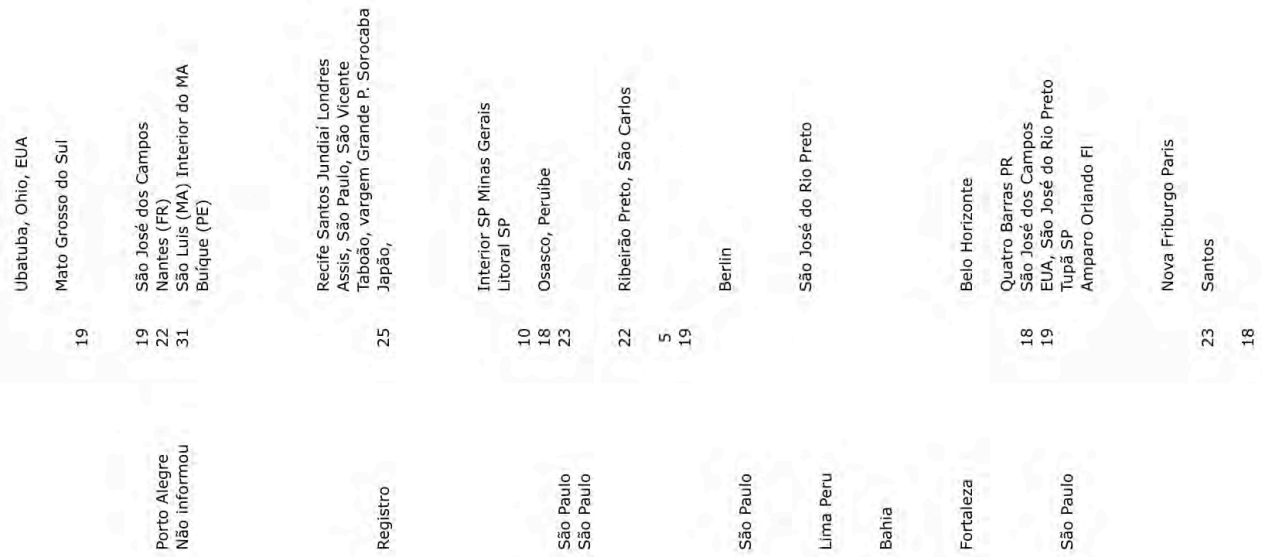

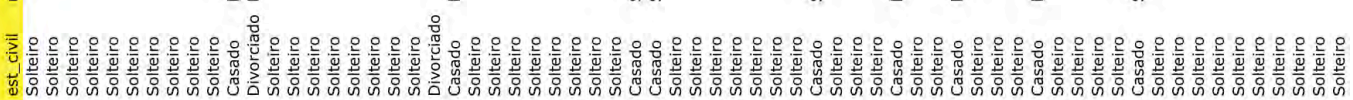
Une

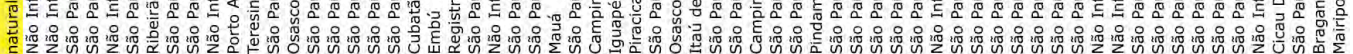

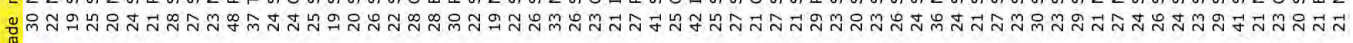
(ᄄ)

\&

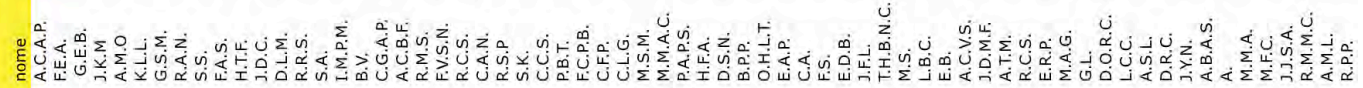
密

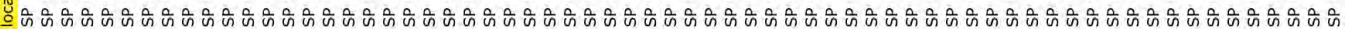

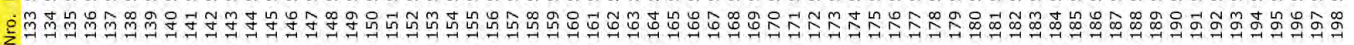




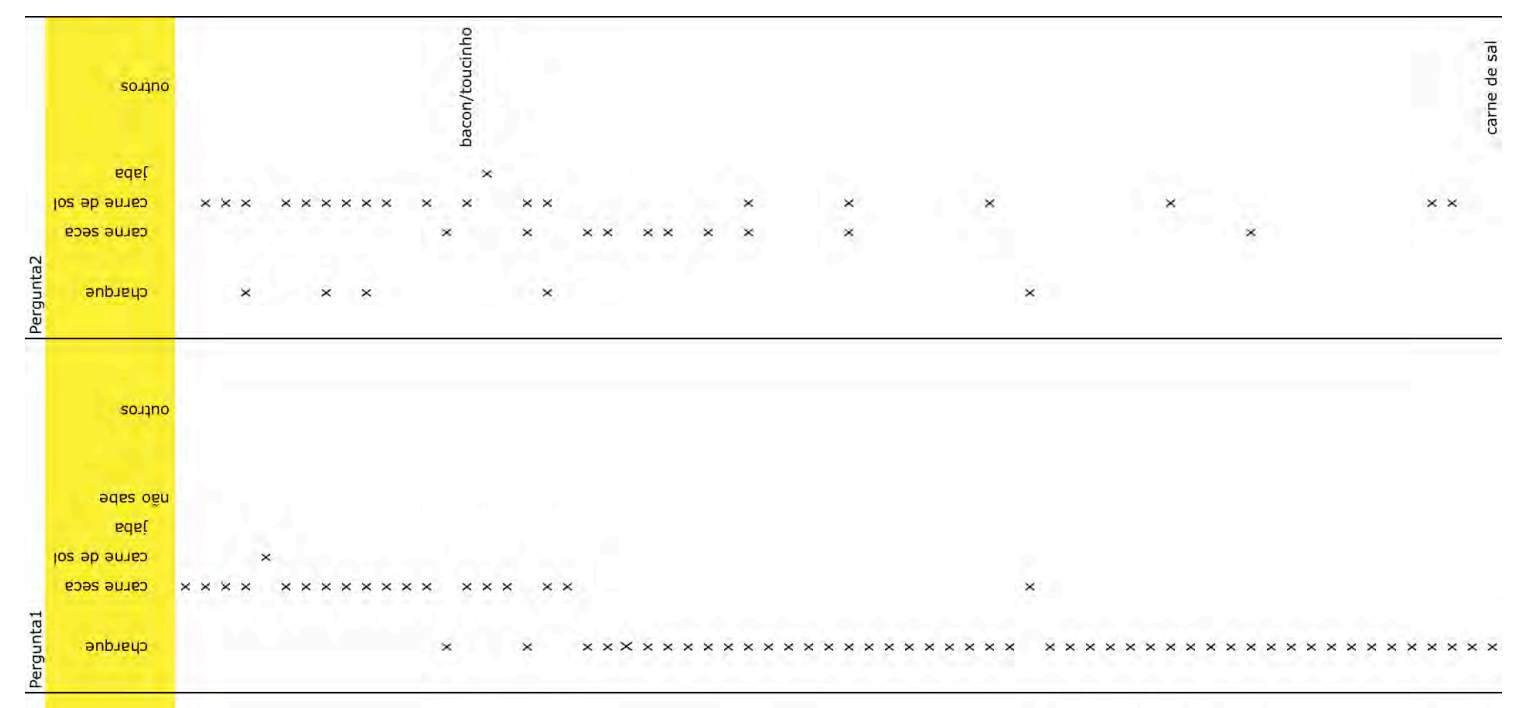

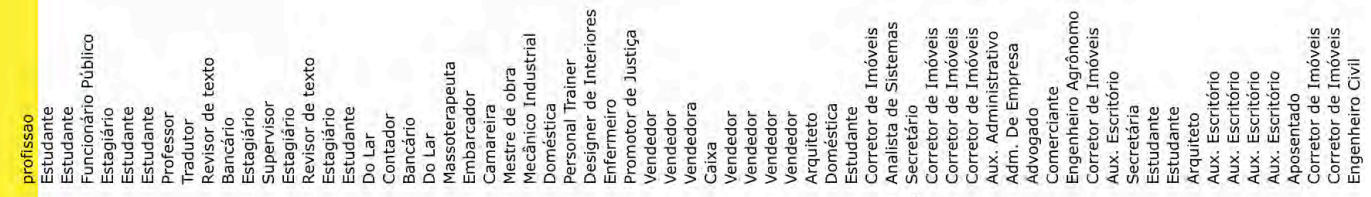

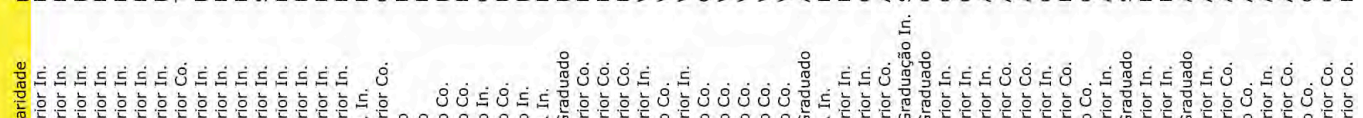

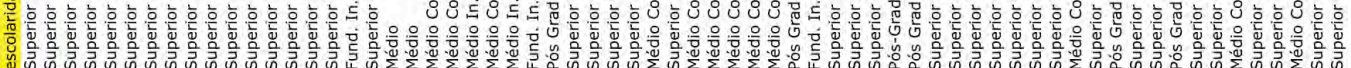

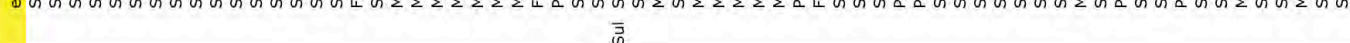

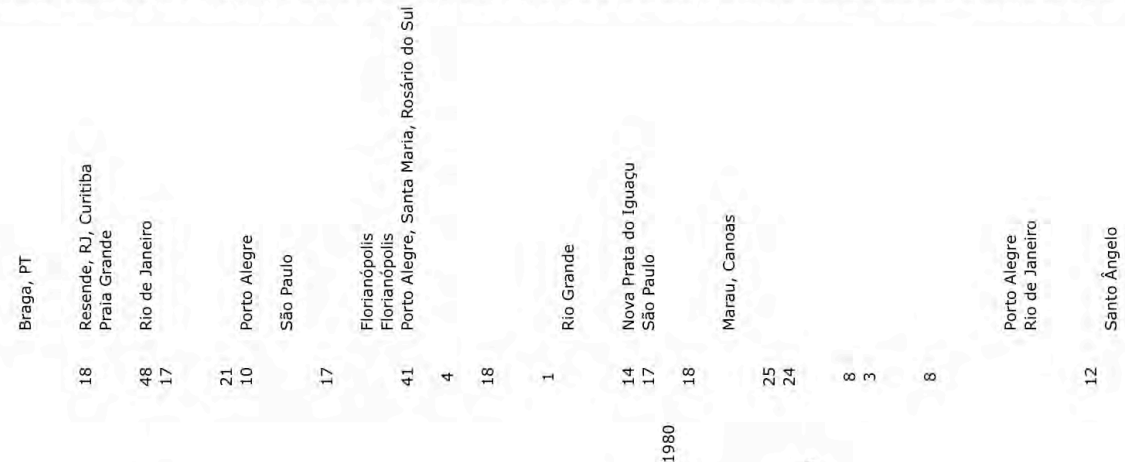

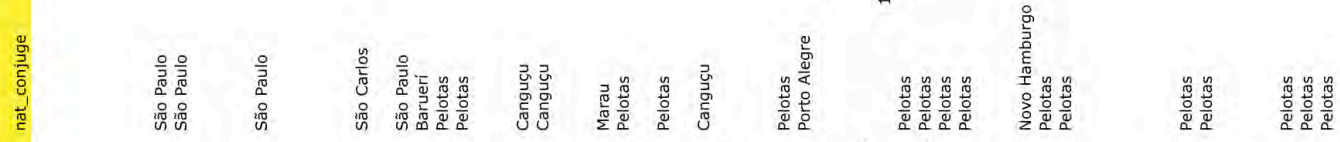

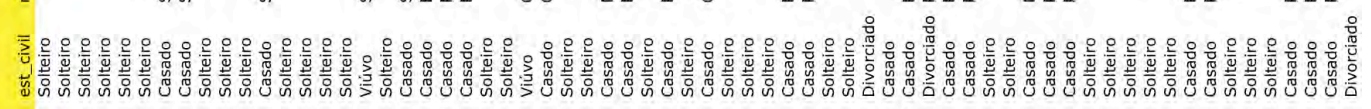

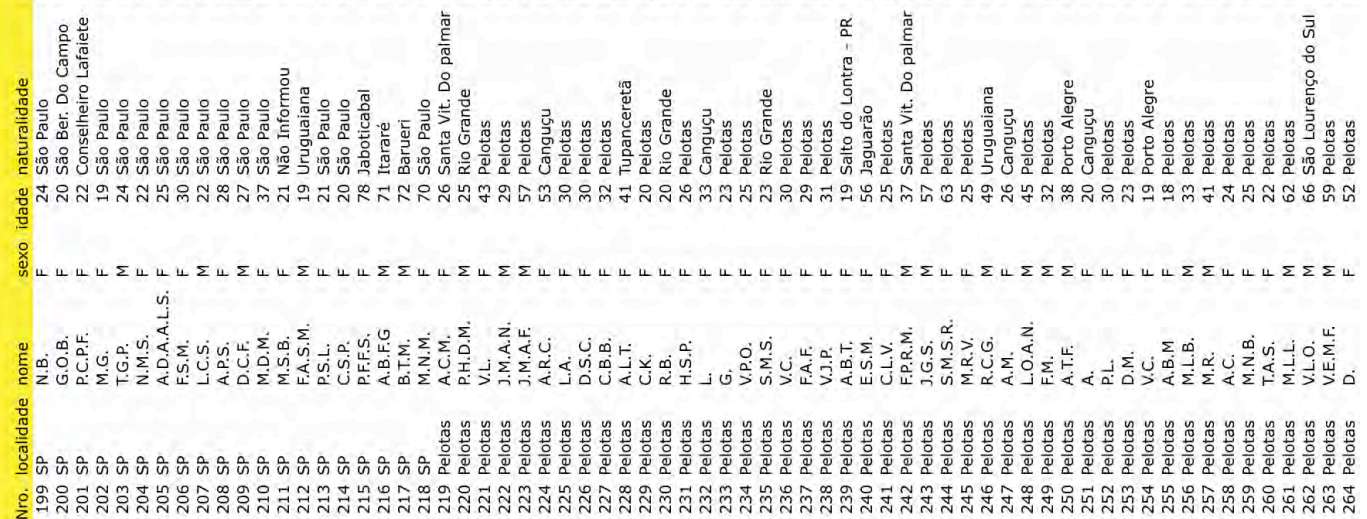




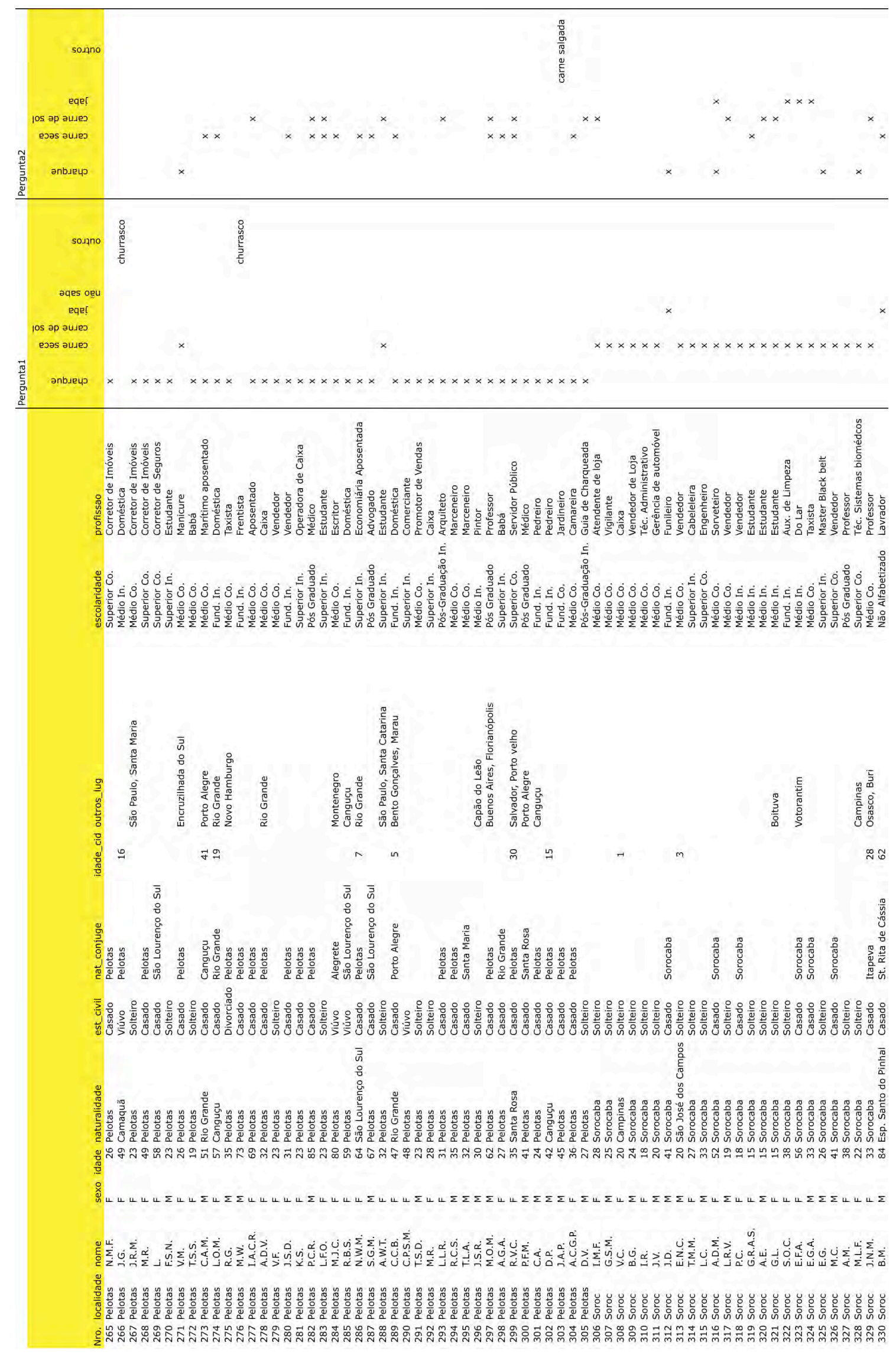




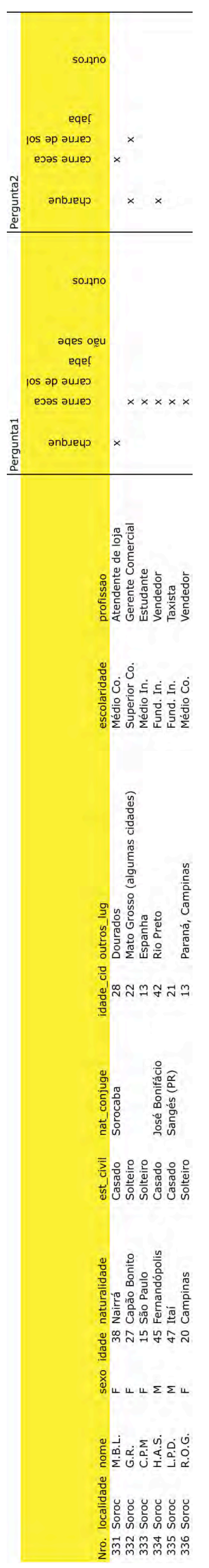




\section{RESUMO DOS DICIONÁRIOS}

\section{Raphael Bluteau}

\section{Vocabulario Portuguez e Latino}

Datado em 1712, o dicionário pode ser considerado um marco nos estudos do léxico da Língua Portuguesa. O autor era "clérigo regular, doutor na sagrada teologia, pregador da rainha da Inglatérra, Henriqueta Maria de França e calificador no sagrado tribunal da Inquisição de Lisboa." Estes dados biográficos encontram-se ao pé da primeira página, em letras pretas e vermelhas, na edição facsimilada da publicação impressa em um total de 10 volumes, em 2002.

O volume $1^{62}$ foi impresso em Coimbra, no "Colegio das Artes da Companhia de Jesu", ano de 1712. As especialidades do dicionário em questão são listadas logo abaixo do título da obra, em total de 57 que vão do aulico até o zoológico. Consta também, nesta folha de rosto, as informações dos exemplos das acepções, que, segundo o autor, foram autorizadas e coletadas dos melhores escritores portugueses e latinos.

O dicionário é oferecido ao "Muyto Alto e Muyto Poderoso" rei de Portugal, Dom João V. A seguir, a obra apresenta uma extensa carta escrita em Alcobaça, datada de 28 de março de 1711, dirigida ao monarca onde o autor explica as origens de seu trabalho, que iniciou 30 anos atrás e ressalta que espera que o rei tenha, com a obra, uma margem das idéias de sua duplicada eloquência. Fazendo uma narrativa sobre a afinidade do português com o latim, o autor observa que este é a fonte da Língua Portuguesa e que é imprescindível a um autor de dicionário, pois é dele provêm muitas cópias de palavras épicas. Bluteau informa que as entradas estarão em ordem alfabética, observando que esta é própria deste gênero.

Este primeiro volume apresenta, então, as cópias traduzidas de algumas cartas que foram dirigidas ao autor, dentre elas a carta que o calificador do Santo Ofício, o Prior e Cancelário da Universidade de Coimbra autoriza a impressão dos volumes por não ter encontrado nada que desabonasse os bons costumes e pureza da santa fé.

Após o aval da censura, o dicionário apresenta alguns sonetos e o prólogo do autor. Dirigido a todo gênero de leitores, seguido do prólogo dedicado ao leitor benévolo, malévolo, impaciente, português, estrangeiro, douto, indouto, pseudocrítico, impertinente e, por fim, ao leitor mofino. O prólogo encerra-se da seguinte maneira "Parece, que com estas razoens

\footnotetext{
${ }^{62}$ Considera-se a obra facsimilada. Os dados de impressão e local das edições não é a edição de 2002 e sim a que estiver na folha de rosto de cada volume.
} 
tenho provado, que para servir a Republica das letras, não poupei, nem trabalho, nem dinheiro; \& o que mais he, do trabalho, que tomei, \& do dinheiro, que gastei, não espero premio algum; porque como as boas letras se chamam, \& sam, Artes Liberaes, tudo nellas ( para amofinar mofinos) deve ser liberalidade, defenterece, \& grandeza." 63

A seguir a obra compõe-se do catálogo alfabético, topográfico e cronológico dos autores portugueses citados pela maior parte da obra, seguido do catálogo dos autores portugueses, segundo as matérias que tratam. As abreviaturas das citações dos livros portugueses, a declaraçāo, a sumária notícia dos antigos autores latinos citados na obra (para exemplares da boa latinidade), assim como as abreviaturas das citações dos autores latinos e sua declaração, encerram a parte inicial de apresentação da obra.

O autor, antes de apresentar as entradas do dicionário, descreve a letra que irá listar, sendo que todas apresentam o subtítulo: "letra elementar, portugueza e scientifica". Nesta descrição trata de sua parte fônica e fonética, as origens da letra, como esta se comporta em outras línguas, sua representação gráfica, simbologia etc. Este volume 1, inicia só então a marcação de páginas com o léxico pertencente à letra $a$, com o número cardeal 5 , encerrando o volume na página 698 com um desenho de flores.

O volume 2 referente ao léxico das letras $b$ e $c$ apresenta a mesma folha de rosto do volume 1 e imediatamente à folha de rosto, inicia outra página já com a letra $b$, que apresenta as entradas da página 3 a 215. A letra $c$ inicia na página 3 e encerra na página 654 com um desenho grande de um vaso de flor.

O volume 3, exibe as entradas do léxico das letras $d$ e $e$. A folha de rosto varia das anteriores somente no ano, constando a data em numeral romano, MDCCXIII (1713). Este volume divulga um laudo que verifica o vocabulário, as licenças deferidas pela Ordem do Clérigo, do Ordinário e do Santo Ofício. Também apresenta as autorizações da censura de alguns calificadores, contendo os pareceres, licenças e despachos sobre a obra. A letra $d$ inicia-se, na página marcada com o número cardinal 1 e vai até a 319, que encerra-se com a inscrição latina FINIS I e também um desenho com dois anjos e inscrições latinas. O léxico pertencente à letra $e$ reinicia a marcação na página 1 e encerra-se na 407 com a palavra latina FINIS e o mesmo desenho mostrado ao final da letra $c$.

As lexias de letra $f, g, h, i$ e $j$ fazem parte do volume 4. A folha de rosto é igual a do volume 3 e seus aspectos estruturais se assemelham ao anterior, a dizer, este volume contém todas as licenças, despachos e autorizações necessárias para a publicação da obra. As palavras

\footnotetext{
${ }^{63}$ Transcrição diplomática do trecho que encontra-se no prólogo da obra, sem marcação de página.
} 
com a letra $f$ iniciam na página 1 e encerram-se na página 243 , contendo um desenho de um brasão pequeno e o reclame $L E T R A^{64}$. O léxico composto pela letra $g$ inicia com o numeral cardinal 1 e vai até a página 237 com a inscrição FINIS e a figura de brasão grande. A letra $\mathrm{h}$ e o léxico que compõe, recebe sua descrição, seguindo as normas das letras anteriores, reiniciando sua marcação de páginas com o número 1, encerrando na 91 com a inscrição FINIS e a figura de vaso de flor grande igual à letra anterior.

O léxico formado pela letra $i$ inicia na página 1 e vai até a 187. A letra $j$ e as palavras que iniciam com esta letra são apenas inseridas na página seguinte, com as entradas correspondentes, até a página 236. Uma vez que as letras $i$ e $j$ nesta época eram consideradas a mesma letra, o dicionário apresenta consecutivamente em ordem alfabética o léxico iniciado em: jux, juz, ize, izo e encerra a página 237 com o desenho de um brasão em tamanho grande e a inscrição latina FINIS.

O volume 5 apresenta o início da folha de rosto igual aos volumes anteriores, entretanto, este volume indica sua impressão em Lisboa, na "Officina de Pascoal da Sylva", impressor de sua magestade, datado em MDCCXVI (1716). A obra é formada pela exposição de uma epigrama, uma glossa, uma epígrafe de títulos, as licenças de aprovação. Este volume apresenta, pela primeira vez, as erratas e emendas dos 4 primeiro volumes. Não constam entradas de lexias com a letra $k$, mas esta aparece descrita como as anteriores, com um brasão desenhado e o reclame LETRA. A letra $l$ e o léxico que a compõe inicia na página 3 (presumese que a marcação tenha iniciado na letra $k$, que ocupou duas páginas) e vai até a 223 que apresenta no canto inferior direito o reclame: $L E_{-}$. As entradas que iniciam com a letra $m$ apresentam marcação de página consecutiva, a dizer, $225^{65}$ até 654 , que termina com um desenho de um vaso médio de flores e o reclame: $L E_{-}$. A seguir são apresentadas as entradas pertencentes à letra $n$ com paginação corrida iniciando em 655 até 778 com a inscrição em latim: FINIS LAUS DEO. e um desenho grande de vasos e flores.

O volume 6 apresenta a mesma folha de rosto, indicando sua impressão em Lisboa, na “Officina de Pascoal da Sylva", impressor de sua magestade, porém datado em MDCCXX (1720). Este contém as licenças necessárias para a publicação e o léxico referente à letra $o$ inicia na página 1 até 166 com o desenho do brasão e reclame LETRA. As entradas com a letra $p$ mantêm a contagem das páginas em forma corrida, iniciando em 167 e encerrando na página 839 com a inscrição latina: LAUS DEO. O volume 7 foi impresso no mesmo ano e

\footnotetext{
${ }^{64}$ Esta inscrição apresenta as características de reclame, mas na página seguinte por se tratar do início da letra g, a palvra que inicia a página é

${ }^{65}$ A página 224 está em branco, mas foi considerada na sequência numérica.
} 
apresentando um número inferior de licenças que o anterior. O léxico formado pela letra $q$ inicia a contagem das páginas no número 1 e termina na página 75, com a marcação do tomo: TOM VII e Reclame LE. Ao iniciar a letra $r$, a formatação do dicionário muda, e, durante sua descrição não há o uso de duas colunas, como foi usado até então. A marcação de páginas é contínua, iniciando na página 76 terminando na 403, onde se vê um desenho de um anjo tocando trombetas e a marcação $S$. $L E$-. As palavras iniciadas com a letra $s$ também aparece em numeração contínua, sendo da 404 até a página 824, com a inscrição LAUS DEO.

O oitavo volume apresenta a folha de rosto igual às demais, sendo a única diferença o local e data da impressão. Este volume apresenta a indicação de "Lisboa Occidental, na Officina de Paschoal da Sylvia, impressor de sua magestade, MDCCXXI" (1721), apresentando as licenças e aprovações e também outras erratas e emendas dos 4 primeiro volumes impressos em Coimbra. Estas emendas e erratas são diferentes das que estão na introdução do quinto volume. A letra $t$ aparece descrita inicialmente em texto corrido e não em duas colunas, como comumente foi feito. A paginação inicia no número 1 e termina na página 340, com um desenho de um vaso de flor e as inscrições V.LE. O léxico referente à letra $v$ inicia com texto corrido, a marcação de páginas é continuado, iniciando na página 341 finalizando na 585. Como na época, as letras u e v eram consideradas a mesma letra, entradas com a letra $u$ são usadas para apresentar somente alguns topônimos e poucos são os substantivos e verbos descritos no dicionário. As entradas com $v$ e $u$ alternam-se das páginas 586 até 606, terminando com a inscrição: X.LE. A letra $x$ inicia-se na 607 e termina na 618 com um desenho de vaso de flor com o reclame: $Y L E$. A letra y é apresentada e constituída de seu léxico em apenas 3 páginas, a dizer, da 619 a 621 com o desenho de flor e o reclame: Z.LE. Há um erro observado no que diz respeito à paginação das entradas da letra $z$. Ao invés de constar como 622, a letra $z$ continua a marcação de páginas apontada como 620, terminando na 653.

Na página 653 do volume 8 é apresentado o Diccionario castellano, y portuguez, para facilitar a los curiosos La noticia de la lengua latina, com el uso del Vocabulario Portuguez, y Latino. De acordo com as informações abaixo do título do dicionário que se segue, este dicionário castelhano foi feito por ordem de Rei de Portugal, Dom Juan V. Na página 3 do dicionário é apresentado um discurso que foi intitulado: Prosopopeia del idioma Portuguez, a su hermana la lengua castellana. Segue deste discurso uma tabela de palavras portuguesas 
remotas da Língua Castelhana ${ }^{66}$. Este dicionário inicia na página 25 e termina na página 189 com a palavra: FINIS.

A obra de número 9 trata de um suplemento dos 8 primeiro volumes, publicado em "Lisboa Occidental, na officina de Joseph Antonio da Sylva, impressor da Academia Real MDCCXXVII" (1727). Dedicado a Dom João V, o autor inicia o suplemento dizendo que este volume é um tributo à sua obediência ao rei. Bluteau diz saber o quanto um vocabulário pode crescer ao longo dos anos e que nenhum dicionarista pode se gabar de as ter juntado todas. Encerra a dedicatória de forma retórica reforçando que este suplemento é a prova de dedicação máxima dele ao Rei.

A seguir, o autor apresenta um "PROLOGO SEGUNDO, ou segunda advertencia do author aos leitores, já nomeados nas primeiras folhas do primeiro volume do Vocabulario, a saber" e repete o leitor benévolo, malévolo, impaciente, português, estrangeiro, douto, indouto, pseudocrítico, impertinente e mofino. Ao final do segundo prólogo, Bluteau faz advertências a todo leitor para o uso deste suplemento dizendo que, quando este achar que a ortografia não está certa, não há como se certificar, pois ele próprio não encontrou regras de ortografia e nem autores uniformes que comprovassem tal processo. Como exemplo deste problema apresenta o uso do $h$ ou $i$ no início de certos vocábulos, e do uso do $y$ ou $i$ em outros. Bluteau também adverte os leitores que no suplemento falta, em muitos vocábulos, o latim - por serem estes jocosos ou chulos ou por serem expressões ignoradas pelos romanos.

A seguir seguem-se cópias de cartas, sonetos, licenças e cartas de aprovação de censura. As erratas dos outros 4 volumes que ainda não haviam sido feitas estão listadas a seguir, assim como consta deste suplemento um catálogo com mais de 5 mil vocábulos acrescentados aos 8 volumes. Não há marcação de páginas neste catálogo. O suplemento do vocabulário inicia na página 1 e encerra-se na 568 , juntamente com um desenho de um vaso de flores e a palavra FIM.

$\mathrm{O}$ volume 10 também trata-se de um suplemento. Anterior à folha de rosto habitual dos outros volumes, informa o autor: "SUPPLEMENTO AO VOCABULARIO PORTUGUEZ, E LATINO, que acabou de sahir a luz, anno de MDCCXXI. DIVIDIDO EM OUTO VOLUMES. PARTE II." A folha de rosto é muito semelhante às demais, com a informação de que este volume foi impresso na "Lisboa Occidental, na patriarca Officina da Musica ano de

\footnotetext{
${ }^{66}$ Foi feita uma leitura rápida das palavras listadas neste dicionário procurando encontrar as entradas do glossário elaborado do vocabulário charque. Foram encontradas as seguintes palavras: açougue:carneceria/ bexigas: viruelas / fornalha: hornaza fragua / gancho: garavato / pilha: rima / tanoeyro: tonolero o botero / tanque ou viveyro de peyxe: alberna o estanque de pescado.
} 
MDCCXXVIII" (1728). A página 1 inicia-se com o léxico referente à letra $m$ e encerra na página 324 ao término das palavras com a letra $z$ e a inscrição: FINIS.

A seguir, o autor agradece a Deus de inúmeras maneiras por ter chegado ao fim da obra, usando o português e o latim para isso. Ao término deste capítulo é apresentado um desenho de brasão e as anotações: TOM. II Ee OU-. Bluteau então dispõe outros 10 vocabulários pertencentes à obra, iniciados na página 1 até a 548, a dizer: nomes próprios; masculino e feminino; antigos e não usados; vulgares; raros; muito raros; sinônimos; frases portuguesas; nomes de plantas tomadas do latim; do grego para evitar circunlocuções; vocabulário de cavalaria; termos comumente ignorados, mas antigamente usados em Portugal, outros do Brasil ou da Índia introduzidos; vocabulários de palavra da Beira, Minho etc; títulos eclesiásticos e seculares; professores de artes nobres, e mecânicas e vocabulário de vocabulários.

O autor ainda informa, ao fim da página, que no final destes vocabulários achará o leitor a apologia do leitor. Ao término da apologia do vocabulário e do suplemento revela-se a censura do Conde da Ericeira Dom Francisco Xavier de Menezes. Encerra-se a descrição desta primeira obra, com um pequeno trecho do último parágrafo do autor: "Cousas grandes naõ podem dizer os que em si nã̃ tem nada de grande, naõ nos dà cuidado o seu dizer; de minimis non curat Prator. Laus Deo."

\section{Antonio de Moraes Silva}

\section{Diccionario da Lingua Portugueza}

A edição que se utilizou para a pesquisa consta de uma edição recopilada dos vocabulários impressos até agora, e, nesta segunda edição novamente emendada e muito acrescentada. A obra é composta por 2 volumes, sendo o tomo primeiro formados pelas letras $a$ até $e$ e o segundo das letras $f$ até $z$. Na folha de rosto consta a informação de que foi oferecida ao "muito alto, e muito poderoso principe regente nosso senhor", foi impresso em Lisboa na tipografia Lacérdina no ano de 1813.

A obra após a folha de rosto apresenta uma carta em que o autor agradece ao príncipe por ter apoiado as letras e os estudos da Língua Portuguesa, fazendo uma analogia entre a profissão das letras e dos exércitos, pois ambos combatem e apresentam "laboriosas fadigas em sua profissão". Suplica que o príncipe aceite a obra dedicada a ele e que este conceda a graça de estampar o seu nome em um autêntico testemunho de régia aprovação da obra. A carta encerra-se com a inscrição "Borel, Borel, e Campanhia, * ii”. 
A seguir a obra é oferecida ao leitor benévolo, informando que, neste texto, procurou corrigir os erros da edição anterior, usando para isso o Dicionário Portuguez da Real Academia das Sciencias de Lisboa, assim como também muitos artigos extraídos dos Inéditos da História Portugueza, de poetas, historiadores etc. O autor informa que dá explicações de documentos manuscritos, esperando assim contribuir os estudiosos em antiguidade. Adverte que nos livros antigos é muito comum o uso de consoantes dobradas no início de palavras e que neste dicionário não as faz, por considerar inútil, assim como também indica que palavras que começam com $c$ foram substituídas pela letra $s$, que quando o leitor procurar vocábulos com ph e não os encontrar, deve procurar $\operatorname{com} f$ e vice versa. Moraes informa aos leitores que há o uso indiscriminado de palavras com $g$ e $j$ e que isso deve-se a "incoherencia da actual ortografia", o autor também confirma que "notou" com y todas as vogais precedidas de consoante.

No prólogo da primeira impressão, à página IX, o autor escreve sobre a sua ingenuidade e ignorância no início dos trabalhos e, que depois de alguns anos, ele recorre a Bluteau. Entretanto, Moraes faz a este autor muitas críticas, dizendo que muitos vocábulos estavam faltando e que muito frequentemente Bluteau ficou discorrendo sem propósito em algum assunto e que por isso a sua obra é tão volumosa. Moraes afirma que procurou vender ao público uma obra mais enxuta, composta por menos tomos, mais barata e melhor facilidade de manuseio. Sobre a ortografia, declara que usa e apoia-se na Ortografia Filosófica (fundada na análise dos sons próprios, ou vogais, e na de suas modificações). Encerrando o prólogo, Moraes pede aos literatos que apontem os seus erros e descuidos.

Na página XIII, encontra-se a Explicação das Abreviaturas Usadas Neste Diccionario. Logo a seguir, a obra fornece uma lista das Abreviaturas das Citações dos Livros Portugue (sic) com que se Autorisa o Uso das Palavras. Na Epitome da Grammatica Portugueza, também dedicada ao leitor benévolo, Moraes informa que procurou dar, neste dicionário, idéias mais claras e exatas do que comumente se acha nos livros desse assunto. Entretanto, o autor aconselha os leitores a não tomarem esta obra como único guia gramatical e sim, use esta obra como um guia para ler bons autores, pois dele tirou os exemplos e analogias.

$\mathrm{Na}$ Introducção Moraes elenca vinte e dois (22) itens em que discorre brevemente sobre a gramática, a sentença, as palavras, as sílabas, os sons das vogais e consoantes, sobre ditongos etc. Na página V, o capítulo intitulado Livro I. das palavras por si sós ou partes da sentença, Moraes Silva informa que as palavras de que consta qualquer sentença, são as seguintes: nomes ou substantivos, os adjetivos articulares, os adjetivos atributivos, os verbos, 
os advérbios, as preposições, as conjunções e as interjeições. No capítulo I, dos nomes, ou substantivos o autor discorre que os nomes são as palavras com que indicamos as coisas, que existem por si, ou as qualidades, que representamos como existindo sobre si; podendo ser comuns ou individuais, singular ou plural, masculinos ou femininos. Discorre sobre os casos, pronomes, diminutivos e aumentativos.

No capítulo II, dos adjetivos articulares, Moraes os denomina de articulares aqueles que "ajuntão se aos nomes geráes, ou communs, para determinarem o numero, ou quantidade de individuos, de que falamos". Entre estes encontra-se o artigo simples, o artigo repetido e o articular (relativo e conjuntivo); assim como também, discorre sobre os casos em que não usam estes adjetivos. No capítulo III, dos adjetivos atributivos, o autor afirma que estes significam as qualidades existentes em algum objeto. Estes podem ser simples ou positivo, comparativo, superlativo, dentre outros.

Já no capítulo IV, trata de alguns accidentes communs aos nomes, e adjetivos, no capítulo V, Moraes cita os verbos, e seus modos, atributos, tempos, e pessoas. Segundo o autor o verbo é a palavra, em que declaramos que a alma julga, ou quer sobre o sujeito, dos atributos das sentenças com os verbos afirmamos e mandamos. $\mathrm{O}$ autor classifica o modo indicativo ou mostrador e o imperativo, ou mandativo como os modos verdadeiros. As variações verbais são expressas no modo conjuntivo ou subjuntivo. No infinitivo puro representamos somente um atributo verbal sem afirmar, nem querer, nem manter relação com pessoas ou tempos, segundo ele, estes são verdadeiros nomes verbais abstratos. $\mathrm{O}$ autor ainda discorre sobre as variações verbais, sobre os verbos estar, ser, ter e haver etc.

Capítulo VI os advérbios, são classificados como palavras que se substituem às frases modificantes do verbo. Segundo Moraes, os advérbios regem, ou pedem outras palavras, que completem e determinem a significação de uma das palavras de que os mesmos advérbios se compõem. Podem ser de tempo, de lugar, de quantidade, de modo, de ordem etc. No sétimo capítulo, apresenta as preposições, que, segundo ele, assim são chamadas porque se prepõem, ou se põem antes dos nomes a que se referem, servindo de conexão e correlação para conceder um entendimento entre dois objetos significados pelos nomes ou modificados por adjetivos ou verbos.

Capítulo VIII trata das conjunções informando que estas unem as sentenças, que tenham alguma conexão, ou correlação entre si, e semelhança de juízo, de oposição ou modificação. As conjunções segundo Moraes podem ser: copulativas, disjunctivas, condicionais, de causa, de conclusão, comparativas, adversativas e permissivas. No capítulo 
nono, das interjeições, encerra o livro I. Moraes descreve as interjeições como "paixões violentas que exprimem em uma ou poucas palavras, às vezes completando o sentido ou se equivalendo a uma sentença; são palavras arremessadas entre as da linguagem analisada, para exprimir as tais paixões".

O Livro II, da Composição das partes da Sentença entre si, ou Syntaxe é composto por quatro capítulos. O primeiro é introdução em que Moraes discorre longamente sobre a boa composição das partes da oração entre si, resultando na sentença, com que nos fazemos entender falando com palavras. Para ele todo artifício de compor sentenças consiste em mostrar as conexões, ou correlações entre os nomes de coisas, que tenha alguma relação, ou dizem respeito a outras coisas. O autor nesta introdução trata da sintaxe de concordância e da sintaxe da regência. Capítulo II entitulado da sintaxe, ou composição figurada discorre sobre a composição das sentenças incorretas. Segundo ele, às vezes a incorreção é aparente gerando uma nova figura, por isso diz-se figurada. Classifica estas composições em: ellipse, pleonasmo, enallage, hyperbato ou synchise e perissologia. O terceiro capítulo trata das composições viciosas que, de acordo com Moraes, são composições viciosas quando os adjetivos, e os verbos não se usam nas variações correspondentes ao gênero e número dos nomes. Também quando não aparece claramente quem é o paciente quem é o agente, a quem se referem os pronomes etc. Moraes também discorre sobre o uso de palavras estrangeiras e frases compostas com sintaxes estrangeiras denominando-as de barbarismo ou estrangeirismo. Outra composição viciosa, segundo ele é o solecismo (qualquer ofensa, ou erro de declinação dos casos, dos pronomes, das concordâncias e preposições mal usadas).

O capítulo IV dos sindes ortografico, e da pontuação discorre brevemente sobre a ortografia em que o autor afirma que esta ensina a regra de escrever bem, representando aos olhos os sons com letras distintas e cada uma para seu som próprio. Ainda compõem-se esta parte introdutória do dicionário algumas "taboas" das conjugações e exemplos de verbos. Antonio de Moraes encerra este epítome da gramática da seguinte maneira: "Acabou se este Epítome da Grammatica Portugueza ao Engenho novo da Moribeca em Pernambuco aos 15 de Julho de 1802."

O Diccionario da Lingua Portugueza inicia na página 1, encerrando à página $806 \mathrm{com}$ a inscrição "Fim do Tomo Primeiro". Na página seguinte, o autor apresenta as erratas afirmando que, apesar de toda aplicação e deligência do impressor e do corretor, não deixaram de haver erros. No volume 2, corresponde ao dicionário das letras $f$ a $z$. É composto pela mesma folha de rosto do primeiro volume em que se alteram somente as indicações de 
tomo segundo e de letra $f$ a $z$. O dicionário inicia na letra $\mathrm{f}$ reiniciando a contagem das páginas, e não as marcando continuamente como se deu em outras obras. $\mathrm{O}$ volume encerra na página 872 com a inscrição "Fim”.

\section{Domingos Vieira}

\section{Grande Diccionario Portuguez ou Thesouro da Língua Portugueza}

A primeira página encontra-se a inscrição Diccionario Portuguez, no verso encontra a inscrição: Imprensa de Livraria Franceza Nacional. Na próxima página Vieira dedica a obra À Sua Magestade, O Senhor Dom Pedro II, Imperador do Brazil, datado em 1 de março de 1872. Na página seguinte inicia com o nome do dicionário Grande Diccionario Portuguez ou Thesouro da Lingua Portugueza pelo Dr. Frei Domingos Vieira (dos eremitas calçados de Santo Agostinho), sendo esta uma publicação feita sobre o manuscrito original inteiramente revisto e consideravelmente aumentado. Ao pé da página encontram-se indicações dos editores datado de 1871.

Chardron e Henrique de Moraes assinam a carta de apresentação do dicionário destinada à Magestade Imperial em que contemplam a soberania do rei e reverenciam humildemente a ele pedindo a permissão de inscrever o nome do filho, Dom Pedro IV na primeira página da obra. Os editores a seguir apresentam uma carta de advertência ao público informando que não acharam conveniente apresentar ao público a obra manuscrita de Frei Domingos Vieira sem as retificações, adicionando acepções a algumas palavras, colocando observações de gramática sinonímia, retificando a etimologia de outras palavras, dentre outras alterações e procurando oferecer uma obra que ficasse a altura da lexicologia moderna.

A introdução da obra é dividida em dois textos. O primeiro é sobre a língua portuguesa escrito pelo Frei Adolpho Coelho e o segundo é sobre a literatura portuguesa escrito por Theophilo Braga. Coelho inicia a discussão sobre a Língua Portuguesa discorrendo sobre a diversidade das origens étnicas das missões, das nações neolatinas ou românicas, discursando o quão aparentado nas formas gramaticais, sintaxe e prosódia estas parecem ser , entretanto, é necessário considerar que apresentam alterações especiais de fundo comum. Citando autores como Alexandre Herculano, George Cornewal Lewis etc, o autor discorre sobre o latim e suas desinências, sobre a ciência da linguagem, sobre a linguagem em si, seu metamorfismo, arcaísmo, neologismos, sobre alterações fônicas e no sistema de formas gramaticais. Coelho ainda cita as alterações simpáticas de uma língua afirmando que a sintaxe de uma língua não é mais que coleção de modas por que essa língua emprega em suas formas 
de expressão do pensamento, condições do emprego e funções destas formas. Para o autor a sintaxe é a parte da língua que se sujeita mais às influências individuais.

$\mathrm{Na}$ segunda parte deste texto Adolpho Coelho apresenta as diferenças entre o vocabulário latino e o português, sobre as palavras portuguesas provenientes do latim vulgar, sobre as palavras substituídas pelos sinônimos, sobre as formas divergentes, sobre as palavras substituídas por derivadas da mesma raíz ou tema, pelas substituídas por derivados de outros temas e raízes, e pelas palavras alteradas pela etimologia popular. $\mathrm{O}$ autor ainda escreve as mudanças de significação, sobre palavras latinas perdidas (apresentando listas de palavras renovadas pela erudição, pertencentes à linguagem poética ou didática), encerrando com o tratamento das alterações nas famílias de palavras corradicais (co radicais) (exemplificando com inúmeros exemplos). A quarta parte deste texto diz respeito ao consonantismo, em que Coelho apresenta um quadro das consoantes latinas, discorre e exemplifica sobre as regras das consoantes isoladas, sobre abrandamento, sobre degeneração das momentâneas e contínuas, da degeneração do jota inicial, das contínuas mudadas e momentâneas, das trocas das contínuas entre si, também trata sobre as relações da dental d com as líquidas, da síncope de consoantes e vogais, das leis da desinência consonantal simples e dos grupos consonantais.

O vocalismo, que compõe o capítulo $\mathrm{V}$, trata das vogais acentuadas. Já o capítulo VI, intitulado a conjugação, o autor trata das desinências pessoais da voz ativa, da voz passiva, dos sufixos modais, dos temas temporais e dos verbos derivados. Encerrando o texto, Coelho forma o capítulo VII intitulado Lance d'olhos Sobre a História da Língua Portuguesa, classificando sua genealogia, discorrendo sobre as línguas faladas na Península Espânica antes do latim, da vulgarização do latim na Espanha, também acerca do latim vulgas, origem das línguas romanas, os bárbaros usados na Espanha, finalizando com o português língua escrita.

Na página seguinte, Coelho, em um texto post-scriptum desabafa sobre o quanto o trabalho dele poderia ter sido mais completo, e que, devido à problemas financeiros, de tempo e de acordos com os editores, sentia-se ofendido e muito aborrecido por eles considerá-lo inútil, pois trata-se do fruto do trabalho de anos de pesquisa.

A parte II da introdução desta edição do dicionário de Frei Vieira é intitulada, como foi dito anteriormente, Sobre a Literatura Portugueza. Neste texto Braga revela que acredita que só a ciência da história literária é como a ciência da linguagem, para ela não há parte insignificante. Não se pode considerar somente literatura, segundo ele, aqueles textos que se pareçam com os textos gregos, pautando as emoções nas categorias traçadas por Aristóteles, 
pois sendo assim, trata-se de síntese. A verdadeira literatura de um povo é escrita quando este descobre a consciência da nacionalidade para assim construir seu senso histórico literário.

O autor, então continua discorrendo sobre estes fatos, dividindo o capítulo em itens, denominados de: elementos constitutivos da raça, formação da nacionalidade e antinomias da civilização. Na secção I de seu texto, Braga escreve sobre as formas épicas (romanceiro: epopêa cyclica nacional, os cyclos das epopêas medievais em Portugal, transformação erudita do romance no seculo $\mathrm{XV}$, os tres centros ethnologicos dos cantos nacionaes); sobre as novellas de cavalleria: degeneração erudita das epopêas (origem do cyclo dos Amadizes, familia dos Palmeirins, pastoraes e allegorias, as novellas de cordel, conto decareronico, o anexim e a locução). Na secção II do texto o autor discorre sobre as formas lyricas (eschola provençal, eschola hespanhola, eschola hispano-italica, eschola italiana, eschola seiscentista, eschola arcadica e sobre o romantismo). Na terceira e última secção, Theophilo Braga trata das formas dramáticas, dividindo esta parte em: eschola nacional e a eschola classica. O autor, então, conclui que a história da literatura portuguesa é dolorosa, pois os portugueses, segundo ele, só tem coragem para encarar a fatalidade da lógica, esperando provas de que este povo ainda está vivo, se saiu para sempre da vida histórica e se se sente, por fim justiçado.

Anterior ao dicionário propriamente dito, com o início das entradas do léxico, a obra apresenta dois índices. Um é o índice do texto de Adolpho Coelho sobre a língua portuguesa e o segundo é sobre o texto de literatura portuguesa, escrito, como foi dito anteriormente, por Coelho Braga. A letra $a$ inicia na página 1, com um desenho rebuscado de crianças angelicais enlaçadas à letra desenhada em capital maiúscula. Este primeiro volume encerra na página 836, correspondendo ao final da letra $b$, sob a inscrição: fim do primeiro volume. O segundo volume da obra inicia com a folha de rosto semelhante ao do primeiro, somente com a notação de que este trata do segundo volume. Na página seguinte, os editores apresentam um texto de ADVERTENCIA, em que anunciam que, graças à aceitação do público, que enviou notas com novas acepções e palavras, que poderão ser consideradas em um suplemento. Indica que as vastas introduções apresentadas no primeiro volume, as quais foram resumidas acima, no intento de não prolongar mais a introdução daquele tomo, o segundo volume apresenta uma Chrestomathia historica da lingua portuguesa, onde estão expostas ao leitor, as mudanças que a língua tem passado.

Intitulada de Latim Barbaro apresenta uma seleção de documentos em latim barbáro, revelando o mais antigo documento remontando ao século VIII. O texto, que inicia à página 
V, terminando à página XXIV não será aqui resumido, nem tampouco apresentado, pois apresenta-se em latim. O mesmo motivo cabe ao segundo texto, intitulado Portuguez da Edade Media. A obra de Vieira ainda contém na introdução do segundo volume alguns cancioneiros, poesias de autores conhecidos e anônimos portugueses, um livro de linhagens, um segundo livro de linhagens atribuído ao Conde Dom Pedro, algumas crônicas, um opúsculo, um número pequeno de textos comparados, findando sua parte inicial na página LXXX.

A letra $c$ tem seu princípio na página 1, apresentando um desenho próximo ao das letras $a$ e $b$. Este volume termina na página 1159, com a inscrição: fim do segundo volume. $\mathrm{O}$ terceiro volume não apresenta, por sua vez, nenhum capítulo introdutório, restringindo suas páginas iniciais à folha de rosto semelhante às dos dois volumes anteriores. A letra $e$ inicia com o mesmo desenho das crianças angelicais dos outros tomos, iniciando sua paginação à página 5 até a 1360, com o término da letra $l$. Este tomo tem a mesma inscrição dos anteriores, a dizer: fim do terceiro volume. O quarto volume apresenta-se com um número consideravelmente inferior de páginas do que os tomos I, II e III. A letra capital $m$ também conta com os anjos infantes, logo após a folha de rosto, que, como as demais, modifica somente a referência do número do volume que compõe. Este volume inicia a paginação no número 5 e termina com a letra $p$, à página 1037, igualmente com a inscrição: fim do quarto volume.

Datado em 1874, o quinto e último volume que compõe a obra Grande Diccionario Portuguez, apresenta logo após a folha de rosto as palavras que iniciam com a letra $q$. $\mathrm{O}$ desenho segue com o mesmo padrão dos anteriores e as páginas começam a contagem no número 5, até a página 1038. A inscrição final deste tomo indica o fim da obra: fim do quinto e ultimo volume. Na página seguinte, apresenta-se uma lista das abreviaturas usadas neste dicionário. Ao pé desta lista indica-se que grande parte das abreviaturas das desinências dos adjetivos e substantivos femininos foi omitida por obedecer à regra geral.

\section{Laudelino Freire}

\section{Grande e Novíssimo Dicionário da Língua Portuguesa}

A obra de Laudelino Freire é composta de 5 volumes. O primeiro tomo apresenta na primeira página o título da obra. A folha de rosto, além do título apresenta também as informações de que o dicionário foi organizado por Laudelino Freire com a colaboração técnica do professor J.L. Campos. A editora é exposta ao pé da página, mas não há, 
entretanto, marcação de data. Os editores apresentam a obra na página seguinte, informando aos leitores que este é o primeiro grande dicionário feito no Brasil. Apresenta o organizador e o colaborador, informando que Freire faz parte da Academia Brasileira de Letras, tendo sido também membro da Academia das Ciências de Lisboa. De acordo com os editores, esta obra foi escrita com clareza e simplicidade, de acordo com os modernos preceitos da lexicografia, constituindo, portanto, uma obra útil ao idioma e ao povo. Os editores também informam que as acepções deste dicionário não são cópias de outros, com pequenas alterações e sim uma obra que intenta contribuir com a cultura tanto portuguesa como brasileira.

A introdução, escrita por Freire, inicia com uma alusão à contribuição de outro dicionarista - Cândido Figueiredo - cujos serviços prestados foram imensos. Freire também admite as falhas desta edição, mostrando-se aberto às sugestões e críticas dos leitores. A parte II desta introdução lista o que compreende a obra, a dizer: vocábulos em geral, palavras da língua, palavras estrangeiras que fazem parte do cotidiano brasileiro, expressões idiomáticas, modismos, brasileirismos, regionalismos, locuções em geral, locuções latinas já incorporadas ao vocabulário, indianismos, africanismos, termos técnicos e científicos, neologismos, termos consagrados de escritores, prefixos, sufixos, abreviaturas, siglas, gírias, variantes morfológicas, dentre outros itens. Segundo Freire, não houve a preocupação de distinguir regionalismos de provincianismos, nem de grafar o que é brasileirismos, dada a dificuldade de afirmar tais denominações.

Com relação às gírias, o autor empenhou-se em evitar termos chulos, barbarismos ou "troças e plebeísmos de esquina". As siglas e abreviaturas, assim como termos de química são apresentados com discrição. Freire encerra esta segunda parte da introdução dizendo que, de modo geral, procurou registrar primeiramente as acepções naturais ou históricas das palavras, para, em um segundo momento, registrar o sentido extenso ou figurado. A terceira parte discorre e apresenta as regras de ortografia empregadas, sendo seguidas as normas do acordo de 1931, entre a Academia Brasileira de Letras e a Academia de Ciências de Lisboa. A quarta parte trata da regência verbal. Criticando dicionaristas como Bluteau, Moraes e Veira, Freire afirma que sua obra o diferencia dos demais por apresentar, ao lado da etimologia e acepção dos verbos encontrados, um quadro corroborado por exemplos clássicos de todas as modalidades de construção a que pode prestar.

A quinta parte desta introdução discorre sobre o quanto sua obra deseja ser útil ao povo brasileiro, sendo de grande valia ter sido escrito aqui no Brasil e não em Lisboa ou Londres como outros autores o fizeram. Freire, entretanto, afirma que valoriza o mérito da 
nação lusitana, mas que era tempo de se fazer um dicionário por alguém que conhece de fato a língua falada no Brasil. A sexta e última parte é tão somente para exprimir o desejo de ser reconhecido e amparado pelo público e pela imprensa.

Após a introdução, o volume I contém na íntegra as regras que compõe o formulário ortográfico. A seguir apresenta a chave de abreviaturas e sinais, iniciando a letra $a$ com um desenho floral em preto e a letra em capital maiúscula em vermelho. A marcação de páginas inicia com o número cardeal 1 e encerra na página 928 com a inscrição: fim do primeiro volume. $\mathrm{O}$ volume 2 apresenta as mesmas folhas inicias do volume anterior, alterando somente a indicação de tratar-se do volume II. A letra $b$ inicia imediatamente à folha de rosto, sem apresentar nenhum texto introdutório. A letra também apresenta o desenho com a padronagem semelhante à letra $a$, com a marcação de páginas corrente, ou seja, o tomo 2 inicia na página 929, terminando na página 2017, com a inscrição: fim do segundo volume. $\mathrm{O}$ terceiro e quarto volumes mantém a mesma padronagem, tanto de folha de rosto, desenho das letras que se iniciam, inscrições finais etc. $\mathrm{O}$ volume III corresponde às letras $e$ a $i$, das páginas 2019 a 3052. Já o volume quatro corresponde às letras $j$ até $p$, páginas 3053 a 4209 . O último e quinto volume corresponde às letras $q$ a $z$. De forma semelhante aos demais volumes, iniciando na página 4210, encerrando as palavras na página 5272.

Na página seguinte, o quinto volume ainda apresenta um capítulo intitulado: Palavras Finais, escrito por J.L.Campos. Neste texto são apresentadas, na primeira parte, 45 questões que devem ser consideradas e resolvidas pelo dicionarista antes de fixar seu trabalho, de modo a permanecer coerente com um trabalho lexicográfico. Na segunda parte, informa-se que foram consultados todos os vocábulos dos grandes dicionários portugueses publicados até o momento, apresentando um esboço estatístico das letras e entradas da obra. A terceira parte é dedicada à prosódia, enfatizando a necessidade do dicionarista conhecer a língua, os valores fonéticos das vogais e consoantes, os fonemas, etc. O texto final de Campos ainda expõe as regras de acentuação empregadas no trabalho e encerra o posfácio demonstrando a saudade e admiração a Laudelino Freire. Ainda contam alguns outros agradecimentos aos colaboradores, redatores, dicionaristas, e, após o nome do autor do texto, a inscrição que constou semelhante em todos os tomos: fim do quinto volume. 


\section{Caldas Aulete}

\section{Dicionário Contemporâneo da Língua Portuguêsa}

A obra datada em 1958 denominada Dicionário Contemporâneo da Língua Portuguêsa de Caldas Aulete apresenta esta como sua edição brasileira. Segundo os organizadores, a edição brasileira foi atualizada, revista e consideravelmente aumentada pela introdução dos vocábulos em uso no Brasil, pelo registro completo dos termos técnicos e científicos e pela averbaçāo sistemática dos étimos por Hamílcar de Garcia. Esta obra compõe-se, ao todo, de 5 volumes assim organizados:

O volume 1: consta do primeiro volume um estudo sobre a Origem e Evolução da Língua Portuguesa, sua expansão no Brasil e uma exposição da pronúncia normal brasileira feita por Antenor Nascentes. A seguir é introduzida a nota dos editores e os agradecimentos a todos que participaram da elaboração deste volume. Um texto de Antenor Nascentes intitulado $O$ que vale o "Dicionário Contemporâneo" de Caudas Aulete afirma que o dicionário de Aulete veio para substituir o de Antônio de Moraes Silva ${ }^{67}$ que ficou conhecido como representante da história do português em tudo que antecede o século XIX. Entretanto, como a primeira obra de Aulete neste gênero foi feito em 1884, este também agora precisa de reedições e veio para somar-se às outras no intuito de representar e ser o melhor dicionário de Língua Portuguesa existente. Um dos pontos favoráveis deste dicionário, segundo Nascentes, vem a ser o uso de abonações com indicação de livro e página, dos maiores escritores, sendo, pela primeira vez, usados muitos escritores brasileiros. Outros pontos também favoráveis citados por nascentes são: o aumento de verbetes, sobretudo de brasileirismos, a etimologia das palavras com as retificações dentre outros.

Dois textos curtos sobre Origem e Evolução da Língua Portuguesa e Expansão da Língua Portuguesa no Brasil igualmente escrito por Antenor Nascentes são parte integrante da introdução do volume I. O primeiro texto sobre a Pronúncia Normal Brasileira da Língua Portuguesa consagra a fala do Rio de Janeiro como a pronúncia tida como normal brasileira, não só por ser a capital do país, mas por ter sido julgada por vários autores como de bom uso da ortoépia carioca (ortoépia aqui é compreendida como a boa emissão das vogais e a boa articulação das consoantes). O autor discorre sobre a pronúncia exemplificando, em 9 páginas, o uso empregado no dicionário.

\footnotetext{
${ }^{67}$ Esta obra já foi apresentada neste capítulo.
} 
A seguir, o volume I apresenta o prefácio $^{68}$ escrito por Hamilcar de Garcia. Este prefácio é composto por um grande número de itens, sendo estes os seguintes: plano da edição; história deste dicionário; amplitude da atualização; definições; semântica; abonações; Brasil e Portugal; zona linguística; regionalismos; linguagem familiar e popular, gíria; arcaísmos; palavras e expressões estrangeiras; sinônimos; prefixos e sufixos; remissões; ortografia; gramática; etimologia; siglas e abreviaturas; vocabulário onomástico; ilustrações; caráter enciclopédico; aeronáutica; agricultura; anatomia; antropologia; arquitetura e construção; astronomia; artes gráficas; belas artes; biologia; botânica; cinema e fotografia; comércio e indústria; comunicações e transportes; culinária; eletrônica; embriologia; engenharia; estatística; direito; farmácia e terapêutica; filosofia; fisiologia; folclore; garimpo; genética; gentílicos; geologia; geomorfologia; índios brasileiros; literatura; liturgia; maquinaria e ferramentas; marinharia; matemática; medicina; microbiologia; mineralogia; mitologia; música; odontologia; origem da língua; pesos e medidas; petrologia e petrografia; pronúncia normal brasileira; psicologia; química e física; rádio e tv; religião; sociologia; veterinária e zoologia. Por fim, aparece o nome dos colaboradores.

Ainda no volume I são listados alguns dos autores e obras que foram citadas na obra e suas principais abreviaturas. A letra $A$ inicia-se com marcação de página 1 até página 1152 . O volume II é composto pela mesma folha de rosto do volume anterior, mudando somente a indicação de que trata-se do volume II. Este inicia na página 1153, com o vocábulo coreclise e termina na página 2240. O volume III é organizado de forma semelhante ao volume anterior, também alterando na folha de rosto somente a indicação de que trata do terceiro volume. Este inicia-se com o vocábulo flabílio com marcação de página contínua - 2241 e encerra-se na página 3328. O volume IV é organizado como os volumes II e III, iniciando sua paginação sequencial na página 3329 com a lexia Mônica e termina na 4448.

$\mathrm{O}$ volume $\mathrm{V}$, como foi dito anteriormente é a última parte componente desta obra. A folha de rosto também é semelhante às demais, sendo diferenciada pelo esclarecimento de se trata do quinto volume. Inicia sua paginação no número 4449 e encerra a exposição da última lexia à página 5393. Na página seguinte, portanto, a 5394, apresenta o registro de abreviaturas que conclui-se na página 5408. A lista de siglas utilizadas na obra segue a lista de abreviatura e encerra-se na página 5524. Este último volume apresenta um formulário ortográfico com o título: Instruções para a organização do vocabulário ortográfico da Língua Portuguesa. Segundo o organizador, as normas que foram aprovadas unanimemente pela academia

${ }^{68}$ Como foi dito, por ser um grande número de itens, estes não serão explicitados e somente serão citados conforme a ordem em que aparecem no capítulo. 
Brasileira de Letras, sessão de 12/08/1943, serão obedecidas rigorosamente durante esta edição. São elas: 1) inclusão dos brasileirismos; 2) inclusão de estrangeirismos e neologismos de uso corrente no Brasil; 3) substituição de certas formas usadas em Portugal pelas usadas no Brasil; 4) fixação da grafia de vocábulos que ainda não possuem a etimologia perfeitamente demonstrada; 5) fixação da grafia de vocábulos sincréticos e que apresentam variação; 6) evitar duplicidade gráfica ou prosódica; 7) registro de um significado ou da definição de todos os vocábulos homófonos não homógrafos; 8) registro entre parênteses da vogal ou sílaba tônica; 9) registro entre parênteses do timbre da vogal tônica de palavras sem diacrítico; 10) fixação dos femininos e plurais irregulares; 11) registro de formas irregulares dos verbos mais usados e 12) todos os vocábulos devem ser escritos e acentuados de acordo com a ortoépia usual brasileira.

O volume IV apresenta, ainda, uma pequena discussão sobre pontos importantes do formulário ortográfico tais como: alfabeto e o uso das letras $k, w$ e $y$; o uso do $h$; o uso das consoantes mudas (ex. asma ao invés de asthma, oficio ao invés de officio etc); o uso do sc (eliminação em palavras como ciencia, cenografia); letras dobradas ( $r r$ ou $s s, c c$ ou $c c ̧$ só em posição medial); vogais nasais; ditongos; hiatos; parônimos e vocábulos de grafia dupla; nomes próprios (mantendo a grafia usual, ex. Bahia); acentuação gráfica; apóstrofo (indicar a supressão por exigência métrica, reproduzir algumas populares como: 'tava etc); hífen ( ex. el precisa ser usado com hífen em El-Rei); divisão silábica; o emprego de iniciais maiúsculas e, por fim, os sinais de pontuação. Logo após a discussão sobre o formulário ortográfico, o dicionário de Caldas Aulete apresenta um índice geral, como se formasse um único volume, a dizer, o índice no volume IV enumera todos os itens das obras, desde as primeiras páginas do volume I até as últimas considerações do volume $\mathrm{V}$.

\section{Aurélio Buarque de Holanda Ferreira}

\section{Novo Dicionário Da Língua Portuguesa}

O editor inicia o dicionário com uma nota, informando ao leitor que esta segunda edição vem consagrar a obra como um todo, pois atingiu a marca de 5 milhões de exemplares e traz metonímia Aurélio como sinônimo de dicionário. Esta edição oferece ao leitor aproximadamente $35 \%$ a mais de acréscimo lexical, sendo esta segunda edição não so aumentada, como também revista e atualizada pelo próprio autor.

A seguir apresenta-se um índice geral do dicionário e, logo abaixo, o prefácio. Neste texto, Ferreira relembra os esforços de outros dicionaristas que acabaram não se consagrando 
e/ou os que tendo consequências desfavoráveis tanto na vida profissional quanto pessoal. Neste prefácio dramatizado, o próprio autor faz a ressalva que com isto não só pretende chamar a atenção "às dores dos lexicógrafos", mas pedir que o leitor tenha paciência, ele mesmo procura ser breve e conciso, e leia o prefácio. Ferreira, então, enumera 14 informações sobre a obra: 1) pretendeu-se fazer um dicionário médio, etimológico, atualizado, atento não só a linguagem dos textos escritos como também a língua dos jornais, teatro, televisão, e ao falar do povo; 2) informa que entre os autores, os cronistas figuram com frequência, assim como os sambistas etc; 3 ) recorreu aos comentaristas políticos e econômicos e aos repórteres em geral; 4) destas diversas fontes é que brotaram palavras, ou enriqueceram as acepções e abonações; 5) adotou-se em relação à fraseologia o critério adotado pelo Diccionario da Real Academia Española; 6) certos adjetivos (os que representam espécies de determinada coisas) aparecem no competente substantivo; 7) há informações sobre a conjugação dos verbos; 8) a sinonímia também é abundante neste dicionário; 9) as remissões servem para mandar o leitor a uma forma vocabular verdadeiramente boa ou a um ou dois sinônimos, assim como também remeter um adjetivo a locução a que ele pertence; 10) a regência verbal recebeu grande atenção; 11) houve muitas correções ao que ele chama de cochilos do Vocabulário Ortográfico de 1943 ; 12) homônimos com étimos diferentes foram sereados; 13) acredita ser de muita utilidade, e, por isso, faz uso de registros de elementos de composição, vernáculos de origem latina e grega; 14) utilizou-se não só variedade de tipos, mas também siglas e sinais para destacar graficamente e melhorar a legibilidade das entradas. $\mathrm{O}$ autor então encerra com uma análise breve de um verso de Carlos Drummond de Andrade e em nota faz todos os agradecimentos aos colaboradores.

Esta segunda edição ainda oferece um pequeno prefácio, denominado de Prefácio da segunda edição, sendo este exposto logo abaixo do anterior, constando, basicamente, mais agradecimentos aos novos colaboradores. Na pagina IX apresenta o capítulo - Formulário Ortográfico - instruções para a organização do vocabulário ortográfico da língua portuguesa. Neste capítulo, fornece os itens que a obra obedeceu rigorosamente e que tem como base o Vocabulário Ortografico da Língua Portuguesa da Academia das Ciências de Lisboa, edição de 1940.

Após a citação das normas seguidas, a apresentação do dicionário trata dos seguintes itens $^{69}$ : alfabeto (formado por 23 letras); k,w,y (letras que serão usadas em casos especiais); $\mathrm{h}$ (que se conserva no início de algumas palavras e no fim das interjeições); consoantes mudas

\footnotetext{
${ }^{69}$ Não será apresentado o comentário de todos os itens, apenas dos que se julgou mais pertinentes, dada a extensão de seu conteúdo.
} 
(foi eliminado o uso daqueles que não se proferem); sc ( eliminação do s do grupo inicial); letras dobradas; vogais nasais; ditongos; hiatos; parônimos e vocábulos de grafia dupla (procurou-se manter a mais rigorosa distinção nestes casos, devendo registrar a grafia que seja mais conforme a etimologia do vocábulo, em harmonia com a prosódia geral brasileira e não lusitana); nomes próprios (topônimos de tradição histórica secular não sofrem alteração na grafia); acentuação gráfica (cita todas as regras que seguem a acentuação gráfica); apóstrofo (indicada a supressão de uma ou mais letras se for exigência métrica de verso, reprodução de pronúncias populares e indicação de supressão de vogal em uso consagrado); hífen; divisão silábica (que obedece a critérios de soletração e não etimológicos); empregos das inicias maiúsculas (apresenta todos os casos e regras que foram seguidas) e sinais de pontuação (quando são usadas as aspas, parênteses, travessão e ponto final)

Dando continuidade à introdução do vocabulário, são apresentadas a lei numero 5.765 de 1971, que refere-se às alterações na ortografia portuguesa, e a portaria número 36 de 1959 que refere-se à unificação gramatical brasileira. Das páginas XVI até XIX são listados 5 itens e seus subitens componentes da primeira parte, a dizer, fonética, 11 itens e seus subitens componentes da segunda parte, a morfologia e 2 itens e seus subitens componentes da terceira parte, a dizer, sintaxe.

Na página seguinte encontra-se uma lista de abreviaturas, siglas e sinais convencionais usados no dicionário. Ao término desta lista é apresentado o alfabeto fonético internacional. A letra $A$ e o léxico correspondente iniciam a marcação de páginas no número 1 e a letra $Z$ encerra o léxico à página 1809. A obra ainda expõe a bibliografia completa consultada para elaboração do dicionário e os nomes dos revisores, operadores de computador, composição, programação etc.

\section{Zeno e Rui Cardoso Nunes}

\section{Dicionário de Regionalismos do Rio Grande do Sul}

A folha de rosto da obra indica o nome dos autores com a informação de que ambos são membros efetivos da Academia Rio-Grandense de Letras e da Estância da Poesia Crioula. A edição estudada é a sétima da obra, do ano de 1996. Na página seguinte à folha de rosto os autores homenageiam os "confrades" da Academia e da Estância da Poesia. A apresentação, que vem a seguir é assinada por Hugo Ramírez, datada de 13 de agosto de 1982. Nesta apresentação, marcada pelo tom quase poético, ambos os autores são muito elogiados, orienta o leitor que esta obra pretende abraçar as tropilhas vocabulares, pois fornece uma visão do 
panorama dialetal gaúcho. Ramírez ao mesmo tempo em que expõe ao consulente que os autores são considerados expoentes da estrutura literária gaúcha e que este dicionário valoriza o patrimônio semantológico e coloquial do Brasil, divagando em informações como se vê neste trecho: "Poetas, embalados pelos ritmos do velho Portugal, trançam no decassílabo os tentos de seu mágico encantamento diante da terra fechada e enevoada onde nasceram, olhos e emoção erguidos em asas de unção e enlevo até os hemeciclos verde-azulados dos candelabros do Sul...”

Após a apresentação, a obra exibe uma nota dos autores bastante concisa. Nesta nota os autores informam ao que o dicionário foi iniciado há mais de meio século e que em seu princípio continha apenas os termos tipicamente usados no interior do estado, aos poucos é que foram sendo agregadas outras palavras e expressões, retiradas de um corpus composto de obras literárias, outras obras do gênero e de pesquisas de campo. Na página seguinte são mostradas as abreviaturas utilizadas no dicionário, sendo o léxico iniciando com a letra $a$ numerado na página 13. As últimas lexias a serem exibidas são numeradas na página 537, sendo, a seguir apresentado um índice onomástico que se encerra à página 552 . Na última folha da obra informa-se onde a obra foi composta e impressa.

\section{Antônio Houaiss e Mauro de Salles Villar \\ Dicionário Houaiss da Língua Portuguesa}

O dicionário de Antônio Houaiss e Mauro de Salles Villar é conhecido como dicionário Houaiss. Em sua primeira página, apresenta o nome do dicionário sobre o desenho de um antigo copista trabalhando em um scriptorium. Desenho que se repete na página seguinte, onde há informações sobre os autores, editora etc. A seguir, a obra apresenta um breve texto que relata um pouco da vida e obras mais importantes do principal idealizador deste dicionário - Antônio Houaiss. Nascido em 1915, trabalha incansavelmente em favor da cultura e aprimoramento da Língua Portuguesa. Alguns trabalhos como: Sugestões para uma política da língua, O Português do Brasil, Vocabulário Ortográfico da Língua Portuguesa, dentre outros, somados ao trabalho nas áreas de crítica textual, literária, tradução e lexicografia etc, fazem deste autor um dos mais importantes escritores de nosso país. Segundo o texto apresentado, este dicionário foi iniciado em 1986 e teve uma interrupção em 1992. No ano seguinte com a associação de Villar e Melo Franco, o Dicionário Houaiss de Língua Portuguesa teve sua conclusão em 2000, um ano após a morte de seu idealizador. 
Algumas citações são utilizadas na introdução da obra, seguidas das listas dos apoios financeiros, agradecimentos e homenagens póstumas. O sumário é composto por 10 itens, que serão apresentados resumidamente neste capítulo. A equipe editorial: na página XII, elanca inúmeros nomes de colaboradores, redatores, tradutores, revisores, editores etc. No prefácio, escrito por Houaiss, o autor acredita que os usos linguísticos em Língua Portuguesa estão carentes na atualização das obras, e segundo eles, são igualmente carentes em um trabalho lexicológico que, em suas palavras, honre os lexicógrafos do passado. Houaiss informa aos leitores que esta obra empenhou-se em registrar o que era conhecido e algo mais, buscando registrar também a universalidade lusofônica, ressaltando as variantes regionais e consentâneas. Os componentes mórficos das palavras apresentam mais riqueza investigativa que as obras precedentes, cabendo ao leitor julgar o que foi conseguido.

À página XV, a apresentação do dicionário, escrita por Villar inicia-se alencando os três principais fundamentos do dicionário que são: levantar uma moninata abrangente de entradas que ganhassem definições suportadas etimologicamente; levantar minuciosamente os elementos mórficos da língua, estabelecendo as famílias lexicais e esforçar-se na definição de data das unidades lexicais.

O trabalho, segundo Villar, resultou em um total de 13.295 unidades, transformadas em verbetes. A etimologia mergulhou na história dos étimos, sem precisar repetir em cada verbete dados comuns à família a qual a palavra pertence. A obra levou um total de 15 anos para ser concluídas, contando com 34 redatores e especialistas e 43 colaboradores, além de outros profissionais envolvidos. A segunda fase do trabalho foi conferência do material coletado, e a incorporação de mais informações úteis aos leitores. A base documental, segundo o autor, originou-se de pesquisas de milhares de obras literárias, técnicas, didáticas, dentre outras. Autor ainda informa na apresentação que a obra resultou em 228.500 unidades léxicas, versando diacronicamente sobre fenômenos do português, servindo como um espaço ecumênico da língua.

A chave do dicionário apresenta um esboço com exemplos verbetes que remetem para o texto de detalhamento das informações das entradas, indicando em qual item está minuciada no texto que se segue. O detalhamento dos verbetes e outras informações técnicas, também escritas por Villar, iniciam na página XVIII e encerra-se na página XLIII. Dada sua extensão e nível de detalhamento, muitos dos itens especificados nesta parte da obra serão, neste capítulo, somente citados. 
O item 1 entradas: também chamados de cabeça de verbete ou unidade léxica. Neste item informa-se que a unidade léxica pode ser uma palavra simples, composta, locução, redução, ou até uma pequena frase. As letras maiúsculas são usadas em alguns símbolos científicos, siglas, marcas comerciais, palavra de língua estrangeira que no original se escreve com letra maiúscula etc. Os homônimos homógrafos homófonos, os homônimos homógrafos não homófonos, os elementos mórficos, alguns casos especiais de entrada na nominata e entradas de substantivos femininos também são especificados neste item.

O item 2 campo da ortoépia e da pronúncia. O autor informa que a ortoépia é indicação normativa da pronúncia enquanto a transcrição fonética é apenas informativa e são apresentadas entre barras, imediatamente a seguir à entrada. Este item também trata do acento de intensidade, acento melódico, tom lexical, duração, quadro de transcrições fonéticas das vogais e das consoantes e marcas registradas. No esquema estrutural do verbete, a classificação gramatical da unidade léxica, que corresponde ao item 3, ocupa-se dos elementos como: substantivos, verbos, adjetivos, numerais, conjunções etc. O item 4 denominado campo da datação é marcado entre parênteses logo após a classe gramatical. Este campo, segundo Villar, anota-se a data do primeiro registro conhecido ou estimado de uma palavra, com indicação da fonte onde ocorre.

O item 5, campo do conteúdo ou das definições, é o campo essencial, onde, segundo o autor se estabelece a relação entre os significantes da língua e seus significados. No caso do verbete contar com mais de uma acepção, cada uma delas vem antecedida de um numeral negrito. Este dicionário não abona com textos literários as acepções que registram, dado o volume que a obra alcançaria. Por outro lado, a obra fornece exemplos de uso das palavras, locuções e regências registradas, inspirados em abonações colhidas em livros, jornais, revistas etc. O quinto item ainda trata da ordem de sucessão das acepções, os elementos mórficos e fraseologias. O item 6 não recebe subtítulos como os anteriores, a marcação numérica 6 (seis) expõe sobre o plural de vocábulos compostos. O sétimo item ocupa-se das remissões do dicionário. $\mathrm{O}$ autor informa que as remissões não referem números de acepções de outros verbetes, utilizando em lugar disso uma minidefinição da acepção para a qual se remete.

O item 8, por sua vez, trata dos elementos periféricos, a dizer: as indicações do campo do conteúdo, incluindo: derivação semântica (por extensão de sentido, por analogia, por metáfora, por metomínia, por sinédoque, galicismo e anglicismo semântico); rubricas temáticas, dados de regionalismo, nível de uso, estatística de emprego (forma não preferencial (palavra ou forma a evitar) e mais usada, forma não preferencial e menos usada, mais correto 
e mais usado e menos correto e mais usado) e registro diatrônico. Com relação às rubricas temáticas, item 9, trata das informações que o dicionário fornece ao leitor sobre a área do saber ou do fazer humano a que a unidade lexical pertence. O item 10, por sua vez, trata da indicação de regionalismo, informando sobre os limites geográficos da utilização de determinada unidade léxica ou acepção (podem ser mais minuciosas informando a cidade do estado a que pertence, províncias convencionais, brasileirismo, lusismo, outros locais de área lusofônica, regionalismo não localizado etc).

O item 11 trata do nível de uso, que vem a ser, segundo o autor, a faixa linguística de expressão em que a palavra ou acepção é empregada. No dicionário Houaiss os níveis de uso foram classificados em: sentido absoluto; linguagem formal; linguagem informal; linguagem policial, do crime e da droga; tabuísmo; uso impróprio; eufemismo; pejorativo; ironia; jocoso e hiperbólica. O registro diacrônico, item numérico 12, indica a vigência cronológica do verbete. São classificados em: arcaísmo, vocábulo antigo, obsoleto, obsolescente e arqueologia verbal. O item 13 foi tratado pelo autor para indicar o uso da observação, que significa o uso de um sinal de índica que antecede as observações empregadas em algumas remissões ou informações. O item 14 elanca as normas empregadas quanto ao uso das maiúsculas e minúsculas, sendo estas normas baseadas no Formulário Ortográfico e outras criadas pelos dicionaristas da obra. $\mathrm{O}$ item 15 repete a informação quanto à numeração das acepções; o 16 refere-se ao uso de parênteses e colchetes; o 17 diz respeito ao emprego de elou nos casos de informação aditiva como alternativa. O item 18 refere-se ao uso dos sufixos -ita, -ita,-ite, utilizados em geologia sobretudo em rochas, o 19 serve-se da informação de que este dicionário optou em não usar de modo metódico advérbio de sufixo -mente. O número 20 trata dos derivados gráficos de nomes próprios estrangeiros, informando ao leitor que a obra preserva a grafia original, mesmo que estas sejam estranhas ao português.

$\mathrm{O}$ item 21 refere-se às antonímias, sendo estas marcadas no caso de observação. Em 22 Villar informa que evitou-se usar abreviações dentro das acepções. Os sinônimos, numerais, topônimos, espaçamento de abreviação, uso de metalinguagem e uso de vírgula antes de etc são itens tratados que correspondem aos números 23, 24, 25, 26, 27 e 28 respectivamente. Do item 29 ao 40, foram discutidos e exemplificados os seguintes assuntos: verbos (alguns esclarecimentos quanto à regência e usos); adjetivos ( alguns esclarecimentos quanto ao uso de remissões com verbetes de vocábulos que remetam um adjetivo a uma entrada que seja substantiva e adjetiva, quanto ao raro registro de adjetivos femininos etc ); palavras compostas com o ante positivo não-; translineação e hífen; etnônimos da 
antropologia brasileira; biologia (os gêneros científicos não estão grafados em latim e sim com forma aportuguesada); zoologia (uso de propostas empíricas que vão de 322 a.C. até 1950, denominação de grupo, família, ordem, uso de classificação tradicional); química, fisioquímica e farmácia (os substantivos destas áreas receberam classificação geral, informação sobre origem, e dados sobre aplicação e uso); remissões (o item 36 reforça o item 7, sendo que este trata também das remissões excludentes, discretas, imperativas, com o "confira" e "conferir", genérica); gentílicos (os brasileiros fornecidos pelo IBGE e os portugueses facultados pelo Dicionário da Língua Portuguesa Contemporânea); a alteração de terminologia anatômica de acordo com a forma atual e anterior à mudança de 2000; palavra forma com timbre fechado não foi acentuada; e o acento circunflexo em pôde.

O subcampo do plural com sentido próprio refere-se ao item 41. Já o item 42 trata do subcampo das locuções e da fraseologia (casos de polissemia, cada acepção vem antecedida de número em negrito). O número 43 pertence ao campo da gramática, ou da gramática e uso, ou do uso (informações gramaticais, dados sobre o emprego na língua, da unidade léxica etc); o próximo assunto tratado pelo autor no detalhamento dos verbetes expõe o tratamento adotado nos casos pertencentes ao campo da etimologia (étimo próximo, étimo remoto, comentários nos casos de etimologias díspares, vocábulos de outras línguas recebem étimos de acordo com a tradição dicionarizada da língua a que pertence, adjetivos gregos, etimologia de gentílicos etc). Neste item 44, que trata das etimologias o autor recorre ao uso de quadros para exemplificar ao leitor as transliterações do alfabeto grego, as transliterações de vogais, casos especiais, indicação de sílaba tônica em vocábulos indígenas e um último quadro de transliteração de consoantes.

Encerrando esta longa lista de detalhamento, o autor ainda expõe o tratamento dado ao campo dos sinônimos, campo dos antônimos, campo dos coletivos, dos homônimos e dos parônimos (homônimos aqui entendidos como duas ou mais palavras de grafia idêntica, mas étimos diferentes e parônimos como dois ou mais vocábulos quase homônimos, mas que se diferem ligeiramente na grafia e pronúncia). Por fim, Villar menciona o campo das vozes de animais e campo da onomasiologia.

Com relação aos verbos, já na página XLIV, a obra apresenta, como no caso anterior, um detalhamento acerca do tratamento dispensado a esta classe gramatical de modo que o leitor ou consulente possa atentar para certas recapitulações ou convenções. Neste capítulo são tratadas as seguintes questões: número, pessoa, modo, tempo, voz, aspecto, conjugação, o verbo pôr, regularidade, irregularidade, intensidade, alternância vocálica, sínclise e 
formação dos tempos simples. Logo a seguir, é apresentado um quadro das conjugações. Antes de iniciar os verbetes, o dicionário exibe uma lista geral de reduções e uma relação por ordem alfabética das abreviaturas convencionais adotadas, denominadas de bibliografia das fontes de datação e etimologia. O sumário, citado no início do resumo desta obra, consta como uma de suas unidades o dicionário que inicia, adotando a numeração cardinal e não mais romana, na página 1 e encerra na página 2913.

As referências bibliográficas ao final da obra indicam ao leitor em uma pequena nota à margem lateral esquerda que se minuciar todas as obras consultadas nestes 10 anos seria impraticável e que, a fim de tornar-se o mais possível completa, mas praticável, acabou por excluir as obras consultadas nos trabalhos de datação e etimologia. O dicionário Houaiss finda na página 2922, sendo que na página seguinte, há somente indicação gráfica e de impressão, e, mais uma vez, é usada a figura do copista em seu scriptorium.

\section{Francisco da Silva Borba}

\section{Dicionário de usos do Português do Brasil}

O dicionário de Francisco Borba - Dicionários de usos do português do Brasil apresentam, no início da obra, alguns nomes de colaboradores: Sebastião E. Ignácio, Maria Helena de M. Neves, Beatriz N. de Oliveira, Marina Bortolotti Bazzoli e Maria C. C. Dezotti. Em nota, o editor, esclarece que este dicionário é uma obra da língua escrita no Brasil na segunda metade do século XX. O corpus foi composto de textos de literatura romanesca, dramática, técnica, oratória e jornalística de língua escrita em prosa.

Sobre os verbetes, indica-se que estes obedeceram a critérios organizacionais da língua, com uma seleção de traços taxonômicos, objetivando orientar as definições para clarificar e torná-las acessíveis. Neste dicionário há uma ou mais abonação para cada acepção, contextualizando onde esta mais ocorre. Há informações quanto ao registro de uso, a dizer: coloquial, chulo, grosseiro, solene etc. Na apresentação do dicionário, escrita em Araraquara, em 2001, Francisco Borba revela os objetivos da obra, sendo basicamente três, a dizer: prover os usuários de um instrumento de agilização do uso escrito; estimular a pesquisa vocabular e fornecer elementos de avaliação sintático-semânticas do léxico.

Logo após a apresentação, o item 2 trata da organização da nomenclatura, informando ao leitor que houve preocupação com as relações gramaticais e as propriedades colocacionais; que a obra tem absoluta predominância de textos jornalísticos e o critério de entrada adotado foi o de ocorrência combinado com o de colocação contextual. Foi inclusive, segundo o autor, 
a frequência que determinou a rotulação do gênero, a entrada e/ou grafia de estrangeirismos, a eliminação de alguns advérbios de modo e dos adjetivos pátrios. Com relação aos nomes próprios, estes somente foram selecionados quando constituíam pontos de partida para derivação de acepções.

A introdução da obra também expõe aos leitores que as variantes fonéticas e fonológicas foram registradas com barras, os nomes de povos indígenas entraram na ortografia oficial e os femininos irregulares tiveram entradas independentes. As entradas são constituídas de palavras simples, compostas ou expressões. As subentradas são todas as construções dependentes, a dizer, aquelas que começam por preposição ou como sintagmas nominais que iniciam com artigo; sintagmas preposicionais e verbais fixos; conjunções complexas e as frases feitas.

A seguir, a estrutura da obra apresenta um novo item denominado: A base gramatical. Neste item indica-se que foram usados os princípios gerais da linguística descritiva sincrônica, sendo as informações ligadas ao sistema da língua marcado entre colchetes e a informação sobre a localização regional ou social do uso vem antes das definições marcadas entre parênteses. Os exemplos vêm depois de dois pontos e seguidos de uma sigla entre parênteses remete ao banco de dados ou corpus. As palavras gramaticais são identificadas pela classificação tradicional e cada verbete apresenta-se como uma minigramática do item léxico. Os verbos, segundo Borba, são subclassificados em grupos: ação, processo, açãoprocesso, estado, auxiliar, modalizador e suporte. Os nomes são classificados em concretos e abstratos e os adjetivos em qualificadores e classificadores.

Sobre as palavras gramaticais, a parte inicial da obra indica que os advérbios são subclassificados pelo valor semântico oracional, os artigos em definidos e indefinidos, os pronomes apresentam sete subclasses, os numerais quatro. As preposições e interjeições, por sua vez, não apresentam subclasses. As conjunções são classificadas em coordenativas e subordenativas. Em outro item, denominado organização dos verbetes, o autor indica que estes foram organizados em cinco níveis de informação: taxionomia (classe e subclasse), variação (regional e de discurso), sintaxe (sistema de complementação), semântica/ pragmática (conjunto de acepções quando o verbete apresentar mais de uma) e a contextualização (representada pelas abonações). Para encerrar a apresentação da obra, Borba ainda indica que toda a informação adicional vem ao final do verbete, separada com o uso de barras oblíquas. 
O dicionário, na página 11 , demonstra como se apresenta o $\mathrm{DUP}^{70}$, expõe um verbete indicando com cada item tratado anteriormente, logo a seguir aparece o índice de abreviaturas (contento 40 abreviaturas ao todo). Em seguida apresenta as entradas iniciando a letra $A$ na página 1 terminando com a letra $Z$ na página 1653. Na página 1655 o autor apresenta o significado das siglas que foram utilizadas, e, dando continuação, apresenta de uma lista de expressões latinas. A obra, por fim, exibe outra lista, a geral das siglas do corpus principal, que termina na página 1674.

\section{Batista Bossle}

\section{Dicionário gaúcho Brasileiro}

A obra de batista Bossle já na sua capa informa aos leitores que o dicionário contém: mais de 10 mil termos e expressões; cerca de 1.500 exemplos práticos e as fontes de pesquisas. Ainda na capa, no canto superior esquerdo há um desenho de um gaúcho tipicamente "pilchado" $" 71$ montado em um cavalo. A folha de rosto apresenta as mesmas informações da capa, mudando somente a figura do gaúcho, que desta vez aparece de lado, como se estivesse cavalgando em velocidade. Este dicionário foi editado em 2003, onde, em nota, a editora informa o leitor que por ser esta obra específica de uma região, ela deve ser cercada de maiores cuidados. Discorre também sobre as dimensões continentais brasileiras, e que, reunir, escutar e descrever o significado de termos e palavras que para alguns são familiares e para outros bizarrices é uma ferramenta fundamental para a fixação de uma língua. A editora descreve a obra como sistemática e criteriosa e afirma que, possivelmente, seja a mais completa e rigorosa do gênero. Esta nota, assim como a nota do autor que descreve-se a seguir continuam sendo acompanhadas de gravuras de gaúchos montados em cavalos, sempre devidamente trajados.

O autor continua a introdução da obra escrevendo aos leitores quase que diálogo direto, ou seja, o autor vai discorrendo os motivos que o fizeram formar este dicionário usando um tom saudosista, o mesmo sentimento que, segundo ele, o fez começar a reunir o léxico gauchesco. Bossle narra sua partida do estado natal e o hábito que adquiriu de ouvir músicas rio-grandenses para amenizar a saudade que sentia. Quando evidenciou o quanto as letras das músicas eram incompreendidas pelos amigos e pessoas que frequentavam sua casa, percebeu o quanto o léxico dos pampas era desconhecido. Sendo assim, iniciou o seu trabalho

\footnotetext{
${ }^{70}$ Dicionário de Usos do Português

${ }^{71}$ Vestido com os trajes típicos dos habitantes do Estado do Rio Grande do Sul. 
usando como fonte as muitas músicas (há uma nota de rodapé indicando que foram estudadas mais de 1700 canções) que tinha em sua discoteca particular, ao mesmo tempo em que procurou na literatura as definições e a ampliação vocabular.

Dando prosseguimento à apresentação das estruturas da obra, expõe-se a organização do dicionário informando que: neste são citados mais de 400 autores, compositores, cantores, etc; milhares de termos trazem sua etimologia; em muitos termos há a indicação da região do estado onde são mais usados (missões, fronteira, litoral etc); são identificados em alguns termos o emprego e as relações com as diversas áreas de conhecimento e são especificados o seu uso (se muito usado, se é antigo, etc). Acerca dos exemplos, o autor informa que estes são impressos em itálico, os termos em negrito e que a referências entre parênteses trazem os autores, título da música, o ritmo musical, o título e subtítulo do CD (em negrito) e, por último, a gravadora.

Na página seguinte há uma lista considerável dos agradecimentos, das empresas e entidades e também o nome da revisora da obra. As abreviaturas usadas aparecem logo a seguir, e, na folha ao lado já se iniciam as entradas. A letra $a$ começa sua marcação à página 12, terminando à página 534. A bibliografia - há uma nota indicando que nesta consta inclusive a literatura de apoio - inicia na página 535, mais uma vez contendo uma gravura de um gaúcho montado em um cavalo. A obra encerra-se na página 541. 


\section{REFERÊNCIAS BIBLIOGRÁFICAS}

AGUILERA, V. A. ALPR: atlas lingüístico do Paraná. Londrina: Editora da Uel, 1996. Atlas Lingüístico do Paraná: Veredas. In: SANTOS, I. P. dos. Estudos geolinguísticos no Brasil: caminhos e propostas. São José do Rio Preto: ENESP/GEL, 1998.

ALVES, I. M. Polissemia e homonímia em uma perspectiva terminológica. São Paulo: Alfa, 2000. Atividades terminológicas no Brasil. Terminômetro - A terminologia no Brasil. Barcelona: n.3, 1998a. Número Especial. . (org.) Glossário de termos neológicos da economia. São Paulo: Humanitas, 1998b.

Definição terminológica: da teoria à prática. São Paulo: Tradterm, n.3, 1996.

AMARAL, A. (1920). O dialeto caipira: gramática, vocabulário. São Paulo: Anhembi; $2^{\mathrm{a}}$. ed., São Paulo: Hucitec, 1982.

AULETE, F. J. C. Dicionário contemporâneo da língua portuguesa. $3^{\mathrm{a}}{ }^{\mathrm{e}} \mathrm{d}$. vol 1 - 5, Lisboa: Delta, 1974 .

AULETE, F. J. Caldas; GARCÍA, H. de; NASCENTES, A. Dicionário contemporâneo da língua portuguêsa. Rio de Janeiro: Delta, 1958.

BARBOSA, M. A. Dicionário, vocabulário, glossário: concepções. In: ALVES, I. M. (Org.). A constituição da normalização terminológica no Brasil. 2 ed. São Paulo: FFLCH/CITRAT, 2001.

BECHARA, E. Minidicionário da língua portuguesa. Rio de Janeiro: Nova Fronteira, 2009.

BERTOLDI, V. Enciclopedia Italiana di Scienze, Lettere ed Arti. Roma: Treccani, 1935. Citado por BABINI, M. Do conceito à palavra: os dicionários onomasiológicos. Artigo 
publicado na Revista Ciência e Cultura. vol.58 no. 2. São Paulo Apr./June 2006. Disponível em: http://cienciaecultura.bvs.br/pdf/cic/v58n2/a15v58n2.pdf. Acesso em 25/05/2010.

BIDERMAN, M. T. (org.) Lexicografia e lexicologia. Alfa, 28 (Suplemento) 1-149, 1984. Teoria lingüística. 2a. ed. São Paulo: Martins Fontes, 2001. A estrutura mental do léxico. In: Estudos de filologia e linguiística. São Paulo: T.A. Queiroz / Edusp, 1989, p. 131-145.

BLUTEAU, R. Vocabulário portuguez e latino. Coimbra: Colégio das Artes, 1712-1713. v. 1-4; Lisboa : Paschoal da Silva, 1716-1721. v. 5-8.

BLUTEAU, R.; OLIVERA, L. Vocabulario portuguez, e latino, aulico, anatomico, architectonico, bellico, botanico autorizado com exemplos dos melhores escritores portuguezes e latinos e offerecido a El Rey de Portugal D. Joa ̃̃ V. Coimbra: No Collegio das Artes da Companhia de Jesu, 1712.

BORBA, F. S., IGNÁCIO, S. E. Dicionário de usos do português do Brasil.1 ${ }^{\text {a }}$ Ed. São Paulo: Editora Atica, 2002.

BOSSLE, B. Dicionário gaúcho brasileiro. Porto Alegre: Artes e Ofícios, 2003.

BUNSE, H. A. W. Estudos de dialitologia no RS: problemas, métodos e resultados. Porto Alegre: Ed. UFRGS, 1969.

CABRÉ, M.T. La terminología. Teoria, metodología, aplicaciones. Barcelona: Editorial Empuries, 1993.

La terminología. Representación y comunicación. Barcelona: IULA Pompeu Frabra, 1999.

CAMBRAIA, C.N. Introdução à crítica textual. São Paulo: Martins Fontes, 2005.

CARUSO, P. Atlas lingüístico do Estado de São Paulo: questionário. Assis: UNESP, 1983. $1 \mathrm{v}$. 
CESAR, G. História do Rio Grande do Sul. $3^{\text {a }}$. Ed. Porto Alegre: Martins Livreiro Editor, 2002.

CIDADES BRASIL ESCOLA. Disponível em: http://cidadebrasileira.brasilescola.com/saopaulo/sorocaba.htm . Acesso em: 22 de abril de 2012.

COMITÊ NACIONAL DO PROJETO ALIB (BRASIL). Atlas linguístico do Brasil: questionários. Londrina: Editora da UEL, 1998.

COMITÊ NACIONAL DO PROJETO ALIB (BRASIL). Atlas linguístico do Brasil: questionário 2001. Londrina: Editora da UEL, 2001.

COROMINAS, J.; PASCUAL, A. Diccionario critico etimológico castellano e hispánico. Madrid: Editora Credos, 1991, v. 2

COSERIU, E. O Homem e a sua linguagem. São Paulo: Universidade de São Paulo, 1982.

COUTINHO, I. L. Gramática histórica. $4^{\mathrm{a}}$ ed. Rio de Janeiro: Livraria Acadêmica, 1958.

COUTY, L. A erva mate e o charque. Pelotas: Seiva 2000, 2 ed.

CUNHA, A. G. da . Dicionário etimológico da língua portuguesa. $4^{\text {a. }}$ ed. revista pela nova ortografia. Rio de Janeiro: Lexikon, 2010.

CUNHA, E. A. L. O Rio Grande do Sul - contribuição para o estudo de suas condições econômicas. Rio de Janeiro: Imprensa Nacional, 1908.

DOCCA, E. F. de S. História do Rio Grande do Sul. Rio de Janeiro: Organizações Simões, 1954.

DUBOIS, J. et al. Dicionário de Linguística. São Paulo: Cultrix, 2006. 
FAGUNDES, A. A. História do Rio Grande do Sul (uma nova visão da formação da terra e do povo gaúcho). Porto Alegre: Martins Livreiro Editor, 2006.

FERREIRA, A. B. de H. Novo dicionário da língua portuguesa. $2^{\mathrm{a}}$ ed. Rio de Janeiro: Nova Fronteira, 1986.

FERREIRA, C.; CARDOSO, S. A. M. A dialetologia no Brasil. São Paulo: Contexto, 1994.

FRANCO, A. A de M. Síntese de história econômica do Brasil. Publicações da Universidade da Bahia, 1958.

FREIRE, L. JUNIOR, J. L. C. Grande e novissimo dicionario da lingua portuguesa. Rio de Janeiro: A Noite, 1940.

GOVERNO DO ESTADO DE SANTA CATARINA. Disponível em: http://www.sc.gov.br/. Acesso em: 01 de fevereiro de 2011.

GUERRA, A.M.M. (coord). Lexicografía española. Barcelona: Ariel, 2003.

GUIMARÃES, A. Série: Senhores do Charque. Diário Popular. Pelotas, 05, 06, 07 jul. 2007.

GUTIERREZ, E. J. B. Sítio Charqueador Pelotense. Porto Alegre: Paisagem do Sul, 2010.

HAENSCH, G. Tipología de las obras lexicográficas e Aspectos prácticos de la elaboración de diccionarios. In: ETTINGER, S. etalli. La lexicografía de la lingüística teórica a ala lexicografia práctica. Madrid: Gredos, 1982.

HOLANDA, S. B. de. História geral da civilização brasileira - I A época colonial 2. administração, economia, sociedade. São Paulo : Difusão Européia do Livro, 1960.

HOUASSIS, A. (1915-1999) e VILLAR, M. de S. (1939-). Dicionário da Língua Portuguesa. Rio de Janeiro: Objetiva, 2001. 
IBGE. Disponível em: http://www.ibge.gov.br. Acesso em: 30 de janeiro de 2011.

IBGE. Disponível em http://www.ibge.gov.br/cidadesat/painel/painel.php?codmun=355220. Acesso em: 22 de abril de 2012.

IBGE. Disponível: http://www.ibge.gov.br/home/presidencia/noticias/noticia_visualiza.php. Acesso em: 04 de maio de 2012.

ISQUERDO, A. N. Estudos geolinguísticos e dialetais sobre o português. Campo Grande: UFMS, 2008.

KOCK, W. (org). KLASSMANN, M.S. (org). ALTENHOFEN, C.V. (org). ALERS: atlas linguiístico-etnográfico da Região Sul do Brasil. Porto Alegre: Editora UFRS/UFSC/UFPR, 2002. 2 v.

LARA, L.F. Teoría del diccionário monolingue. México: El Colégio de México, 1997.

LEITE, J. A. M. “Xarqueadas” de Danúbio Gonçalves: um resgate para a História. Pelotas: Ed. Universitária, 2009, 2 ed.

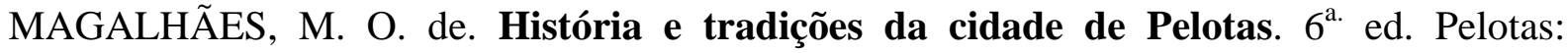
Ardotempo, 2011.

MARQUES, A da F. A economia do charque. Porto Alegre: Martins Livreiro Editor, 1992.

MEGALE, H. (org.). Normas para transcrição de documentos manuscritos para a história do Português do Brasil. In: II Seminário para a história do Português brasileiro. Campos do Jordão:Mimeo, 1998.

NASCENTES, A. Bases para a elaboração do Atlas linguístico do Brasil. Rio de Janeiro: Ministério da Educação e Cultura, Casa de Rui Barbosa, 1958.

NUNES, J. H. História do saber lexical e constituição de um léxico brasileiro. São Paulo: 
Humanitas/FFLCH/USP: Pontes, 2002.

NUNES, Z.C. ; NUNES, R.C. Dicionário de regionalismos do Rio Grande do Sul. Porto Alegre: Martins Livreiro Editor, 1996.

OLIVEIRA, A.M.P.P; ISQUERDO, A.N. (org.) As ciências do léxico: lexicografia, lexicologia, terminologia. Campo Grande: UFMS, 1998.

OLIVEIRA, D. P. de. (org.). ALMS - Atlas linguístico de Mato Grosso do Sul. Campo Grande: Editora UFMS, 2007.

PORTAL DO GOVERNO DO ESTADO DE SÃO PAULO. Disponível em: http://www.saopaulo.sp.gov.br/ . Acesso em: 01 de fevereiro de 2011.

PRADO JR., C. Formação do Brasil contemporâneo - colônia. São Paulo: Editora Brasiliense, 1965.

História econômica do Brasil. São Paulo: Editora Brasiliense, 1945.

REY, A. La terminologie: nomsetnotions. Paris: Presses Universitaires de France, 1979.

RIBEIRO, J. et al. Esboço de um atlas lingüístico de Minas Gerais. Rio de Janeiro: Ministério da Educação e Cultura, Fundação Casa de Rui Barbosa, 1977.

ROMERO, F.C. Diccionario quechua ancashino - castellano. Madrid: Iberoamericana Vervuert, 2003.

SAINT-HILAIRE, A de. Viagem ao Rio Grande do Sul, 1820-1821. Belo Horizonte: Editora Itatiaia, 1999.

SANTOS, I. P. dos; SILVA, M. P. S. C. da. Bibliografia de geolinguística. São Paulo: Plêiade, 2000. 


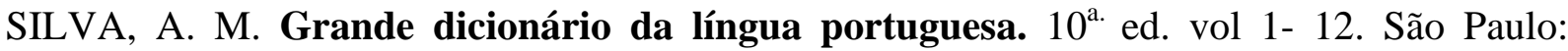
Editora Confluência, 1945.

SILVA, G.G. Breve dicionário etimológico de la lengua espanhola. México: Fondo de Cultura Economica, 1993.

SILVA NETO, S. da. História da Língua Portuguesa. 2.ed. Rio de Janeiro: Presença, 1979.

SIMONSEN, R. C. História ecomônica do Brasil 1500-1820. São Paulo: Companhia Editora Nacional, 1937.

SPINA, S. Introdução à Edótica (Crítica textual). São Paulo: Cultrix; EDUSP, 1977.

VERDELHO, T. Os dicionários bilingues até o fim do séc. XVIII. Fonte privilegiada da lexicografia portuguesa. In: Actas do colóquio de lexicografia e lexicologia 26/27. Lisboa: Universiadde Nova, 1990.

VIEIRA, D. Grande diccionario portuguez ou thesouro da língua portugueza. Porto: Ernesto Chardron e Bartolomeu H. de Moraes, 1873. 